\title{
VIGAS DE CONCRETO COM TAXAS REDUZIDAS DE ARMADURA DE CISALHAMENTO: INFLUÊNCIA DO EMPREGO DE FIBRAS CURTAS E DE PROTENSÃO
}

Tese apresentada à Escola de Engenharia de São Carlos, da Universidade de São Paulo, como parte dos requisitos para obtenção do Título de Doutor em Engenharia de Estruturas.

ORIENTADOR: Prof. Dr. João Bento de Hanai

São Carlos

1995 


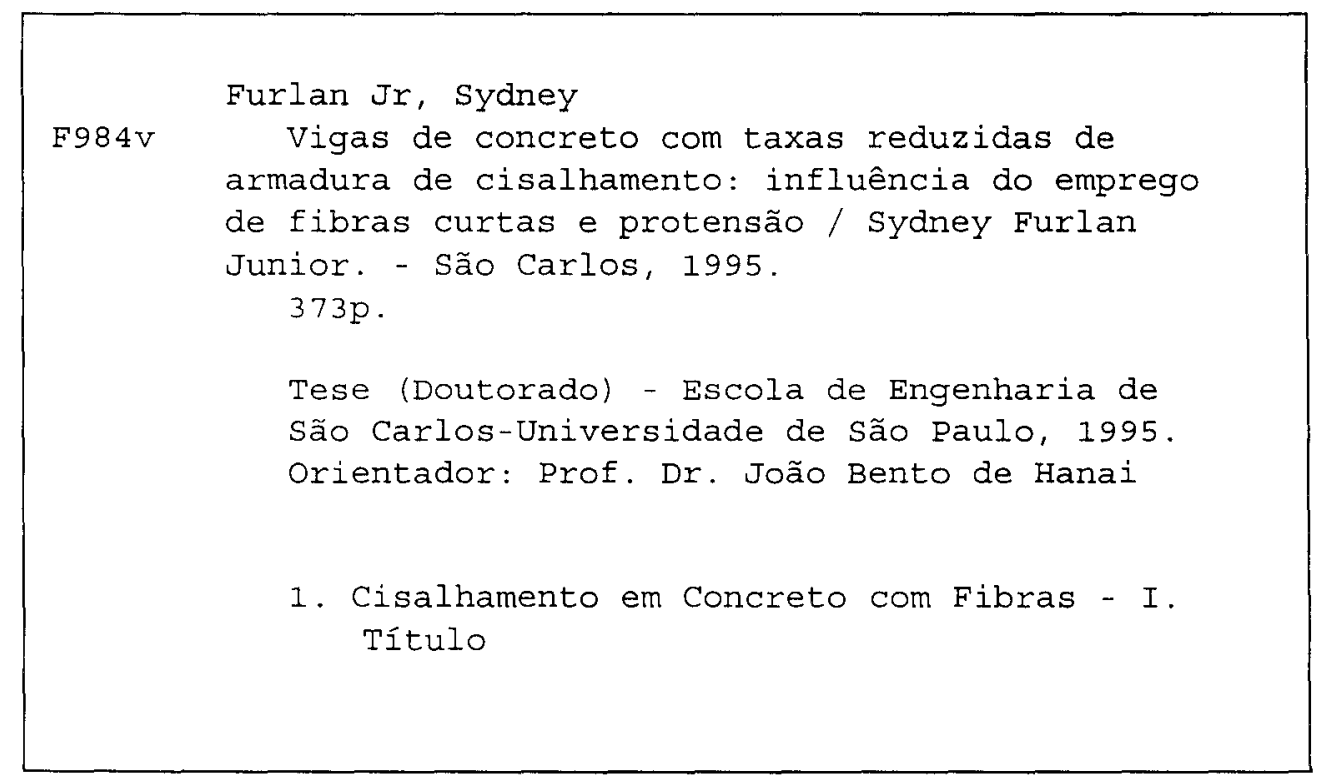




\section{AGRADECIMENTOS}

Ao Professor João Bento de Hanai, pela orientação ao longo do trabalho, sempre segura e incentivadora, e pela amizade.

Ao Professor Toshiaki Takeya, pela participação e acompanhamento na parte experimental, imprescindiveis.

Ao Professor Mounir Kalil El Debs, pelas sugestões inciais.

Aos Técnicos do Laboratório de Estruturas, Amauri, Jorge, Mário. Waldir, Mauri e Lineu, pela colaboração nos ensaios.

Ao Dimas Milanetto, da UFSCar, pela elaboração dos desenhos.

Ao Flávio, pela amizade e apoio.

A FAPESP, pelo financiamento do trabalho experimental.

E a todos os que me ajudaram direta ou indiretamente no decorrer deste trabalho. 


\section{SUMÁRIO}

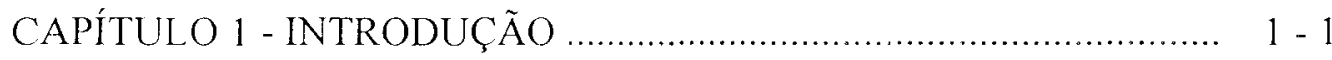

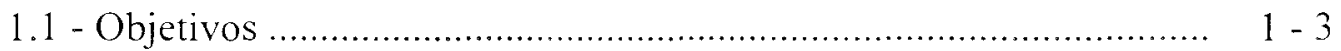

1.2 - Estrutura do trabalho ............................................................... 1 - 3

CAPÍTULO 2 - A RESISTÊNCIA AO CISALHAMENTO ….............. 2 - 1

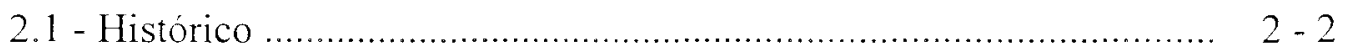

2.1.1 - Vigas sem armadura transversal .......................................... 2 - 2

2.1.2 - Vigas com armadura transversal ............................................. 2 - 4

2.2 - Considerações gerais sobre os mecanismos resistentes ................. 2 - 6

2.3 - Peças sem armadura transversal ................................................. 2 - 11

2.3.1 - Modelos de cálculo ........................................................... 2 - 13

2.3.2 - A ruptura nas peças sem estribos …........................................... 2 - 19

2.4 - Peças com armadura transversal ............................................... 2 - 21

2.4.1 - Modelos de treliça ........................................................... 2 - 22

2.4 .2 - Outros modelos ........................................................... 2 - 27

2.4 .3 - A ruptura nas peças com estribos ......................................... 2 - 29

2.5 - Peças protendidas ................................................................ 2 - 32

2.6 - Concretos de alta resistência .................................................. 2 - 36 
CAPÍTULO 3 - CONCRETOS E ARGAMASSAS COM FIBRAS....... 3 - 1

3.1 - Introdução ............................................................................ $3-1$

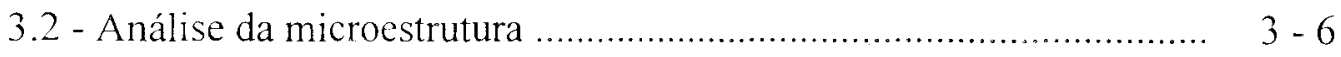

3.3 - Mecanismo de reforço: interação fibra-matriz ............................ $3-8$

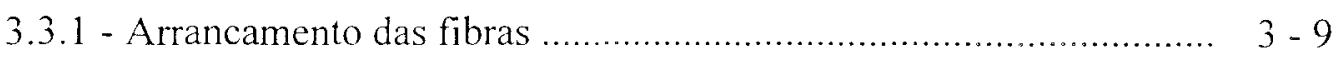

3.3.2 - Eficiência das fibras ......................................................... $3-16$

3.3.2.1 - Comprimento da fibra ................................................... $3-17$

3.3.2.2 - Orientação da fibra ...................................................... $3-18$

3.4 - A mecânica dos compósitos .................................................. $3-20$

3.4.1 - Método dos materiais compostos ........................................... $3-23$

3.4 .2 - Mecânica da fratura ............................................................... 3 - 24

3.4.3 - Etapa da fissuração múltipla .................................................. 3 - 31

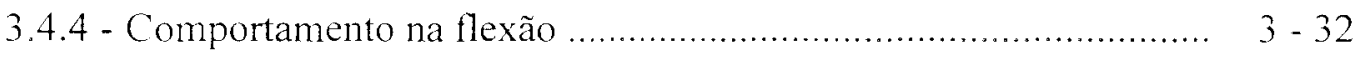

3.5 - Ensaios de caracterização ..................................................... 3 - 34

3.5.1 - Ensaios na mistura fresca ...................................................... $3-34$

3.5.2 - Ensaios na mistura endurecida ............................................. 3 - 36

3.5.2.1 - Ensaios de tração direta e tração na flexão ................................ 3 - 36

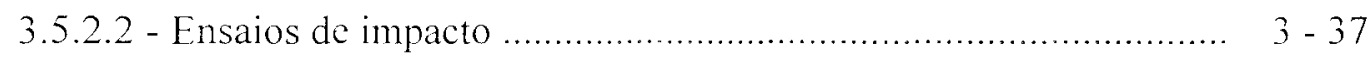

3.5.2.3 - Ensaios de arrancamento .................................................. 3 - 38

3.5.2.4 - Outros ensaios ............................................................. 3 - 38

3.6 - Sistemas com fibras ............................................................. 3 - 39

3.6 .1 - Fibra de aço .................................................................. 3 - 39

3.6 .2 - Fibra de polipropileno ….................................................... 3 - 43

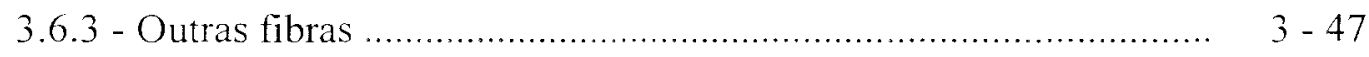

3.6.3.1 - Fibra de vidro ............................................................. $3-47$

3.6.3.2 - Cimento amianto ..................................................... $3-48$

3.6.3.3 - Fibras vegetais ............................................................. $3-48$

3.6 .4 - Sistemas especiais .......................................................... $3-50$

3.7 - As fibras e o cisalhamento .................................................... $3-50$

3.7.1 - A influência das fibras ......................................................... 3 - 52

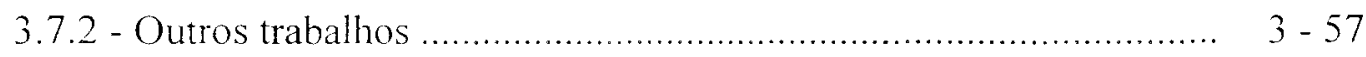


CAPITULO 4 - ENSAIOS DOS MATERIAIS E DOS PRISMAS.......... 4 - 1

4.1 - Objetivos ........................................................................... $4-1$

4.2 - Metodologia ..................................................................... 4 -

4.3 - Caracterização dos materiais utilizados ................................... 4 - 3

4.3.1 - Agregados ...................................................................... 4 - 3

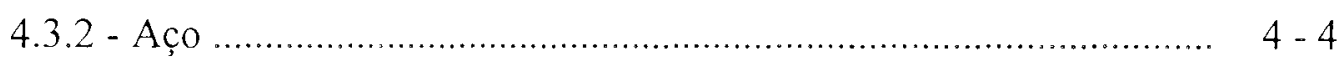

4.3 .3 - Fibras …................................................................ 4 - 6

4.3.4 - Outros materiais .............................................................. 4 - 6

4.4 - Microconcreto - determinação do traço ......................................... 4 - 5

4.5 - Vigas de seção quadrada....................................................... $4-7$

4.5.1 - Dimensionamento ........................................................ 4 - 9

4.5 .2 - Instrumentação ............................................................. 4 - 12

4.5.3 - Resultados e considerações gerais .......................................... $4-15$

4.5.3.1 - Modelos P1A e P1B ........................................................... $4-19$

4.5.3.2 - Modelos P2A e P2B ….................................................. 4 - 26

4.5.3.3 - Modelos P3A e P3B …..................................................... 4 - 34

4.5.3.4 - Modelos P4A e P4B ….................................................... 4 - 39

4.5.3.5 - Modelos P5A e P5B ......................................................... 4 - 46

4.5.3.6 - Modelos P6A e P6B …..................................................... 4 - 51

4.5.3.7 - Modelos P7A e P7B …................................................... 4 - 57

4.6 - Análise dos resultados ............................................................... 4 - 64

4.6.1 - Propriedades do concreto ........................................................ $4-65$

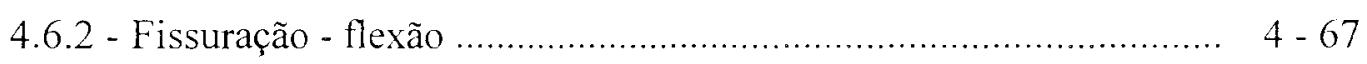

4.6 .3 - Fissuração - cisalhamento ……................................................ 4 - 72

4.6.4 - Deslocamentos transversais ................................................ 4 - 73

4.6.5 - Capacidade resistente (flexão e cisalhamento) …....................... 4 - 81

4.6.6 - Tensão nos estribos ......................................................... 4 - 84

4.6.7 - Tensão na armadura longitudinal ................................................ 4 - 91

4.6.8 - Tensão no concreto ........................................................... 4 - 96

4.7 - Conclusões parciais .......................................................... 4 - 99 
CAPÍTUlO 5 - ENSAIOS DAS VIGAS DE SEÇÃO DUPLO-T …….. 5 - 1

5.1 - Objetivos ........................................................................ $5-1$

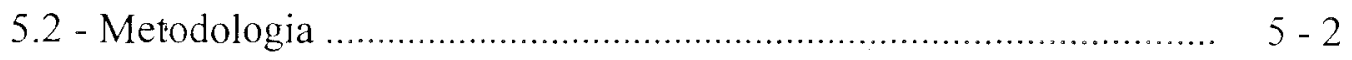

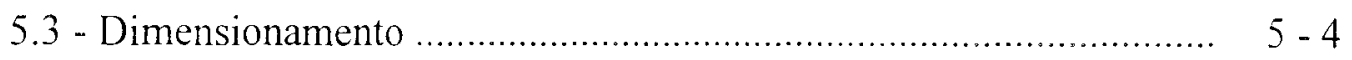

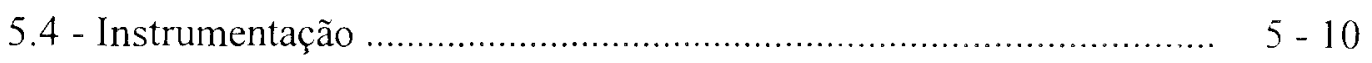

5.5 - Execução da protensão e moldagem …….................................. $5-12$

5.6 - Ensaios ....................................................................... $5-16$

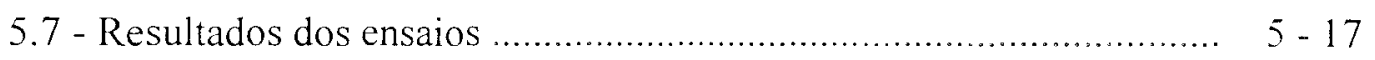

5.7.1 - Modelo V1 .................................................................... $5-23$

5.7.2 - Modelo V2 ….............................................................. $5-33$

5.7 .3 - Modelo V3 .................................................................... $5-40$

5.7.4 - Modelo V4 …............................................................. 5 - 46

5.7 .5 - Modelo V5 ................................................................. $5-54$

5.7.6 - Modelo V6 ..................................................................... $5-61$

5.7.7 - Modelo V7 .................................................................. $5-69$

5.7.8 - Modelo V8 .............................................................. 5 - 75

5.7 .9 - Modelo V9 …........................................................... $5-80$

5.8 - Análise dos resultados ........................................................ $5-93$

5.8.1 - Propriedades do concreto .................................................... $5-94$

5.8 .2 - Fissuração - flexão ……….................................................... 5 - 98

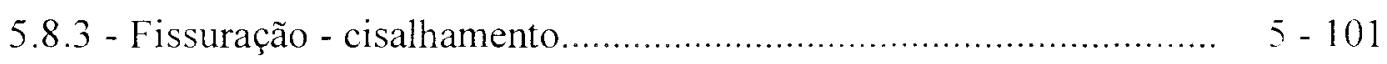

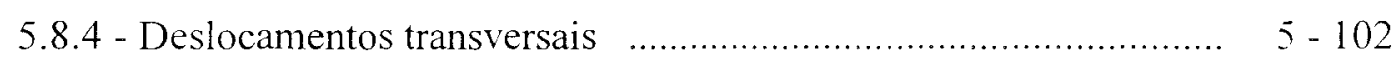

5.8 .5 - Capacidade resistente .................................................... $5-107$

5.8 .6 - Estribos ....................................................................... $5-111$

5.8.7 - Armadura longitudinal ................................................... $5-128$

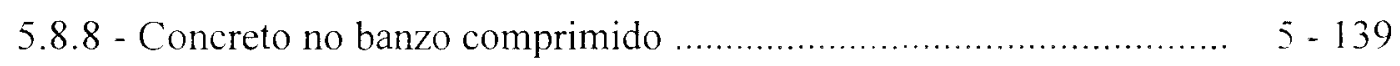

5.8 .9 - Concreto na alma ......................................................... $5-143$

5.8 .10 - Força de protensão ...................................................... $5-144$

5.9 - Conclusões parciais ............................................................. $5-154$

CAPÍTULO 6 - CONCLUSÕES ….................................................. 6 - 1

REFERÊENCIAS BIBLIOGRÁFICAS _...................................... RB - 1 


\section{NOTAÇÃO}

\section{LETRAS ROMANAS}

$\mathrm{A}_{\text {Sw.e }}$ - armadura transversal existente

$\mathrm{a} / \mathrm{d}$ - relação entre a distância do ponto de aplicação da carga concentrada até o apoio e a altura útil da peça

$\mathrm{a} / \mathrm{c}$ - fator água/cimento

$a_{0} .2 a$ - comprimento da fissura

$a_{c}$ - comprimento crítico da fissura

b - largura da peça

$b_{\mathrm{u}}, \mathrm{b}_{\mathrm{o}}$ - largura da alma

C - resultante das tensões de compressão

c - cobrimento; altura do diagrama retangular de tensões de compressão no concreto na seção transversal de uma peça fletida

$\mathrm{CH}$ - portlandita

D - diâmetro da armadura longitudinal

d - altura útil da peça

E - módulo de deformação longitudinal

$E_{a}$ - módulo de deformação longitudinal aparente das cordoalhas

$\mathrm{E}_{\mathrm{c}}$ - módulo de deformação longitudinal do compósito

$\mathrm{E}_{\mathrm{f}}$ - módulo de deformação longitudinal da fỉbra

$\mathrm{E}_{\text {teo }}$ - módulo de deformação longitudinal teórico (calculado com $\mathrm{f}_{\mathrm{c}}$ experimental)

$\mathrm{E}_{\mathrm{rel}}$ - módulo de deformação longitudinal relativo (dividido pelo valor do modelo de referência)

exp/teo - relação entre valores teóricos e experimentais

$\mathrm{F}$ - força indicada na célula de carga nos ensaios das vigas I (igual à força cortante)

$F_{m o b}$ - força aplicada no instante da mobilização efetiva da armadura (tensão de 40 $\mathrm{MPa})$

$\mathrm{F}_{\text {r.exp }}$ - força que provoca o aparecimento da primeira fissura de flexão

$\mathrm{F}_{\mathrm{r} \text {.teo }}$ - valor teórico da força que provoca o aparecimento da primeira fissura de flexão

$\mathrm{F}_{\mathrm{rl}}$ - força correspondente ao instante em que fissuras de flexão começam a inclinar

$\mathrm{F}_{\mathrm{r} 2}$ - força que provoca o aparecimento da primeira fissura inclinada diretamente na alma

$\mathrm{F}_{3 \mathrm{~mm}}$ - força correspondente ao instante em que a flecha atingiu $3 \mathrm{~mm}$ 
$\mathrm{F}_{6 \mathrm{~mm}}$ - força correspondente ao instante em que a flecha atingiu $6 \mathrm{~mm}$

$\mathrm{F}_{9 \mathrm{~mm}}$ - força correspondente ao instante em que a flecha atingiu $9 \mathrm{~mm}$

$\mathrm{F}_{\varepsilon=0,15 \%}$ - força aplicada correspondente ao instante em que a deformação na armadura longitudinal atingiu $0,15 \%$

$\mathrm{f}$ - tensões correspondentes às "forças de costura" da fibra na fissura

$\mathrm{f}_{\mathrm{c}}$ - resistência à compressão do concreto

$\mathrm{f}_{\text {py }}$ - resistência de escoamento das cordoalhas

$f_{t}$ - resistência à tração do concreto

$\mathrm{f}_{\mathrm{t}, \mathrm{teo}}$ - resistência à tração do concreto calculada conforme expressão da NBR-6118

utilizando a resistência à compressão experimental

GP - grau de protensão

$\mathrm{K}_{\mathrm{c}}$ - fator crítico de intensidade de tensão

$1_{c}$ - comprimento crítico da fibra

1/d - relação de aspecto da fibra (comprimento/diâmetro equivalente)

$\mathrm{l} / \mathrm{h}$ - relação entre o comprimento e a altura

$\mathrm{M}$ - momento fletor

$M_{r}, M_{c r}-$ momento fletor de fissuração

$\mathrm{M}_{\mathrm{o}}$ - momento fletor de descompressão

$P$ - força axial na fibra

$\mathrm{P}_{\mathrm{a}}$ - força de protensão imediatamente após a ancoragem

$P_{\text {máx }}$ - força axial máxima na fibra; força de arrancamento

$\mathrm{P}_{\mathrm{o}}$ - força de protensão após a liberação da protensão

$\mathrm{P}_{\mathrm{t}}$ - força de protensão no instante do ensaio

PVAc - acrilato

$\mathrm{S}$ - espaçamento entre os estribos; escorregamento da fibra na matriz

$\mathrm{S}_{\text {crit }}$ - escorregamento da fibra correspondente ao instante da perda da aderência

$\mathrm{T}$ - resultante das tensões de tração

$\mathrm{V}$ - força cortante

$V_{\text {crit }}$ - volume crítico de fibras

$\mathrm{V}_{\mathrm{a}}$ - parcela da força cortante absorvida pelo atrito nas fissuras

$\mathrm{V}_{\mathrm{c}}$ - parcela da força cortante absorvida pelo concreto

$\mathrm{V}_{\mathrm{cL}}$ - parcela da força cortante absorvida pelo banzo comprimido de concreto

$\mathrm{V}_{\mathrm{d}}$ - parcela da força cortante absorvida pelo efeito de pino

$V_{\mathrm{f}}$ - volume de fibras

$\mathrm{V}_{\mathrm{o}}$ - força cortante que provoca a descompressão da seção

$\mathrm{V}_{\mathrm{r}}, \mathrm{V}_{\mathrm{cr}}$ - força cortante que provoca o aparecimento de fissuras inclinadas

$V_{r \text { exp }}$ - força cortante experimental que provoca o aparecimento de fissuras inclinadas 
$\mathrm{V}_{\mathrm{r} . \mathrm{teo}}$ - força cortante teórica que provoca o aparecimento de fissuras inclinadas

$\mathrm{V}_{\mathrm{rl}}$ - força cortante no instante em que fissuras de flexão começam a se inclinar

$\mathrm{V}_{\mathrm{r} 2}$ - força cortante no instante do aparecimento de fissuras inclinadas na alma

$V_{S}$ - parcela da força cortante absorvida pelos estribos

$\mathrm{V}_{\mathrm{u}}$ - força cortante última

$\mathrm{V}_{\text {u.c }}$ - força cortante de ruptura devido a tensões tangenciais (ruptura por cisalhamento)

$V_{\text {u. exp }}$ - força cortante última experimental

$\mathrm{V}_{\mathrm{u} .1}$ - força cortante de ruptura devido a tensões normais (ruína por flexão)

$\mathrm{V}_{\text {u.rel }}$ - força cortante última dividida pela raiz quadrada da resistência do concreto

$V_{12 \mathrm{~mm}}$ - força cortante no instante em que as flechas atingiram $12 \mathrm{~mm}$

$V_{25 \mathrm{~mm}}$ - força cortante no instante em que as flechas atingiram $25 \mathrm{~mm}$

$\mathrm{V}_{37 \mathrm{~mm}}$ - força cortante no instante em que as flechas atingiram $37 \mathrm{~mm}$

$V_{k=0,15^{\ldots} \ldots}$ - força cortante correspondente ao instante em que a deformação na armadura longitudinal atingiu $0,15 \%$

W - energia consumida no arrancamento da fibra

w - abertura de fissura

$w_{c r}$ - abertura limite da fissura (até onde atuam "forças de costura")

\section{LETRAS GREGAS}

$\beta_{1}$ - coeficiente que majora a contribuição do concreto na resistência ao cisalhamento

$\varepsilon_{\mathrm{cu}}$ - deformação limite do compósito

$\varepsilon_{\text {máx }}$ - deformação máxima

$\varepsilon_{\mathrm{mc}}$ - deformação na fibra ao final da fissuração múltipla da matriz

$\varepsilon_{\text {inu }}$ - deformação na fibra no início da fissuração múltipla da matriz

$\varepsilon_{\mathrm{s} 1}$ - deformação na armadura longitudinal

$\varepsilon_{\mathrm{S} \text {.máx }}$ - deformação máxima na armadura longitudinal

$\eta$ - grau de armação ao cisalhamento

$\theta$ - inclinação das bielas em relação ao eixo da viga: inclinação da fibra em relação à força de arrancamento

$\theta_{\text {crit }}$ - inclinação da fissura crítica

$\theta_{\text {min }}$ - inclinação mínima das bielas

$\rho_{\|}$- taxa geométrica da armadura de cisalhamento

Pu.e - taxa geométrica da armadura de cisalhamento existente 
$\rho_{\mathrm{w}, \mathrm{M}}$ - taxa geométrica da armadura de cisalhamento calculada com a treliça de Mörsch para permitir o escoamento da armadura longitudinal

$\rho_{\mathrm{w}, \min }$ - taxa geométrica mínima da armadura de cisalhamento

$\sigma$ - tensão normal

$\sigma_{\text {comp }}$ - tensão normal de compressão no concreto

$\sigma_{\mathrm{cu}}$ - resistência limite do compósito

$\sigma_{\mathrm{c} \theta}$ - tensão de compressão na biela de concreto

$\sigma_{\mathrm{fu}}$ - resistência limite da fibra

$\sigma_{t}$ - tensão normal de tração no concreto

$\sigma_{\mathrm{t}, \text { fab }}$ - tensão de tração no concreto na borda tracionada pela força de protensão

$\sigma_{\text {Sw }}$ - tensão nos estribos

$\tau$ - tensão tangencial

$\tau_{\mathrm{au}}$ - resistência de aderência (tensão máxima de cisalhamento por aderência)

$\tau_{c}$ - tensão de cisalhamento resistida pelo concreto: tensão de aderência crítica

$\tau_{\mathrm{f}}$ - tensão de cisalhamento por atrito

$\tau_{f u}$ - tensão limite de cisalhamento por atrito

$\tau_{\mathrm{wu}}, \tau_{\mathrm{ou}}$ - tensão de cisalhamento convencional limite

$\phi_{1}$ - coeficiente para determinação de $\tau_{c}$

$\Delta$ - flecha; escorregamento da fibra

$\Delta_{\text {crit }}$ - escorregamento da fibra correspondente ao início da perda da aderência

$\Delta_{\text {máx }}$ - escorregamento da fibra correspondente a $\mathrm{P}_{\text {máx }}$

$\Delta_{0}$ - escorregamento da fibra correspondente à perda total da aderência 


\section{RESUMO}

FURLAN Jr, Sydney. Vigas de concreto com taxas reduzidas de armadura de cisalhamento: influência do emprego de fibras curtas e de protensão. São Carlos, 1995. Tese (Doutorado) - Escola de Engenharia de São Carlos. Universidade de São Paulo.

Neste trabalho investiga-se o comportamento resistente de vigas de concreto com taxas reduzidas de armadura transversal, analisando-se as possibilidades de melhoria de desempenho pelo reforço do concreto com fibras curtas de aço e polipropileno e pela aplicação da protensão, através de ensaios em vịas de seção quadrada e vigas protendidas de seção duplo- $T$. Apresenta-se também uma revisão de conhecimentos sobre o comportamento estrutural de elementos de concreto armado ou protendido, com ênfase nas solicitações por força cortante, e os principais conceitos sobre os compósitos constituídos de matriz de cimento reforçada com fibras.

As principais alterações decorrentes da introdução das fibras foram o aumento da resistência ao cisalhamento, da rigidez após a fissuração e da dutilidade. A protensão aumenta a resistência ao cisalhamento, a resistência à fissuração e a extensão da zona não fissurada, e torna as bielas mais abatidas. Tanto as fibras quanto a protensão proporcionam alívio da tensão nos estribos.

Palavras-Chave: cisalhamento, concreto, fíbra, protensĩo, seção delgada 


\section{ABSTRACT}

FURLAN Jr. Sydney. Concrete beams with reduced shear reinforcement ratios: effect of prestressing and short fibers. São Carlos, 1995. Tese (Doutorado). Escola de Engenharia de São Carlos, Universidade de São Paulo.

This thesis presents an experimental analysis of the structural behavior of concrete beams with reduced shear reinforcement ratios. Improvements on performance due to prestressing and steel and polypropilene fibers are analized in rectangular and $\mathrm{T}$ beam models. A state-of-the-art is presented on shear strength of reinforced and prestressed concrete beams and on fiber reinforced cement-based composites. The main effects due to fiber addition are the increasing of the shear strength, post-cracking stiffiness and ductility. Prestressing helps to increase the shear strength, cracking strength and extension of the non-cracked zone and it turns the struts less inclined. Fibers as well prestressing reduce the stresses on stirrups.

Keywords: shear, concrete, fiber, prestressed, thin-walled section 


\section{CAPÍTULO 1 - INTRODUÇÃO}

Este trabalho se insere num contexto mais amplo sobre o estudo de elementos pré-moldados de concreto, com enfoque especial para as peças constituídas de seção delgada, em que a diminuição da espessura dos elementos incorpora leveza e amplia o potencial de aplicação desta alternativa estrutural.

O uso da armadura de protensão é freqüente na produção de peças prémoldadas, pois, além de melhorar o desempenho estrutural, em muitos casos torna o processo produtivo mais eficiente.

A montagem da armadura transversal constitui uma das etapas mais trabalhosas do processo produtivo. Assim, a diminuição das taxas de armadura transversal pode favorecer o aumento da mecanização e da produtividade, com possíveis vantagens em relação ao custo. Em algumas situações especiais pode-se prescindir do uso da armadura transversal, como nas lajes alveolares protendidas.

Para os elementos que apresentam taxa reduzida de armadura transversal e que têm comportamento típico de viga. mesmo que se garanta uma resistência compatível com a sua solicitação persiste o problema da ruptura frágil, caso haja o colapso devido às solicitações tangenciais. Assim como no caso das lajes, desde que se respeitem alguns requisitos, como a limitação da tensão tangencial e a segurança contra a fissuração e ruptura do concreto, a resistência pode ser obtida através de mecanismos alternativos. Portanto, no caso das vigas, a redução da armadura transversal passa principalmente pelo efetivo controle da fissuração e por um comportamento mais dútil na ruptura.

Ou seja, a viabilidade estrutural das peças de concreto protendido de seção delgada com pouca ou nenhuma armadura transversal depende de se equacionar alguns aspectos relativos ao seu desempenho, especialmente para as solicitações tangenciais. 
Normalmente se define a intensidade da protensão em função do tipo de solicitação. das condições de exposição e das exigências de desempenho do elemento. As implicações decorrentes desta escolha estão bem delineadas em relação ao comportamento estrutural, especialmente para as solicitações normais. Além disso, a capacidade resistente à flexão de uma peça pode ser facilmente ajustada às suas exigências de desempenho, variando-se o grau de protensão. Para as solicitações tangenciais, no entanto, a influência da protensão na resistência ao cisalhamento, além de ser usualmente considerada como benefício secundário do dimensionamento à flexão, é objeto de algumas controvérsias, como mostram os registros da bibliografia específica. A relevância deste tema se acentua no caso das peças de seção delgada com pouca armadura transversal.

Sabe-se que a protensão aumenta a resistência proporcionada pelos mecanismos alternativos. ao retardar a fissuração do concreto. A ruptura por compressão da biela de concreto, mesmo quando a alma é fina, não deve ser o fator limitante, já que nos elementos pré-fabricados se trabalha com concretos de resistência relativamente elevada. Resta a possibilidade de haver fissuras de cisalhamento muito abertas em estados de utilização e o colapso sem aviso, no caso da eventual ruptura por força cortante, que é sempre indesejada.

É neste aspecto que a utilização das fibras curtas como reforço para o concreto pode ser importante. Além das vantagens decorrentes do controle da fissuração e do aumento da resistência proporcionado por elas, há uma melhoria nas características de dutilidade do elemento de concreto.

Portanto, este estudo envolve diversos temas, tais como:

- elementos de concreto de seção delgada;

- taxas reduzidas de armadura transversal;

- comportamento resistente sob solicitações tangenciais;

- efeito da protensão na resistência ao cisalhamento;

- efeito das fibras no comportamento resistente no cisalhamento. 


\section{1 - OBJETIVOS}

Dentro do contexto apresentado, os principais objetivos deste trabalho são:

- revisar e sintetizar os conhecimentos existentes sobre o comportamento estrutural, com ênfase nas solicitações por força cortante, de elementos de concreto armado e protendido, efetuando-se uma projeção sobre o comportamento das vigas de seção delgada de microconcreto ou concreto de granulometria fina;

- avaliar as possibilidades de melhoria de desempenho (resistência, fissuração. deformações, dutilidade, etc), com ênfase no cisalhamento, pelo reforço do concreto com adição de fibras curtas e pela aplicação da protensão. Avaliar também o comportamento dos elementos de concreto de seção delgada protendidos e com fibras, com pouca ou nenhuma armadura transversal;

- Produzir novas informações, a partir de ensaios de laboratório, sobre o desempenho estrutural das peças de microconcreto, estudando-se principalmente a influência do volume e tipo de fibras, da protensão e da taxa de armadura transversal. Sintetizar os resultados e fornecer indicações sobre a avaliação da resistência à força cortante desses elementos, incorporando conclusões sobre o efeito da protensão e das fibras. e sobre a possibilidade de redução da armadura de cisalhamento. conforme as condições específicas e eventuais restrições levantadas neste estudo.

\section{2 - ESTRUTURA DO TRABALHO}

Além da introdução e contextualização apresentados neste primeiro capítulo, o trabalho está estruturado em outros cinco capítulos, cujos conteúdos são brevemente descritos a seguir.

O Capítulo 2 trata do estudo da resistência ao cisalhamento por força cortante em vigas de concreto, onde se apresenta um breve estado-da-arte e os principais conceitos sobre o assunto, destacando-se os mecanismos resistentes, os principais modelos de cálculo e a forma de ruptura, correspondentes aos elementos de concreto com ou sem armadura transversal. As especificidades das peças de concreto protendido e de concreto de alta resistência também são discutidas. 
O reforço do concreto pela adição de fibras curtas é estudado no Capítulo 3, onde se apresenta uma conceituação geral dos compósitos formados pela matriz de cimento reforçada com fibras curtas. Destacam-se os temas relativos à microestrutura da zona de transição e sua influência nas propriedades mecânicas, ao mecanismo de reforço (estudado através do fenômeno do arrancamento das fíbras) e à Mecânica dos Compósitos, analisada sob a ótica dos conceitos utilizados para o estudo do comportamento dos compósitos à tração, tais como a Lei das Misturas e a Mecânica da Fratura. Posteriormente, descrevem-se sucintamente os principais ensaios de caracterização e as propriedades dos sistemas formados por vários tipos de fibra. destacando-se a fibra de aço e a fibra de polipropileno, utilizadas na etapa experimental deste trabalho. E finalmente discute-se a influência das fibras na resistência ao esforço cortante, destacando-se os trabalhos mais recentes.

No Capítulo 4 são apresentados os resultados dos ensaios de caracterização dos materiais utilizados no trabalho experimental e dos ensaios preliminares de flexão, realizados em quatorze vigas de seção quadrada de concreto reforçado com fibras de aço e de polipropileno. Além dos aspectos relacionados com a produção dos compósitos, foram obtidos os primeiros resultados sobre a influência do tipo e volume de fibras no desempenho estrutural, sob diferentes situações de armadura transversal. através da comparação das propriedades do concreto, da fissuração, das flechas, das deformações no concreto e nas armaduras, e da resistência.

O Capítulo 5 é dedicado às vigas protendidas de microconcreto de seção transversal duplo-T com taxas reduzidas de armadura transversal. Além da metodologia e do planejamento dos ensaios, descreve-se com detalhes a etapa da execução da protensão destas peças. A análise dos resultados sobre a influência da protensão e das fibras de aço e polipropileno no comportamento resistente destes elementos enfoca principalmente a fissuração devido à flexão e ao cisalhamento, os deslocamentos verticais. a ruptura, a resistência, e as deformações no concreto, na armadura longitudinal e na armadura transversal.

No Capítulo 6 apresentam-se as conclusões do trabalho, apontando-se lacunas que não foram preenchidas com estes ensaios e algumas perspectivas de trabalhos futuros nesta área. 


\section{CAPÍTULO 2 - A RESISTÊNCIA AO CISALHAMENTO}

Neste capítulo apresentam-se os principais conceitos relativos ao comportamento resistente das vigas de concreto submetidas a solicitações tangenciais, especialmente aqueles sobre os mecanismos resistentes, os modelos teóricos a eles associados e os modos de ruptura. O estudo do cisalhamento é tema bastante complexo, pois, além das diversas variáveis intervenientes no fenômeno, a natureza da ruptura ainda não está completamente resolvida sob o ponto de vista do equacionamento matemático. Porisso, as formulações normalmente são baseadas em expressões empíricas ou semi-empíricas, mesmo com os contínuos esforços desenvolvidos para associar um modelo físico consistente ao fenômeno.

A utilização dos modelos de treliça é a base dos principais códigos e normas técnicas para o dimensionamento de vigas com armadura transversal, dentre eles, a NBR-6118, o ACI-318 e o CEB-90. Recentemente também têm sido utilizados modelos mais refinados, aplicando-se técnicas de elementos finitos com as relações constitutivas dos materiais e dos mecanismos resistentes, considerando-se a nãolinearidade do concreto. Outros modelos também podem ser citados, incluindo aqueles baseados em conceitos da Mecânica da Fratura, especialmente úteis no caso das vigas sem armadura transversal, onde a ruptura por cisalhamento é tipicamente frágil.

Inicialmente, apresenta-se um breve histórico sobre a evolução dos estudos nesta área. Posteriormente, os conceitos gerais e o comportamento resistente são apresentados de modo sucinto e qualitativo, abordando os principais modelos disponíveis para análise do cisalhamento e os mecanismos resistentes alternativos, decorrentes da contribuição do concreto na transferência das forças transversais, os quais assumem maior relevância nas peças com pouca armadura transversal. Estes mecanismos eventualmente podem ser considerados nos modelos de cálculo, mas normalmente são quantificados empiricamente. 


\section{1 - HISTÓRICO}

As primeiras referências bibliográficas sobre o assunto datam do início deste século, desde os primeiros trabalhos de Mörsch, em 1908. Acreditava-se que a fissura de cisalhamento surgia quando as tensões tangenciais convencionais superassem a resistência à tração simples do concreto. Percebeu-se que isso era uma simplificação grosseira e que, na verdade, parte da força transversal seria resistida pela inclinação da tensão principal de compressão no banzo comprimido e pelo concreto situado entre as fissuras de flexão, que poderia fletir e induzir o aparecimento de forças de pino na armadura, que também contribuiriam na resistência à força cortante.

Segundo REGAN (1993), de 1915 até 1950, pouco se estudou sobre o cisalhamento. Quando o assunto foi retomado, surgiram várias teorias e fómulas que consideraram basicamente os mesmos dados empíricos. Muitos modelos se originaram a partir de observações experimentais. Neste caso, muitas vezes os cuidados na execução dos modelos podem ser mais importantes do que o tratamento teórico.

Os trabalhos sobre o cisalhamento se concentram basicamente na determinação da força cortante que provoca o aparecimento da fissura diagonal $\left(\mathrm{V}_{\mathrm{cr}}\right)$ e da força cortante última $\left(V_{\mathrm{u}}\right)$. O interesse na determinação do início da fissuração inclinada está relacionado com a resistência de vigas sem estribos (já que nestas peças, normalmente o valor de $\mathrm{V}_{\mathrm{cr}}$ é associado à ruptura) e com o comportamento em serviço das vigas com estribos. Outros temas relevantes são os mecanismos resistentes, a forma de ruptura e a influência da protensão na resistência ao cisalhamento.

Os trabalhos citados aqui estão resumidamente descritos em REGAN (1993) e no CEB-180 (1987). Os estudos mais recentes são apresentados posteriormente, ao longo do texto, para ilustrar o panorama atual das pesquisas nesta área.

\subsection{1 - VIGAS SEM ARMADURA TRANSVERSAL}

Em 1964. o "tooth model" proposto por Kani considerava que a região do concreto entre as fissuras ficava engastada na zona comprimida da viga, como um consolo, sendo submetida à flexão devido à variação da força na armadura longitudinal ao longo do eixo da peça. decorrente da aderência existente entre o aço e o concreto. A resistência estaria esgotada quando a tensão de tração na seção do engaste do consolo superasse o valor da resistência à tração do concreto. A força cortante seria transmitida através das tensões de tração e compressão na região comprimida. Este modelo 
simplista deu origem a vários trabalhos que o implementaram, e estabeleceu a existência da flexão do concreto entre fissuras.

Simultaneamente, Lorentsen sugeriu que o comportamento de uma peça sem armadura transversal na região fissurada pela flexão resultaria da combinação de dois mecanismos resistentes: mecanismo de viga (devido à variação da força na armadura longitudinal) e mecanismo de arco (devido à variação da posição da resultante das forças de compressão). O equilíbrio da força cortante seria decorrente da variação do momento fletor, provocada pela variação da posição da força resultante no banzo comprimido e da força na armadura longitudinal, que proporciona a transferência de forças verticais através do efeito de pino. Caso a força cortante fosse maior que a resistência oferecida pelo mecanismo de viga. ou seja. o momento aplicado fosse maior que o momento de fissuração, o mecanismo de arco seria mobilizado na seção. Assim. a inclinação do banzo dependeria do valor do momento fletor e, portanto, da relação $\mathrm{a} / \mathrm{d}$.

Em 1968. Fenwick observou a diminuição da força cortante de ruptura em vigas sem estribos, ao eliminar as parcelas de resistência proporcionadas pelo engrenamento dos agregados e pelo efeito de pino da armadura longitudinal, demonstrando a importância destes fenômenos.

A partir de 1970, surgiram vários trabalhos específicos sobre a contribuição do efeito de pino e do atrito nas físsuras inclinadas na resistência ao cisalhamento. Segundo Walraven, os parâmetros principais que influem no engrenamento dos agregados são as tensões (normal e de cisalhamento), a abertura da fissura e o deslocamento provocado pela força cortante.

Em 1980, Regan e Hamadi retomaram e modificaram o modelo do consolo de concreto, incluindo a ação do atrito e o efeito de pino na transferência da força cortante. A fissura diagonal ocorreria quando o momento fletor no consolo produzisse uma deformação limite na extremidade das fissuras, descontadas as parcelas resistidas pelo atrito nas fissuras e pela ação de pino. Ou seja, a tensão de tração na seção do engaste seria o fator limitante da resistência.

Em 1991, também baseado no modelo do consolo, e desprezando o efeito de arco e a flexão do concreto entre fissuras, REINECK (1991) afirma que o atrito nas fissuras se constitui no principal mecanismo resistente em vigas delgadas sem armadura transversal. Para vigas sem armadura transversal, a parcela resistente correspondente à contribuição do banzo comprimido estaria limitada em aproximadamente $30 \%$ da força cortante última. As possiveis falhas do modelo. segundo REGAN (1993), decorrem da necessidade de se conhecer a posição da fissura diagonal e da desconsideração da flexão do consolo. que é um fato experimental. 
O CEB-180 apresenta inúmeros trabalhos empíricos para o cálculo da resistência ao cisalhamento e vários estudos específicos sobre os mecanismos resistentes alternativos. Destaca também, entre outros, os trabalhos de Regan-Hamadi e Reineck citados anteriormente e o modelo das duas diagonais de Kupfer, que considera o engrenamento dos agregados segundo as hipóteses de Walraven.

Os modelos baseados em critérios de resistência não contemplam a ocorrência da ruptura por instabilidade, relacionada com a energia necessária para o aparecimento de novas fissuras ou com a propagação de uma fissura quando ela atinge seu comprimento crítico, conforme a teoria da Mecânica da Fratura. O modelo proposto por Bazant. baseado no mecanismo de viga asșociado ao modelo de biela-tirante. estabelece um critério de transição entre os parâmetros de resistência e instabilidade. A energia liberada na fratura depende da extensão da fissura, representada pela altura da peça, e da área da região microfissurada junto à fissura. representada pelo diâmetro do agregado. Neste modelo calcula-se a carga de ruptura, ao invés da carga correspondente à fissuração diagonal, como é usual. e que nem sempre leva as peças sem estribos à ruptura, exceto em grandes estruturas. Para peças onde a relação entre a altura e o diâmetro do agregado é reduzida $(<25)$. prevalece o critério de resistência. Caso contrário, predomina o critério de instabilidade.

\subsection{2 - VIGAS COM ARMADURA TRANSVERSAL}

Até 1970, utilizava-se o modelo de treliça com bielas a 45 graus e banzos paralelos para o cálculo da resistência ao cisalhamento. Eventualmente, considerava-se uma parcela resistente adicional, igual à resistência da viga similar sem estribos, sem preocupação com a coerência física da formulação. Esta parcela adicional variava com a resistência à compressão do concreto e ajustava os valores teóricos aos resultados obtidos experimentalmente.

Posteriormente, surgiu a teoria do cisalhamento-compressão, que considerava que a ruptura ocorria na zona comprimida do concreto. cuja altura era reduzida pela penetração da fissura de cisalhamento. Os limites da tensão de compressão do concreto seriam minorados devido aos efeitos do cisalhamento na região. As primeiras pesquisas eram empíricas, mas abordavam a principal causa do fenômeno: a redução da linha neutrạ, que leva a peça à ruptura prematura por compressão, mesmo no caso de vigas sub-armadas. Segundo REGAN (1993), a aplicação do modelo seria restrita aos casos de ruptura da alma, já que a transferência de forças significativas através de fissuras muito abatidas seria difícil, como no caso de cargas distantes dos apoios. 
Quando ressurgiu o interesse pelos modelos de treliça, que tradicionalmente subestimavam a resistência ao cisalhamento, Lipsky apresentou a teoria das três barras, onde acrescentou um tirante inclinado de concreto. Ele não resistiria tensões nas fissuras, mas representaria a contribuição do concreto entre elas ("tension stiffening"), devido ao engrenamento dos agregados. Ainda não se analisava a transferência de forças ao longo das fissuras, por atrito, mas já se considerava que a biela na alma atravessava as fissuras, ou seja, que tensões poderiam ser transmitidas através delas.

O maior avanço nos modelos de treliça veio a partir da teoria plástica do limite inferior, que limita as tensões nos elementos da treliça. L'ma solução ótima considera a tensão nos estribos igual à sua resistência de escoamento, e no concreto, igual a um valor menor que o de sua resistência uniaxial, a ser estabelecido em função do estado de tensão atuante no elemento considerado. Este conceito é utilizado no CEB-90 e em um dos métodos do EuroCode para a análise do cisalhamento de peças fissuradas. A limitação da resistência à compressão do concreto na alma. discutida posteriormente. além de prevenir a ruptura por esmagamento do concreto, limitaria os movimentos relativos nas fissuras (não simples aberturas de fissuras associadas a tensões de tração. mas deslocamentos tangenciais).

No estado da arte apresentado no CEB (1987), destaca-se também a combinação do modelo de treliça com o modelo de bielas e tirantes, para cargas próximas do apoios. Conforme se comenta posteriormente, este procedimento se assemelha a um dos métodos do CEB-78 ("Accurated Method"), ao particularizar o caso de cargas próximas do apoio, onde a transmissão direta da carga não é apenas uma questão de configuração do carregamento, mas da relação de rigidez entre os componentes que absorvem a carga.

Para as vigas protendidas, o estudo do cisalhamento ainda é objeto de controvérsias. Independentemente do efeito da inclinação dos cabos, persistem discordâncias sobre os efeitos da influência da carga axial nas tensões principais.

Pela solução da treliça plástica, uma peça protendida com cabo reto tem a mesma capacidade resistente que uma peça similar sem protensão. Segundo REGAN (1993), isto somente deve ser correto para taxas de armadura transversal muito elevadas. Em outros casos, a protensão incorpora aumento significativo de resistência. pois a resistência à compressão do concreto na alma é maior, devido à diminuição da fissuração. Além disso, a redução das deformações longitudinais de tração favorece a diminuição da inclinação das bielas na alma. 
Na verdade, é necessário generalizar o estudo do cisalhamento, já que há uma sucessão de fórmulas distintas, idealizadas para casos particulares. Atualmente, para as vigas com estribos, há poucas objeções ao modelo de treliça com banzo inclinado (efeito de arco) e bielas complementares na região das cargas concentradas (efeito de leque). O método plástico do limite inferior parece adequado. Para as vigas sem estribos, o modelo de treliça poderia ser substituído pelo consolo de concreto entre fissuras de flexão. Em qualquer caso, o efeito do atrito nas fissuras da alma e a ação de pino da armadura longitudinal devem ser considerados. Normalmente, o mecanismo de viga (ação da alma) e o mecanismo de arco são tratados separadamente, já que as forças da alma influem na componente horizontal do arco.

\section{2 - CONSIDERAÇÕES SOBRE OS MECANISMOS RESISTENTES}

Em elementos de concreto armado, o dimensionamento normalmente não se baseia nas tensões principais de tração e compressão, mas em tensões de referência. $\mathrm{Na}$ região submetida a momento fletor e força cortante, o estado de tensões principais de tração e compressão é inclinado, pois a força cortante produz tensões de cisalhamento que alteram a inclinação das tensões principais provocadas pela flexão e, em menor importância, alteram os seus valores. As tensões principais são decompostas em tensões de cisalhamento e em componentes normais nas direções $\mathrm{x}$ e $\mathrm{y}$, esta última desprezível em seções distantes da região de introdução das cargas (POLILLO, 1977).

Quando ocorre a fissuração da alma, a presença da armadura transversal controla a abertura das fissuras, permitindo que as tensões principais de compressão desenvolvam-se normalmente entre elas (LEONHARDT \& MÖNNIG, 1977). Para limitar a abertura das fissuras de cisalhamento, normalmente se estabelece um valor limite para a tensão na armadura dos estribos. Além disso, aços de resistência muito elevada apresentam dificuldades para serem dobrados (ACI-426R, 1987).

O comportamento de uma viga de concreto armado no início do carrregamento é próximo ao de um material homogêneo resistente à tração. Somente após a fissuração generalizada ele pode ser associado a uma treliça. Porém. o modelo de treliça é uma simplificação, já que outros mecanismos resistentes (aqui denominados alternativos) contribuem na transferência da força cortante até os apoios, conforme se discute posteriormente. Mesmo assim, é o modelo mais utilizado para a análise da resistência ao cisalhamento de vigas com estribos

Com a evolução da fissuração. a segurança da peça deve ser garantida pela limitação das tensões de compressão no concreto. principalmente das bielas diagonais. 
e por um arranjo conveniente das armaduras transversal e longitudinal, de modo que nenhum componente da treliça falhe sob as cargas de projeto. A limitação da tensão convencional de cisalhamento procura evitar que a ruptura por esmagamento da biela ocorra antes do escoamento da armadura transversal (PFEIL, 1978).

A redução da resistência do concreto na região das bielas deve-se principalmente à fissuração existente nesta região próximo da ruptura. $\mathrm{Na}$ verdade, ela está associada a diversos fatores (REGAN, 1993):

- estado biaxial de tensões causado pela aderência do concreto com o estribo (o enfraquecimento do concreto é pequeno enquanto o aço está na região elástica, mas é significativo quando ele escoa, já que ocorre intensa fissuração);

- tensões e deformações não uniformes na alma, devido à concentração de tensões no nó formado pela biela e pela armadura longitudinal, principalmente em vigas curtas sem estribos;

- transmissão de forças em fissuras muito abatidas.

A resistência ao cisalhamento é influenciada por vários parâmetros: o carregamento (tipo e posição da carga), a armadura longitudinal (taxa, escalonamento, ancoragem e aderência), a armadura transversal, a forma da seção transversal, a força normal e outros que interagem com os vários mecanismos resistentes (resistência do concreto, altura da peça, granulometria) (LEONHARDT \& MÖNNIG, 1977).

O tipo de carregamento influi na mobilização dos mecanismos resistentes. Para cargas concentradas próximas dos apoios, é possivel a transmissão direta (efeito de arco) e a seção crítica normalmente se localiza a uma distância igual a 2,5-3,0d dos apoios. À medida que a distância do ponto de aplicação da carga até o apoio aumenta, este mecanismo de transferência direta se torna menos relevante. Neste caso, a resistência depende mais da ação de pino, do atrito nas fissuras e da resistência à tração do concreto. Para cargas distribuídas o fenômeno é semelhante, mas sempre haverá uma parcela da carga que pode ser transferida diretamente ao apoio e porisso a resistência ao esforço cortante é maior. Neste caso, o parâmetro de referência é a relação de esbeltez $\mathrm{l} / \mathrm{h}$, crítico para valores entre 10-14. Segundo LEONHARDT \& MÖNNIG (1977), não há perigo de ruptura por cisalhamento para valores de a/d e $1 / \mathrm{h}$ acima de 7 e 24 , respectivamente, mesmo em vigas sem armadura transversal.

A taxa de armadura longitudinal define a rigidez do banzo tracionado, que influi decisivamente no desenvolvimento das fissuras de cisalhamento (penetração das fissuras na zona comprimida), no efeito de pino e no mecanismo de arqueamento dos esforços internos. Os ensaios parecem mostrar que a partir de uma taxa acima de $2 \%$. a resistência ao cisalhamento não se altera (FUSCO, 1984). 
Os estribos, além da sua contribuição direta, melhoram a contribuição do atrito nas fissuras inclinadas, ao limitar a abertura das fissuras, da ação de pino, ao evitar o fendilhamento do concreto e proteger a armadura longitudinal, e do banzo comprimido, ao limitar a propagação das fissuras de cisalhamento e proporcionar confinamento ao concreto.

A seção retangular se adapta facilmente à inclinação do banzo comprimido. cuja componente absorve a maior parte da força cortante. No caso de vigas T. a componente do banzo comprimido é quase horizontal até próximo do apoio, quando então penetra na alma. Assim, o banzo absorve pequena parte da força cortante, que é resistida principalmente pelas bielas de concreto e pelos estribos. pois o banzo é mais rígido que as bielas e muito mais rígido que os estribos. Nas vigas delgadas, as bielas são menos abatidas (com inclinação próxima de 45 graus) e pode haver compressão excessiva da alma. A maior inclinação das bielas foi confirmada em ensaios de vigas de argamassa armada (NOBRE. 1992). Além disso, observou-se que os deslocamentos devido à força cortante são significativos somente próximo da ruptura (até $20 \%$ do deslocamento total).

A força normal altera o valor e a direção das tensões principais. Quando de compressão, retarda a fissuração e diminui a inclinação das fissuras de cisalhamento (ou das bielas), provocando redução da tensão na armadura transversal e aumento da tensão nas bielas. Porisso, a protensão aumenta a resistência ao cisalhamento. especialmente em peças sem estribos, já que normalmente elas não atingem um estado de fissuração excessivo e o acréscimo de resistência corresponde à força que causa a descompressão da seção analisada, tracionada pelos esforços de flexão. Esta influência está associada às tensões normais de compressão introduzidas pela protensão, que retardam o aparecimento de fissuras na borda tracionada na região de maior força cortante, onde surge a fissura diagonal crítica (FUSCO, 1984).

$O$ efeito do tamanho da peça e dos agregados estão relacionados com a energia de fratura e com a abertura das fissuras, sendo mais importantes para as vigas sem estribos. A altura da viga influencia o valor da abertura das fissuras: logo, ela influi na ação de pino e, principalmente, no atrito nas fissuras. Para vigas de altura elevada. o controle de fissuras através da armadura longitudinal é menos eficiente. Esta variação deixa de ser significativa para alturas maiores que $60 \mathrm{~cm}$. Possivelmente, o efeito do engrenamento dos agregados também seja mais significativo nas peças delgadas, desde que não se diminua muito o diâmetro dos agregados, devido ao efeito de escala entre a espessura da peça e o diâmetro dos agregados. 
A resistência do concreto influi principalmente na transferência de forças por atrito e na capacidade de absorção das forças devido à ação de pino na região da armadura longitudinal.

A variação da altura da viga também pode favorecer a resistência ao cisalhamento, desde que ela seja contrária à variação do momento fletor. MACLEOD e HOUMSI (1994) analisam a influência das mísulas na inclinação da biela, que se torna mais inclinada e facilita a transferência da carga. Além disso, a biela fica mais estreita e, portanto, submetida a maiores tensões de compressão, que dificultam a penetração das fissuras diagonais.

A Figura 2.1 ilustra a contribuição dos diversos mecanismos na resistência à força cortante e o instante em que eles são mobilizados. A Figura 2.2 ilustra a variação da contribuição dos mecanismos resistentes com a espessura da alma, para carga de utilização e nas proximidades da ruptura .

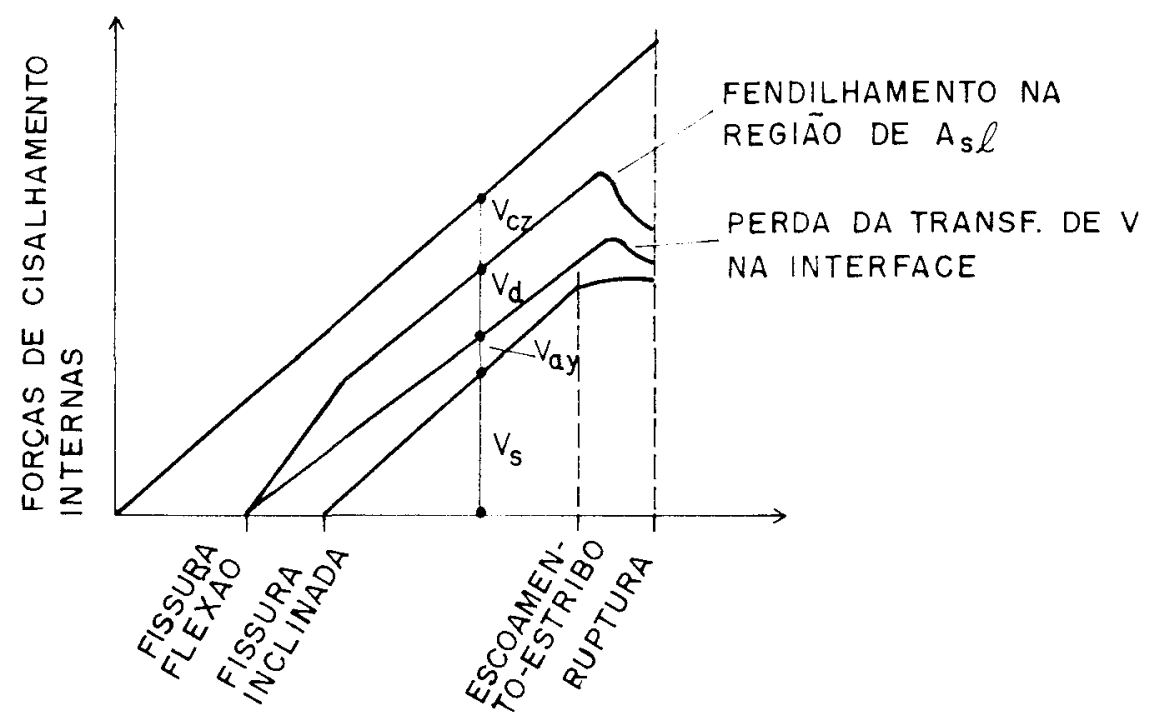

Figura 2.1 - Resistência ao cisalhamento - mecanismos resistentes (ACI-426R, 1987)

É usual considerar a resistência de uma viga ao cisalhamento a partir de duas parcelas: a contribuição da armadura transversal $\left(V_{s}\right)$ e a contribuição do concreto $\left(V_{c}\right)$. $O$ termo do concreto é determinado empiricamente e a contribuição da armadura transversal é estimada com base nos modelos de treliça. As Normas Brasileira e Americana seguem este procedimento. Nas recomendações do CEB-90, a contribuição do concreto só é considerada indiretamente, através da inclinação do banzo comprimido próximo dos apoios e da variação da inclinação das bielas.

$O$ valor de $V_{c}$ pode ser considerado igual à resistência da viga similar sem estribos ou igual à força cortante que provoca a fissuração diagonal. Nas vigas com 
estribos ele representa um fator de ajuste para quantificar a contribuição do concreto na resistência ao cisalhamento, sem significado físico. $\mathrm{Na}$ prática, o valor de $\mathrm{V}_{\mathrm{c}} \mathrm{e}$ considerado constante para os dois tipos de vigas. Segundo CHANA (1987), isso pode gerar alguns problemas de interpretação, como por exemplo, a extrapolação da influência da altura da peça no valor de $V_{c}$ para as vigas com estribos, onde ela é muito menor do que nas vigas sem armadura transversal.
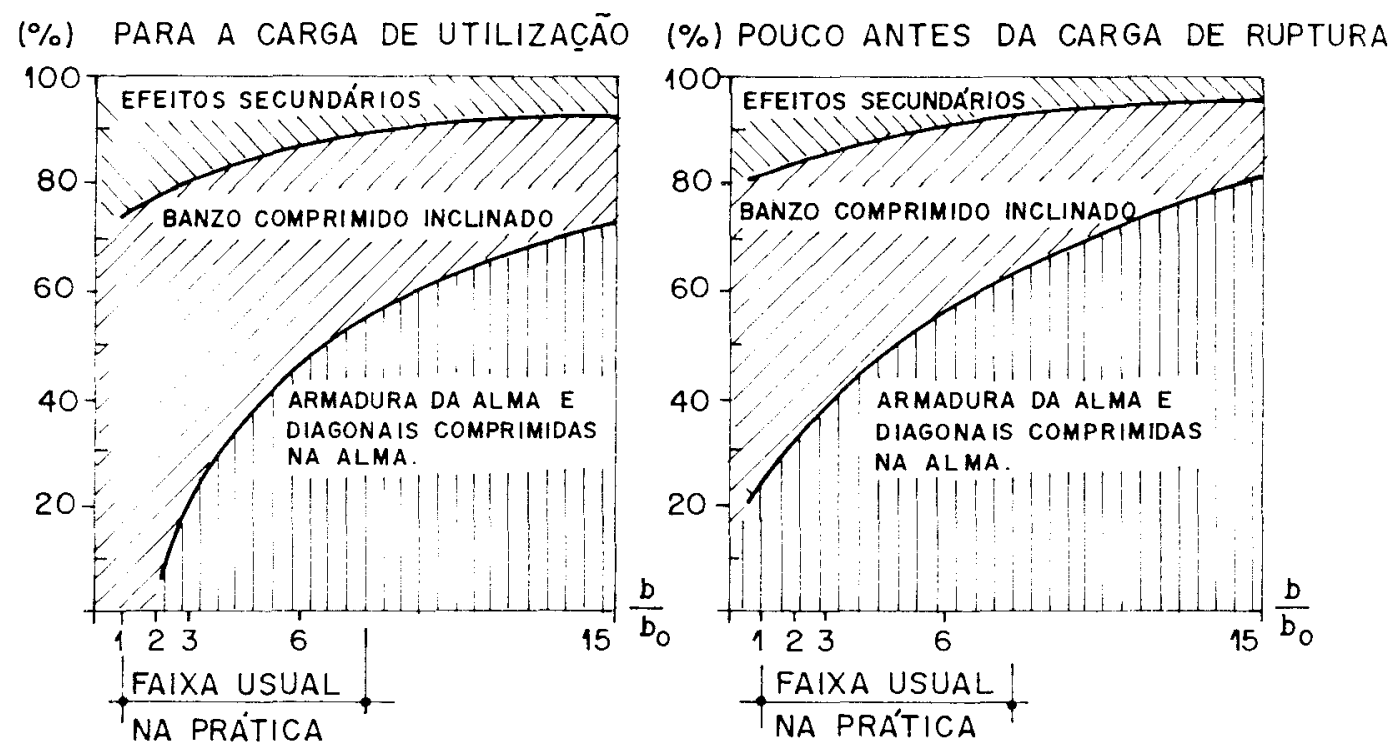

Figura 2.2 - Variação dos mecanismos resistentes com a espessura da alma (LEONHARDT \& MÖNNIG, 1977)

Além disso. geralmente não se considera as vantagens indiretas dos estribos nos outros mecanismos resistentes, correspondentes à contribuição do concreto. Na zona comprimida, devido ao confinamento do concreto e à limitação do avanço da fissura. $\mathrm{Na}$ ação de pino, devido à maior proteção da armadura e ao aumento da resistência ao fendilhamento. No atrito nas fissuras, devido à limitação da abertura e espaçamento das fissuras. Estes fatos explicariam a variação do fator de segurança em algumas expressões utilizadas para o cálculo da resistência ao cisalhamento, especialmente para taxas de armadura longitudinal reduzida. Tais expressões são contra a segurança sem os estribos e conservativas com os estribos, uma vez que elas não consideram o efeito positivo indireto dos estribos.

Porisso, algumas expressões acrescentam constantes multiplicadoras às parcelas de resistência do concreto e dos estribos, para amenizar o caráter conservativo da formulação (MPHONDE, 1989). Segundo BAZANT \& SUN (1987), o efeito dos estribos na contribuição do concreto depende da taxa de armadura transversal e da relação a/d. já que sua importância é menor para valores de a/d reduzidos. 


\section{3 - PEÇAS SEM ARMADURA TRANSVERSAL}

Exceto para vigas de pequena importância estrutural e para estruturas laminares com carregamento transversal à superfície, submetidas a tensões tangenciais limitadas, sempre se exige uma armadura transversal mínima, para evitar a ruptura brusca quando se esgota a resistência do concreto na transferência de forças transversais. Nas peças sem armadura transversal, a resistência é mobilizada através dos mecanismos alternativos. Nestes casos não é usual a aplicação dos modelos de treliça.

Apesar da existência de várias estruturas sem armadura de cisalhamento. especialmente as lajes, o seu comportamento ainda é pouco compreendido. Há poucos modelos associados ao fenômeno e o projeto destes elementos normalmente se baseia em equações totalmente empíricas. que muitas vezes extrapolam seus limites de validade (REINECK, 1991).

As lajes vazadas produzidas por extrusão, normalmente protendidas, por exemplo, são calculadas utilizando-se expressões empíricas, de uso limitado para as seções não fissuradas pela flexão. Segundo PISANTY (1992), neste tipo de elemento, são particularmente importantes os aspectos relativos ao valor da resistência à tração do concreto na alma, à seção onde se verifica a resistência ao cisalhamento. à transferência da protensão nesta seção e ao grau de protensão.

Conforme se comenta no CEB-180, os ensaios em vigas com seção transversal $\mathrm{T}$ ou duplo- $\mathrm{T}$ sem armadura transversal não tem significado prático relevante. As imperfeições no concreto podem reduzir a capacidade resistente ao cisalhamento a níveis inaceitáveis. Os ensaios em elementos de seção retangular, ao contrário, refletem o comportamento das lajes estendidos numa direção, onde a inexistência da armadura transversal é comum, devido à boa capacidade de redistribuição de esforços.

Enquanto a peça não está fissurada, a força cortante é transmitida aos apoios por tensões de cisalhamento, de modo similar ao de um material homogêneo resistente à tração. Segundo FUSCO (1984), com a evolução da fissuração, mas enquanto o afastamento entre as fissuras é significativo, o modelo de consolos transversais formados pelo engastamento do concreto entre fissuras na zona comprimida pode ser adotado. Acima das fissuras o concreto não está fissurado e pode haver transferência de força cortante através de tensões de tração no concreto. Para isso, as fissuras devem estar espaçadas de tal modo que as dimensões do consolo sejam compatíveis com as tensões de tração mobilizadas na transferência da força transversal.

$\mathrm{Na}$ verdade. há outros mecanismos responsáveis pela resistência ao cisalhamento. Eles também atuam nas peças com armadura transversal, mas são mais relevantes nas vigas sem estribos, quer pelas características da configuração de fissuras 
próximo da ruptura, quer pela predominância da resistência proporcionada pelos estribos, a despeito do efeito positivo que os estribos incorporam a estes mecanismos.

$\mathrm{O}$ atrito nas fissuras $\left(\mathrm{V}_{\mathrm{a}}\right)$ permite a transmissão de forças oblíquas, através do engrenamento dos agregados ao longo das fissuras, ampliando a zona colaborante do concreto tracionado na transferência da força cortante até os apoios. As forças de pino $\left(\mathrm{V}_{\mathrm{d}}\right)$ também aumentam a colaboração do concreto tracionado, já que a armadura longitudinal, por ser mais rígida que o concreto, funciona como um pino de ligação entre as faces separadas pelas fissuras. A Figura 2.3 ilustra os mecanismos de transferência da força cortante numa viga sem estribos.

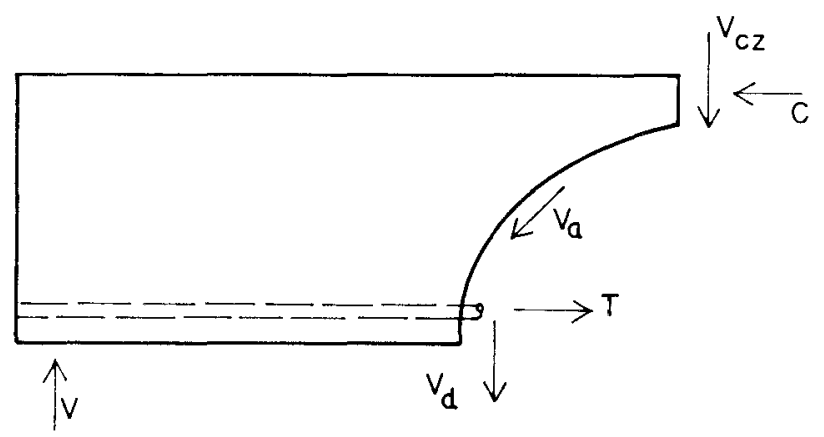

Figura 2.3 - Transferência da força cortante em vigas sem estribos

A parcela da carga transferida diretamente aos apoios (ação de arco) não se constitui num mecanismo de transferência de tensões de cisalhamento, já que não há transferência de forças tangenciais a um plano paralelo vizinho, mas alivia os outros mecanismos resistentes (ELZANATY. 1986 e CEB-90).

Segundo SWAMY e BAHIA (1979), a ação de pino depende da rigidez das barras longitudinais e da área de concreto entre elas. Os autores observaram que as deformações nas barras junto à fissura são maiores na parte inferior do que na parte superior. devido à superposição das tensões de tração decorrentes da flexão da viga e da flexão localizada, especialmente para força cortante elevada. Fenômeno inverso ocorre junto aos estribos. A região afetada pelas forças de pino pode ser estimada a partir da variação das deformações no concreto ao longo da altura. A distribuição de tensões nesta zona pode ser representada conforme esquema da Figura 2.4.

A quantificação da transferência da força cortante pelo efeito de pino proporcionado pela armadura longitudinal é complexa. CHANA (1988) desenvolveu uma técnica para medir estas forças, através da colocação de estribos sem aderência em forma de $\mathrm{U}$, prolongando-se além da borda superior da viga, onde são ligados a células de carga. Além de monitorar as forças induzidas pela armadura longitudinal nestes estribos. o procedimento oferece a possibilidade de remover estas forças a qualquer 
tempo. Observou-se a ruptura imediata no instante da remoção, no caso de vigas sem estribos. para carga um pouco acima da carga de ruptura verificada em vigas similares sem estes estribos especiais. Ou seja, as forças de pino provocam a ruptura do concreto ao longo da armadura e são responsávies pela ruptura das vigas sem estribos. Quando se evita as fissuras nesta região ("dowel cracks") com armadura conveniente, a capacidade resistente aumenta significativamente.

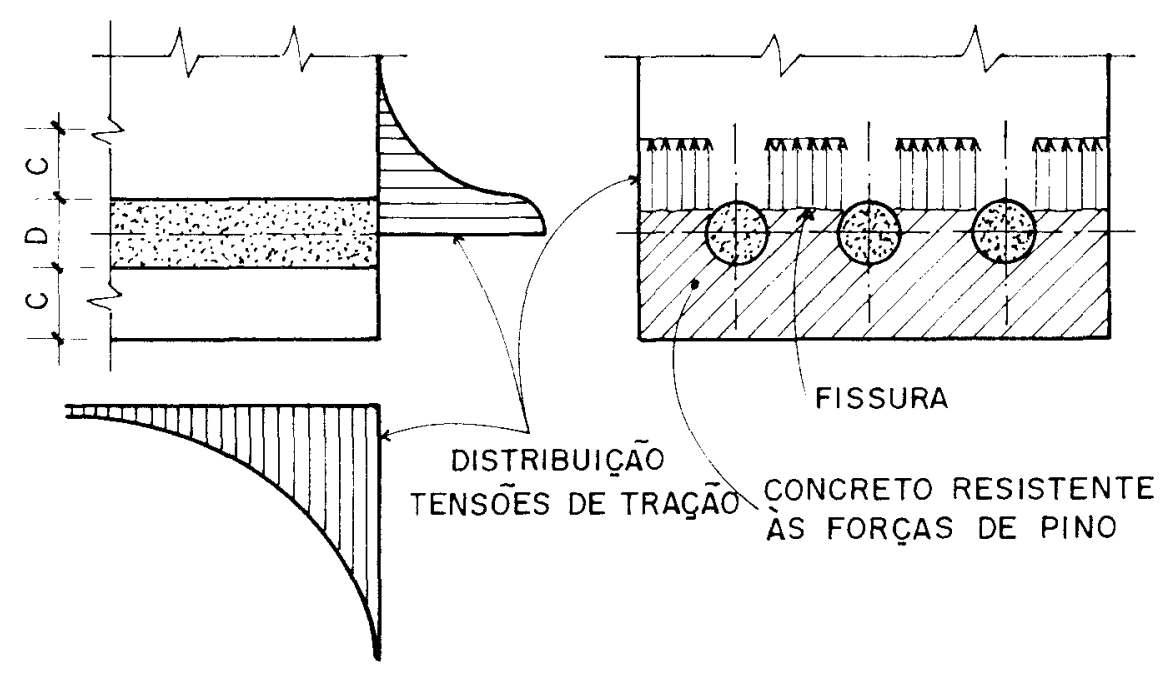

Figura 2.4 - Distribuição de tensões na região afetada pelo efeito de pino (SWAMY \& BAHIA, 1979)

A resistência de uma peça sem armadura transversal também pode ser analisada em termos da tensão tangencial limite numa dada seção crítica. $O$ valor da tensão limite depende principalmente da taxa de armadura longitudinal. da altura do elemento. da resistência à tração do concreto, do tipo de carregamento e da força normal. conforme se discutiu anteriormente (FUSCO, 1984).

\subsection{1 - MODELOS DE CÁLCULO}

A NBR-6118 trata da resistência de elementos sem armadura transversal somente no caso das lajes, quando se dispensa a armadura transversal para tensões tangenciais menores que uma determinada tensão limite. Este valor depende da resistência do concreto, da taxa de armadura longitudinal e da altura da laje. além do tipo e posição do carregamento. 
No ACl-383 (1987), a resistência de vigas sem estribos, de uso restrito, é equivalente à força cortante que provoca o aparecimento da fissura diagonal. A expressão varia com a resistência do concreto e com a taxa de armadura longitudinal.

As recomendações do CEB-78 apresentavam uma expressão empírica para o cálculo da resistência ao cisalhamento das vigas sem estribos, baseada na análise estatística de resultados de ensaios em vigas que apresentaram ruptura sistemática por cisalhamento-flexão (CEB-180). A resistência ao cisalhamento dependia da resistência do concreto, da taxa de armadura longitudinal e da altura da peça. Segundo se comenta no CEB-180, a ruptura diagonal de vigas sem armadura transversal também pode ser prevista a partir da análise do círculo de Mohr, mas este procedimento não foi incorporado ao Código Modelo.

Em todos os casos se considera a influência positiva da protensão na resistência ao cisalhamento. No CEB-78 e na NBR-6118, ela é quantificada multiplicando-se a resistência de uma peça similar sem protensão por um coeficiente que depende do momento de descompressão e do momento solicitante máximo. A filosofia desta expressão se baseia na hipótese de que o comportamento da viga protendida é igual à similar não protendida a partir do instante em que se anula a tensão de tração no banzo tracionado. Anteriomente, a expressão do CEB considerava o acréscimo na força cortante igual à força cortante de descompressão, sem preocupação com a consistência física da equação. No CEB-90 não há referências sobre o assunto.

No ACI-383, a expressão para o cálculo de $V_{c}$ também se altera com a protensão, pois a fissuração diagonal é retardada. Segundo MATTOCK \& WANG (1984), as expressões seriam conservadoras, já que estão baseadas em resultados de ensaios de vigas submetidas à carga axial muito reduzida.

Apesar do caráter empírico da maioria das expressões utilizadas para a determinação da resistência de peças sem armadura transversal, vários trabalhos procuram estabelecer modelos físicos compatíveis com o fenômeno. Alguns destes modelos são comentados a seguir.

Segundo REINECK (1991), a análise das tensões que atuam no concreto fissurado, decorrentes do atrito e das forças de pino. mostra que as tensões entre as fissuras são governadas por um campo biaxial de tração e compressão inclinado, que pode ser representado por uma treliça simples. A componente da força cortante transferida pelo efeito de pino é estendida por toda a alma e é suspensa por tirantes de concreto inclinados, perpendiculares à biela inclinada delimitada pelas fissuras.

A ruptura por cisalhamento não seria explicada pela ruptura do tirante de concreto, mas pelo esgotamento da capacidade de transferência da força cortante pelo atrito na fissura crítica e pelo efeito de pino, cujos limites de resistência dependem da 
resistência à tração do concreto e podem ser obtidos por modelos e relações constitutivas adequados.

Baseado no modelo do consolo, o autor sugere que a resistência estaria associada ao estado de deformação do consolo entre fissuras ou ao deslocamento entre as fissuras, representados por uma abertura de fissura crítica, que governa os mecanismos de atrito e de pino. O efeito da contribuição do concreto entre fissuras ("tension-stiffening") seria importante somente para alturas elevadas, onde a abertura da fissura crítica é menor, assim como a parcela de força transmitida pelo atrito e pelo efeito de pino. $\mathrm{O}$ valor da abertura crítica da fissura depende dos principais parâmetros envolvidos na transferência da força por atrito (altura da peça) e pelo efeito de pino (taxa de armadura longitudinal). A influência do tamanho seria menor para o caso de a/d reduzido, onde as fissuras são mais controladas e a desvantagem de alturas excessivas seria relativizada.

Nas peças delgadas sem armadura transversal. a maior parcela da força transversal seria transmitida ao apoio na zona tracionada do concreto (ação de pino e. principalmente, atrito entre as fissuras). A parcela máxima de força transferida pelo banzo comprimido seria igual a $30 \%$, para o valor máximo da altura do banzo comprimido. correspondente a uma taxa de armadura longitudinal igual a $2 \%$.

A relação do atrito nas fissuras com o tamanho da peça e sua influência na resistência ao cisalhamento é questionada. Além disso, o parâmetro de referência mais apropriado para se considerar o atrito nas fissuras seria a resistência à compressão do concreto, ao invés da resistência à tração, mesmo que as tensões sejam distribuídas em toda a face fissurada (WALRAVEN, 1992). Questiona-se também o uso da resistência à tração do concreto como parâmetro fundamental do modelo, ainda que a tração desenvolvida nas fissuras deva-se ao atrito e que as tensões sejam bem menores do que a resistência à tração do concreto (BRAESTRUP, 1992).

O modelo baseado nas trajetórias das tensões de compressão ("Compressive Force Path Model") propõe que a transferência da carga para os apoios pode ser ilustrada por um pórtico de concreto atirantado pela armadura longitudinal. A região comprimida. onde se daria efetivamente a transferência das forças transversais em vigas sem estribos. resiste a esforços de flexão e cisalhamento, transmitindo as forças resultantes de compressão até os apoios. A região inferior, do consolo de concreto. teria contribuição insignificante na resistência ao cisalhamento, através das forças de aderência entre o concreto e a armadura longitudinal. Apesar de serem insuficientes para causar a ruptura por flexão do consolo, essas forças são importantes, já que a ruptura da aderência provoca redistribuição de tensões na zona comprimida. Nas vigas 
sem estribos, a ruptura ocorre logo após a fissura diagonal, devido à penetração da fissura na zona comprimida.

Segundo KOTSOVOS \& BOBROWSKI (1993), a posição do nó do pórtico depende do tipo de carga e da esbeltez da viga, ou da forma de ruptura. Para valores extremos de a/d, muito baixos e muito altos, a capacidade resistente à flexão é esgotada antes do cisalhamento. O critério de ruptura envolve o projeto do trecho horizontal do pórtico e da diagonal de concreto. através do ajuste da seção para limitação de tensões nessa diagonal. O modelo é discutido novamente no item 2.4.

O modelo gera controvérsias (REINECK, 1991 e REGAN, 1993). O pórtico atirantado seria, na verdade, um modelo de biela-tirante e não haveria embasamento físico para o modelo, exceto quando o valor de a/d é reduzido.

Os modelos de treliça também podem ser utilizados para as vigas sem estribos. AL-NAHALAWI \& WIGHT (1992) apresentam uma formulação baseada no fluxo de forças nas vigas, obtido através de modelos de bielas e tirantes. A treliça deve ter elementos de concreto (tirantes com direção perpendicular às bielas), especialmente no caso de cargas distantes dos apoios, para resistir às forças de tração e para manter a inclinação das bielas dentro de intervalos possíveis. Ao contrário do modelo anterior. ele contempla a variação da força na armadura longitudinal e a limitação da inclinação das bielas. As treliças podem ser simples, nas regiões contínuas da viga, ou podem considerar o efeito de leque, nas regiões descontínuas.

A formulação proposta por KIM \& WHITE (1991) para a previsão da resistência ao cisalhamento de vigas sem estribos se aplica somente para as fissuras que se originam a partir de fissuras de flexão, devido a uma concentração de tensões que ocorre na região da armadura longitudinal. As descontinuidades geométricas na viga (as fissuras) e a combinação de materiais diferentes (aço-concreto) torna a distribuição das tensões mais complexa. que pode ser analisada a partir dos efeitos da aderência e do arqueamento após a fissuração por flexão.

A força na armadura é transmitida ao concreto por aderência. Como a aderência varia ao longo da peça, as tensões de cisalhamento na interface concreto-armadura também variam, de modo similar. A tensão de cisalhamento na seção crítica, próxima da posição da fissura diagonal, conforme indica a variação das tensões de aderência. é maior do que o valor médio usualmente empregado. Ou seja, o aparecimento da fissura inclinada é favorecido pela concentração de tensões de cisalhamento acima da armadura longitudinal após a fissuração por flexão. Antes disso, a variação da força na armadura e da tensão de aderência é quase uniforme. 
$\mathrm{O}$ arqueamento dos esforços na região comprimida também provoca aumento da força na armadura longitudinal após o aparecimento das fissuras de flexão, devido à diminuição do braço interno do momento resistente da viga. Isto também resulta num aumento da tensão de cisalhamento na seção crítica.

Segundo os autores, estes dados explicariam porque os valores experimentais de $\mathrm{V}_{\text {cr }}$ são menores do que os valores teóricos calculados convencionalmente. Porém, a expressão obtida para $V_{\text {cr }}$ que considera estes fenômenos só vale quando a força cortante calculada é maior do que a força cortante que provoca a fissuração por flexão. ou seja, o valor de $\mathrm{V}_{\mathrm{cr}}$, que depende da relação a/d, é obtido pela intersecção das curvas de variação de $\mathrm{V}_{\mathrm{cr}}$ (obtida por este equacionamento) e $\mathrm{M}_{\mathrm{cr}}$ com $\mathrm{a} / \mathrm{d}$, assim como a posição da seção crítica.

Diversos modelos consideram a redução da resistência à flexão devido à interação do momento fletor com a força cortante. onde a capacidade resistente da peça varia de acordo com a relação a/d, havendo um um intervalo de valores de a/d em que a ruptura por cisalhamento é prematura. O modelo proposto por RUSSO e outros (1991) se baseia em tensões tangenciais limites, onde se supõe que a resistência ao cisalhamento de peças sem armadura transversal resulta da ação conjunta dos mecanismos de viga e de arco, que dependem principalmente da relação a/d e da taxa de armadura longitudinal.

No intervalo de a/d em que há redução da resistência à flexão, pode haver dois tipos de ruptura por cisalhamento: esmagamento da biela e tração do concreto. No primeiro caso, a fissura diagonal é estável e o mecanismo de arco governa o fenômeno (carga próxima do apoio). No segundo, ela é instável e o mecanismo de viga é predominante (carga distante do apoio). O valor crítico de a/d correspondente à resistência mínima separa estes dois tipos de ruptura. Segundo os autores, este valor depende da taxa de armadura longitudinal e da resistência do concreto. Para este valor crítico, a contribuição dos mecanismos de arco e de viga na resistência ao cisalhamento seria de $40 \%$ e $60 \%$, respectivamente.

Recentemente, tem-se utilizado os conceitos da Mecânica da Fratura para se estudar o comportamento das vigas sem armadura transversal, supondo-se que a ruptura ocorre devido à propagação de uma zona de fissuras. A teoria convencional, baseada na análise de resistência, não explica a ruptura catastrófica e o efeito do tamanho observados nestas peças (que tem sido analisados com base na influência de falhas microscópicas), onde usualmente se emprega um fator de correção (1.6 - d) para ajustar os resultados aos valores experimentais. 
A Mecânica da Fratura estuda as condições nas proximidades e à frente da extremidade de uma fissura, onde ocorre a microfissuração do concreto ("tensionsoftening"). A propagação da fissura e a posterior fratura do material ocorrem quando a taxa de liberação de energia de deformação atinge um determinado valor crítico. $\mathrm{Na}$ zona de fratura, a tensão residual de tração depende da abertura da fissura e da resistência à tração do concreto, de modo que os conceitos da Mecânica da Fratura Linear (tensões elásticas) não se aplicam corretamente (SO \& KARIHALOO, 1993).

Uma das principais aplicações da Mecânica da Fratura é a análise do efeito do tamanho na resistência ao cisalhamento, especialmente em vigas sem armadura transversal. Segundo o modelo da fissura fictíca. que considera os conceitos da Mecânica da Fratura Não-Linear, GUSTAFSSON \& HILLERBORG (1988) afirmam que este efeito pode ser normalizado através de um parâmetro de comprimento intrínseco do concreto, associado ao diâmetro máximo do agregado, que é proporcional à energia de fratura. Assim como a resistência ao cisalhamento varia com a resistência à tração do concreto, ela também varia com a energia de fratura.

A variação dos resultados da resistência ao cisalhamento poderia ser parcialmente explicada pela consideração simplista apenas dos parâmetros de resistência para representar a influência das propriedades do concreto $\left(f_{t}\right.$ ou $\left.f_{c}\right)$. A consideração da fragilidade, representada pelo parâmetro de comprimento, que varia bastante com o tipo ou a resistência do concreto. diminuiria a dispersão dos resultados. A relação entre a tensão tangencial limite e a resistência à tração do concreto, por exemplo, é menor no concreto de alta resistência devido à sua maior fragilidade. Assim, sugere-se acrescentar um parâmetro que represente a fragilidade do concreto nas expressões para o cálculo da resistência ao cisalhamento, que seria tabelado para algumas classes de concreto, já que sua obtençâo caso a caso seria inviável, apesar da simplicidade do ensaio, pois depende da energia de fratura e, portanto, do agregado.

A aplicação do modelo ao estudo do cisalhamento com o Método dos Elementos Finitos considera o desenvolvimento da fissura diagonal através de cálculos incrementais. a partir de uma determinada configuração de fissura até atingir a configuração da fissura crítica. As propriedades da zona de fratura são modeladas por forças entre os nós da malha, onde a diminuição gradual das forças é determinada a partir da variação da abertura da fissura. O modelo não considera a transferência de forças pelo engrenamento dos agregados na zona de fratura e nem o efeito de pino.

A ruptura começa com o crescimento estável da zona de fratura e o simultâneo escorregamento da armadura longitudinal. Posteriormente. o desenvolvimento da zona de fratura torna-se instável e ela pode avançar para a região comprimida. 
Segundo BAZANT \& SUN (1987), a análise linear da Mecânica da Fratura superestima o efeito do tamanho nos casos de ruptura frágil de estruturas de concreto. A análise não linear, baseada na existência de uma extensa zona fissurada à frente da fratura, leva a uma consideração mais apropriada do fenômeno. A influência do tamanho se relaciona com a quantidade de energia de deformação liberada durante o desenvolvimento da zona de fissuração, maior nas estruturas de altura elevada.

De acordo com a formulação que rege o efeito do tamanho, a força cortante de ruptura nos casos de ruptura diagonal é minorada por uma expressão que depende da relação entre a altura da peça e o diâmetro máximo dos agregados. A fórmula foi desenvolvida a partir da hipótese de que a perda de energia durante a fissuração depende da extensão da fratura e da área da zona de fissuração, considerada com abertura constante à frente da fissura, proporcional ao diâmetro do agregado.

No caso de estruturas pequenas, ela se aproxima da solução obtida com a análise plástica. Nas grandes estruturas, ela se aproxima da análise linear da Mecânica da Fratura. O valor não depende da largura da peça, pois assume-se que a fissura ocorre instantaneamente em toda a sua extensão, ao invés de se propagar gradativamente nesta região.

\subsection{2 - A RUPTURA NAS PEÇAS SEM ESTRIBOS}

A ruptura de vigas sem armadura transversal (ou com espaçamento excessivo) se dá por tração excessiva do concreto, especialmente se a relação a/d não é muito reduzida. A fissura crítica não é atravessada por estribos. Nestes casos. a resistência está associada apenas com a estrutura interna do concreto resistente à tração ou com os mecanismos resistentes alternativos.

A ruptura normalmente ocorre logo após o aparecimento da fissura inclinada, sem que a viga apresente reserva de resistência significativa (ruptura frágil). As fissuras de cisalhamento podem surgir antes ou após as fissuras de flexão. O instante em que ocorre a fissuração por cisalhamento é difícil de ser avaliado corretamente. Porisso, prefere-se estabelecer como referência a força cortante de ruptura. ao invés da força cortante de fissuração (ELZANATY, 1986). Distingue-se dois tipos de fissura inclinada: as fissuras independentes na alma, que ocorrem antes do aparecimento de uma fissura de flexão na sua vizinhança, e as fissuras de flexão-cisalhamento. que se formam a partir de fissuras de flexão devido a acréscimos de carga.

Segundo LEONHARDT \& MÖNNIG (1977), as fissuras independentes na alma ocorrem principalmente em vigas I, quando a tensão principal de tração é maior 
que a resistência do concreto. As fissuras de flexão-cisalhamento são mais comuns em vigas retangulares, onde as fissuras de flexão se inclinam devido ao aumento da tensão tangencial na extremidade da fissura, quando a tensão principal de tração devido à combinação das tensões de cisalhamento e de flexão ultrapassa a resistência do concreto (ACl 318-83). Quando a taxa de armadura longitudinal é elevada. a profundidade da fissura e as tensões são menores, melhorando a resistência à formação destas fissuras (ELZANATY, 1986).

A análise do comportamento das vigas sem estribos nas proximidades da ruptura (antes da carga máxima e no pós-pico) é difícil, dada a dificuldade de se manter a força aplicada. A ruptura tem sido atribuída ao início da fissuração na região da armadura longitudinal (fissuras decorrentes da ação de pino), à ruptura da zona comprimida ou à instabilidade da fissura diagonal.

Os mecanismos de ruptura por cisalhamento nestas vigas foram estudados por CHANA (1987). que acompanhou o valor da abertura da fissura diagonal com a evolução do carregamento. Instrumentos posicionados após o início da fissuração mediam continuamente a abertura da fissura crítica em três posições, definidas em função da trajetória da ruptura observada em ensaios preliminares: na posição da fissura diagonal. na posição das fissuras na região da armadura longitudinal e na extensão da fissura diagonal em direção à zona comprimida.

As primeiras fissuras apareceram na região da armadura longitudinal. imediatamente antes da ruptura. Após o pico de tensão, quando a força aplicada diminui, a velocidade de abertura destas fissuras é maior que a da fissura diagonal. Os primeiros indícios da propagação da fissura na zona comprimida surgiram somente quando as fissuras próximas à armadura longitudinal e a fissura diagonal tinham aberturas de $0,66 \mathrm{~mm}$ e $0,40 \mathrm{~mm}$, respectivamente.

Após a fissuração diagonal, aparecem forças de atrito nas fissuras e ocorre o aumento da força de pino na armadura longitudinal, que provoca o aparecimento de fissuras nesta região devido à perda da aderência. A carga máxima é atingida quando um ou ambos os mecanismos atingem sua resistência limite (atrito e pino). Os valores médios obtidos para a abertura da fissura diagonal e para as fissuras na região da armadura para a carga máxima foram de $0,25 \mathrm{~mm}$ e $0,08 \mathrm{~mm}$, respectivamente. Para estes valores, o autor sugere que o engrenamento dos agregados ainda não estaria esgotado. ao contrário da ação de pino.

Portanto, a fissura inclinada torna-se instável quando ocorre o fendilhamento do concreto abaixo da armadura longitudinal. A perda de rigidez do pino permite que a fissura diagonal se abra rapidamente, diminuindo a resistência por atrito. Há, portanto. uma relação direta entre a ação de pino e o engrenamento dos agregados. pois a 
armadura longitudinal, unindo as partes fissuradas como um grampo, permite o desenvolvimento de forças ao longo das superfícies fissuradas. Como o estado de tensões na região do fendilhamento do concreto é complexo, a análise teórica deste tipo de ruptura é difícil, o que encaminha a solução para uma formulação empírica.

Quando o fendilhamento do concreto é evitado com a colocação de armadura adequada, a capacidade resistente da viga aumenta, alterando o mecanismo de ruptura. Neste caso. a fissura diagonal permanece estável até uma abertura de $1 \mathrm{~mm}$, quando pode haver o esmagamento do concreto na zona comprimida. O aumento da resistência estaria associado com o aumento da resistência obtida pela ação de pino.

\section{4 - PEÇAS COM ARMADURA TRANSVERSAL}

Nas vigas estruturais, sempre se exige a colocação de armadura transversal mínima para se evitar a ruptura frágil. Além disso, o espaçamento entre os estribos deve ser limitado, para garantir o controle da abertura das fissuras. Um espaçamento máximo igual a $\mathrm{d} / 2$, por exemplo, garante que toda fissura seja atravessada por pelo menos dois estribos, mesmo para uma configuração de fissuras desfavorável.

$O$ projeto das vigas com armadura transversal geralmente é baseado nos modelos de treliça, onde se supõe que a ruptura ocorra quando a capacidade resistente da seção crítica é excedida. A formulação da NBR-6118 considera a resistência ao cisalhamento como a soma das contribuições do concreto e dos estribos. A contribuição dos mecanismos resistentes alternativos não é considerada diretamente. mas o termo empírico $\tau_{\mathrm{c}}$ representa genericamente a contribuição do concreto. $O$ efeito de arco pode ser considerado para o cálculo da armadura transversal através da redução da força cortante próximo dos apoios. A contribuição dos estribos é calculada com base na analogia clássica de treliça.

As recomendações do ACI-318 são similares. O termo empírico do concreto corresponde à resistência de uma viga similar sem estribos, equivalente à força cortante que provoca o aparecimento da fissura diagonal, e é independente da fissuração da viga. Assim como o anexo da NBR-6118. a influência da protensão também é considerada majorando-se a contribuição do concreto, já que a resistência à físsuração diagonal é maior. Para o cálculo dos estribos, também se considera a analogia clássica da treliça.

Antes da última versão, de 1990, as recomendações do CEB apresentavam dois procedimentos de cálculo (CEB-180, 1987 e CEB-78). Ambos consideravam a contribuição do concreto e limitavam a tensão de cisalhamento para garantir a 
segurança contra a ruptura da biela. O "Standard Method" é similar ao procedimento adotado na NBR-6118. O termo do concreto depende da resistência à compressão do concreto, o termo dos estribos é calculado com base na treliça clássica e a influência da protensão considera o aumento da contribuição do concreto, baseado na relação entre o momento de descompressão e o momento máximo no trecho em análise.

O "Accurated Method" despreza a influência da protensão. Ele se baseia no conceito de que o momento fletor é resistido pelas mesas e a força cortante pela alma, havendo uma interação entre a taxa de armadura transversal e a inclinação das bielas, que dá liberdade no dimensionamento. Há uma transição entre as peças submetidas a forças cortantes reduzidas, onde se considera a contribuição do concreto, e as peças submetidas a forças cortantes elevadas, onde se aplica o modelo de treliça plástica generalizada. quando a contribuição do concreto é nula. Portanto, o termo do concreto depende da intensidade da força cortante.

No CEB-90 manteve-se o modelo da treliça generalizada. Não se considera o termo independente do concreto. As bielas são verificadas na seção de força cortante máxima, permitindo-se uma redução no caso de cargas concentradas próximas do apoio para o cálculo dos estribos.

No caso das vigas protendidas, apresenta-se três procedimentos distintos, dois deles de caráter geral. Em cada um se faz a superposição de dois modelos. O primeiro, para considerar a influência da componente vertical da protensão; o segundo, o próprio modelo de treliça adotado nas peças de concreto armado.

O primeiro modelo representa a ação da componente vertical dos cabos de protensão e, eventualmente, do arco de concreto comprimido, que equilibram parte do carregamento externo, sem necessidade de armadura. Em qualquer caso, a força de protensão nas extremidades é tratada como um carregamento externo.

Os dois procedimentos gerais representam as combinações dos dois modelos, considerando-se ou não o efeito de arco. Para verificação dos elementos as tensões são superpostas, observando-se que o banzo tracionado e a armadura transversal só são solicitados no modelo de treliça. Quando se despreza o efeito de arco, o método se torna conservativo, especialmente para almas espessas. Mas sua aplicação é facilitada. já que se consideram todas as ações no modelo de treliça. inclusive a protensão.

\subsection{1 - MODELOS DE TRELIÇA}

$\mathrm{Na}$ analogia clássica, os banzos da treliça são paralelos e a inclinação das bielas é igual a 45 graus. Além disso, não são considerados os mecanismos resistentes 
alternativos, cuja importância varia caso a caso. Com a treliça clássica, a tensão na armadura transversal é superestimada, principalmente para vigas de almas espessas. Isso resulta em taxas de armadura transversal maiores do que as necessárias, ou seja, subestima-se a resistência da peça. A Figura 2.5 mostra a variação da tensão nos estribos com a espessura da alma.
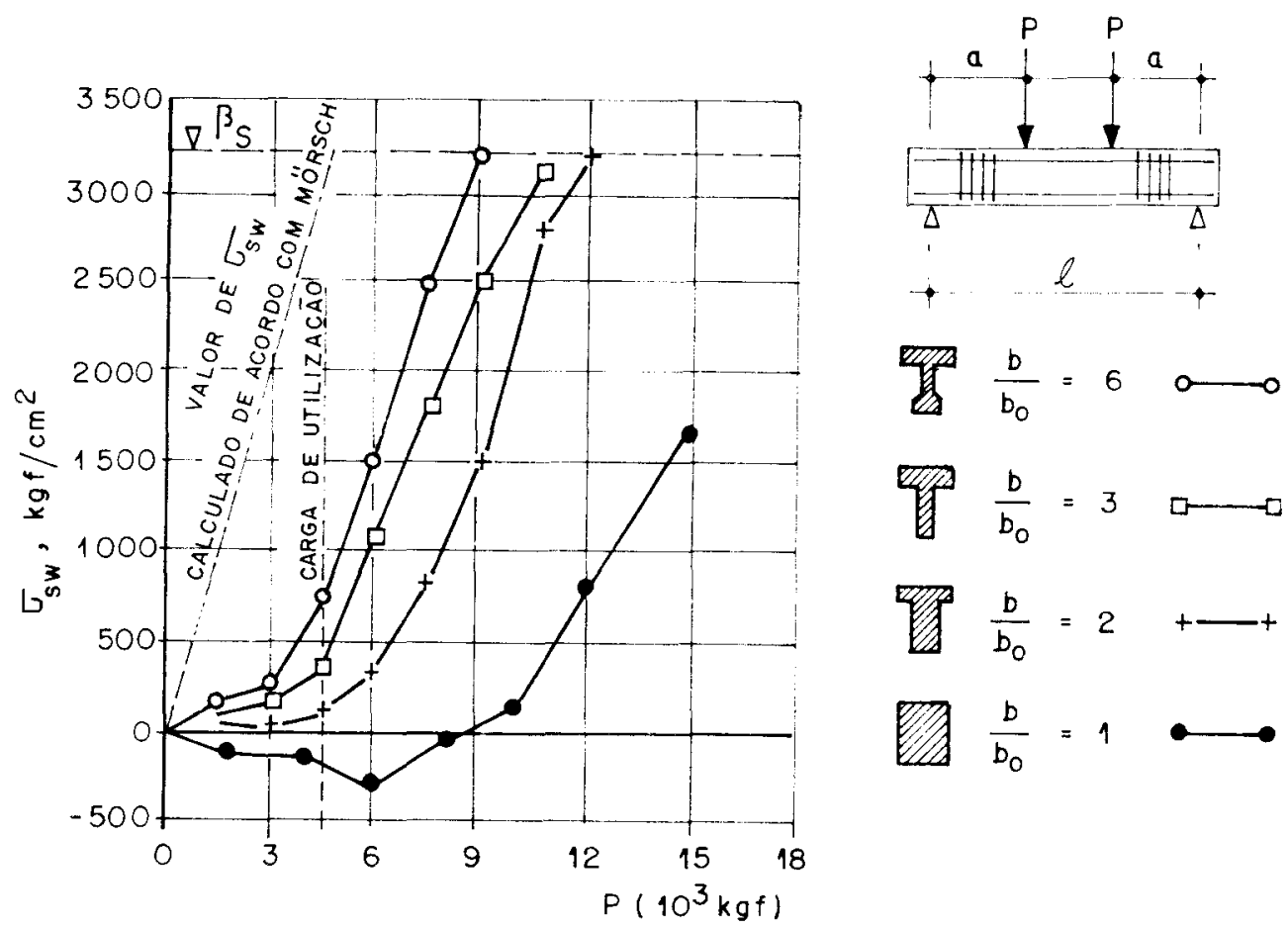

Figura 2.5 - Variação da tensão nos estribos com a espessura da alma

(LEONHARDT \& MÖNNIG, 1977)

O modelo da treliça generalizada corrige esta distorção, ao considerar a variação na inclinação das bielas e a inclinação do banzo comprimido. além de possíveis bielas complementares. A tensão nos estribos torna-se mais próxima do seu valor real. A consideração de algum outro mecanismo resistente, ainda atuante na etapa correspondente ao cálculo, se constitui num refinamento do modelo. Independente do modelo de treliça adotado, é usual a utilização do cálculo plástico do limite inferior.

Os resultados experimentais mostram que a inclinação das bielas pode variar com o carregamento. A rotação seria possível devido à resistência das fissuras contra o deslocamento por força cortante, devido ao engrenamento dos agregados. Ou seja. a parcela de resistência do concreto nas fissuras pode ser explicada a partir dos deslocamentos verticais devido à força cortante. As forças de atrito nas fissuras alteram o estado de tensões, diminuindo a inclinação das tensões principais de compressão, que ficam menos inclinadas que a fissura, e provocando o aparecimento de novas tensões 
de tração, perpendiculares às tensões de compressão. Estas tensões podem ser representadas por tirantes de concreto e dependem dos seguintes fatores (CEB-180): resistência do concreto (relacionada com as forças causadas pelo engrenamento dos agregados); forças axiais; rigidez, aderência e ancoragem dos estribos; e rigidez da armadura longitudinal (todos relacionados com o controle da abertura de fissuras).

O valor da inclinação das primeiras fissuras depende do estado de tensões na alma. A capacidade de redistribuição de forças é limitada, pois depende de grandes deformações nas armaduras e de aumento de tensão nas bielas. Porisso, a existência de bielas na ruptura com ângulos muito menores que os das primeiras fissuras são questionáveis, pois são acompanhados de fissuras de cisalhamento muito abertas (KAUFMAN \& RAMIREZ, 1988).

O ângulo das bielas é menor que 45 graus na maioria das situações de ruptura. Segundo LEONHARDT \& MÖNNIG (1977), as forças internas se distribuem de acordo com a rigidez dos elementos resistentes da peça, de modo que a energia de deformação seja mínima. Assim, para almas espessas as bielas são rígidas, se comparadas com o banzo comprimido, e a tração na alma é menor, pois a biela é menos inclinada. A diminuição da resistência à compressão do concreto compensa a desconsideração do efeito da fissuração nas bielas.

Pela análise de deformações e compatibilidade de deslocamentos do banzo tracionado pode-se determinar a inclinação mínima das bielas, limitando-se os valores da deformação nas direções das armaduras longitudinal e transversal, em função do estado de fissuração limite. Sugere-se que a inclinação mínima vale 26.5 graus (FUSCO, 1984). No entanto, o CEB-78 considerava um valor mais conservador (31 graus), havendo ainda sugestões mais ousadas, com ângulos de 18,4 graus (CEB-90).

O maior abatimento das bielas resulta numa diminuição da tensão nos estribos, pois mais estribos são mobilizados, e num pequeno aumento das tensões de compressão nas bielas. Somente quando a taxa de armadura transversal é muito reduzida. e então as bielas são muito abatidas, o aumento das tensões nas bielas pode ser significativo.

A inclinação do banzo comprimido é um dos fatores mais importantes para a adequação do modelo aos resultados experimentais. Como a resultante de compressão do banzo pode ser muito maior que a força cortante, a redução da força cortante devido à inclinação do banzo é significativa.

O efeito de arco também pode ser considerado nos modelos de treliça. através de uma biela de concreto adicional próximo dos apoios. especialmente para cargas próximas a eles. Quando a relação a/d é maior, a biela adicional que representa a contribuição do concreto assume outro significado, ao permitir a mobilização de mais 
estribos no trecho do cisalhamento. Isso implica em aumento da resistência, pois melhora a eficiência dos estribos, mas também no aumento da tensão na biela e da força na armadura longitudinal próximo nos apoios. Nos casos em que houver perigo de ruptura do concreto na alma, o uso de concretos de alta resistência pode melhorar 0 efeito de arco e evitar a ruptura prematura. (KAUFMAN \& RAMIREZ, 1988).

A tensão nos estribos se desenvolve praticamente paralela ao que prevê a analogia clássica, conforme mostra a Figura 2.6. Porisso. frequentemente se supõe que a parcela de contribuição do concreto seja igual à carga correspondente à fissuração diagonal. Porém. os resultados experimentais devem ser analisados com cautela. A tensão nos estribos é calculada a partir de deformações obtidas, mas a consideração do "tension stiffening" altera os resultados. Como não há uniformidade nos procedimentos de análise, as diferenças podem ser grandes, especialmente para carga de utilização. quando as fissuras estão controladas e o fenômeno é mais significativo. Mas, o que é relevante é a reserva de resistência proporcionada pelos diversos mecanismos resistentes na ruptura, pois isso possibilita o aumento da carga após o escoamento dos estribos, devido à redistribuição de forças na alma.

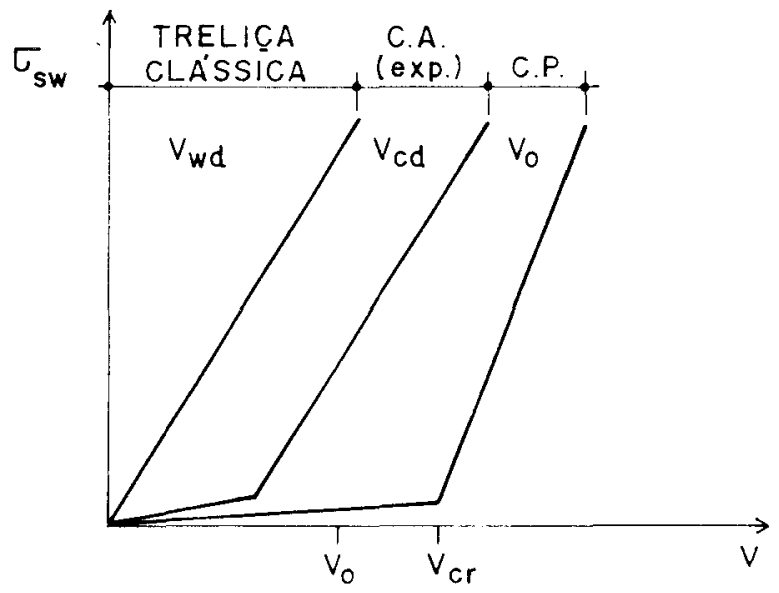

Figura 2.6 - Desenvolvimento da tensão nos estribos (CEB-1987)

O modelo plástico de treliça considera que a tensão nos estribos é uniforme ao longo dos ramos e que eles escoam na ruína. Porém. se forem consideradas as condições de compatibilidade das deformaçôes baseadas na Teoria da Elasticidade. a tensão nos estribos deve variar, aumentando linearmente de cima para baixo.

No modelo plástico, considera-se o comportamento rígido-plástico perfeito do aço e não se leva em conta a aderência com o concreto. Portanto, a transferência de forças entre os membros da treliça só ocorre nos nós. não havendo interação na intersecção das bielas com os estribos na alma. No caso de carga concentrada no meio 
do vão, a equação de equilíbrio, por si só, estabelece a distribuição uniforme de tensão nos estribos, ou seja, não importam as propriedades dos materiais, elásticas ou plásticas. Com carga distribuída, no entanto, esta hipótese resulta em tensões uniformes nas bielas e nos estribos e em um diagrama de força cortante escalonado.

Quando se considera o equilíbrio e a compatibilidade de deformações entre os estribos e o concreto na alma, a tensão nos estribos varia ao longo de sua altura. Além disso, a força nos estribos também varia longitudinalmente, conforme a distribuição triangular da força cortante.

Segundo BELARBI \& HSU (1990), o modelo de compatibilidade se aproxima do comportamento real quando as fissuras de cisalhamento são mais abatidas, pois a parte superior dos estribos não escoa. Neste caso não vale a teoria plástica, que considera a contribuição de todos os estribos ao longo da fissura diagonal. Quando as fissuras são mais inclinadas o modelo plástico apresenta melhores resultados. já que vários estribos atingem o escoamento. Portanto, a força nos estribos depende da inclinação das fissuras, sendo maiores para fissuras mais inclinadas.

Segundo os autores, a abertura das fissuras de cisalhamento também acompanha a variação da deformação nos estribos, mas não é afetada pela taxa de armadura longitudinal, ao contrário da tensão nos estribos. que é menor nesta região quando a armadura longitudinal é abundante.

Como o modelo da treliça plástica supõe a mobilização plena do estribo, a ancoragem deve prever ganchos na zona comprimida e o prolongamento do estribo na zona tracionada. onde o confinamento proporcionado pelo concreto fissurado é discutivel e, portanto, os ganchos são menos eficientes. A uniformidade das tensões nos estribos também torna alguns detalhes construtivos questionáveis para o caso de força cortante elevada. Em vigas largas, quando os estribos envolvem apenas as barras externas da armadura longitudinal, há um direcionamento das forças para estas barras (nos nós da treliça), sobrecarregando os nós e sub-utilizando as barras internas. O espaçamento excessivo dos estribos na direção longitudinal também sobrecarrega os nós, além de aumentar a tensão nas bielas.

A influência do detalhamento dos estribos foi estudada por ANDERSON \& RAMIREZ (1989), que sugerem a maior eficiência dos estribos fechados ou em forma de $U$, se comparados com os estribos de um ramo. O dobramento dos estribos em torno de uma barra longitudinal também melhora a ancoragem. especialmente se houver contato direto entre eles. Além disso, observou-se que a tensão nos estribos é maior nas proximidades da intersecção com a fissura diagonal, independente de estar acima ou abaixo da metade da altura da alma. Como não se conhece a priori a posição da fissura. 
deve-se prever a ancoragem para toda a altura. Porisso, recomenda-se evitar a ancoragem dos estribos somente por trecho reto, que pode ser insuficiente no caso de vigas estreitas quando ele intercepta a fissura diagonal nesta posição.

No caso de vigas largas, os ramos internos dos estribos aliviam os nós externos e aumentam a capacidade resistente ao cisalhamento, além de proporcionar a contribuição uniforme das barras da armadura longitudinal.

\subsection{2 - OUTROS MODELOS}

O modelo de treliça é, na verdade, uma particularidade do modelo de bielas e tirantes, que é muito utilizado na análise de vigas altas, consolos e regiões de transição ou de descontinuidade geométrica (TAN \& MANSUR, 1992). Nestes elementos, a distribuição de tensões não é linear e o comportamento depende mais das características do carregamento e dos apoios. A análise preliminar elástico-linear fornece a trajetória de tensões principais de compressão, que orienta a posição das bielas de concreto. Os tirantes são adicionados para tornar a estrutura estável para o caminhamento das cargas. O processo é iterativo, pois a largura das bielas e o tamanho dos nós dependem da força nas bielas e tirantes.

Nestes modelos, o tamanho dos nós críticos, sob as cargas concentradas, é controlado pela dimensão da biela que se apoia nele, pela dimensão da placa de apoio e pela largura da peça. Nos nós em que chegam apenas barras comprimidas (sob as cargas), como há um estado duplo de compressão, pode-se considerar a resistência integral do concreto. Nos apoios, onde há uma barra tracionada, a resistência deve ser reduzida, assim como nas bielas, devido à presença de estribos tracionados e possíveis fissuras atravessando as bielas. (ALSHEGEIR \& RAMIREZ ,1992).

Os modelos de bielas e tirantes também são úteis para estudar os efeitos da protensão, do atrito nas fissuras e do detalhamento da armadura (ALSHEGEIR \& RAMIREZ, 1992). A força de protensão pode ser representada por uma força externa equivalente; o efeito do atrito na interface das fissuras de cisalhamento, por barras diagonais na direção das fissuras. A rigidez destas barras é escolhida de modo que a força resistida por elas seja equivalente ao atrito desenvolvido na fissura. Isso leva a uma diminuição da força nos estribos, na armadura longitudinal e no concreto. Os procedimentos gerais de cálculo do modelo de bielas e tirantes e os procedimentos adotados por vários Códigos e Normas que nele se baseiam podem ser encontrados em SILVA (1991). 
O modelo baseado na trajetória das forças de compressão, citado anteriormente, supõe que as forças transversais sejam transmitidas aos apoios através de uma trajetória bi-linear. Segundo KOTSOVOS (1988), mesmo que a altura da zona comprimida seja reduzida, o concreto pode resistir às tensões de tração provocadas pela força cortante, pois, devido ao estado triaxial de tensões nesta região, a resistência do concreto é maior do que a sua resistência uniaxial. A armadura de cisalhamento é calculada conforme o tipo de ruptura e deve resistir às forças de tração adicionais àquelas que não podem ser resistidas pelo concreto na zona comprimida.

No caso de vigas biapoiadas submetidas a duas cargas concentradas com relação a/d reduzida, a ruptura ocorreria no meio do vão, devido ao fendilhamento do concreto (KOTSOVOS, 1984). O esmagamento do concreto quando a fissura caminha em direção à carga seria improvável, já que, na região crítica, próximo da carga, a resistência à compressão do concreto é favorecida pelo estado multiaxial de compressão. Sugere-se que os estribos no trecho onde atua a força cortante evitam a ruptura diagonal, mas nem sempre proporcionam aumento da resistencia ou da dutilidade. que seria obtido com estribos no trecho central, pois eles evitam que as fissuras se propaguem nesta direção.

Segundo KOTSOVOS \& LEFAS (1990), o dimensionamento de acordo com o modelo baseado na trajetória das forças de compressão é mais seguro e econômico do que os métodos tradicionais. As tensões de tração na região comprimida estão associadas, entre outras causas, à mudança na direção das tensões de compressão, à variação do valor das tensões de compressão e à ruptura da aderência junto à armadura longitudinal entre as fissuras inclinadas (SERAJ e outros, 1993).

No caso de vigas biapoiadas, o modelo é representado por um pórtico constituido por um trecho central horizontal e por trechos inclinados nas extremidades, atirantado pela armadura longitudinal. O colapso pode ocorrer nos trechos horizontal e inclinado, ou na junção destes elementos, no nó do pórtico. Quando ele ocorre para uma carga menor do que a resistência à flexão, a ruptura é frágil e deve ser evitada (KOTSOVOS \& BOBROWSKI, 1993).

Para cargas muito próximas do apoio $(\mathrm{a}<\mathrm{d})$. a seção deve ser ajustada para se evitar o colapso do concreto na alma e a armadura transversal é posicionada de acordo com os critérios utilizados para vigas altas. Quando a ruptura ocorre na região do nó. devido à penetração das fissuras inclinadas na zona comprimida, para $\mathrm{d}<\mathrm{a}<2 \mathrm{~d}$. deve-se colocar estribos nesta região. Para a $>2 \mathrm{~d}$, a causa mais provável da ruptura é a força de tração que se desenvolve na região do nó, necessária para balancear a ação da resultante das forças de compressão na direção dos componentes do pórtico, ou seja, ela decorre da mudança da trajetória das forças de compressão. A armadura transversal 
deve ser calculada para resistir a força de tração que excede a força resistida pelo concreto. Segundo os autores, o modelo pode ser estendido a várias outras estruturas, além da viga bi-apoiada.

O modelo baseado na Teoria dos Campos de Tensões ("Modified CompressionField Theory") se baseia em equações de equilíbrio e compatibilidade, considerando-se tensões e deformações médias (VECCHIO \& COLLINS, 1986). Originalmente, as tensões de tração no concreto fissurado eram desprezadas. Quando modificado, adotouse uma relação $\sigma-\varepsilon$ baseada em valores experimentais de elementos submetidos a tensões biaxiais.

Com o surgimento e a propagação das fissuras, as forças resistidas por elementos de concreto unidos por barras de aço são parcialmente transferidas a elas. cujas tensões são máximas junto às fissuras. Os elementos de concreto são ligados por fissuras "ásperas", capazes de transferir forças de compressão e cisalhamento, sendo que o concreto entre fissuras fica submetido a tensões de tração. O modelo baseado na teoria dos campos de tensões tenta reproduzir este comportamento, que é relevante quando se depende mais das características do concreto e menos do escoamento da armadura, quando há abundância de armadura.

Outros modelos refinados que aplicam o Método dos Elementos Finitos e consideram a não-linearidade do concreto podem ser utilizados para análise dos deslocamentos na etapa pós-pico e das variáveis que influem na ruptura por cisalhamento: concreto $\left(f_{c}, f_{t}\right.$ e diagrama $\sigma-\varepsilon$ na tração). geometria do carregamento (a/d) e armaduras (taxas de armadura longitudinal e transversal, espaçamento dos estribos). Segundo CHUNG \& AHMADI (1994), a forma do diagrama $\sigma-\varepsilon$ do concreto na tração mais conveniente é aquela correspondente ao modelo de ruptura frágil ou de ruptura com diminuição gradual da tensão ("softening behavior"). O modelo plástico. por sua vez, superestima a rigidez e a carga de ruptura.

\subsection{3 - A RUPTURA NAS PEÇAS COM ESTRIBOS}

Os principais modos de ruptura nas vigas com armadura transversal efetiva são. segundo FUSCO (1984) e LEONHARDT \& MÖNNIG (1977):

- ruptura por força cortante-compressão: quándo ocorre o esmagamento da biela diagonal de concreto. Este tipo de ruptura é típico de almas finas com armadura transversal abundante e pode ser evitado através da limitação da tensão tangencial: 
- ruptura por força cortante-tração: quando ocorre a ruptura por tração da armadura transversal, que é insuficiente. As fissuras de cisalhamento penetram muito na zona comprimida, que também pode romper. No caso de alma espessa, a fissura crítica normalmente surge a partir de fissuras de flexão, e para alma delgada, diretamente na alma;

- ruptura por força cortante-flexão: quando ocorre o esmagamento do concreto no banzo comprimido, devido à penetração das fissuras diagonais nesta região. É comum no caso de cargas concentradas elevadas. A seção de ruptura normalmente situa-se junto ao ponto de aplicação da carga. Este modo de ruptura pode ser evitado pelo adequado dimensionamento à flexão, com um arranjo de armaduras que reduza a fissuração diagonal;

- ruptura por flexão da armadura longitudinal: quando surgem deficiências localizadas na região da armadura longitudinal, que tem resistência deficiente para suportar a flexão localizada causada pelo apoio das bielas entre os estribos. normalmente muito espaçados. Este tipo de ruptura pode ser evitado pelo arranjo adequado dos estribos e da armadura longitudinal.

Nos ensaios com carregamento concentrado, é comum a ocorrência de ruptura por cisalhamento-flexão, junto ao ponto de aplicação da carga, na região de momento fletor e força cortante máximos. Os resultados devem ser interpretados com cautela. pois, na prática, as cargas usualmente são distribuídas. Neste caso, a força cortante é maior junto aos apoios, ao contrário do momento fletor. A região crítica se aproxima dos apoios e a ruptura por cisalhamento-tração torna-se mais provável, especialmente no caso de peças pré-tracionadas. já que a transferência da protensão ainda pode ser parcial nesta região (CEB-180).

Devido à variedade dos tipos de ruptura por força cortante, algumas com colapso brusco, o projeto dos elementos submetidos a solicitações tangenciais deve considerar a diminuição da resistência dos materiais para as solicitações normais. de modo que as solicitações tangenciais não sejam condicionantes da ruína. As dimensões da estrutura são então determinadas para atender os requisitos das solicitações normais. Os arranjos de armadura e as espessuras das peças esbeltas são estabelecidos de modo que as solicitações tangenciais não invalidem este dimensionamento (FUSCO, 1984).

Muitas vezes, a ruptura está associada com a ação de pino da armadura longitudinal. mesmo que não ocorra o fendilhamento do concreto nesta região. A eficiência deste mecanismo resistente em estruturas de concreto fissuradas depende do confinamento exercido pelo concreto ao seu redor e dos estribos. Porisso, a interação da ação de pino com os estribos e o cobrimento é importante, especialmente quando o 
cobrimento é reduzido. Os parâmetros intervenientes mais importantes no fenômeno são o diâmetro da barra, o cobrimento de concreto e a distância do estribo ao plano de cisalhamento da barra longitudinal (DEI POLI e outros, 1993).

O mecanismo é governado pela plastificação da armadura longitudinal ou transversal. Após a fissuração do cobrimento, a contribuição do concreto é muito limitada. A capacidade resistente depende da posição do estribo mais próximo, especialmente para barras finas, quando eles são mais importantes. Quando ele está distante do plano de cisalhamento da barra longitudinal, seu efeito é limitado. Quando próximo. os danos no concreto são maiores.

Nas vigas sem estribos, o colapso ocorre devido ao fendilhamento do concreto. Com estribos, pode haver escoamento da armadura longitudinal (quando o diâmetro é pequeno). do estribo (quando ele está próximo do plano de cisalhamento da barra e o diâmetro da barra longitudinal é elevado), ou de ambos.

A espessura do cobrimento altera pouco a resistência final, mas influi na rigidez inicial, assim como na transição entre o comportamento inicialmente linear e o comportamento plástico final. Portanto, o aumento do cobrimento torna o efeito de pino mais eficiente para cargas de utilização.

Segundo CHANA (1988), na análise do fendilhamento do concreto pode-se supor que na região influenciada pelas forças de pino. o momento que provoca a plastificação da armadura longitudinal seja menor. Se o fendilhamento for impedido, no caso de estribos pouco espaçados, pode haver escoamento da armadura ou ruptura do banzo comprimido. Quando se posiciona o estribo na base da fissura diagonal, há um esmagamento parcial do concreto nesta região. indicando a existência de forças de pino muito elevadas. Havendo o escoamento da armadura, a ruptura, apesar de dútil, é prematura. pois a força desenvolvida é menor do que a esperada, devido à sobreposição das forças de pino. A fissura diagonal penetra na zona comprimida, que se torna incapaz de equilibrar a força de tração. Isso explicaria a redução da linha neutra observada nestes casos de ruptura por cisalhamento.

Quando o espaçamento dos estribos é elevado. as forças de pino que provocam o escoamento da armadura longitudinal são menores, mas o concreto fica desprotegido. O colapso é atribuído à ruptura do concreto junto à armadura, antes que ela escoe. Nas peças sem estribos, quando surgem as fissuras decorrentes das forças de pino, há uma redistribuição das forças até então resistidas por este mecanismo. As fissuras diagonais estendem-se à zona comprimida, que rompe devido ao aumento da tensão principal de tração.

O espaçamento em que o escoamento da armadura e o fendilhamento do concreto ocorrem simultaneamente é o valor que delimita a ruptura dútil, devido ao 
escoamento da armadura, da ruptura frágil, devido ao fendilhamento. Portanto, a ruptura por cisalhamento pode ocorrer devido ao fendilhamento do concreto junto à armadura longitudinal, ao escoamento da armadura longitudinal ou à ruptura da zona comprimida, ou à combinação destes mecanismos.

\section{5 - PEÇAS PROTENDIDAS}

Atualmente, há uma tendência de se uniformizar a análise das peças de concreto armado e protendido, incorporando as especificidades da protensão numa análise mais genérica. A zona de transferência da força de protensão, o cálculo dos deslocamentos e a influência da protensão na resistência à flexão e ao cisalhamento ilustram algumas destas particularidades.

Nas extremidades das vigas pré-tracionadas, surgem tensões decorrentes da transferência da força de protensão para o concreto, por aderência, conforme mostra a Figura 2.7. O comprimento do trecho da zona de transferencia pode ser calculado a partir da tensão de aderência ou pode ser estimado experimentalmente. No caso das cordoalhas, a transferência se dá por adesão, atrito, aderência mecânica e efeito Hoyer. Estes dois últimos mecanismos não são considerados no ensaio tradicional de arrancamento. Métodos alternativos para determinação da zona de transferência são propostos por COUSINS e outros (1992) e NANNI e outros. (1992).
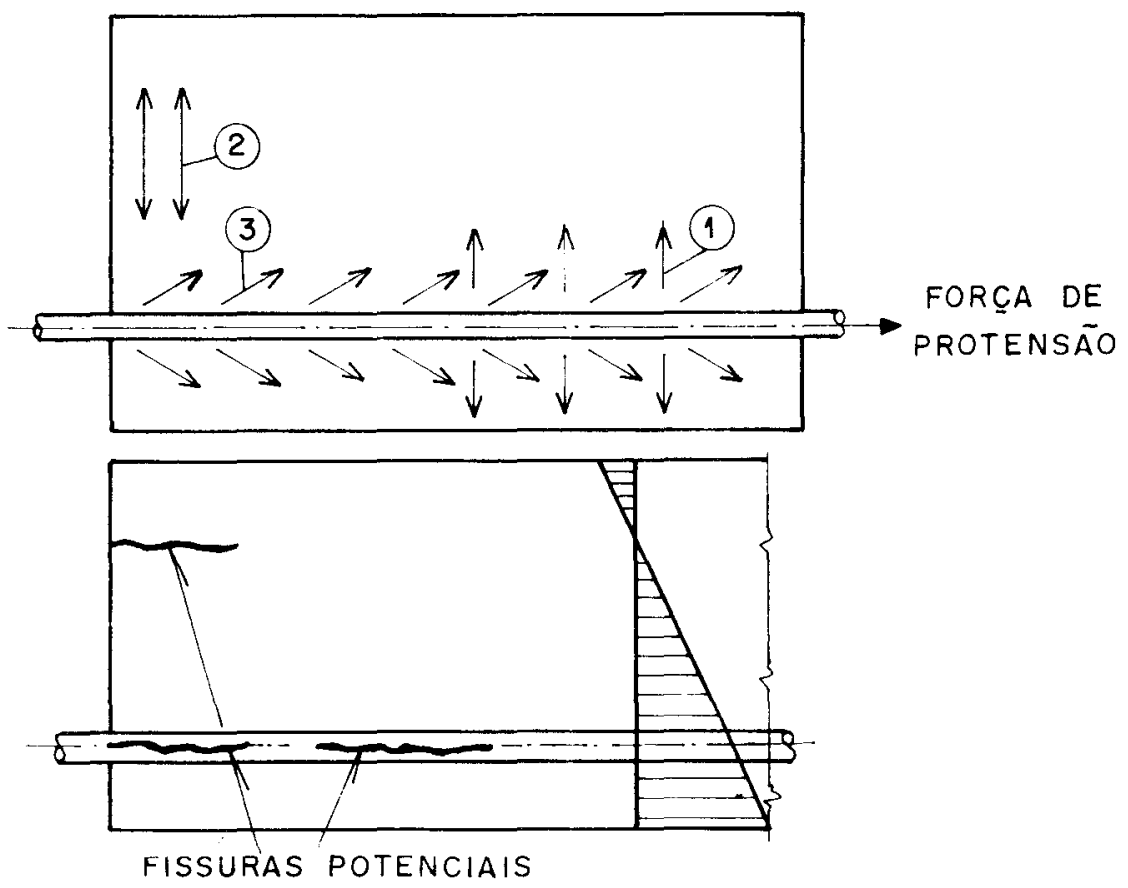

Figura 2.7 - Tensões na região de introdução da protensão por pré-tração (CEB-181) 
Nesta região, deve-se verificar a possibilidade do escorregamento da armadura de protensão após o aparecimento das fissuras inclinadas, o que provocaria o colapso brusco da viga, já que não se conseguiria mobilizar os estribos após a fissuração diagonal. Nos casos mais críticos, pode-se prever um trecho da viga posterior aos apoios (KAUFMAN \& RAMIREZ, 1988).

Nos deslocamentos, a análise é similar ao concreto armado, exceto pela maior extensão da etapa linear. O diagrama carga-flecha apresenta três estágios: elástico, elástico-fissurado e plástico, que pode inexistir caso a taxa de armadura seja alta. A contribuição do concreto fissurado pode ser considerada no enrijecimento da armadura pela camada de concreto aderente entre as fissuras, ou pela diminuição gradual da tensão de tração com o aumento da deformação. Ela é importante no estágio elásticofissurado. mas desprezível no estágio plástico. quando as fissuras estão muito abertas (CHERN e outros, 1992).

A influência da protensão na resistência ao cisalhamento pode ser atribuída a diversas causas: esforços hiperestáticos de protensão, inclinação dos cabos e tensões longitudinais de compressão no concreto. No caso de peças pré-tracionadas com cabo reto, enfocadas neste trabalho. somente as tensões longitudinais de compressão as diferenciam das peças de concreto armado.

O comportamento das vigas de concreto armado e protendido é qualitativamente o mesmo, alterando-se a extensão das zonas físsuradas e o instante da fissuração, em função do grau de protensão. Assim como na flexão, o início da fissuração inclinada é retardado pela protensão, devido à introdução de tensões longitudinais de compressão, o que resulta em diminuição da armadura transversal.

Além disso, na região de transição entre a zona fissurada e a zona não fissurada pela flexão (região $B$, onde as fissuras de cisalhamento resultam da ação simultânea da força cortante e do momento fletor), as fissuras de cisalhamento que surgem diretamente na alma são mais inclinadas nas peças protendidas, pois acompanham a direção da tensão principal de compressão. Com isso, há um alívio de tensão nos estribos. pois mais estribos são mobilizados, e um aumento na compressão das bielas.

No entanto, a tensão nos estribos em vigas idênticas com graus de protensão diferentes, difere apenas enquanto o panorama de fissuração é distinto. Próximo da ruptura, quando as vigas estão intensamente fissuradas, supondo-se o escoamento da armadura longitudinal, as tensões nos estribos se aproximam, conforme mostra a Figura 2.8. Após a fissuração, a contribuição do concreto diminui com a evolução do carregamento e a tensão nos estribos aumenta mäis do que o previsto pela analogia de treliça. ao contrário das peças de concreto armado. Segundo o CEB-180, isso se deve à menor rigidez do banzo. o que acarreta a evolução mais rápida das fissuras. Ou seja. 
próximo da ruptura, a contribuição do concreto é similar, exceto pela possível diferença na inclinação das bielas.

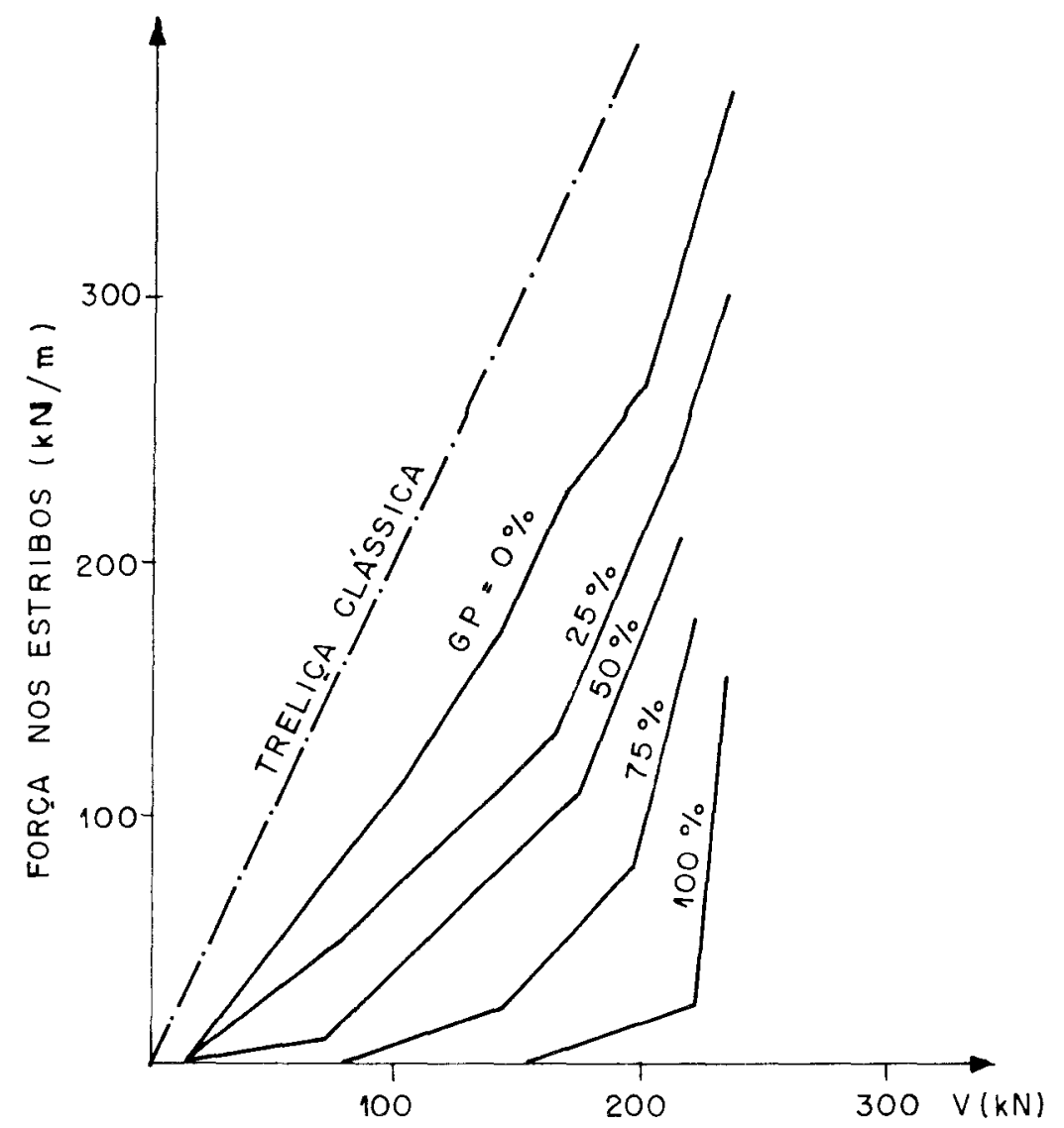

Figura 2.8 - Tensão nos estribos em vigas com GP diferentes (LEONHARDT \& MÖNNIG, 1977)

Quando a protensão é completa o fenômeno é semelhante, mas o instante da fissuração se aproxima ainda mais do instante da ruptura. A parcela de força transmitida pelos mecanismos alternativos atua durante mais tempo, mas, caso a ruptura ocorra acompanhada do escoamento da armadura longitudinal, com fissuração intensa, a influência da protensão também diminui.

Porém, caso a ruptura ocorra sem o escoamento da armadura longitudinal, e portanto, antes da fissuração generalizada, num caso de ruptura frágil, que contraria a regra básica de dimensionamento, a influência da protensão na resistência ao cisalhamento é muito maior. É o que ocorre nas vigas sem armadura transversal, onde ela é proporcional à etapa até a descompressão da seção analisada.

Caso o dimensionamento fosse feito em serviço, a influência da protensão seria maior, proporcional ao grau de protensão. Porém, na existência de um carregamento excepcional que resultasse em intensa fissuração, a ruptura seria brusca. Mas seria precedida de aviso, o que permite estabelecer um certo grau de dutilidade para este tipo 
de ruptura, ainda que muito menor do que aquele alcançado com o escoamento da armadura longitudinal.

A NBR-6118 quantifica a influência da protensão através da relação entre o momento fletor de descompressão e o momento solicitante máximo no trecho analisado, a qual reflete o grau de fissuração da peça. Não depende, portanto, da resultante das tensões normais na seção, mesmo porque, na ruptura, a resultante do banzo comprimido não é afetada pela protensão, e portanto, não pode alterar a parcela de resistência proporcionada pela inclinação do banzo comprimido.

Assim, a influência da protensão é menor para as seções mais afastadas do apoio, pois a força cortante necessária para a descompressão da seção é menor. Ou seja, a descompressão ocorre antes para as seções mais distantes do apoio. Segundo FUSCO (1984), os resultados experimentais confirmam este fato, pois a tensão nos estribos mais distantes dos apoios é maior, no caso de carga concentrada e zona fissurada. A mesma conclusão é apresentada, em outras palavras, no CEB-180: a tensão nos estribos da região $B$ (onde existem somente fissuras de cisalhamento que surgem diretamente na alma) é menor que nos estribos da região $C$ (onde existem também as fissuras de flexão), devido à contribuição da mesa tracionada não fissurada.

Portanto, as vigas protendidas também podem ser calculadas com os modelos de treliça, majorando-se o termo da contribuição do concreto, caso ele seja considerado explicitamente. O ACI-426R registra que, no caso das cordoalhas, a ação de pino seria menor. Além disso, como a evolução da abertura das fissuras é mais rápida após a fissuração, o atrito nas fissuras também seria menor. No entanto, a contribuição do banzo comprimido seria implementada, já que a altura da zona comprimida é maior.

Mesmo quando não existe aderência entre a armadura de protensão e o concreto, KORDINA e outros (1989) sugerem que, devido à semelhança da configuração das fissuras de cisalhamento, o modelo de treliça é mais adequado que o modelo de arco atirantado, idealizado em função da limitação da variação da força na armadura longitudinal somente na região não fissurada ou na região de ancoragem.

A eliminação da armadura transversal, exceto nas extremidades, foi estudada por BURNLEY \& ASWAD (1989), que concluiram que ela não traria prejuizos no desempenho à flexão e ao cisalhamento em vigas protendidas de grande comprimento e seção transversal duplo-T.

Segundo KANG e outros (1987), a protensão em vigas pré-tracionadas proporciona aumento da resistência ao cisalhamento somente até um determinado valor do grau de protensão, quando pode ocorrer ruptura por cisalhamento-compressão, com decréscimo de resistência. Nos casos de protensão parcial, a parcela adicional de resistência seria decorrente da maior altura da zona comprimida e do aumento da ação 
de pino e do atrito. Ela poderia ser representada pela força cortante que provoca a descompressão da seção analisada. A contribuição dos estribos, apesar das bielas mais abatidas, não seria alterada, já que a maior altura da zona comprimida elimina a vantagem do abatimento das bielas, pois a projeção horizontal da fissura crítica não seria alterada.

Conclusão similar é obtida por SERAJ e outros (1993), baseados no modelo das trajetórias das forças de compressão. Sugere-se que a resistência depende da capacidade do concreto de transmitir forças de compressão do ponto de aplicação do carregamento até os apoios. Caso o grau de protensão seja muito alto, o concreto na zona comprimida pode ficar submetido a tensões muito elevadas e a resistência da peça pode diminuir, mesmo com o aumento da resistência do concreto ao cisalhamento. Isto também contraria a idéia predominante segundo a qual a quantidade de estribos diminui com o aumento do grau de protensão. devido à maior contribuição do concreto, ao retardamento da fissuração ou à variação na inclinação das bielas.

\section{6 - CONCRETOS DE ALTA RESISTÊNCIA}

A utilização de concretos de resistência mais elevada constitui uma tendência irreversivel. Porisso, os estudos nesta área são atuais e procuram confirmar as principais propriedades do concreto de resistência normal. de modo a estender para o concreto de alta resistência a validade dos modelos de cálculo usuais, introduzindo, quando for o caso, possiveis modificações.

Segundo MONTEIRO (1993), a forma do diagrama tensão-deformação do concreto está associada à progressão da microfissuração interna, que se inicia na interface pasta-agregado e se propaga para a argamassa com o carregamento crescente. Para o concreto de resistência normal, o diagrama é inicialmente linear, enquanto as microfissuras estão estáveis na interface. Esta etapa vai até aproximadamente $30 \%$ da resistência total. Quando surgem microfissuras na argamassa, até $60 \%$ da resistência, o diagrama torna-se curvo, inclinando-se bruscamente quando a fissuração fica instável, acima de $75 \%$ de sua resistência.

No concreto de alta resistência a etapa linear é mais extensa, até próximo da ruptura, até 65 a $80 \%$ da resistência do concreto, pois a microfissuração fica restrita à zona de transição, que é mais resistente. A partir dai, quando a fissuração evolui, o diagrama também fica curvo. sendo que a ruptura é mais frágil que no concreto comum. A deformação última é maior que no concreto de resistência normal. Neste 
caso, portanto, é importante reverter a desvantagem da menor dutilidade, especialmente em peças comprimidas, através de arranjos adequados de armadura.

Segundo MEHTA \& MONTEIRO (1994), o concreto de alta resistência tem mais microfissuras que o concreto normal porque o aumento da resistência à tração é maior que o aumento da energía de fratura. A ruptura normalmente se dá com superfícies lisas. que cortam os agregados, ao contrário do concreto de resistência normal, onde ela é áspera e irregular, contornando os agregados. Porisso, a relevância da qualidade do agregado é maior no concreto de alta resistência.

O concreto utilizado nos ensaios deste trabalho se encontra numa região transitória entre o concreto de resistência normal e o concreto de alta resistência. Com resistências médias à compressão da ordem de $50 \mathrm{MPa}$ aos sete dias. com o uso de cimento de alta resistência inicial, ele poderia ser enquadrado nesta categoria especial, dependendo dos critérios utilizados.

A variação da resistência à tração e à compressão do concreto altera a rigidez da viga, antes e após o aparecimento da fissura diagonal. Além disso, em concretos de alta resistência. o comportamento pós-pico muda, sendo que o gráfico carga-flecha se torna mais íngreme na ruptura (CHUNG \& AHMADI, 1994).

Há inúmeros estudos sobre a resistência ao cisalhamento das vigas de concreto de alta resistência. Segundo FERNANDES (1992), o modelo da treliça generalizada é válido. A mobilização efetiva dos estribos ocorre próximo do instante da fissuração inclinada. a partir de $40 \%$ da força cortante última, em função da taxa de armadura longitudinal. Quando ela é alta, o acionamento dos estribos é retardado e a resistência é maior. A tensão resistida pelo concreto $\left(\tau_{c}\right)$, suposta proporcional à força cortante que provoca o aparecimento das fissuras inclinadas, é menor do que a correspondente resistência de uma peça similar sem armadura transversal. Ou seja, a contribuição do concreto que permanece até a ruptura é apenas uma parte da força cortante resistida pelos mecanismos resistentes da viga sem estribos.

O escoamento da armadura longitudinal seria possivel mesmo para taxas reduzidas de armadura transversal, mas com grande sacrifício do concreto, observandose intensa fissuração. Os parâmetros da NBR-6118 para a ruptura por flexão estariam adequados. mas o deslocamento do diagrama de momento fletor para o cálculo da armadura longitudinal e a força prevista nesta armadura junto aos apoios deveriam ser maiores.

MPHONDE (1988) estudou o efeito da variação da resistência do concreto nos mecanismos resistentes ao cisalhamento. A contribuição do banzo comprimido não sofreria alteração significativa. O efeito de pino seria muito maior com o aumento da resistência. desde que houvesse aumento da resistência à tração do concreto, pois 
haveria a mobilização de maiores tensões ao redor da armadura, retardando a fissuração e a ruptura nesta região. A contribuição do atrito nas fissuras seria menor, mesmo se a taxa de armadura transversal for elevada. Além da superfície plana e lisa das fissuras. a rotação do consolo entre fissuras inclinadas seria menor, reduzindo os deslocamentos ao longo da fissura e o atrito entre as superfícies separadas.

O autor confirmou também os erros da hipótese do modelo de natureza aditiva, já que os estribos, além da contribuição direta, aumentam a contribuição do concreto.

Portanto, os principais efeitos do aumento da resistência do concreto são o acréscimo na contribuição da armadura longitudinal por efeito de pino e a diminuição da contribuição oferecida pelo engrenamento dos agregados (MPHONDE, 1989).

Segundo KIM \& PARK (1994). o efeito que a variação da resistência do concreto tem na influência de outros parâmetros (taxa de armadura longitudinal e relação a/d) seria desprezível para as vigas retangulares sem estribos. O mesmo ocorreria com o efeito do tamanho, apesar da ruptura se tornar mais frágil com o aumento da resistência do concreto.

Para ELZANATY e outros (1986), a variação da resistência do concreto também teria efeito desprezível na influência da taxa de armadura longitudinal. $O$ termo do concreto seria subestimado para o concreto normal. mas superestimado para o concreto de alta resistência. Nas vigas com estribos, no entanto, a segurança poderia aumentar, ao contrário dos resultados de outros pesquisadores, dependendo do modo de ruptura: a eficiência dos estribos seria maior quando ocorre a ruptura por cisalhamento-tração do que para a ruptura por cisalhamento-compressão.

Para compensar o erro decorrente do exagero na estimativa da contribuição do concreto, ROLLER \& RUSSELL (1990) sugerem que a taxa mínima de armadura transversal nas vigas de concreto de alta resistência seja maior. Ou seja. ela deveria estar vinculada à resistência do concreto, pois as vigas de concreto de alta resistência seriam inseguras quando a taxa da armadura transversal é próxima da armadura mínima convencional.

O aparecimento da primeira fissura na alma ocorreria para força cortante menor do que a resistência de vigas sem estribos, mas esta diferença diminui gradualmente para taxas de armadura transversal mais elevadas. Portanto, a contribuição do concreto seria maior nas vigas com estribos.

Resultados similares foram obtidos por JOHNSON \& RAMIREZ (1989). Em vigas de concreto de alta resistência com taxa de armadura transversal reduzida, a reserva de resistência após a fissuração por forçà cortante diminui com o aumento da resistência do concreto, pois o valor da força cortante que provoca o aparecimento da fissura diagonal é maior. As forças transversais resistidas pela ação de pino, pela zona 
comprimida, pelo atrito nas fissuras e pelos estribos são, portanto, maiores. Logo, as fissuras são mais abertas, além de mais lisas, diminuindo o atrito nas fissuras e sobrecarregando os estribos. Não se espera a mesma redução da reserva de resistência para cargas mais próximas dos apoios, onde a ação de arco é predominante.

A diferença entre os valores experimentais e teóricos observada nas vigas de concreto de alta resistência com armadura transversal minima, decorrente da superestimativa da contribuição do concreto, poderia ser minorada estabelecendo-se um limite para o valor de $f_{c}$. No entanto, isso penalizaria indevidamente as vigas com taxas de armadura transversal maiores, pois, apesar da diminuição da parcela do atrito no concreto de alta resistência, o enrijecimento dos elementos de concreto da treliça aumenta a contribuição do concreto não fissurado, além de melhorar a capacidade de redistribuição das forças internas, devido a maior mobilização dos estribos. Ou seja, a resistência nestas vigas pode aumentar, desde que o arranjo das armaduras seja adequado. Sugere-se. então, que a melhor solução seria obtida com o aumento da taxa de armadura mínima para os concreto de alta resistência. Sugestão semelhante é proposta por AHAMAD e outros (1986).

A validade das expressões empíricas utilizadas para o cálculo da resistência ao cisalhamento em vigas de concreto de alta resistência tem sido verificada por vários pesquisadores, em função das diferenças de comportamento levantadas anteriormente. Para o concreto leve, por exemplo, o comportamento seria similar ao do concreto normal, independente da resistência do concreto (AHAMAD e outros, 1994).

A contribuição do concreto normalmente é considerada como função da sua resistência à compressão, cuja variação se dá proporcionalmente à raiz quadrada da resistência, ou à raiz cúbica, de acordo com algumas formulações. Para o concreto de alta resistência. os ensaios mostram que o primeiro valor superestima a resistência à força cortante, especialmente para a/d elevado, onde a posição das fissuras inclinadas seria pouco relevante, já que há um ajuste na trajetória até os apoios. Nas vigas curtas, a posição inicial é crítica, pois determina a capacidade do desenvolvimento da ação de arco, onde a influência da resistência do concreto é mais significativa. Nestes casos, a variação nos resultados de vigas sem estribos é muito maior. pois a fissura é repentina e aparece com comprimento extenso (MPHONDE \& FRANTZ, 1984).

Segundo SARSAM \& AL-MUSAWI (1992), as principais fórmulas utilizadas para calcular a resistência ao cisalhamento são conservativas. No entanto, geralmente o fator de segurança diminui para valores de a/d elevados. acima de 5,0, e para altas taxas de armadura transversal, onde predominam os esforços de flexão. independentemente da resistência do concreto. 


\section{CAPÍTULO 3 - CONCRETOS E ARGAMASSAS COM FIBRAS}

Apresenta-se neste capítulo os principais conceitos sobre os compósitos formados pela matriz à base de cimento portland (microconcreto, concreto ou argamassa) reforçada com fibras, com ênfase na caracterização da microestrutura e sua relação com as propriedades macromecânicas e nos modelos de simulação da interação fibra-matriz e do comportamento mecânico dos compósitos. Posteriormente, descrevem-se os diferentes sistemas com fibras, especialmente aqueles utilizados neste trabalho, e os principais ensaios para caracterização dos compósitos. E, finalmente, analisa-se a aplicação das fibras como armadura secundária de cisalhamento.

Os conceitos relacionados com o comportamento dos compósitos valem genericamente para todos os tipos de fibras. No entanto, as especificidades dos diferentes tipos de fibra e da matriz introduzem características próprias aos diversos sistemas com fibras, já que as propriedades mecânicas da fibra, sobretudo o módulo de deformação longitudinal e a resistência, assim como a qualidade da aderência entre a fibra e a matriz, são fatores determinantes do seu desempenho.

\section{1 - INTRODUÇÃO}

A idéia de se reforçar a matriz frágil de concreto para torná-la mais homogênea e mais dútil vem desde o século passado, mas ganhou impulso no concreto armado após 1960. A introdução de fibras curtas melhora as características de dutilidade, a resistência ao impacto e à fadiga, o controle da fissuração, o comportamento pósfissuração e. em alguns casos, a resistência à tração. Algumas destas vantagens são sensíveis à quantidade e ao tipo de fibra adicionada (TESUKA, 1989). Segundo AGOPYAN (1993), as fibras, em quantidade, comprimento e formato adequados. podem incorporar à matriz deformações plásticas significativas, adequando-a para o uso na Construção Civil, já que se pode alterar o comportamento pós-fissuração e tornar menos súbita a ruptura do material. 
No concreto, as fibras têm sido utilizadas principalmente para vencer algumas das suas limitações: fragilidade, pequena capacidade de deformação e baixa resistência à tração. Geralmente, a adição das fibras não visa o aumento de resistência, embora em algumas situações ele ocorra, mas o melhor controle da fissuração e o aumento da dutilidade na etapa posterior à fissuração.

Por ser descontinua, a fibra é menos eficiente que a armadura contínua de fios e barras na função de resistir aos esforços de tração e de cisalhamento. No entanto, em função do espaçamento reduzido entre elas, sua atuação como obstáculo ao desenvolvimento das fissuras é superior. Ao interceptar as microfissuras que surgem durante o endurecimento da pasta, as fibras impedem sua progressão e evitam o aparecimento prematuro de macrofissuras. Na mistura endurecida, a abertura e o comprimento das fissuras também se tornam mais limitados. Com isso. a permeabilidade do concreto e a região exposta ao ambiente são menores. melhorando as condiçôes de durabilidade.

As propriedades do concreto relacionadas com o desenvolvimento das fissuras também são alteradas com as fibras, tais como a rigidez, a dutilidade, a absorção de energia e a resistência à flexão, ao impacto e à fadiga (TESUKA, 1989).

Quando as fibras são combinadas com armadura contínua. ambos se tornam mais eficientes, pelo efeito sinergético. Além de "costurar" as fissuras. as fibras melhoram a aderência do concreto com a armadura, inibindo a fissuração na região de transferência de forças. Desta forma, ao invés de substituir a armadura, as fibras podem se constituir num reforço adicional (BENTUR \& MINDESS, 1990).

A quantidade máxima de fibras que pode ser adicionada ao concreto é influenciada pela dimensão máxima dos agregados. Quando apresentam granulometria predominante de partículas graúdas, eles dificultam a uniformização das fibras na mistura. Porisso, normalmente se limita o diâmetro do agregado em aproximadamente $20 \mathrm{~mm}$, ou $19 \mathrm{~mm}$, segundo o ACI-544, priorizando-se valores próximos de $10 \mathrm{~mm}$. Isso explica a maior facilidade de se adicionar fibras em argamassa do que em concreto (volumes de até $10 \%$ e $2 \%$. respectivamente, segundo HANNANT, 1978).

Segundo TESUKA (1989), as fibras com relação de aspecto (relação entre o comprimento e o diâmetro) entre 80-120 satisfazem os requisitos de homogeneidade, trabalhabilidade e resistência. MEHTA \& MONTEIRO (1994), no entanto, registram a possibilidade de ocorrer o empelotamento no caso de fibras de aço com relação de aspecto maior que 100. para volume de 1,13\%. A Figura 3.1 mostra a variação da consistência com o volume de fibras para diferentes tamanhos de agregados. representada pela medida do tempo Vebe. 


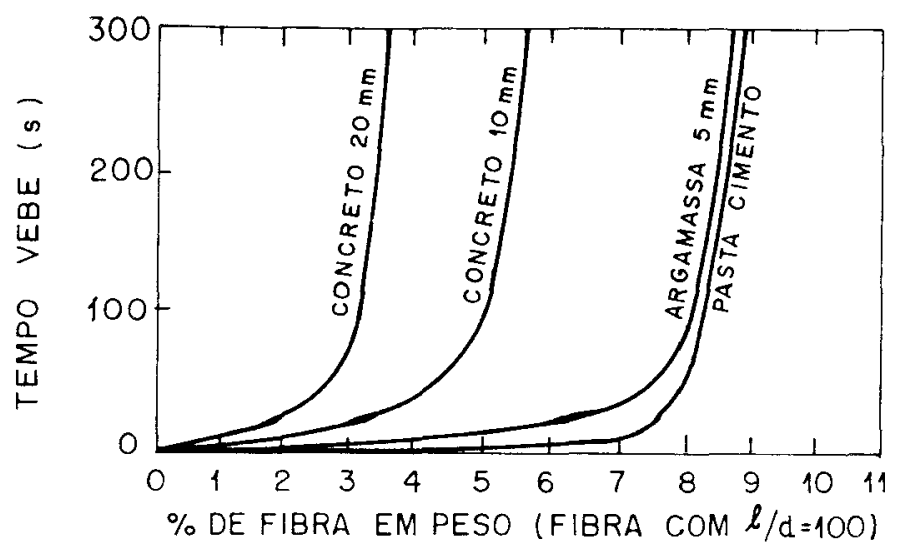

Figura 3.1 - Variação da consistência com o volume de fibras para concretos com agregados de diferentes granulometrias (BENTUR \& MINDESS, 1990)

A dificuldade de uniformizar a distribuição das fíbras na matriz devido ao embolamento e agrupamento das fibras são comuns a quase todos os tipos de fibra, embora em níveis diferentes. Algumas causas deste fenômeno são o agrupamento das fibras antes da mistura. a adição muito rápida durante a produção, o volume excessivo de fibras, a ineficiência dos equipamentos de mistura e a adição das fibras no misturador antes dos outros componentes (BENTUR \& MINDESS, 1990). O ACI-544 sugere que as fibras devem ser introduzidas antes da água, para se obter melhor uniformidade, exceto quando elas se apresentam na forma de feixes. caso em que podem ser adicionadas ao concreto pronto.

Outro problema comum às fibras é a tendência de inibir a fluidez do concreto, embora ela diminua com a vibração. $O$ uso de aditivos superplastificantes e a substituição de parte do cimento por pozolanas são as alternativas usuais para melhorar a trabalhabilidade. $\mathrm{O}$ aumento da relação água/cimento também pode ajudar, em detrimento da resistência, mas acima de um determinado valor torna-se ineficiente.

Segundo BENTUR \& MINDESS (1990), a utilização recente das fibras como reforço para o concreto ocorreu em duas frentes distintas: nas peças delgadas, na busca de compósitos substitutivos do cimento-amianto (com volumes acima de 5\%, para melhorar a tenacidade, a durabilidade e a resistência da matriz de cimento) e em peças de concreto. como armadura secundária (com volumes reduzidos, até $2 \%$ ), para melhorar a tenacidade, o controle da fissuração induzida e o desempenho sob cargas dinâmicas. Destaca-se ainda a importância das pesquisas com fibras em concretos de alta resistência.

Nos compósitos produzidos a partir de técnicas convencionais de mistura, com volumes reduzidos, a primeira evidência da influência das fibras no concreto tracionado ocorre somente após a ruptura da matriz, cuja resistência não se altera. A diminuição gradativa da tensão com o aumento da deformação ("strain softening") é 
expressa pela relação entre as forças de costura das fibras ("fiber-bridging closing pressure") e a abertura das fissuras, que pode ser determinada experimentalmente ou por análise micromecânica. Nos compósitos produzidos com técnicas especiais, com volumes de até $15 \%$, ao contrário, altera-se a natureza da matriz, aumentando muito os valores do módulo de deformação longitudinal e da resistência à tração. Seria uma nova classe de materiais, cujo comportamento à flexão se aproxima do comportamento do aço (SHAH \& OUYANG, 1991).

O mecanismo básico do reforço com fibras se deve à diferença na capacidade de deformação das fibras e da matriz. Portanto, ele é mais eficiente após a fissuração da matriz. Inicialmente, as fibras e a matriz se deformam conjuntamente, até a ruptura da matriz, quando a força resistida por ela é transferida para as fibras. Caso o volume de fibras seja maior que um determinado valor, denominado volume crítico, $V_{\text {crit }}$. de modo que as fibras consigam absorver esta força, há um aumento da resistência. sem que a fissuração seja catastrófica. Além disso, a dutilidade também aumenta, devido principalmente à energia necessária para o arrancamento ("pull-out") das fibras da matriz, que pode ser precedido pela fissuração múltipla da matriz, conforme representação da Figura 3.2. O aumento da dutilidade é mais significativo no caso de fibras com baixo módulo de deformação longitudinal.

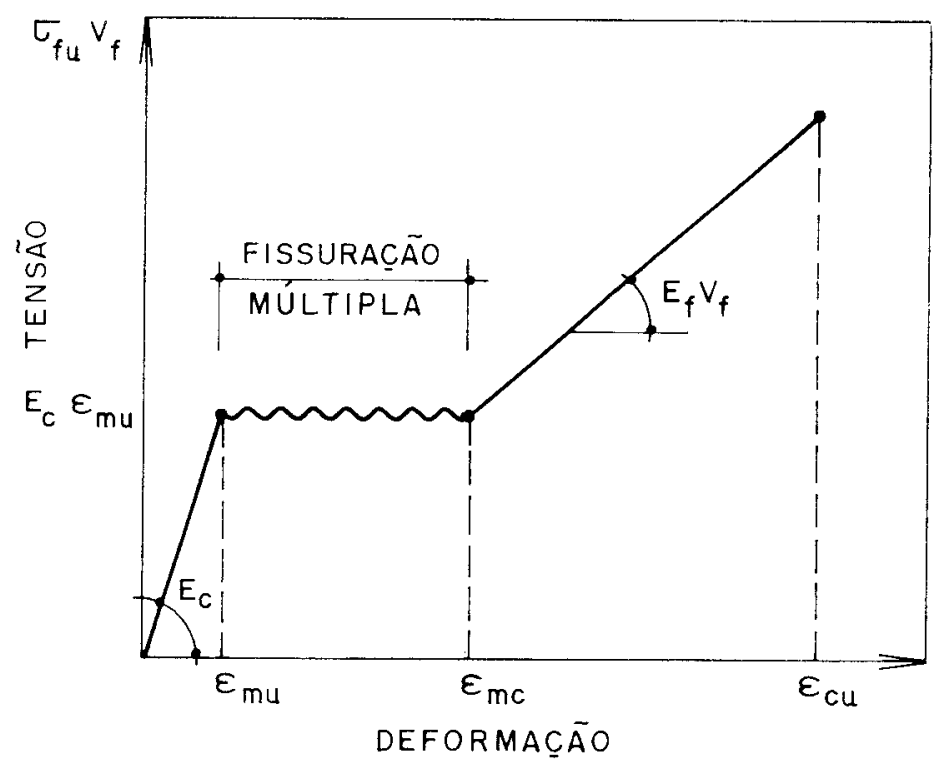

Figura 3.2 - Curva tensão-deformação baseada no modelo de ACK (BENTUR \& MINDESS, 1990)

A idealização deste comportamento se bảseia na transferência de tensões de aderência na interface entre as fibras e a matriz junto às fissuras. Portanto, ele depende das propriedades da fibra e da matriz e, principalmente, da tensão de aderência que 
pode se desenvolver na interface. A dutilidade e a resistência nem sempre melhoram na mesma proporção com a adição das fibras. Conforme se explica posteriormente, o controle da resistência de aderência e das propriedades da fibra e da matriz é importante para se adequar a resistência e a tenacidade aos valores desejados.

$\mathrm{O}$ acréscimo da resistência à tração do concreto com a adição das fibras é eventual, ocorrendo normalmente quando o volume de fibras é elevado, de modo a viabilizar a configuração da múltipla fissuração. A tenacidade, ao contrário, sempre aumenta, pois a energia necessária para a ruptura é dissipada na deformação da fibra. na separação da interface fibra-matriz e no atrito provocado pelo escorregamento da fibra. O aumento da dutilidade está associado à fissuração múltipla da matriz, à ruptura da interface fibra-matriz e ao seu posterior arrancamento.

O volume crítico de fibras na matriz depende da geometria e das propriedades da fibra. Segundo BENTUR \& MINDESS (1990), um valor típico para as fibras de aço, polipropileno e vidro situa-se próximo de $0.3-0.8 \%$, no caso de fibras alinhadas. Na prática, porém, as fibras são dispostas de forma aleatória, numa situação em que sua eficiência é menor, conforme se discute posteriormente. Assim. o volume crítico fica acima de 1,0-3,0\% e nem sempre é possível de obtê-lo. Além disso, a influência da geometria da fibra é contraditória sob os aspectos de produção e eficiência: fibras com relação de aspecto elevada apresentam maior resistência de aderência, pois têm maior superfície específica, sendo mais eficientes como reforço. Porém, são mais difíceis de misturar.

Para vencer este antagonismo, três altemativas são possíveis: modificação da fibra (na geometria, para melhorar a aderência. ou na superfície. para melhorar a aderência e/ou facilitar a mistura em meio aquoso), modificação das propriedades reológicas da matriz e desenvolvimento de técnicas especiais de produção.

Para o uso convencional das fibras no controle da fissuração, deve-se priorizar a possibilidade de produção em equipamentos normalmente disponíveis. Assim. a forma e a superfície da fibra e as propriedades da matriz seriam mais importantes. Alguns tipos de fibra de aço e de polipropileno são eficientes como reforço, e a adição de microssílica e aditivos superplastificantes para melhorar as propriedades da mistura fresca parecem ser a solução ideal neste caso. Para a substituição do cimento-amianto. as três alternativas podem ser combinadas. $O$ uso de fibras artificiais (duráveis e afins com a matriz, com alta resistência e módulo de deformação longitudinal elevado) e de sistemas híbridos (com dois tipos de fibras) também podem se constituir em alternativas viáveis (BENTUR \& MINDESS. 1990).

A Tabela 3.1 apresenta as características de algumas fibras utilizadas como reforço ao concreto, incluindo, para comparação. os valores da matriz de cimento. 
Tabela 3.1 - Principais características das fibras (BENTUR \& MINDESS, 1990)

\begin{tabular}{|c|c|c|c|c|c|}
\hline Tipo de Fibra & $\begin{array}{c}\text { diâmetro } \\
(\mu \mathrm{m})\end{array}$ & $\begin{array}{c}\text { massa } \\
\text { específica } \\
\left(\mathrm{g} / \mathrm{cm}^{3}\right)\end{array}$ & $\begin{array}{c}\text { módulo de } \\
\text { elasticidade } \\
(\mathrm{GPa})\end{array}$ & $\begin{array}{c}\text { resistência } \\
\text { à tração } \\
(\mathrm{GPa})\end{array}$ & $\begin{array}{c}\text { alongamento } \\
\text { na ruptura } \\
(\%)\end{array}$ \\
\hline aço & $5-500$ & 7,84 & 200 & $0,5-2,0$ & $0,5-3,5$ \\
\hline $\begin{array}{c}\text { polipropileno } \\
\text { fibrilada }\end{array}$ & $20-200$ & 0,9 & $5-77$ & $0,5-0,75$ & 8 \\
\hline vidro & $9-15$ & 2,60 & $70-80$ & $2-4$ & $2-3,5$ \\
\hline amianto & $0,02-0,4$ & $2,6-3,4$ & $164-196$ & $3,1-3,5$ & $2-3$ \\
\hline polietileno & - & 0,95 & 0,3 & 0,0007 & 10 \\
\hline sisal & $10-50$ & 1,5 & - & 0,8 & 3,0 \\
\hline $\begin{array}{c}\text { matriz de } \\
\text { cimento }\end{array}$ & - & 2,5 & $10-45$ & 0,0004 & 0,02 \\
\hline
\end{tabular}

\section{2 - ANÁLISE DA MICROESTRUTURA}

O interesse pelo estudo da microestrutura do concreto é recente. Segundo MONTEIRO (1993), ele se deve principalmente ao desenvolvimento do concreto de alta resistência e à tentativa de se reduzir gastos na recuperação e manutenção das estruturas, constituindo-se num caminho promissor para a produção de um material de melhor desempenho.

A microestrutura do concreto é das mais complexas dentre os materiais estruturais. A microestrutura da interface pasta-agregado (zona de transição) é diferente da microestrutura da pasta. Na interface, onde se desenvolve a microfissuração, o fator a/c é maior. devido à exsudação interna. Isso resulta numa morfologia cristalina diferente e em menor resistência mecânica. Segundo MEHTA \& MONTEIRO (1994), a zona de transição influencia as propriedades do concreto, já que é o elo mais fraco da corrente, devido ao grande volume de vazios e às microfissuras pré-existentes. A ela se deve a ruptura do concreto a um nível de tensão mais baixo do que a resistência dos seus dois constituintes principais.

Para se obter um concreto de resistência mais elevada, deve-se reduzir a porosidade da interface e assim uniformizar a microestrutura. Isso pode ser conseguido através do uso de microssílica, superplastificantes e alto consumo de cimento. Com a melhoria da zona de transição, altera-se o comportamento do concreto à compressão. $O$ 
agregado, antes inerte, passa a participar mais ativamente na resistência. $O$ comportamento se torna linear quase até a ruptura, já que se melhora o controle das microfissuras na interface pasta-agregado. O fenômeno é análogo na interface açopasta. Além disso, o concreto de alta resistência apresenta mais microfissuras finas que o concreto de resistência normal, pois o aumento da resistência à tração é maior que o aumento da energia de fratura (MEHTA \& MONTEIRO, 1994).

No concreto reforçado com fibras, as características da zona de transição entre a fibra e a matriz na região da interface destes materiais também são decisivas no comportamento mecânico do compósito, pois a região é mais porosa que o restante da matriz e é determinante nas condições de aderência. Segundo AGOPYAN (1991), o melhor conhecimento da zona de transição permite a elaboração de modelos mais precisos sobre o comportamento do compósito e a possibilidade de alterar as características da interface e, portanto, as propriedades macromecânicas do material.

As fibras normalmente se apresentam em feixes ou em filamentos isolados. Quando na forma de feixe, os filamentos não se dispersam totalmente durante a mistura, mantendo-se parcialmente a estrutura original. A penetração dos grãos da matriz nos reduzidos espaços entre as fibras é difícil. Assim, a unidade básica de reforço consiste num feixe flexível. onde o movimento relativo entre as fibras do feixe é praticamente livre. Caso o compósito envelheça em ambiente úmido, estes vazios podem ser gradativamente preenchidos pelos produtos da hidratação do cimento, transformando o feixe numa unidade rígida.

Para as fibras compostas de filamentos isolados, a zona de transição mais frágil não se localiza necessariamente na interface fibra-matriz. mas um pouco afastada dela, na região mais porosa das camadas formadas pelos produtos de hidratação.

Quando existe afinidade da fibra com as partículas da matriz e o processo de produção é eficiente. a diferenciação da zona de transição com o restante da matriz é menos clara e a resistência de aderência é muito maior.

SAVASTANO JR (1992) estudou as características da zona de transição e sua interrelação com as propriedades mecânicas do compósito, especialmente para a matriz de cimento reforçada com fibras vegetais, fibra de polipropileno e amianto. A zona de transição foi caracterizada através de análise microestrutural. onde se avaliou também a influência da idade de hidratação e do fator a/c. As propriedades mecânicas avaliadas a partir de ensaios mecânicos (tração direta, tração na flexão, tração no fendilhamento e arrancamento) foram relacionadas com a aderência fibra-matriz.

Segundo o autor. a porosidade, principalmente próximo à interface. aumenta quando se utiliza um fator a/c mais elevado. Isso implica em menor resistência à tração, mas num maior índice de tenacidade. Quando a idade de hidratação é maior. há 
uma diminuição da resistência e da tenacidade, no caso das fibras vegetais, devido à redução da resistência da fibra e da sua capacidade de deformação em meio alcalino. Para a fibra de polipropileno, estas propriedades não são afetadas. Apenas se observa a diminuição do comprimento crítico, já que diminui a porosidade da zona de transição.

Para a fibra de polipropileno do tipo multifilamentos, observou-se também que a zona de transição não é muito porosa e nem muito espessa. Como a fibra é impermeável e se forma uma película de água junto à superfície da fibra, pelo efeito parede, ela não apresenta variação dimensional no interior da matriz.

A principal conclusão de seu trabalho foi a comprovação da relação entre as caracteristicas da zona de transição, que variam conforme o tipo de fibra. com a aderência fibra-matriz e, portanto, com o comportamento mecânico do compósito. Quando a resistência de aderência é elevada, há um acréscimo na resistência à tração. A dutilidade também pode melhorar, desde que o comprimento crítico não seja muito pequeno. de modo que ocorra o arrancamento da fibra da matriz. antes de sua ruptura.

\section{3 - MECANISMO DE REFORÇO: INTERAÇÃO FIBRA-MATRIZ}

A eficiência das fibras na melhoria das propriedades da matriz de cimento é controlada por dois fenômenos: transferência de tensões entre a matriz e as fibras, por aderência, e efeito de costura na matriz fissurada, nos estágios mais avançados do carregamento. A aderência é determinante no fenômeno de propagação das fissuras. pois a ruptura da aderência e o escorregamento da fibra consomem energia no processo da fratura. A análise das tensões de aderência na interface normalmente se baseia no fenômeno do arrancamento das fibras, já que a ruptura da fibra é rara nos compósitos de cimento (SHAH \& OUYANG, 1991; BENTUR \& MINDESS, 1990).

O estudo do arrancamento das fibras é fundamental para se entender o aumento da dutilidade nos compósitos. Segundo ALWAN e outros (1991). a capacidade de absorção de energia depende de dois mecanismos: deformação do material e. eventualmente, formação de novas superfícies fissuradas. Nos materiais frágeis. a tenacidade é baixa. pois a deformação resistida é limitada. A introdução das fibras melhora os dois mecanismos, pois o arrancamento das fibras envolve a ruptura da aderência, que altera a configuração das fissuras. e a deformação da fỉbra, que aumenta a capacidade de deformação do material.

Os modelos idealizados para representar o mecanismo de reforço das fibras e sua interação com a matriz são limitados. Eles simplificam a geometria das fibras e a configuração das fissuras. Além disso, não consideram o efeito da flexão localizada da 
fibra quando ela não está perpendicular à fissura, que é a situação real no caso de fibras aleatórias, e as peculiaridades da zona de transição, determinantes no comportamento da interface. As tensões decorrentes da flexão localizada na intersecção da fissura com a fibra pode provocar a ruptura prematura da fibra, quando ela é frágil, ou o seu escoamento e posterior esmagamento localizado da matriz, quando ela é dútil. A existência de uma zona de transição mais fraca que a matriz, anterior à interface, torna a configuração das fissuras mais complexa, pois ela provoca um desvio na trajetória das fissuras, conforme se discute posteriormente. Neste caso, pode haver flexão localizada da fibra mesmo quando ela está alinhada com a força.

O entendimento da natureza da aderência e das tensões na interface junto às fissuras é fundamental para se compreender o comportamento global dos compósitos. Assim, a análise da transferência de tensões e do arrancamento e a dependência destes mecanismos com a microestrutura na região da interface deve preceder a análise do comportamento global (BENTUR \& MINDESS, 1990).

\subsection{1 - ARRANCAMENTO DAS FIBRAS}

As configurações dos ensaios de arrancamento são variáveis. A força axial pode ser aplicada na fibra ou na matriz, que contém uma fibra imersa em seu interior. As tensões tangenciais na interface fibra-matriz e as tensões normais nas fibras para um ensaio típico de arrancamento são ilustradas na Figura 3.3.

Normalmente se considera que o arrancamento ocorre quando a tensão de cisalhamento na interface supera a resistência de aderência e que, inicialmente, a fibra está aderente à matriz. Após a perda da aderência, persiste uma tensão de cisalhamento durante o escorregamento, causada pelo atrito entre a fibra e a matriz, desde que haja tensão normal à fibra.

Alguns modelos consideram que somente com a existência de deslocamentos relativos entre a fibra e a matriz pode haver transferência de tensões na interface. Ou seja, supõe-se que a fibra não está aderente à matriz, e que o deslizamento ocorre desde o início do carregamento, desprezando a adesão entre a fibra e a matriz (SHAH \& OUYANG, 1991). Na verdade, há três condições possíveis para a aderência: região de aderência perfeita (desenvolvimento de tensões elásticas), região não aderente (desenvolvimento de tensões de atrito) e uma combinação destas duas situações.

Antes da fissuração. as fibras e a matriz se deformam conjuntamente. Como os valores do módulo de elasticidade da fibra e da matriz são distintos. surgem tensões na interface. Supõe-se que a aderência nesta etapa seja perfeita. Conforme a distribuição de tensões na fibra, pode haver a perda prematura da aderência. 


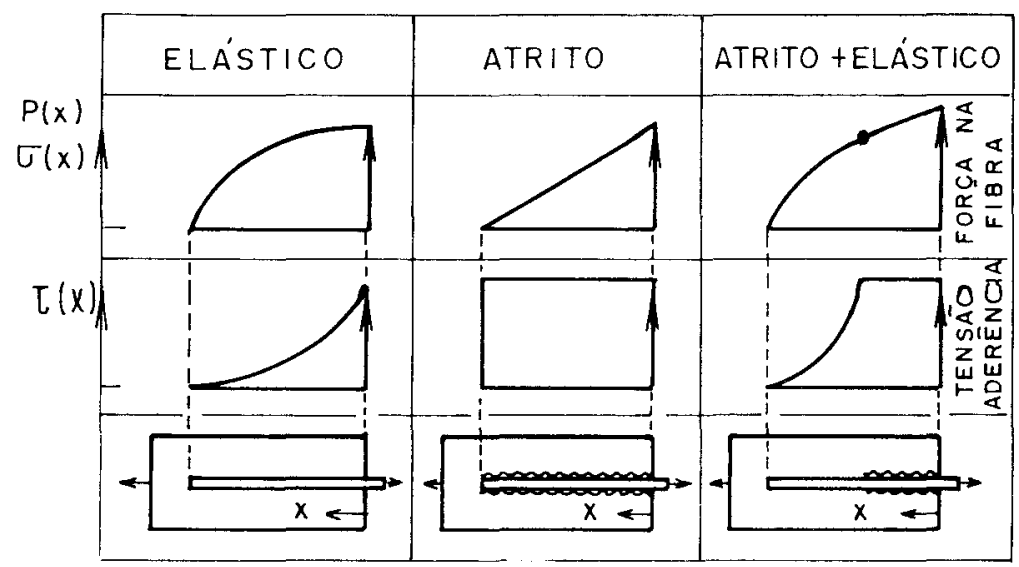

Figura 3.3 - Distribuição de tensões tangenciais na interface e de tensões normais nas fibras durante o arrancamento (BENTUR)

Se a perda da aderência precede a fissuração da matriz e não há o arrancamento brusco da fibra, uma resistência adicional ao deslizamento é mobilizada, pois surgem tensões de atrito na interface, normalmente suposta constante ao longo da região não aderente. A perda de aderência é progressiva e a ruptura é gradual. As tensões de cisalhamento nesta etapa resultam da combinação da tensão elástica. na zona aderente. e da tensão por atrito, na zona onde houve perda da aderência. como mostra a Figura 3.4 .

Quando a fissuração da matriz ocorre antes, há uma concentração de tensões na fibra nas proximidades da extremidade da fissura, como se mostra posteriomente na Figura 3.6. que potencializa a perda da aderência. Os mecanismos de transferência de tensão são os mesmos da etapa anterior à fissuração, mas a posição da tensão de cisalhamento máxima é diferente.

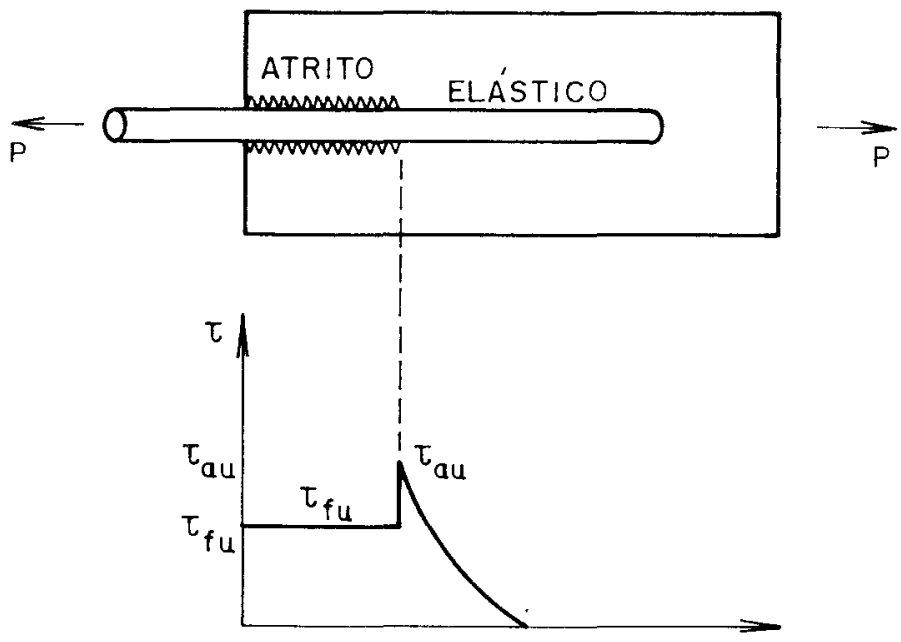

Figura 3.4 - Distribuição das tensões de cisalhamento ao longo da fíbra 
$\mathrm{Na}$ verdade, o atrito pode surgir antes da perda da aderência, se a resistência à tração da matriz é alta e a resistência de aderência é baixa. Nesta situação, a transferência simultânea de tensões de aderência por adesão e por atrito ocorre antes da fissuração. Caso a resistência à tração da matriz seja pequena e a perda da aderência ocorra após a fissuração, o fenômeno é estudado pela Mecânica da Fratura, a partir da análise das tensões à frente da extremidade das fissuras nas proximidades das fibras.

Vários trabalhos quantificam os resultados dos ensaios de arrancamento em função da tensão média de cisalhamento. Segundo BENTUR \& MINDESS (1990) e SHAH \& OUYANG (1991), este enfoque tem pouco significado físico, pois a tensão tangencial máxima é muito maior que a tensão média. Dai a necessidade de se adotar modelos mais realistas. Além disso, a ocorrência das tensões de atrito depende da existência de força normal às fibras. Portanto, ela é sensivel a diversos parâmetros, tais como a variação da temperatura. cargas externas adicionais, coeficiente de Poisson e outros. Assim, o fenômeno do arrancamento da fibra e da transferência de tensões é muito mais complexo do que supõem os modelos unidimensionais.

No caso de fibras não retas (com ancoragem mecânica), não se pode explicar o fenômeno do arrancamento em termos de tensões de cisalhamento. Durante o arrancamento. um volume maior da matriz é mobilizado. Neste caso. as variações nos resultados dos ensaios são menores, pois são menos sensiveis às variações de tensões transferidas por atrito e às propriedades da zona de transição.

Segundo BENTUR \& MINDESS (1990). ao contrário da resistência da matriz, a microestrutura da zona de transição influi na resistência de aderência. conforme mostra a Figura 3.5, onde o fator a/c representa a caracteristica da zona de transição. Para incorporar o efeito desta zona mais frágil. pode-se considerar um parâmetro adicional no modelo, além da tensão na interface. por atrito e adesão. e que representa a menor rigidez da zona de transição (SHAH \& OUYANG. 1991).

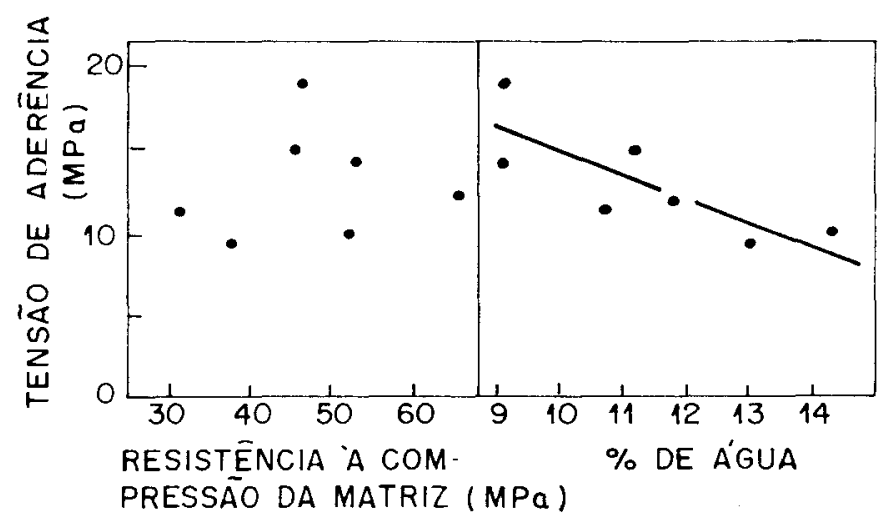

Figura 3.5 - Resistência de aderência no ensaio de arrancamento com fibras retas de aço em função da resistência da matriı c do fator a/c (BENTUR) 
As fissuras são desviadas pelas fibras quando as interceptam. Elas tomam a direção das fibras, influenciadas pela perda da aderência, que não ocorre na superfície da fibra. mas um pouco distante, onde a tensão de aderência é máxima, conforme mostra a Figura 3.6. A alteração da trajetória da fissura, que assume a direção da fibra, corresponde à perda da aderência na zona de transição, mais frágil. Portanto, a fissura percorre um caminho de menor energia, onde a aderência é fraca. Com a mudança na trajetória. há um aumento da dutilidade. Quando a fissura encontra os poros da camada dos produtos de hidratação, ela atravessa a fibra. No modelo do arrancamento, considera-se simplificadamente que a ruptura da aderência ocorre na interface. Logo. a configuração de fissuras é muito mais complexa, como mostra a Figura 3.7.

Nos compósitos em que o volume de fibras é maior, o mecanismo é mais complexo. As fissuras, poucas, curtas e espaçadas, surgem sob tensão reduzida. A tensão aumenta até o ponto em que a contribuição da matriz é máxima, que neste caso pode ser até cinco vezes maior do que da matriz sem fibras, quando pode ocorrer perda da aderència e deslizamento da fibra. A partir daí, há uma homogeneização da configuração de fissuras com o aumento dos deslocamentos.
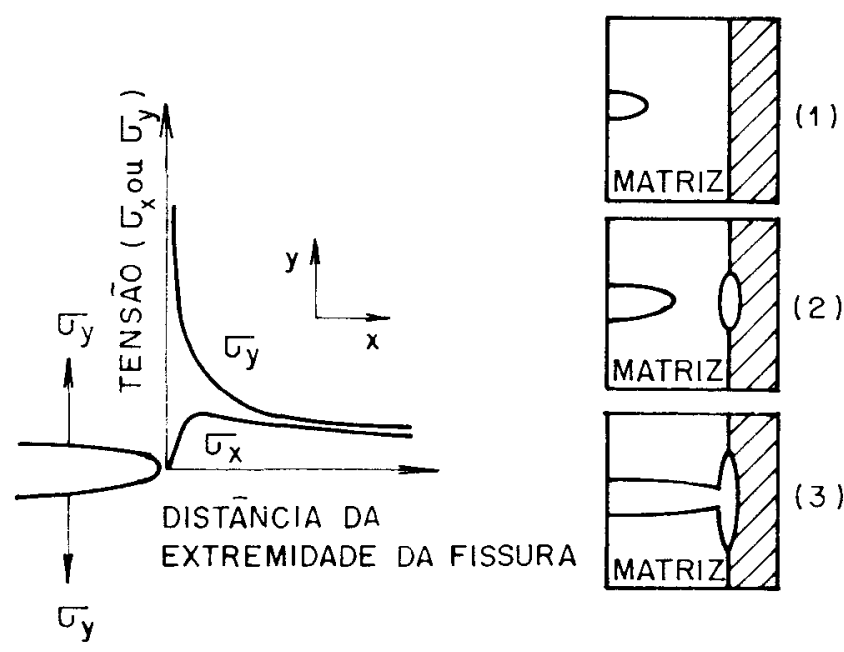

Figura 3.6 - Tensões nas proximidades da fissura (BENTUR \& MINDESS. 1990)

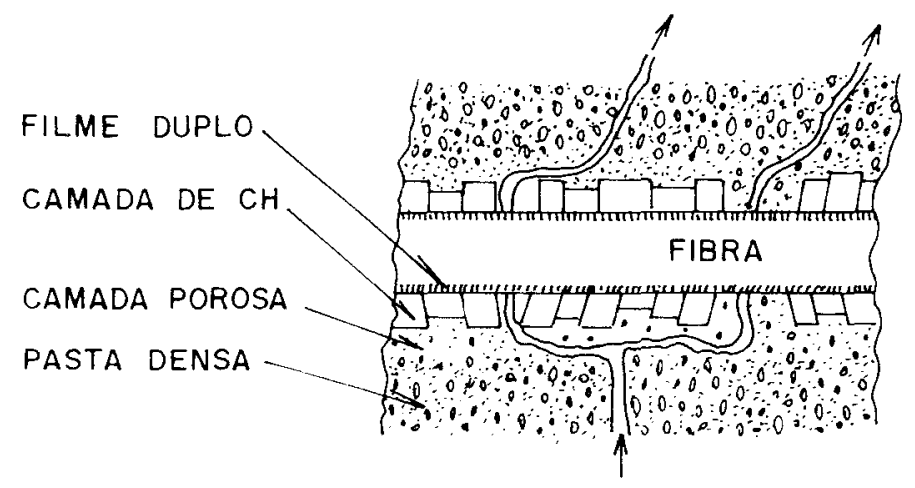

Figura 3.7 - Trajetória da fissura na zona de transição (BENTUR\&MINDESS. 1990) 
Normalmente, os resultados do ensaio de arrancamento são avaliados a partir da variação da força de arrancamento com o escorregamento e o comprimento da fibra, que dependem da relação entre a contribuição dos dois mecanismos de transferência de tensão de aderência, adesão e atrito. Assim, a grande variedade nos resultados dos ensaios se deve basicamente às diferenças nas hipóteses adotadas para a transferência de tensões na interface. A Figura 3.8 mostra o aspecto destas curvas para as três condições de aderência anteriormente citadas. $\mathrm{Na}$ figura, as tensões limites de aderência elástica e por atrito são representadas por $\tau_{\mathrm{au}}$ e $\tau_{\mathrm{fu}}$, respectivamente.
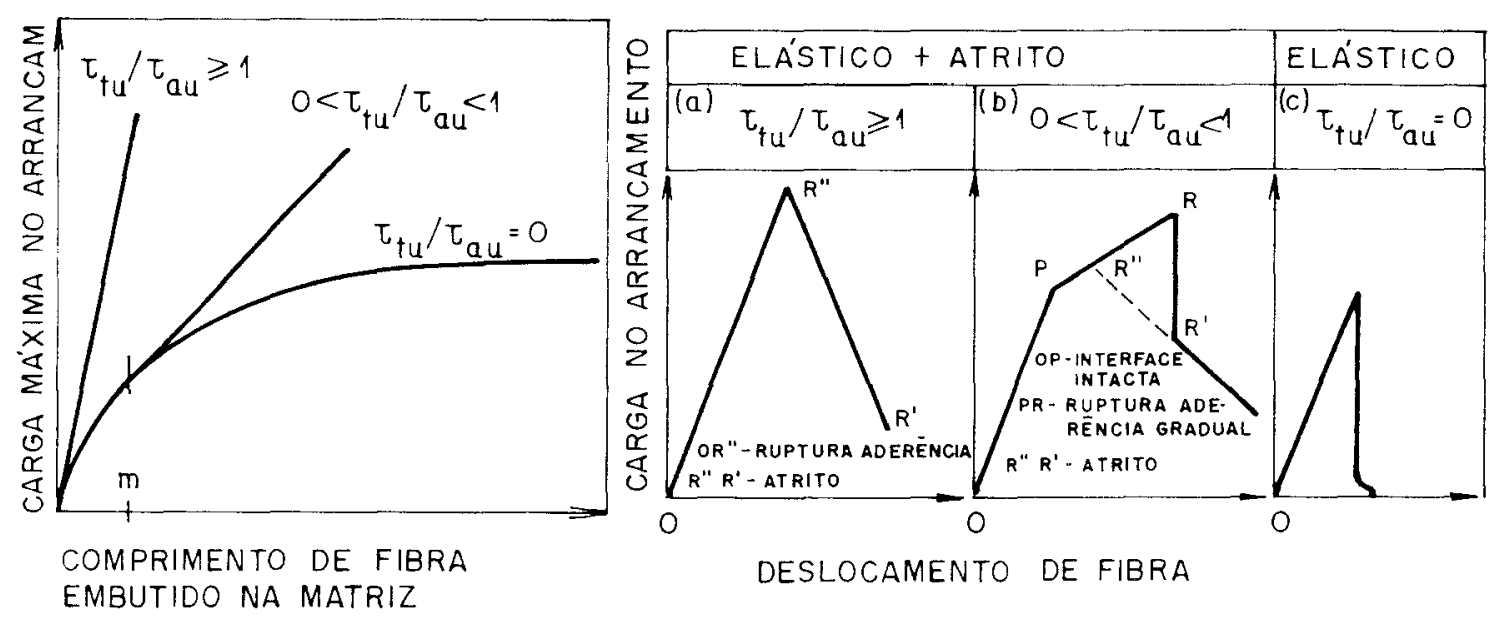

Figura 3.8

a) Variação da força máxima de arrancamento com o comprimento da fibra

b) Variação da força de arrancamento com o deslocamento da fibra

(BENTUR \& MINDESS, 1990)

Quando a aderência por atrito é maior que a aderência elástica. a perda da aderência é gradual, a partir do instante em que o valor da tensão de cisalhamento supera a resistência de aderência elástica. Caso contrário, a maneira como ocorre a perda da aderência depende da relação entre o comprimento da fíbra e o comprimento crítico. Quando se considera somente as tensões elásticas. o arrancamento é brusco. após a força máxima. Observa-se que a força de arrancamento varia linearmente com o comprimento da fibra somente no primeiro caso.

Além da diferença nas hipóteses adotadas para a tensão de aderência, os resultados também dependem das condições do ensaio (temperatura. retração e tensões externas) e das características da fibra, que podem alterar as tensões devidas ao atrito.

Quando o coeficiente de Poisson da fibra, por exemplo, é menor que o da matriz, há um aumento da tensão normal e. consequentemente. da aderência por atrito. pois a contração da matriz é maior que a contração da fỉbra. O fenômeno inverso 
ocorre no caso de fibras dúteis muito extensas, quando pode haver o escoamento da fibra, e de fibras com coeficiente de Poisson elevado, tais como a maioria das fibras de baixo módulo, onde o arrancamento é prematuro (BENTUR \& MINDESS. 1990 e HANANT, 1978).

ALWAN e outros (1991) desenvolveram um modelo para determinar o diagrama carga-deslizamento no ensaio de arrancamento. baseado na relação experimental entre as tensões de aderencia com o escorregamento da fibra, cujas relações típicas são apresentadas na Figura 3.9. O atrito que surge após a carga máxima pode ser constante ou decrescente, neste último caso. devido à desintegração do concreto ao redor da fibra. que a "lubrifica". Ele pode ser representado por um parâmetro de dano. que mede a extensão do decréscimo de resistência de atrito.
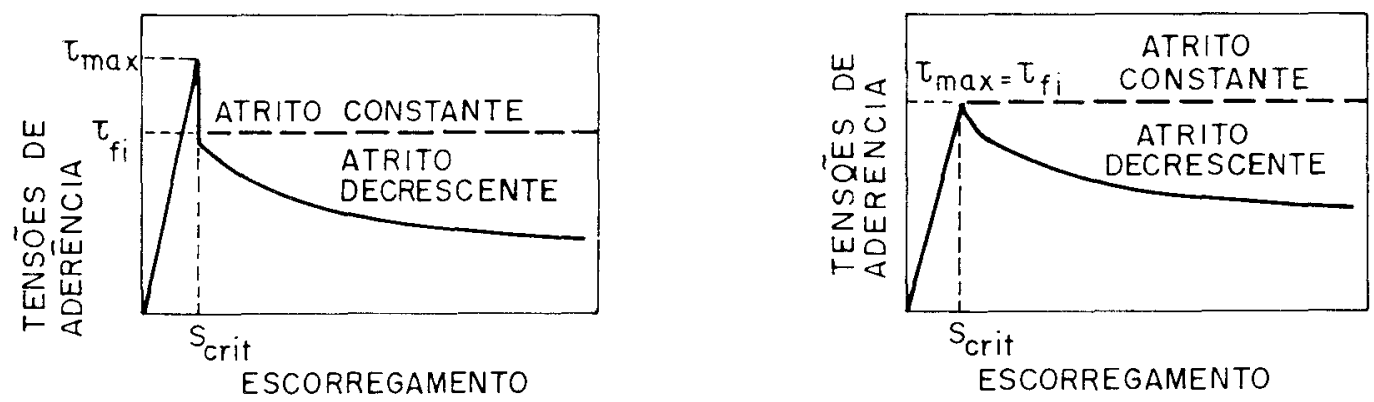

Figura 3.9 - Variação da tensão de aderência com o escorregamento da fibra

A curva típica obtida é ilustrada na Figura 3.10. Ela apresenta três etapas: aderência perfeita, região parcialmente aderente (onde o comportamento é governado pela tensão de aderência elástica máxima e pela tensão de atrito inicial) e região de arrancamento (perda total da aderência, onde o comportamento é governado pela tensão de atrito). A relação entre a energia total e a energia necessária para a perda da aderência vale entre 2,0 e $3,0$.

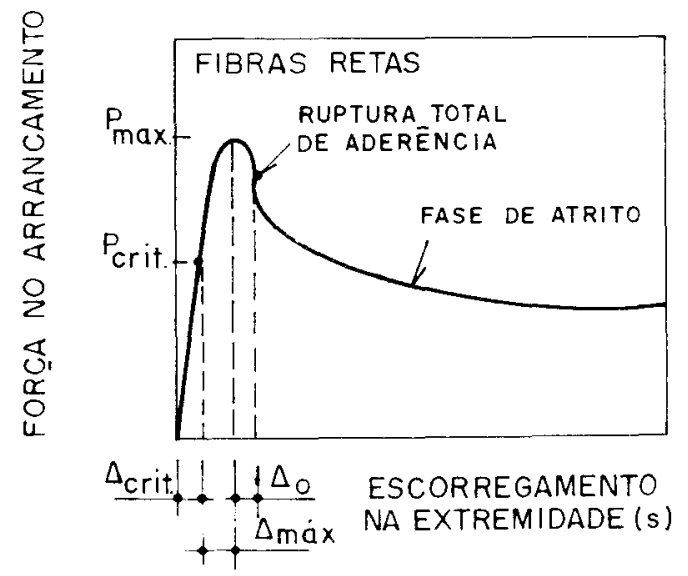

Figura 3.10 - Relação entre força de arrancamento e o deslocamento da fibra 
Os principais parâmetros do modelo são a aderência elástica máxima, o atrito inicial, o coeficiente de dano e a geometria da fibra. A aderência elástica máxima influi somente na parte ascendente da curva, sendo proporcionalmente pouco significativa. $O$ coeficiente de dano, entre 0 (atrito constante) e 0,9 , influi quando o escorregamento é significativo, pois ele afeta apenas a parcela do atrito. $O$ atrito inicial influi tanto na energia para a perda da aderência quanto para o arrancamento. Os dois últimos parâmetros são os mais importantes. A geometria da fibra mais favorável, ou seja. a que requer maior energia para o arrancamento, é aquela de maior diâmetro e, principalmente, maior comprimento, desde que não haja ruptura da fibra. Combinandose estes parâmetros, a maior energia absorvida no arrancamento é obtida com a fibra de maior relação de aspecto.

Os mecanismos de aderência de fibras de aço em concreto também foram estudados por NAAMAN \& NAJM (1991), através de ensaios de arrancamento empregando diferentes tipos de fibra (fibras retas, com vários comprimentos e diâmetros, e fibras com extremidades em gancho e endentadas) e de matriz (matriz de resistência variada, matriz de calda de cimento e matriz com aditivos, tais como latex. microssílica e pozolana).

Observou-se que na fibra reta. a perda da aderência é rápida, pois com o início do escorregamento a resistência de aderência diminui. O valor do escorregamento correspondente à carga máxima é bem menor do que para as outras fibras, até 2 a 3 vezes. Para as fibras endentadas e com gancho nas extremidades, a parte ascendente da curva carga-escorregamento é similar à anterior. sendo que o escorregamento ocorre para a mesma carga. Porém a resistência aumenta. devido à parcela adicional das forças mecânicas na superfície das fibras. Na fibra endentada, o comportamento é cíclico para deslocamentos elevados, apresentando resistência oscilante devido ao movimento não uniforme na matriz, correspondendo ao fenômeno localizado de cada segmento entre os dentes.

$\mathrm{Na}$ fibra com ganchos nas extremidades há uma tendência de retificação do gancho durante o arrancamento. O acréscimo de resistência é significativo, 3 a 4 vezes maior que para a fibra reta. O escorregamento para este valor pode ser até 100 vezes maior, proporcionando um aumento muito grande na energia absorvida no fenômeno. O decréscimo da carga ocorre quando ocorre a perda total da aderência.

Além disso, a matriz mais resistente apresenta escorregamentos menores para forças iguais, inclusive após a força máxima; mas o decréscimo da força é mais brusco. A variação do volume de fibras da matriz, até $3 \%$, provoca aumento insignificante na força máxima de arrancamento, ou seja, as fibras acrescentam pequena resistência de 
aderência, exceto para o concreto produzido através de infiltração de calda de cimento em fôrma com fibras previamente posicionadas ("SIFCON"), onde um outro componente da aderência está presente, o engrenamento entre as fibras.

Os aditivos influem de modo variado. O latex aumenta a força máxima e a pozolana melhora o comportamento geral, mas em menor intensidade que o latex. $\mathrm{O}$ efeito da microssílica é desprezível, exceto pelo aumento da resistência da matriz.

O comprimento da fibra embutido na matriz também influi de maneira diferente conforme o tipo de fibra. Para a fibra reta, altera-se somente o ramo descendente. Na fibra com gancho, ele é desprezivel, já que o efeito do gancho é predominante, e na fibra endentada a variação da resistência com o comprimento é linear, mostrando-se proporcional ao número de dentes.

Os autores ainda isolaram os componentes da aderência decorrentes do atrito e da parcela mecânica, no caso das fibras não retas. Superpondo estas parcelas com o comportamento da fibra reta, obteve-se resultados similares aos das fibras originais. Os componentes mecânicos da aderência seriam responsáveis pelo aumento da força e escorregamento máximo.

A partir dos resultados obtidos, propõem-se valores de resistência de aderência iguais a 1-2.8 MPa. para a fibra reta, 3,5-7.0 MPa, para a fibra com ganchos e 2,8-6.7 MPa, para a fibra endentada. Com latex, consegue-se valores até 9,8 MPa. Estas diferenças tendem a diminuir nos compósitos, onde a resistência ao arrancamento da fibra diminui com o sucessivo arrancamento de fibras anteriores. A contribuição das três fibras é similar na resistência à fissuração, pois a parte ascendente do gráfico é semelhante. Ou seja, a aderência mecânica não influi na resistência à fissuração.

\subsection{2 - EFICIÊNCIA DAS FIBRAS}

Na prática, a adição de fibras curtas à matriz é feita de forma aleatória. Neste arranjo, elas são menos eficientes do que quando contínuas e alinhadas. Os efeitos do comprimento e da orientação das fibras dependem da natureza de sua interação com a matriz, que pode ser analisada a partir das tensões transferidas na interface e das propriedades da microestrutura da interface. O resultado desta análise é usualmente expresso em termos de fatores de eficiência, cujos valores estão compreendidos entre zero e um. Ou seja. a situação real é comparada com os modelos teóricos, onde o reforço é proporcionado por fibras contínuas e alinhadas, em termos das propriedades macromecânicas (resistência e dutilidade). 


\subsubsection{1 - COMPRIMENTO DA FIBRA}

O comprimento mínimo no qual podem se desenvolver tensões de aderência iguais à resistência da fibra é denominado comprimento crítico. Ele pode ser calculado a partir da distribuição de tensões de cisalhamento nas fibras ou a partir da variação da força máxima no ensaio de arrancamento com o comprimento da fibra na matriz. Ou seja, ele depende dos mecanismos de transferência de tensões tangenciais considerados. Caso o comprimento seja inferior ao comprimento crítico, a tensâo na fibra não atinge o valor máximo de sua resistência. Neste caso, o aproveitamento da fibra é apenas parcial.

A influência do comprimento da fibra após a fissuração é ilustrada na Figura 3.11. Observa-se que a partir do comprimento crítico, apesar do aumento da resistência e da aderência para valores crescentes do comprimento, a força máxima de arrancamento e a energia consumida na ruptura diminuem. A ruptura, até então dútil. devido à perda da aderência, e com grande consumo de energia, especialmente no arrancamento da fibra, passa a ser frágil, pois ocorre a ruptura da fibra. com pouco consumo de energia. Portanto, o comprimento crítico corresponde à situação de dutilidade máxima. Para fibras mais extensas que o comprimento crítico. há una contradição entre os valores de resistência e dutilidade da peça. O mesmo raciocínio se aplica para a variação da resistência de aderência.

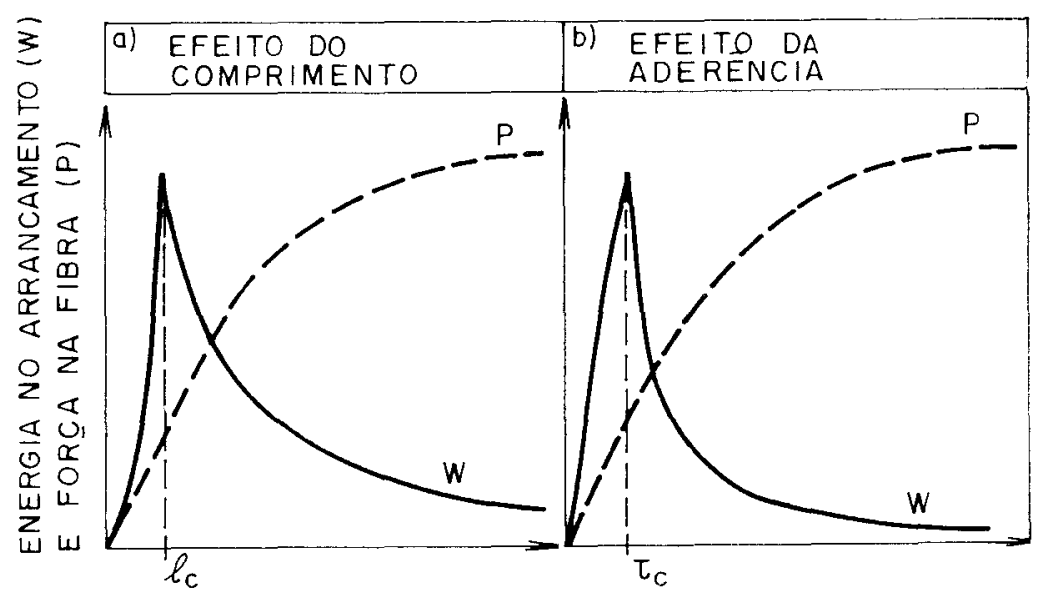

Figura 3.11 - Efeito do comprimento da fibra e da resistência de aderência na força máxima e na tenacidade no ensaio de arrancamento (BENTUR \& MINDESS. 1990) 


\subsubsection{2 - ORIENTAÇÃO DA FIBRA}

Embora a princípio a orientação das fibras na matriz normalmente seja aleatória, o tipo de produção do componente pode favorecer alguma orientação preferencial. como ocorre no caso de utilização de mesa vibratória, onde as fibras tendem a ficar em posição vertical.

Segundo BENTUR \& MINDESS (1990), vários estudos baseados na hipótese de que as fibras só suportam cargas axiais levaram a resultados equivocados sobre a contribuição das fibras na capacidade resistente do compósito. Na verdade, especialmente após a fissuração, pode haver a flexão localizada da fíbra na região da fissura, conforme mostra a Figura 3.12.
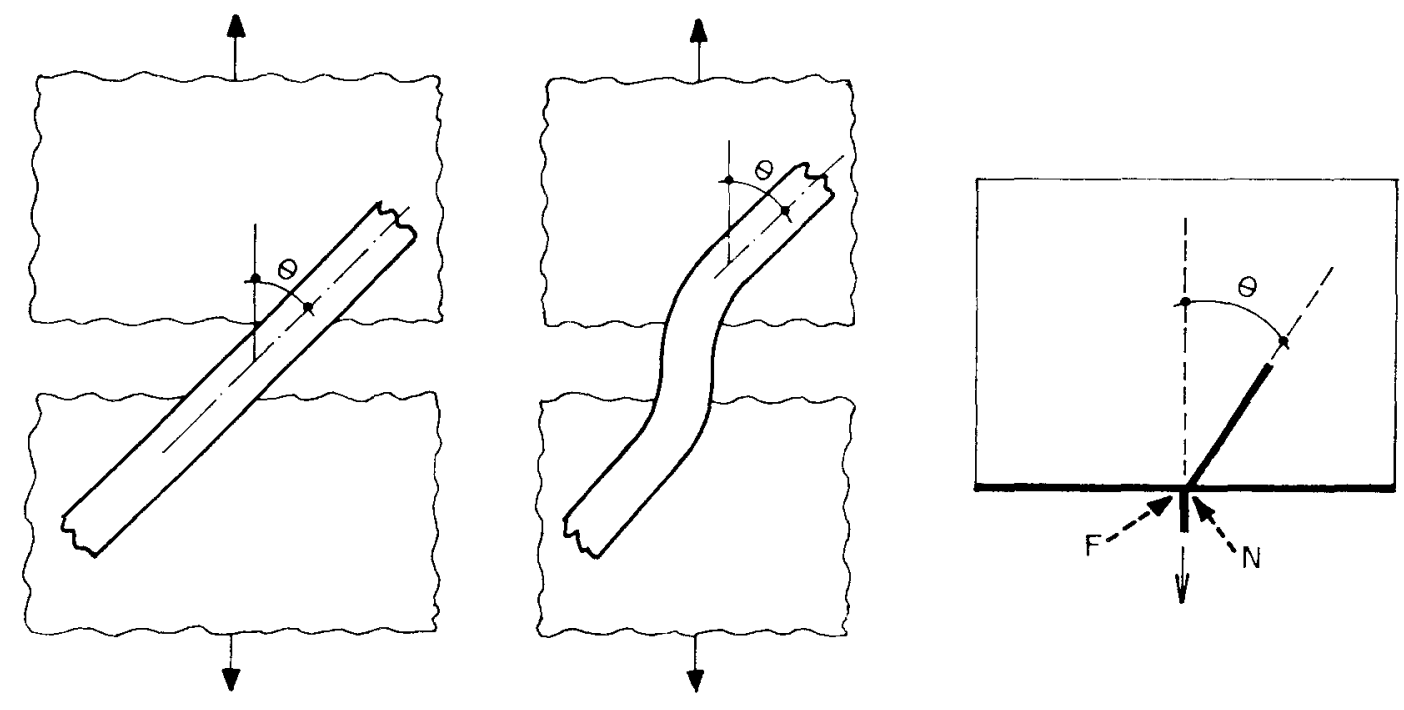

Figura 3.12 - Intersecção de uma fibra inclinada com a fissura (BENTUR \& MINDESS. 1990; SHAH \& OUYANG, 1991)

No arrancamento das fibras inclinadas, a matriz aplica uma força normal na fibra, responsável pela mudança de direção da força, que causa a flexão da fibra e possibilita o surgimento de uma força de atrito adicional, como mostra a Figura 3.12. Assim, a flexão da fibra e as tensões adicionais de atrito são os principais mecanismos de transferência de forças no arrancamento da fibra inclinada (SHAH \& OUYANG. 1991). No caso de fibras dúteis e longas. parte da força de arrancamento e da energia consumida podem advir da deformação plástica da fibra, devido à flexão localizada.

As tensões de compressão na matriz decorrentes das tensões de flexão na fibra devem ser consideradas no arrancamento de fibras não alinhadas. A tensão resistida pela fibra pode ser menor do que aquela prevista no ensaio de arrancamento de fibras alinhadas. Neste caso, a eficiência da fibra diminui. Este fenômeno também é 
importante quando ocorre densificação da zona de transição com a idade. Há um enrijecimento da interface, que passa a resistir às tensões de flexão, o que pode levar à ruptura prematura da matriz na zona fissurada.

Segundo SHAH \& OUYANG (1991), pode haver aumento de resistência para as fibras inclinadas. A energia é sempre maior, devido aos efeitos citados acima. Caso a fibra tenha pouca rigidez à flexão, o efeito da flexão localizada é minimizado e a força no arrancamento pode ser menor do que no caso de fibras alinhadas. $O$ decréscimo da força máxima e da energia no arrancamento para ângulos acima de 45 graus está associado ao esmagamento do concreto. A Figura 3.13 ilustra estes dados.
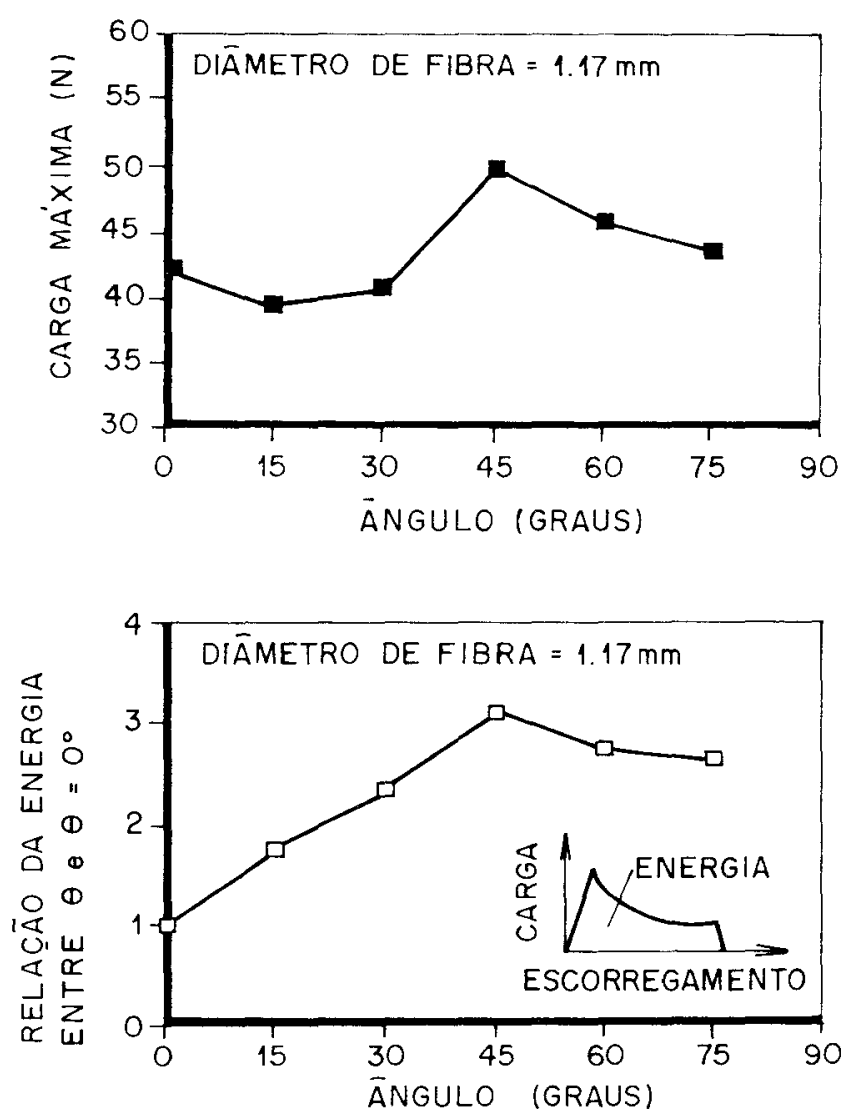

Figura 3.13 - Efeito da inclinação da fibra no arrancamento (SHAH \& OUYANG, 1991)

Segundo SHAH \& RANGAN (1971), a eficiência das fibras aleatórias em relação às fibras alinhadas avaliadas em ensaios de tração direta seria da ordem de $85 \%$. As fibras perpendiculares à direção dó carregamento seriam totalmente ineficientes 


\section{4 - A MECÂNICA DOS COMPÓSITOS}

Entendido o mecanismo de reforço unitário da fibra e sua interação com a matriz, através da análise do arrancamento e das tensões desenvolvidas na interface, pode-se analisar o comportamento global dos compósitos solicitados à tração.

O modelo idealizado para representar a matriz frágil de cimento reforçada com fibras sob solicitação de tração foi inicialmente proposto por Aveston e outros ("ACK model"). Ele prevê a ruptura múltipla da matriz quando a deformação atinge um determinado valor limite. A influência das fibras é significativa somente após a fissuração. O aumento de resistência se deve à transferência de forças na superfície de ruptura, onde as forças são resistidas pelas fibras, que a transferem parcialmente à matriz na região íntegra através de tensões na interface, considerada intacta (o que não é correto, conforme se discutiu anteriormente). Porém, o maior benefício das fibras é o aumento da dutilidade proporcionado pelo arrancamento, precedido pela perda da aderência. A curva tensão-deformação típica do compósito, quando o volume de fibras é maior que o volume crítico, apresenta três estágios, como se mostrou na Figura 3.2: matriz não fissurada, estágio de múltipla fissuração e etapa pós-múltipla fissuração.

Quando surge a primeira fissura, a força é absorvida pelas fibras. Com o acréscimo da força aplicada, surgem novas fissuras, sob tensão aproximadamente constante, até que elas se estabilizem. Esta etapa corresponde à múltipla fissuração. A partir daí o comportamento é governado somente pelas fibras. até a ruptura ou o arrancamento da fibra.

Os principais parâmetros que influem no comportamento do compósito são a resistência e o módulo de deformação longitudinal da fibra e a resistência de aderência. Fibras de baixo módulo apresentam a etapa da fissuração múltipla mais extensa. Quando a aderência é boa, aumenta a deformação correspondente à fissuração e diminuem as deformações na etapa pós-fissuração. Neste caso, o compósito pode se tornar mais frágil, como se discutiu anteriormente em termos do fator de eficiência da fibra e da interação fíbra-fissura. Isto ressalta a importância do controle da aderência na otimização dos compósitos, em relação à sua resistência e dutilidade, através da modificação das propriedades da matriz, da superfície da fibra ou da geometria da fibra. Neste último caso, é importante lembrar que os conceitos aqui apresentados não se aplicam, pois eles só valem para fibras retas.

Segundo SHAH \& OUYANG (1991), a análise do comportamento do concreto na tração axial também é representativa da interação fibra-matriz, tanto quanto o fenômeno do arrancamento. Neste caso, pode-se considerar três etapas distintas, cuja extensão depende das propriedades da matriz, da fibra e da interface: estágio linear (até 
o ponto correspondente ao pico de tensão, onde a contribuição da matriz é máxima), estágio da múltipla fissuração ("strain hardening") e comportamento pós-pico ("strain softening").

Antes da propagação das fissuras, as fibras estão aderentes à matriz. A perda da aderência e o deslizamento da fibra podem ocorrer muito cedo, e se intensificam com a propagação das fissuras. Consideram-se três tipos de interface, conforme mostra a Figura 3.14: fibras perfeitamente aderentes, fibras parcialmente aderentes (com perda de aderência e deslizamento parciais em algumas partes da fibra, conforme o estágio da fissura) e fibras não aderentes (com deslizamento em toda a interface).

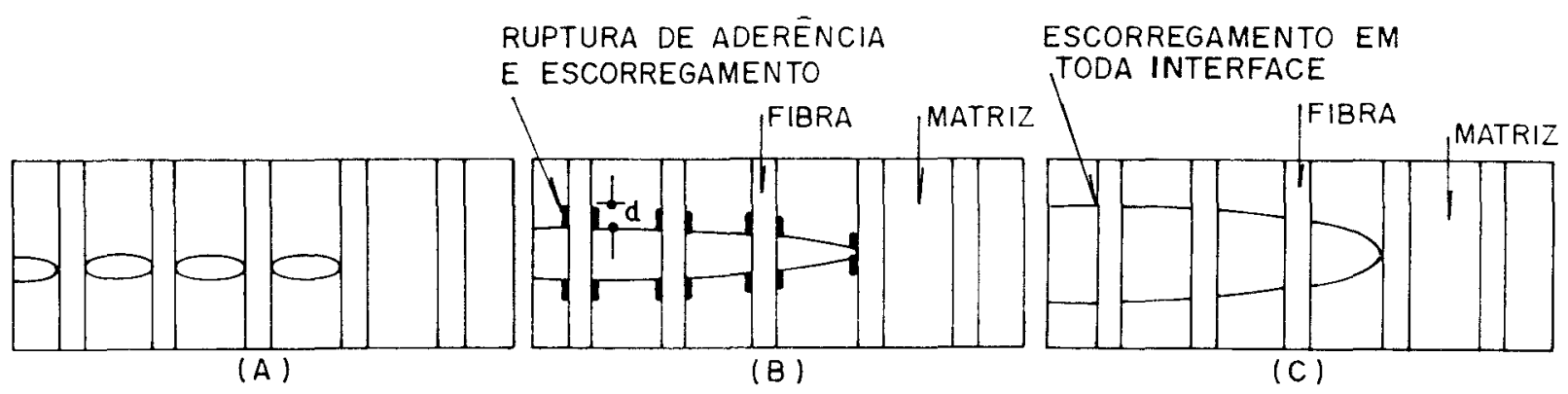

Figura 3.14 - Tipos de interface (SHAH \& OUYANG, 1991)

Quando grande parte da matriz está fissurada. considera-se que o estado de fissuração esteja estabilizado, imediatamente após o pico de tensão, e que as fissuras se propagam sob tensão constante. Segundo o modelo de ACK, a partir de uma distribuição linear de tensões de cisalhamento na região não aderente e de um determinado espaçamento entre fissuras no início desta etapa. as tensões e deformações no compósito e o espaçamento mínimo entre fissuras para a deformação crítica são calculados por balanceamento de energia. Posteriormente $o$ modelo foi complementado, incluindo-se outras condições de aderência da interface: condição inicial, de fibras aderentes, e intermediária, de aderência e escorregamento parciais.

Segundo SHAH \& OUYANG (1991), a geometria da fissura pode ser desprezada quando seu comprimento é excessivo, como na etapa da múltipla fissuração. Antes, porém, ela deve ser considerada, para se definir a intensidade da tensão de aderência, que depende da extensão da fissura ao longo das fibras. O enrijecimento da matriz proporcionado pelas fibras se deve às forças de costura nas fissuras ("closing pressure"), cujo valor e distribuição dependem das propriedades da interface. Estas forças dependem também da posição da fibra ao longo da fissura, do volume e tipo de fibra e da abertura da fissura. Oú seja, a geometria da fissura é afetada pelas forças de ligação ("bridging forces"). 
Os diversos parâmetros do modelo de ACK tem sido calculados a partir de vários procedimentos: a Lei das Misturas, para se determinar o módulo de deformação inicial, a resistência à primeira fissura e a resistência última, a Mecânica da Fratura, para calcular a deformação e a tensão correspondente à primeira fissura e, em alguns casos, a energia de fratura, e os mecanismos da fissuração múltipla, para prever o comportamento pós-fissuração e a deformação ao final do estágio de estabilização das fissuras. Na verdade, somente a combinação destes conceitos permite quantificar ou caracterizar o comportamento dos compósitos (BENTUR \& MINDESS, 1990).

Quando o volume de fibras é reduzido. normalmente não há acréscimo de resistência à tração do concreto, como prevê a Lei das Misturas. Ao volume de fibras, relaciona-se o conceito de espaçamento entre as fibras. introduzido incialmente por Romualdi e Batson para o caso da armadura de reforço (fibras ou armadura contínua). Segundo os autores, para o mesmo volume de armadura, a resistência à tração do concreto seria significativamente maior para espaçamentos reduzidos, principalmente quando menores que $1,0 \mathrm{~cm}$, baseados na equação de Griffith para a fratura do concreto e supondo-se que o comprimento da fissura crítica tem a mesma ordem de grandeza que o espaçamento entre os fios. O aumento da resistência seria decorrente da diminuição do tamanho das falhas, ou do fator de intensidade de tensão na extremidade das fissuras internas (ACI 544.1R).

Segundo SHAH \& RANGAN (1971), o espaçamento teria influência muito menor do que previam os autores. pois os ensaios utilizados para aferir estes resultados foram feitos com fios de maior resistência e menor diâmetro, para manter o mesmo volume e diminuir o espaçamento, o que mascarou os resultados. A influência do espaçamento das fibras na resistência à tração seria mais significativa para valores menores que $2,5 \mathrm{~cm}$. Assim como acontece com elementos reforçados com armadura contínua, onde a influência do aço é insignificante na resistência à fissuração (na flexão, tração e compressão), a não ser para quantidades mais elevadas, quando a resistência à fissuração, no caso das fibras, pode aumentar até 5 vezes (SHAH, 1991).

Isto não significa que a resistência à tração não seja influenciada pelas fibras. Elas estabilizam a propagação das fissuras, pois a carga máxima só é atingida após um crescimento substancial das fissuras. A influência das fibras pode ser entendida a partir da curva-R, como se mostra posteriormente na Figura 3.17. No concreto (material quase-frágil), a fissura é heterogênea e tortuosa. A propagação da fissura é acompanhada do engrenamento dos agregados. o que requer aumento da energia necessária. proporcional aos valores das tensões de costura. Isso é subestimado pela Mecânica da Fratura Linear. Com as fibras. haveria ainda uma parcela de energia adicional. similar a dos agregados. correspondente ao arrancamento das fibras na 
região da fissura. Quando a distribuição das fibras é uniforme e o espaçamento é menor do que o tamanho da fissura crítica, seu efeito é menos importante que o volume de fibras e as relações da interface (SHAH, 1991).

A utilização do conceito de espaçamento entre as fibras (Mecânica da Fratura Linear) e da Lei das Misturas para a determinação da resistência à fissuração na flexão também são sugeridos no ACI 544.1R (1987).

\subsection{1 - MÉTODO DOS MATERIAIS COMPOSTOS}

O método dos materiais compostos se baseia na Lei das Misturas, que considera as propriedades dos compósitos iguais às médias ponderadas das propriedades individuais dos componentes. Ele é utilizado nos compósitos de fibro-cimento solicitados à tração axial para a determinação do módulo de deformação longitudinal inicial e da tensão correspondente à primeira fissura, ou seja, na etapa elástica não fissurada, supondo-se a aderência perfeita entre a fibra e a matriz. Para volumes pequenos, a contribuição das fibras nesta etapa é praticamente desprezível. Mesmo para volumes maiores e fibras de alto módulo, a resistência e o módulo do compósito variam pouco, de 10 a $20 \%$.

Após a fissuração, o método pode ser usado para o cálculo da resistência última, considerando-se apenas a contribuição das fibras e supondo-se que a resistência de aderência é maior que a resistência da fibra. No caso de fibras curtas, onde o arrancamento é prematuro, a resistência depende do comprimento da fibra. Neste caso. adota-se a resistência ao arrancamento como referência, ao invés da resistência da fibra (BENTUR \& MINDESS, 1990 e DANTAS, 1987).

Outra aplicação importante é na determinação do volume crítico, que pode ser calculado, segundo HANNANT (1978), pela intersecção das curvas de resistência das etapas linear e pós-fissuração, onde se considera somente a ação das fibras. O volume crítico depende principalmente da relação de aspecto da fibra, mas também varia com a aderência e a distribuição das fibras na matriz, conforme mostra a Figura 3.15. Quando a relação de aspecto é elevada, o volume crítico é menor, já que a superfície específica. onde se desenvolvem as tensões de aderência, é maior. Raciocínio análogo se aplica para a resistência de aderência. Em relação à distribuição das fibras, a eficiência aumenta para as fibras distribuídas numa dimensão, ou seja, o volume crítico é menor neste caso. 

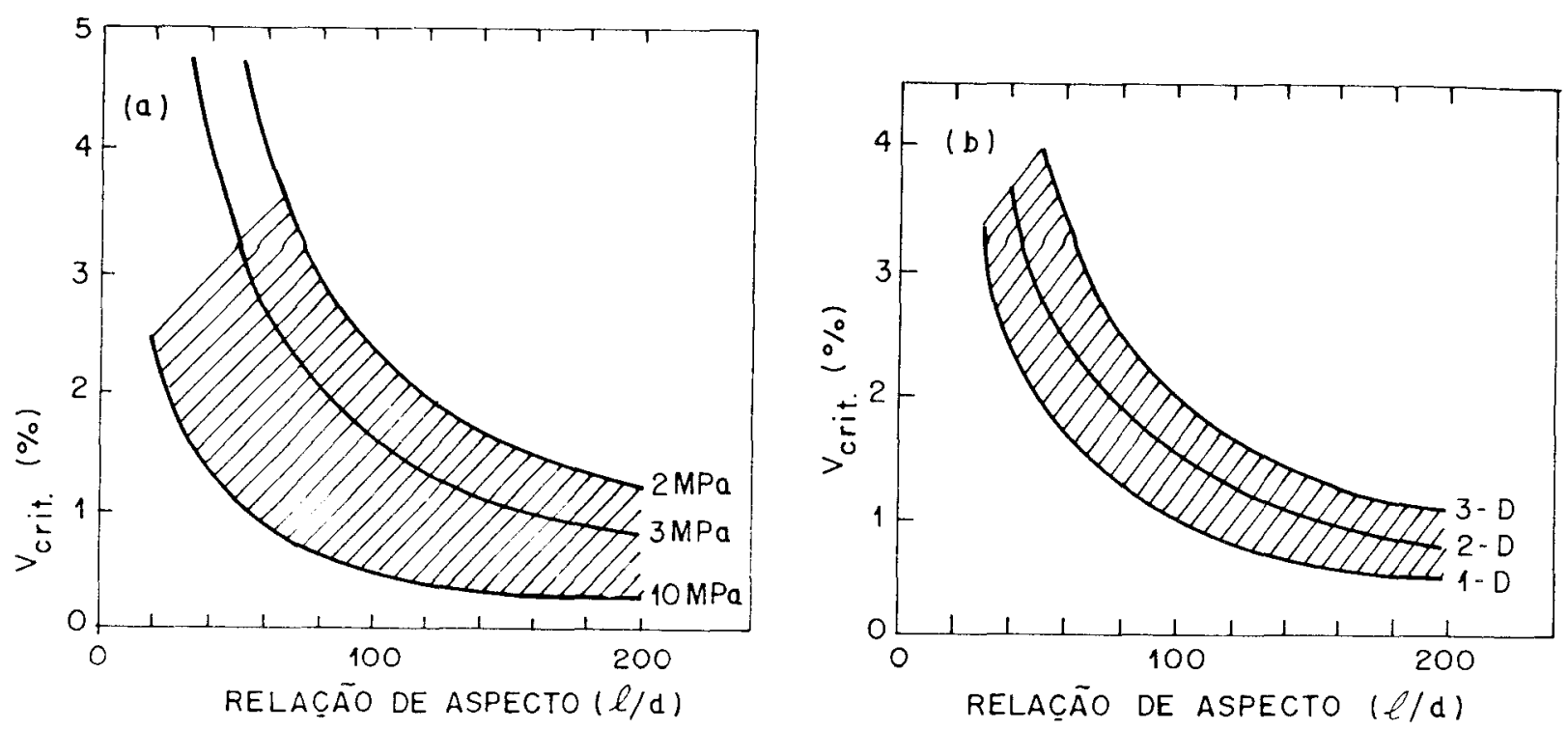

Figura 3.15 - Variação do volume crítico com a relação de aspecto, a resistência de aderência e a distribuição das fibras (BENTUR \& MINDESS, 1990)

Quando o volume de fibras na matriz é maior que o volume crítico, a contribuição das fibras é mais significativa, já que ocorre a múltipla fissuração da matriz. Ou seja. após a fissuração, a transferência de forças entre a matriz e as fibras ocorre sem o arrancamento ou ruptura da fibra, resultando em acréscimo da resistência, além da dutilidade.

\subsection{2 - MECÂNICA DA FRATURA}

A Mecânica da Fratura analisa a ruptura do concreto a partir da propagação das fissuras. Devido à sua heterogeneidade, o processo de fratura do concreto não é linear. já que as zonas microfissuradas que surgem incorporam descontinuidades ao fenômeno. A zona de fratura ("fracture process zone") ou as microfissuras descontínuas que surgem à frente das fissuras são responsáveis pelo "softening behavior" do concreto (SCHLANGEN, 1993), que representa a diminuição gradual das tensões com a evolução da deformação no concreto fissurado. Outro fenômeno importante relacionado com a propagação das fissuras e com a consequente redistribuição de forças entre o concreto e a armadura é o "tension-stiffening". que representa o enrijecimento ou a diminuição da tensão na armadura, devido ao concreto aderente entre fissuras (LEONHARDT, 1988).

Segundo os conceitos da Mecânica da Fratura, a ruptura do material com o crescimento rápido de uma fissura pré-existente ocorre quando a energia armazenada é tal que, durante o crescimento da fissura. a energia liberada pelo material é maior que a 
energia que ele absorve, ou a energia necessária para o incremento da fissura. A equação de Griffith é a base da Mecânica da Fratura Linear. Ela fornece o valor da resistência de fratura de um material frágil e elástico-linear, que depende do comprimento da fissura e da taxa crítica de liberação de energia.

Ou seja, a fratura ocorre quando a fissura atinge um comprimento crítico, ou quando, para uma determinada fissura, a tensão atinge o valor crítico, correspondente ao fator critico de intensidade de tensão, $K_{c}$. Segundo o modelo de Griffith, a ruptura de materiais frágeis decorre das imperfeições naturais na estrutura (microfissuras ou descontinuidades, que no concreto são inerentes à sua estrutura cristalina e aos vazios incorporados no processo produtivo). Na borda destas falhas, ocorre uma concentração de tensões que direciona o processo de ruptura. O tamanho do elemento tem influência no valor da tensão de ruptura. pois peças maiores têm mais e maiores falhas aleatórias. Ou, conforme MEHTA \& MONTEIRO (1994), as pequenas imperfeições tem efeitos mais danosos do que as grandes imperfeições nas propriedades dos materiais, ao contrário do que previam os critérios de ruptura, desde que seja mantida a similaridade da geometria das falhas. A Mecânica da Fratura, ao contrário da modelagem simplista de resistência, considera o balanço energético e relaciona a dimensão das imperfeições com a resistência à tração do material.

O critério de ruptura de Griffith é ideal para os materiais frágeis. Mesmo assim. sua aplicação deveria ser restrita às seções de grande tamanho, onde os danos são maiores. Elementos de tamanho "normal" deveriam ser estudados pela Mecânica da Fratura Não Linear. Porém. segundo SHAH \& OUYANG (1991), mesmo desprezando a natureza "quase-frágil" da matriz de cimento e o efeito do tamanho. o critério é muito utilizado para prever o comportamento mecânico de compósitos com matriz de cimento.

Os conceitos da Mecânica da Fratura associados ao Método dos Elementos Finitos tem sido utilizados para modelar os mecanismos de enrijecimento da armadura e a diminuição gradual da tensão no concreto fissurado, onde os danos internos provocados pela microfissuração são relacionados com parâmetros de energia. Segundo FEENSTRA \& DE BORST (1993), o comportamento do concreto armado na tração pode ser representado pela superposição de três mecanismos: o comportamento elasto-plástico da armadura. o "tension-softening" do concreto e o "tension-stiffening".

Segundo GUINEA (1994), a redução gradual da tensão no concreto tracionado após o pico de tensão pode ser modelada através de uma função bilinear, que varia com a resistência à tração, a energia específica de ruptura e com parâmetros geométricos da curva de variação da abertura de uma fissura pré-existente no ensaio de flexão, onde a 
parte ascendente da curva representa a ruptura da aderência dos agregados e a parte descendente corresponde ao arrancamento dos agregados.

O fenômeno é localizado e representa o decréscimo gradual da resistência mecânica devido ao aumento da deformação imposta ao material, característico de materiais "quase-frágeis". Ele também ocorre no concreto comprimido, mas sua modelagem é mais complexa. Nestes casos, pode-se utilizar modelos micromecânicos, que descrevem o crescimento das fissuras e sua relação com o "softening behavior" e a estrutura interna do material. Considera-se as duas fases do concreto, agregado e pasta. e as características da interface onde inicia a fissuração, que pode ser descrita a partir de modelos constitutivos para a ruptura da interface (VONK, 1993).

A resistência à compressão do concreto com fibras analisada sob a ótica dos modelos micromecânicos foi proposta por LI (1992), baseado em modelos clássicos de ruptura à compressão de sólidos frágeis. A ruptura é analisada em termos do parâmetro de intensidade de tensão e a influência das fibras é considerada pela sua resistência à propagação das fissuras e pela possível degradação que elas incorporam ao concreto. devido à maior quantidade de poros e de microfissuração. Ou seja, as fibras reforçam o concreto. mas também introduzem falhas. A resistência é inicialmente maior mas, com o aumento do volume, pode diminuir, pois aumentam os vazios e a densidade de microfissuras. Estas falhas são sensíveis ao tipo de fibra, da matriz e ao processo de produção. Em função da eficiência e da quantidade das fibras nas fissuras e dos defeitos incorporados, pode haver aumento ou diminuição da resistência. Portanto, a correlação entre a resistência e o volume de fibras não é tão simples. Além disso, as vantagens das fibras sob compressão biaxial devem aumentar.

Segundo SCHORN \& RODE (1991), o processo de ruptura numa peça de concreto submetida à tração axial pode ser dividido em três etapas: formação de microfissuras (que ocorre inclusive após a carga máxima), acúmulo de microfissuras (que começa um pouco antes da carga máxima) e propagação das macrofissuras (até a fratura). Os autores avaliam a energia da fratura, para a formação de novas fissuras e para a propagação das fîssuras. através de simulação numérica.

No concreto reforçado com fibras. a capacidade de deformação das fibras é muito maior que da matriz. Assim, a matriz rompe antes da mobilização de toda a resistência das fibras. Portanto, a influência das fibras é mais significativa após a fissuração (HANNANT, 1978). A interação fibra-matriz ou o modo como as fibras aumentam a resistência e, principalmente, a tenacidade do concreto ("crack arrest mechanism"), também podem ser estudados pela Mecânica da Fratura. 
Porém, a análise linear da Mecânica da Fratura não é adequada para a etapa pós-fissuração. Por isso, nesta etapa normalmente se considera a não linearidade, devido à descontinuidade da fissuração (zona de fratura à frente da fissura). Neste caso, os parâmetros da Mecânica da Fratura variam, pelo menos, com o volume de fibras, ao contrário da análise linear (BENTUR \& MINDESS, 1990). Segundo MEHTA \& MONTEIRO (1994). os parâmetros mais importantes na consideração da zona de evolução da fratura são a posição da extremidade da fissura, o traçado da abertura da lissura e o estado geral da microfissuração à frente da extremidade da fissura. Normalmente são utilizados modelos simplificados para determinar a distribuição de deformação. tais como o modelo da faixa de fissuração difusa, onde a zona de fratura é representada por uma faixa de material microfissurado de largura constante, e o modelo da fissura fictíca. onde a zona de evolução da fratura é substituída por uma fissura fictíca equiralente.

Quando se considera a interação fibra-fissura com os conceitos da Mecânica da Fratura. pode-se tratar de três problemas distintos: o aumento da resistência de fissuração. a estabilização da fissuração e a ruptura da aderência devido à propagação da fissura na interface. como se explica a seguir.

Antes da fissuração, as deformações na fibra e na matriz são iguais. Quando surge uma fissura, a matriz tende a se alongar mais do que a libra, devido à concentração de tensões à frente da fissura. A fibra, por ser mais rígida, se opõe a essa tendência e. através de tensões de aderência na interface, aplica forças de obstaculização que reduzem a concentração de tensões na matriz. diminuindo o fator de intensidade de tensão. Como resultado, são necessárias novas forças aplicadas para que haja a propagação da fissura. de modo que o campo de tensões à frente da fissura corresponda ao valor crítico do fator de intensidade de tensão. Quanto menor o espaçamento entre as fibras, mais se acentua este efeito (BENTUR \& MINDI:SS, 1990 e SHAH \& OUYANG. 1991). A Figura 3.16 ilustra estes dados.

A determinação da resistência à fissuração pela Mecânica da Fratura também pode ser feita pela análise das trocas de energia envolvidas na formação de uma fissura de um elemento submetido à tração. tais como o trabalho realizado pelas tensões aplicadas (aumento do comprimento). redução da energia de deformação clástica da matriz após a fissuração (encurtamento), trabalho consumido na ruptura da aderência. trabalho consumido no deslizamento da fibra (aderência por atrito) e trabalho consumido no alongamento da fibra. após a fissuração da matriz.

A fissura ocorre quando a energia realizada na deformação da matriz (as duas primeiras parcelas) é maior que a energia consumida na ruptura. A deformação 
correspondente à primeira fissura aumenta proporcionalmente com o aumento do volume de fibra, da tensão de aderência por atrito e com a diminuição do diâmetro da fibra. Portanto, o método é coerente com o conceito do espaçamento das fibras.

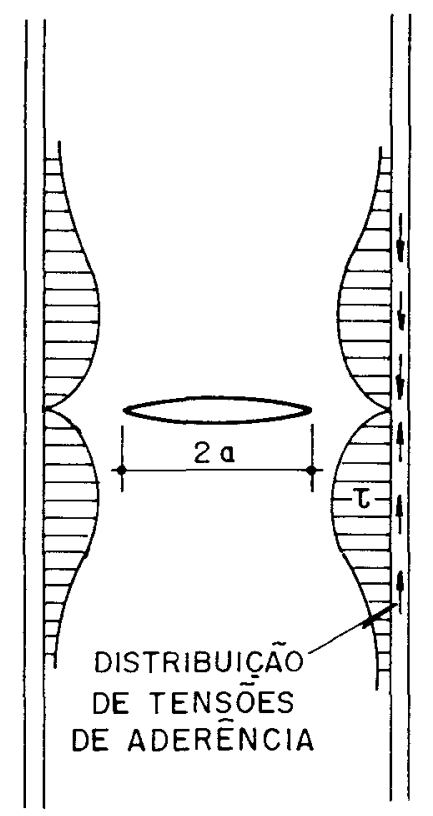

Figura 3.16 - Forças de obstaculização e distribuição de tensões tangenciais (BENTUR \& MINDESS, 1990)

Após o início da fissuração, as fibras devem inibir a propagação instável das fissuras. Em virtude da complexidade da configuração das fissuras nesta etapa, quando existem microfissuras próximas e à frente da fissura principal, torna-se difícil prever a geometria da fissura e aplicar os conceitos lineares da Mecânica da Fratura. A transferência de tensões através das fissuras ocorre por vários mecanismos. Pode-se identificar três zonas distintas: zona de tração livre, zona de transferência de tensões pelo escorregamento das fibras (por atrito) e zona de microfissuração. mas com continuidade e engrenamento dos agregados suficientes para que ocorra alguma transferência de tensão na matriz. Vários modelos foram propostos para considerar estes efeitos.

Finalmente, para a análise da perda da aderência e arrancamento da fibra, a Mecânica da Fratura também pode ser utilizada como uma alternativa ao método de transferência de tensões de cisalhamento na interface, descrito anteriormente. Segundo BENTUR \& MINDESS (1990), os parâmetros utilizados na Mecânica da Fratura são mais fáceis de se medir experimentalmente do que as tensões de aderência. A zona não aderente pode ser tratada como uma fissura na interface, pois a tensão tangencial na 
matriz é nula nesta região, onde se pode aplicar a teoria de Griffith para estudar a sua propagação e eventualmente considerar a contribuição do atrito na zona não aderente.

Pelo que se expôs, a análise da fissuração em elementos de concreto é representada com maior fidelidade pela Mecânica da Fratura Não Linear. O modelo proposto por OUYANG \& SHAH (1994) para elementos de concreto armado tracionados, por exemplo. considera o concreto um material quase-frágil, onde a sua natureza coesiva (zona de fratura) no processo de fratura é representada pela curva de resistência à fratura, curva $R$, com a qual se calcula a energia necessária para a propagação da fissura.

A abertura e o espaçamento das fissuras podem ser previstos através do balanceamento da energia de deformação liberada na fissuração, considerando-se a fissuração múltipla, compatível com a presença da armadura, com a energia necessária para a ruptura da aderência, para o deslizamento da armadura e para a fratura do concreto.

A energia de fratura do concreto é determinada pelas curvas de resistência à fratura, onde a taxa de liberação de energia depende da extensão de uma fissura iniciada por um chanfro em " $\mathrm{V}$ ". A curva $\mathrm{R}$, portanto, representa a energia necessária para a evolução de uma fissura inicial de comprimento conhecido. A quantidade de energia liberada na propagação da fissura, energia de deformação, é fornecida pela curva $G$. Quando $G=R$ a fissura se propaga, ou seja, ela atinge seu comprimento crítico. Para os materiais frágeis, a propagação da fissura é catastrófica, conforme se observa na Figura 3.17. No concreto, devido aos mecanismos de obstaculização da fissuração, tais como as forças de ligação dos agregados, a propagação é estável, até que a variação da energia liberada com o crescimento do comprimento da fissura seja igual à variação da energia consumida.

No caso dos compósitos, o mecanismo de enrijecimento proporcionado pelas fibras também pode ser explicado pelo comportamento da curva-R (SHAH \& OUYANG, 1991). Na matriz frágil, a taxa crítica de liberação de energia de deformação independe do tamanho da falha, segundo o modelo de Griffith. Na matriz de cimento, ao contrário, o crescimento da fissura é heterogêneo, acompanhado por vários mecanismos de fratura, que requerem mais energia para a propagação da fissura. conforme mostra a curva- $\mathrm{R}$ dos materiais quase-frágeis, o que resulta num crescimento estável da fissura. Nos compósitos. existe um mecanismo adicional ("bridging forces") que impede que as microfissuras se tornem macrofissuras. que resulta no aumento da resistência ao crescimento da fissura. O ponto em que a fissura se torna instável corresponde ao início da fissuração generalizada ou ao pico de tensão. 


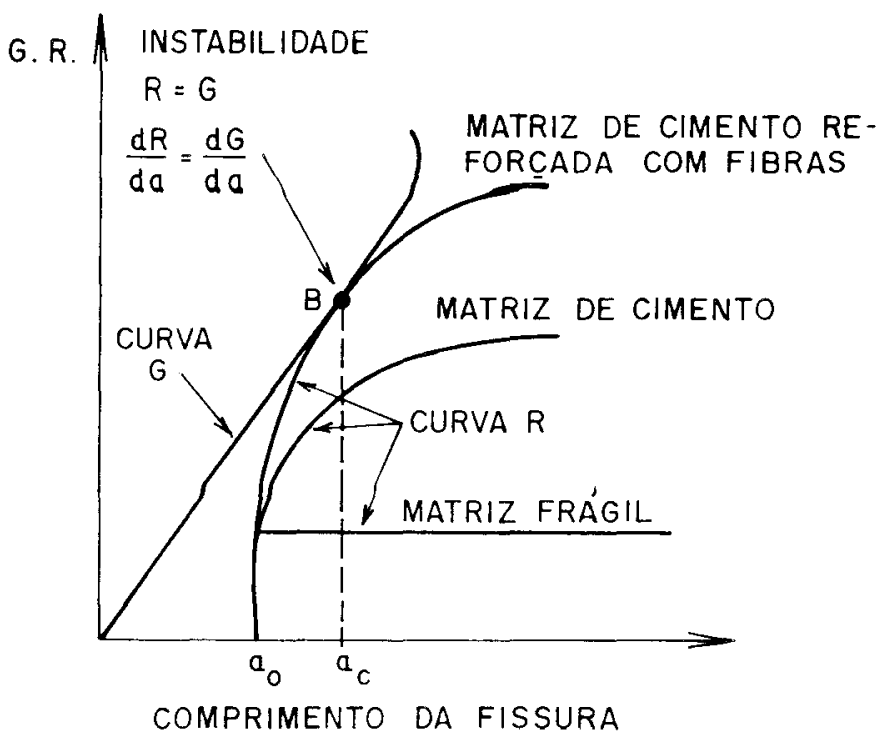

Figura 3.17 - Curva R de materiais frágeis e quase-frágeis (SHAH \& OUYANG, 1991)

Vários outros modelos tem sido propostos para a matriz quase-frágil de cimento. O modelo da fissura fictícia considera a fratura coesiva do concreto, em que as tensões de coesão na zona microfissurada diminuem gradualmente. Ele descreve a formação de microfissuras. que surgem quando a tensão de tração atinge a resistência do material e que iniciam o "softening behavior". A macrofissura, livre de tensões coesivas, forma-se quando a abertura da fissura atinge um valor crítico. Logo, os parâmetros principais são a resistência à tração, a abertura crítica da fissura e a energia de ruptura (VONK, 1993). O comportamento do concreto é representado através da curva $\sigma-\varepsilon$ das partes não fissuradas e fissurada, considerando-se que as tensões de ligação diminuem com o aumento da abertura da fissura, como mostra a Figura 3.18.
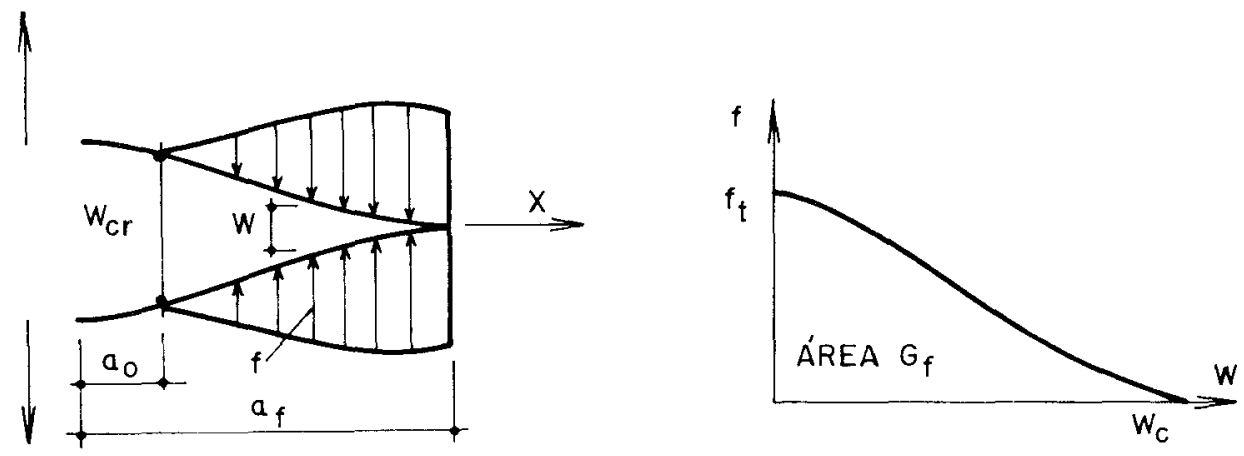


\subsection{3 - ETAPA DA FISSURAÇÃO MÚLTIPLA}

A fissuração múltipla é a etapa correspondente à formação de várias fissuras sob tensão aproximadamente constante (comportamento pseudo-plástico), decisiva para o aumento da dutilidade do concreto. O modelo de ACK foi o primeiro a descrevê-la completamente, através da relação tensão-deformação e da configuração das fissuras. Inicialmente para o caso de fibras contínuas e alinhadas, considerava-se somente a transferência de tensões de atrito. A fissuração era idealizada em blocos, cujo comprimento, correspondente ao espaçamento entre as fissuras, era determinado em função da transferência de tensões na interface. A formação de novas fissuras continuaria até que a matriz se separasse totalmente em segmentos com comprimentos definidos. Então, cargas adicionais provocariam o alongamento da fíbra até a sua ruptura ou arrancamento. Mais tarde, o modelo foi modificado para considerar os efeitos do comprimento e orientação das fibras e de outros mecanismos de transferência de tensões na interface.

Segundo HANNANT (1978), a etapa posterior à fissuração múltipla que corresponde ao acréscimo de resistência normalmente não se verifica na prática, pois, além do volume reduzido, as fibras são curtas e aleatórias, incapazes de absorver a carga após a fissuração da matriz.

As condições para a existência da fissuração múltipla também podem ser estudadas por análise micromecânica baseada na Mecânica da Fratura. Os parâmetros micromecânicos que determinam o volume crítico de fibras estariam relacionados com a tenacidade da matriz. a aderência fibra-matriz e as características da fibra que, quando combinados de modo adequado, resultam em redução do volume crítico; por exemplo, com matriz fraca e aderência e relação de aspecto elevadas. Além de satisfazer a exigência do volume crítico, a ocorrência do fenômeno depende de condições relacionadas com a energia de fratura do material (WU \& LI, 1994).

O mecanismo de enrijecimento e de aumento da capacidade de deformação do concreto proporcionado pelas fibras foi estudado por TJIPTOBROTO \& HANSEN (1991), baseado nas trocas de energia durante a fissuração da matriz. Para volumes pequenos de fibras haveria apenas aumento da dutilidade. sem a ocorrência da fissuração múltipla. com variação desprezivel da resistência à tração. Para volumes elevados, a capacidade de deformação do concreto seria muito maior, com ocorrência da fissuração múltipla, pois a energia necessária para a propagação das fissuras iniciais seria maior do que a necessária para abertura de novas fissuras, principalmente devido à energia necessária para a ruptura da aderência. Em ensaios com concreto de alta resistência reforçado $\mathrm{com}$ até $12 \%$ de fibras de aço, não se observou fissuras visíveis 
até o escoamento da armadura longitudinal. Ou seja, as fibras limitaram a propagação das microfissuras e a concentração das tensões. A Figura 3.19 ilustra estes dados.

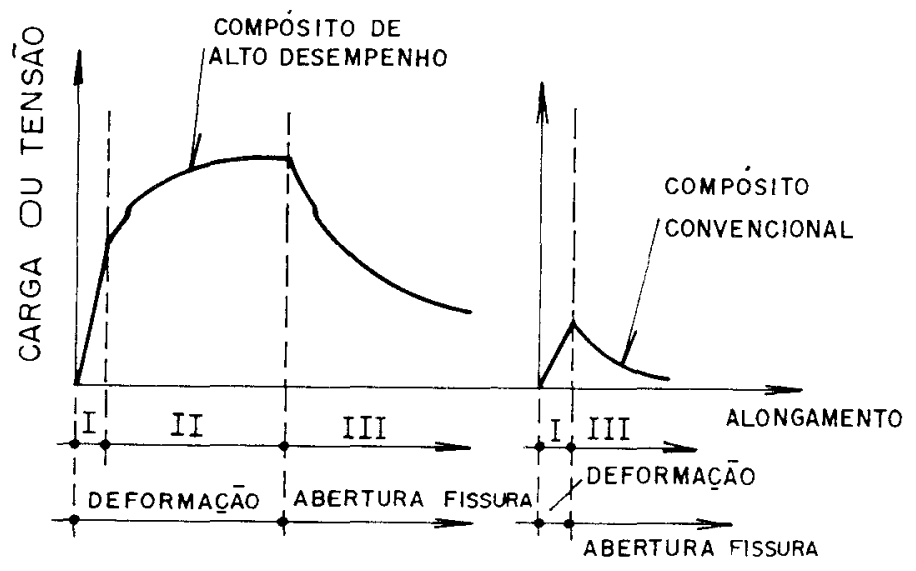

Figura 3.19 - Influência do volume de fibras no concreto tracionado (TJIPTOBROTO \& HANSEN, 1991)

\subsection{4 - COMPORTAMENTO NA FLEXÃO}

Segundo HANNANT (1978), a necessidade de se dar um tratamento teórico especial para a flexão decorre da grande diferença entre a resistência à flexão, representada pelo módulo de ruptura no ensaio de tração na flexão, e a resistência à tração axial, que, de acordo com a Teoria da Elasticidade, representariam a medida do mesmo valor. Esta diferença é mais significativa no caso do concreto com fibras do que no concreto normal, devido ao comportamento quase-plástico do compósito na tração, decorrente principalmente do arrancamento das fibras após a fissuração do concreto. O aumento no valor do módulo de ruptura depende do volume de fibras, da relação de aspecto e da resistência de aderência.

A distribuição de tensões na flexão é muito sensível ao aumento da dutilidade proporcionado pelas fibras, conforme mostra a Figura 3.20. Mesmo sem alteração da resistência à tração, a resistência à flexão de um material com comportamento elastoplástico pode ser muito maior do que a de um material elástico-frágil, que rompe quando se atinge a deformação limite. Para o material elasto-plástico, a distribuição de tensões se modifica, a linha neutra sobe e o diagrama de tensões de tração se aproxima da forma retangular. Consequentemente, a curva carga-flecha continua ascendente após o limite elástico. Ou seja, a maior dutilidade associada ao comportamento pseudoplástico leva a um aumento da capacidade de carga do material. Portanto, ao contrário da resistência à tração, o aumento da resistência à flexão pode ser significativo, mesmo 
com volume de fibras pequeno. Como as aplicações frequentemente envolvem solicitação por flexão, o aumento da dutilidade se torna mais relevante.

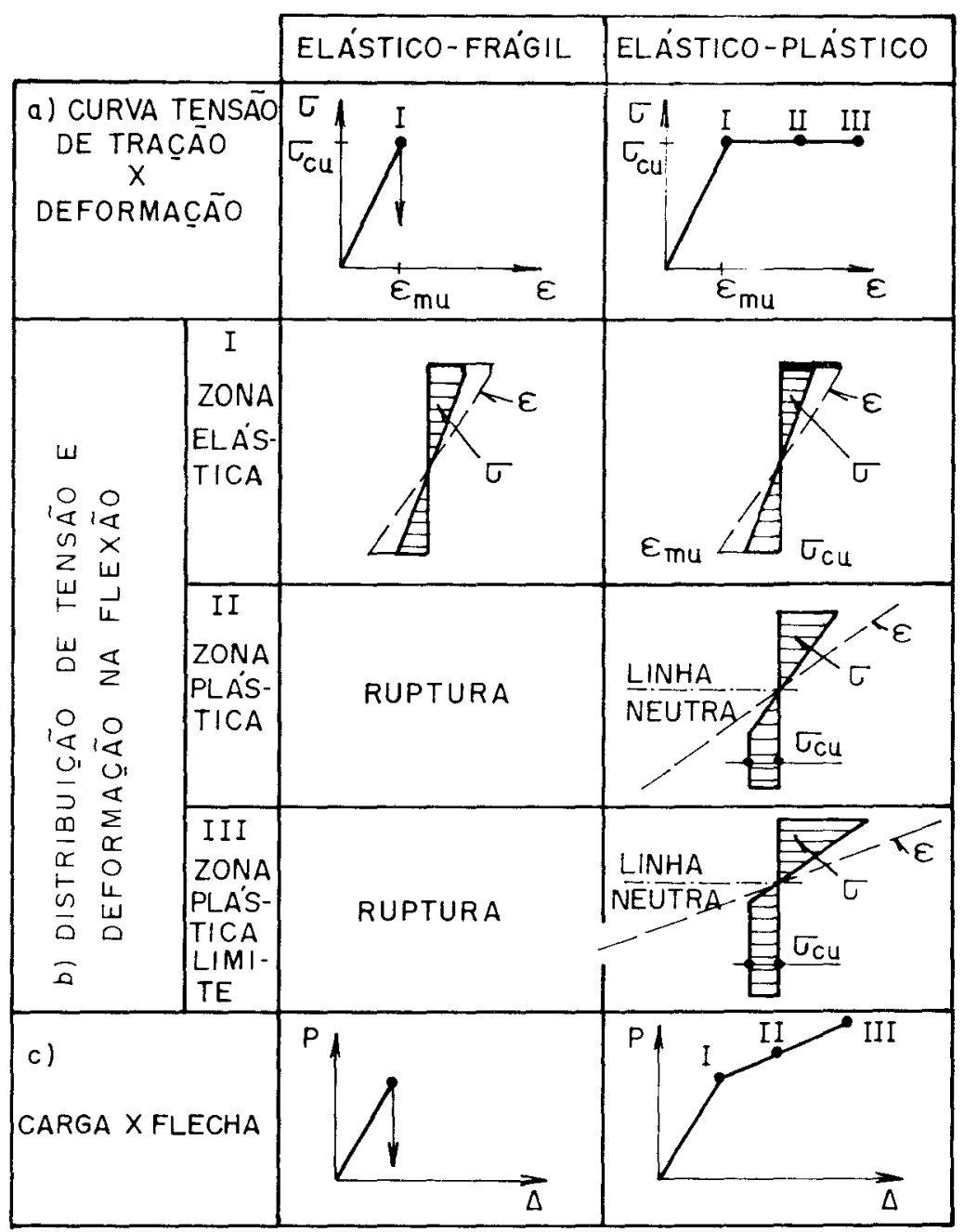

Figura 3.20 - Distribuição de tensões e deformações na flexão (BENTUR \& MINDESS, 1990)

Assumindo-se que a posição da linha neutra esteja na posição indicada $(0,75 \mathrm{~h})$ e a distribuição de tensões conforme esquema da Figura 3.21, a capacidade resistente à flexão de um material elasto-plástico aumenta 2,44 vezes em relação à resistência do material elástico-linear de mesma resistência à tração. Segundo HANNANT (1978), este seria um limite superior, alcançado quando a deformação máxima pudesse atingir um valor próximo de $0,9 \%$. Isto sugere que, para a flexão, o volume crítico de fibras seja menor que na tração axial, na mesma proporção em que se aumenta a resistência à flexão em relação ao material elástico. 


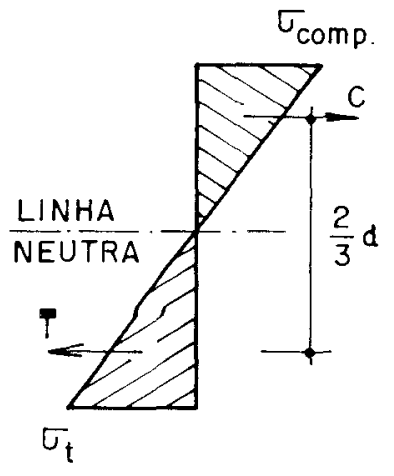

(a)

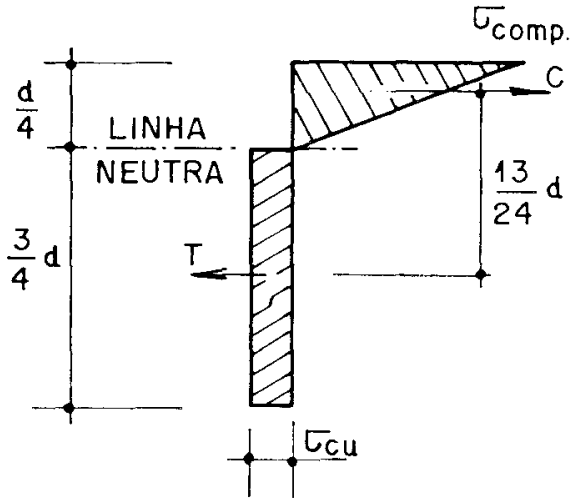

(b)

Figura 3.21 - Distribuição de tensões de flexão (HANNANT, 1978)

Raciocínio similar se aplica para a perda progressiva de dutilidade. A resistência à flexão pode diminuir mesmo sem a diminuição da resistência à tração. Ela pode estar associada à diminuição da resistência à tração ou à diminuição da dutilidade. ou de ambos. A variação da resistência de aderência. se provocar diminuição da dutilidade e aumento da resistência à tração, tem influência contraditória na resistência à flexão. Portanto, a interpretação dos resultados de ensaios deve considerar estas características

\section{5 - ENSAIOS DE CARACTERIZAÇÃO}

Neste item, apresenta-se sucintamente os principais ensaios de caracterização dos compósitos e alguns resultados de trabalhos recentes, principalmente sobre os ensaios específicos que diferenciam o concreto com fibras do concreto convencional.

\subsection{1 - ENSAIOS NA MISTURA FRESCA}

Os principais ensaios na mistura fresca são os ensaios de consistência e de retração. que medem a intensidade da retração. ou a fissuração associada à retração impedida. Outro ensaio menos comum determina o teor de fibras na mistura.

Normalmente, a introdução das fibras piora a consistência do concreto. Contudo. frequentemente esta mudança é apenas aparente. Enquanto a mistura está parada, a desvantagem é visivel. No entanto. quando vibrada. o comportamento melhora. Portanto. o ensaio de abatimento não é um bom índice da trabalhabilidade. pois as fibras conferem estabilidade à massa de concreto fresco. O lançamento e a 
compactação do concreto podem ser satisfatórios mesmo que o abatimento seja reduzido (BENTUR \& MINDESS, 1990; MEHTA \& MONTEIRO, 1993).

Os ensaios dinâmicos mais utilizados para medir a consistência dos compósitos são a medida do tempo Vebe e o ensaio de "slump" invertido. Neste último caso, medese o tempo gasto para a descida do concreto colocado no cone invertido, sem compactação, com auxílio de vibração. Portanto, ambos os procedimentos medem o tempo para a mistura se mover a uma certa distância sob vibração. A Figura 3.22 mostra a relação do "slump" comum e do "slump" invertido com o tempo Vebe. Observa-se que, mesmo para "slump" reduzido, o resultado do tempo Vebe é muito bom. No caso do "slump" invertido, a linearidade do gráfico indica que ambos os procedimentos são sensíveis à mobilidade e fluidez no concreto com fỉbras.
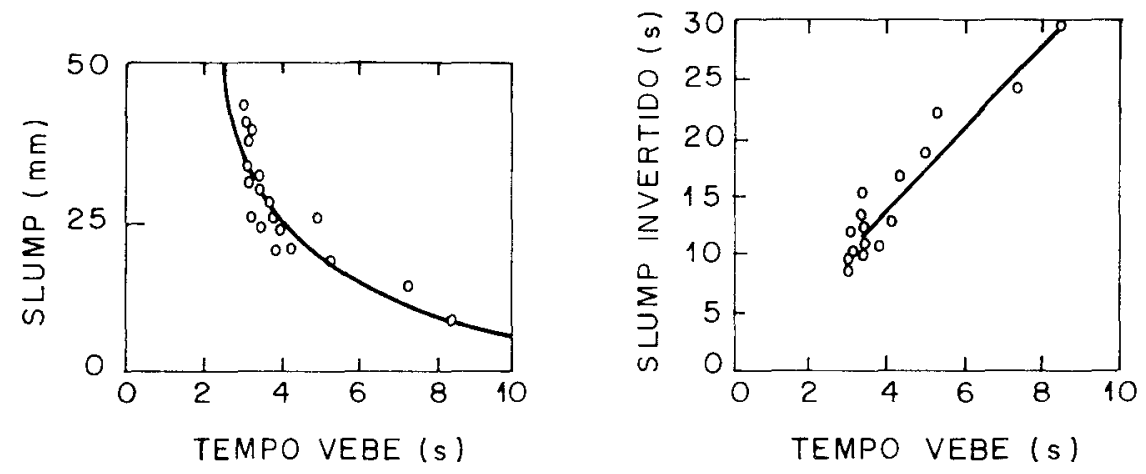

Figura 3.22 - Relação entre os testes de consistência para concreto com fibras (BENTUR \& MINDESS)

Segundo SACHAN \& RAO (1988). os ensaios convencionais utilizados em concreto simples não são apropriados para o concreto com fibras, pois a estrutura interna e a fluidez são diferentes. Os autores sugerem que a simplicidade e a representatividade da trabalhabilidade tornam o ensaio de consistência obtido com o cone invertido o mais indicado para os compósitos. Ele diferencia claramente as misturas com boa trabalhabilidade daquelas com trabalhabilidade inadequada para o concreto reforçado com fibras, ao contrário do ensaio tradicional.

Os ensaios de retração no concreto normalmente são comparativos. Na fissuração por retração, por exemplo. quando a deformação é impedida. os resultados são comparados com modelos similares sem fibras. em termos do número e abertura de fissuras. Segundo BALAGURU (1994), os corpos-de-prova retangulares seriam mais apropriados para avaliar a retração plástica na mistura fresca, enquanto os anéis seriam melhores para a retração na mistura endurecida. Neste caso. DANTAS (1987) registrou 
as vantagens proporcionadas pelo reforço de fibras de polipropileno em concretos de baixo consumo de cimento no panorama de fissuração devido à retração.

A contribuição das fibras na redução da fissuração de compósitos de cimento durante o processo de endurecimento foi investigada por BALAGURU (1994). Através de ensaios em placas retangulares com deformação impedida em matriz de cimento reforçada com fibras de aço, sintética (nylon, polietileno, polipropileno) e de celulose (de alto módulo), analisou-se a influência do tipo de fibra (material, comprimento, diâmetro e volume), do tipo de matriz (argamassa, rica e pobre, concreto e concreto leve) e das dimensões do modelo na retração por secagem

O desempenho foi avaliado a partir da área de fissuras (comprimento e abertura), procedimento trabalhoso e relativamente subjetivo, de difícil padronização. Dentre outras conclusões a respeito do desempenho de cada tipo de fibra e da influência dos parâmetros estudados, observou-se sistematicamente uma diminuição da área fissurada e da abertura máxima das fissuras nos modelos com fibras.

\subsection{2 - ENSAIOS NA MISTURA ENDURECIDA}

Os ensaios na matriz endurecida mais utilizados para a determinação das propriedades mecânicas dos compósitos são o ensaio de compressão simples, tração direta, tração na flexão, ensaios de arrancamento e ensaios de impacto. Os principais objetivos são a estimativa da dutilidade, do controle da fissuração e, eventualmente, da resistência. que são as propriedades mais influenciadas pela presença de fibras curtas no concreto. O ensaio de compressão, apesar de muito utilizado por vários pesquisadores, apresenta resultados similares aos do concreto sem fibras. Logo, não desperta tanto interesse. Além desses, outros parâmetros importantes podem ser avaliados experimentalmente: durabilidade, orientação e percentual das fibras (devido à distribuição e compactação não uniformes), retração, tração por fendilhamento (evolução de uma fissura pré-induzida por entalhe) e outros.

\subsubsection{1 - ENSAIOS DE TRAÇÃO DIRETA E TRAÇÃO NA FLEXÃO}

Eles são importantes como indicativos do potencial de controle das fissuras, da capacidade de deformação e da dutilidade do concreto, normalmente mais relevantes do que a resistência no caso do concreto com fibras. Devido à facilidade de execução. o ensaio de flexão é o mais comum. Além da medida indireta da resistência à tração, ele 
é utilizado para determinação dos índices de tenacidade. Inicialmente, a tenacidade era obtida através da área da curva do diagrama carga-flecha até um determinado valor da carga de ruptura (por exemplo, 40\% da carga última), que representava a energia consumida até aquele deslocamento. Os resultados dependiam do tamanho do corpode-prova e da geometria do carregamento, além da qualidade da matriz. Atualmente, procura-se minorar estes efeitos, dividindo-se a área do diagrama calculada para um dado deslocamento pela área correspondente à primeira fissura, ou seja, dividindo-se a energia total pela energia elástica, para tentar associar a propriedade ao material.

O ASTM define os índices de dutilidade $\mathrm{I}_{5}, \mathrm{I}_{10}$ e $\mathrm{I}_{30}$, obtidos para os deslocamentos iguais a 3,0,5,5 e 15,5 vezes o valor do deslocamento correspondente à primeira fissura. Para um material elasto-plástico perfeito, estes índices valem 5, $10 \mathrm{e}$ 30 , respectivamente, decorrendo daí a simbologia adotada. Para um material com curva ascendente na etapa pós-fissuração, os valores são maiores. No $\mathrm{ACI}$, o índice de dutilidade é obtido pela relação entre a área sob a curva desde o instante do aparecimento da primeira fissura até a flecha de $1,9 \mathrm{~mm}$ e a área correspondente à etapa elástica. Neste caso, o corpo-de-prova e o carregamento são padronizados. A norma japonesa (JCI) adota um índice absoluto, igual a área do diagrama até a flecha igual ao vão livre da viga no ensaio de flexão dividido por 150 .

Num programa desenvolvido por várias universidades americanas, GOPARALATNAN e outros (1991) estudaram a influência do tipo de medida dos deslocamentos transversais, do corpo-de-prova, do tipo e volume de fibras e do entalhe nos ensaios de flexão realizados para análise da tenacidade. Observou-se que o valor da flecha correspondente à primeira fissura pode variar muito, conforme o método utilizado para medi-la, que pode incluir ou não as deformações estranhas ao corpo-deprova. Com isso, altera-se significativamente a energia consumida na etapa elástica. Como consequiência, os valores do módulo de deformação e os índices de tenacidade calculados em função deste parâmetro também se alteram na mesma proporção. Baseados nestes resultados, propõem um método alternativo para quantificar a tenacidade, em função da evolução da abertura da fissura induzida, menos suscetível a estas variações.

\subsubsection{2 - ENSAIOS DE IMPACTO}

São utilizados principalmente como medida da tenacidade dos compósitos. Hles podem ser qualitativos (análise visual), semi-quantitativos (mais comuns) e quantitativos. No ensaio semi-quantitativo, a variação de energia antes e após o 
impacto provocado por um peso no corpo-de-prova representa a energia consumida na ruptura. Para que o resultado tenha significado físico, a energia total é dividida pela área do corpo-de-prova, de modo a se ter a energia por unidade de área. Os resultados não representam uma propriedade do material, pois são sensíveis a vários parâmetros do ensaio: geometria do corpo-de-prova e outras formas de dissipação de energia. Nos ensaios quantitativos, elimina-se a parcela de energia dissipada.

A escolha entre o ensaio estático de flexão e o ensaio dinâmico para a avaliação da dutilidade deve considerar a solicitação real a que a peça estará submetida. No entanto, normalmente se prefere o ensaio estático, já que somente o ensaio quantitativo tem significado físico, e ele exige equipamentos especiais. Segundo BENTUR \& MINDESS (1990). os resultados destes ensaios são controversos. Alguns trabalhos registram aumento de tenacidade similar nos ensaios estático e dinâmico, enquanto outros sugerem que o acréscimo de dutilidade é mais significativo no ensaio dinâmico.

\subsubsection{3.- ENSAIOS DE ARRANCAMENTO}

Vários métodos têm sido propostos para se determinar a resistência ao arrancamento das fibras da matriz de cimento. Nos métodos indiretos, a resistência de aderência é calculada em termos da aderência média, a partir da determinação das propriedades do compósito, por exemplo, calculando-se a resistência em função do volume de fibras e da relação de aspecto e determinando-se a aderência média com base na Lei das Misturas. No métodos diretos, uma ou mais fibras imersas na matriz de concreto são arrancadas. A aplicação da carga não deve introduzir tensões radiais na matriz, para eliminar a influência do coeficiente de Poisson.

O arrancamento de várias fibras com comprimentos variáveis permite a obtenção do comprimento crítico. Considerando-se a tensão de cisalhamento na interface uniforme e conhecendo-se a resistência da fibra, pode-se determinar a resistência de aderência e, conseqüentemente, o comprimento crítico.

\subsubsection{4 - OUTROS ENSAIOS}

Os ensaios de retração na mistura endurecida são similares ao ensaio na mistura fresca. A orientação e porcentagem de fibras pode ser avaliada através de raio-X ou eletromagnetismo, no caso da fibra de aço. A durabilidade normalmente é estudada a 
partir do acompanhamento das propriedades mecânicas (resistência e dutilidade) ou por análise microestrutural, em elementos submetidos a envelhecimento natural ou acelerado, sob diversas condições de exposição. Os ensaios devem considerar as causas potenciais da degradação, que variam conforme o tipo de fibra, para a escolha do melhor método de aceleração da degradação. Os efeitos do envelhecimento podem estar associados à matriz, às fibras ou a mudanças nas características da interface.

\section{6 - SISTEMAS COM FIBRAS}

Neste item apresentam-se algumas características específicas dos compósitos produzidos com diferentes tipos de fibras, especialmente a fibra de aço e a fibra de polipropileno, além de alguns trabalhos mais recentes. Apesar das inúmeras pesquisas e dos resultados geralmente positivos, deve-se destacar a recomendação do ACI-544 sobre a utilização das fibras, de modo a assegurar a sua utilização criteriosa e cautelosa: em aplicações estruturais, elas devem ser usadas somente como material suplementar, para inibir a fissuração, melhorar a resistência ao impacto ou ao carregamento dinâmico e impedir a desintegração do material. Para solicitação de flexão ou tração (vigas, pilares, etc), a armadura convencional deve ser capaz de resistir a todo o carregamento.

\subsection{1 - FIBRA DE AÇO}

As fibras de aço são usadas em diferentes geometrias. Além da forma reta e lisa, outros tipos de fibra foram produzidos para aumentar a aderência com o concreto e melhorar o seu desempenho. Dentre eles. podem ser citadas a fibra com as extremidades em gancho, a fibra ondulada e a fibra retorcida.

Segundo SOROUSHIAN \& BAYASI (1991), a trabalhabilidade avaliada pelo ensaio de slump invertido varia muito pouco com o tipo de fibra de aço empregada. sendo que a mistura com fibra ondulada mostrou-se um pouco mais plástica. No entanto, a trabalhabilidade sempre piora com a introdução das fibras, especialmente quando elas tem relação de aspecto elevada. O ensaio de slump convencional não apresenta os mesmos resultados.

Segundo GRONDZIEL (1993), a principal utilização das fibras em matriz de concreto na Europa se dá nas lajes, além de túneis, pré-moldados e outras aplicações. Elas substituem parcialmente a armadura e proporcionam a diminuição da espessura. 
da ordem de 3 a $4 \mathrm{~cm}$. Segundo MEHTA \& MONTEIRO (1994), as primeiras aplicações estruturais ocorreram na execução de túneis com concreto projetado, em painéis para garagens de estacionamentos em pistas de aeronaves.

Inúmeros trabalhos abordam a utilização das fibras de aço na construção de túneis com concreto projetado, em substituição às telas. Segundo ARMELIN (1993), além dos ganhos em produtividade e custo global, elas melhoram o revestimento. Usualmente são utilizadas fibras de 25 mm ou mais. em volumes de $1 \%$ a $2 \%$.

Segundo BENTUR \& MINDESS (1990), as fibras de aço são especialmente eficientes no aumento da resistência à tração na flexão, ao cisalhamento, ao impacto e à fadiga. Na resistência à compressão, a contribuição das fibras é pequena do ponto de vista de resistência, mas a dutilidade após a fissuração é maior. No caso de fibras alinhadas. registram-se aumentos da resistência à tração axial de até 130\%. Para fibras aleatórias, até $60 \%$. Mas estes números correspondem a volumes elevados e processos de produção especiais. Para volumes de até $2 \%$, os aumentos são bem mais modestos, próximos de $10 \%$. Na resistência à flexão, conforme citado anteriormente, o aumento é mais significativo, e depende da relação de aspecto e do volume adicionado.

A influência do tipo de fibra de aço nas propriedades mecânicas do concreto foi estudada por SOROUSHIAN \& BAYASI (1991). Os melhores desempenhos foram obtidos pela fibra com ganchos nas extremidades. Os piores, pela fibra ondulada, principalmente na flexão, já que a resistência à compressão se mantém praticamente constante.

Os efeitos do reforço com fibras de aço de extremidade em gancho nas propriedades mecânicas do concreto de alta resistência foram investigados por WAFA \& ASHOUR (1992). Observou-se que a resistência à compressão aumenta muito pouco (até 5\%), mas o comportamento é mais dútil. Na flexão, além da maior dutilidade, os acréscimos de resistência são mais significativos (até 87\%) e variam quase linearmente com $V_{f}$ até $1,5 \%$. A tenacidade, avaliada pelos resultados de ensaios de flexão, pode aumentar até 3,8 vezes $\left(\mathrm{I}_{5}\right)$ ou 18,7 vezes $\left(\mathrm{I}_{30}\right)$. A resistência à tração indireta também pode aumentar bastante, até $160 \%$. Baseados nestes resultados, os autores propõem expressões empíricas para o cálculo destes parâmetros de resistência, baseadas na resistência à compressão simples e em $\mathrm{V}_{\mathrm{f}}$.

SILVA \& TESUKA (1992) estudaram a influência do reforço com fibras de aço carbono onduladas, sub-produto da fabricação de esponjas de aço, em elementos de argamassa. microconcreto e concreto submetidos a ensaios de flexão, tração na flexão e compressão simples. As fïbras tinham comprimento de 1", 1.5" e 2" e seção retangular de $0,2 \mathrm{~mm} \times 2.3 \mathrm{~mm}$, iguais às fibras utilizadas neste trabalho, com volumes variando de $1 \%$ a $3 \%$. 
Em todos os elementos reforçados com fibras observou-se aumento da resistência ao impacto, da dutilidade e a manutenção da integridade do material. Os resultados dos ensaios de tração na flexão foram variáveis para a argamassa, microconcreto e concreto. No entanto, de um modo geral, os melhores resultados foram obtidos com a fibra mais longa, devido à melhor ancoragem, especialmente para volume próximo de $2 \%$. Nos ensaios de compressão simples não se observou aumento significativo de resistência. Nos ensaios de flexão de placas de argamassa armada, onde o volume de fibras foi mantido constante e igual a $3 \%$, variando-se a quantidade de telas de aço, observou-se que as fibras são eficientes na melhoria do panorama da fissuração e aumentam o momento de fissuração e a resistência das peças, quando em conjunto com as telas. A variação do comprimento da fibra influiu pouco nestes resultados.

Segundo $\mathrm{OH}$ (1992), a abertura das fissuras de flexão em vigas de concreto reforçado com fibra de aço reta é menor do que em vigas similares sem fibra. O valor aumenta quase linearmente com a deformação na armadura longitudinal. Além disso, elas melhoram a resistência e a dutilidade. As vantagens foram mais evidentes para taxas reduzidas de armadura longitudinal, onde o controle da fissuração foi mais efetivo. Observou-se também o aumento da resistência à compressão (até 17\%), à flexão (até 60\%) e ao fendilhamento (maior que 100\%), além da diminuição do encurtamento no concreto no meio da viga no ensaio de flexão e do espaçamento de fissuras, para a mesma tensão na armadura.

DWAVARAKANAT \& NAGARAJ (1992) registram que o desempenho na flexão de vigas reforçadas com fibras de aço somente na região tracionada é similar ao das vigas reforçadas em todo o volume, ou seja, pode-se conseguir desempenhos iguais com grande economia de material. Em qualquer caso, as fibras reduzem as deformações na armadura longitudinal e as flechas, principalmente em serviço. o que é um indicativo de um controle de fissuras mais eficiente.

ALSAYED (1993) desenvolveu formulação empírica para cálculo dos deslocamentos devido à flexão em vigas de concreto com fibras, modificando a rigidez EI da viga através de um coeficiente que varia $\operatorname{com} \mathrm{V}_{\mathrm{f}} \mathrm{e} / / \mathrm{d}$, devido ao controle mais eficiente da fissuração.

$\mathrm{Na}$ resistência ao cisalhamento, os resultados são, inexplicavelmente. muito diversos. Segundo BENTUR \& MINDESS (1990), registra-se desde a ineficiência das fibras, até aumentos da ordem de $27 \%$ e. em alguns casos, até 100\%. Talvez neste aspecto se dê a maior contribuição das fỉbras no comportamento estrutural, devido ao espaçamento reduzido entre as fíbras, ao aumento da resistência de fissuração e de 
ruptura e à maior contribuição do mecanismo de transferência da força cortante por atrito. Este assunto, segundo os autores, deve ser mais estudado, mas uma conclusão parcial e segura, por enquanto, é a possibilidade de substituição parcial dos estribos pelas fibras.

Segundo NANNI (1991), a resistência à fadiga de elementos de concreto submetidos a ensaios de flexão, compressão e tração indireta melhora com o reforço com fibras de aço. Além disso, os ensaios estáticos revelaram também a melhoria da dutilidade na compressão diametral, pois na tração indireta a compressão transversal à direção do arrancamento da fíbra aumenta sua eficiência.

A influência das fibras de aço na aderência entre o concreto e as barras da armadura longitudinal nas ligações viga-pilar, onde o concreto fica confinado pelas armaduras transversal e longitudinal do pilar, foi investigada por SOROUSHIAN \& outros (1994), mostrando-se especialmente indicadas para carregamento dinâmico (em terremotos, por exemplo, onde ocorre o escorregamento da armadura e a rotação na ligação). para limitar as fissuras horizontais e inclinadas ao redor da armadura decorrentes da perda da aderência e do escorregamento das barras. As fibras retardam a propagação das fissuras e diminuem o escorregamento, pois a resistência de aderência aumenta. Com isso, melhoram a resistência, a dutilidade e a rigidez, permitindo diminuição da armadura de confinamento, sem alterar a qualidade da ancoragem da barra no nó. Segundo os autores, a relação de aspecto e o tipo de fibra tem influência desprezivel na resistência de aderência. ao contrário do escorregamento correspondente à tensão máxima.

$\mathrm{Na}$ retração, as fibras proporcionam diminuição das deformações, quando livres, e alteração da fissuração, para deformação restringida. Alguns resultados contrariam esta tendência, registrando pequena influência das fibras, já que a fissuração por retração não envolveria a formação de macrofissuras.

Apesar do cobrimento reduzido, a corrosão das fibras normalmente fica limitada às fibras mais externas. Há indicações de que, para peças com abertura de fissura limitada a $0,25 \mathrm{~mm}$, não haveria sinal de corrosão nas fibras internas, mesmo em ambiente agressivo (BENTUR \& MINDESS, 1990). Segundo GRONDZIEL. (1993), a expansão volumétrica devido à corrosão é muito pequena, mas podem surgir manchas de ferrugem na superfície da peça. 
Em alguns casos mais críticos, a diminuição do diâmetro e o aumento da aderência (aspereza) causados pela corrosão podem favorecer a ruptura da fibra, ao invés do seu arrancamento, provocando diminuição da dutilidade. Com a tendência de uso da microssílica para melhorar a trabalhabilidade, a zona de transição se torna menos porosa, implementando também a durabilidade da matriz. Este fato, combinado com a expectativa de fissuração reduzida, alivia a preocupação com a durabilidade.

\subsection{2 - FIBRA DE POLIPROPILENO}

O polipropileno é um polímero termo-plástico que pode ser obtido pelo craqueamento do petróleo. Durante o processo de extrusão, o arranjo polimérico se torna cristalino e resulta num material muito dútil, com alta resistência e capacidade de deformação. A superfície é hidrófuga e impermeável, mas isto reduz a aderência com a matriz de cimento. Porisso, normalmente se prefere utilizar a fibra do tipo fibrilada. que apresenta maior superfície específica. No entanto, nesta fibra a possibilidade de incorporar vazios é maior e pode anular este efeito (SAVASTANO Jr, 1992).

As propriedades da fibra de polipropileno podem variar conforme o processo de produção. inclusive o módulo de deformação longitudinal. O polipropileno é sensível aos raios ultra-violetas, podendo haver oxidação se houver exposição prolongada. Porém, no concreto, as fibras ficam protegidas (DANTAS, 1987).

A principal preocupação com a durabilidade se deve à degradação das fibras submetidas a altas temperaturas. Ensaios de envelhecimento natural indicam pequeno aumento no módulo de deformação Iongitudinal, não acompanhado por qualquer alteração na aderência.

Segundo BENTUR \& MINDESS (1990), as principais vantagens do uso da fibra de polipropileno no concreto são a disponibilidade. o baixo custo e a insensibilidade ao álcali. Os fatores preocupantes são a aparente incompatibilidade mecânica com a matriz, o baixo módulo de elasticidade, a aderência fraca e a dificuldade de produção, sendo as duas últimas devidas à pequena afinidade com a matriz fresca. SAVASTANO JR e outros (1993) registram a possibilidade de se adicionar até $1 \%$ da fibra do tipo multifilamentos com comprimento entre $15 \mathrm{~mm}$ e 30 $\mathrm{mm}$, sem embolamento.

Segundo BAYASI \& ZFNG (1993), os resultados de ensaios de consistência ("slump" e "slump" invertido) não se alteram para até $0.3 \%$ da fibra do tipo fibrilada. mas a consistência fica muito prejudicada para volume de $0.5 \%$, especialmente para as 
fibras mais longas. Os mesmos dados valem para a porcentagem de ar incorporado. A permeabilidade do concreto, portanto, pode aumentar, devido à maior porosidade.

A adesão físico-química entre a fibra de polipropileno e o cimento é desprezivel. Novas fibras tem sido desenvolvidas para melhorar a aderência, tentando incorporar uma parcela mecânica através da modificação do processo de produção. Outra possibilidade é o tratamento da superfície da fibra, para melhorar a adesão (PELED e outros, 1992).

As vantagens da fibra fibrilada em relação à fíbra multifilamentosa são a melhor aderência devido à ancoragem mecânica, e a ausência do efeito desfavorável do coeficiente de Poisson. Porém, estes dados não são consensuais na literatura, pois outros fatores podem alterar o comportamento destas fibras.

PELED e outros (1992) estudaram a influência do tipo de fibra de polipropileno (monofilamento, feixe e filme) e do tratamento superficial no reforço da matriz de cimento através de ensaios de flexão, seguidos de análise microscópica de fragmentos do corpo-de-prova para caracterização da superfície da fibra e da microestrutura da interface, que pode mudar muito com o tratamento da fibra. O melhor desempenho na flexão foi obtido com a fibra de monofilamentos, que estaria associado à melhor aderência, devido à maior densidade da matriz na superfície da fibra observada na análise microscópica. Mesmo assim, os resultados foram pouco satisfatórios, pois o aumento da resistência de fissuração e da resistência última foi modesto para volume de fibra até $4 \%$.

Os ensaios foram refeitos após vários tratamentos na fibra de multifilamentos: químicos (porificação - indução de aspereza através de poros superficiais - lavagem com detergente, tratamento com PVAc - após porificação -- e tratamento com ácido sulfúrico - que torna mais áspera a superfície) ou físicos (fricção com lixa - aumenta a superfície e a aspereza da fibra - e retorcimento da fibra). Apenas a fricção. a lavagem com detergente e a aplicação do ácido sulfúrico proporcionaram algumas vantagens. Os dois últimos. na resistência à tração, devido à melhor adesão, talvez física, mais importante para a resistência correspondente à primeira fissura; e o primeiro, no comportamento pós-fissuração, devido à melhor ancoragem mecânica - devido à penetração da matriz nas asperezas - e ao entrelaçamento das fibras, garantindo a integridade da interface até o arrancamento da fibra.

A fibra fibrilada é produzida pelo alongamento e abertura de fendas longitudinais do polímero sintético em uma lâmina delgada. Soltando-se as fendas. formam-se fibras finas. que são presas transversalmente ao longo do comprimento. $A$ fita esticada é então retorcida ao longo do seu comprimento, formando um feixe. Segundo SOROUSHIAN e outros (1993), os monofilamentos do feixe têm relação de 
aspecto muito alta quando dispersos no concreto. Porisso a aderência é melhor, além de ser mais fácil de se misturar na matriz de cimento.

BENTUR e outros (1989) sugerem que a aderência da fibra de polipropileno fibrilada em forma de malha se deve a dois efeitos: adesão, devida ao contato íntimo entre a fibra e o concreto e à densidade da zona de transição, e ancoragem mecânica, devida aos efeitos do engrenamento mecânico obtido pela segregação parcial dos feixes em filamentos (que permite a penetração da matriz nos vazios da malha), aos ramos de fibrilas e às microfibrilas superficiais. Estas conclusões foram obtidas através de análise microscópica de caracterização da interface fibra-matriz e da geometria da fibra após a mistura, quando as fibras foram separadas, lavadas e secas. Após a mistura, as fibras ainda conservam um certo entrelaçamento, ou seja, o reforço unitário consiste em filamentos conectados entre si por ramos e microfibrilas superficiais. Além disso. a zona de transição. normalmente porosa e heterogênea para outros tipos de fibras. mostrou-se densa e homogênea. Estes mecanismos de aderência podem variar para outros tipos de fibra ou de processo produtivo.

Segundo OHNO \& HANNANT (1994), as teorias convencionais utilizadas para determinação da transferência de tensões entre a fibra fibrilada e a matriz (supondo tensões elásticas e de atrito na interface, como o modelo de ACK, que considera livre o movimento fibra-matriz - aderência por atrito) não são indicadas para a fibra fibrilada. Quando a estrutura da fibra é mais complexa, o fenômeno é diferente. Baseado em observações microscópicas de elementos fraturados sob tração direta, observou-se que durante a fissuração múltipla, além do escorregamento das fibras em relação à matriz, ocorre escorregamento entre as fibras, pois a distribuição das tensões entre os fios não é uniforme. Além disso, a aderência entre os fios não é uniforme, pois varia conforme sua posição, externa ou interna, em relação ao feixe.

A influência da fibrilação em diferentes tipos de fibra de polipropileno também foi estudada por CURRIER \& GARDINER (1989), através de ensaios de arrancamento para análise da aderência entre a fibra e a matriz de cimento.

As principais aplicações em concreto armado objetivam o aumento da tenacidade e da resistência ao impacto, como em anéis para revestimento de estacas pré-moldadas (MEHTA \& MONTEIRO, 1994) e o melhor controle da fissuração por retração na mistura fresca e endurecida. Para isso, elas podem ser usadas com volumes muito reduzidos. até $0,3 \%$. Apesar de reduzida. a aderência é suficiente para estabelecer a ação de compósito, mesmo para a fibra do tipo monofilamentos. Também há registros de aplicações com volumes elevados no revestimentos de túneis em 
substituição às telas com concreto jateado, com desempenho similar e com economia em relação à fibra de aço (RICHARDSON, 1990).

A eficiência no controle da fissuração por retração é maior na mistura fresca, quando a resistência e o módulo de deformação da matriz ainda são reduzidos. A resistência à compressão do concreto com fibras de polipropileno pode diminuir, especialmente se a compactação for ineficiente. A resistência à flexão aumenta devido ao melhor comportamento após a físsuração (devido ao aumento da dutilidade), que pode ser alcançado com deformações excessivas, o que é aceitável do ponto de vista da segurança.

Devido ao valor reduzido do módulo de deformação longitudinal, a zona de fissuração múltipla nos compósitos com fibra de polipropileno é muito extensa. No modelo de $\mathrm{ACK}$, a etapa correspondente ao arrancamento das fibras, após a múltipla fissuração, é praticamente horizontal.

Os resultados de ensaios realizados por BAYASI \& ZENG (1993) registram pequeno aumento da resistência à compressão. no caso de fibras curtas, e nenhuma influência para as fibras longas. Em qualquer caso. a tenacidade aumenta muito, assim como a resistência ao impacto, especialmente quando não há prejuízo da trabalhabilidade. A resistência à flexão praticamente não se altera, mas a dutilidade no pós-pico aumenta bastante. Neste caso, as fibras longas foram melhores para volumes até $0,3 \%$, sendo que para $0,5 \%$ as fibras curtas foram mais eficientes.

O melhor comportamento pós-fissuração em ensaios de flexão de placas de concreto reforçado com fibras de polipropileno do tipo multifilamentos, em volume de até $2 \%$, também foi observado por BENTES (1993), quando as fibras foram utilizadas em substituição de parte da tela em peças de argamassa armada produzidas na fábrica de pré-moldados da Prefeitura de São Paulo. para facilitar a produção e diminuir os custos. Para o volume adotado na produção destas peças $(0,25 \%)$, a trabalhabilidade praticamente não se alterou.

Segundo SOROUSHIAN e outros (1992). a fibra de polietileno de alto módulo é mais eficiente que a fibra de polipropileno fibrilada nas solicitações por flexão. impacto e compressão simples. No entanto, a compatibilidade com a matriz de concreto é maior para a fibra de polipropileno que, além disso, é quimicamente inerte no meio alcalino e apresenta superfície hidrófuga.

A melhoria nas propriedades mecânicas de argamassas reforçadas com fibras sintéticas (polipropileno, Aramid e polietileno de alto módulo) submetidas à tração direta também foi verificada por WANG e outros (1990), onde se registra o aumento da resistência, da energia de ruptura - avaliada pela curva tensão-abertura da fissura e das características das fissuras de retração em anéis sob deformação restringida. 
AGOPYAN (1991) destaca a possibilidade de se obter grandes avanços na área de concreto reforçado com fibras com o desenvolvimento de fibras de polipropileno de alto módulo de deformação longitudinal a um custo mais baixo. Além da possibilidade de substituição do cimento-amianto, ele aponta o crescimento das pesquisas com fibras nas aplicações estruturais.

\subsection{3 - OUTRAS FIBRAS}

Outras fibras fibras têm sido utilizadas como reforço para a matriz de cimento. Dentre elas, destacam-se a fibra de vidro e as fibras vegetais, além do amianto, tradicionalmente empregado na Construção Civil.

As fibras sintéticas artificiais de alto desempenho (carbono, Aramid-Kevlar, acrílica, PVA, polietileno) geralmente apresentam módulo de deformação longitudinal elevado e boa estabilidade química em meio alcalino. Porém, além do custo mais elevado, têm pouca afinidade com a matriz de cimento, resultando em resistência de aderência baixa e em dificuldades de produção, o que tem levado a tentativas de modificação da superfície e geometria destas fibras.

\subsubsection{1 - FIBRA DE VIDRO}

A fibra de vidro se compõe de cordas formadas por vários filamentos muito finos. Com técnicas convencionais de mistura consegue-se obter compósitos com até $5 \%$ em volume, o que é suficiente para se aumentar a dutilidade e a resistência da matriz. Segundo BENTUR \& MINDESS (1990), a fibra de vidro comum é sensivel ao ataque dos álcalis. Porisso, foram desenvolvidas fibras especiais ("AR-glass"), quase imunes ao álcali. Mesmo assim, o ataque químico não pode ser desprezado.

Uma particularidade observada nos compósitos formados por argamassa de cimento e fibra de vidro é a perda da resistência e tenacidade com o envelhecimento em ambiente úmido. A mudança está associada à alteração da zona de transição e, consequentemente, da aderência entre a fibra e a matriz. Durante a produção. os filamentos $(10 \mu \mathrm{m})$ não se dispersam completamente e os grãos de cimento $(10 \mu \mathrm{m})$ não penetram no espaço entre eles $(3 \mu \mathrm{m})$. Desta forma, quase não se formam produtos de hidratação no cordão, que constitui a unidade de reforço. Com o envelhecimento em ambiente úmido, pode haver depósito dos produtos de hidratação entre os filamentos. Isto aumenta a aderência e torna o compósito mais frágil. $\mathrm{O}$ uso de polímeros e outras 
adições minerais tais como a microssílica, além de possibilitar a redução da alcalinidade, ajuda no preenchimento dos vazios entre os filamentos e diminui este efeito.

\subsubsection{2 - CIMENTO AMIANTO}

O cimento-amianto é o primeiro e o mais tradicional compósito de cimento. As fibras de amianto são produzidas a partir de minerais naturais e têm bastante afinidade com a matriz de cimento, permitindo facilmente a adição de até $10 \%$ de fibra. Elas se constituem de feixes de filamentos muito finos (menos de $0,1 \mu \mathrm{m}$ ), de elevada resistência e módulo de deformação longitudinal, com boa resistência de aderência. Assim, quando comparado com as outras fibras, o compósito apresenta boa resistência. mas a dutilidade é menor.

O cimento-amianto não apresenta problemas de durabilidade, exceto pela possivel perda progressiva da dutilidade após alguns anos. O fenômeno é semelhante ao da fibra de vidro. pois ocorre aumento da densidade da zona de transição, melhorando a aderência devido à deposição lenta de produtos da hidratação entre os filamentos do cordão. inicialmente insignificante.

Apesar do excelente desempenho e da boa durabilidade, a utilização do cimento-amianto vem sendo rediscutida, devido aos possíveis danos à saúde das pessoas envolvidas no processo produtivo do amianto. Isto tem originado intensas pesquisas, direcionadas tanto para a busca de uma outra fibra sintética que apresente o mesmo comportamento e eficiência como reforço, quanto para se evitar a contaminação durante a produção da fibra.

\subsubsection{3 - FIBRAS VEGETAIS}

As fibras vegetais despertam o interesse dos pesquisadores especialmente pela sua disponibilidade e baixo custo, tendo como principal aplicação o uso nas habitações de baixo custo.

Segundo BENTUR \& MINDESS (1990), os problemas para a utilização das fibras vegetais na matriz de cimento são o baixo módulo de elasticidade e a aderência fraca, o retardo na hidratação do cimento, a instabilidade dimensional do compósito e a durabilidade. Para tentar vencer estas dificuldades várias alternativas são possíveis, dentre elas o tratamento da fibra e a modificação das propriedades da matriz. 
Devido ao baixo módulo de deformação, a principal modificação na matriz ocorre na dutilidade. A capacidade de reforço destas fibras é limitada, pois o controle da fissuração é pouco eficiente, a menos que se consigam novos processos de produção que possibilitem a adição de maiores volumes de fibras mais longas. Segundo AGOPYAN (1991), no Brasil, as fỉbras vegetais são selecionadas pelas suas propriedades mecânicas (resistência, módulo e deformação limite). físicas (peso específico, absorção de água), geométricas (relação de aspecto), durabilidade e disponibilidade.

JOHN \& AGOPYAN (1993) avaliaram a durabilidade de sete tipos de fibras vegetais de baixo módulo. entre 2 a $4 \mathrm{GPa}$, escolhidas a partir de suas propriedades e de aspectos relativos ao custo e cultivo, através da análise da quantidade de energia dissipada em ensaios de flexão. A observação direta da degradação da fibra e da interface é mais difícil. pois a remoção das fibras da matriz altera suas propriedades. () mecanismo de degradação das fibras vegetais e o desenvolvimento de técnicas de proteção (impregnação ou revestimento da fibra e, principalmente, redução da agressividade do meio alcalino na matriz) são descritos em detalhes por AGOPYAN (1991). Segundo o autor. é possível melhorar a durabilidade dos compósitos com fibras vegetais sem o tratamento da fibra, alterando-se as propriedades da matriz sem custos adicionais, embora não se descarte outros procedimentos. No desenvolvimento de aglomerantes alternativos, menos alcalinos, pode-se utilizar aglomerante de escória e de cinza de casca de arroz. No entanto, sempe haverá degradação progressiva. principalmente da dutilidade.

Segundo SAVASTANO JR e outros (1993), há uma interrelação direta entre a zona de transição e as propriedades macroscópicas de compósitos de cimento reforçado com fibras vegetais (coco, malva e sisal), devida principalmente à dependência das características da aderência fibra-matriz em relação às propriedades da zona de transição. Algumas propriedades podem se alterar com o tempo, devido a modificações nas propriedades das fibras, tais como o enfraquecimento da fibra ou a redução do comprimento crítico de ancoragem. A microestrutura das fibras vegetais apresenta uma zona de transição muito porosa, além do descolamento da fibra devido à variação dimensional. que prejudicam a resistência de aderência.

Diversos trabalhos registram a influência das fibras vegetais como reforço para o concreto. CARVALHO FILHO (1993) observou as vantagens da utilização da fibra de sisal no concreto. tais como o melhor controle da fissuração, o aumento da dutilidade. da resistência ao impacto e da resistência à flexão. Segundo AZIZ e outros (1981), os principais fatores que afetam as propriedades dos materiais reforçados com fibras naturais são o tipo de fibra, a geometria (comprimento, diâmetro. seção 
transversal, conformação), a forma (mono ou multifilamentos), a superfície (áspera, polida, recoberta), as propriedades da matriz (cimento, granulometria, aditivos), a dosagem (quantidade de água, volume de fibra, consistência), o tipo de mistura (betoneira, sequência de mistura dos materiais, tempo), o tipo de moldagem e a cura.

\subsection{4 - SISTEMAS ESPECIAIS}

Os sistemas especiais de concreto com fibras são aqueles em que se consegue introduzir grandes quantidades de fibra e modificar significativamente as propriedades da matriz, como por exemplo. quando as fibras são previamente posicionadas na fôrma e a matriz, formada por uma calda de cimento, é infiltrada através de bombeamento ("SIFCON").

PARAMESWARAN e outros (1990) observaram valores de resistência à tração na flexão da ordem de $40 \mathrm{MPa}$ para argamassas reforçadas com $8 \%$ de fibra reta de aço, 500\%. 100\% e 300\% maiores, respectivamente, do que a resistência de peças similares de argamassa sem fibras, argamassa reforçada com telas de galinheiro e com reforço convencional de fibras com volume até $3 \%$. A dutilidade e o panorama da fissuração também melhoram muito.

Outra aplicação recente das fỉbras se dá no concreto de alta resistência. A aderência fibra-matriz é melhor, e portanto, o comprimento critico da fibra é menor, conseguindo-se obter misturas com maior quantidade de fibras. No entanto, devido à maior resistência da matriz, o volume crítico é maior.

\section{7 - AS FIBRAS E O CISALHAMENTO}

A melhoria no desempenho de elementos de concreto submetidos a solicitações tangenciais com a introdução das fibras tem sido registrada por diversos pesquisadores, pelo aumento da capacidade resistente e, eventualmente, pela alteração da forma de ruptura. É praticamente consensual a possibilidade de substituição parcial dos estribos por um volume conveniente de fibras. Ela seria vantajosa sob vários aspectos: obtenção de resistência igual em todas as direções, maior resistência à fissuração e propagação das fissuras. facilidade de produção e outros. A limitação das fissuras e dos deslocamentos. em particular. são importantes nos estados de utilização, principalmente quando se empregam aços de alta resistencia, pois melhoram a proteção 
da armadura e a transferência da força cortante pelos mecanismos de pino e de atrito (LI e outros, 1992).

A substituição dos estribos pela fibras é especialmente atraente em regiões de força cortante elevada e armadura muito densa, onde a facilidade de execução, o controle da fissuração e a manutenção da integridade da peça na ruptura são os aspectos mais favorecidos (LIM, 1987).

Segundo DEI POLI e outros (1993), a influência das fibras no mecanismo de pino é similar a um aumento do cobrimento. Ou seja, elas melhoram a etapa de transição entre o comportamento inicialmente linear do concreto e o comportamento plástico final. Porém, não levam necessariamente ao aumento da resistência final, especialmente se houver problemas durante a produção, no que se refere à homogeneidade e porosidade.

A influência das fibras na resistência às forças de pino foi estudada por SWAMY \& BAHIA (1979) em ensaios com vigas de concreto de seção duplo-T com fissuras diagonais pré-existentes. A resistência, que depende da resistência à tração do concreto e da flexão localizada da armadura, aumenta com as fibras. Além disso, as fibras controlam a propagação das fissuras nesta região e preservam o cobrimento do concreto, melhorando, portanto, a rigidez e a dutilidade. Como a aderência da armadura com o concreto também aumenta, a resistência ao arrancamento da armadura é maior. Em função destes mecanismos, o acréscimo da resistência ao cisalhamento é significativo, maior do que o acréscimo na resistência à formação das fissuras horizontais na região das forças de pino.

As fibras influem ainda nas deformações da armadura longitudinal e do concreto nesta região. A capacidade de deformação destes materiais aumenta. mas as deformações diminuem para um dado carregamento. No caso da armadura, isto se deve à preservação da aderência. Além disso, as fibras retardam o aparecimento da primeira fissura visível, que ocorre sob maior deformação no concreto. e controlam o seu desenvolvimento. Porisso, os deslocamentos verticais sob os pontos de aplicação do carregamento diminuem quase linearmente com o volume de fibras.

A consideração das fibras na resistência ao cisalhamento normalmente é feita de forma empírica, através de una parcela resistente adicional. No entanto, existem alguns modelos teóricos consistentes sobre a atuação das fibras, baseados em modelos convencionalmente aplicados para as peças de concreto armado ou protendido.

Segundo ROSSI \& WU (1992), a metodologia para o estudo do comportamento de compósitos de concreto com fibras deve se basear em modelos numéricos capazes de justificar, mecanicamente. o interesse neste tipo de aplicação. Ou seja, deve-se considerar adequadamente no projeto a capacidade de limitação da fissuração 
proporcionada pelas fibras. A utilidade estrutural mais óbvia das fibras seria em substituição aos estribos. A análise da influência das fibras baseada no modelo da treliça considerando-se a tensão residual de tração resistida pelo concreto com fibras após a fissuração não seria indicada.

Na verdade, a influência da fibra se daria ao nível do material, na limitação da fissuração e no aumento da resistência, e pode ser medida através de ensaios de tração e compressão; e ao nível da estrutura, pelo aumento da dutilidade, que pode ser medida em ensaios de tração direta com macrofissura pré-existente. Para as utilizações correntes, somente se consegue aumento da dutilidade (ROSSI, 1994).

Apresentam-se a seguir alguns modelos utilizados para a quantificação da influência das fibras na resistência ao cisalhamento e, posteriormente, uma descrição dos trabalhos mais recentes nesta área.

\subsection{1 - A INFLUENCIA DAS FIBRAS}

Segundo LI e outros (1992), a atuação das fibras como armadura de cisalhamento varia conforme o comportamento resistente da viga. A eficiência seria maior quando predomina o mecanismo de viga (onde normalmente não se prescinde dos estribos). devido à atuação das fibras na transferência de forças na fissura diagonal e ao aumento da resistência às forças de pino. No mecanismo de arco, a formação do arco, ou seja. o desenvolvimento de tensões de compressão entre a carga e os apoios, seria pouco influenciado pelas fibras. No entanto, esta conclusão não é consensual.

Em vigas sem estribos com cargas distantes dos apoios, a ruptura normalmente é brusca e ocorre logo após o aparecimento da fissura diagonal. Após a fissuração por flexão, a variação da tensão na armadura longitudinal entre as fissuras tende a fletir e cisalhar o consolo de concreto engastado na zona comprimida. As fissuras de flexão se inclinam com o aumento da carga. devido às tensões de flexão e cisalhamento. Diversos mecanismos resistem à propagação destas fissuras. como o atrito, o efeito de pino e o cisalhamento na zona comprimida. Quando a abertura das fissuras aumenta, diminui o atrito nas fissuras e aumentam a ação de pino e a contribuição da zona comprimida. A ruptura ocorre pelo esgotamento da ação de pino, devido à fissuração ao longo da armadura, ou pela ruptura da zona comprimida, sob tensões combinadas de cisalhamento e compressão.

Além da atuação direta das fíbras na fissura diagonal. a limitação da propagação das fissuras melhora a transferência de forças através das fissuras, especialmente no 
caso de fibras longas, e a ação de pino. Portanto, há um acréscimo na resistência ao cisalhamento e, eventualmente, na resistência à fissuração inclinada, o que permite a formação de mais fissuras inclinadas antes da ruptura. Se a armadura longitudinal for mais abundante, a influência das fibras deve ser maior, pois o controle da abertura das fissuras melhora ainda mais. Raciocínio inverso pode ser aplicado para as vigas altas. Neste caso, a substituição dos estribos pelas fỉbras não seria tão interessante, já que a influência do tamanho da peça não afeta os estribos.

Quando o carregamento é próximo dos apoios e predomina a ação de arco, a ruptura normalmente ocorre devido à tração excessiva na alma. Eventualmente as fibras podem melhorar a resistência à tração do concreto e retardar a ruptura. A resistência adicional após a fissuração para este tipo de mecanismo é maior do que no anterior, exceto se houver esmagamento do concreto. Esta resistência residual aumenta com as fibras, especialmente quando elas são longas, pois melhora a transferencia de tensões após a fissuração e o diagrama carga-flecha se torna mais abatido no pós-pico.

Estas conclusões foram obtidas através de ensaios em vigas de concreto e argamassa sem estribos, reforçadas com diversos tipos de fibra de aço e sintéticas. em diversos volumes, variando-se ainda a relação a/d (1,0 a 4.25), a taxa de armadura longitudinal $(1,1 \%$ a $3,3 \%)$ e a altura da viga $(10,2$ ou $20,4 \mathrm{~cm})$.

Para os autores. a previsão da resistência ao cisalhamento e à flexão dos compósitos não deve se basear na resistência à compressão do concreto, já que este parâmetro é pouco modificado pelas fibras. A resistência à tração na compressão e na flexão seriam bons indicadores do melhor desempenho dos compósitos. A primeira. por captar a melhoria da ação de pino. A segunda, porque reflete o comportamento pós-fissuração do material e a transferência de forças através das fissuras diagonais. Quando a carga estivesse próxima dos apoios, a resistência à tração seria desprezada.

A formulação empírica proposta para a resistência ao cisalhamento de vigas sem estribos reforçadas com fibras é similar às equações de Zutsy, variando com os parâmetros de resistência do concreto citados acima, a taxa de armadura longitudinal. a relação a/d e a altura da peça. Para a/d>2,5, as expressões podem considerar ainda $o$ engrenamento dos agregados. diferenciando o concreto da argamassa. Para a/d<2.5, o tipo da matriz seria irrelevante, assim como a resistência à tração e a altura da peça.

Os autores sugerem ainda que a eficiência das fibras deve ser menor para matrizes de alto desempenho, já que o volume de fibras necessário ou a resistencia de aderência deve ser maior. de modo a aumentar a resistência à tração do concreto e. consequentemente, a resistência ao cisalhamento. 
Vários autores quantificam a influência das fibras considerando-se a contribuição das componentes verticais das forças de arrancamento das fibras nas fissuras diagonais. Eles se baseiam em modelos convencionais, diferindo basicamente no tipo de ruptura considerado. Além disso, as expressões adotadas para a determinação da resistência de arrancamento podem variar.

O modelo proposto por AL-TA'AN \& AL-FEEL (1990) para vigas de concreto de seção retangular sem estribos reforçadas com fibras de aço considera a influência dos principais parâmetros intervenientes no cisalhamento, tais como a relação a/d, a taxa de armadura longitudinal, a resistência à compressão do concreto, o volume e o tipo de fibra. Ele parte da formulação de Zutsy, onde se considera a resistência ao cisalhamento decorrente da transferência de forças no banzo comprimido e da ação de pino (de difícil quantificação), desprezando a parcela do atrito nas fissuras.

A contribuição das fibras é considerada conforme a transferência de forças ao longo da fissura crítica, como mostra a Figura 3.38. É necessário conhecer a posição da linha neutra, para delimitar a região de atuação das fibras e do banzo comprimido (pode ser desprezada a influência das fibras neste cálculo. já que ela é pequena).

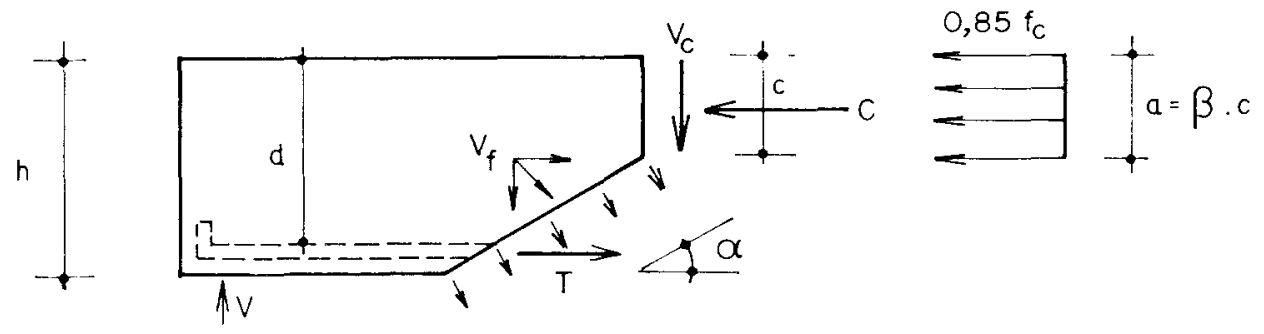

Figura 3.23 - Transferência de forças transversais no concreto com fibras (AL-TA'AN \& AL-FEEL, 1990)

Definida a geometria da fissura diagonal, pode-se obter o número de fibras por unidade de área. Admitindo-se a ocorrência do arrancamento da fibra. determina-se a tensão resistida pelas fibras na direção perpendicular à fissura. A componente vertical representaria a contribuição das fibras. Observa-se que o processo é iterativo. pois a posição da linha neutra depende da força cortante última.

O valor mais representativo da tensão de aderência na resistência ao arrancamento quando a distribuição das fibras é aleatória é aquele calculado a partir de ensaios de flexão. Na ausência de dados, os autores recomendam o valor médio de 4,15 MPa, para fibras retas de aço. Para outras geometrias, ele pode ser aumentado em até $30 \%$. Através de regressão linear aplicada aos resultados da bibliografia obteve-se expressões para a força cortante última e a força cortante de fissuração. 
Procedimento semelhante é adotado por NARAYANAN \& DARWISH (1987). No entanto, neste caso se considera também a influência das fibras na resistência à tração do concreto (representada pelo "fator da fibra - F ", igual ao produto entre a relação de aspecto, o volume e o fator de aderência da fibra), na ação de pino e na ação de arco. baseada em resultados de inúmeros ensaios em vigas retangulares de concreto. Observou-se nestes ensaios que, para "F" maior, a resistência ao cisalhamento aumenta. especialmente para a/d reduzido. Além disso, o aumento é mais significativo quando a resistência à compressão do concreto e a taxa de armadura longitudinal são maiores.

Até um determinado volume de fibras ( $1 \%$. neste caso), registrou-se a similaridade de comportamento das vigas com estribos e das vigas com fibras sem estribos. Ou seja, para valores compatíreis de $\rho_{\mathrm{W}}$ e $V_{\mathrm{f}}$ pode-se manter a capacidade resistente substituindo-se os estribos pelas fibras, preservando a resistência adicional após o aparecimento da fissura diagonal e a configuração das fissuras diagonais, devido à redistribuição de tensões no arrancamento das fỉbras junto às fissuras. Além disso, para volumes crescentes de fibra, a ruptura por cisalhamento pode ser substituída pela ruptura por flexão-cisalhamento ou por flexão, o que confirma a maior influência das fibras na resistência ao cisalhamento. Quando a carga está distante dos apoios. forças adicionais podem ser aplicadas após a fissura diagonal enquanto ocorre $o$ arrancamento das fibras. resistidas pelo concreto comprimido e pela ação de pino.

O modelo proposto por LIM (1987) utiliza a Teoria da Plasticidade, com pequenas alterações, para analisar o comportamento resistente de elementos de concreto reforçado com fibras de aço submetidos a solicitações tangenciais. Segundo o autor, neste caso pode-se idealizar com mais propriedade o comportamento rígidoplástico do concreto comprimido. Considera-se duas situações distintas, de acordo com o tipo de ruptura esperado. Na primeira, para cargas próximas dos apoios, parte-se do modelo de plasticidade proposto por Nielsen e Braestrup. onde a ação das fibras seria similar à ação dos estribos, resistindo forças na região da ruptura diagonal iguais àquelas correspondentes ao arrancamento das fibras. Para cargas distantes dos apoios, na região de momentos fletores elevados. de acordo com o modelo de treliça. as fibras formariam campos de tensões de tração perpendiculares às tensões de compressão. Portanto, as diferenças entre os dois casos devem-se à geometria da ruptura ou da fissura crítica e às considerações empíricas específicas de cada caso.

No primeiro, considera-se o concreto submetido a um estado plano de tensões e a armadura longitudinal com comportamento rígido-plástico perfeito, com força correspondente à tensão de escoamento. capaz de absorver somente forças na direção 
axial (ou seja, despreza-se o efeito de pino). Supõe-se que a ruptura ocorre devido ao escoamento dos estribos ou ao esmagamento do concreto.

A análise do equilibrio de forças na direção vertical ao longo da fissura fornece a expressão para a força cortante. A inclinação da fissura crítica determina o tipo de ruptura, se pelo escoamento da armadura transversal ou pelo esmagamento do concreto. O limite superior de resistência corresponde à ruptura por esmagamento da biela de concreto.

No segundo caso, do modelo de treliça. considera-se somente a ruptura devido ao escoamento das armaduras. As fibras formam um campo de tensões de tração perpendicular ao campo de compressão, com valores iguais à resistência ao arrancamento das fibras. Ou seja. elas também contribuem na resistência à flexão.

Com una equação de interação para ruptura combinada por flexão a cisalhamento e com a limitação da inclinação das bielas. obtém-se o valor máximo da capacidade resistente ao cisalhamento. No cálculo da resistência à flexão considera-se o diagrama retangular de tensões de tração do concreto; além disso, o coeficiente que reduz a resistência à compressão do concreto é maior, devido à maior dutilidade e ao pequeno acréscimo da resistência do concreto com fibras. Mesmo asssim. a contribuição das fỉbras é muito pequena na flexão.

Segundo os autores, a possibilidade de substituição total ou parcial dos estribos pelas fibras é possível, desde que se mantenha a taxa de armação ao cisalhamento. A similaridade da ação dos estribos e das fibras se estende também para a contribuição no efeito de pino, desprezada neste modelo. Porém, além do controle da propagação e da abertura das fissuras de pino, as fibras evitam a desintegração do concreto nesta região. ao contrário dos estribos.

O modelo proposto por SWAMY e outros (1993) também se baseia na analogia da treliça, considerando-se a inclinação das bielas a 45 graus e a contribuição empírica do concreto. A influência das fỉbras na fissura diagonal é quantificada de modo similar aos estribos, adotando-se para a resistência à tração do concreto após a fissuração o valor calculado pela Lei das Misturas. que é equivalente ao valor das forças de arrancamento ou de ruptura das fibras. considerando-se ainda os fatores de eficiência da fíbra. Na ausência de resultados experimentais. recomenda-se adotar para a resistência de aderência valores entre $4 \mathrm{MPa}$ e $5 \mathrm{MPa}$. O modelo foi ajustado com os resultados de ensaios em vigas de concreto leve de seção duplo-T. Observou-se que a resistência fica subestimada para valores reduzidos de $\mathrm{a} / \mathrm{d}$. 
Inúmeras vantagens proporcionadas pelas fibras já destacadas anteriormente foram observadas: aumento da rigidez após a fissuração, da dutilidade e da capacidade resistente, diminuição das deformações no concreto e na armadura longitudinal, manutenção da integridade do concreto comprimido e redução das fissuras na região das forças de pino. E o efeito mais significativo, na fissuração, onde as fissuras são mais finas, menos espaçadas e mais abundantes nas extremidades.

Segundo os autores, a eficiência das fibras é maior em vigas de argamassa, já que estão livres da interferência dos agregados, e em vigas de alma fina, já que se consegue um melhor alinhamento das fibras na direção da tensão principal de tração.

A Teoria das Trajetórias das Forças de Compressão, que estuda o equilíbrio e a compatibilidade de um elemento fissurado, também pode ser utilizada. As fibras seriam consideradas pela alteração do comportamento pós-pico do concreto tracionado (TAN e outros, 1992). Em ensaios em vigas de concreto de seção duplo-T reforçadas com fibras de aço de extremidade em gancho, observou-se aumento significativo da resistência para volumes reduzidos de fibras, até 1\%. Além disso, a deformação na armadura longitudinal diminui, principalmente após a fissuração diagonal.

\subsection{2 - OUTROS TRABALHOS}

Neste item são apresentados alguns resultados recentes sobre a influência das fibras na resistência ao cisalhamento, sem a preocupação de se associar a eles um modelo físico que represente o comportamento resistente.

BATSON e outros (1972) observaram a possibilidade de substituição dos estribos por fibras de aço como armadura de cisalhamento em vigas retangulares de argamassa e a maior influência das fibras na resistência ao cisalhamento do que na resistência à flexão. já que o valor crítico de a/d diminui com o aumento de $\mathrm{V}_{\mathrm{f}}$.

Através de ensaios em vigas de concreto de seção retangular e seção $T$, SWAMY \& BAHIA (1985) verificaram o aumento da resistencia, da dutilidade. a manutenção da integridade do concreto e a diminuição dos deslocamentos verticais, da deformação no concreto comprimido e na armadura longitudinal, com a adição de fibras de aço ao concreto. Quando o reforço se limitou à região tracionada. o acréscimo de resistência foi insignificante. Além disso, na região das fissuras de pino. a deformação do concreto diminui, mas a capacidade de deformação é maior.

Nas vigas sem estribos, houve acréscimo de resistência da ordem de $80 \%$. Com estribos. a contribuição nominal das fỉbras diminuiu. possivelmente devido ao 
arrancamento das fibras próximo da ruptura, quando as fissuras estão muito abertas e as forças são transferidas para os estribos. Mesmo assim, a influência das fibras em serviço é significativa. Sugere-se quantificar a influência das fibras no cisalhamento empiricamente, adotando-se como parâmetro fundamental a resistência à tração na flexão (a variação da resistência ao cisalhamento com este parâmetro é quase linear).

Os resultados de ensaios em vigas retangulares de concreto reforçado com fibras de aço realizados por NIYOGI \& DWARAKANATHAN (1985) sugerem que a influência das fibras é maior em traços mais pobres, onde os acréscimos de resistência são mais significativos. Observou-se também o aumento da resistência à fissuração e à ruptura e da dutilidade com o aumento do volume de fíbra.

MANSUR e outros (1986) também registram a maior eficiência das fibras na resistência ao cisalhamento do que na flexão (diminuição do valor crítico de a/d). principalmente para cargas próximas do apoio. através de ensaios em vigas retangulares de concreto sem estribos reforçadas com fibras de aço. As fibras seriam mais eficazes após a fissuração, pois o aumento de $\mathrm{V}_{\mathrm{u}}$ é maior que o aumento de $\mathrm{V}_{\mathrm{cr}}$.

SHARMA (1986) destaca as vantagens das fibras sobre os estribos. especialmente quando os substitui parcialmente, observadas em ensaios de vigas retangulares de concreto reforçado com fibra de aço. Sugere ainda que a resistência à força cortante deve considerar empiricamente a influência das fibras no temo que representa a contribuição do concreto $\left(\mathrm{V}_{\mathrm{c}}\right)$.

Baseados em resultados de ensaios em vigas retangulares de argamassa. NARAYANAN \& DARWISH (1988) registram a desrantagem na substituição total dos estribos por fibras de aço, para $p_{W}=0,5$ e $V_{1}=0.5 \%$. A substituição parcial. ao contrário, melhora o desempenho das peças. Ou seja. quando combinada com os estribos, a eficiência das fibras é maior.

LUB \& MATHEWS (1989) realizaram ensaios em vigas retangulares vazadas de parede fina de concreto reforçado com fibras de aço. As fibras da mesa inferior foram alinhadas em uma direção preferencial (direção do eixo da viga) e as fỉbras da alma ficaram alinhadas em duas direções. devido à pequena espessura da parede. Com estas características, não se observou aumento da resistência à flexão, mas registrou-se aumento significativo da resistência ao cisalhamento. maior que $70 \%$, atribuída à capacidade das fibras de costurar as fissuras, melhorando a sua distribuição e possibilitando a obtenção de maiores deformações no concreto comprimido. Além disso, a rigidez e a dutilidade também aumentaram, conforme o valor de a/d. Segundo os autores, a eficiência das fibras no cisalhamento depende da relação a/d.

DARWISH (1990) desenvolveu ábacos e equações empíricas para estimar a capacidade resistente ao cisalhamento de vários tipos de elementos de concreto 
reforçado com fibras de aço (vigas convencionais, vigas altas, lajes e vigas protendidas). A contribuição das fibras dependeria do volume de fibras, da relação de aspecto e da aderência fibra-matriz, que varia conforme a geometria e a superfície da fibra, com valores entre 0,5 e 1,0. A partir destes parâmetros, define-se o "fator da fibra - F", que quantifica a influência das fibras majorando-se o parâmetro de resistência do concreto, $\mathrm{O}$ autor registra ainda que, apesar dos inúmeros ensaios sobre o assunto, as normas ainda não incoporaram e regulamentaram estes resultados.

ANDREWS (1990) estudou a aplicação das fíbras de aço em reparos de estruturas de concreto danificadas. Comparando-se os resultados de ensaios da estrutura antes da ruptura por cisalhamento e após a ruptura. na estrutura recuperada. observou as vantagens da estrutura recuperada: ruptura mais suave, acompanhada de menores deformações no concreto, além do aumento da rigidez e da resistência. principalmente para cargas próximas do apoio.

A técnica de reparo consistiu na retirada do concreto e recolocação dos estribos na região da ruptura. escovamento da superfície de ruptura e posterior concretagem utilizando concreto com fibras.

ASHOUR e outros (1992) realizaram ensaios em vigas retangulares de concreto de alta resistência sem estribos reforçadas com fibras de aço, onde observaram que a resistência aumenta com o volume de fibras para qualquer valor de $\mathrm{a} / \mathrm{d}$, mas o aumento é mais significativo para cargas próximas dos apoios. No entanto, a dutilidade aumenta mais para a/d maior, pois a ruptura não ocorre após a formação da fissura diagonal. mas apćs o arrancamento das fibras na posição da fissura crítica. A forma de ruptura também pode mudar, conforme os valores de $a / d$ e $V_{f}$. Mesmo quando ela permanece frágil com a adição das fibras, ela se torna menos catastrófica. Baseados nestes resultados. propõem-se uma formulação empírica derivada de equações similares utilizadas para concreto usuais.

Os ensaios em vigas de concreto sem estribos com polímeros e eventualmente reforçado com fibras de aço realizados por RIBEIZ e outros (1993) mostram as vantagens das fibras no controle das fissuras, na dutilidade e na manutenção da integridade do concreto. Porém, quando adicionadas em volume acima de 1,3\%, o desempenho pode piorar, devido às condições insatisfatórias da trabalhabilidade. Outras observações importantes foram o aumento da resistência após a fissuração diagonal para cargas próximas dos apoios e o aumento da resistência à força cortante para taxas de armadura longitudinal elevadas, sem variação da resistência à fissuração diagonal. Segundo os autores, isto sugere a atuação do mecanismo de pino somente após a fissuração. 
Para analisar a influência da resistencia do concreto e das fibras de aço e polipropileno no cisalhamento, VALLE \& BUYUKOZTURK (1993) realizaram ensaios de compressão axial em prismas com fendas transversais próximas às extremidades, avançando até a metade da largura, em lados opostos, formando um plano de cisalhamento na direção da carga. Observou-se que a eficiência das fibras é maior no concreto de alta resistência, devido à melhor aderência obtida com o uso de microssílica. Para o concreto de alta resistencia reforçado com fibra de aço, a dutilidade é influenciada pelo escoamento e ruptura de algumas fibras que atravessam as fissuras. além do arrancamento. Para o concreto de resistência normal e para a fibra de polipropileno, predomina o arrancamento da fỉbra. Porisso. as fibras de aço são mais eficientes no aumento da resistência, embora também melhorem a dutilidade, e a fibra de polipropileno são mais eficientes no aumento da dutilidade, embora também melhorem a resistência. Ambas, quando combinadas com estribos, melhoram muito mais a dutilidade do que a resistência.

Outros trabalhos investigam a influência das fỉbras em vigas altas, onde as tensões verticais e as deformações por cisalhamento são significativas. NARAYANAN \& DARWISH (1988) observaram o aumento da rigidez, da dutilidade e da resistència ao cisalhamento obtidos com o reforço de fibras de aço no concreto. A resistência poderia ser estimada pela resistência à tração do concreto. majorada pelo "fator da fibra". O acréscimo de resistência estaria associado à melhor coesão do concreto. o que aumenta a sua resistência à tração transversal. de modo similar à melhoria do efeito de arco em rigas comuns.

Resultados similares foram obtidos por SACHAN \& RAO (1990). que propõem quantificar a influência das fibras na resistência através das forças de arrancamento na fissura crítica, considerando-se of fator de eficiência igual a 0.41 e a resistência de aderência igual a $4 \mathrm{MPa}$.

HUGHES \& FATTHI (1989) realizaram ensaios em consolos de concreto reforçado com fibras de aço e de polipropileno. Os resultados são semelhantes aos anteriores. variando quantitativamente com o tipo de fibra utilizada. Registra-se que a estimativa da carga correspondente à primeira físsura pelo diagrama carga-flecha superestima o seu valor real.

Em SHAH \& BATSON (1987) e SWAMY \& BARR (1989) encontram-se coletâneas de trabalhos sobre concreto reforçado com fibras: propriedades, aplicações e desenvovimento do material. 


\section{CAPÍTULO 4 - ENSAIOS DOS MATERIAIS E DOS PRISMAS}

Este capítulo trata dos ensaios preliminares que antecederam o estudo do cisalhamento das vigas de seção transversal duplo-T, desde os estudos para a definição do traço a ser empregado, onde havia a preocupação inicial de se familiarizar com a utilização das fibras, até os ensaios de cisalhamento na flexão de vigas de seção quadrada, onde foram feitas as observações iniciais sobre a produção e o desempenho dos compósitos de cimento.

\section{1 - OBJETIVOS}

Os objetivos principais destes ensaios são a familiarização com o uso das fibras no concreto, como armadura difusa complementar, e a análise da sua influência no desempenho estrutural de vigas de microconcreto.

No primeiro caso, são abordados aspectos relacionados com a produção do compósito e às propriedades da matriz no estado fresco, que envolvem principalmente variações na consistência do concreto, além da possível alteração de algumas das principais propriedades da mistura endurecida.

Para a avaliação da influência das fibras no comportamento resistente e dos mecanismos associados a ele, dois parâmetros são considerados: o tipo e o volume de de fibra adicionado. Em cada caso analisou-se a influência das fibras em situações de diferentes taxas de armadura transversal de aço.

Com isso, pretende-se caracterizar preliminarmente o comportamento do compósito constituído por diferentes tipos e volumes de fibras, para se definir o tipo e o volume mais adequados a serem utilizados nos ensaios principais, onde a influência de outros parâmetros na resistência ao cisalhamento também é investigada. 


\section{2 - METODOLOGIA}

Para alcançar os objetivos propostos foram executadas quatorze vigas prismáticas de seção quadrada, moldadas a partir de sete misturas diferentes, nas quais se variou apenas o tipo e a quantidade das fibras que reforçaram o concreto. As fibras utilizadas foram de polipropileno, do tipo multifilamentos, e de aço, ondulada, em dois comprimentos distintos. O traço foi mantido constante em todos os modelos.

Os aspectos relacionados com a produção do concreto com fibras e com as caracteristicas do concreto fresco, principalmente a consistência, também foram analisados durante a execução destas peças. As propriedades mecânicas do concreto (resistência à tração. resistência à compressão e módulo de deformação longitudinal) de cada uma das sete misturas foram determinadas através de ensaios de compressão axial e compressão diametral de corpos-de-prova cilíndricos.

Para cada mistura foram executadas duas vigas para avaliação do desempenho estrutural em ensaios de cisalhamento na flexão, variando-se apenas a armadura transversal. Una viga era armada com armadura transversal e longitudinal (modelos da série $\mathrm{A}$ ) e a outra não tinha estribos, apenas armadura de flexão (modelos da série $\mathrm{B}$ ).

$\mathrm{Na}$ série $\mathrm{A}$, os modelos são solicitados praticamente até o seu limite de resistência. na flexão e no cisalhamento. Os modelos da série B representam um caso limite de armadura transversal reduzida, onde se analisa a eficiência das fibras na resistência ao cisalhamento nesta situação. Ainda que a possibilidade de projeção destes resultados para os ensaios principais seja limitada. dada a diferença na geometria dos modelos, eles são importantes como indicativos do desempenho dos compósitos.

Algumas restrições de caráter metodológico ou de viabilidade do trabalho limitam a abrangência dos ensaios realizados para a caracterização dos materiais. Como se focaliza principalmente o comportamento de vigas submetidas a cisalhamento por força cortante. nào se faz um estudo aprofundado das fibras utilizadas, o que exigiria ensaios relativamente complexos. A análise do desempenho se faz por comparação.

Em relação ao concreto, somente são considerados os dados relativos ao seu comportamento macroscópico, supostos essenciais para a avaliação quantitativa do desempenho estrutural. Ou seja. não são feitos estudos sobre a microestrutura do concreto e sua interação com as fibras, que são determinantes do comportamento estrutural. nem sobre as propriedades de durabilidade do concreto ou dos componentes estruturais. embora o requisito de durabilidade seja uma referência importante para o projeto e execução de estruturas delgadas.

Este e outros aspectos que possam restringir o alcance deste trabalho deverão ser analisados futuramente. 


\section{3 -CARACTERIZAÇÃO DOS MATERIAIS UTILIZADOS}

Os ensaios realizados para a determinação das propriedades dos materiais utilizados tinham o objetivo de subsidiar a análise do comportamento estrutural dos modelos estudados. As características das cordoalhas, utilizadas somente nos ensaios dos modelos de seção transversal duplo- $T$, descritos no capítulo 5 , também são apresentadas neste item.

\subsection{1 - AGREGADOS}

Os resultados da análise granulométrica dos agregados são apresentados na Figura 4.1. A Tabela 4.1 mostra as principais características da areia e da brita.

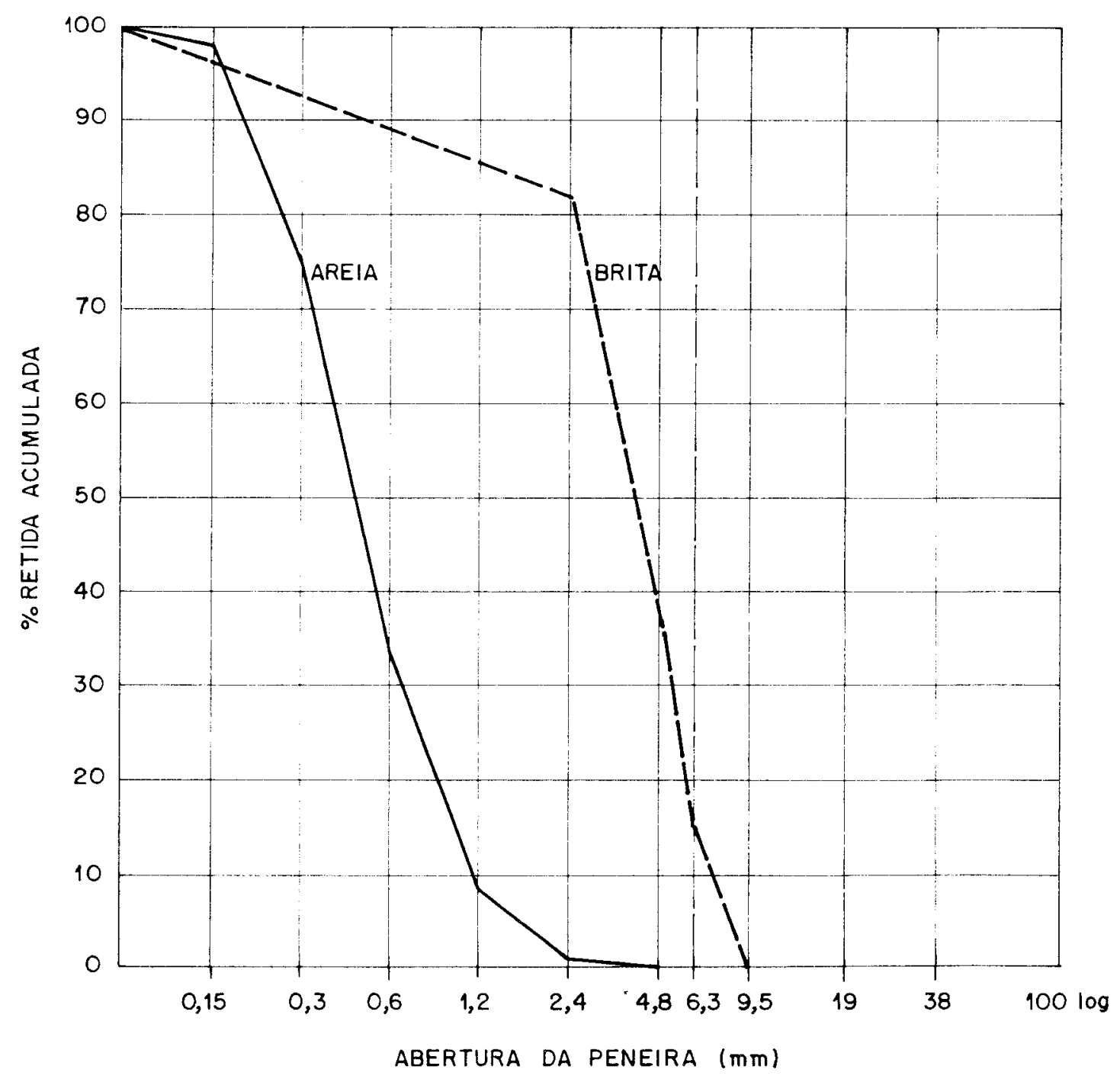

Figura 4.1 - Análise granulométrica da areia e da brita 
Tabela 4.1 - Caracteristicas dos agregados

\begin{tabular}{|c|c|}
\hline areia & pedra britada \\
\hline procedência: rio Mogi-Guaçu & procedência: Araraquara (SP) \\
\hline módulo de finura: 2,15 & origem: basáltica \\
\hline zona 2 & diâmetro máximo: $9,5 \mathrm{~mm}$ \\
\hline areia fina & módulo de finura: 5,21 \\
\hline
\end{tabular}

\subsection{2 - ACO}

As armaduras utilizadas no trabalho experimental foram:

- fios de $3.4 \mathrm{~mm}$ : CA-60B (armadura transversal);

- barras de 9,5 mm: CA-50A (armadura longitudinal das vigas prismáticas);

- fios de $4.2 \mathrm{~mm}$ : CA-60B (armadura construtiva das vigas principais);

- barras de $6.3 \mathrm{~mm}$ : CA-50A (armadura construtiva das vigas principais);

- cordoalhas de $9,5 \mathrm{~mm}$ de7 fios: CP-190RB (armadura longitudinal das vigas I).

O diàmetro efetivo das barras de $9.5 \mathrm{~mm}$ apresentou variação significativa em relação ao diâmetro nominal. O valor considerado em todos os cálculos foi de 9,27 $\mathrm{mm}$. As propriedades dos fios de $3.4 \mathrm{~mm}$. das barras de $9.5 \mathrm{~mm}$ e das cordoalhas foram determinadas através de ensaios de três corpos-de-prova de cada tipo. Os diagramas tensão-deformação destes aços estão nas Figuras 4.2 e 4.3 .

Nas cordoalhas foram colados dois extensometros em fios diametralmente opostos ná seção instrumentada. (Os resultados mostraram a consistência deste procedimento. pois a diferença entre as leituras nestes fios foi pequena. e o valor médio representou com boa aproximação o comportamento da cordoalha.

Confirmando as conclusões de trabalho anterior com cordoalhas de três fios (FURLAN. 1990), as deformações medidas foram um pouco menores que a deformação teórica, pois a direção dos extensômetros não coincide com o eixo da cordoalha, constituida por fios agrupados em forma de hélice. Isso resulta num valor maior para o módulo de deformação longitudinal. Este valor será referido neste trabalho como módulo de deformação longitudinal aparente, com significado diferente do termo utilizado na nomenclatura convencional. correspondente ao valor obtido nos ensaios de caracterização do material. que registra valores de deformações maiores que o real devido à acomodação dos fios da cordoalha. 


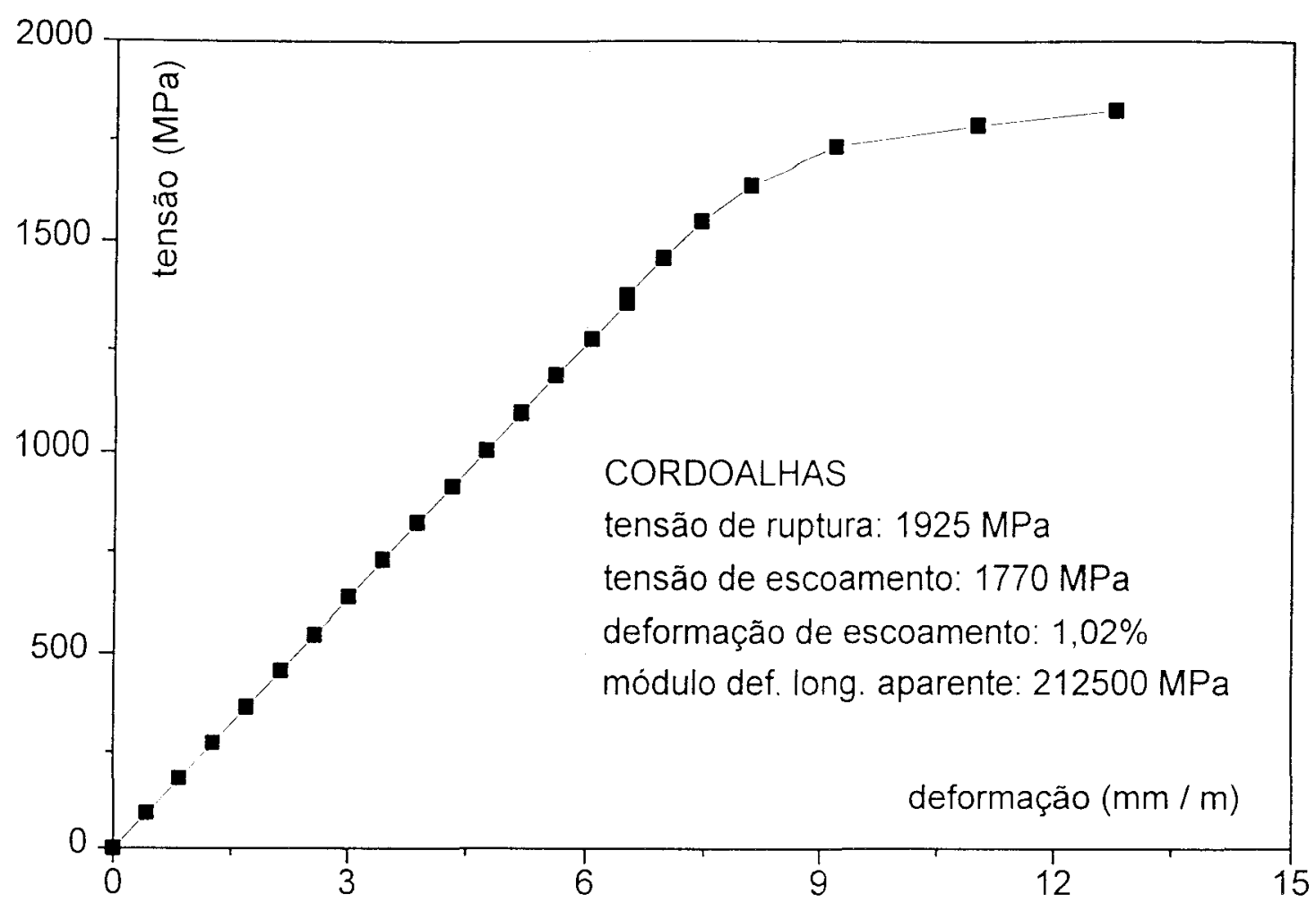

Figura 4.2 - Diagrama tensão-deformação das cordoalhas

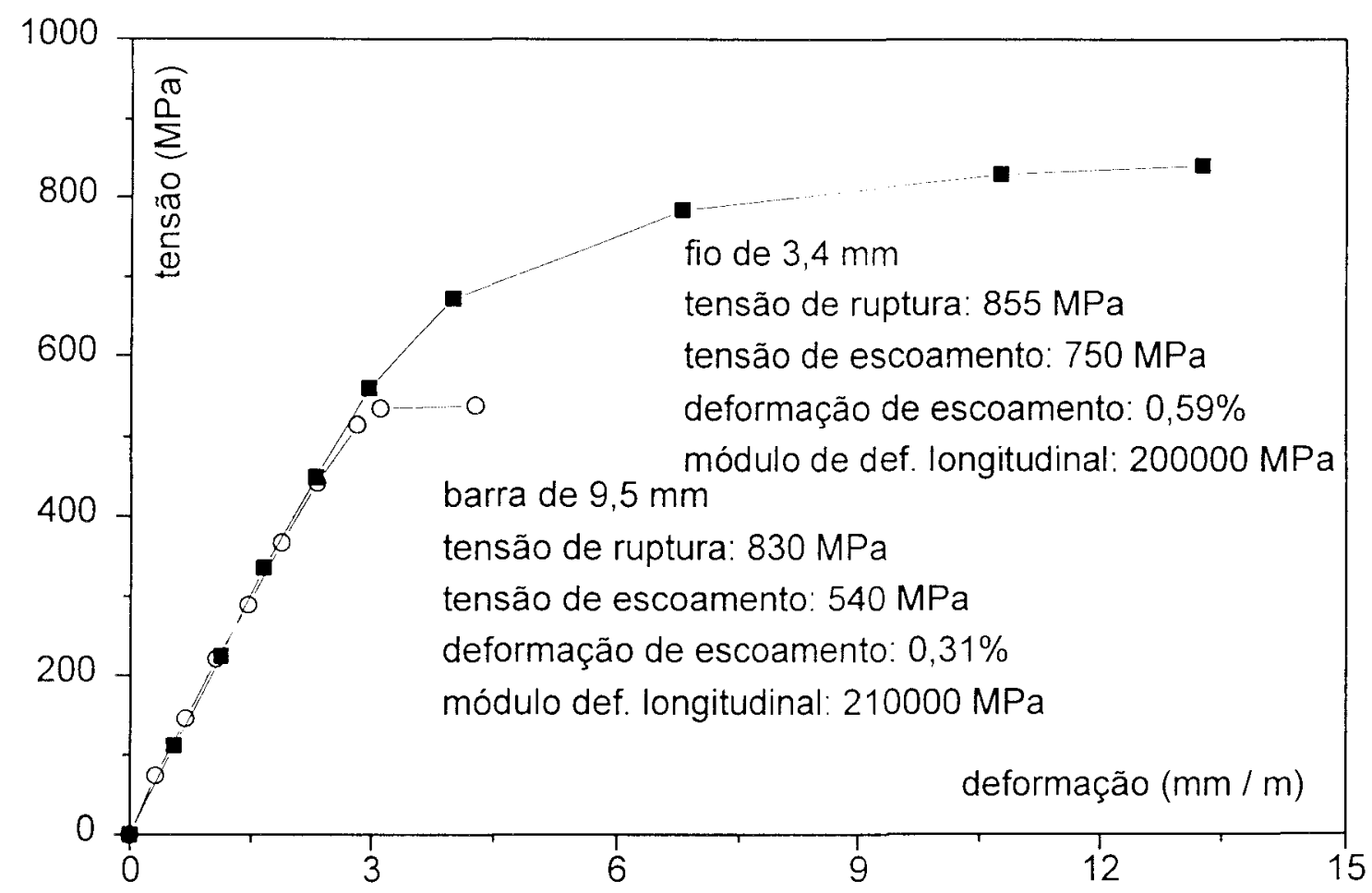

Figura 4.3 - Diagrama tensão-deformação do aço comum $(9,5 \mathrm{~mm}$ e $3,4 \mathrm{~mm})$ 


\subsection{3 - FIBRAS}

As fibras utilizadas neste trabalho foram de polipropileno, do tipo multifilamentos, e de aço, subproduto da fabricação de esponjas de limpeza. Elas foram escolhidas pela sua facilidade de obtenção no mercado e pelos seus diferentes níveis de potencialidade como reforço para o concreto para melhorar o seu desempenho estrutural. Conforme já se discutiu no capítulo anterior, a fibra de polipropileno apresenta rárias deficiências, principalmente devido ao seu baixo módulo de deformação longitudinal e à aderência limitada com a matriz de concreto. Quanto à fibra de aço empregada, apesar da geometria ondulada melhorar as condições de aderência com a matriz. sua relação de aspecto não é muito favorável. Na Tabela 4.2 encontram-se as principais características das fibras.

Tabela 4.2 - Características das fibras utilizadas

\begin{tabular}{|c|c|c|}
\hline características & fibra de aço & fibra de polipropileno \\
\hline comprimento & $2.54 \mathrm{~cm}(1 ")$ e $3,81 \mathrm{~cm}(1,5 ")$ & $42 \mathrm{~mm}$ \\
\hline seção transversal & retangular $(0,2 \mathrm{mmx} 2,3 \mathrm{~mm})$ & circular $(50 \mu \mathrm{m})$ \\
\hline relação de aspecto $(\mathrm{l} / \mathrm{d})$ & 33 e 50 & 840 \\
\hline perfil longitudinal & ondulado & reto \\
\hline módulo de deformação & $2000000 \mathrm{MPa}^{*}$ & $5000 \mathrm{a} 77000 \mathrm{MPa} *$ \\
\hline tensão de ruptura & $500 \mathrm{a} 2000 \mathrm{MPa}^{*}$ & $500 \mathrm{a} 750 \mathrm{MPa} *$ \\
\hline alongamento na ruptura & $0,5 \mathrm{a} 3,5 \%{ }^{*}$ & $22 \% * *$ \\
\hline peso especifico & $7,84 \mathrm{~g} / \mathrm{cm}^{3}$ & $0,9 \mathrm{~g} / \mathrm{cm}^{3}$ \\
\hline * BENTUR \& MINDESS $(1990)$ & $* *$ dado do fabricante \\
\hline
\end{tabular}

\subsection{4 - OUTROS MATERIAIS}

O cimento utilizado em todos os ensaios foi o CP-32 da Ciminas, de alta resistência inicial (ARI). () aditivo superplastificante empregado foi o Sikament 300.

\section{4 - MICROCONCRETO - DETERMINAÇÃO DO TRAÇO}

A relação entre os agregados graúdo e miúdo que proporcionava a maior massa específica aparente. e que. para o mesmo consumo de cimento deveria resultar em maior resistência do concreto. era de $50 \%$ de areia e $50 \%$ de pedrisco. 
A partir desta proporção. a quantidade de areia foi aumentada gradativamente, para análise da consistência do concreto. Optou-se por flexibilizar a relação inicial com o aumento da quantidade de areia, de modo a se obter melhor homogeinização e ancoragem das fibras na mistura.

A melhor trabalhabilidade foi obtida com $60 \%$ de areia e $40 \%$ de pedrisco. Esta proporção correspondia à segunda maior massa específica, e foi considerada ideal. Nestes ensaios. o consumo de cimento e de água foram mantidos constantes, com aproximadamente $500 \mathrm{Kg}$ de cimento por $\mathrm{m}^{3}$ de concreto e relação a/c igual a 0,45 (valor máximo suposto compativel com aspectos de durabilidade em peças de seção delgada). A resistência à compressão desejada era da ordem de $45 \mathrm{MPa}$ aos sete dias. O traço final. em massa. foi de 1:2:1.3: 0.45. de cimento, areia, brita e água.

O traço se manteve constante em todos os modelos. No concreto com fibras. imaginou-se que a adição de superplastificante permitiria a manutenção da mesma relação a/c. com pequena variação na consistência e na resistência. Em misturas preliminares com a fibra de polipropileno. a produção de concreto com $0,5 \%$ de fibras (em relação ao volume de concreto) e 1\% de superplastificante (em relação ao peso de cimento) confirmou esta hipótese.

No caso dos compósitos. os ensaios tradicionais de consistência, abatimento do tronco de cone e mesa de fluidez. são pouco representativos para análise da trabalhabilidade. A quantidade máxima de fibras foi definida, em cada caso, a partir da análise da trabalhabilidade do concreto durante a produção das vigas prismáticas.

\section{5 - VIGAS DE SEÇÃO QUADRADA}

A Tabela 4.3 resume as características dos sete tipos diferentes de mistura, que diferem apenas pelo tipo e/ou volume de fibra e pela quantidade de superplastificante.

Tabela 4.3 - Características das misturas das vigas de seção quadrada

\begin{tabular}{|c|c|c|c|}
\hline mistura & tipo de fibra & volume (\%) & aditivo (\%) \\
\hline 1 & - & - & - \\
\hline 2 & polipropileno & 0.5 & 1,0 \\
\hline 3 & aço l" & 1,0 & 1,0 \\
\hline 4 & aço $1^{\prime \prime}$ & 2,0 & 1,0 \\
\hline 5 & aço $1.5^{\prime \prime}$ & 1.0 & 1,0 \\
\hline 6 & aço $1.5^{\prime \prime}$ & 2,0 & 1,0 \\
\hline 7 & aço $1.5 "$ & 0.5 & 1.0 \\
\hline
\end{tabular}


No caso da fibra de polipropileno, mesmo com aumento do consumo de aditivo não se conseguiu trabalhar com volume acima de $0,5 \%$, pois a trabalhabilidade resultante era incompatível com a produção dos modelos.

Para a fibra de aço, o limite superior não foi imposto pela variação da consistência, mas por questões econômicas. A quantidade de aditivo nestas peças poderia ser menor. mas foi mantida igual a $1 \%$ nestes ensaios.

Para cada tipo de compósito foram executadas duas vigas de seção quadrada (10 $\times 10 \times 100 \mathrm{~cm}$ ), totalizando quatorze modelos. As duas vigas eram moldadas em uma forma de madeira. a partir de apenas uma mistura na betoneira. Numa delas. a armadura transversal era constituída de estribos de $3,4 \mathrm{~mm}$, espaçados a cada $10 \mathrm{~cm}$. Na outra, não havia estribos. A armadura longitudinal era a mesma em todos os modelos, constituída por duas barras de $9,5 \mathrm{~mm}$. As Fotos 4.1 e 4.2 mostram o detalhe das armaduras das duas vigas posicionadas nas fôrmas.

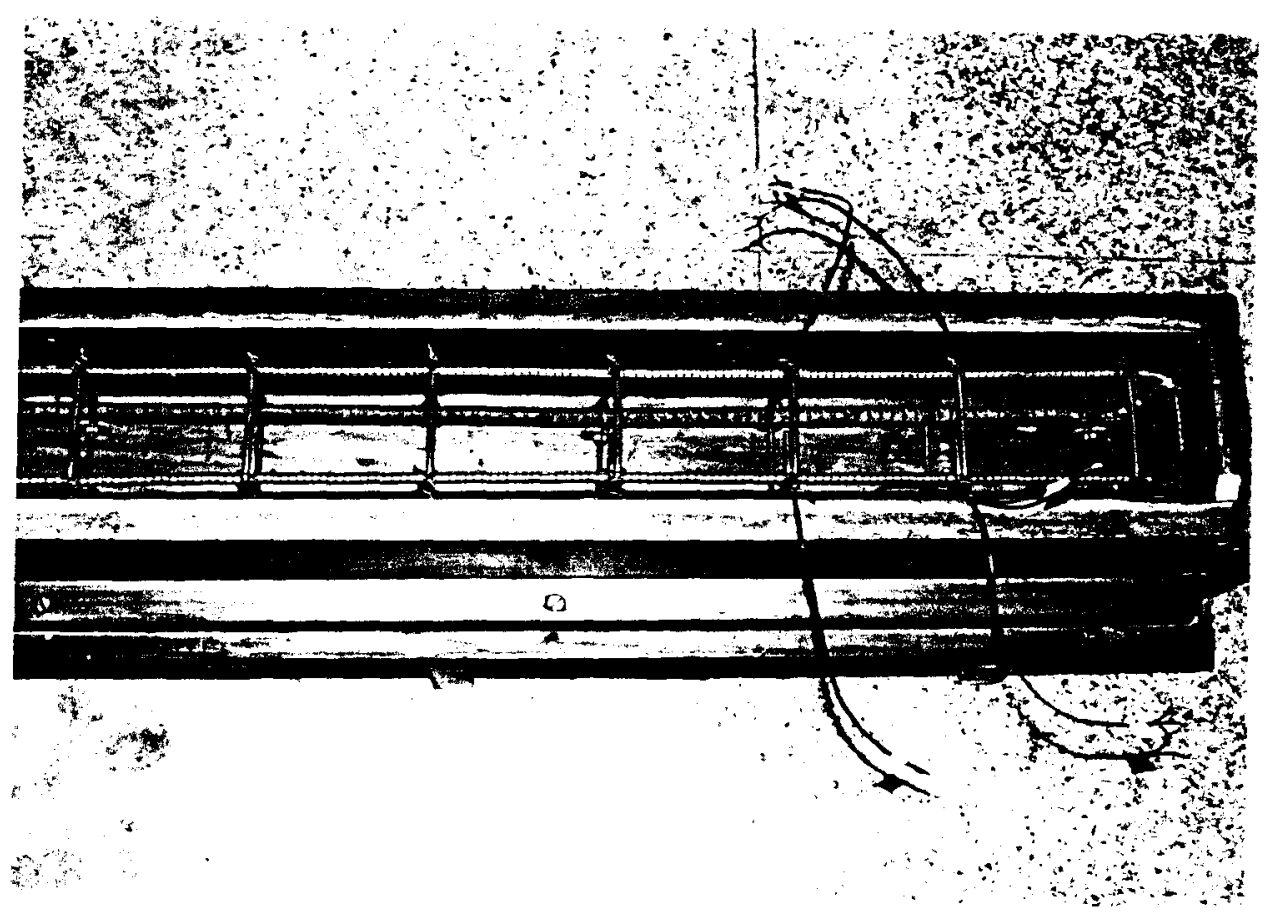

Foto 4.1 - Detalhe da armadura das vigas da série A na fôrma

As vigas com estribos constituem a SÉRIE $A$ e as vigas sem estribos constituem a SÉRIE B. Simultaneamente à produção dos modelos, em cada caso foram moldados quatro corpos-de-prova cilíndricos de $15 \times 30 \mathrm{~cm}$, para determinação da resistência à tração (ensaio de compressão diametral) e à compressão axial, sendo dois corpos-deprova para cada tipo de ensaio. Um destes corpos-de-prova era instrumentado para determinação do módulo de deformação longitudinal. 


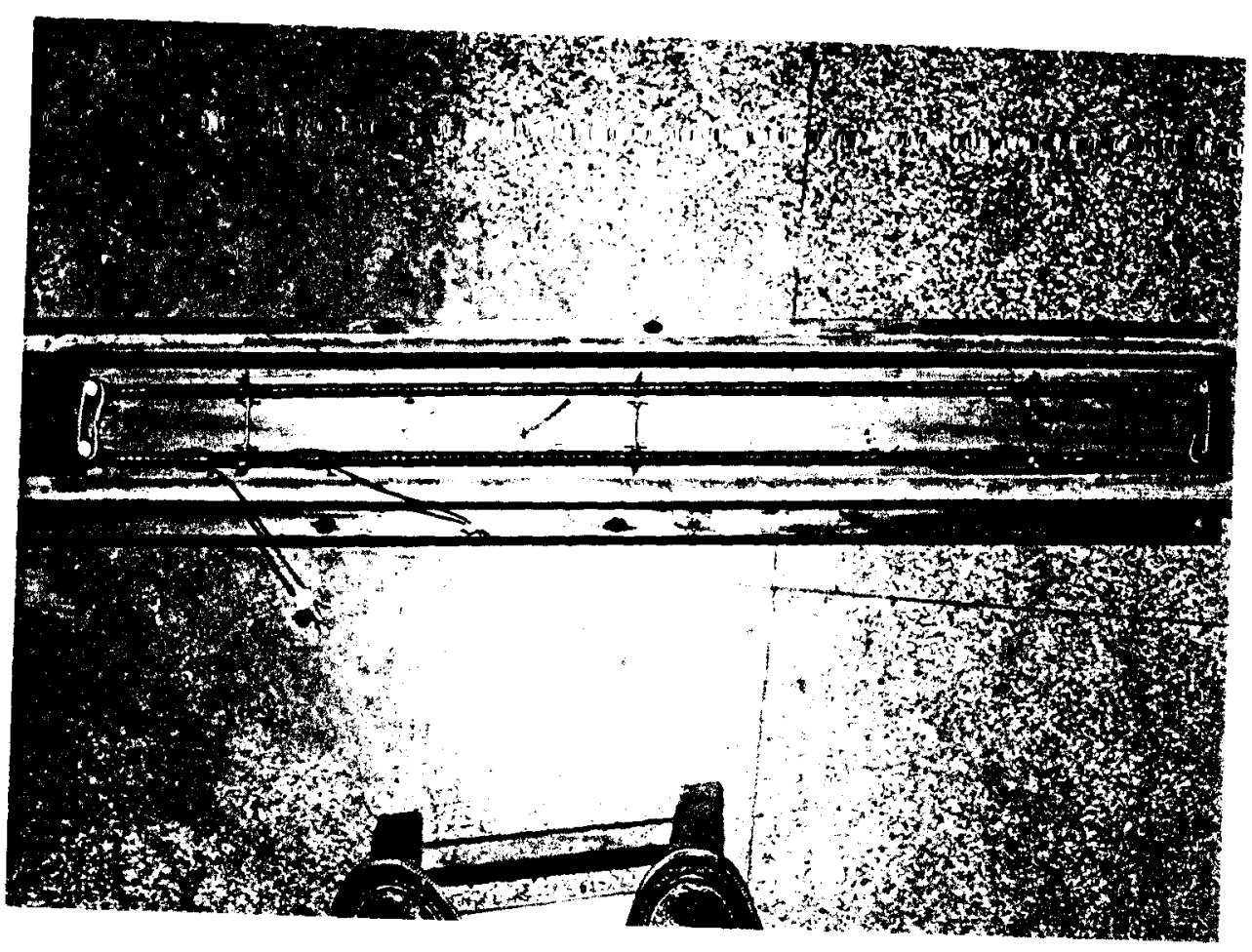

Foto 4.2 - Detalhe da armadura das vigas da série B na fôrma

\subsection{1 - DIMENSIONAMENTO}

As vigas foram ensaiadas aplicando-se duas cargas concentradas nos terços do vão. com relação a/d igual a 3,5. Os modelos da série $A$ foram dimensionados para que a carga teórica de ruptura por cisalhamento, devido ao escoamento da armadura transversal, fosse próxima daquela correspondente à ruptura por flexão, devido ao escoamento da armadura longitudinal. Com as hipóteses da NBR-6118 e os valores efetivos das características dos materiais, exceto do concreto, cuja resistencia foi estimada em $45 \mathrm{MPa}$, a força cortante correspondente ao escoamento dos estribos, à ruptura dos estribos e ao escoamento da armadura de flexão vale $17.4 \mathrm{kN}, 18.6 \mathrm{kN}$ e $18,3 \mathrm{kN}$. respectivamente.

A utilização da resistência efetiva do concreto obtida com os corpos-de-prova, en cada caso, altera pouco os resultados. Na flexão, a ruptura ocorre sempre no dominio 2, e se altera principalmente a posição da linha neutra. O escoamento da armadura longitudinal ocorre para força cortante entre $18.2 \mathrm{kN}$ e $18.8 \mathrm{kN}$. conforme o valor da resistência do concreto obtido. No cisalhamento. a força cortante que provoca o escoamento dos estribos está compreendida entre $17.3 \mathrm{kN}$ e $18.2 \mathrm{kN}$; para a ruptura dos estribos. entre $18,6 \mathrm{kN}$ e $19,5 \mathrm{kN}$. 
A armadura transversal que foi adotada $\left(1,8 \mathrm{~cm}^{2} / \mathrm{m}\right)$ é, portanto, um pouco menor do que aquela necessária para possibilitar o escoamento da armadura longitudinal $\left(1.96 \mathrm{~cm}^{2} / \mathrm{m}\right.$, para força cortante de $\left.18,3 \mathrm{kN}\right)$. Segundo a NBR-6118, a armadura mínima seria de $0,14 \% \mathrm{~d}$, ou $0,14 \% \mathrm{~b}_{\mathrm{w}}$, o menor destes valores. Portanto, neste caso. ela vale $1,19 \mathrm{~cm}^{2} / \mathrm{m}\left(\rho_{w}=0,119\right)$. Se a viga fosse dimensionada com os valores nominais de resistência do aço, a armadura necessária para permitir 0 escoamento da armadura longitudinal com $18,3 \mathrm{kN}$ seria de $2.45 \mathrm{~cm}^{2} / \mathrm{m}$.

A escolha de um espaçamento excessivo entre os estribos, maior que a altura útil da peça foi proposital. O grau de armação ao cisalhamento das peças da série A vale $0.54(\eta$ - relação entre a armadura transversal existente e a calculada pela treliça de Mörsch para a carga que provoca o escoamento da armadura longitudinal) .

Ainda para os modelos da série A, de acordo com o CEB-90, a inclinação das bielas proximo da ruptura seria igual a 29 graus. Mesmo dentro dos limites admissíveis. o concreto seria muito sacrificado, e a fissuração excessiva limitaria a utilização da peça. Seģundo o (EB-90. o menor valor de $\rho_{w}$ para aplicação do modelo da treliça generalizada é igual a $0.09 \%$. O valor de $\rho_{w \text { min }}$ varia de acordo com a classe do concreto e do aço.

Nas peças da série B. a ruptura teórica por cisalhamento calculada pela NBR6118 ocorre para a força cortante igual a $7,4 \mathrm{kN}$. De acordo com a formulação do CEB78 , a força cortante de ruptura vale $6.4 \mathrm{kN}$. Na verdade, estas cargas se referem ao instante de formação da fissura diagonal. que nem sempre leva a peça imediatamente à ruína. No caso de vigas sem estribos. a resistência do concreto altera os resultados de modo significativo.

A Tabela 4.4 resume os principais parâmetros do dimensionamento dos modelos. As características geométricas das vigas, os detalhes das armaduras e o esquema de carregamento são apresentados na Figura 4.4.

Tabela 4.4 - Parâmetros relativos ao cisalhamento - valores experimentais

\begin{tabular}{|c|c|c|c|c|c|c|c|}
\hline série & $\begin{array}{l}A_{\text {Sin. }} \\
\left(\mathrm{cm}^{2} / m\right)\end{array}$ & $\begin{array}{l}\rho_{w . c} \\
(\%)\end{array}$ & $\begin{array}{l}\mathrm{V}_{\mathrm{u} . \mathrm{c}} \\
(\mathrm{kN})\end{array}$ & $\begin{array}{l}V_{u . f} \\
(k N)\end{array}$ & $\begin{array}{c}P_{w, \min } \\
(\%)\end{array}$ & $\begin{array}{c}\rho_{W, M} \\
(\%)\end{array}$ & $\eta$ \\
\hline$\therefore$ & 1.8 & 0,18 & 17.4 & 18,3 & 0,12 & 0,31 & 0,54 \\
\hline$B$ & - & - & 7.4 & 18,3 & 0.12 & 0,31 & - \\
\hline
\end{tabular}

Nas vigas de seção transversal retangular, o momento fletor solicitante que provoca o aparecimento da primeira fissura de flexão, calculado no estádio $\mathrm{Ib}, \mathrm{M}_{\mathrm{r}}$, vale 
$0,25 \mathrm{~b} \mathrm{~h}^{2} \mathrm{f}_{\mathrm{tk}}$. Com o valor da resistência à tração estimada a partir da resistência à compressão de $45 \mathrm{MPa}(3,4 \mathrm{MPa})$, a força cortante correspondente é de $5,7 \mathrm{kN}$, para forças aplicadas a $30 \mathrm{~cm}$ dos apoios.

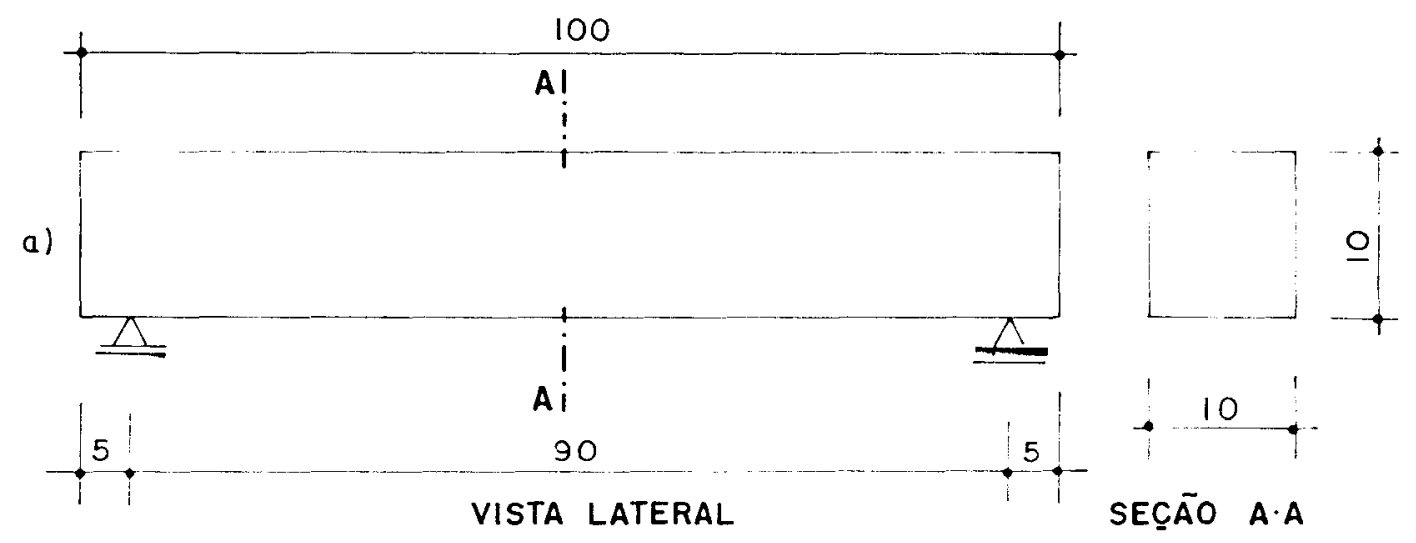

b)
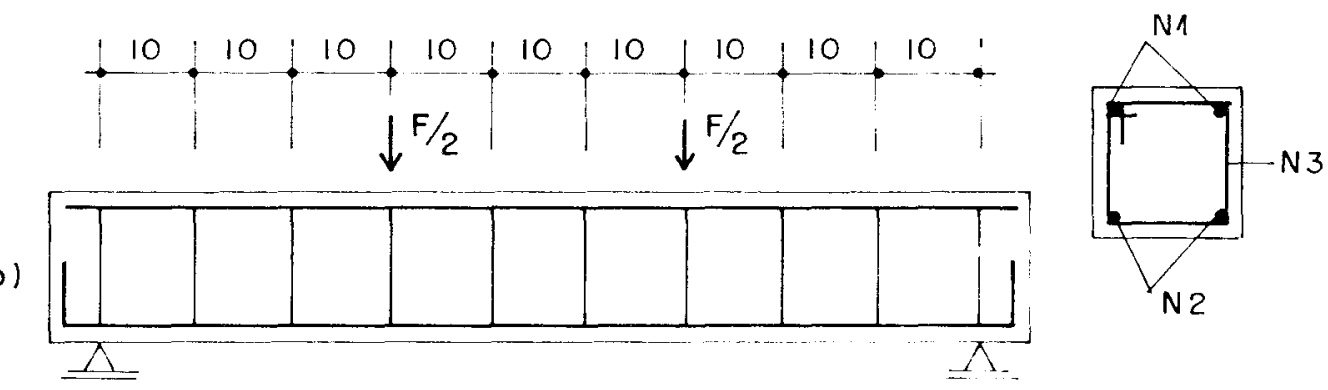

$N 1-2 \varnothing 6.3 \mathrm{~mm} \quad(.95)$
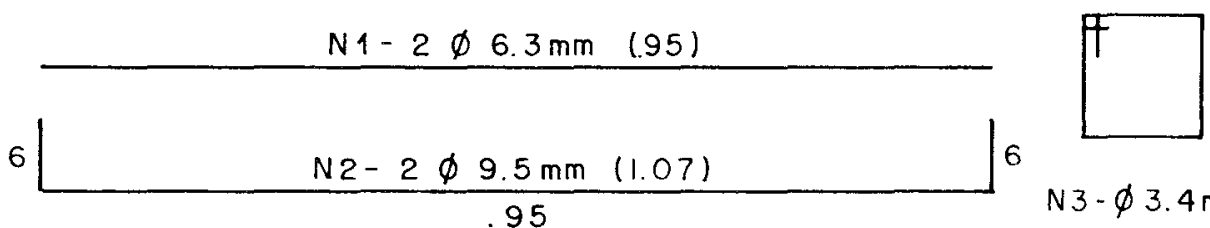

$\mathrm{N} 3-\varnothing 3.4 \mathrm{~mm}$

c)
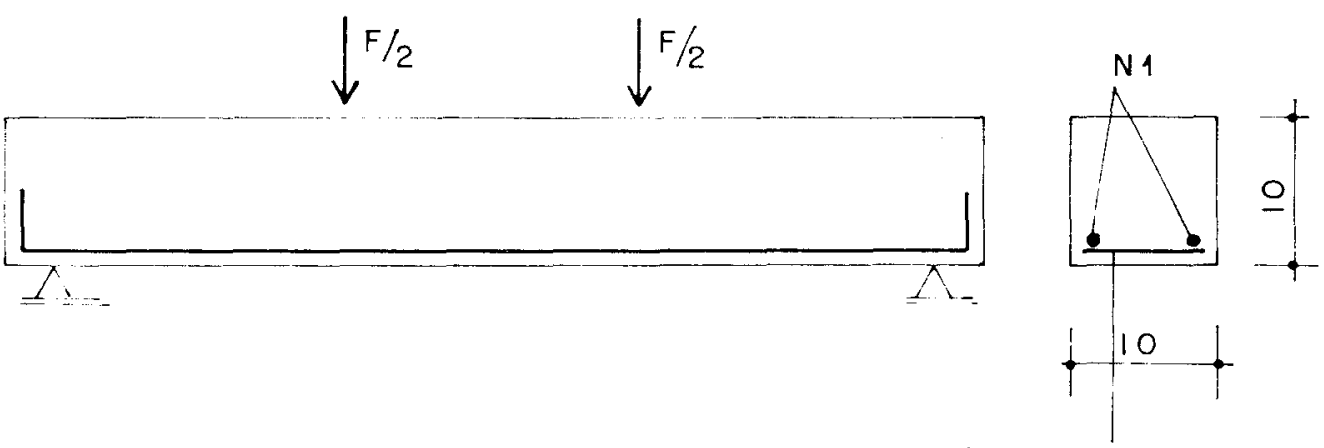

6 $N 1-2 \emptyset 9.5 \mathrm{~mm}(1.07)$ 6 $2 \mathrm{~N} 2-\phi 6.3 \mathrm{~mm}$

Figura 4.4 - a) Características geométricas

b) Detalhe da armadura das vigas da série $\mathrm{A}$

c) Detalhe da armadura das vigas da série $B$ 


\subsection{2 - INSTRUMENTAÇÃO}

As vigas foram instrumentadas com extensômetros elétricos na zona comprimida do concreto. na armadura longitudinal e nos estribos, além de defletômetros mecânicos para o acompanhamento das flechas. Os estribos escolhidos para instrumentação foram os dois compreendidos entre o ponto de aplicação da carga e o apoio, dos dois lados da viga. Os estribos posicionados sobre os apoios, sob as cargas e no trecho central não foram instrumentados.

$\mathrm{O}$ concreto e a armadura longitudinal foram instrumentados em seções coincidentes. em dois pontos de cada lado da viga, a $5 \mathrm{~cm}$ e $15 \mathrm{~cm}$ dos apoios, sempre entre dois estribos. Todos os extensômetros foram ligados a um sistema de aquisição de dados, qu registrava a deformação de cada ponto sempre que solicitado, normalmente após um incremento de carga.

Nos dois primeiros modelos, P1A e P1B, foram colados dois extensômetros no concreto, na face comprimida, próximo das faces laterais. e dois na armadura longitudinal, um em cada barra, em cada uma das quatro seções instrumentadas. Em todos os estribos instrumentados foram aplicados dois extensômetros, um em cada ramo. Eram 24 extensômetros no prisma P1A e 16 extensômetros no prisma P1B. Julgou-se importante uma instrumentação mais completa nos primeiros modelos para que, a partir destes resultados, ela pudesse ser simplificada nos modelos seguintes, sem que se perdesse as informações mais importantes.

Nos outros doze modelos, P2 ao P7, das séries A e B, optou-se por conservar os dois extensômetros de cada estribo e posicionar apenas um extensômetro por seção no concreto, na borda da face comprimida, e um extensômetro na armadura longitudinal, numa das harras. Além de ser mais sensível à variação do comportamento entre as faces laterais, devido à alma espessa, a instrumentação dos estribos traz as informações mais importantes para o objetivo principal do trabalho. A Foto 4.3 ilustra o detalhe dos extensômetros no concreto no modelo P3B. Os extensômetros nas armaduras aparecem na Foto 4.2.

Os relógios comparadores foram posicionados junto aos apoios e no meio do vão. Nos apoios, eles mediam os deslocamentos do perfil metálico preso ao pórtico onde a viga se apoiava, conforme se observa na Foto 4.4, empregados para se descontar o deslocamento vertical dos apoios da flecha no meio do vão. Nos dois primeiros modelos foram utilizados defletômetros indutivos. posteriormente substituídos devido à sensibilidade inadequada para deslocamentos pequenos, que prejudicava a análise dos resultados na etapa inicial do ensaio. 


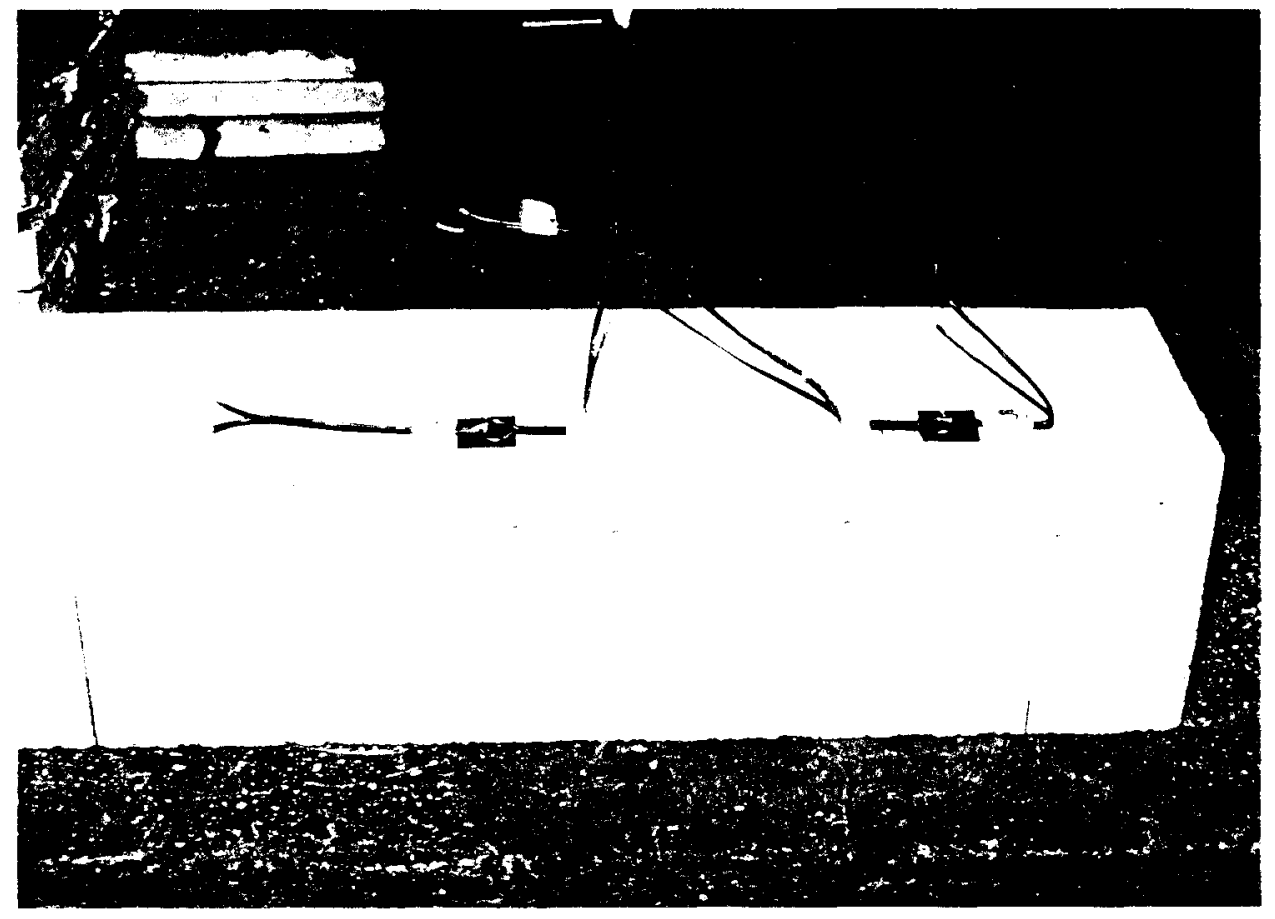

Foto 4.3 - Detalhe do extensômetro no concreto

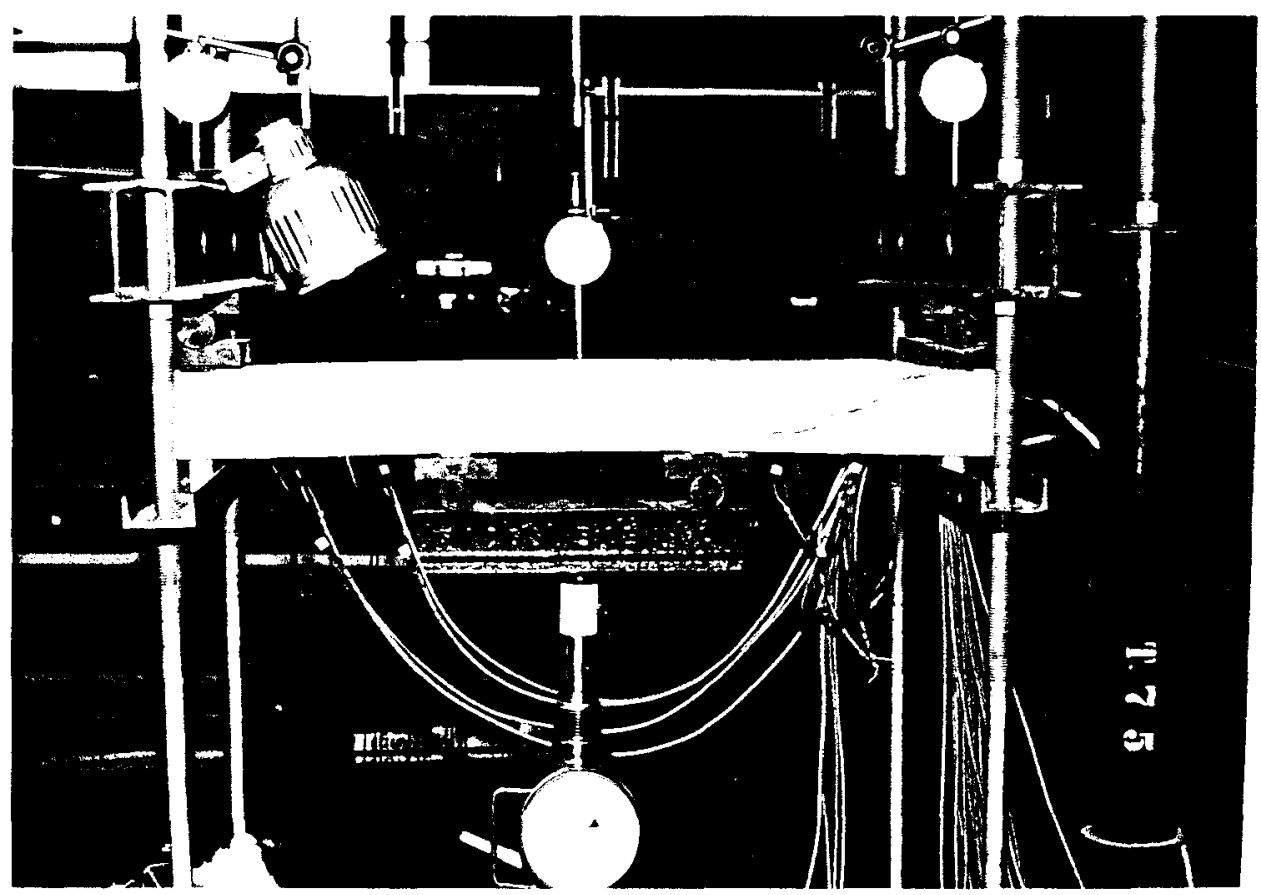

Foto 4.4 - Panorama geral dos aparelhos de ensaio

A Figura 4.5 mostra a instrumentação dos modelos. com a numeração e a simbologia adotadas. O lado correspondente aos extensômetros ímpares é referido como o lado esquerdo. Ao lado direito correspondem os extensômetros pares. Para os estribos utiliza-se a letra E. seguida do número correspondente à sua posição e da letra 
que identifica o ramo do estribo. (Os números 1 e 2 referem-se aos estribos instrumentados mais próximos dos apoios esquerdo e direito, respectivamente. Os estribos mais internos são os de número 3 e 4 . Os ramos são identificados pelas letras $\mathrm{f}$ (frente) e 1 (trás). Para a armadura e o concreto vale a mesma regra, sendo que as letras utilizadas são A e C, respectivamente. Nos modelos P2 a P7 das duas séries, em que havia apenas um extensômetro por seção no concreto e na armadura, prescinde-se do uso das letras fe t nestes elementos.

a )

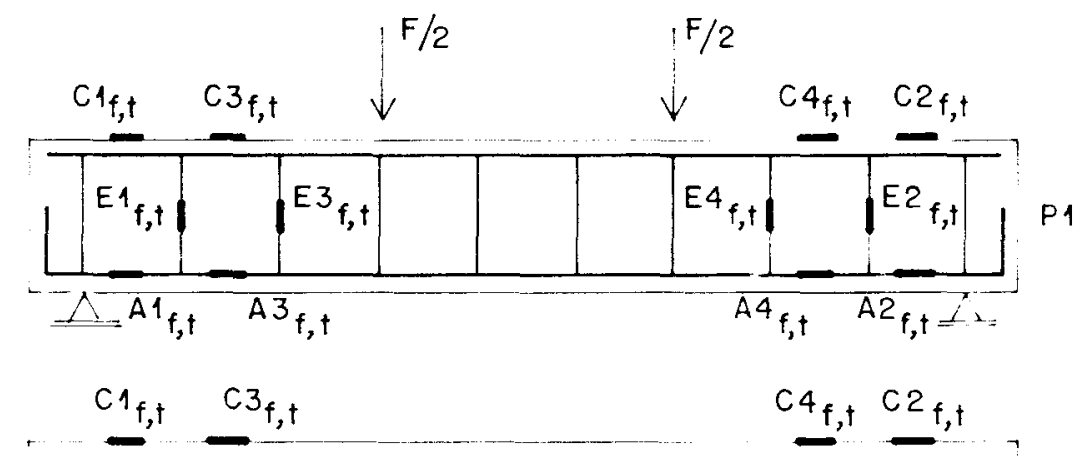

b) $P 2, P 7$

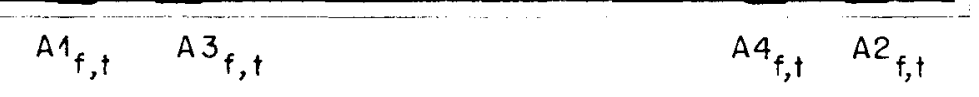

Figura 4.5 - Numeração dos extensòmetros

$\Lambda$ aplicação das cargas foi feita com um macaco com capacidade para $200 \mathrm{kN}$, ligado a uma bomba de acionamento manual. A força era transmitida aos terços da viga por um perfil metálico, sendo que ela era aplicada de baixo para cima. com a viga na sua posição invertida. Uma célula de carga conectada ao macaco e ligada ao sistema de aquisição de dados controlava a força aplicada, registrando o valor da força total, igual a duas vess a valor da força cortante. Os apoios eram do tipo móvel. com rotação e translação livres. A liberdade de translação na direção longitudinal da peça é obtida pela baixa rigiduz que os tirantes do pórtico de reação apresentam nesta direção. comprovada pelo retorno do tirante do pórtico à posição original quando a carga é retirada. Estes dados são mostrados na Foto 4.4

Inicialmente aplicava-se uma força de $0.4 \mathrm{kN}$ para aliviar o peso próprio da viga e dos aparelhos de apoio. para então zerar os instrumentos. Os incrementos eram de 2,5 $\mathrm{kN}$ até a caróa de $20 \mathrm{kN}$. quando passavam para $5 \mathrm{kN}$ até o final do ensaio. Apenas na peça PlB cle for de $2 \mathrm{kN}$. do início até o final do ensaio. A cada etapa de carga o sistema rusistrara os dados e eram feitas as leituras dos defletômetros e a marcação das fissuras. 
Apús os primeiros ensaios, também foram registradas algumas etapas intermediurias próximas da ruptura. Nas peças com fibras da série $A$, a armadura longitudinal escoou em quase todos os casos, quando os deslocamentos aumentaram muito no final do ensaio, sob carga praticamente constante. A capacidade resistente se esgotava. mas a peça ainda se deformava bastante, revelando um comportamento bastante dutil. As leituras intermediárias nesta etapa auxiliam na avaliação da dutilidade. Vos demais casos em que a ruína efetivamente se concretizou, o sistema não registrou as deformações dos elementos instrumentados neste instante. Os registros intermediários aproximam a última leitura do instante da ruína.

\subsection{3 - RFSULTADOS E CONSIDERAÇÕES GERAIS}

A upresentação dos resultados é feita individualmente, seguindo a sequência cronológica dos ensaios. Para cada modelo das séries A e B apresenta-se uma descrição do ensaio enfocando-se os seus aspectos mais relevantes, onde se analisam os principais fenômenos observados em relação à ruptura. à fissuração, aos deslocamentos e às deformações nos estribos, armadura longitudinal e concreto. Posteriormente. seguem os gráficos com a cvolução das deformações nos estribos. na armadura longitudinal e no concreto, em todos os pontos instrumentados, nas Figuras 4.6 a 4.28 . Eles registram e ilustram o comportamento resistente da peça de um modo geral.

No item 4.6. onde se faz a análise dos resultados obtidos, são enfocados os seguintes parâmetros:

- Propricdades do concreto endurecido;

- Fissuração por flexão e cisalhamento:

- Deslocimentos:

- Dados celationos à ruptura:

- Tensão nos cstribos. na armadura longitudinal e no concreto.

Alim de alguns gráficos e tabelas elaborados para facilitar a análise comparativa que são descritos posteriomente, apresenta-se no item 4.6 outros resultados dos ensaios de forma agrupada para todos os modelos, os quais não foram mostrados explicitamente na apresentação individual, conforme se explica a seguir para facilitar uma consulta prér ia a estes dados. 
- Propriedades da mistura endurecida, na Tabela 4.5, que, entre outros dados, apresenta os resultados dos ensaios dos corpos-de-prova (resistência à compressão, resistência à tração e módulo de deformação longitudinal). O módulo de deformação longitudinal experimental corresponde ao módulo tangente e representa o resultado do ensaio de apenas um corpo-de-prova. Os valores da resistência à tração c compressão do concreto são sempre obtidos pela média de dois valores. Os diagramas $\sigma-\varepsilon$ das sete misturas estão na Figura 4.29.

- Resultados relativos à fissuração por flexão, na Tabela 4.6, com a carga correspondente ao aparecimento da primeira fissura de flexão, a abertura da primcira fissura. e a carga e a deformação máxima na armadura longitudinal no instante $\mathrm{em}$ que a abertura da fissura mais crítica de flexão atingiu a abertura de $0.16 \mathrm{~mm}$. () acompanhamento do valor da abertura de fissuras tem objetivo apenas compamativo pois o método de medição é relativamente precário. Registrou-se a evoluçn da abertura das fissuras mais críticas até o limite da lupa graduada.

- Fissurar de cisalhamento, na Tabela 4.8, que apresenta a carga em que as fissuras de flexào começaram a se inclinar, a carga em que surgiu a primeira fissura inclinadia dirctamente na alma e o valor das respectivas aberturas destas fissuras, quando elas foram anotadas.

- Parâmetros relativos aos deslocamentos, na Tabela 4.9, que mostra a flecha correspondente a carga máxima e as cargas correspondentes aos deslocamentos iguais a $/ 300(3 \mathrm{~mm}) . / 150(6 \mathrm{~mm})$ e $/ / 100(9 \mathrm{~mm})$, para acompanhar o instante em que algumas llechas de referência para projeto são atingidas. Os gráficos das flechas dos modelos da série A estão na Figura 4.33 e os da série B na Figura 4.32. A forma do diagrama permite avaliar o possível escoamento da armadura longitudinal.

- Parâmetros relativos à ruptura, na Tabela 4.10, que apresenta a força cortante máxima a forma de ruptura e a inclinação da fissura crítica. A posição a que se refere a inclinação da fissura diagonal, na metade da altura. foi escolhida porque ela surge inicialmente ncsta região, avançando posteriormente em direção aos apoios e ao ponto de introdução do carregamento.

A carga máxima atingida no ensaio e a carga correspondente ao estado limite último prokem não ser coincidentes. Para o estado limite último, convencionou-se estabelecé-lo no instante do escoamento da armadura longitudinal ou de algum estribo. Porém. cunno a amadura fongitudinal não foi instrumentada no ponto em que o momento thetor era máximo. esta análise ficou parcialmente prejudicada. $A$ evolução dos deslowamentos no final do ensaio pode auxiliar neste caso. 
Fin todos os modelos que atingiram a ruína por cisalhamento, a forma da fissura diagonal foi similar. interligando o ponto de introdução do carregamento e o apoio, com maior inclinação na meia altura da viga. Em alguns casos, a fissura crítica surgiu a partir da bifurcaç̃o de una lissura diagonal, oriunda de uma fissura de flexão ou não. Estes dach podem ser observados em vários modelos da série $\mathrm{A}$. onde a fissura diagonal naw progride imediatamente para a ruína, nas Fotos 4.11 e 4.15.

Ná vigas da sćrie $B$. após o aparecimento da fissura diagonal, a ruptura sobreveio para a maioria das peças no incremento de carga seguinte. No modelo P4B pode ser observada claramente a fissuração ao longo da armadura longitudinal, que se manifestou nas proximidades da ruptura e não foi observada durante o ensaio. As Fotos 4.11 e $4.1^{-}$mostram a deformação plástica na base da fissura crítica, revelada por uma descontinuidide angular neste ponto.

Nom matelos da serie 3 . onde a ruptura diagonal sempre ocorreu, a deformação residual foi praticamente desprezível. exceto em P4B. Neste caso ela é visível, conforme mustra a Foto 4.10. e sugere o escoamento da armadura longitudinal, anterior ao instante da ruina.

Em vigas de seção retangular, a primeira fissura inclinada normalmente aparece como proluigamento de uma físsura de flexão. Este fato ocorreu em todas as vigas de seção quadrada keste trabalho.

O acionamento dos estribos normalmente ocorreu antes do aparecimento de uma fissuri inclinada visivel nas suas proximidades. Quando ela surge na seção do estribo, há : am amento hrusco de tensão. A mobilização dos estribos sempre ocorreu antes para u cstrihos 13 : 14 . pois as fissuras de flexão se inclinam nesta região antes do prolongamento das fissuras diagonais em direção aos apoios. na posição de E1 e E2. Estes fatos pokm ser observados em várias situações. A mobilização efetiva dos estribos também revela o esgotamento da capacidade resistente proporcionada pelos mecanismo altumatios quando então é acionado o mecanismo de treliça.

A «⿺辶̄o de meio do vão não foi instrumentada. Entretanto. pode-se estimar a deformaçã misima no concreto admitindo-se a proporcionalidade de deformaçôes entre a seça muis solicituda e a seção instrumentada. Esta hipótese é grosseira, já que a deformaçã nos pontos ( 3 e C 4 normalmente foi afetada pelo arqueamento das tensões de compresão. o que significa que a deformação no centro da viga deve ser maior do que a estimiuda. I:m todos os modelos a tensão máxima no concreto ficou muito abaixo do seu lima de ruptura. A deformação esperada no meio da viga no instante do escoamenti da maldura longitudinal. próximo de $40 \mathrm{kN}$, era de $0.35 \%$. A ruptura

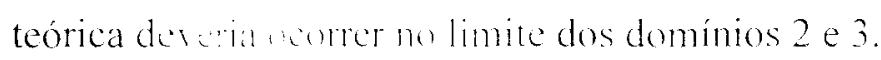


A descompressão do banzo se deve ao arqueamento das tensões de compressão, que se inclinam em direção aos apoios quando a ruptura diagonal se aproxima (a formação do pórtico atirantado representa a última tentativa de transmissão da carga diretamente até o apoio). ( )uando o arqueamento foi intenso, a deformação na armadura junto ao aprin aumentou significativamente. A diminuição das tensões de compressão no concreto ocorreu antes para os pontos $\mathrm{C} 1$ e $\mathrm{C} 2$, e nem sempre atingiu os pontos mais internos. $(3)$ C C cula distância até os apoios era igual a 1,8d. A observação sistemática do fenômeno da descompressão comprova que os banzos da treliça idealizada não são paralelos.

Nos pontus próximos dos apoios, onde há uma concentração do leque de bielas próximo da ruptura. a força na armadura longitudinal a ser ancorada aumentou, especiahmente yuando a ruptura diagonal se concretizou. Este fato foi observado em várias ountic: e nomalmente foi acompanhado da manifestação mais intensa da descompresiú no concretu no lado correspondente, como por exemplo, em P1A e P5A. Em untrus casos. quando a descompressão foi mais sutil. o fenômeno não foi observado. como no modelo P4A.

A análise do valor da deformação máxima da armadura longitudinal nos pontos mais intcrnos auxilia na verificação do seu eventual escoamento. Pode-se estimar o valor da deformação da armadura longitudinal no trecho central da viga admitindo-se a mesma proporcionalidade de deformações entre o ponto de momento fletor máximo e o ponto instrumentado. () s cros desta hipótese decorrem da não consideração do cobrimentu de diagrama de momento fletor e da flexão localizada da armadura devido ao apoiv das biclas. que pode alterar os resultados dependendo da posição dos extensômetros na barra. Assim. o valor real da deformação no trecho de momento fletor máximo possivelmente é menor que o estimado. Em alguns casos, a deformação na armadura longitudinal nos pontos internos instrumentados atingiu o patamar de escoamenti. commo por exemplo. nos modelos P2A e P4A. 


\subsubsection{1 - MODELOS P1A e P1B}

Estas primeiras vigas não contém fibras e são modelos de referência para comparaçán dos resultados dos modelos com fibras. A consistência da mistura sem o uso de aditivo mostrou-se compativel com a fôrma, armadura e sistema de adensamento, e a moldagem transcorreu sem problemas. Os valores obtidos com os corpos-de-prova utilizados para controle de resistência foram os mais baixos dentre todos os modelos desta etapa do trabalho.

\section{modelo P1A}

A ruptura ocorreu no lado esquerdo da viga, com $40 \mathrm{kN}$. Até este instante, não se registru o escoamento da armadura longitudinal ou de algum estribo. Portanto, o estado limite último convencional só foi atingido no instante da ruptura. A viga não apresentou deformação residual (deformação plástica irreversível) significativa após o descarregímento. Isso pode ser comprovado pela análise da Foto 4.19, onde se mostra o panorana geral de todos os modelos desta série após o ensaio.

A viga rompeu de maneira súbita aproximadamente 30 segundos após a carga atingir o valor de $40 \mathrm{kN}$. Imediatamente antes da ruína, o estribo próximo do apoio esquerdo. 1:1. que até então estava pouco solicitado, alongou-se abruptamente. $O$ estribo priximo da carga no lado direito. E4, que já estava sob tensão elevada, atingiu a mesma tensão de L1. $400 \mathrm{MPa}$.

O espaçamento entre os estribos era muito elevado, mas não explica, por si só, a ausência de registro do escoamento de nenhum deles. já que a região da ruptura diagonal atravessou os estribos E1 e E3. Entre o instante em que se atingiu a carga de $40 \mathrm{kN}$ e a ruina. a bomba hidráulica utilizada para a aplicação do carregamento pode ter sido acionada para se manter o nível de carga, e os estribos podem ter escoado neste intervalo.

Mcimo que isso não tenha ocorrido, pode-se justificar este fato devido ao esgotamento repentino da resistência à tração do concreto, onde a ruptura pode ser frágil, devido à instabilidade da fissura diagonal. Imediatamente antes da ruptura, as tensões nos estribos E3 e E4 eram altas porque havia fissuras inclinadas nestas regiões. Próximo hos apoios, apenas El atravessava uma fissura diagonal, que deu origem à fissura critica quando a carga atingiu $40 \mathrm{kN}$. Esta fissura diagonal caminhou para a ruptura rapidamente. ao contrário dos modelos com fibras que romperam por cisalhamento. conforme se observa na Foto 4.15. Entre o instante do último registro dos dados. quindo os estribos ainda evitavam a ruptura, e o instante da ruína, onde ocorre 
ruptura brusca do concreto e há transferência de tensões, o estribo pode romper. A resistência residual, posterior ao escoamento de algum estribo, inexistiu.

Depois que foram acionados, os estribos próximos dos apoios (E1 e E2) mantiveram-se com tensão limitada a $138 \mathrm{MPa}$ até a penúltima etapa de carga. Nos estribos 13 e Et a mobilização ocorreu antes. Neste caso, até a penúltima etapa do carregamento. a tensão máxima foi de $317 \mathrm{MPa}$.

Quando surgiu a fissura diagonal a ruptura era iminente, pois a transmissão da carga do ponto de aplicação até o apoio se fazia quase diretamente. Além da elevação brusca da tensão no estribo E1, houve intensa descompressão no concreto deste lado da peça, que atingiu inclusive o ponto mais interno instrumentado, $\mathrm{C} 3$. distante $15 \mathrm{~cm}$ do apoio, ou $1.8 \mathrm{~d}$.

\section{modelo P1B}

A carga máxima no modelo de referência sem estribos foi de $32 \mathrm{kN}$. quando após alguns segundos ocorreu a ruptura diagonal no lado esquerdo da peça. A primeira fissura inclinada diretamente na alma progrediu para a ruptura no incremento seguinte. devido à ausência de estribos. A dutilidade, portanto, foi muito pequena.

O arqueamento das tensões de compressão praticamente não foi observado. limitando-se a uma leve descompressão no ponto C1. Houve, no entanto, um acréscimo de tensão mais brusco na armadura longitudinal junto ao apoio do lado esquerdo, na última etapa de carga. 

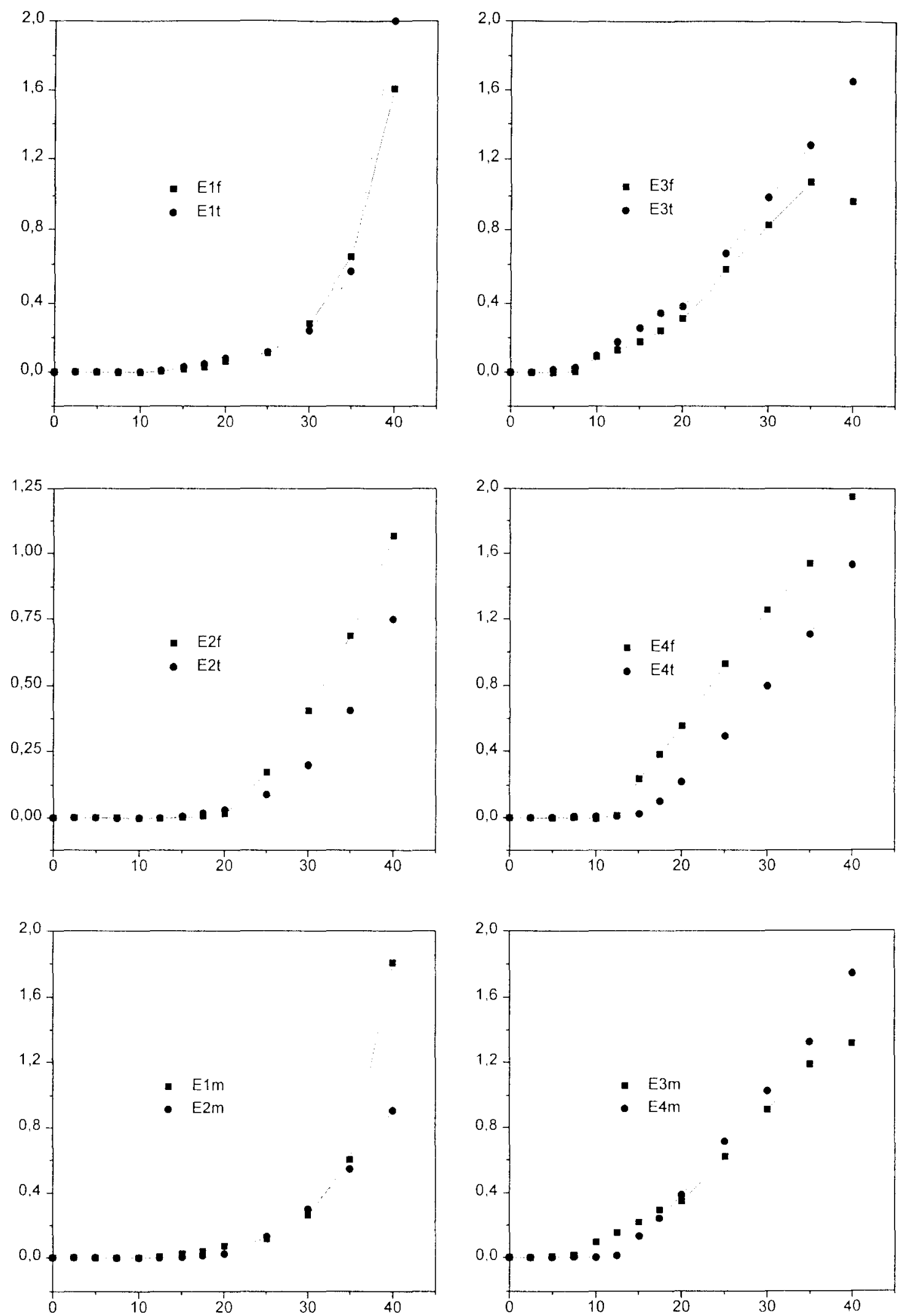

Figura 4.6 - Deformação $(\mathrm{mm} / \mathrm{m}$ no eixo y) x Carga $(\mathrm{kN}$ no eixo $\mathrm{x})$ Estribos - P1A 

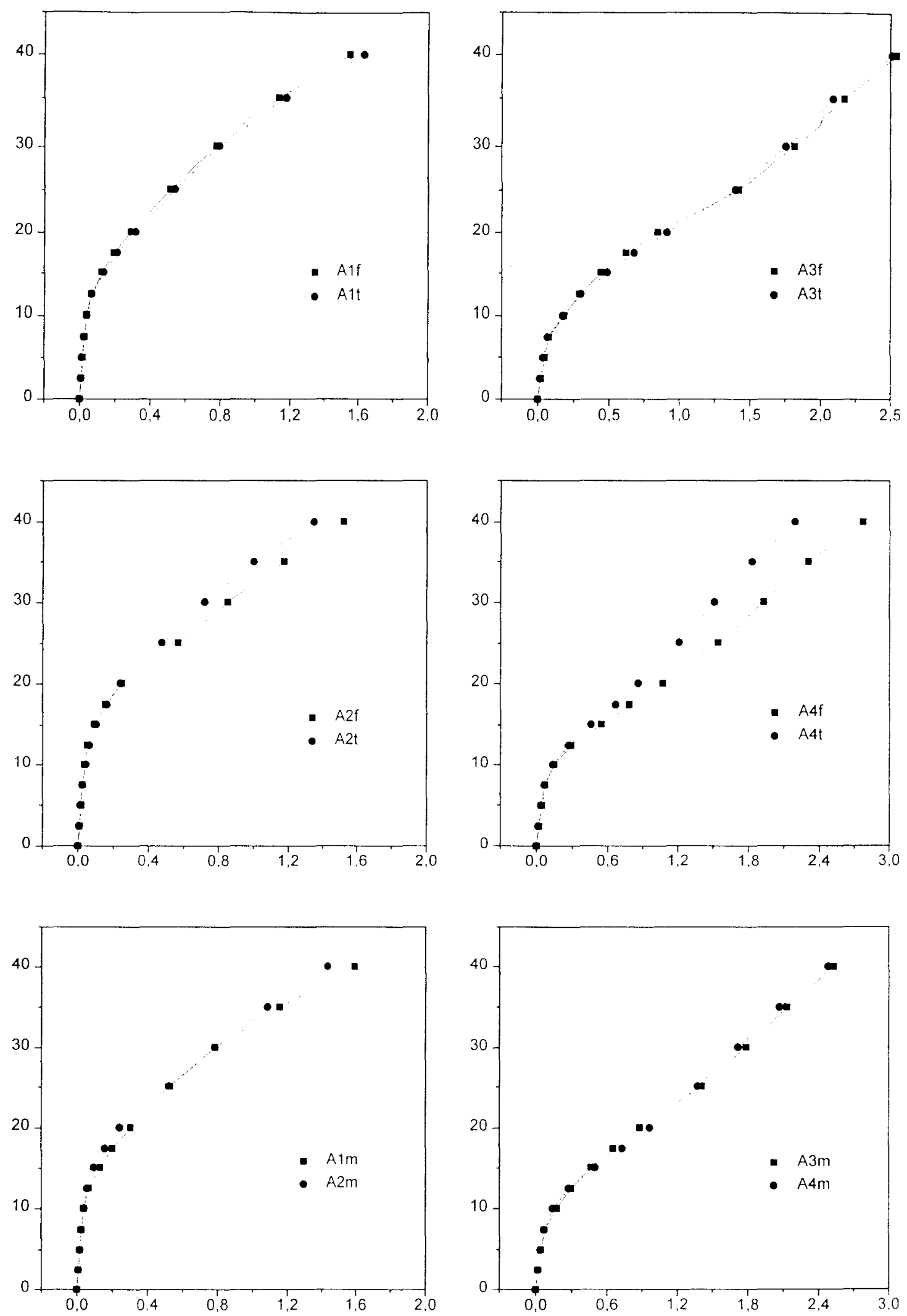

Figura 4.7 - Carga ( $\mathrm{kN}$ no eixo y) x Deformação $(\mathrm{mm} / \mathrm{m}$ no eixo $\mathrm{x})$

Armadura longitudinal - P1A 

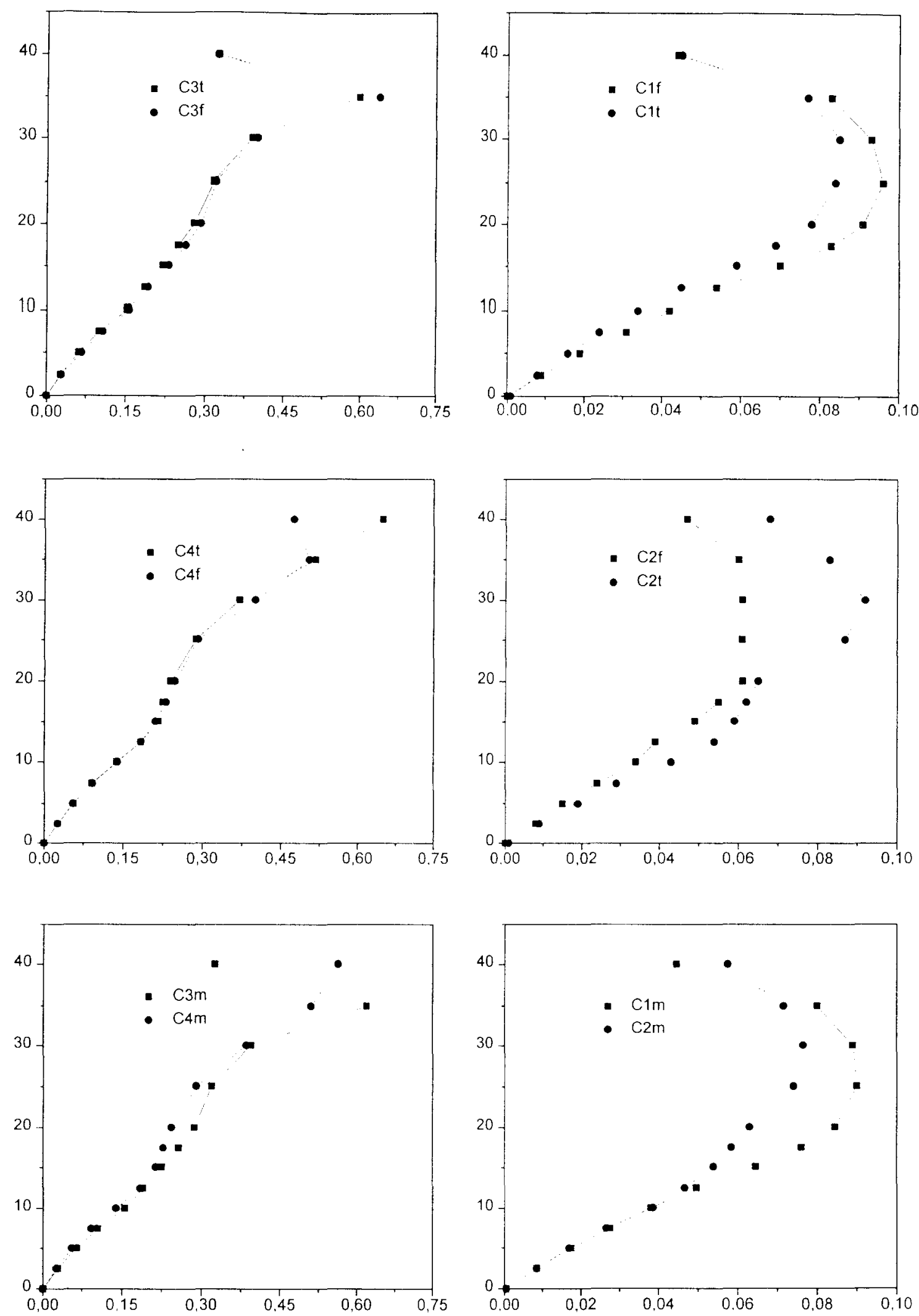

Figura 4.8 - Carga ( $\mathrm{kN}$ no eixo y) $\times$ Deformação $(\mathrm{mm} / \mathrm{m}$ no eixo $\mathrm{x})$ Concreto - P1A 

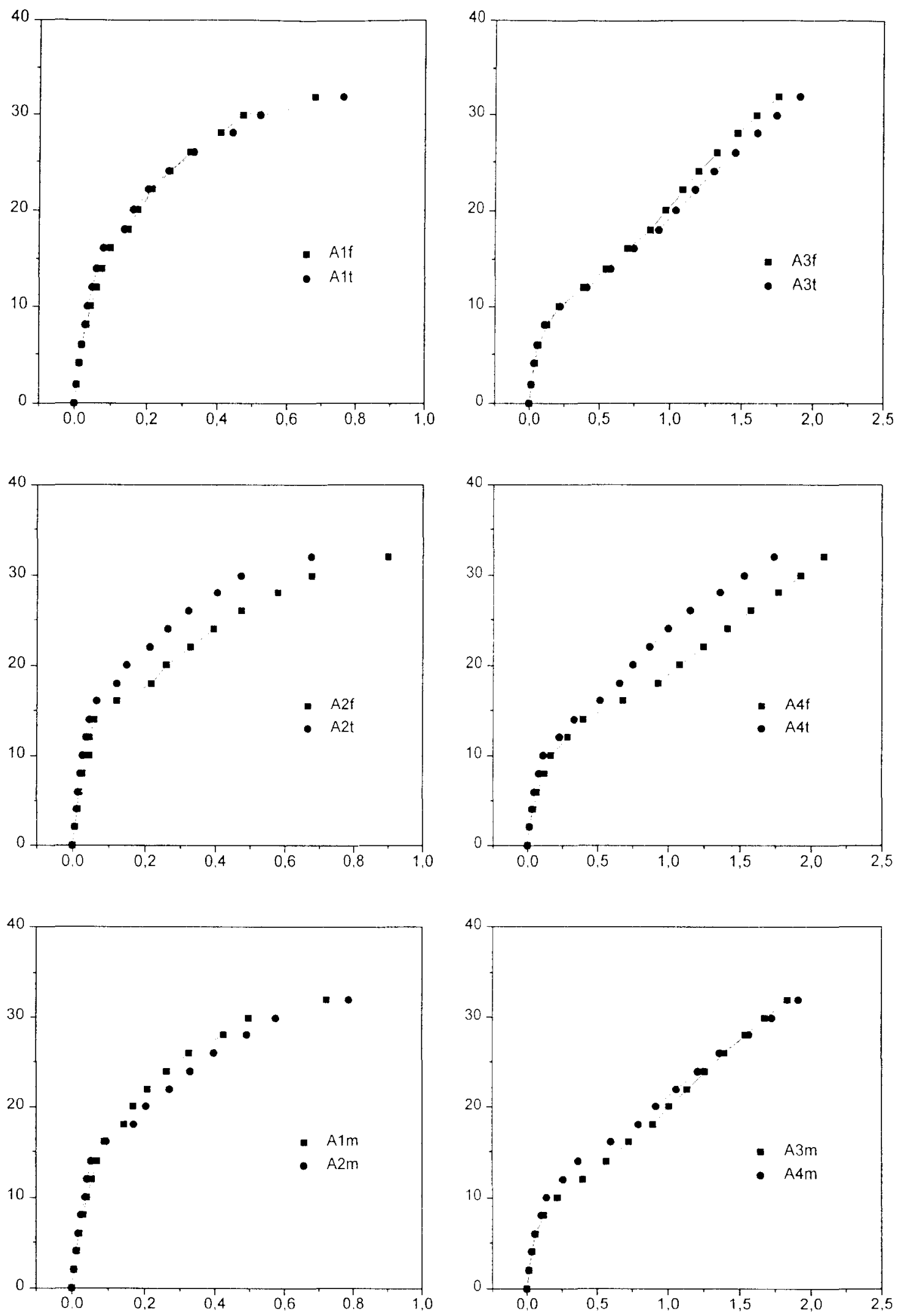

Figura 4.9 - Carga ( $\mathrm{kN}$ no eixo y) $\mathrm{x}$ Deformação $(\mathrm{mm} / \mathrm{m}$ no eixo $\mathrm{x})$

Armadura longitudinal - P1B 

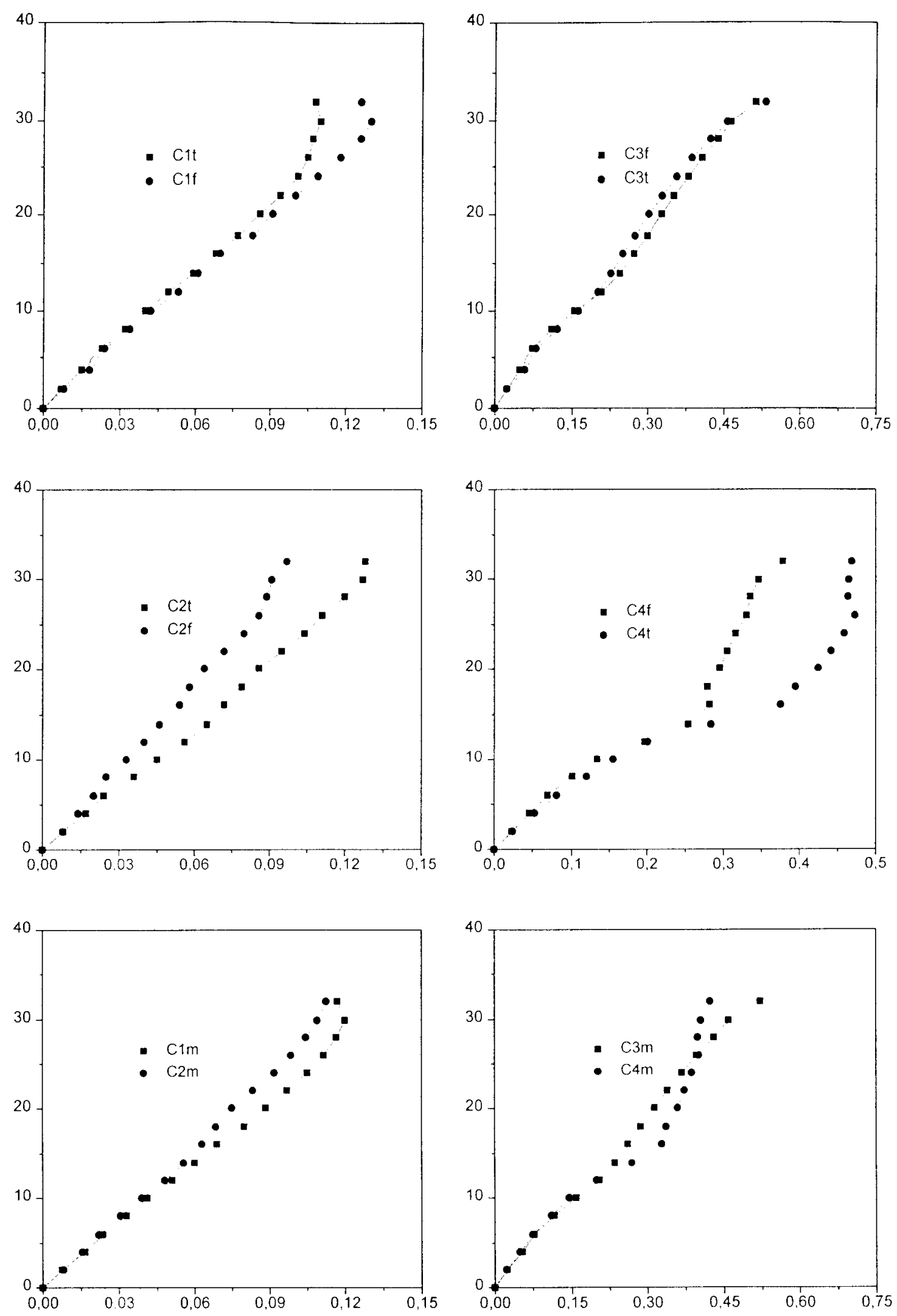

Figura 4.10 - Carga $(\mathrm{kN}$ no eixo y) x Deformação $(\mathrm{mm} / \mathrm{m}$ no eixo $\mathrm{x})$ Concreto - P1B 


\subsubsection{2 - MODELOS P2A e P2B}

Nestas vigas reforçadas com fibra de polipropileno a moldagem ocorreu com alguma dificuldade. O concreto tinha aparência seca. mas fluiu relativamente bem durante o adensamento. A Foto 4.5 mostra o aspecto do concreto pronto.

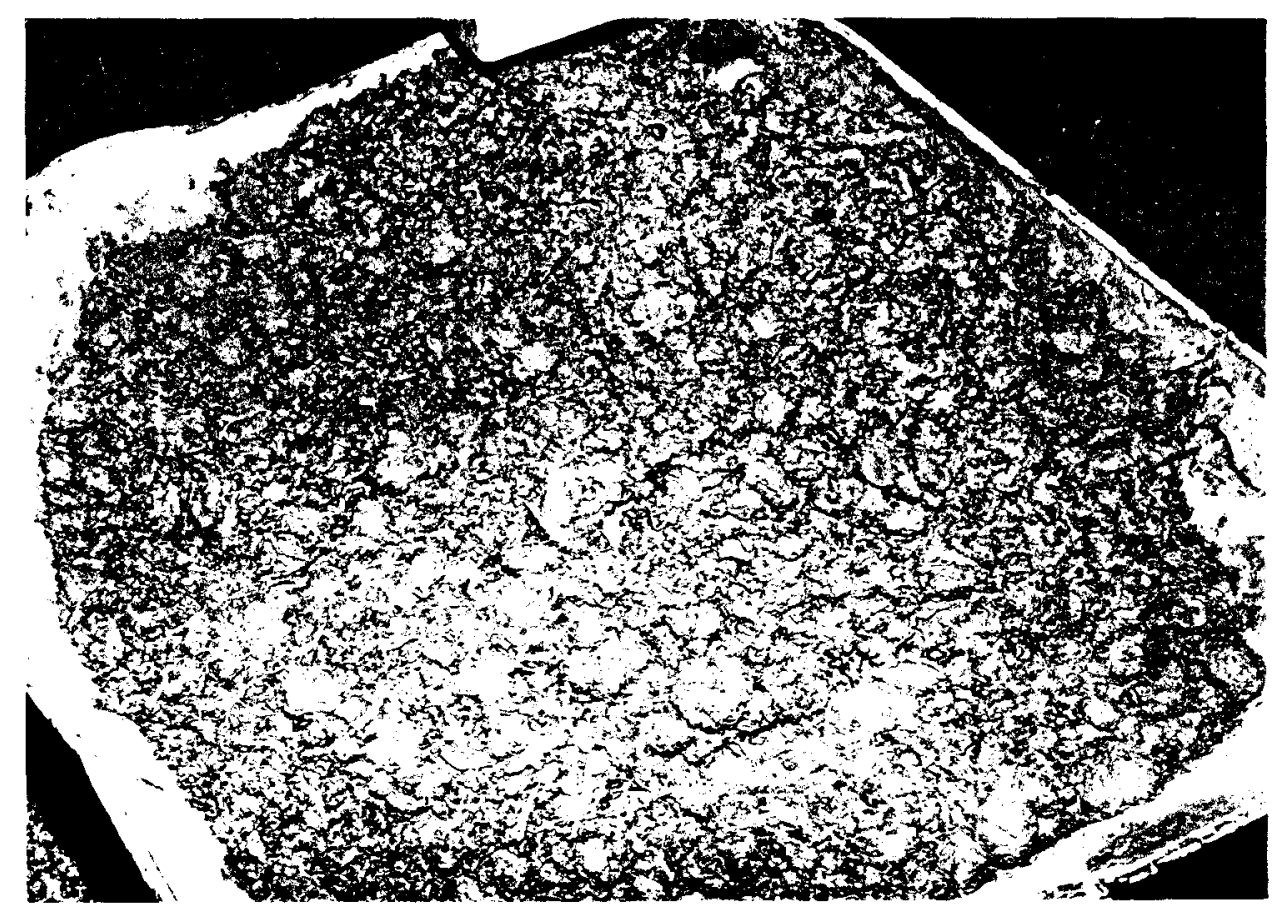

Foto 4.5 - Aspecto do concreto com fibra de polipropileno

As fibras foram adicionadas ao concreto pronto, lentamente, enquanto a betoneira girava. Dois fatos causaram alguma preocupação neste instante:

a) Acúmulo de fibras nas pás da betoneira, como pode ser observado na Foto 4.6. O excesso foi raspado e remisturado. mas em poucos movimentos da betoneira o fato se repetia:

b) Presença de "chumaços" (feixess) de fibra, semelhantes à forma na qual ela se encontra no estado natural, conforme mostra a Foto 4.7. Esse era um indício de que as fibras não se dispersaram completamente durante a produção do concreto.

O acúmulo de fibras nas pás deve-se à inadequação do equipamento de mistura. pois as pás também deveriam ter um movimento próprio para lançar o material contra as paredes da betoneira. Além disso. o processo de mistura. por gravidade. não se mostrou eficiente para esta fibra. A energia fornecida pelo misturador parece ser insuficiente. ou inadequada, para romper as "bolinhas" de argamassa de cimento. areia 
e fibra que se formam, como se observa na Foto 4.6, e deixam a pedra segregada, principalmente para volumes maiores de fibras, conforme se observou posteriormente. A relação de aspecto muito elevada contribui para isso.

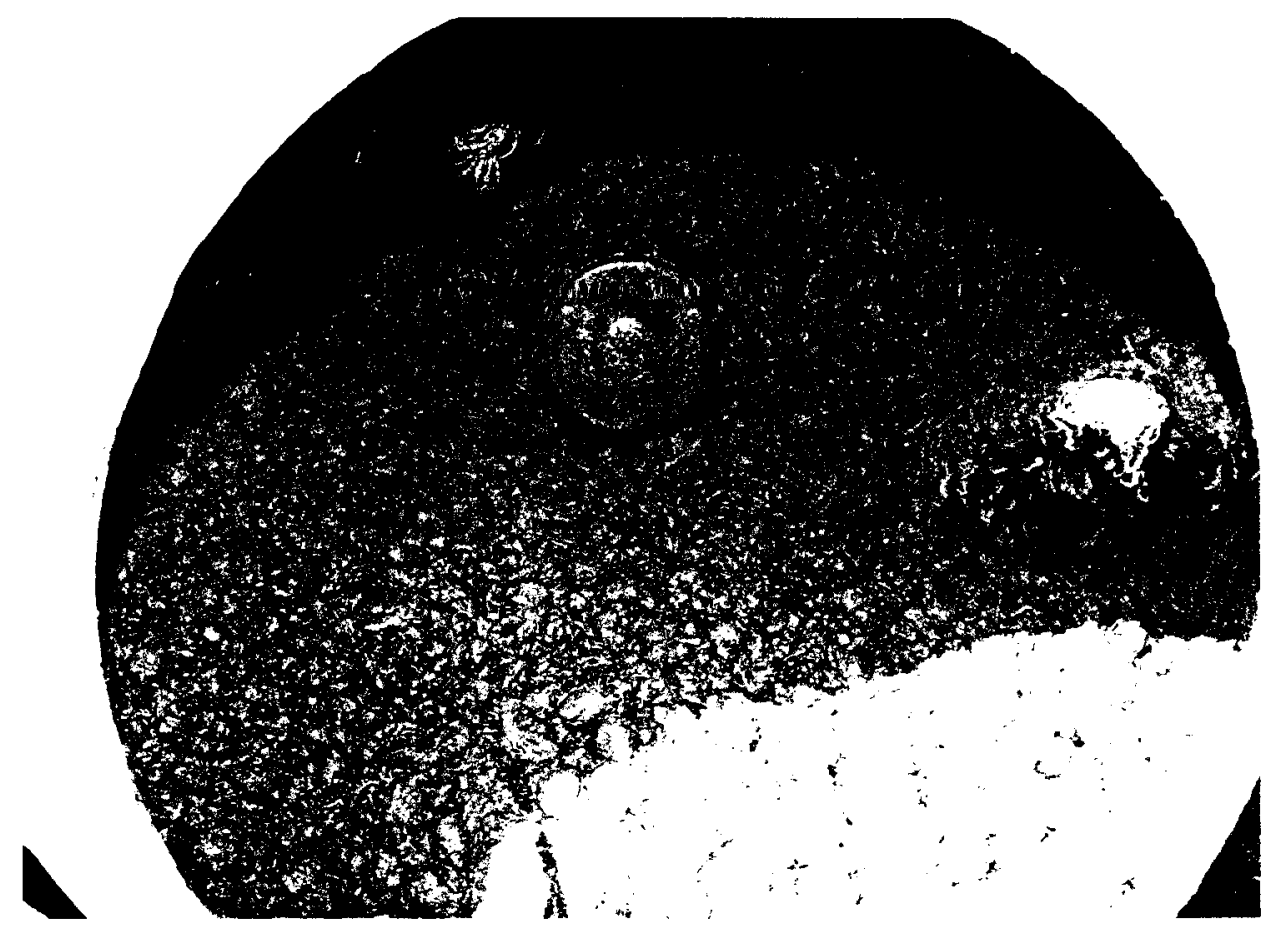

Foto t.6 - Detalhe do acúmulo de fibra nas pás da betoneira durante mistura

O material retido nas pás foi retirado e lavado, para se isolar as fibras do concreto. Depois de secas, as fibras retidas foram pesadas. A quantidade representou apenas $5 \%$ do total da fibra adicionada. Na verdade, após a separação dos filamentos, o volume aparente aumenta muito. Assim, o problema revelou-se menor do que o imaginado inicialmente.

Em relação a presença dos feixes. optou-se por se fazer alguns testes complementares. Foram executadas três misturas com dosagens idênticas dos materiais. aumentando-se. do traço original. a quantidade de água e aditivo (utilizando-se fator a/c $=0.48$ e $1.5 \%$ de superplastificante). Fm cada caso alterou-se apenas o processo de produção:

a) A fibra foi adicionada e misturada com o restante do material sem a água, sendo que a betoneira foi fechada com plástico para se evitar a saída dos finos. A água e o aditivo foram adicionados somente no final do processo. Não houve vantagens. Além disso. o método é pouco prático:

b) As libras loram previamente separadas. A separação dos filamentos foi feita manualmente. durante aproximadamente 15 minutos. $O$ volume aparente aumentou 
bastante, mesmo que vários feixes ainda tenham permanecido intactos. A dispersão das fibras no concreto foi mais eficiente, o que prejudicou bastante a trabalhabilidade. O método também tem pouca praticidade.

c) A fibra foi adicionada ao concreto que continha apenas uma parte da água da mistura, o suficiente para se evitar a saida dos finos. Os resultados foram similares ao procedimento anterior.

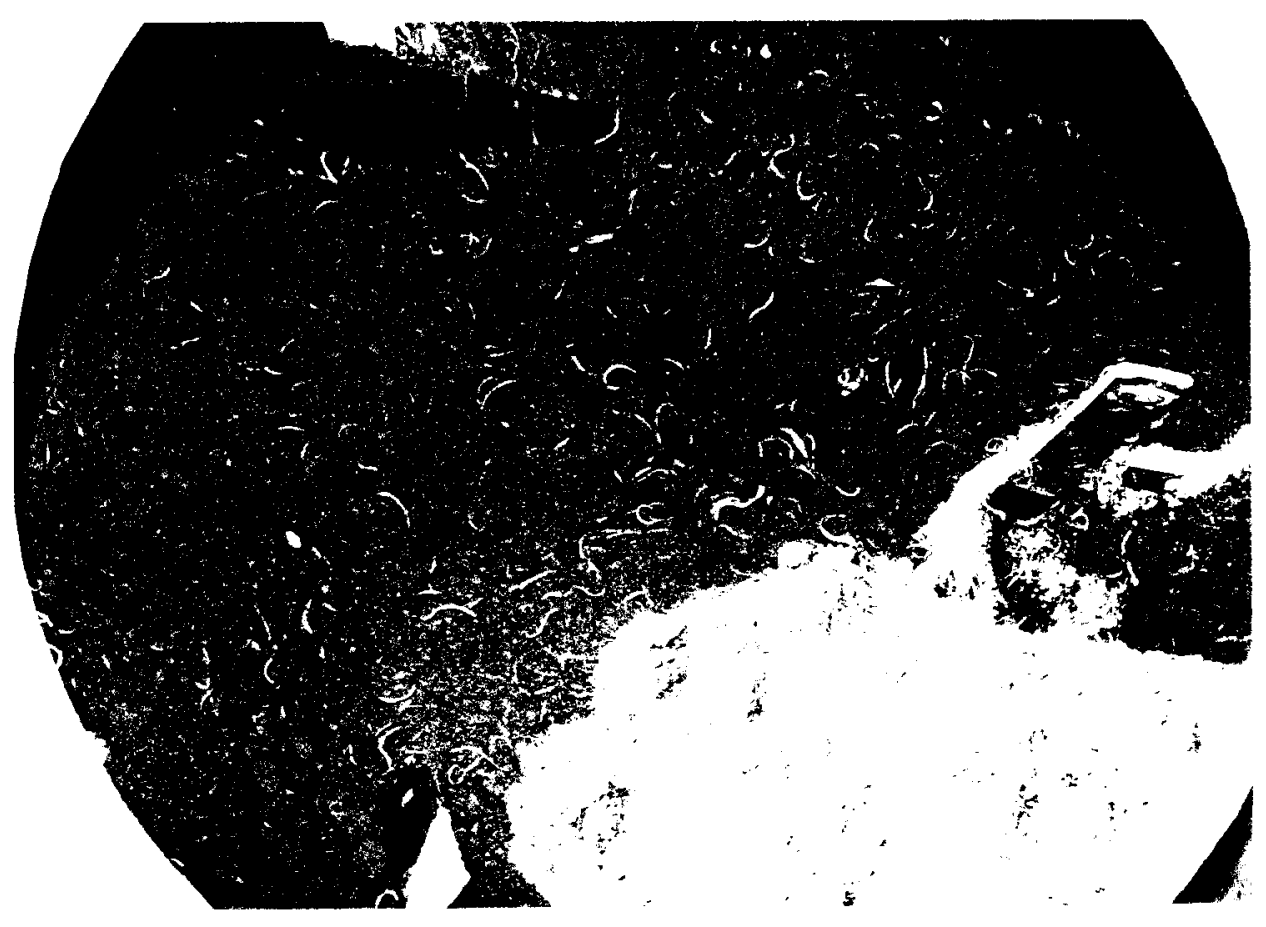

Foto 4.7 - Feixes de fibras após a mistura na betoneira

Na verdade, a fibra de polipropileno utilizada tinha relaçâo de aspecto muito elevada. e a trabalhabilidade limitou a produção destes compósitos. Depois destes testes, julgou-se conveniente manter o processo de produção inicial, que prejudicou menos a trabalhabilidade da mistura. mesmo que os feixes de fibras não se dispersassem completamente.

Outros testes adicionais mostraram a impossibilidade de produção de compósitos com $1 \%$ desta fibra, devido à segregação do pedrisco e à péssima trabalhabilidade. que resultavam em resistências muito baixas. Mesmo com fator a/c de 0.47 e $2.5 \%$ de aditivo, não se obteve sucesso, pois a fibra embolava facilmente.

Portanto. para a fibra de polipropileno, o trabalho se limitou aos compósitos con volume de $0,5 \%$. Nestes dois modelos. P2A e P2B, as fibras tornaram a ruptura mais dútil e suave. preservando parcialmente a integridade do concreto após a ruína. 


\section{modelo P2A}

A ruína por cisalhamento não se concretizou para esta viga. O ensaio foi interrompido quando iniciou o esmagamento do concreto no banzo comprimido, junto ao ponto de aplicação da cargá, no lado esquerdo da peça, quando a carga atingiu 45 $\mathrm{kN}$. O estribo E3 já havia escoado com $40 \mathrm{kN}$, quando atravessava uma fissura diagonal que se estendia em praticamente toda a altura da viga, como se observa na Foto 4.9. A deformação na armadura longitudinal também deve ter atingido o patamar de escoamento com $40 \mathrm{kN}$. Desde o instante em que o estribo escoou até a ruptura, a flecha passou de $8,5 \mathrm{~mm}$ para $30 \mathrm{~mm}$. e a peça ainda resistiu uma carga adicional significativa, revelando grande dutilidade.

Portanto. o estado limite último convencional devido ao escoamento da armadura transversal ocorreu antes do término do ensaio. Além do aumento da carga máxima em relação ao modelo de referência. a resistência residual foi elevada. impedindo a ruptura por cisalhamento mesmo com a intensa fissuração diagonal nos dois lados da viga.

A deformação plástica da peça é visível após o descarregamento. Além disso. a evolução das deformações na armadura e dos deslocamentos verticais no final do ensaio comprovam o escoamento da armadura longitudinal. quando a carga se mantinha constante com o acionamento continuo da bomba.

$\Lambda$ tensão nos estribos próximos dos apoios. E1 e E2. manteve-se abaixo de 200 $\mathrm{MPa}$ até $35 \mathrm{kN}$. quando a fissuração diagonal já era intensa. No final do ensaio ela atingiu $550 \mathrm{MPa}$. Após $40 \mathrm{kN}$. o aumento de tensão em E1 foi brusco, pois a fissura diagonal avançou nesta direção. Ele foi acompanhado de intensa descompressão no concreto deste lado da viga.

As tensões nos estribos foram mais baixas que na peça anterior até a metade do ensaio. quando a situação se inverteu. Isto sug̣ere que um controle inicial mais eficiente das fissuras prolongou c aumentou a contribuição dos mecanismos resistentes alternativos enquanto eles eram atuantes. aliviando a tensão nos estribos. Quando as fissuras se abriram mais. diminuiu a resistencia proporcionada pelo concreto, e a atuação das fïbras junto às físsuras inclinadas não contribuiu para a redução da força nos estribos. Nesta ctapa as fibras tracionadas na região da fissura inclinada se deformam muito. devido ao baixo módulo de deformação longitudinal, o que pode justificar o aumento da tensão nos estribos, embora não se esteja convencido completamente deste fato. Mesmo assim. após o escoamento do estribo e a intensa fissuração. a ruptura por cisalhamento não se concretizou. 
O aumento da capacidade resistente proporcionado pelas fibras não se deve à diferença no valor da resistência à compressão do concreto: ela altera pouco a resistência à flexão, que neste caso é condicionada pelo escoamento da armadura longitudinal; no cisalhamento, o parâmetro mais importante é a resistência à tração, aproximadamente igual nos dois modelos, que influi nos mecanismos resistentes alternativos, conforme registros da bibliografia correspondente.

A configuração das fissuras e o aumento brusco de tensão nos estribos E1 e E3 nas últimas etapas de carga sugerem a trajetória direta da carga até os apoios. A descompressão do concreto no lado esquerdo nas proximidades da ruptura foi muito intensa, praticamente anulando a tensão nos dois pontos instrumentados. $A$ isto se deve a contradição entre o valor reduzido da deformação máxima no concreto e o início do esmagamento observado. A região danificada está livre do fenômeno da descompressão e a deformação no concreto seria muito maior neste ponto.

As tensões na armadura longitudinal foram quase sempre menores que no modelo P1A, exceto no final do ensaio. Próximo do apoio. no entanto, ela foi maior. A adição das fibras deve aumentar a resistência do concreto em relação às forças de pino que surgem devido ao apoio das bielas, possibilitando a transmissão de uma parcela de carga maior diretamente ao apoio. sem provocar a ruína prematura da viga.

\section{modelo P2B}

A ruptura diagonal ocorreu quando a carga atingiu $35 \mathrm{kN}$. no lado esquerdo da viga. Assim como no modelo P1B, a primeira fissura de cisalhamento diretamente na alma progrediu rapidamente para a ruptura no incremento seguinte. Ou seja, apesar de retardar o surgimento desta fissura, e consequentemente aumentar a capacidade resistente da peça, as fibras foram ineficientes para tomar a ruptura mais dútil.

As flechas foram acompanhadas até $32.5 \mathrm{kN}$. pois não houve tempo de se fazer a leitura quando a carga atingiu $35 \mathrm{kN}$. Extrapolando-se linearmente a curva até o instante da ruptura, a flecha seria da ordem de $6,8 \mathrm{~mm}$, idêntica a de P1B.

$O$ arqueamento das tensões de compressão foi muito intenso do lado esquerdo da viga após $30 \mathrm{kN}$, praticamente anulando a tensão nos dois pontos instrumentados. Ele é acompanhado de um acréscimo significativo de tensão na armadura longitudinal junto ao apoio deste lado da peça. A força neste ponto é três vezes maior que no ponto correspondente do outro lado da peça. 

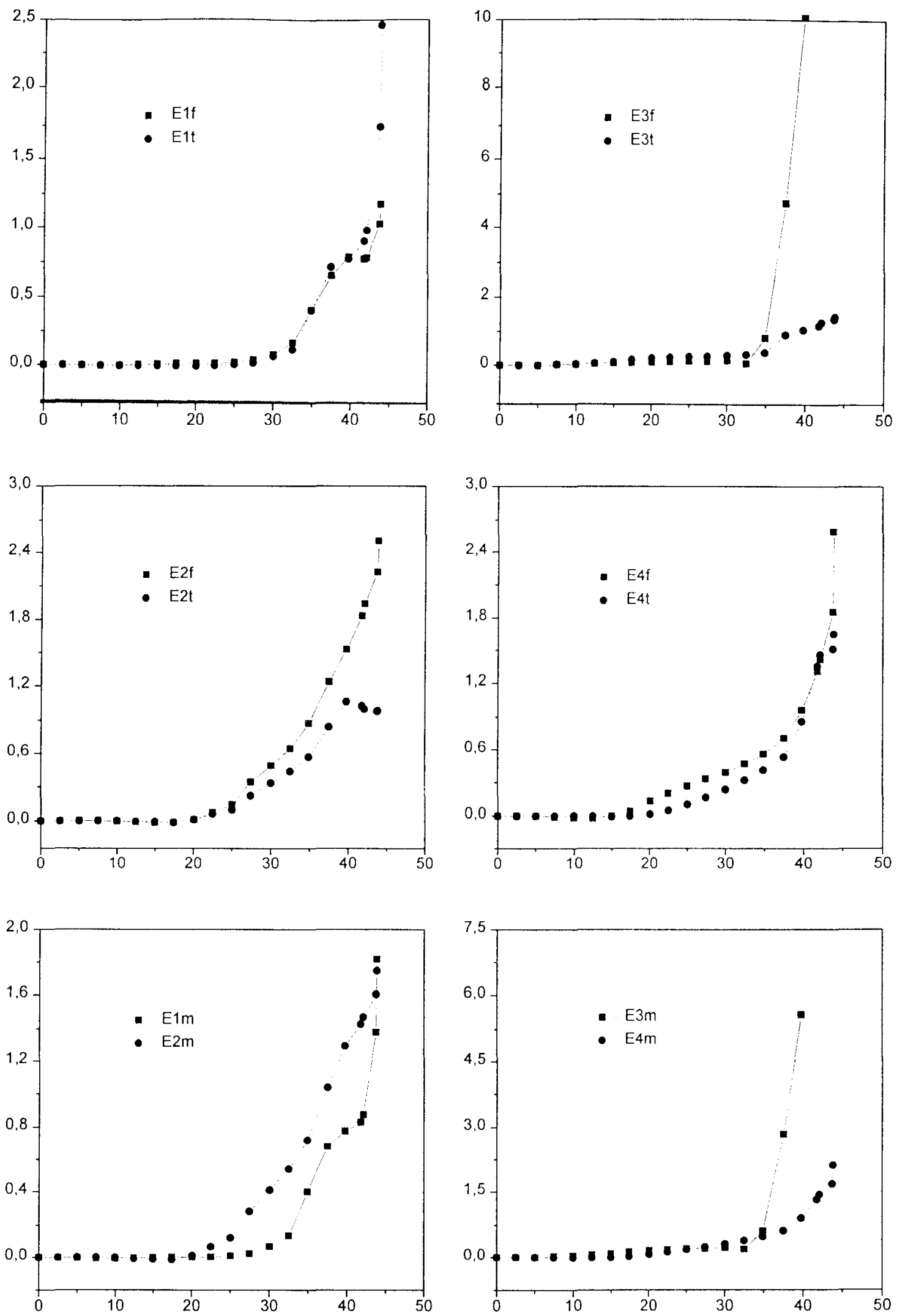

Figura 4.11 - Deformação (mm/m no eixo y) x Carga ( $\mathrm{kN}$ no eixo $\mathrm{x})$ Estribos - P2A 

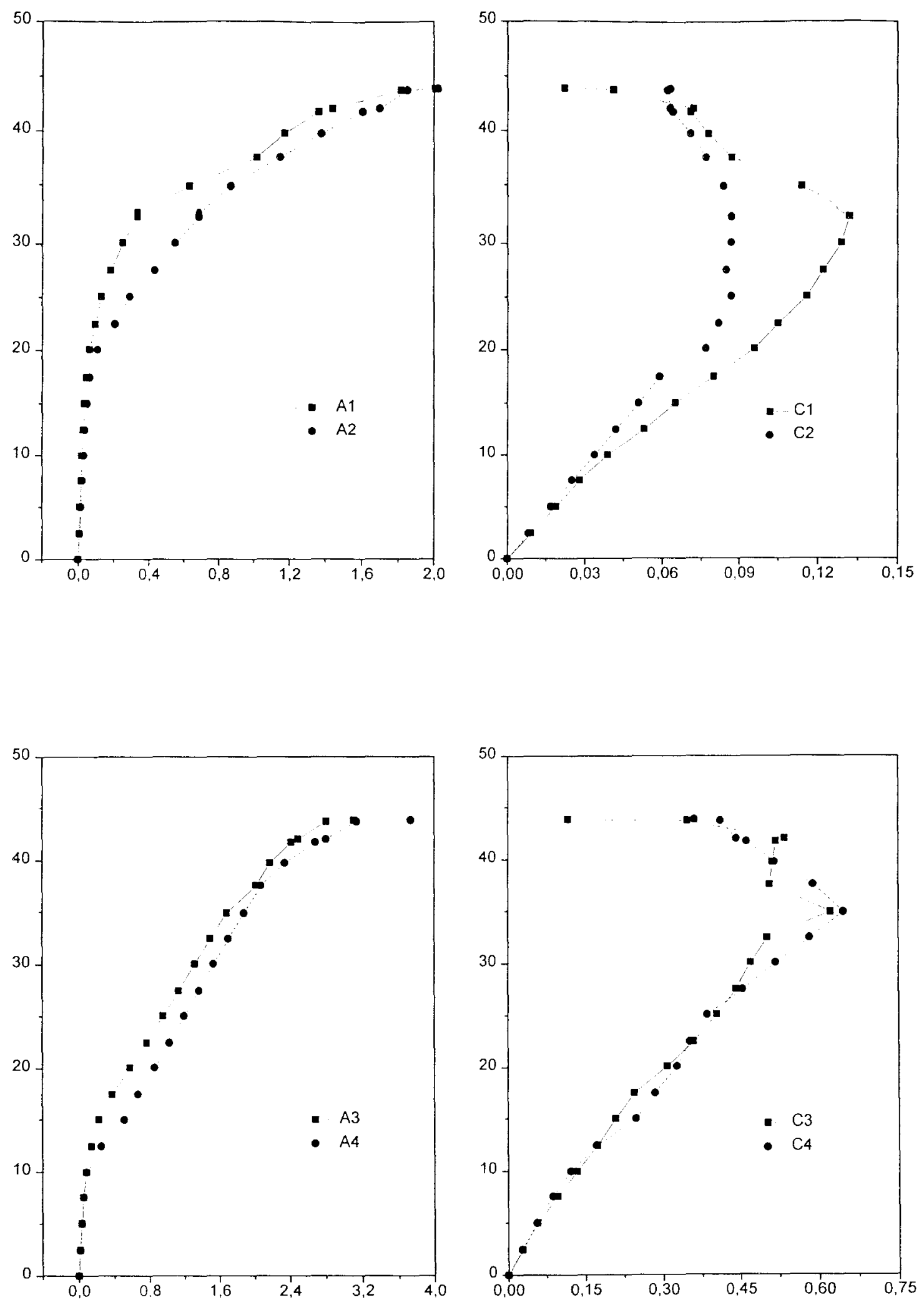

Figura 4.12 - Carga ( $\mathrm{kN}$ no eixo y) x Deformação $(\mathrm{mm} / \mathrm{m}$ no eixo $\mathrm{x})$ Armadura e concreto - P2A 

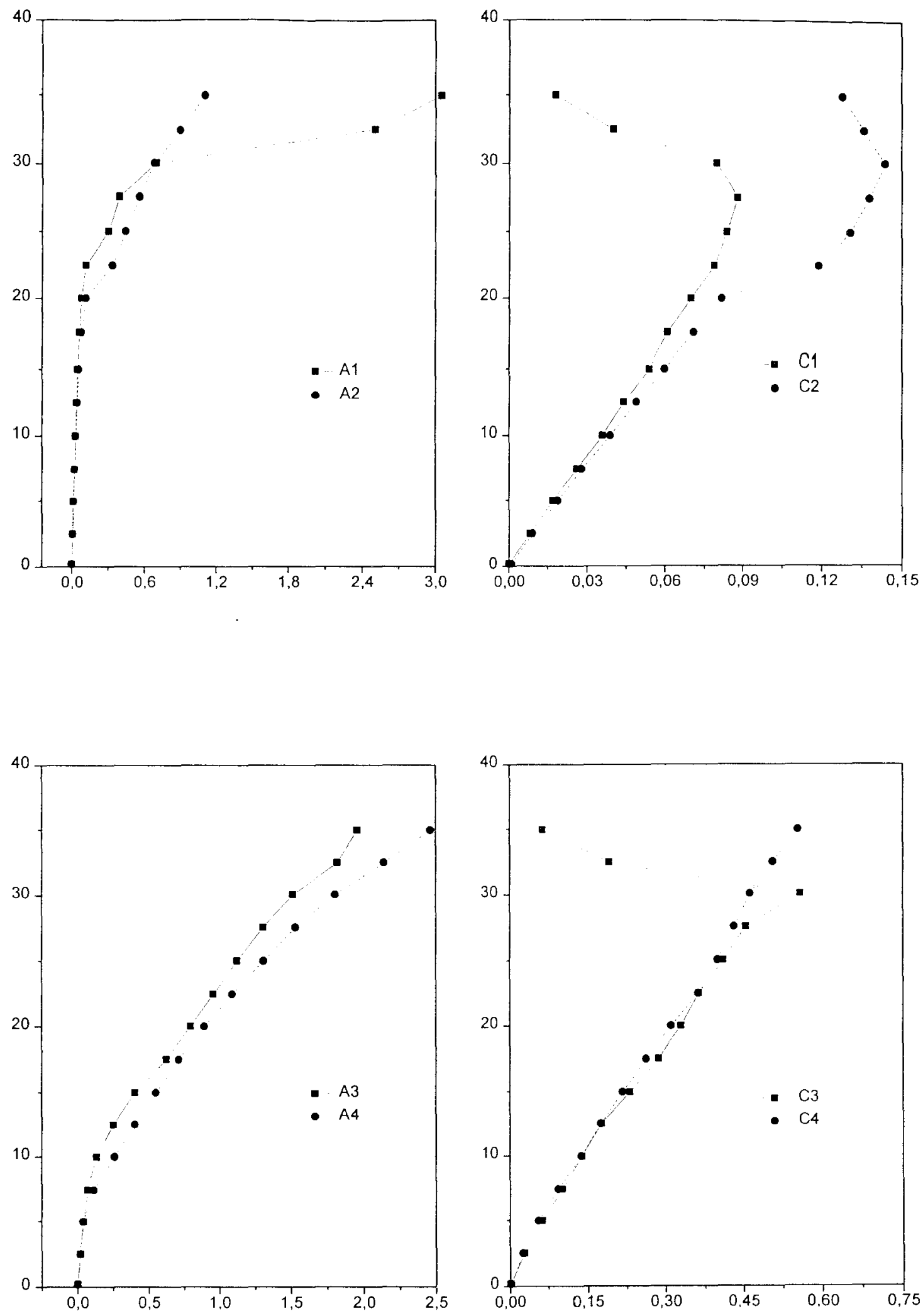

Figura 4.13 - Carga ( $\mathrm{kN}$ no eixo y) $\mathrm{x}$ Deformação ( $\mathrm{mm} / \mathrm{m}$ no eixo $\mathrm{x})$

Armadura e concreto - $\mathrm{P} 2 \mathrm{~B}$ 


\subsubsection{3 - MODELOS P3A e P3B}

Estes modelos foram produzidos com fibra de aço de $2,54 \mathrm{~cm}$, acrescentada no concreto já misturado, que se apresentou extremamente plástico. A resistência à compressão e o módulo de deformação longitudinal foram comparativamente elevados, ao contrário da resistência à tração. que apresentou desempenho praticamente igual ao do concreto sem fibras.

\section{modelo P3A}

Esta viga atingiu a carga máxima de $47 \mathrm{kN}$, quando o ensaio foi interrompido ao iniciar o esmagamento do concreto no banzo comprimido junto ao ponto de aplicação da carga, no lado esquerdo da peça, como mostra a Foto 4.9. Nenhum estribo atingiu o patamar de escoamento.

O estado limite último convencional ocorreu devido ao escoamento da armadura longitudinal. Além da maior capacidade resistente e da mudança na forma da ruptura, a solicitação nos estribos foi comparativamente menor durante todo o ensaio: as tensões máximas ficaram limitadas a $140 \mathrm{MPa}$ e $180 \mathrm{MPa}$, nas posições E1/E2 e E3/E4. respectivamente.

O escoamento da armadura longitudinal ficou confirmado pela deformação plástica observada após o descarregamento e pela evolução das deformações na armadura e dos deslocamentos no tinal do ensaio, quando a carga aplicada no modelo se mantinha constante com o acionamento contínuo da bomba. revelando grande dutilidade.

A partir deste modelo, a marcação das fissuras que aparece nas fotos se refere ao número da etapa do carregamento. Até então, ela correspondia ao valor da carga aplicada, em $\mathrm{kN}$.

O aumento da rigidez em relação ao modelo de referência foi significativo. Além das melhores características do concreto, conforme se observa nos diagramas $\sigma-\varepsilon$ dos corpos-de-prova, o controle da fissuração foi mais eficiente, como sugerem todos os indicadores das tabelas correspondentes.

() aumento brusco da tensão em E2 após a carga atingir $30 \mathrm{kN}$ coincide com o prolongamento de uma fissura diagonal nesta região. Este instante corresponde à etapa 11 do carregamento, na lioto 4.9 .

() mecanismo de arco se manifestou de forma muito sutil após $35 \mathrm{kN}$, especialmente no lado direito da vig̣a. () encurtamento máximo no concreto foi o maior 
entre todas as vigas, no lado esquerdo da viga, onde não houve descompressão. Não se observou variação significativa de tensão na armadura longitudinal junto aos apoios.

\section{modelo P3B}

Neste modelo a ruptura por cisalhamento ocorreu alguns segundos após a carga atingir $40 \mathrm{kN}$, quando surgiu uma fissura diagonal do lado direito da viga. Observa-se uma bifurcação na trajetória da fissura diagonal em direção ao banzo comprimido, que atinge a face superior a $7 \mathrm{~cm}$ do apoio, onde se forma uma saliência angulosa. No instante da ruína, a carga caiu até $34 \mathrm{kN}$. Logo em seguida, as partes separadas pela fissura se afastaram e a carga caiu até $16 \mathrm{kN}$.

Houve uma pequena diminuição nas tensões de compressão no concreto nos dois pontos externos, nos dois lados da viga, após $30 \mathrm{kN}$. Nos pontos internos, ela só ocorreu no lado da ruptura, na última etapa de carga. Não se registrou acréscimo de tensão na armadura longitudinal junto aos apoios próximo da ruptura. 

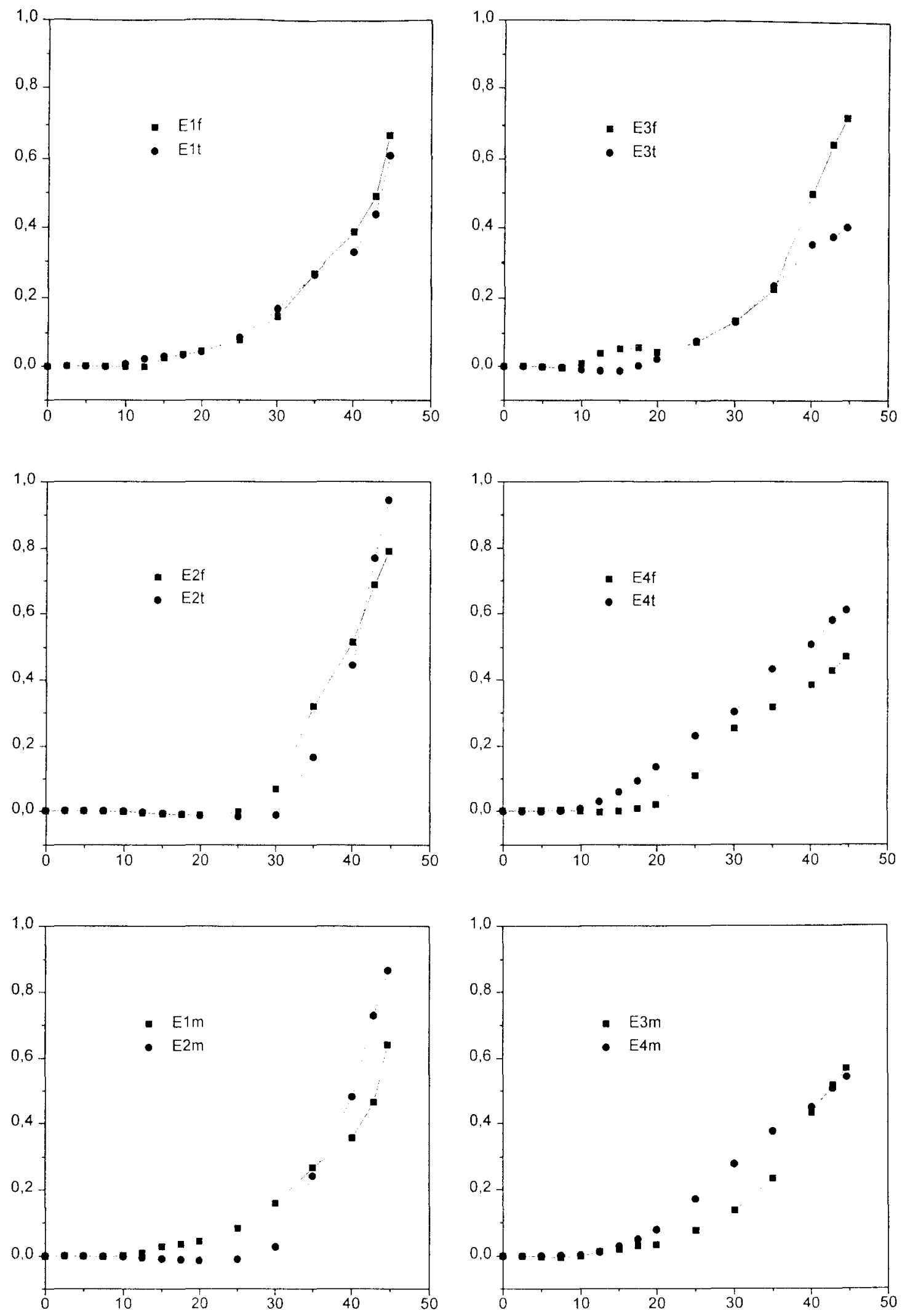

Figura 4.14 - Deformação ( $\mathrm{mm} / \mathrm{m}$ no eixo y) x Carga ( $\mathrm{kN}$ no eixo $\mathrm{x})$ Estribos - P3A 

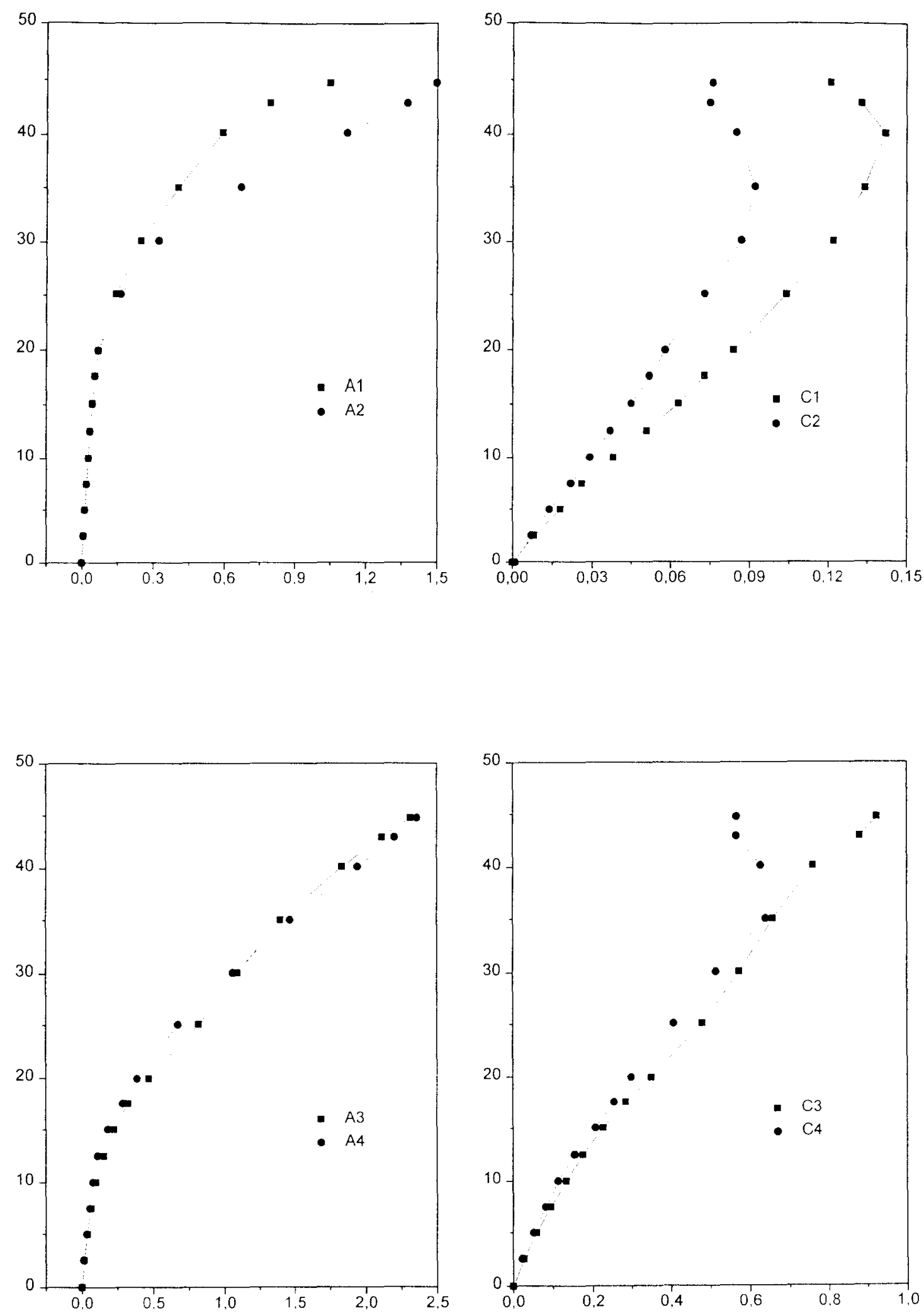

Figura 4.15 - Carga ( $\mathrm{kN}$ no eixo y) x Deformação $(\mathrm{mm} / \mathrm{m}$ no eixo $\mathrm{x})$ Armadura e concreto - P3A 

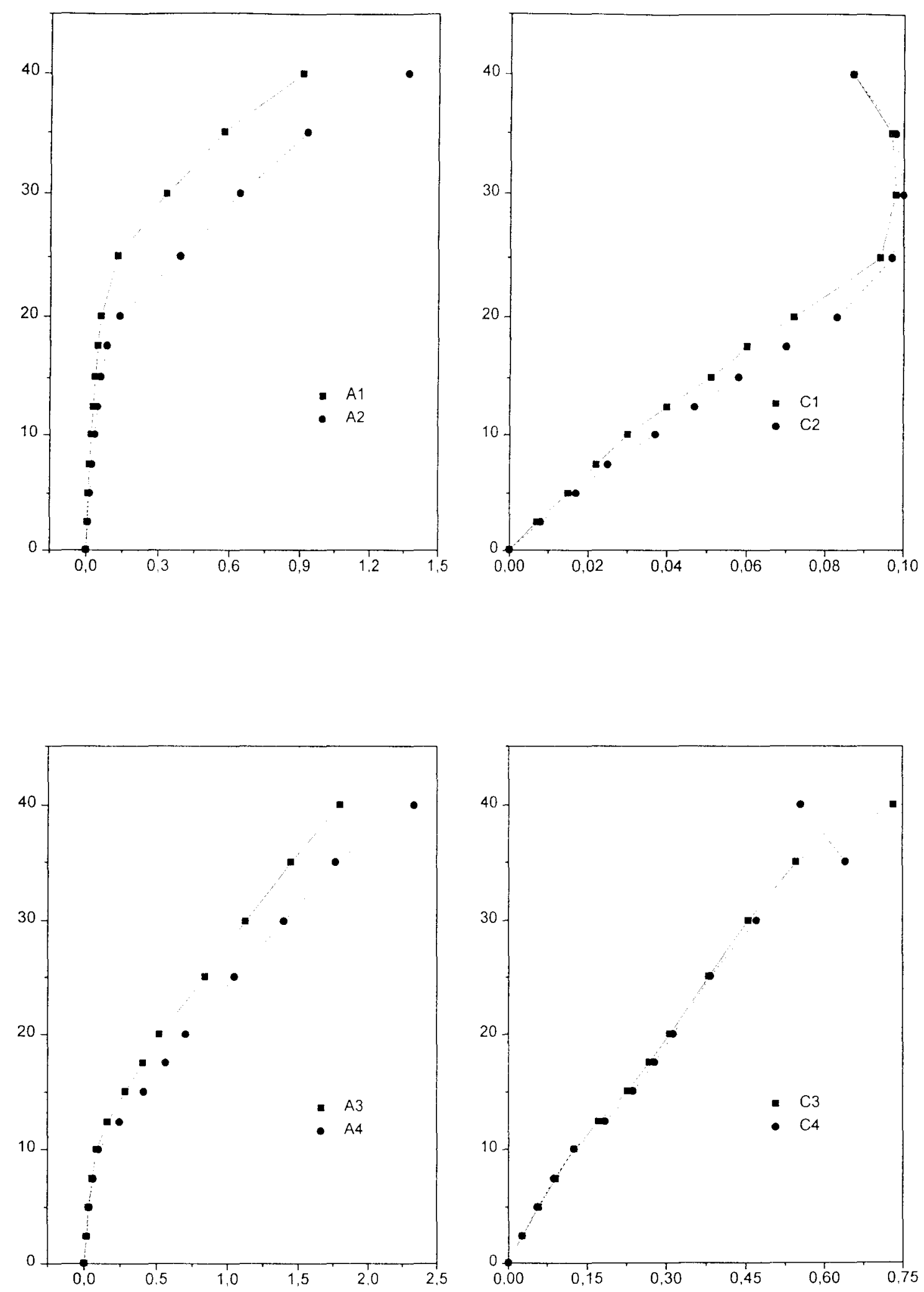

Figura 4.16 - Carga ( $\mathrm{kN}$ no eixo y) x Deformação $(\mathrm{mm} / \mathrm{m}$ no eixo $\mathrm{x})$ Armadura e concreto - P3B 


\subsubsection{4 - MODELOS P4A e P4B}

Mesmo com a maior quantidade de fibra de aço e o mesmo consumo de superplatificinte, a trahalhabilidade se manteve muito boa. Ao contrário dos modelos anteriores. houve aumento da resistencia à tração, $O$ módulo de deformação longitudinal apresentou o maior valor dentre todos os modelos executados.

\section{modelo P4A}

Noramente não houve ruína por cisalhamento. Assim como nas outras peças com fibras da série $A$ a carga não se mantinha nas últimas etapas do carregamento, mesmo wni "acionamento contínuo da bomba. sugerindo o escoamento da armadura longitudinal. () ensaio prosseguiu até o início do esmagamento do concreto no banzo comprimido junto ao ponto de aplicação da carga do lado esquerdo da viga, com $46 \mathrm{kN}$. O esmagamento se deu de modo muito suave. assemelhando-se a um esfarelamento do concreto. Nas últimas ctapas de carga. os deslocamentos aumentaram bastante e as fissuras na fince tracionada expunham as fibras mais externas. O estado limite último devido an excoamento da armadura longitudinal ocorreu para carga próxima de $45 \mathrm{kN}$, conforme mustram a evolução das deformações na armadura e dos deslocamentos. Nenhum estribo atingiu a tensão de escoamento. Quando a carga se estabilizou em 45 $\mathrm{kN}$ os desilocumentos ainda aumentaram bastante. mas a tensão nos estribos se manteve reduzidat.

Após a carga atingir $40 \mathrm{kN}$ houve um aumento brusco de tensão em E2, devido ao aparecimento de uma fissura inclinada naquela região. Este instante corresponde à etapa 12. que aparece no lado esquerdo da Foto 4.9. Mesmo assim, praticamente não houve vuriação de tensão neste estribo nos três últimos registros de carga, pois esta fissura nóno woluiu. Neste intervalo. a flecha aumentou quase $10 \mathrm{~mm}$ e a armadura longitudinal ja har ia escondo.

Confinme também se observou no modelo anterior desta série, a inclinação mais suarc das kensões de compressão no banzo de concreto sugere que a ruptura por cisalhamento-tração ainda era distante.

\section{modelo $P 4 B$}

1 ste mokles aprecentou a maior resistencia dentre todas as vigas da série $\mathrm{B}$. No final do nnsilu a carga nán se mantinha acima de $43 \mathrm{kN}$. No instante da ruína, quando surgiu a tissura diagonal do lado escpucrdo da viga a carga caiu de $44 \mathrm{kN}$ para $13 \mathrm{kN}$. A 
fissura crítica não atingiu o banzo comprimido na região do apoio. A sua trajetória apresenta uma bifurcação que atinge a face superior a $17 \mathrm{~cm}$ do apoio.

As fissuras de flexão apresentaram configuração similar a de algumas peças da série A. As fissuras expunham as fibras na face tracionada, como se observa na Foto 4.8. Pela primeira vez, nos modelos da série B, também surgiu uma fissura diagonal do lado oposto ao lado da ruína, que indicava a proximidade do esgotamento da resistência da peça nesta região. Isso pode ser observado na Foto 4.14. etapa 11 do carregamento.

O comportamento plástico no final do ensaio sugere o escoamento da armadura longitudinal. A flecha foi a maior dentre as vigas da série B. A primeira fissura inclinada diretamente na alma apareceu do lado direito e não evoluiu para a ruptura, que ocorreu do outro lado da peça.

A diminuição das tensões de compressão foi mais intensa no lado esquerdo da viga, atingindo os pontos Cl e C3. nesta ordem. Porém, não se observou variação significativa de tensão na armadura longitudinal nas proximidades do apoio.

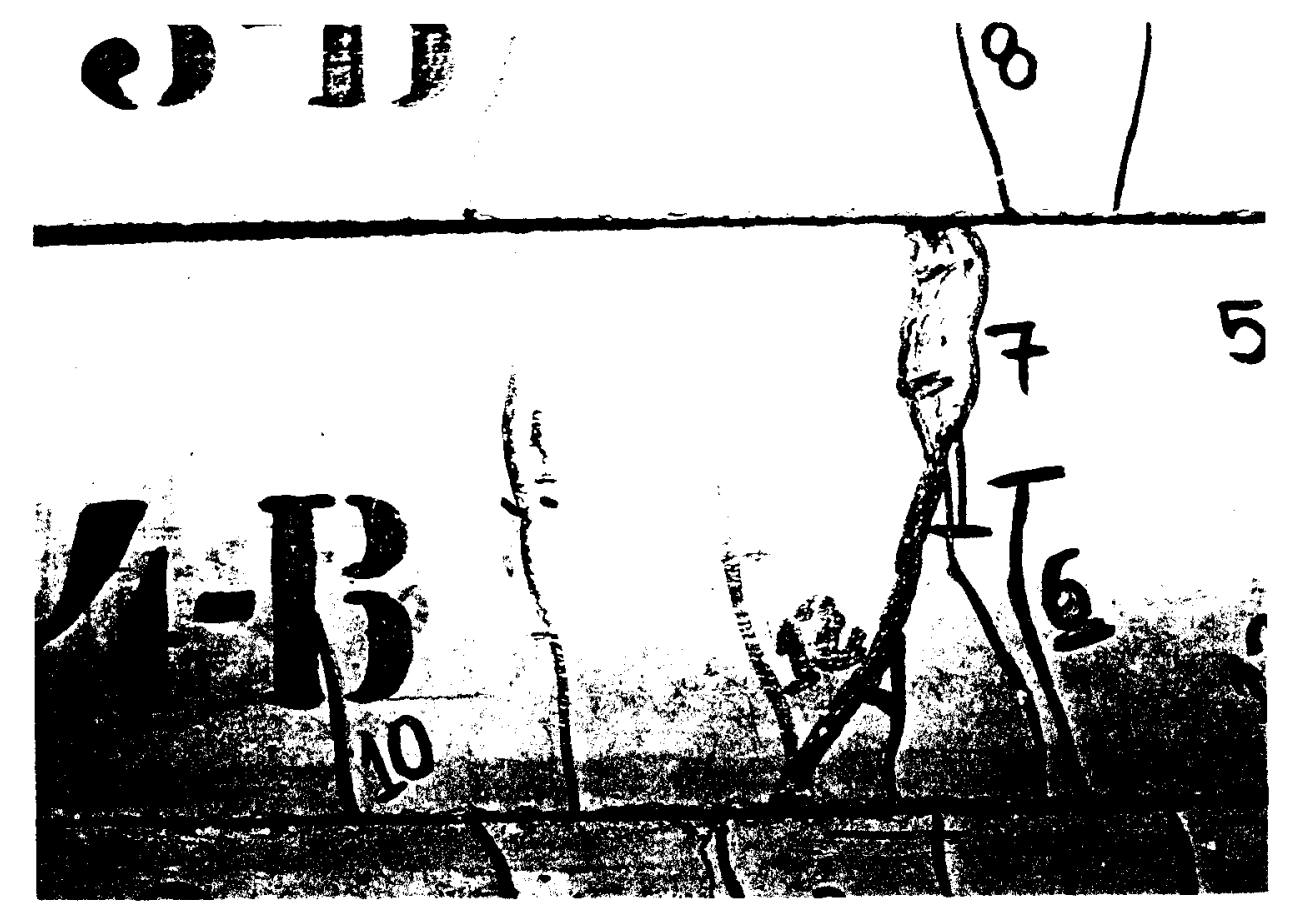

Foto 4.8 - Detalhe das fibras expostas na face tracionada no modelo P4B

As Fotos 4.9 e 4.11 mostram uma vista geral dos modelos P1 a P4 das séries A e $\mathrm{B}$, respectivamente. As Fotos 4.10 e 4.12 , os detalhes do lado da ruptura destes modelos, ou do lado mais fissurado, quando ela não se concretizou. 

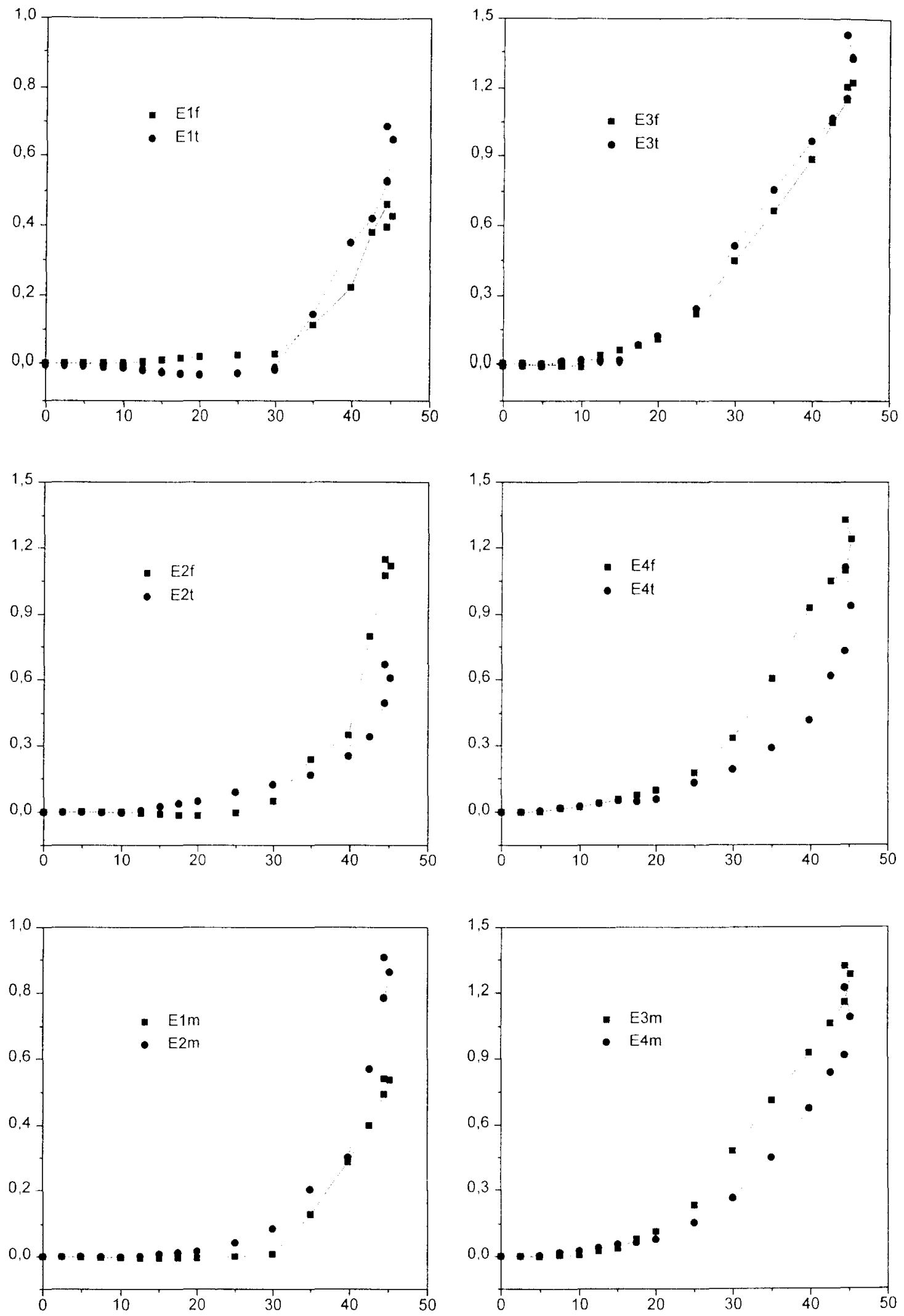

Figura 4.17 - Deformação ( $\mathrm{mm} / \mathrm{m}$ no eixo y) $\mathrm{x}$ Carga $(\mathrm{kN}$ no eixo $\mathrm{x})$ Estribos - P4A 

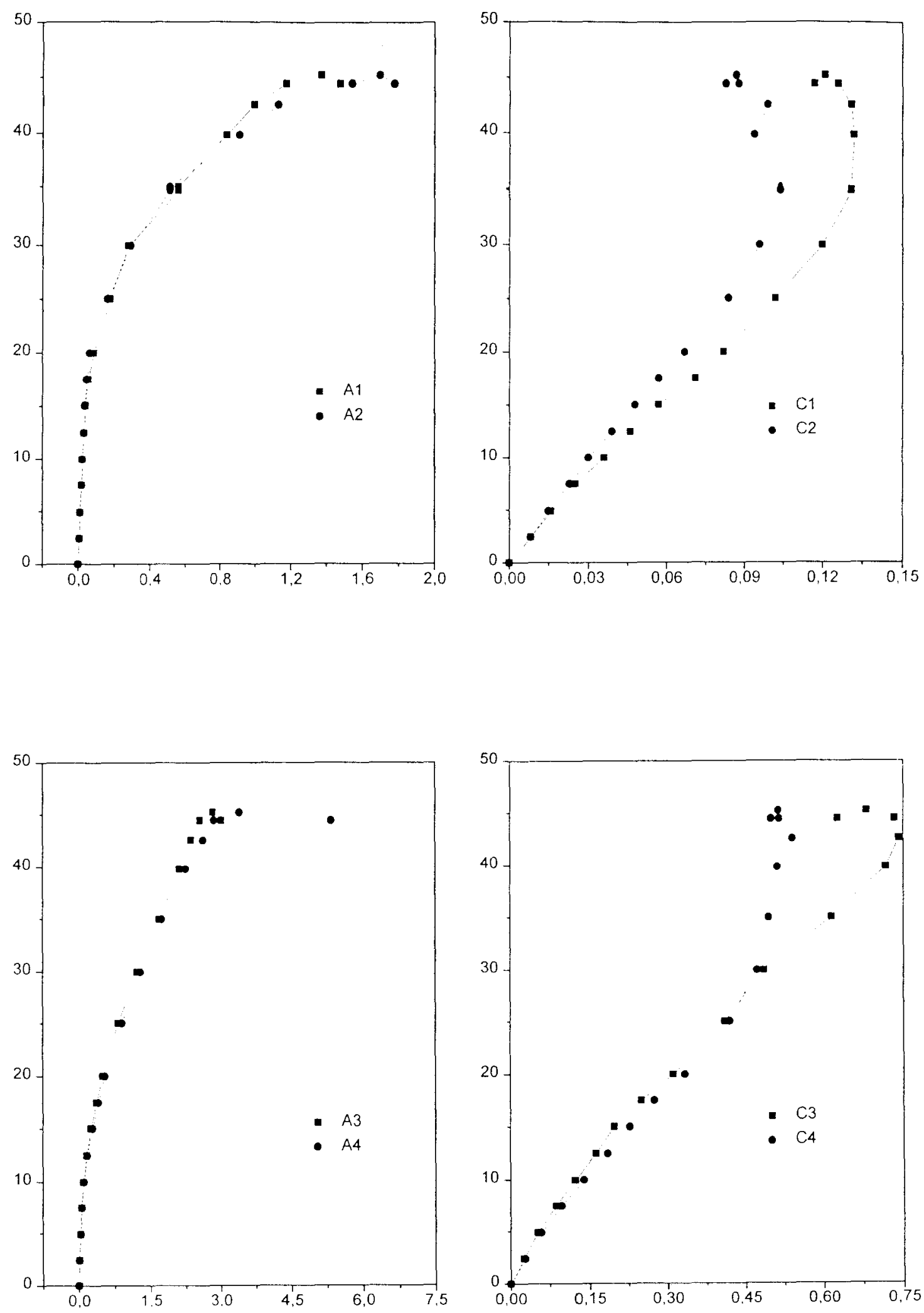

Figura 4.18 - Carga (kN no eixo y) x Deformação ( $\mathrm{mm} / \mathrm{m}$ no eixo $\mathrm{x})$

Armadura e concreto - P4A 

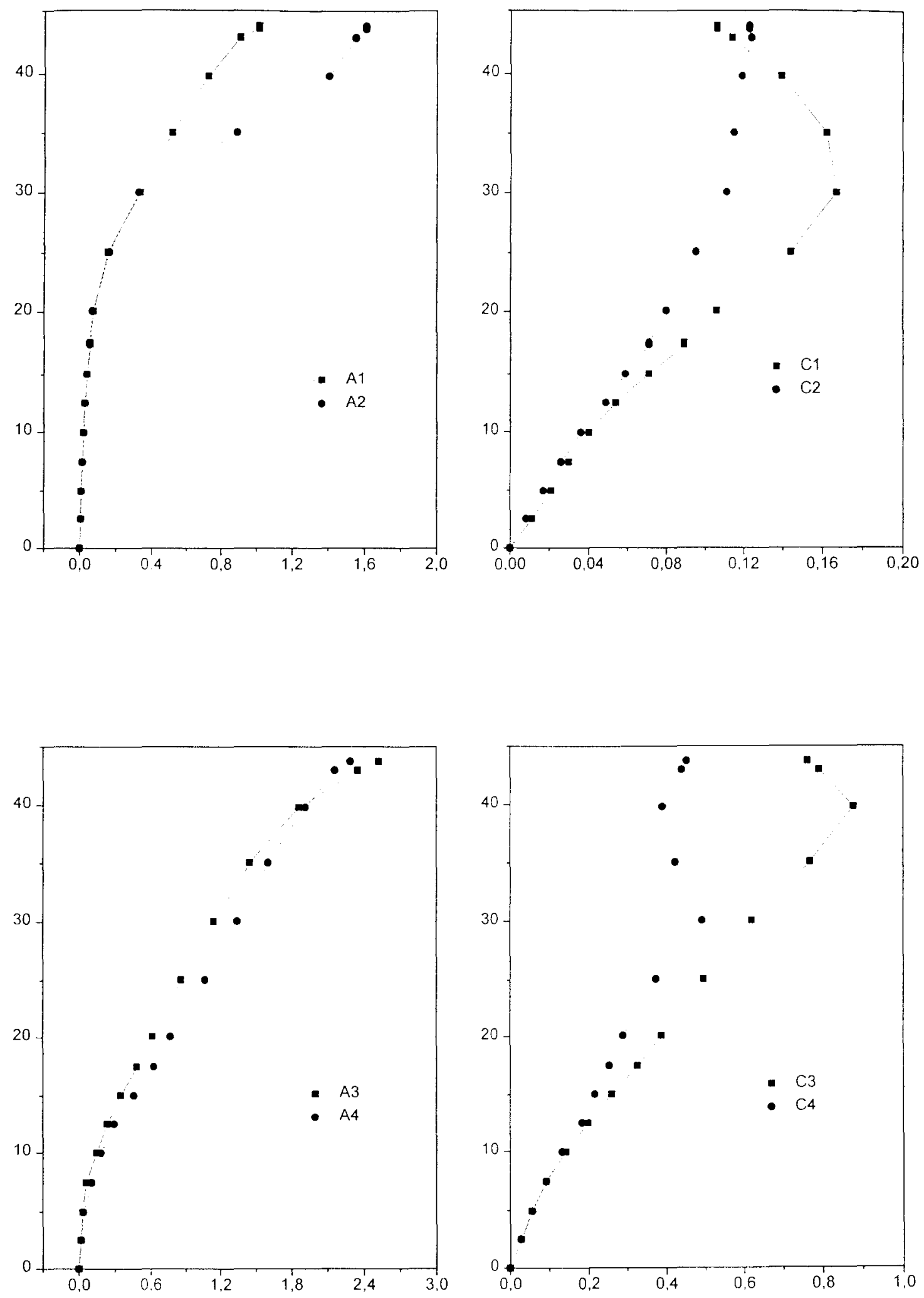

Figura 4.19 - Carga ( $\mathrm{kN}$ no eixo y) x Deformação ( $\mathrm{mm} / \mathrm{m}$ no eixo $\mathrm{x})$ Armadura e concreto - P4B 


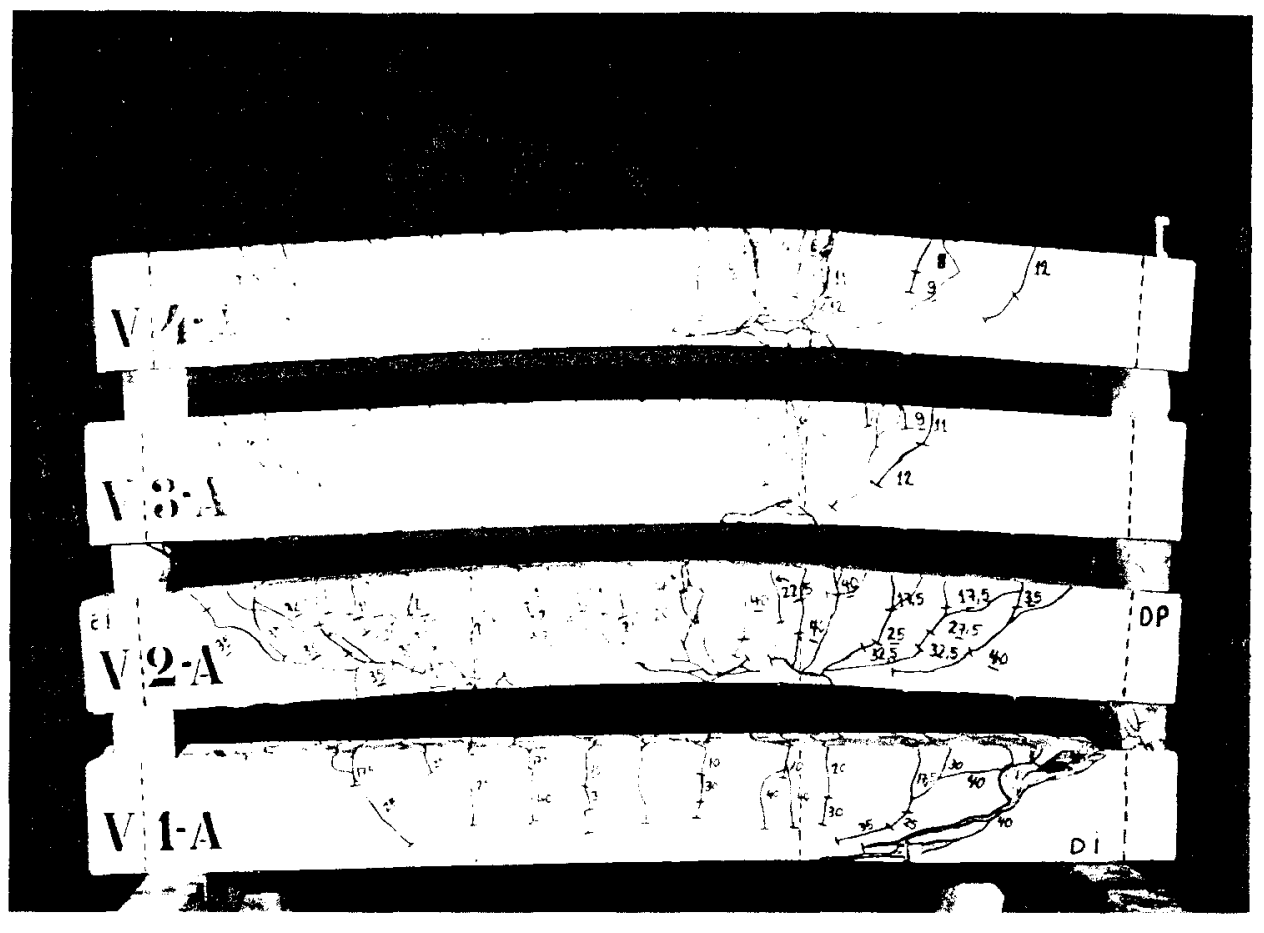

Foto 4.9 - Panorama dos modelos P1A a P4A após o ensaio

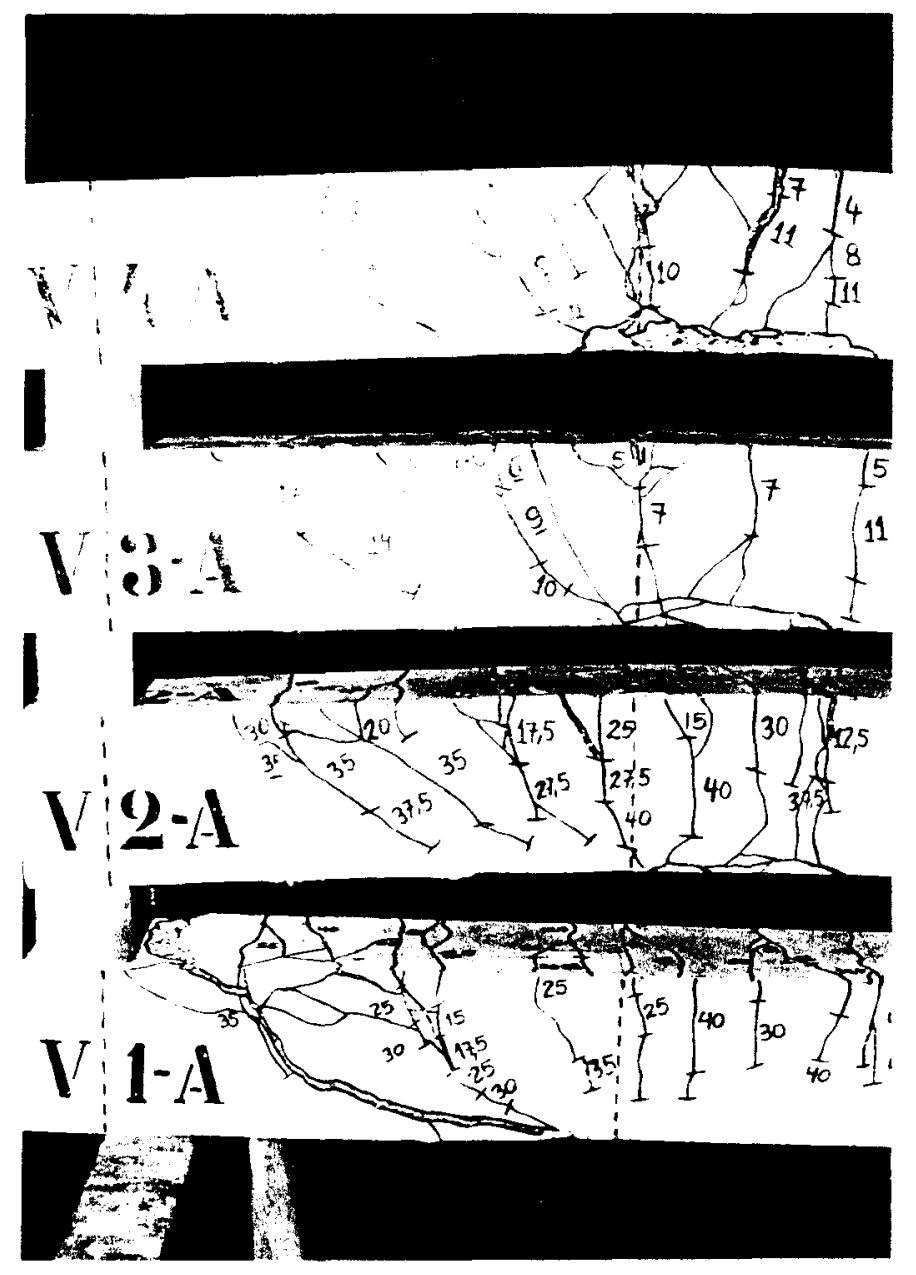

Foto 4.10 - Detalhe do lado da ruptura dos modelos P1A a P4A 


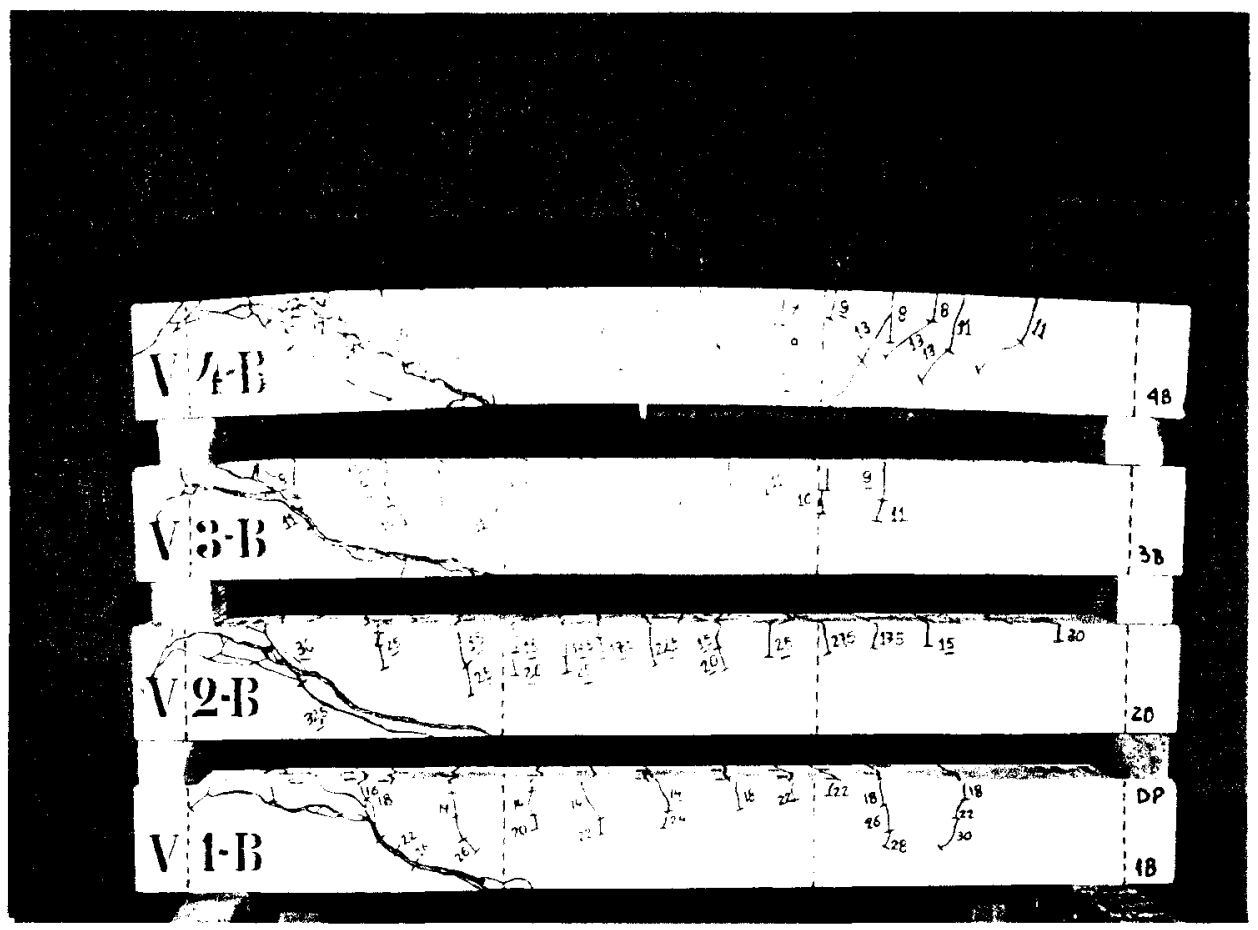

Foto 4.11 - Panorama dos modelos P1B a P4B após o ensaio

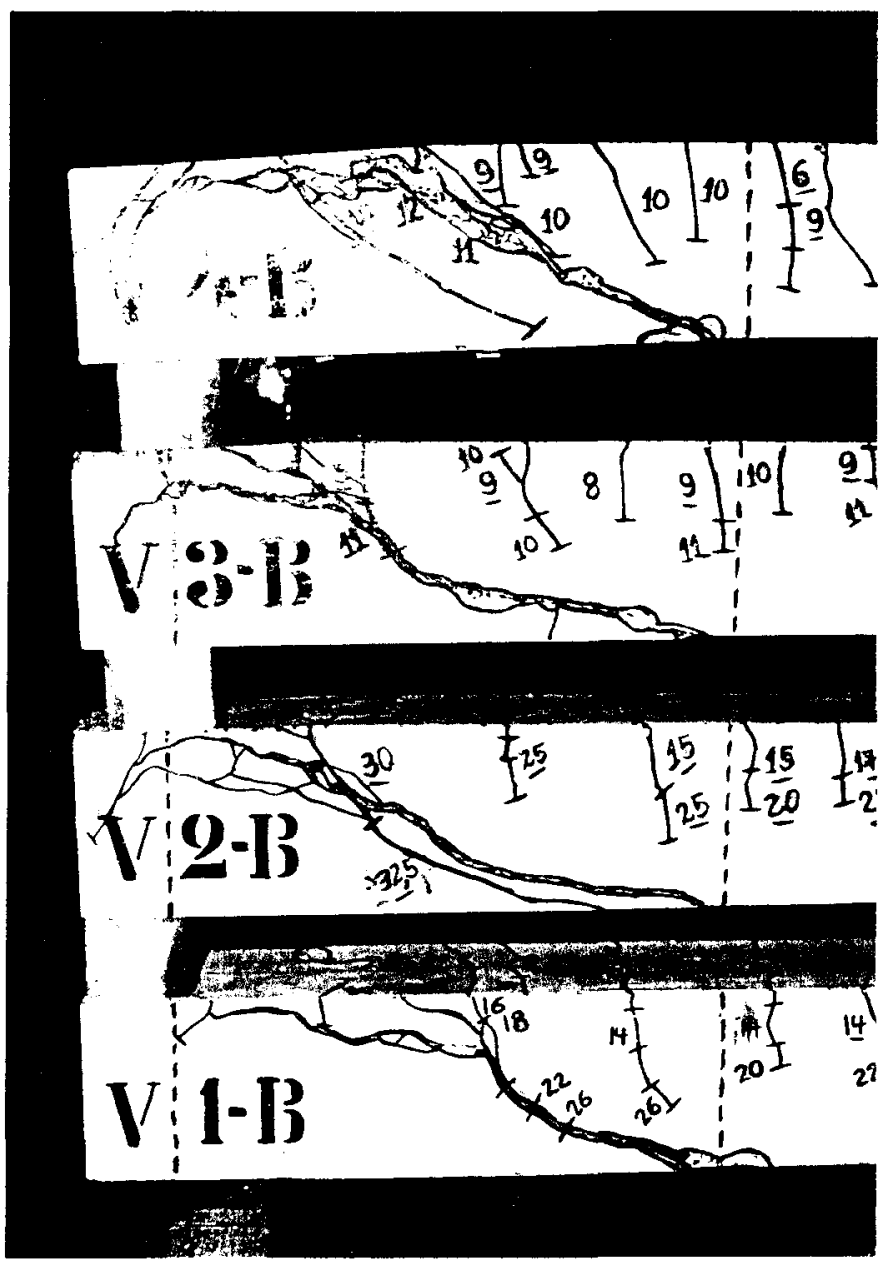

Foto 4.12 - Detalhe do lado da ruptura dos modelos P1B a P4B 


\subsubsection{5 - MODELOS P5A e P5B}

Estes modelos cram similares aos modelos P3, diferindo apenas no comprimento da fíbra de aço. agora mais longa, de $3,81 \mathrm{~cm}$. Ao contrário da fibra mais curta, o volume de $1 \%$ proporcionou aumento da resistência à tração do concreto, mas o valor do módulo de deformação longitudinal é um dos mais baixos, próximo daquele obtido com a fibra de polipropileno.

\section{modelo P5A}

Entre os modelos com libras da série A, esta peça foi a primeira em que ocorreu a ruína por cisalhamento. ( $\mathrm{cm}+3 \mathrm{kN}$ surgiu uma fissura diagonal no lado esquerdo da viga e a callea caiu bruscamente para $3 \mathrm{kN}$. A viga ainda foi recarregada até $30 \mathrm{kN}$, quando a flecha aumentou mais $2 \mathrm{~mm}$.

Após atingir $40 \mathrm{kN}$ a a carga se mantinha apenas com o acionamento contínuo da bomba. Não se verificou o escuamento dos estribos. mas houve um aumento brusco de tensão em $\mathrm{F}$ I após $40 \mathrm{kN}$. c cle pode ter escoado após o último registro dos dados.

Do ounro lado da rig̣ limbém apareceu uma fissura diagonal idêntica à fissura crítica, que não evoluiu pira a ruptura. Este fato e a observação de que as fissuras diagonais nầ surgiram numa única etapa do carregamento evidenciam a atuação das fibras no cisalhamento, proporcionando uma evolução gradual das fissuras até a ruptura. Uma fissura inclinada atravessou o estribo E2 após $35 \mathrm{kN}$, provocando brusca elevação de tensão. Estes dados podem ser observados na Foto 4.15.

A fissura diagonal se abriu mais do que nas vigas anteriores em que houve a ruína por cisalhamento. Ela tioi menos inclinada do que no modelo de referência e não partiu do ponto de aplicação la cirga, mas distante $8 \mathrm{~cm}$ deste ponto, onde se observa uma região danificada no concrito. Mesmo sem apresentar deformação plástica visível, a evolução dis flechas sugere o escoamento da armadura longitudinal, cuja deformação máxima medida foi de $0,25 \%$. na seção onde o momento solicitante é igual à metade do seu valor maximo.

As tensões nos estribos foram um pouco maiores que no modelo similar com fibra de aço mais curta. Nos csuribos E3 e E4, as tensões se mantiveram baixas até o final do ensaio (160 MPa). () aumento brusco de tensão registrado no estribo E2 após $35 \mathrm{kN}$ dec..e ao aparecimenn de uma fissura inclinada nesta região, quando a carga tentou alcancur o apoio dircimnente. Ele só é registrado pelo extensômetro de um dos ramos do estribo. A fissura diagonal surgiu inicialmente numa das faces da viga com $35 \mathrm{kN}$. Na outra face. ela apareceucom $40 \mathrm{kN}$ e aparece na etapa 12 na Foto 4.15. 
Este instante coincide com a descompressão mais intensa do concreto deste lado da peça. que se estendeu até " ponto C4. Isso comprova que a ruptura também era iminente nestat região. () mecinismo de arco se manifestou dos dois lados da viga, de forma mais intensal que no mudelo similar P3A, ratificando as observações anteriores sobre as fissuras diagonais.

\section{modelo P5B}

A ruptura ocorreu do lide esquerdo da viga com $37 \mathrm{kN}$. A carga caiu inicialmente para $33 \mathrm{kN}$. c loğ cu seguida, para $11 \mathrm{kN}$. A peça ainda foi recarregada até $20 \mathrm{kN}$. para posterior descirga. ()s últimos registros de dados se referem às cargas de $35 \mathrm{kN}$. ances do último incremento, e $33 \mathrm{kN}$, após a formação da fissura crítica.

Até a carga de $35 \mathrm{kN}$ não se observou descompressão do banzo comprimido, que se deformava quase lineamente. Com $37 \mathrm{kN}$. quando surgiu a fissura diagonal, não há registro dus dados. Quandı a carga diminuiu para $33 \mathrm{kN}$, observa-se claramente o fenômeno d. arqueamento do hanzo, que possivelmente ocorreu próximo da ruptura. onde a decompressão do cuncreto foi muito intensa no lado da ruptura. O encurtamom no ponto ( 3 diminuiu drasticamente e no ponto $\mathrm{C} 1$ a tensão quase se anulou. Neva mesma ctapal hí um acréscimo significativo de tensão na armadura longitudinal funto ao apoio do ludo esquerdo. onde a deformação passou de $0,02 \%$ para $0,16 \%$.

Supie-se que nos modclos anteriores em que houve ruptura por cisalhamento e estes fenômcnos não foram ohcirrados, eles ocorreram imediatamente antes da ruína e o sistema niin os registrou. 

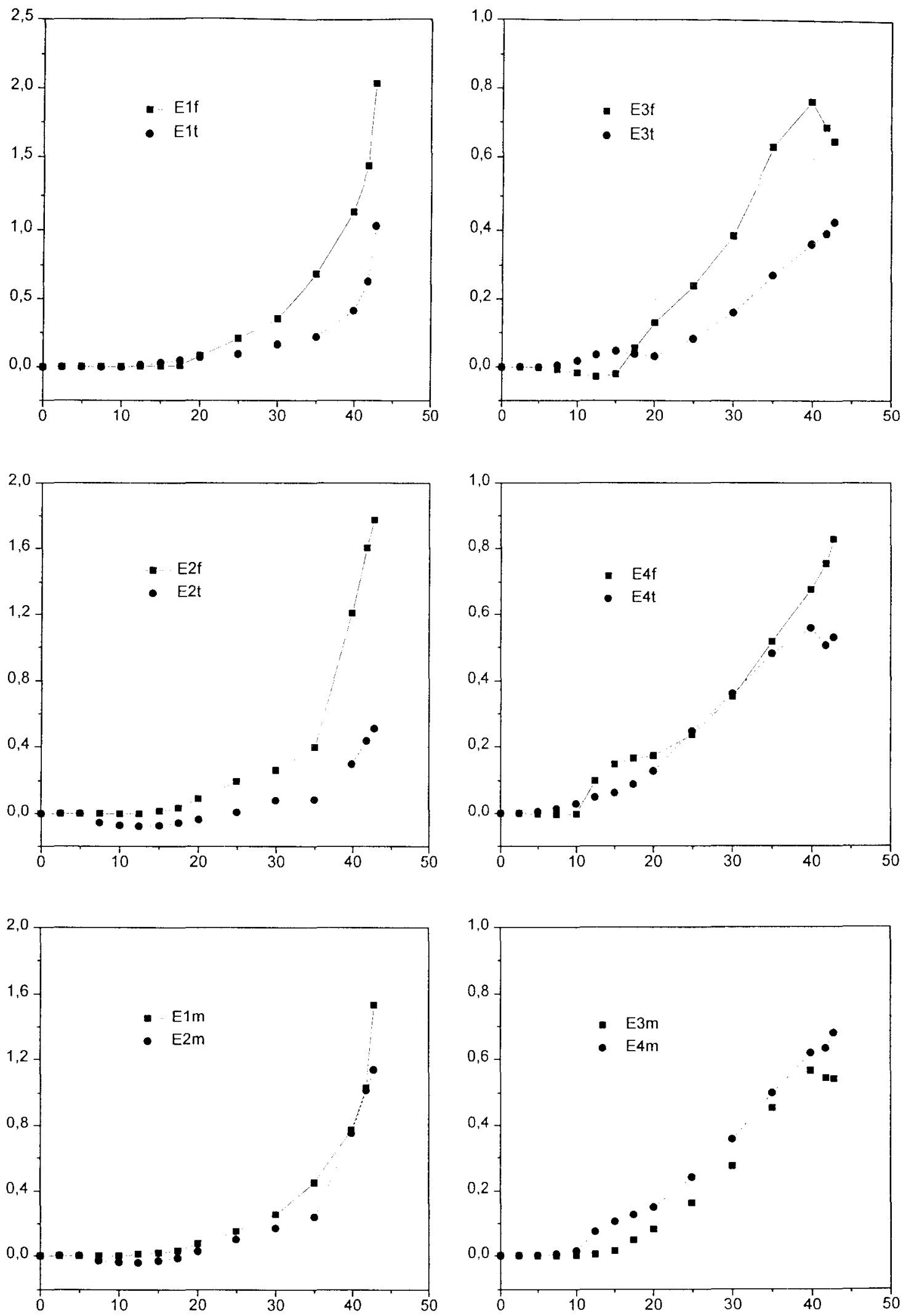

Figura 4.20 - Deformação ( $\mathrm{mm} / \mathrm{m}$ no eixo y) x Carga ( $\mathrm{kN}$ no eixo $\mathrm{x})$ Estribos - P5A 

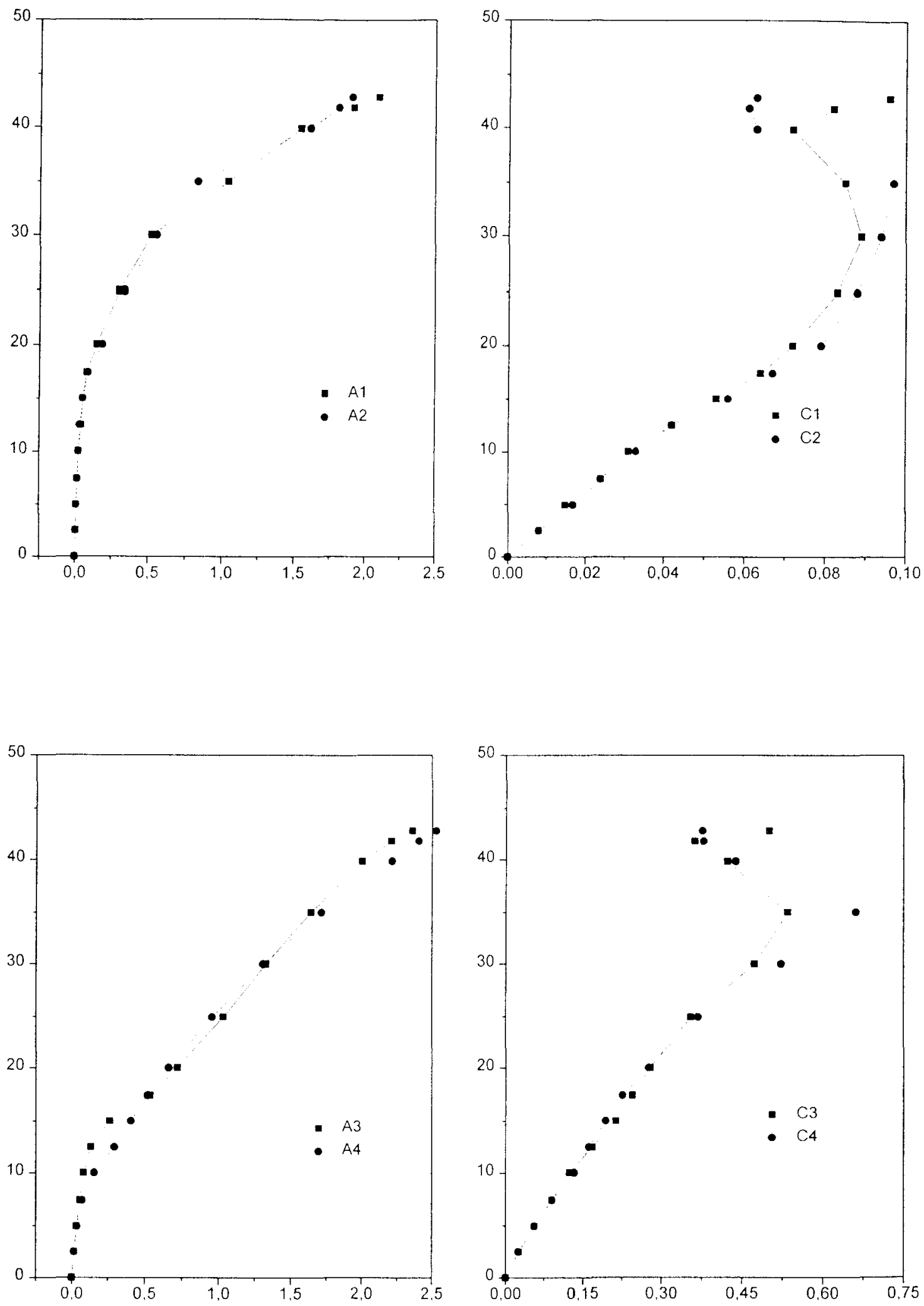

Figura 4.21 - Carga ( $\mathrm{kN}$ no eixo y) x Deformação $(\mathrm{mm} / \mathrm{m}$ no eixo $\mathrm{x})$ Armadura e concreto - P5A 

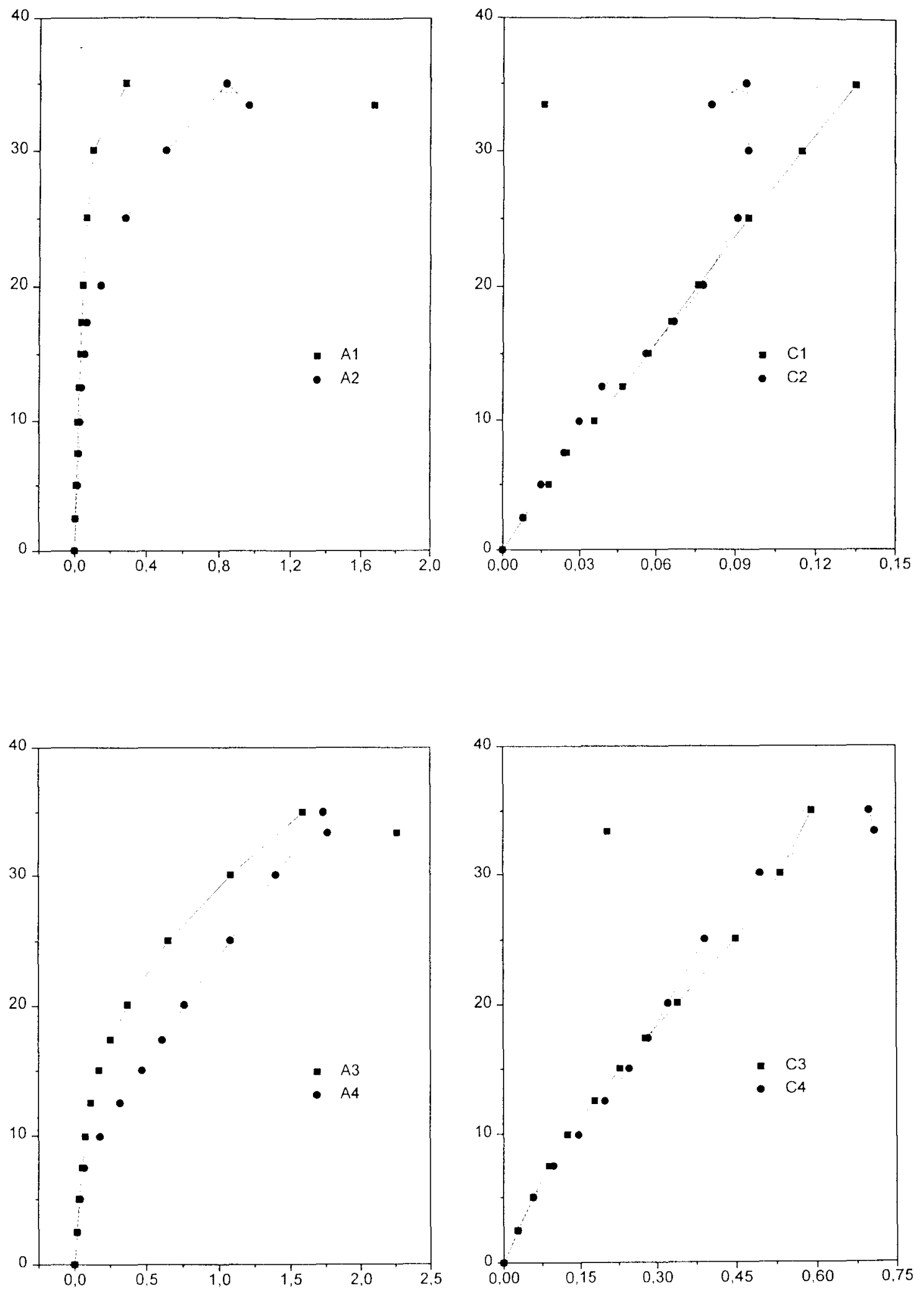

Figura 4.22 - Carga ( $\mathrm{kN}$ no eixo y) $\mathrm{x}$ Deformação $(\mathrm{mm} / \mathrm{m}$ no eixo $\mathrm{x})$

Armadura e concreto - P5B 


\subsubsection{6 - MODELOS P6A e P6B}

Estas vigas eram similares aos modelos $\mathrm{P} 4$, com $2 \%$ de fibras de aço, mas de comprimento igual a $3,81 \mathrm{~cm}$. O aumento na resistência à tração ratifica a tendência observada no modelo anterior. A fibra de aço mais longa melhora esta característica do concreto, especialmente quando a quantidade é maior.

\section{modelo P6A}

Nesta viga não houve ruptura por cisalhamento. Após a carga atingir $47 \mathrm{kN}$. a tensão no estribo E4 aumentou e a carga caiu para $40 \mathrm{kN}$. A fissura nesta região era um prolongamento de uma fissura de flexão, que quase atingia o banzo comprimido, como se observa na Foto 4.15. A peça ainda foi recarregada até $44 \mathrm{kN}$, quando o ensaio foi interrompido. Não há registros de deformações dos elementos nesta etapa. Em nenhum estribo a deformação atingiu o patamar de escoamento.

O estado limite último ocorreu devido ao escoamento da armadura longitudinal. A deformação plástica residual é visível, concentrando-se na região de introdução da carga no lado direito, onde se observa a rótula de plastificação e o esmagamento do concreto no banzo comprimido. no trecho a partir do ponto de introdução da carga até o centro da peça.

As fissuras na região tracionada provocaram o lascamento do concreto em várias posições. A Foto 4.13 mostra o detalhe das fibras aparentes nesta região. A rigidez foi a maior de todo o conjunto, o que revela a situação de melhor eficiência das fibras no controle da fissuração, já que o valor do módulo de deformação longitudinal não justifica este fato. O comportamento pós-pico foi o mais dútil dentre todos os modelos de vigas retangulares.

Quando a primeira fissura de flexão começou a se inclinar na alma, com abertura de $0,04 \mathrm{~mm}$, a abertura máxima das fissuras de flexão era de $0,13 \mathrm{~mm}$. $\mathrm{O}$ deslocamento vertical máximo até o instante em que a carga caiu para $40 \mathrm{kN}$ foi de $24,5 \mathrm{~mm}$. Na recarga, até $44 \mathrm{kN}$. houve um acréscimo de mais $10 \mathrm{~mm}$, e a flecha atingiu $34,5 \mathrm{~mm}(/ / 26)$.

As tensões nos estribos se mantiveram baixas durante todo o ensaio. Na última etapa de carga houve aumento de tensão em E4. Próximo dos apoios, praticamente não há fissuras inclinadas no lado direito da viga.

O mecanismo de arco pode ser observado mais claramente do lado esquerdo da peça, onde ocorreu descompressão do concreto nas duas posições instrumentadas após 
a carga atingir $40 \mathrm{kN}$. Na armadura longitudinal, o acréscimo de tensão próximo dos apoios foi um pouco maior no lado esquerdo, devido ao atirantamento do banzo comprimido, mais inclinado neste caso. A força máxima a ser ancorada foi pequena, coerente com a descompressão mais suave do concreto.

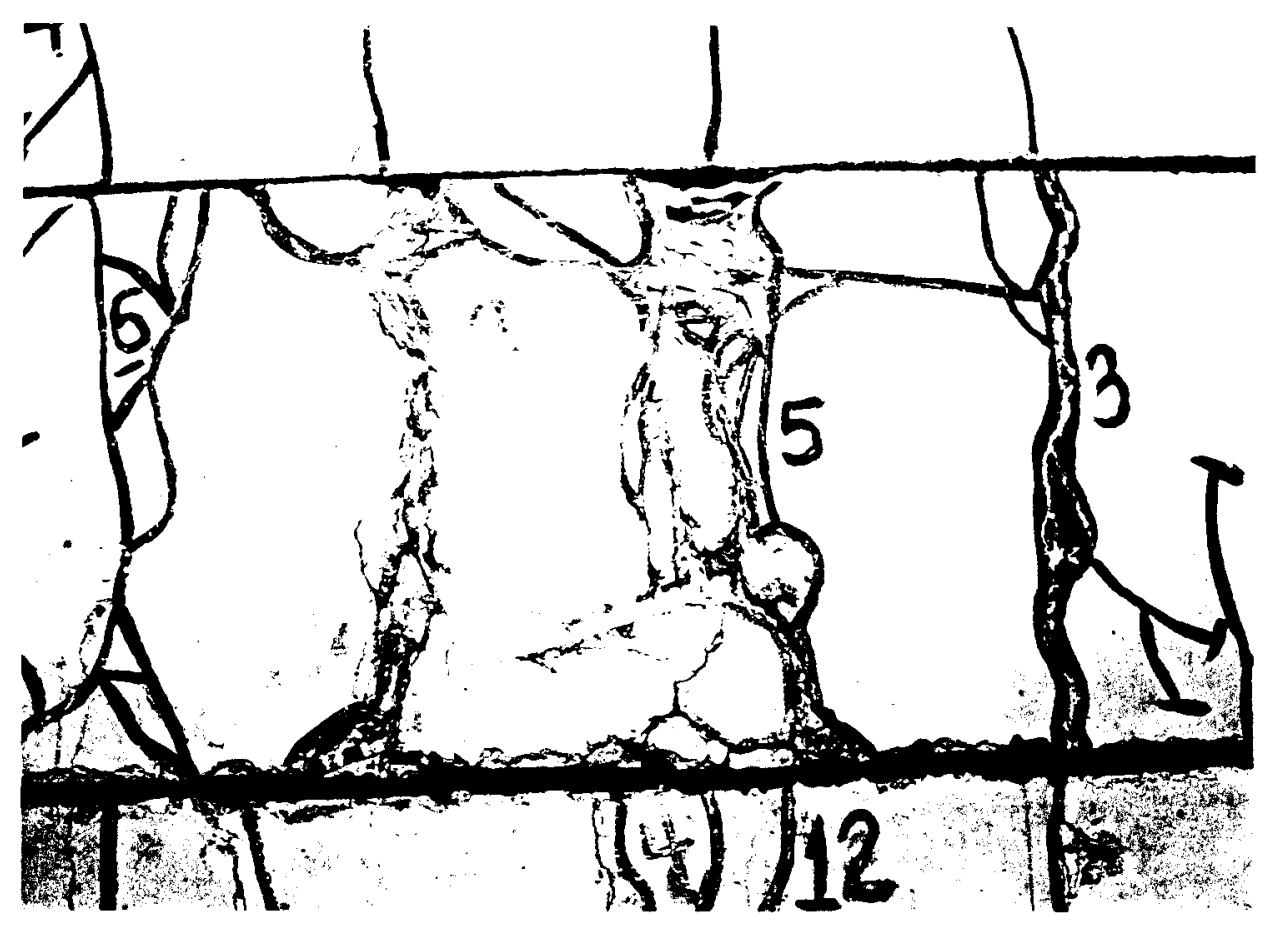

Foto 4.13 - Detalhe das fibras aparentes na face tracionada- modelo P6A

\section{modelo P6B}

A fissura diagonal crítica apareceu com $38 \mathrm{kN}$, no lado esquerdo da peça, e evoluiu para a ruptura no incremento seguinte, com $40 \mathrm{kN}$. instante em que a carga caiu para $33 \mathrm{kN}$. A ruptura foi suave. como em todas as outras vigas. provavelmente porque não há ruptura de estribos.

A fissura crítica se bifurca na sua trajetória, atingindo a borda tracionada a $8 \mathrm{~cm}$ do apoio. Nesta região, entre os ramos da fissura na face tracionada, observa-se a formação de uma rótula. devido ao apoio das bielas na armadura longitudinal.

Assim como aconteceu no modelo $\mathrm{P} 4 \mathrm{~B}$, havia uma fissura diagonal de grande abertura do outro lado da peça. que expunha as tibras de aço, conforme se observa na Foto 4.14. Ela era menos inclinada, atingindo a face superior a $17 \mathrm{~cm}$ do apoio. Novamente. a adição de $2 \%$ de fibra evitou a ruptura que parecia iminente. Deve-se 
lembrar que, mesmo no modelo P1A, com estribos e sem fibra, este fato não foi observado, ou seja, o aparecimento desta fissura levou a viga imediatamente à ruína.

A flecha correspondente à carga de $40 \mathrm{kN}$ foi de $7,2 \mathrm{~mm}(/ / 125)$. Há mais dois registros, para $33 \mathrm{kN}$, imediatamente após a ruptura, e $18 \mathrm{kN}$, quando a ruína se concretizou e elas atingiram $7,5 \mathrm{~mm}$ e $8,5 \mathrm{~mm}$, respectivamente.

A descompressão do concreto nos pontos externos atingiu os dois lados do modelo, sendo mais intensa no lado esquerdo, acompanhada de um acréscimo mais significativo de tensão na armadura junto ao apoio. Nos pontos mais internos, ela ocorreu somente do lado esquerdo da viga.

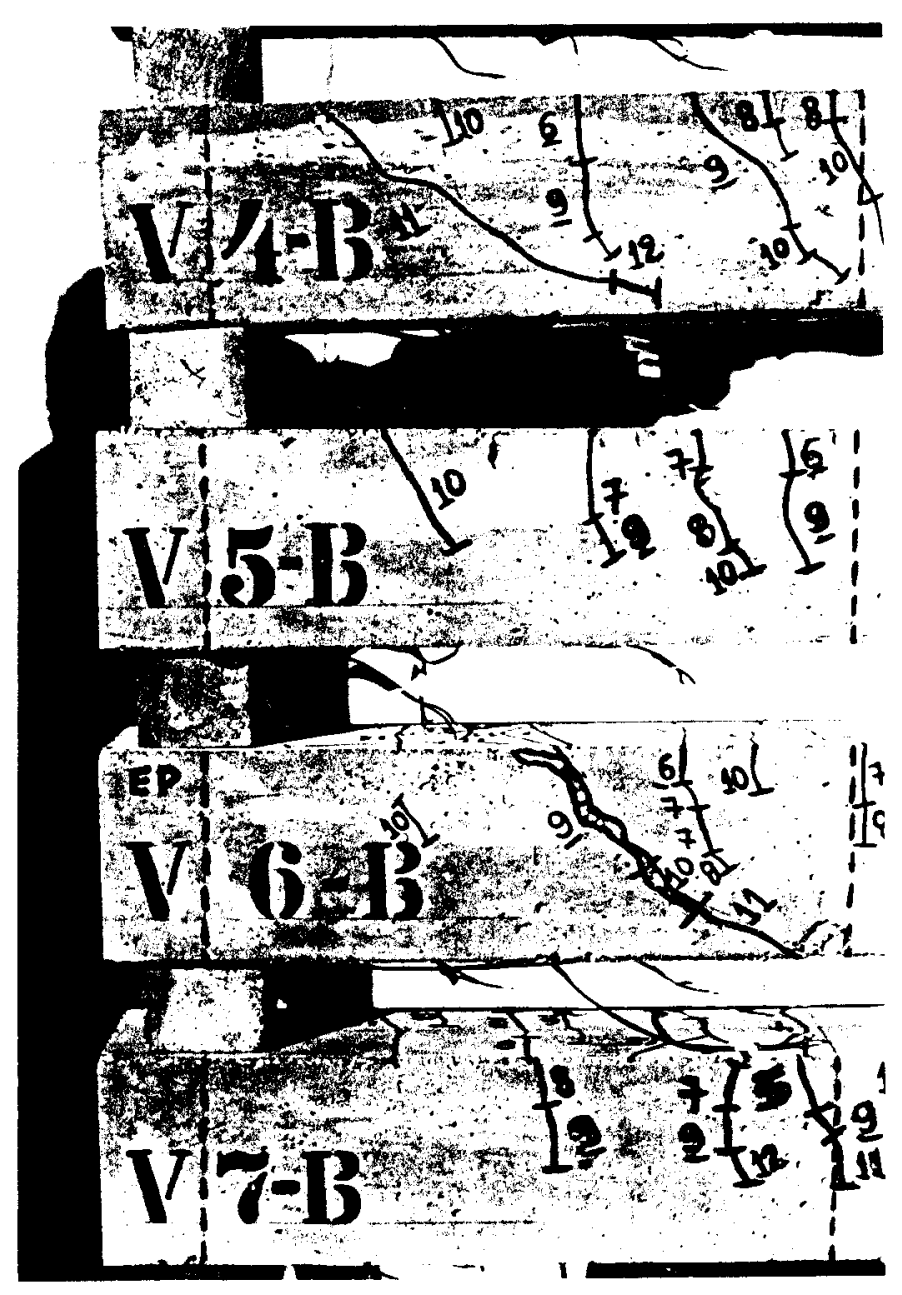

Foto 4.14 - Vista do lado em que a ruptura não se concretizou (P4B a P7B) 

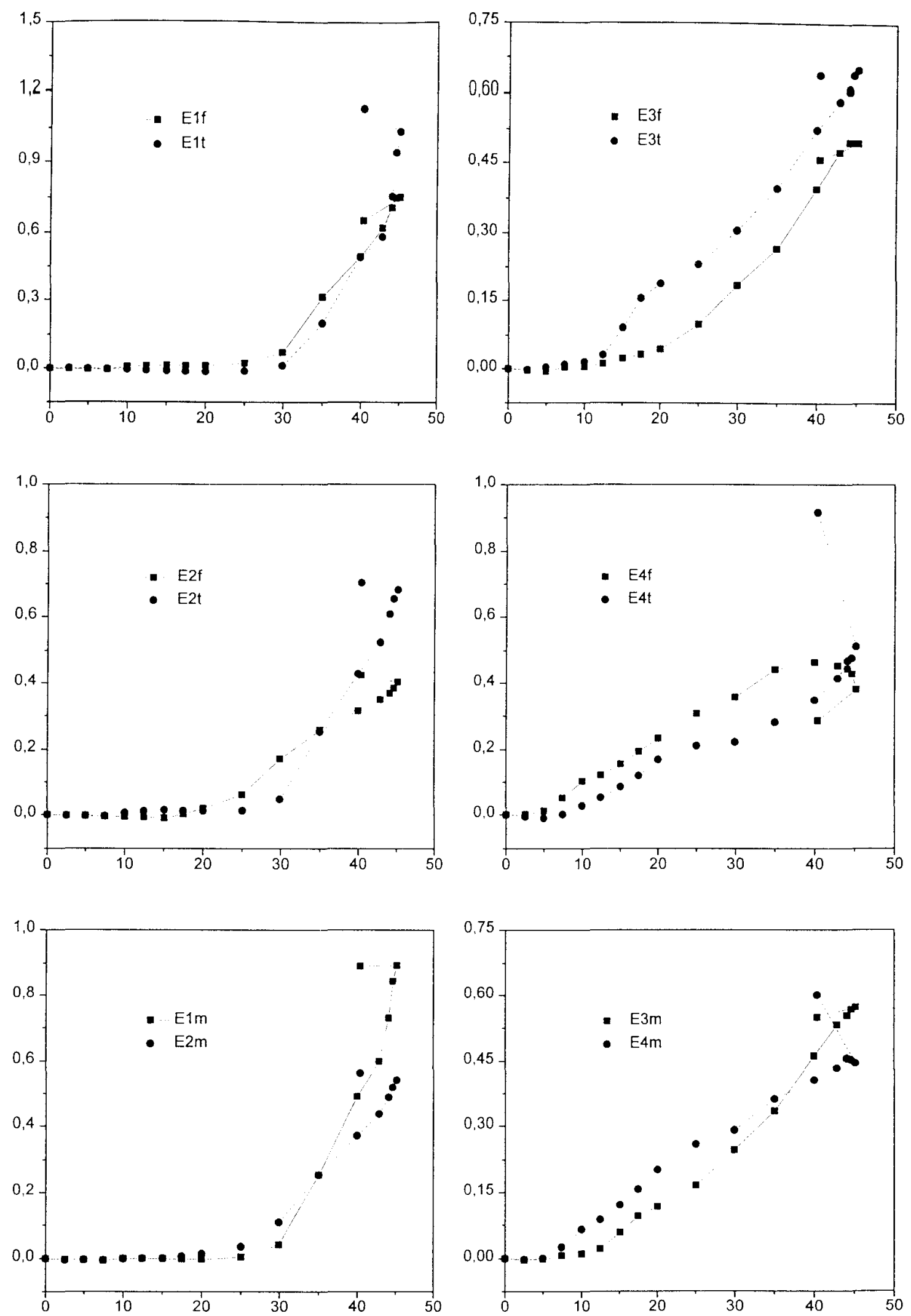

Figura 4.23 - Deformação $(\mathrm{mm} / \mathrm{m}$ no eixo y) x Carga ( $\mathrm{kN}$ no eixo $\mathrm{x})$ Estribos - P6A 

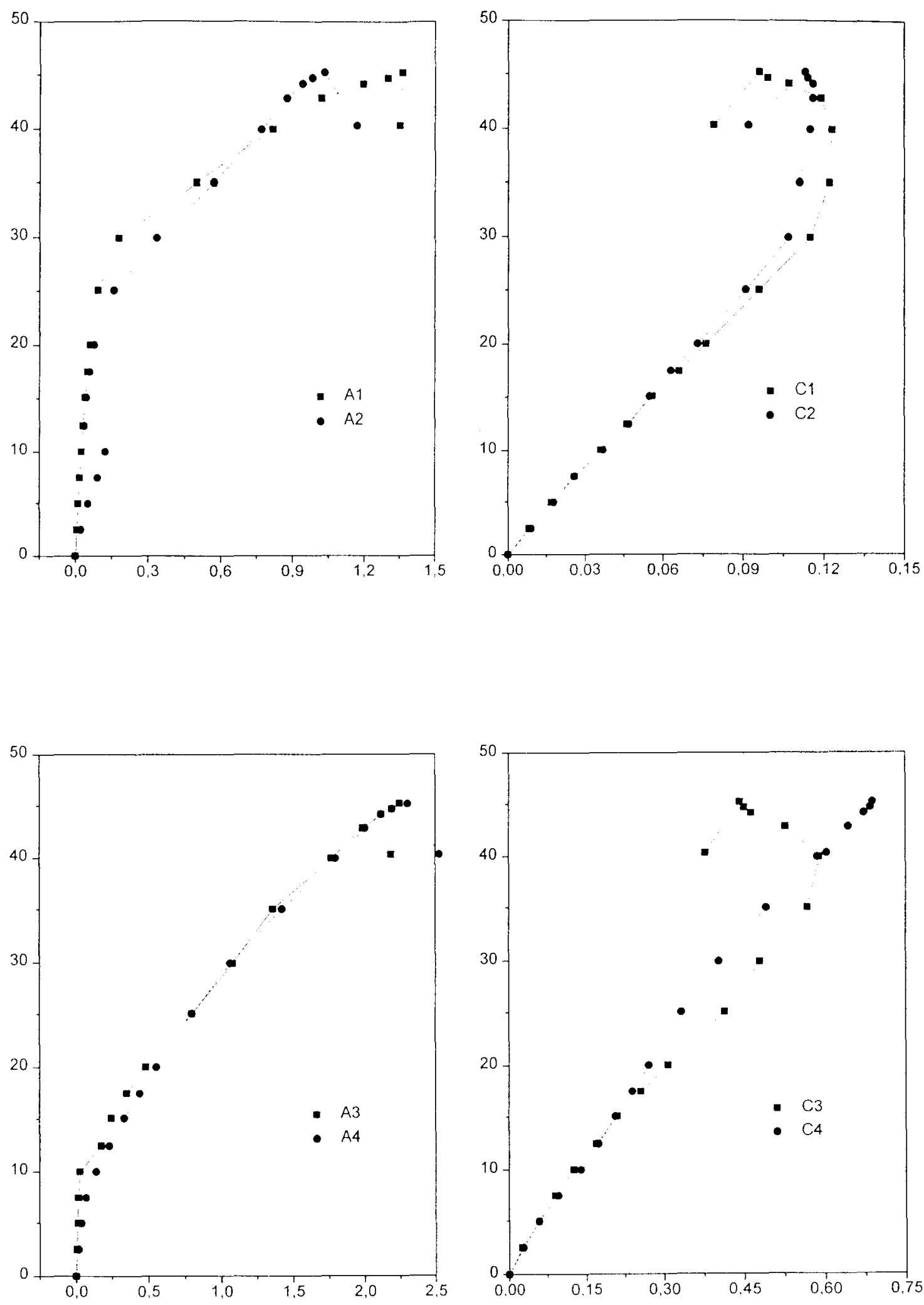

Figura 4.24 - Carga ( $\mathrm{kN}$ no eixo y) $\mathrm{x}$ Deformação $(\mathrm{mm} / \mathrm{m}$ no eixo $\mathrm{x})$ Armadura e concreto - P6A 

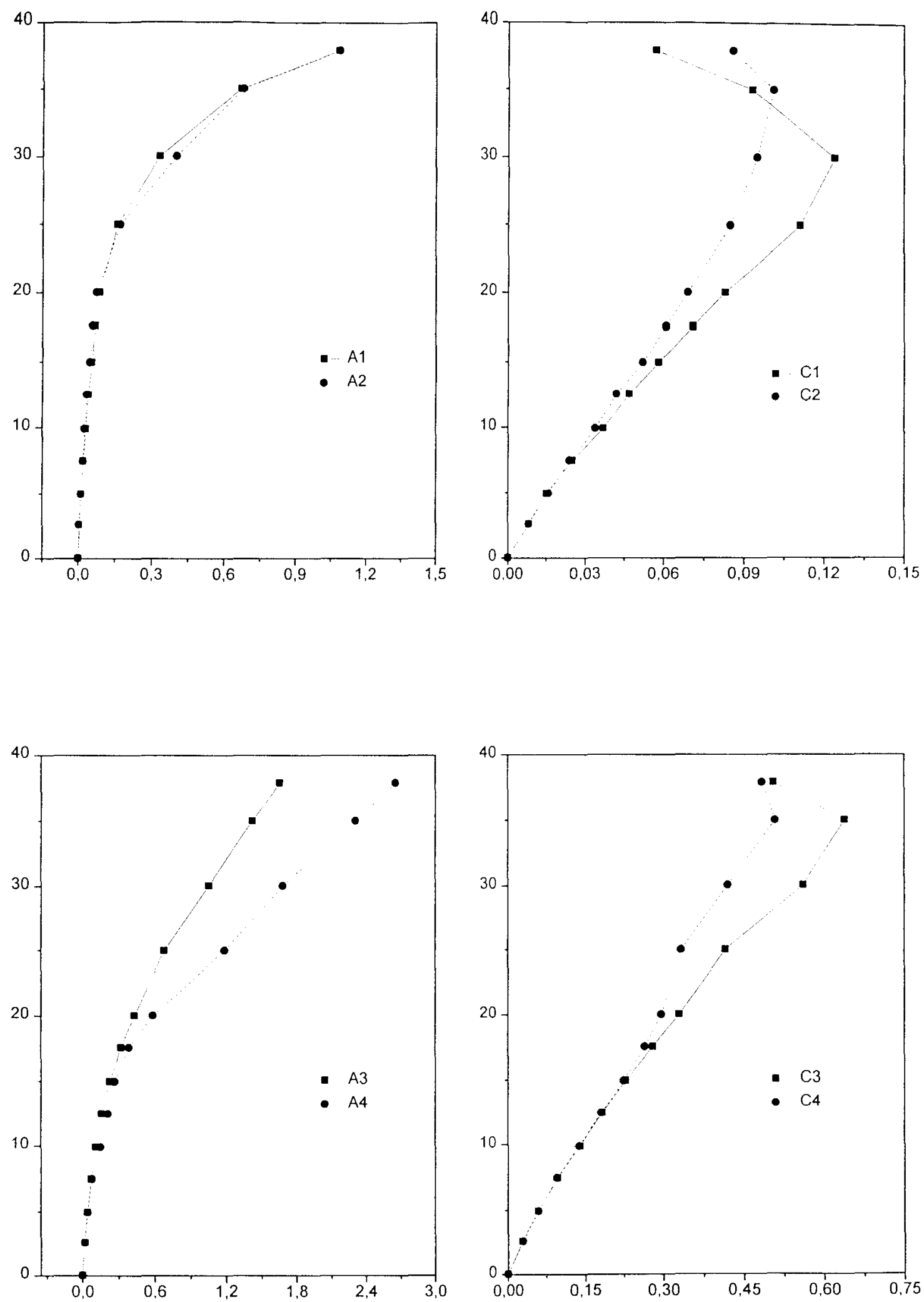

Figura 4.25 - Carga ( $\mathrm{kN}$ no eixo y) x Deformação $(\mathrm{mm} / \mathrm{m}$ no eixo $\mathrm{x})$

Armadura e concreto - P6B 


\subsubsection{7 - MODELOS P7A e P7B}

Os últimos modelos continham o mesmo volume de fibras utilizado nas vigas reforçadas com fibra de polipropileno. A fibra mais longa foi escolhida porque inicialmente imaginava-se que ela teria melhor desempenho. já que sua relação de aspecto era mais favorável.

O pequeno aumento da resistência à compressão observado deve estar associado à melhor consistência proporcionada pelo aditivo. Isso se verificou em todos os modelos com fibras de aço, onde a adição das fibras altera pouco a trabalhabilidade da mistura e, em menor escala, para o modelo com fibra de polipropileno. onde o efeito do aditivo na consistência é praticamente anulado pela adição da fibra. À melhor consistência deve estar associada a redução da porosidade da mistura e. consequentemente. a maior resistência do concreto. Mesmo com a pequena quantidade de fỉbra adicionada. a resistência do concreto à tração melhorou um pouco.

\section{modelo P7A}

Este foi o segundo modelo com fibras da série $\mathrm{A}$ em que a ruptura diagonal se concretizou. Com $44 \mathrm{kN}$ houve o primeiro sinal da ruína. quando a carga caiu para 41 $\mathrm{kN}$. A viga foi recarregada até $45 \mathrm{kN}$, instante em que ocorreu a ruptura diagonal, no lado esquerdo da peça.

A armadura longitudinal pode ter escoado para carga acima de $40 \mathrm{kN}$, já que a deformação máxima nos pontos instrumentados se aproximou do limite de escoamento do aço. Os deslocamentos nesta etapa aumentaram sob carga praticamente constante. No entanto. não se observou deformação plástica residual significativa após a descarga.

Imediatamente antes da ruptura, a tensão no estribo E1 era maior que $600 \mathrm{MPa}$, já que ele atravessava a fissura diagonal, como se observa na parte da direita da Foto 4.15. etapa 12 do carregamento. Do lado direito da viga, a ausência de fissuras na região de E2 justifica o pequeno valor da tensão. Os estribos E3 e E4 foram mobilizados bem antes. mas a deformação esteve limitada a $0.1 \%$ até o final do ensaio.

Quando surgiu a fissura diagonal houve intensa descompressão do concreto deste lado da peça, que atingiu os dois pontos instrumentados, C1 e C3. Do outro lado não houve descompressão.

Após a carga atingir $40 \mathrm{kN}$, a tensão no concreto do lado esquerdo voltou a crescer, acompanhando o aumento da solicitação por flexão. Isto sugere que outros mecanismos resistentes ainda atuavam nesta etapa, complementando a resistência obtida pela transmissão direta da carga ao apoio. Posteriormente. o encurtamento no 
concreto diminuiu novamente. Houve pequeno acréscimo de tensão na armadura longitudinal junto ao apoio no lado esquerdo da viga próximo da ruptura.

\section{modelo P7B}

A ruptura diagonal ocorreu alguns instantes após a carga atingir $35 \mathrm{kN}$. A fissura crítica, localizada do lado esquerdo da viga. foi do ponto de aplicação da carga até o apoio, com inclinação de 20 graus numa face e de 50 graus na outra face lateral. Imediatamente antes da ruína não havia aparecido nenhuma fissura diagonal diretamente na alma.

A rigidez foi a maior de todas as vigas da série B. Depois da ruptura, a flecha era $4 \mathrm{~mm}$ maior que o valor registrado imediatamente antes da ruptura.

A descompressão do concreto não foi observada durante o carregamento. Os valores das deformações quando a carga caiu para $17 \mathrm{kN}$ praticamente coincidem com os valores correspondentes medidos no carregamento. O mesmo ocorreu em relação ao acréscimo de tensão na armadura longitudinal próximo dos apoios. No entanto, a tensão no ponto Al após a diminuição da carga é duas vezes maior que a correspondente à carga máxima, igual a $200 \mathrm{MPa}$. Isto indica que. próximo da ruptura. a armadura foi muito solicitada neste ponto.

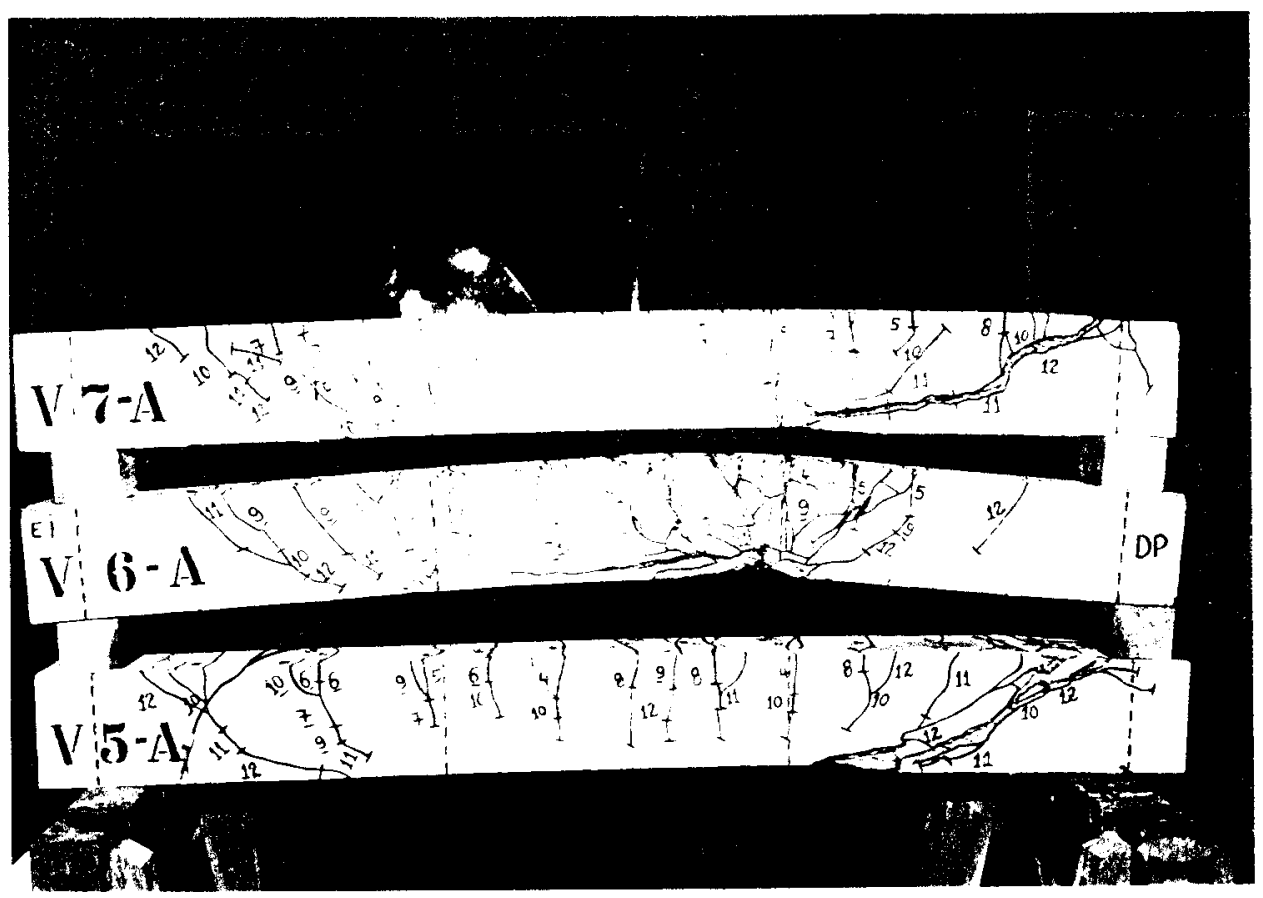

Foto 4.15 - Panorama geral dos modelos P5 A a P7A após o ensaio 

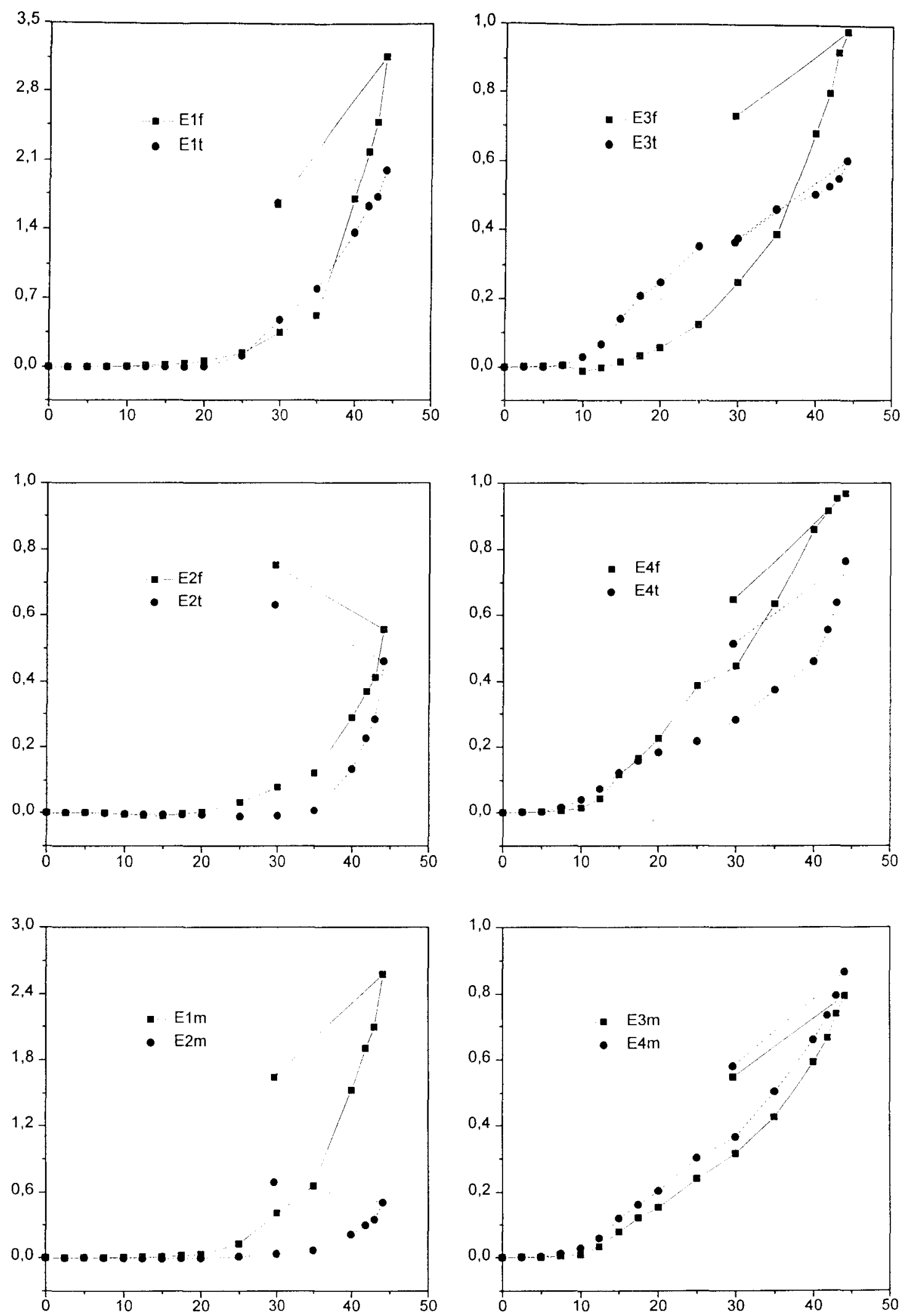

Figura 4.26 - Deformação (mm/m no eixo y) x Carga ( $\mathrm{kN}$ no eixo $\mathrm{x})$ Estribos - P7A 

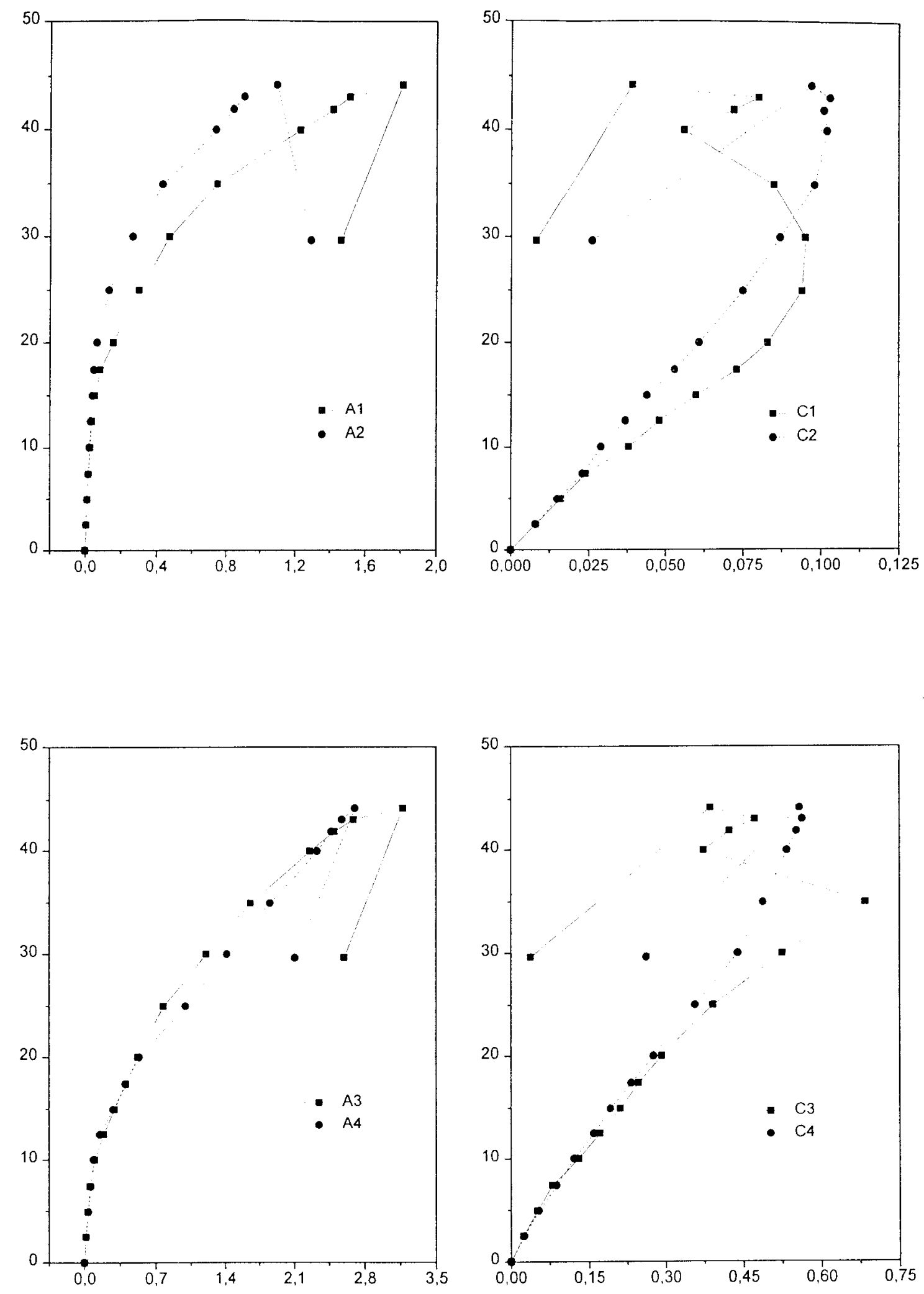

Figura 4.27 - Carga ( $\mathrm{kN}$ no eixo y) $\mathrm{x}$ Deformação $(\mathrm{mm} / \mathrm{m}$ no eixo $\mathrm{x})$ Armadura e concreto - P7A 

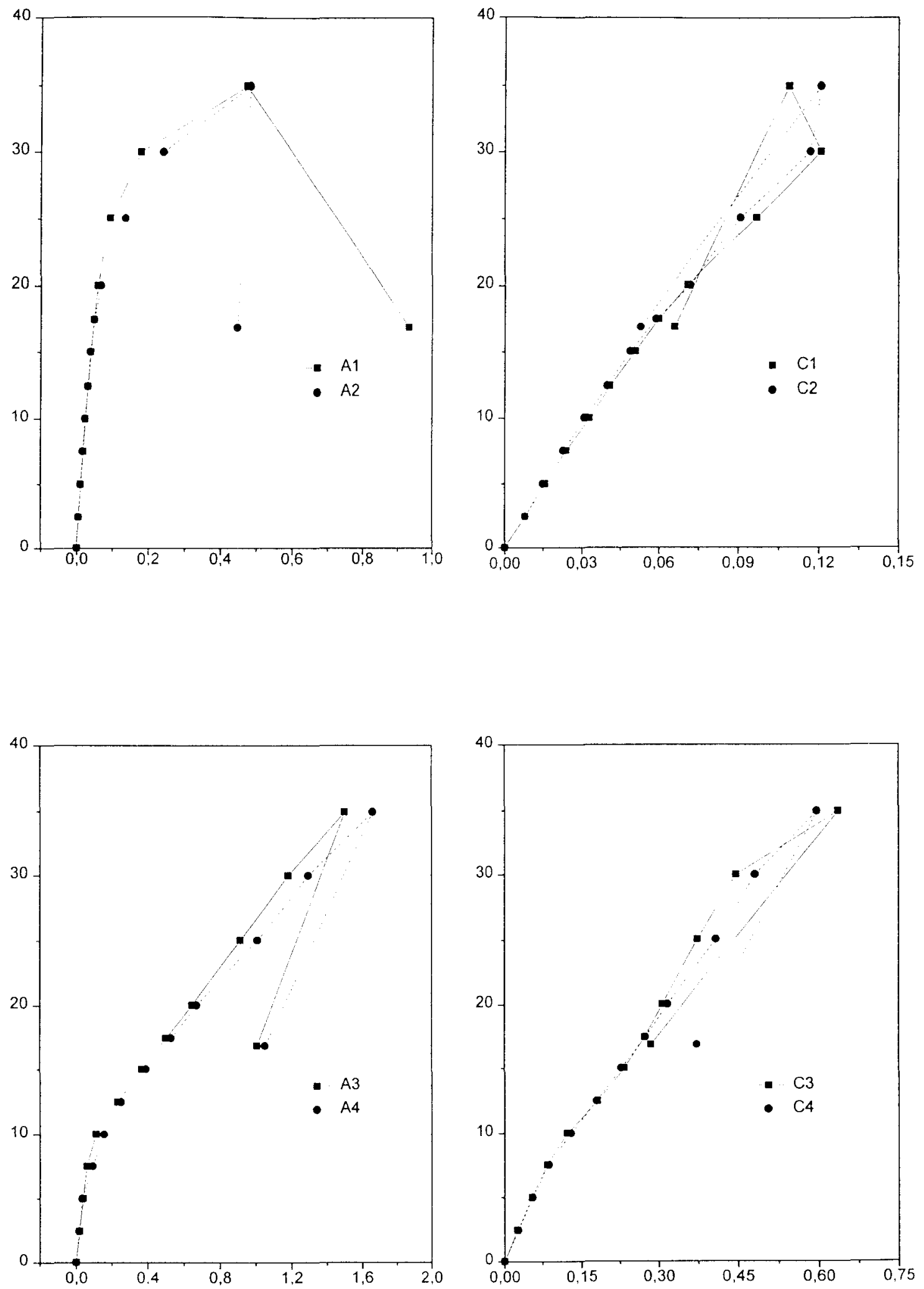

Figura 4.28 -Carga ( $\mathrm{kN}$ no eixo y) x Deformação $(\mathrm{mm} / \mathrm{m}$ no eixo $\mathrm{x})$ Armadura e concreto - P7B 
As Fotos 4.15 e 4.16 ilustram o aspecto geral dos modelos P5 a P7, das séries A e $\mathrm{B}$, respectivamente. As Fotos 4.17 e 4.18 , os detalhes do lado da ruptura destas vigas. As Fotos 4.19 e 4.20 mostram uma vista lateral de todos os modelos das séries A e B, respectivamente.

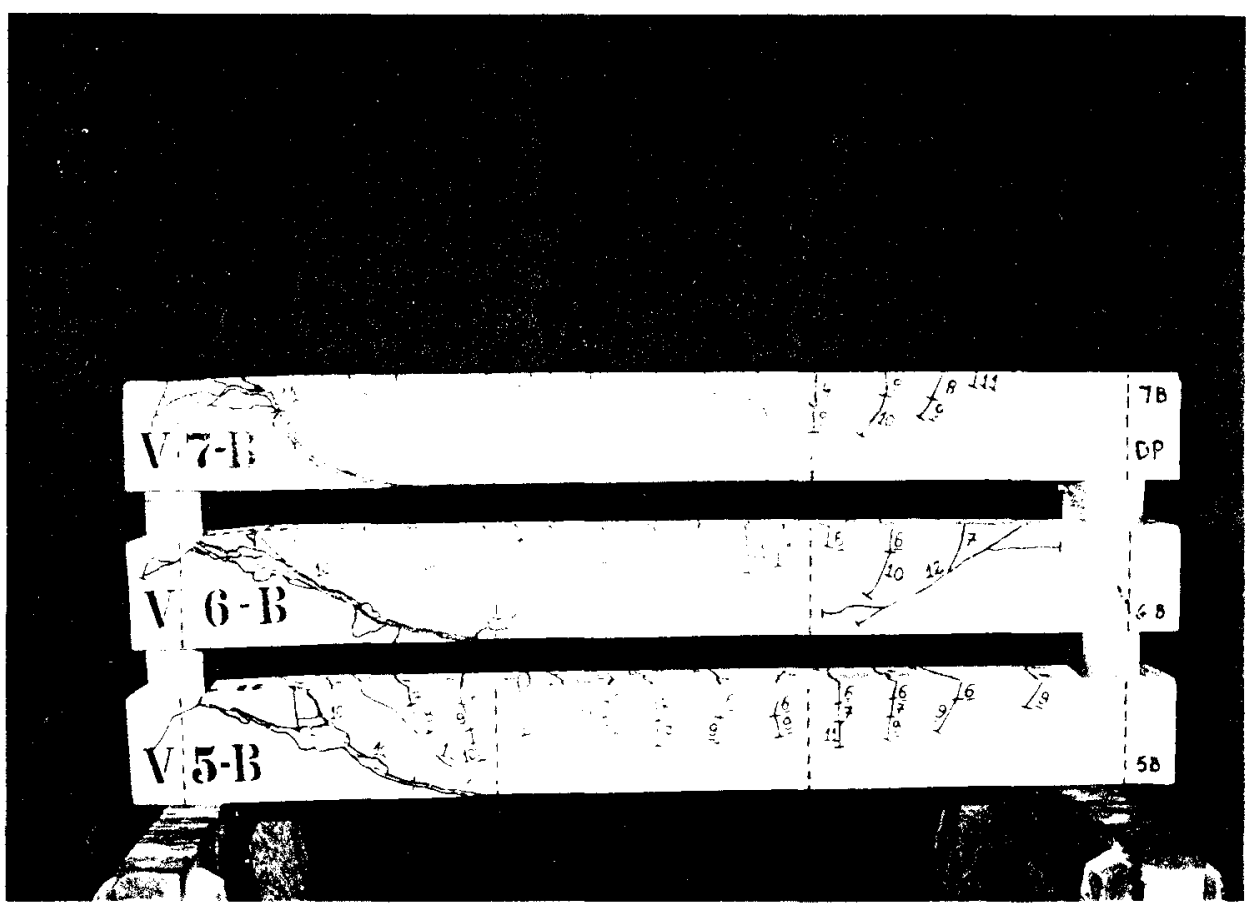

Foto 4.16 - Panorama dos modelos P5B a P7B após o ensaio

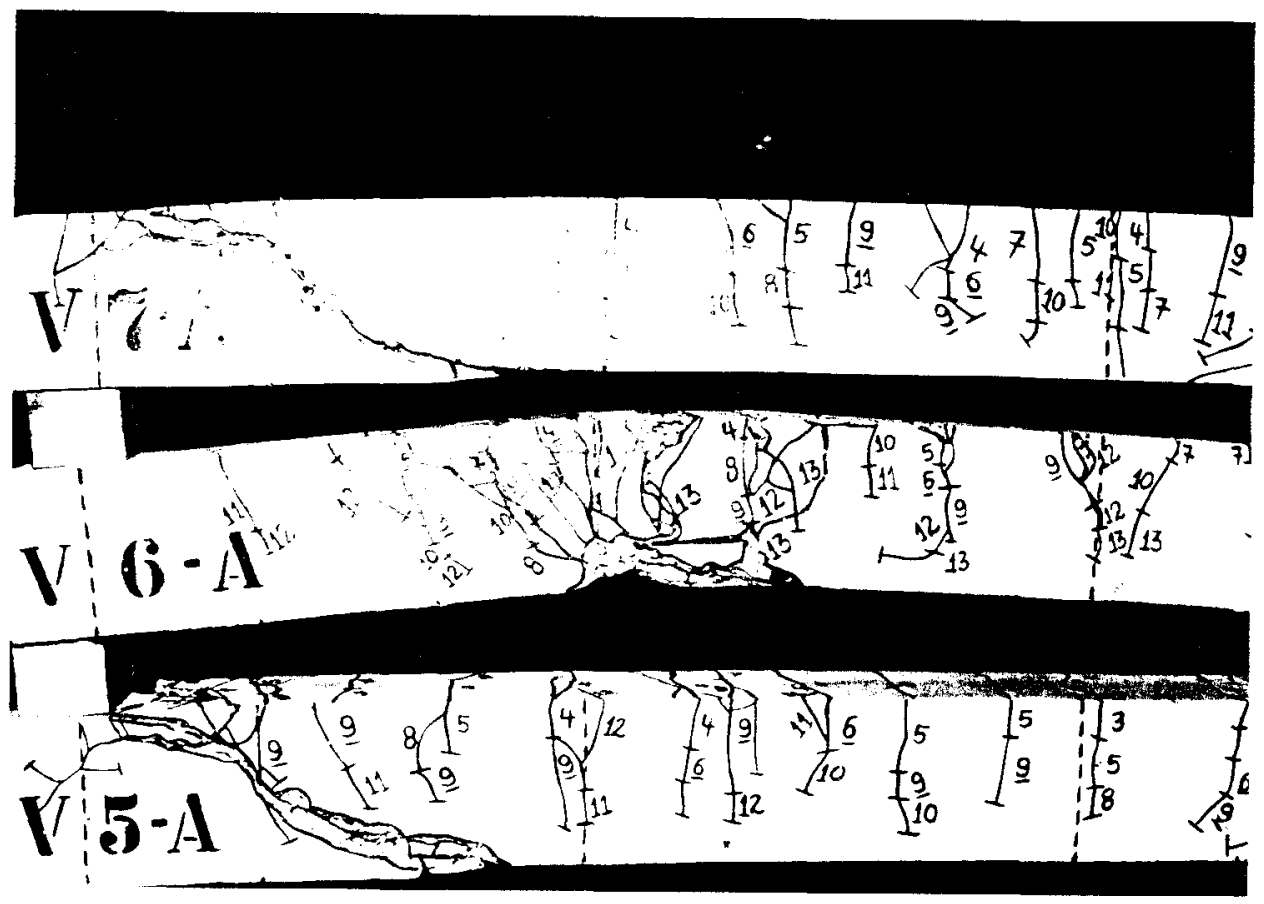

Foto 4.17 - Detalhe do lado da ruptura dos modelos P5A a P7A 


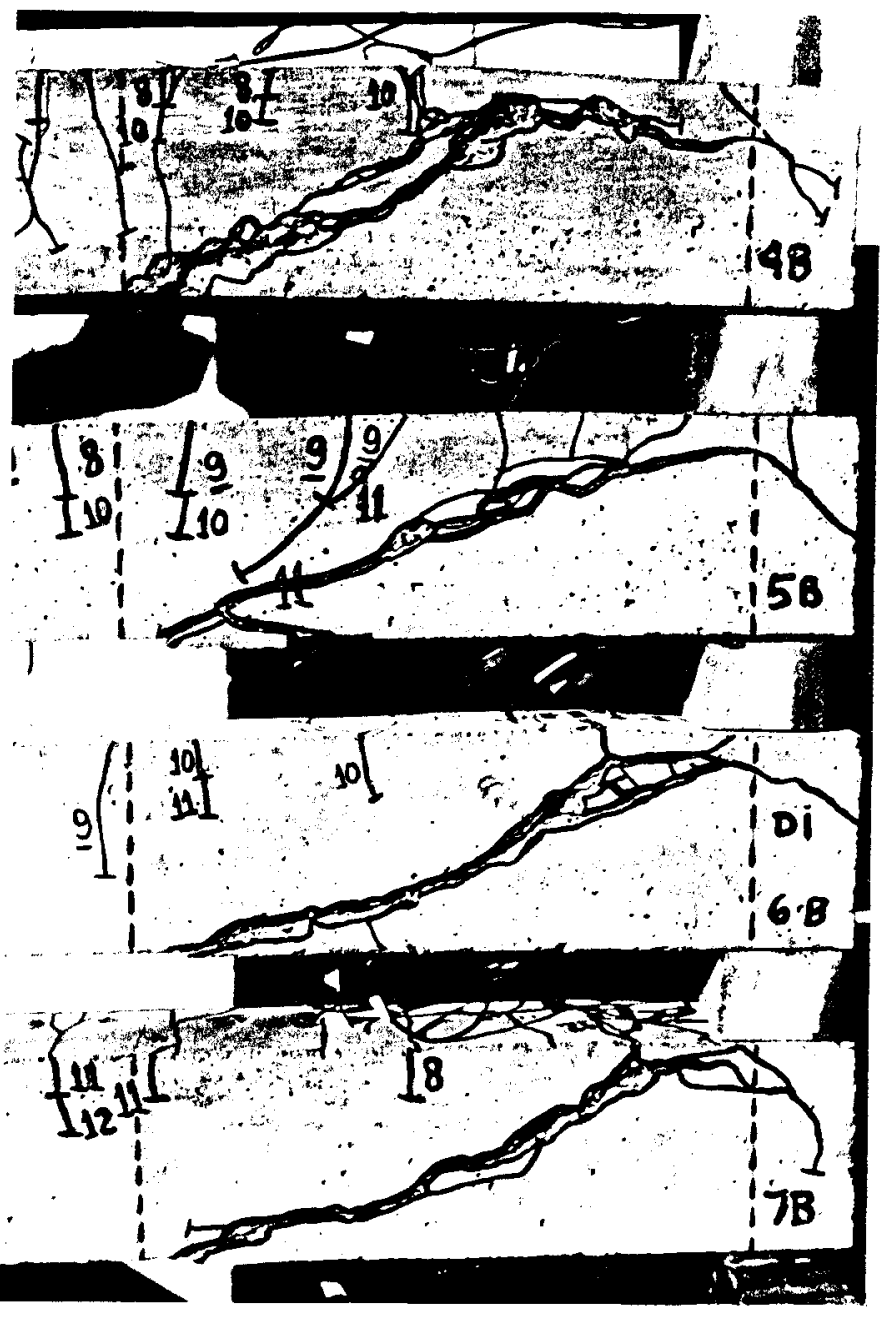

Foto 4.18 - Detalhe do lado da ruptura dos modelos P5B a P7B

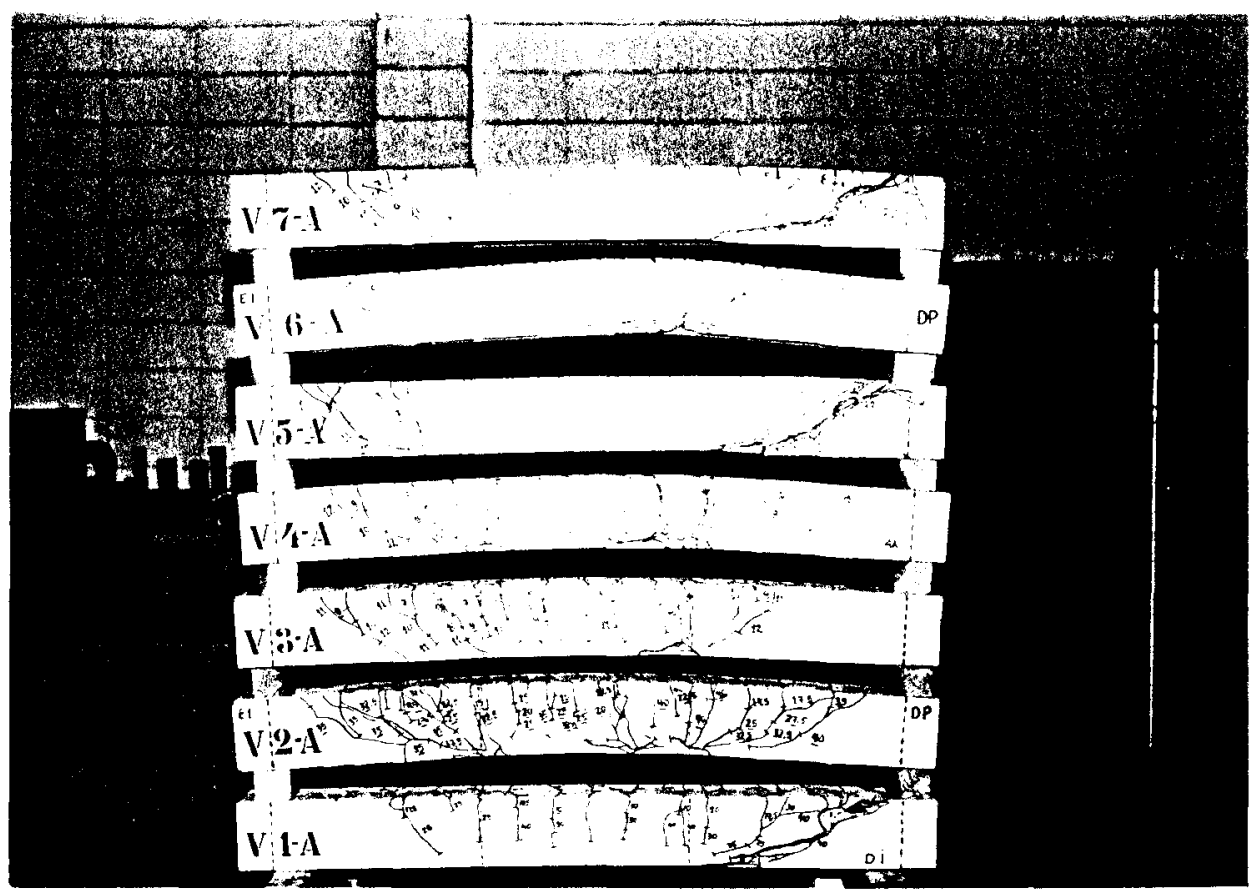

Foto 4.19 - Panorama dos modelos da série A após o ensaio 


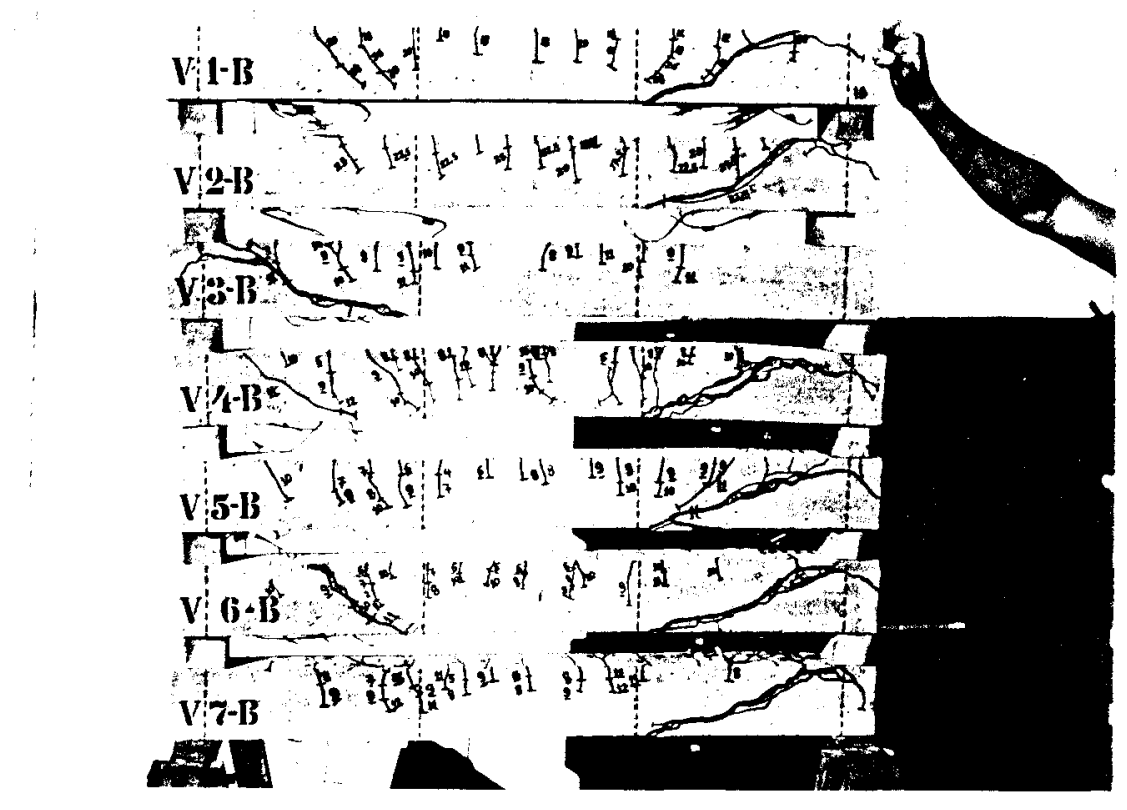

Foto 4.20 - Panorama dos modelos da série B após o ensaio

\section{6 - ANÁLISE DOS RESULTADOS}

Neste item se compara o desempenho dos modelos analisando-se os mesmos fenômenos discutidos durante a apresentação individual dos resultados. Além do comportamento de cada modelo em relação ao conjunto e em relação ao modelo de referência (P1). as vigas foram agrupadas sob diversas combinações para facilitar a análise da influência das fỉbras em alguns parâmetros. tais como a tensão nos estribos e a evolução das flechas. O mesmo procedimento foi utilizado para o comportamento da tensão na armadura longitudinal e no concreto. mas como as diferenças e as conclusões foram menos relevantes, elas não são apresentadas.

A divisão adotada segue os seguintes critérios: modelos sem fibra e com fibra de polipropileno (P1 e P2), sem fibra e com fibra de aço curta (P1. P3 e P4), sem fibra e com fibra de aço longa (P1. P5. P6 e P7), modelos com volumes iguais de diferentes fibras de aço (P3 e P5, P4 e P6) e, finalmente, modelos com fibra de polipropileno e $1 \%$ de fibra de aço curta (P2 e P3). que foram utilizados nos ensaios das vigas de seção transversal duplo- $\mathrm{T}$.

Pretende-se. desta forma. estabelecer a intluencia do tipo e do volume de fibras no comportamento resistente dos compósitos nas situaçôes estudadas e selecioná-los para a execução dos modelos nos ensaios das vigas de seção transversal duplo- $T$. 


\subsection{1 - PROPRIEDADES DO CONCRETO}

Em relação às propriedades do concreto fresco, a adição das fibras piorou a trabalhabilidade principalmente no caso da fibra de polipropileno. Além da menor afinidade com a matriz, a fibra utilizada tem relação de aspecto muito elevada. A fibra de aço, inclusive a mais longa, alterou pouco a trabalhabilidade. Em qualquer caso, o maior volume de fibras intensifica o problema. Outras propriedades da mistura fresca não foram analisadas.

Em relação às propriedades do concreto endurecido, a Tabela 4.5 resume os resultados de resistência à compressão axial, resistência à tração (experimental e teórica, calculada conforme a expressão da NBR-6118) e módulo de deformação longitudinal tangente para as sete misturas diferentes. Na última coluna, o valor do módulo relativo foi calculado dividindo-se o valor do módulo de deformação longitudinal pelo valor obtido para o modelo de referência.

Tabela 4.5 - Propriedades do concreto endurecido

\begin{tabular}{|c|c|c|c|c|c|c|}
\hline mistura & $f_{\mathrm{c}}(\mathrm{MPa})$ & $\mathrm{f}_{\mathrm{t}}(\mathrm{MPa})$ & $\mathrm{f}_{\mathrm{t} . \mathrm{teo}}(\mathrm{MPa})$ & $\mathrm{E}(\mathrm{MPa})$ & $\mathrm{E} / \mathrm{f}_{\mathrm{c}}^{0.5}$ & $E_{\mathrm{rcl}}$ \\
\hline 1 & 43,8 & 3,4 & 3,3 & 29000 & 4381 & 1,0 \\
\hline 2 & 48 & 3,45 & 3,6 & 34740 & 5014 & 1,2 \\
\hline 3 & 54,8 & 3,3 & 4,0 & 38720 & 5230 & 1,33 \\
\hline 4 & 50 & 4,2 & 3,7 & 41490 & 5868 & 1,43 \\
\hline 5 & 49,3 & 3,85 & 3,7 & 33740 & 4805 & 1,16 \\
\hline 6 & 53,7 & 4,3 & 3,9 & 36270 & 4949 & 1,25 \\
\hline 7 & 53,5 & 3,6 & 3,9 & 37550 & 5134 & 1,30 \\
\hline
\end{tabular}

Observa-se a tendência de aumento da resistência à compressão no concreto com fibras. Em todos os casos o valor é superior ao do modelo de referência. Não se define um aumento maior para maiores volumes de fibras.

A resistência à tração aumentou sistematicamente somente para os compósitos com fibra de aço de $3.81 \mathrm{~cm}$. Para volumes de $0.5 \%, 1 \%$ e $2 \%$, o valor é $6 \%, 13 \%$ e $26 \%$ maior que o concreto sem fibras, respectivamente. A resistência à tração, portanto, aumentou proporcionalmente com o volume desta fibra. A mesma tendência se mantém quando se considera a variação da resistência à compressão, que indiretamente influencia a resistência à tração. Para a fibra de aço de $2,54 \mathrm{~cm}$, só houve aumento de resistência à tração para o volume de $2 \%$, pois para $1 \%$ a resistência diminuiu. 


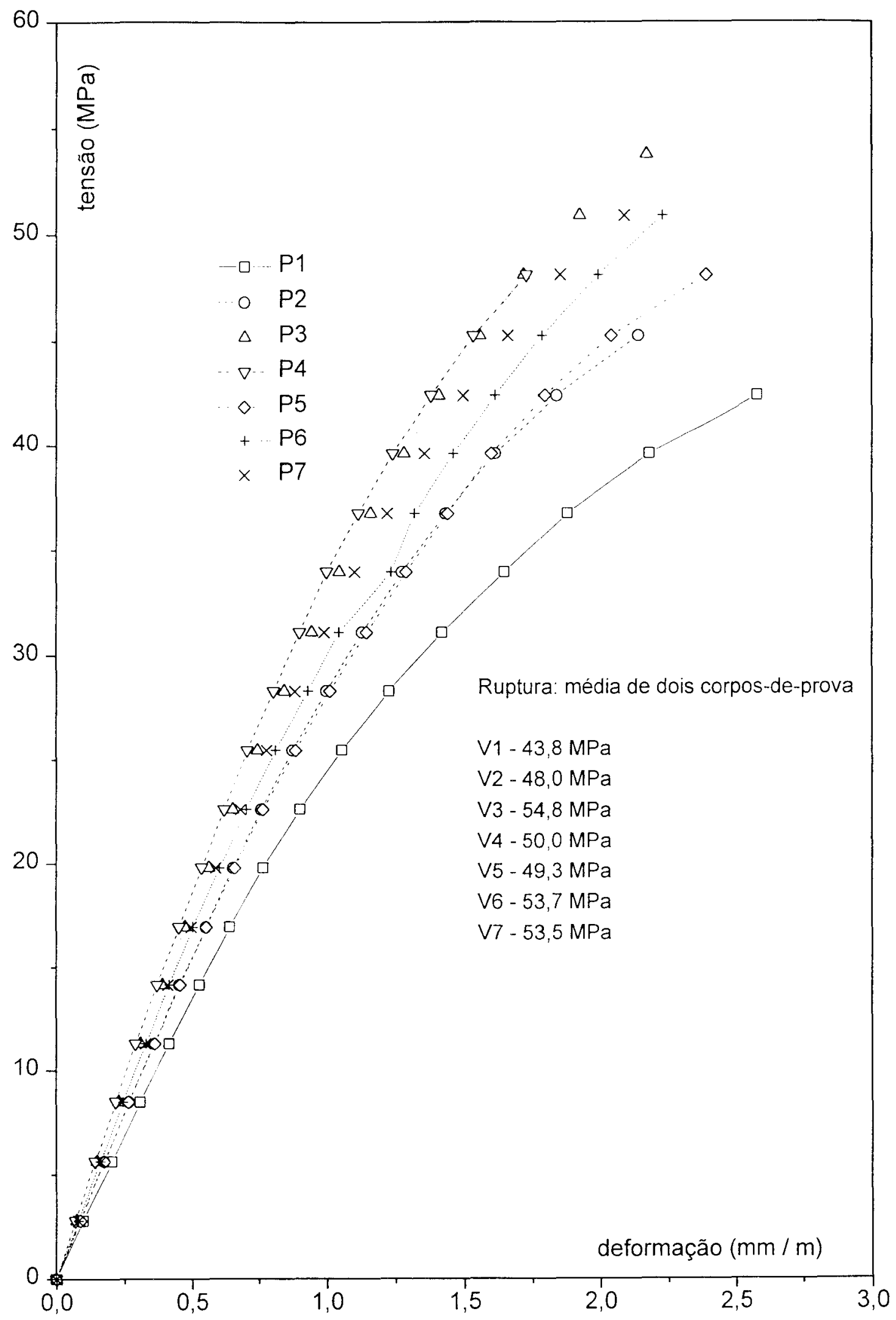

Figura 4.29 - Diagrama tensão-deformação dos corpos-de-prova de concreto 
A Figura 4.29 mostra os diagramas $\sigma-\varepsilon$ das misturas. O módulo de deformação longitudinal do concreto com fibras foi sempre maior. Os maiores aumentos foram obtidos com a fíbra de aço de $2,54 \mathrm{~cm}$, independentemente do valor da resistência à compressão, conforme mostra a penúltima coluna da tabela, onde o valor do módulo é dividido pela raiz quadrada da resistência à compressão do concreto correspondente.

\subsection{2 - FISSURAÇÃO - FLEXÃO}

As Fotos 4.21 e 4.22 mostram uma vista superior das fissuras de flexão nas faces tracionadas dos modelos das séries $A$ e $B$, respectivamente. $\mathrm{Na}$ série $\mathrm{A}, \mathrm{O}$ espaçamento é menor em todos os modelos com fibras, especialmente em P2A, P4A e P6A. Na série B o fato se repete, sendo que em alguns modelos com fibras a fissuração foi mais intensa que no modelo sem fibras da série $\mathrm{A}$.

Nas Fotos 4.19 e 4.20 pode-se observar indiretamente os mesmos resultados através da análise da profundidade das fissuras de flexão. Nos modelos da série $\mathrm{A}$ as fissuras são mais profundas que nos modelos da série B. O mesmo ocorre para os modelos com fibras em relação aos modelos de referência das duas séries. Na série $\mathrm{A}$, as fissuras quase alcançaram a face comprimida, exceto em P1A. Na série B, as fissuras da viga $\mathrm{P} 4 \mathrm{~B}$ são similares às fissuras do modelo $\mathrm{P} 1 \mathrm{~A}$.

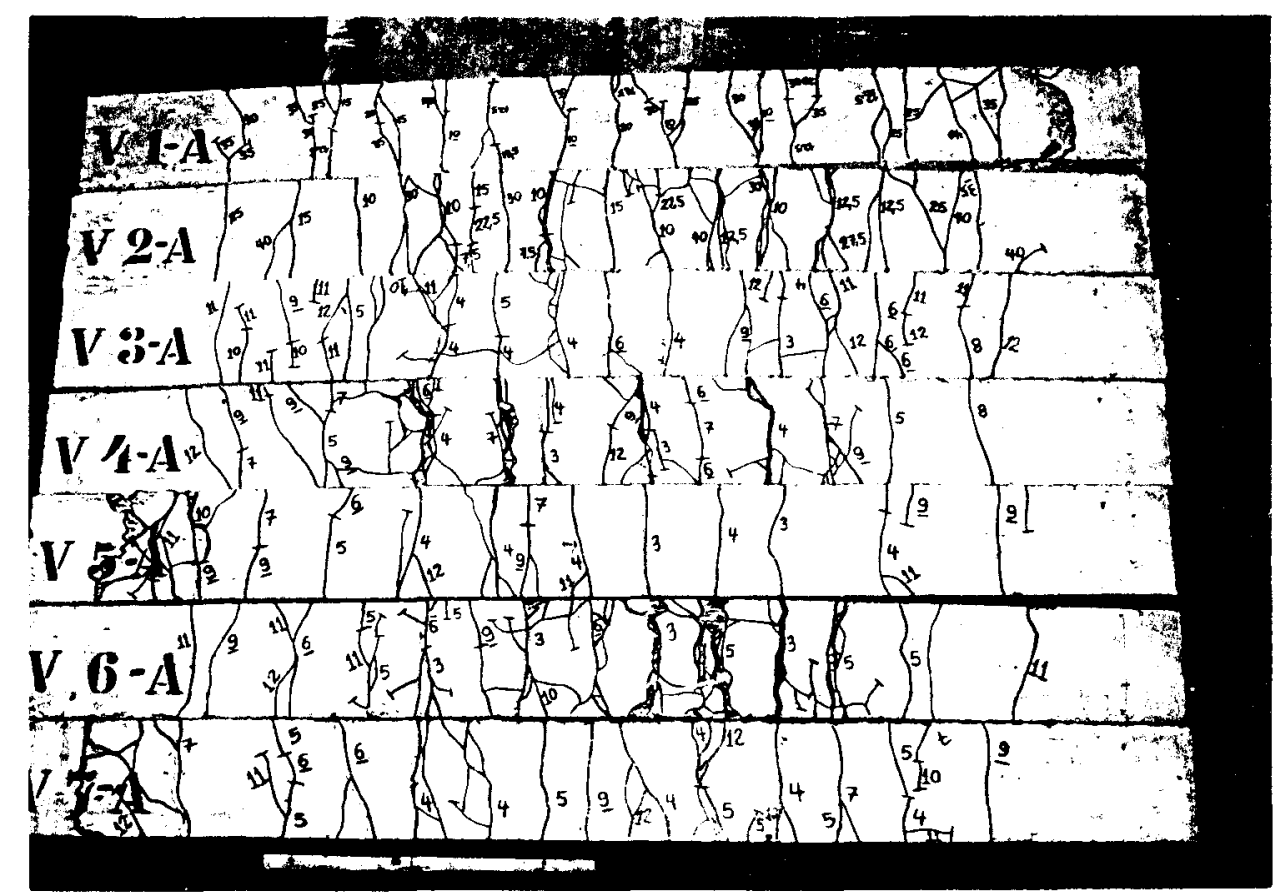

Foto 4.21 - Vista superior da região tracionada dos modelos da série A 


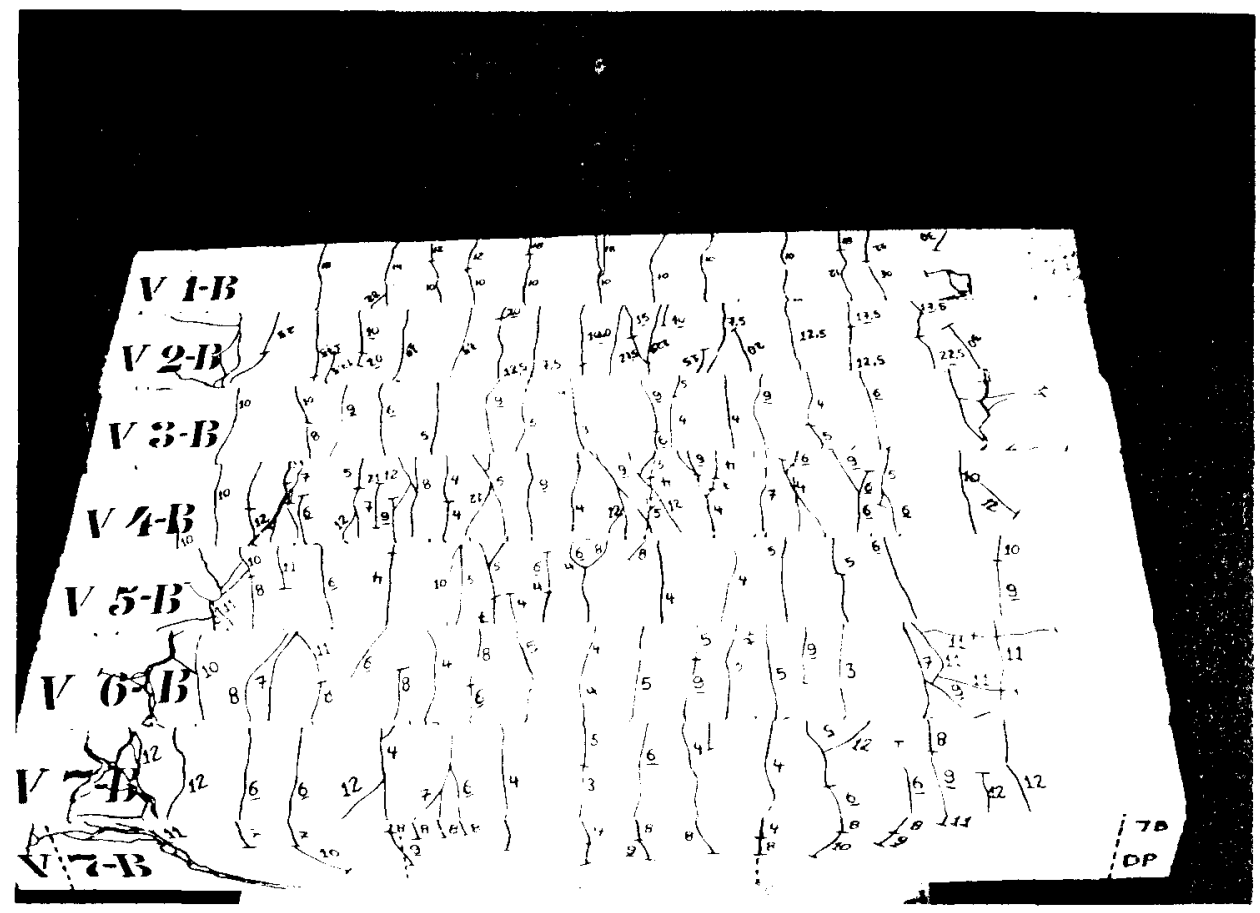

Foto 4.22 - Vista superior da região tracionada dos modelos da série B

O aparecimento da primeira fissura de flexão se relaciona basicamente com a resistência à tração do concreto. que pode ser influenciada pelas fỉbras. Nem sempre. porém, se consegue avaliar corretamente este instante, já que as primeiras físsuras não são visiveis. As fibras também podem retardar o aparecimento da primeira fissura visível, limitando a abertura das microfissuras durante mais tempo e alterando a relação entre os valores da deformação no concreto e da abertura das fissuras (deformabilidade da matriz). A deformação máxima na armadura longitudinal antes do aparecimento da primeira fissura e a deformação para uma determinada abertura de fissura são bons indicativos desta propriedade.

A Tabela 4.6 contém os valores da carga de fissuração por flexão, incluindo os valores teóricos, calculados em função da resistencia à tração, e os experimentais. com o respectivo valor da abertura da fissura no final do incremento de carga. Os valores experimentais foram estimados visualmente e pela diminuição da rigidez no gráfico dos deslocamentos verticais. Estes resultados permitem avaliar a resistência à fissuração e a abertura com que surgem as primeiras fissuras visíveis.

Além disso, aparecem também na tabela o valor da carga a que corresponde a deformação máxima de $0.15 \%$ na armadura longitudinal e os valores da carga e da deformação máxima na armadura no instante em que a abertura da fissura mais crítica atingiu $0.16 \mathrm{~mm}$. Combinando-se estes dados, pode-se avaliar o controle da abertura 
das fissuras e a capacidade de deformação do concreto, ou mesmo detectar leituras de fissuras inconsistentes.

Tabela 4.6 - Parâmetros relativos à carga de fissuração por flexão

\begin{tabular}{|c|c|c|c|c|c|c|c|}
\hline \multirow{2}{*}{ modelo } & \multirow{2}{*}{$\begin{array}{l}F_{\text {r.teo }} \\
(\mathrm{kN})\end{array}$} & \multicolumn{2}{|c|}{$F_{\text {r.exp }}(k N)$} & \multirow{2}{*}{$\begin{array}{c}W \\
(m m)\end{array}$} & \multirow{2}{*}{$\begin{array}{c}\mathrm{F}_{\varepsilon}=0.15 \% \\
(\mathrm{kN})\end{array}$} & \multicolumn{2}{|c|}{$w=0.16 \mathrm{~mm}$} \\
\hline & & visual & gráfico & & & $\mathrm{F}(\mathrm{kN})$ & $\varepsilon_{\mathrm{Sl}}(\%)$ \\
\hline P1A & 5,7 & 7,5 & 5,0 & 0,06 & 25 & 25 & 0,15 \\
\hline$\overline{P 1 B}$ & 5.7 & 8,0 & $\overline{6,0}$ & 0,06 & 25 & 24 & 0,14 \\
\hline $\mathrm{P} 2 \mathrm{~A}$ & 5.8 & $6,5^{*}$ & 5,0 & 0,05 & 30 & 22.5 & 0,10 \\
\hline $\mathrm{P} 2 \mathrm{~B}$ & 5.8 & $6,5^{*}$ & 5,0 & 0,05 & 27,5 & 30 & 0,18 \\
\hline $\mathrm{P} 3 \mathrm{~A}$ & 5.6 & 7.5 & 5,0 & 0.05 & 35 & 35 & 0.15 \\
\hline P3B & 5.6 & 7,5 & 5,0 & 0,04 & 31 & 35 & 0,18 \\
\hline $\mathrm{P} 4 \mathrm{~A}$ & 7.0 & $7,5^{*}$ & 5.0 & 0,03 & 32.5 & 30 & 0,13 \\
\hline $\mathrm{P} 4 \mathrm{~B}$ & 7.0 & $8,0^{*}$ & 5,0 & 0,05 & 34 & 35 & 0,16 \\
\hline$\overline{\mathrm{P} 5 \mathrm{~A}}$ & 6.3 & 7,5 & $\overline{5,0}$ & 0,05 & 32,5 & 30 & 0,13 \\
\hline P5B & 6.3 & $9,0^{*}$ & 5,0 & 0,04 & 31 & 35 & 0,17 \\
\hline P6A & 7.2 & $7,5^{*}$ & 7.5 & 0,04 & 36 & 30 & 0,11 \\
\hline P6B & 7.2 & 7,5 & 5,0 & 0.03 & 29 & 25 & 0,12 \\
\hline P7A & 6.0 & $9,7^{*}$ & 5,0 & 0,05 & 31 & 25 & 0.10 \\
\hline P7B & 6.0 & 7,5 & 7,5 & 0.03 & 33 & 30 & 0,13 \\
\hline
\end{tabular}

Não se define influência das fibras no instante do aparecimento da primeira fissura, apenas se observa a maior abertura da primeira fissura nos modelos sem fibras. Todos os modelos apresentaram resultados consistentes com os valores esperados.

$\mathrm{Na}$ evolução da fissuração. observa-se que a carga em que a abertura das fissuras atingiu $0.16 \mathrm{~mm}$ foi sempre maior nos modelos com fibras, exceto em P2A. O mesmo fato pode ser observado indiretamente pela análise da deformação máxima da armadura longitudinal neste instante. Ela foi menor em todos os modelos com fibras. ou seja, a deformação de referência de $0,15 \%$ ocorreu para cargas maiores. Portanto, conclui-se que as fibras foram eficientes no controle da abertura das fissuras.

A deformação na armadura longitudinal quando a abertura das fissuras mais críticas de flexão atingiu $0,16 \mathrm{~mm}$ ilustra a capacidade de deformação do concreto. Valores maiores seriam obtidos no caso de concretos mais deformáveis. No entanto. dado o caráter grosseiro da leitura de fissuras. sujeita a crros de avaliação, esta comparação não é totalmente confiável. Resultados discrepantes serviriam para checar a consistencia na leitura da abertura das fissuras durante o ensaio. 
Este pode ser o caso do modelo P2A, único dos modelos com fibras em que a abertura de $0,16 \mathrm{~mm}$ ocorreu antes do que no modelo P1A. Nesta viga, a deformação máxima na armadura ainda era de $0,1 \%$ neste instante. As flechas foram menores que em P1A e a diferença do módulo de deformação longitudinal parece ser insuficiente para explicar a diferença de rigidez, que se manifesta principalmente após a fissuração. Possivelmente, ela se deve ao controle mais eficiente da fissuração obtido neste modelo. Em P6B e P7A, a abertura das fissuras atingiu $0,16 \mathrm{~mm} \operatorname{com} 25 \mathrm{kN}$, iguais a P1A. Nestes casos, a deformação máxima na armadura também era menor, $0,12 \%$ e $0,10 \%$, respectivamente. É possivel que haja erro na leitura destas fissuras.

Para finalizar esta análise, apresenta-se na Tabela 4.7 os valores máximos de abertura das fissuras observadas para as cargas de $10 \mathrm{kN}, 20 \mathrm{kN}$ e $25 \mathrm{kN}$. enquanto elas ainda podiam ser acompanhadas pela lupa graduada. Também se apresentam os valores das cargas correspondentes a abertura máxima de fissuras igual a $0.10 \mathrm{~mm}$ e $0.15 \mathrm{~mm}$ e a deformação máxima na armadura longitudinal nestes instantes. A partir desta tabela foram traçados os gráficos das Figuras 4.30 e 4.31 , que permitem acompanhar a evolução das físsuras dos modelos das séries A e B, respectivamente.

Tabela 4.7- Parâmetros relativos à físsuração por flexão

\begin{tabular}{|c|c|c|c|c|c|c|c|}
\hline \multirow{2}{*}{ modelo } & \multicolumn{3}{|c|}{$\mathrm{W}(\mathrm{mm})$} & \multicolumn{2}{c|}{$\mathrm{w}=0,10 \mathrm{~mm}$} & \multicolumn{2}{c|}{$w=0,15 \mathrm{~mm}$} \\
\cline { 2 - 8 } & $\mathrm{F}=10 \mathrm{kN}$ & $\mathrm{F}=20 \mathrm{kN}$ & $\mathrm{F}=25 \mathrm{kN}$ & $\mathrm{F}(\mathrm{kN})$ & $\varepsilon_{\mathrm{s}, \mathrm{max}}$ & $\mathrm{F}(\mathrm{kN})$ & $\varepsilon_{\mathrm{s}, \mathrm{max}}$ \\
\hline P1A & 0,07 & 0,15 & $>0,16$ & 12 & 0,03 & 20 & 0,09 \\
\hline P1B & 0,07 & 0,15 & $>0,16$ & 13 & 0,05 & 20 & 0,11 \\
\hline P2A & 0,08 & 0,15 & 0,16 & 12.5 & 0,03 & 20 & 0,07 \\
\hline P2B & 0,06 & 0,11 & 0,14 & 17,5 & 0,07 & 27,5 & 0,15 \\
\hline P3A & 0,06 & 0,12 & 0,13 & 16 & 0,03 & 32 & 0,12 \\
\hline P3B & 0,05 & 0,10 & 0,13 & 20 & 0,07 & 30 & 0,14 \\
\hline P4A & 0,05 & 0,12 & 0,15 & 17,5 & 0,03 & 25 & 0,08 \\
\hline P4B & 0,05 & 0.12 & 0,14 & 18 & 0,07 & 30 & 0,14 \\
\hline P5A & 0,06 & 0,13 & 0,15 & 16 & 0,05 & 25 & 0,11 \\
\hline P5B & 0,04 & 0,10 & 0,12 & 20 & 0,08 & 30 & 0,14 \\
\hline P6A & 0.06 & 0,13 & 0,15 & 16 & 0,04 & 25 & 0,08 \\
\hline P6B & 0,05 & 0,13 & 0,16 & 16 & 0,03 & 24 & 0,12 \\
\hline P7A & 0,05 & 0,13 & 0,16 & 15 & 0,03 & 24 & 0,1 \\
\hline P7B & 0,05 & 0,10 & 0,14 & 20 & 0,07 & 30 & 0,13 \\
\hline
\end{tabular}

Nos modelos da série A. o melhor desempenho foi obtido pela viga P3A. A evolução das fissuras foi mais rápida nos modelos P1A e P2A. Na série B, a melhoria é mais significativa. e todos os modelos com fibras tiveram desempenho superior ao de 


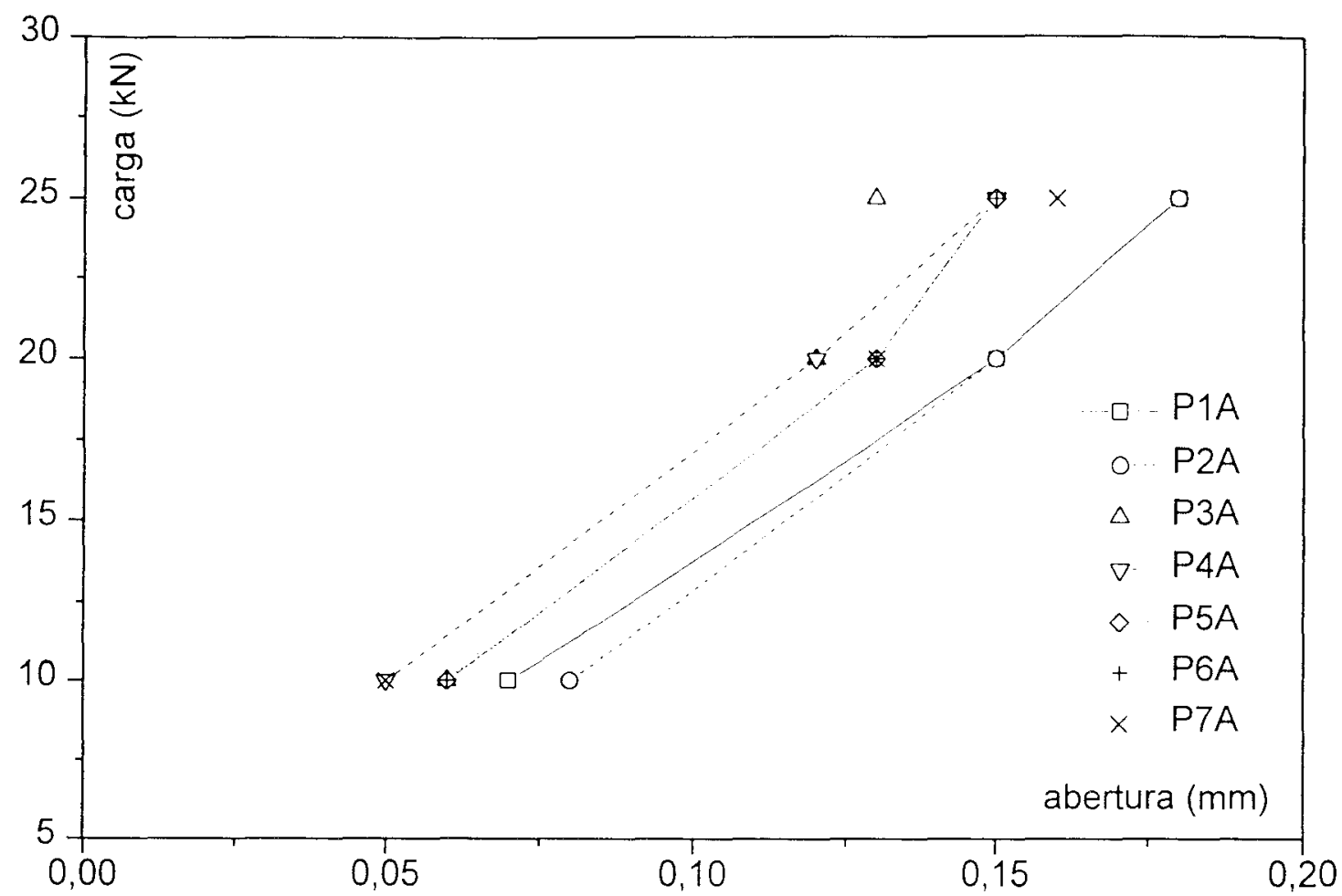

Figura 4.30 - Evolução das fissuras de flexão até $25 \mathrm{kN}$ - SÉRIE A

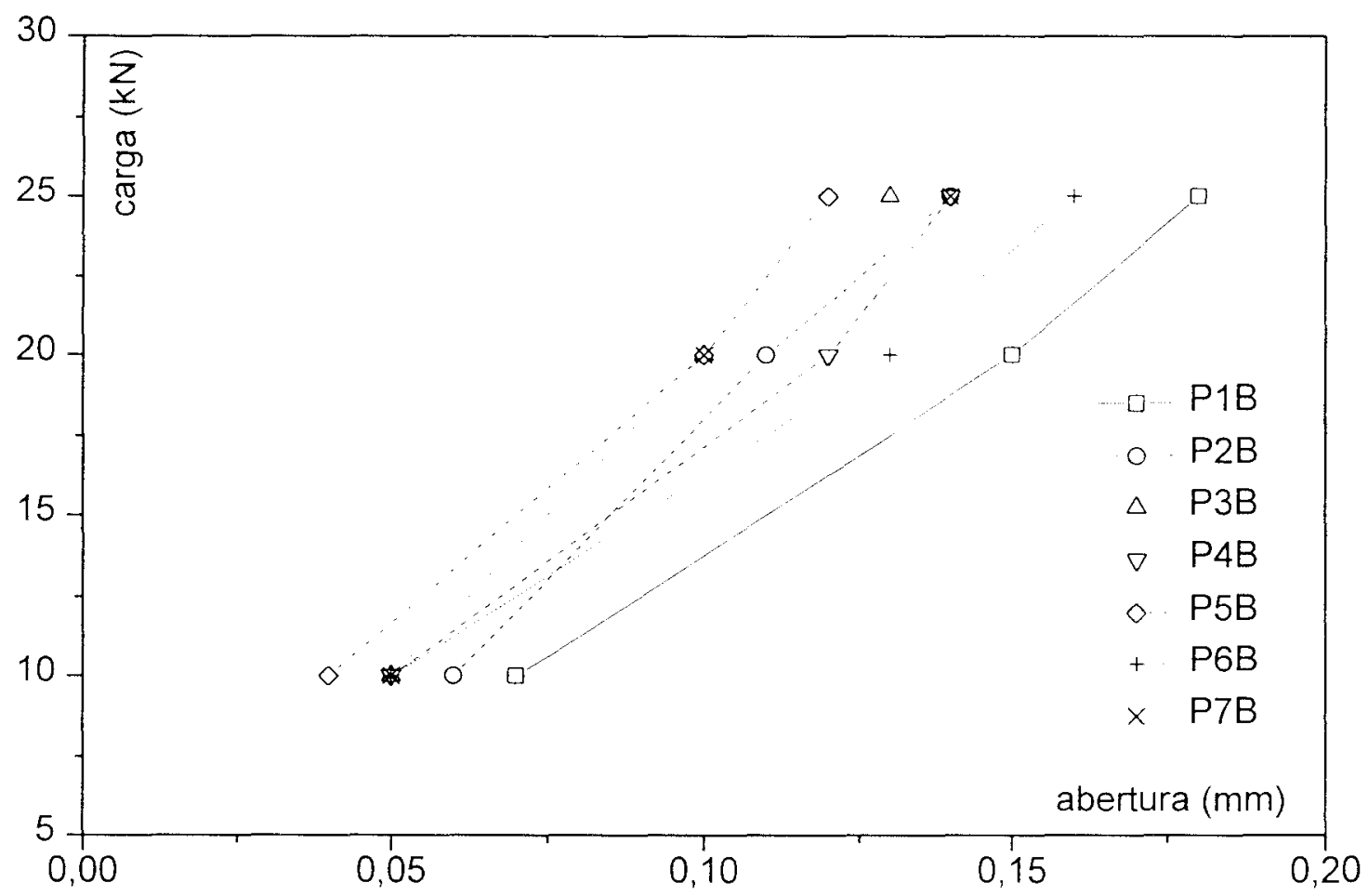

Figura 4.31 - Evolução das fissuras de flexão até $25 \mathrm{kN}$ - SÉRIE B 
referência. O resultado é praticamente uniforme para todos os modelos com fibras, exceto P6B. onde a vantagem das fibras foi mais discreta.

A comparação entre os modelos correspondentes das séries A e B mostra que, na maioria das peças sem estribos, as fissuras atingiram aberturas de $0,10 \mathrm{~mm}$ e 0,15 $\mathrm{mm}$ para cargas superiores às cargas dos modelos com estribos. Pode-se supor que a influência positiva das fibras, neste caso, tenha sido maior nos modelos da série B. já que a diferença praticamente não foi observada nos modelos de referência.

Um resultado surpreendente foi o fraco desempenho dos modelos P6, o pior entre os modelos com fibras. mas as deformações máximas na armadura longitudinal, apresentadas na Tabela 4.6, eram reduzidas neste instante.

\subsection{3 - FISSURAÇ̃̃O - CISALHAMENTO}

As fissuras de cisalhamento foram divididas em dois grupos. As que surgem como continuação de fissuras de flexão, em regiões onde o momento fletor é elevado (tipo 1), e as que surgem diretamente na alma (tipo 2). A Tabela 4.8 mostra os valores da carga em que estas fissuras surgiram para todos os modelos.

Devido à boa resistência à físsuração diagonal proporcionada pela alma espessa. as primeiras fissuras inclinadas surgiram como prolongamento de fissuras de flexão.

Tabela 4.8 - Parâmetros relativos à físsuração por cisalhamento

\begin{tabular}{|c|c|c|c|c|}
\hline \multirow{2}{*}{ modelo } & \multicolumn{2}{|c|}{ tipo 1 } & \multicolumn{2}{c|}{ tipo 2 } \\
\cline { 2 - 5 } & $\mathrm{F}_{\mathrm{r} 1}(\mathrm{kN})$ & $\mathrm{W}(\mathrm{mm})$ & $\mathrm{F}_{\mathrm{r} 2}(\mathrm{kN})$ & $\mathrm{W}(\mathrm{mm})$ \\
\hline P1A & 17,5 & - & 35 & - \\
\hline P1B & 20 & 0,08 & $>30$ & \\
\hline P2A & 20 & 0,04 & 35 & - \\
\hline P2B & 25 & - & 32,5 & 0,15 \\
\hline P3A & 25 & 0,04 & 35 & - \\
\hline P3B & 25 & 0,04 & 35 & - \\
\hline P4A & 20 & 0,05 & 35 & - \\
\hline P4B & 25 & 0,06 & 35 & - \\
\hline P5A & 25 & 0,06 & 30 & 0.10 \\
\hline P5B & 20 & 0,04 & 35 & - \\
\hline P6A & 25 & 0,05 & 35 & 0.04 \\
\hline P6B & 20 & 0,05 & 30 & - \\
\hline P7A & 17.5 & 0,04 & 30 & 0.08 \\
\hline P7B & 25 & 0,06 & 35 & - \\
\hline
\end{tabular}


Há um aumento modesto na carga em que surgem as fissuras de cisalhamento do tipo 1 nos modelos com fibras. Nas fissuras diagonais, tipo 2, o fato não se repete.

Observa-se que nas peças da série $B$, a resistência adicional após o aparecimento da fissura diagonal diretamente na alma é muito pequena para a maioria das vigas. A associação da ruptura com o instante da fissuração diagonal estaria boa em termos práticos, embora conceitualmente os fenômenos sejam distintos. Nos dois modelos com $2 \%$ de fibra de aço, a resistência adicional foi maior. Nesta situação, as fibras foram eficientes como armadura de cisalhamento, cumprindo papel similar ao dos estribos. Nos dois casos houve a formação de fissuras diagonais dos dois lados da viga, conforme mostram as Fotos 4.14, 4.18 e 4.20.

Nos modelos da série $A$, a eficiência dos estribos e das fibras também pode ser medida através da análise da resistência adicional após a fissuração diagonal. A ruína por cisalhamento foi evitada em quatro modelos com fibras. Nas duas em que ela se concretizou. a fissuração diagonal foi mais intensa que no modelo de referência. No modelo com fibra de polipropileno. que não rompeu por cisalhamento. a fissuração foi a mais intensa de todo o conjunto. com a formação de fissuras similares àquelas que levaram várias vigas à ruína, nos dois lados da peça.

\subsection{4 - DESLOCAMENTOS TRANSVERSAIS}

A evolução dos deslocamentos verticais é um bom indicativo da rigidez da peça na etapa pós-fissuração, e portanto, do controle da abertura de fissuras. pois a inércia é diretamente afetada pela fissuração. Outro parâmetro de interesse a ser observado nos gráficos carga-flecha é a forma do diagrama, que possibilita a avaliação do possível escoamento da armadura longitudinal e da forma da ruptura.

Apresenta-se na Tabela 4.9 os valores da flecha e as cargas correspondentes aos deslocamentos de $3 \mathrm{~mm}, 6 \mathrm{~mm}$ e $9 \mathrm{~mm}$, que são valores de referência para projeto.

Nas Figuras 4.32 e 4.33 é apresentada a evolução das flechas dos modelos das séries A e B, respectivamente. Para auxiliar a análise comparativa, as Figuras 4.34 e 4.35 mostram os diagramas carga-flecha para as peças da série A e série B em que as flechas são divididas pela raiz quadrada da resistência à compressão do concreto, para tentar neutralizar a influência do módulo de deformação longitudinal na rigidez.

Na Figura 4.36 apresentam-se os gráficos de cada par de vigas das sete misturas, que permitem uma comparação dos resultados entre os modelos das séries A e B. ou seja. a análise da influência dos estribos nos deslocamentos verticais. 
Finalmente, nas Figuras 4.37 e 4.38 , os resultados das vigas de cada série são agrupados segundo a divisão comentada anteriormente, para ressaltar a influência das fibras. Nestas figuras, três gráficos correspondem aos resultados comparativos entre as peças com o mesmo tipo de fibra e o modelo de referência (P1 e P2 - P1, P3 e P4 - P1, P5. P6 e P7), dois aos resultados das peças que possuem a mesma quantidade de fibras de aço diferentes (P3 e P5 - P4 e P6) e finalmente, um gráfico comparativo entre os modelos com fibra de polipropileno e com $1 \%$ de fibra de aço curta (P2 e P3), usados nos ensaios das vigas de seção duplo-T.

Tabela 4.9 - Parâmetros relativos aos deslocamentos verticais

\begin{tabular}{|c|c|c|c|c|}
\hline modelo & $\Delta_{\text {max }}(\mathrm{mm})$ & $\mathrm{F}_{3 \mathrm{~mm}}(\mathrm{kN})$ & $\mathrm{F}_{6 \mathrm{~mm}}(\mathrm{kN})$ & $\mathrm{F}_{9 \mathrm{~mm}}(\mathrm{kN})$ \\
\hline P1A & 13,5 & 16 & 30 & 36 \\
\hline P1B & 6,8 & 19 & 29 & - \\
\hline P2A & 30 & 22 & 37 & 40 \\
\hline P2B & 6 & 19 & 32,5 & - \\
\hline P3A & 23 & 23 & 38 & 45 \\
\hline P3B & 6,2 & 23 & 39 & - \\
\hline P4A & 29 & 22 & 36 & 40 \\
\hline P4B & 12,1 & 23 & 39 & 43 \\
\hline P5A & 13,5 & 22 & 40 & 41 \\
\hline P5B & 6,8 & 23 & 36 & - \\
\hline P6A & 24,5 & 24 & 40 & 43 \\
\hline P6B & 7,2 & 25 & 38 & - \\
\hline P7A & 17 & 24 & 40 & 42 \\
\hline P7B & 4,8 & 25 & - & - \\
\hline
\end{tabular}

Como se observa nos resultados da tabela, deslocamentos excessivos ocorrem para cargas bem menores que a carga de ruptura, limitando a utilização das vigas.

Todas as peças com fibras apresentaram rigidez maior que o modelo de referência. especialmente após a fissuração. Exceto para o modelo P2B, onde essa diferença se acentua somente a partir de $20 \mathrm{kN}$, em todos os outros ela é visível após o aparecimento da primeira fissura. Esta observação confirma a conclusão anterior sobre o controle mais eficiente das fissuras nos modelos com fibras. Os melhores desempenhos foram obtidos pelos modelos com fibra de aço longa, P4, P5 e P6. e pelos modelos P3. das séries A e B. 


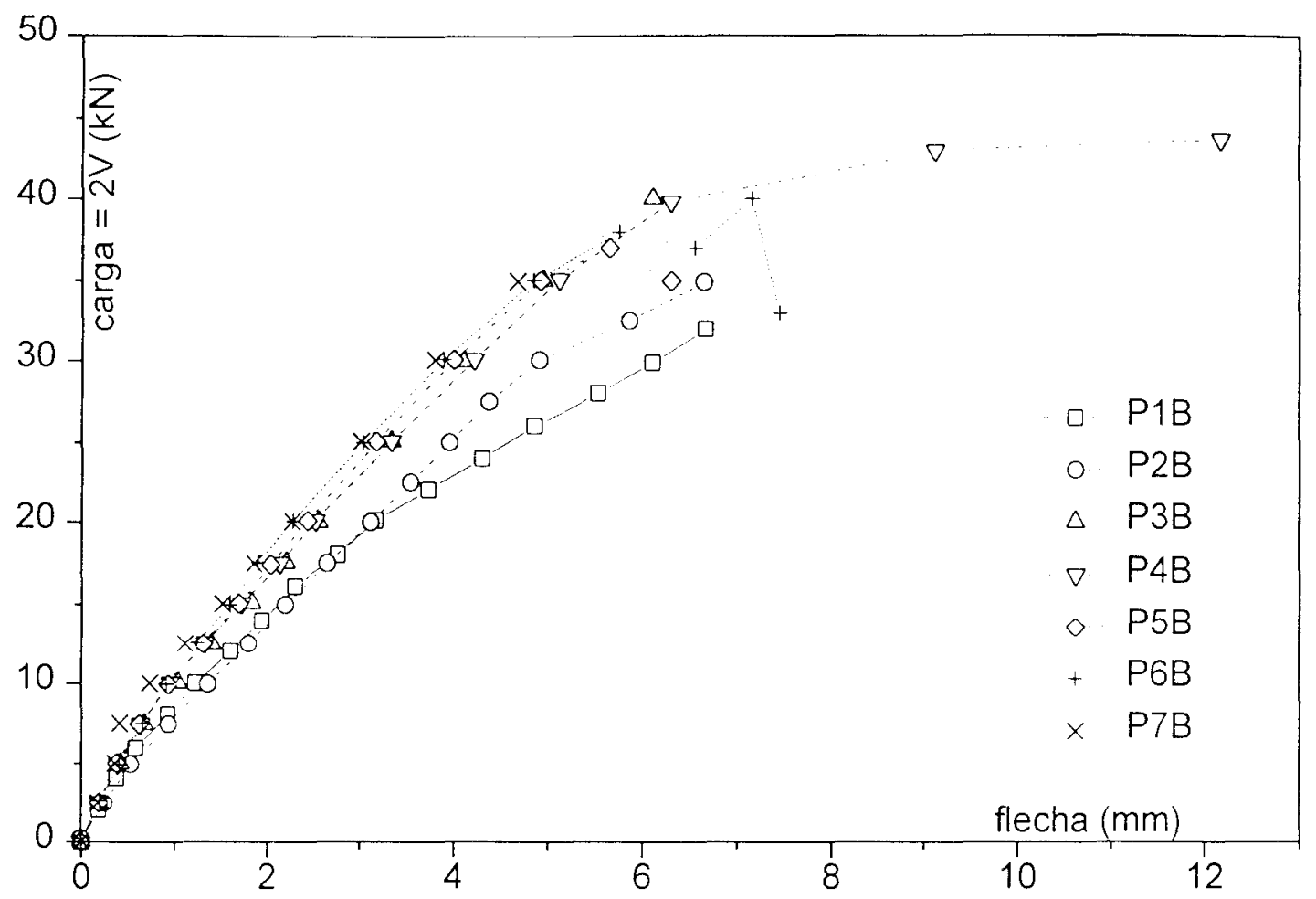

Figura 4.32 - Diagrama carga-flecha dos modelos da série B

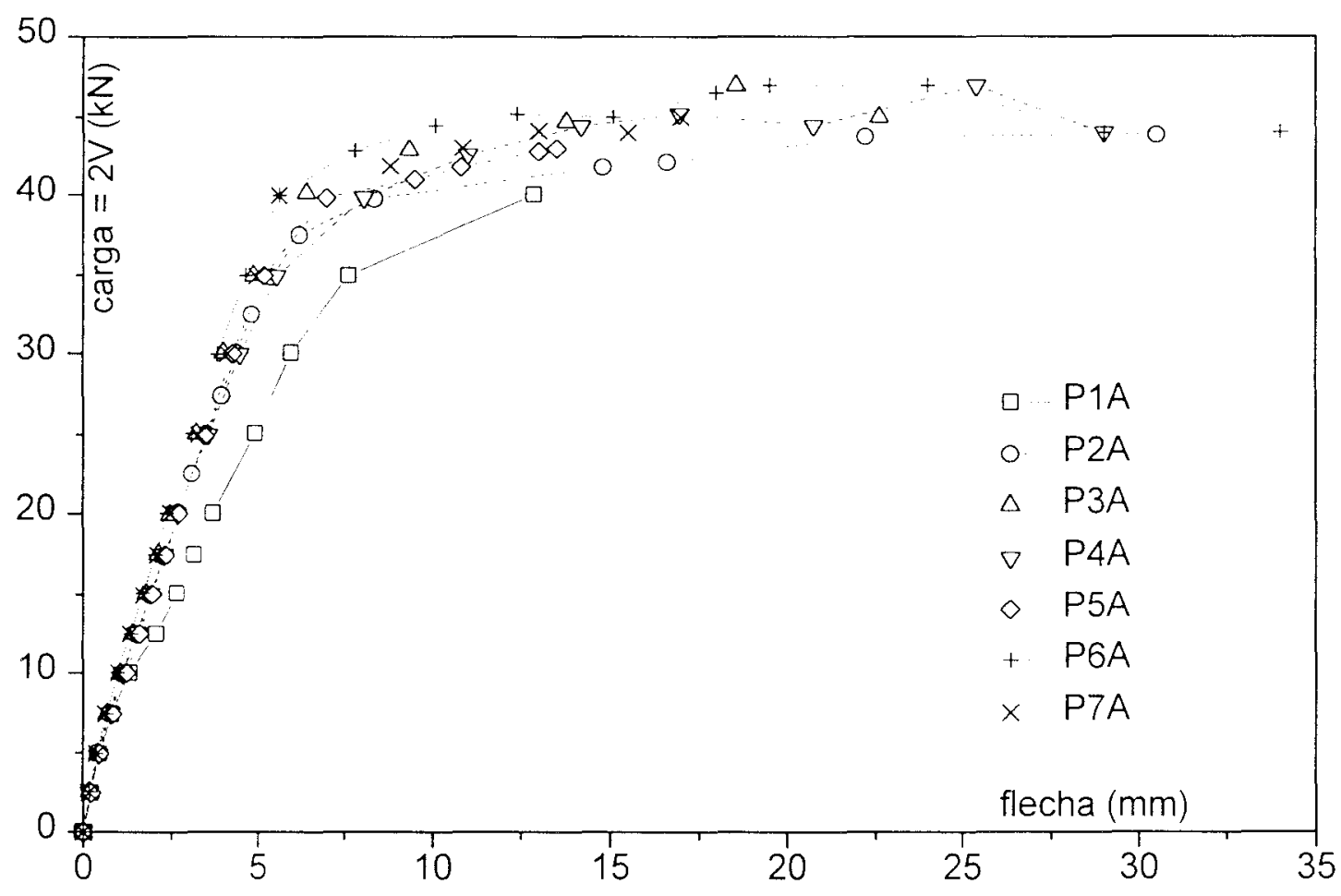

Figura 4.33 - Diagrama carga-flecha dos modelos da série A 


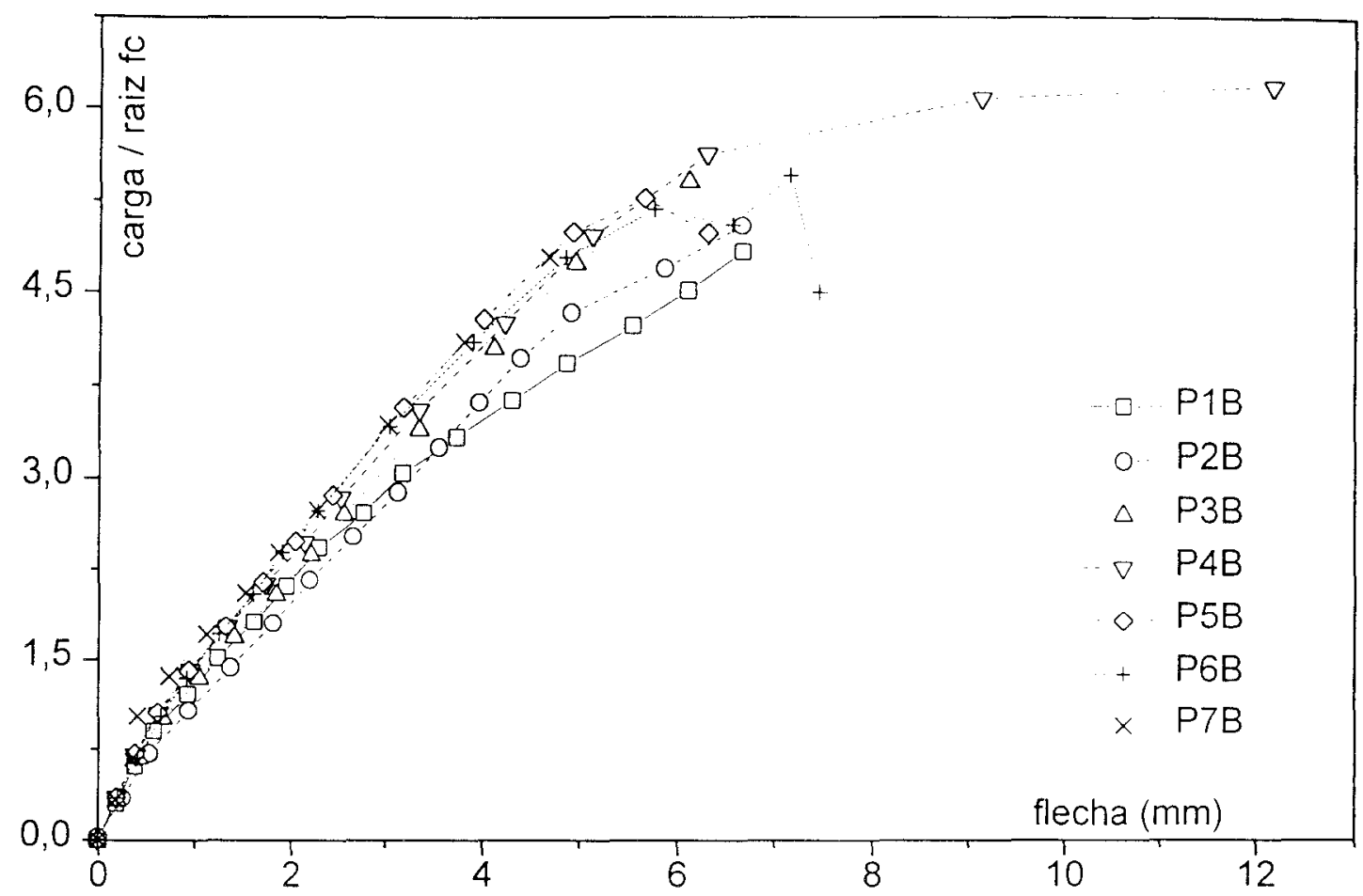

Figura 4.34 - Diagrama carga-flecha ponderado - SÉRIE B

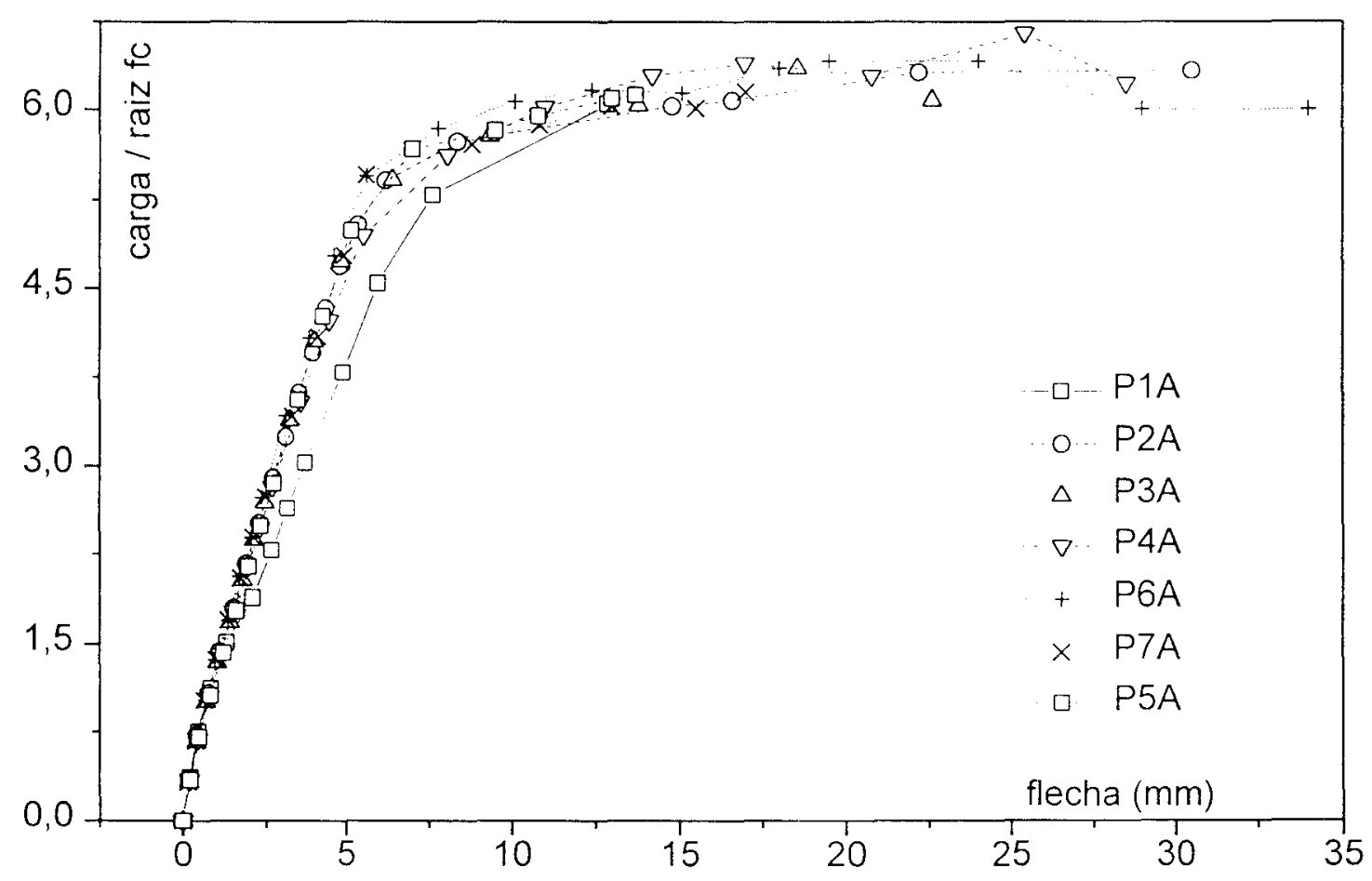

Figura 4.35 - Diagrama carga-flechà ponderado - SÉRIE A 

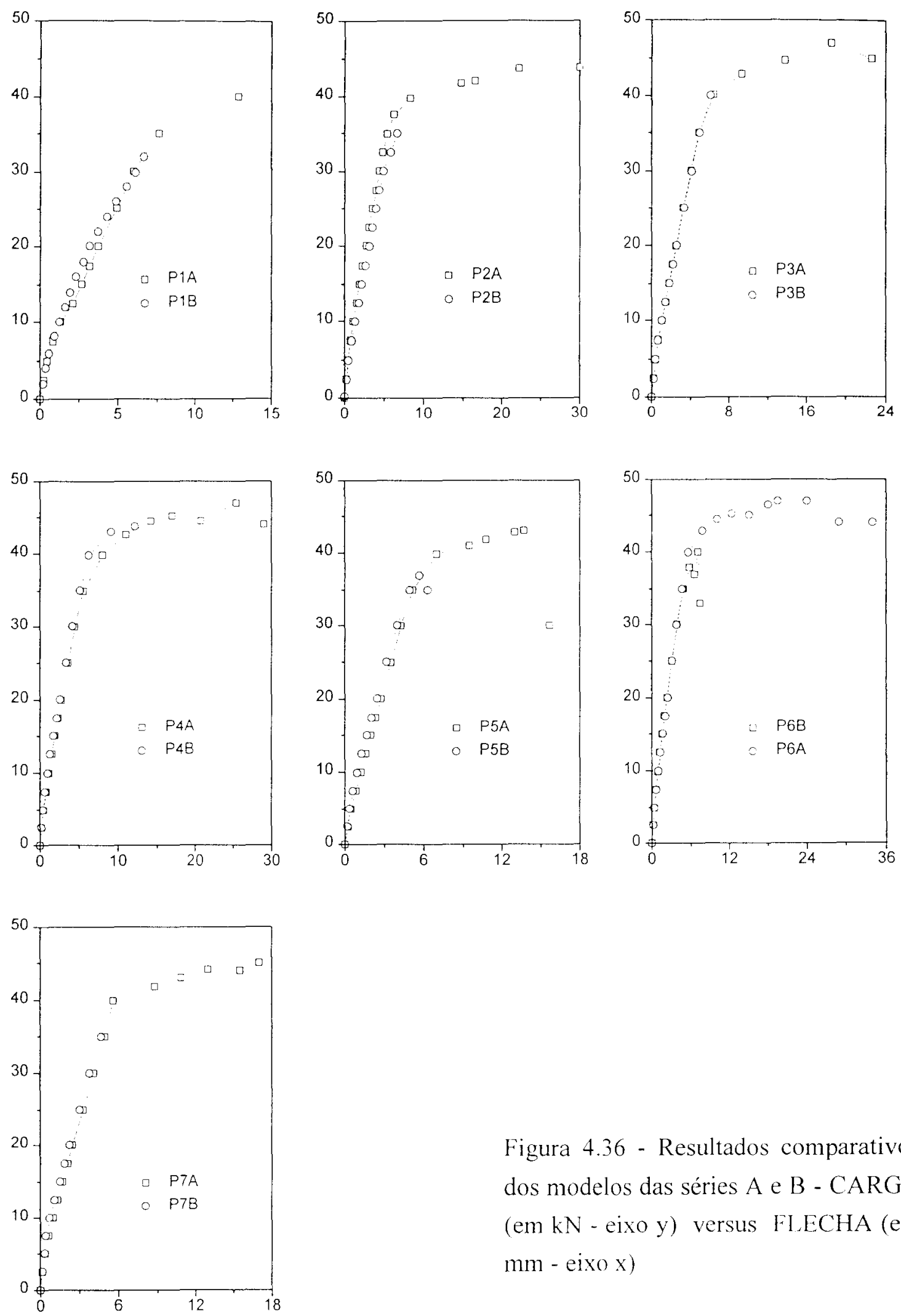

Figura 4.36 - Resultados comparativos dos modelos das séries A e B - CARGA (em kN - eixo y) versus FLECHA (em $m m-$ eixo $x)$ 

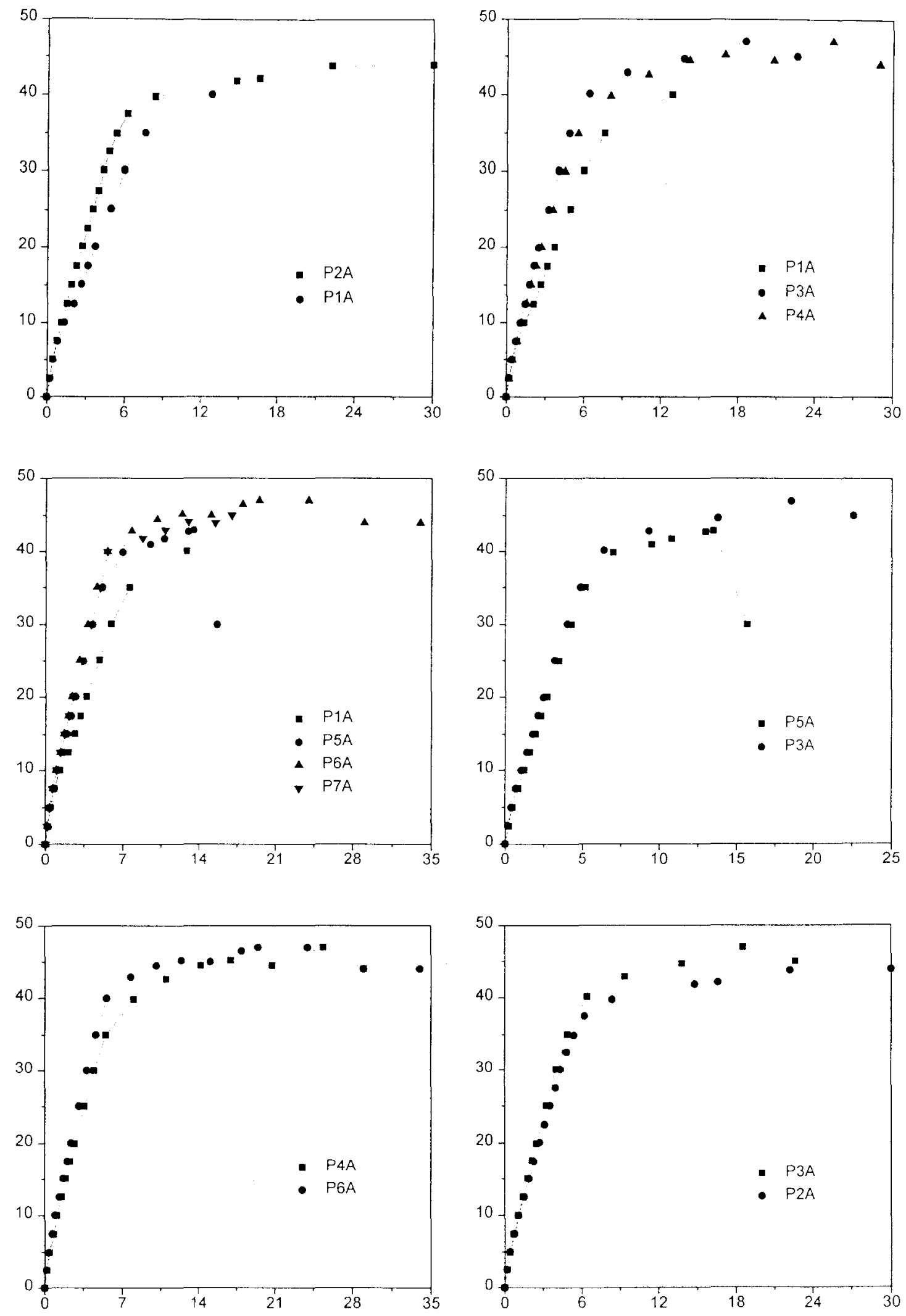

Figura 4.37 - Carga ( $\mathrm{kN}$ no eixo y) x Flecha ( $\mathrm{mm}$ no eixo $\mathrm{x}$ ): comparativo série $\mathrm{A}$ 

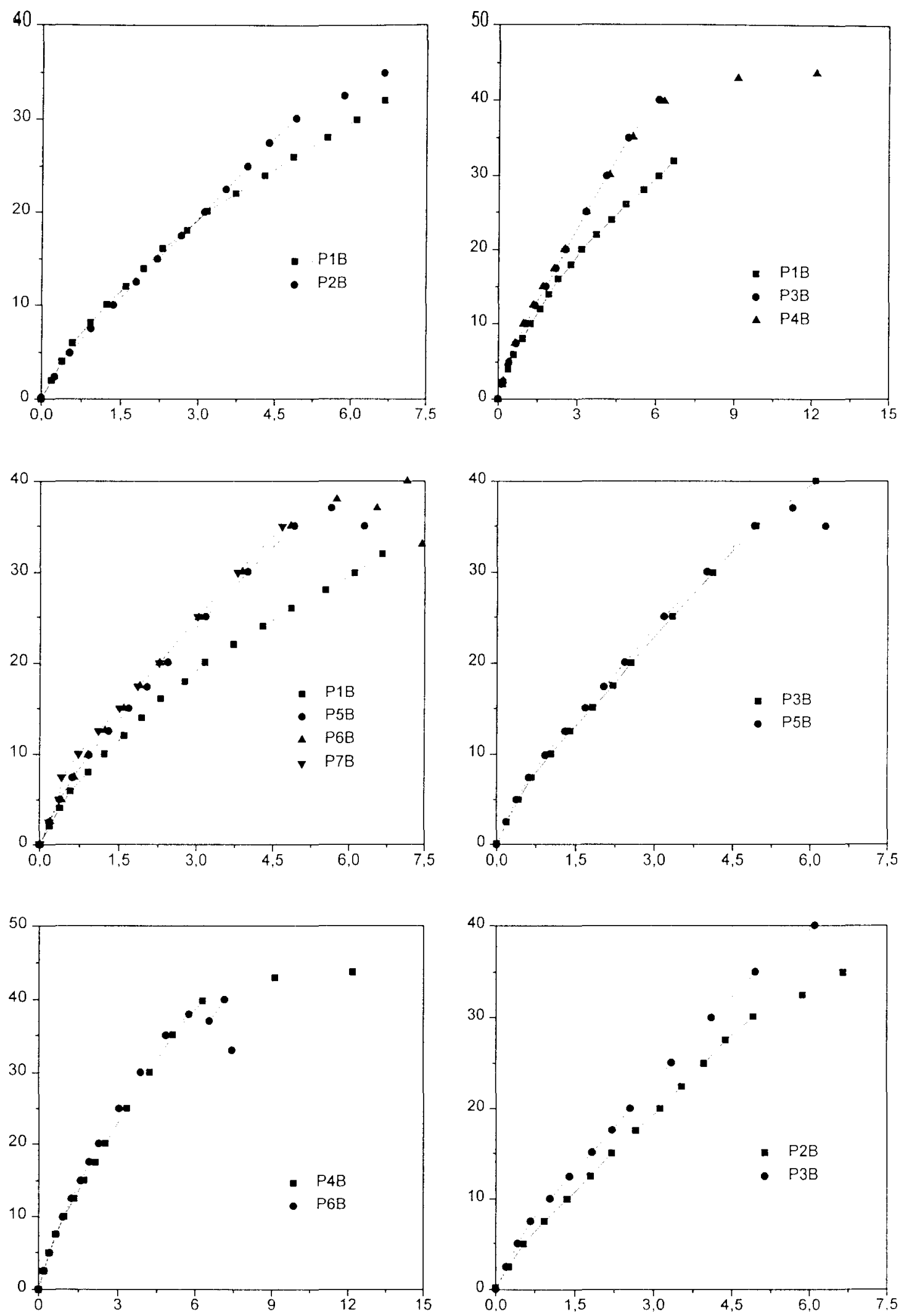

Figura 4.38 - Carga ( $\mathrm{kN}$ no eixo y) x Flecha (mm no eixo $\mathrm{x}$ ) comparativo série $\mathrm{B}$ 
A mesma tendência se mantém nos gráficos dos deslocamentos ponderados, onde se ratifica o melhor desempenho da fibra de aço longa. Neste caso, as curvas são mais próximas. Portanto, a variação da rigidez não se deve somente à variação do módulo de deformação longitudinal, mas especialmente à intensidade da fissuração.

Os deslocamentos dos modelos da série B foram similares aos deslocamentos dos modelos da série A para todas as misturas, praticamente coincidentes até próximo da ruptura. Portanto, os estribos não influem no valor das flechas. Conclusão similar foi obtida na análise da fissuração por flexão, no item 4.6.2. Na maioria dos casos (P1, P4, P5 e P7), as flechas foram ligeiramente menores na série $B$, onde se verificou anteriormente que a abertura das fissuras progrediu mais lentamente, ratificando a relação entre a fissuração e a rigidez.

Para os modelos com fibras de aço curta. a diferença entre as vigas P3 e P4 foi muito sutil nos deslocamentos. mas a ruptura foi mais dútil em P4, especialmente na série B, onde houve escoamento da armadura longitudinal. O desempenho destas vigas foi sempre superior ao dos modelos sem fibras.

Para a fibra de aço longa, a rigidez foi praticamente igual em todas as vigas. Porém, a tenacidade da viga P6 foi muito maior, especialmente na série A. Novamente. a diferença com o modelo de referência é clara.

Para os modelos com a mesma taxa de fibra de aço, o melhor desempenho entre as peças da série A com 1\% de fibra foi obtido pelo modelo P3A, especialmente em relação à tenacidade. Nas vigas sem estribos praticamente não houve diferença. Para o volume de $2 \%$ a situação se inverte.

Portanto, considerando-se o aspecto econômico, pode-se concluir que o melhor desempenho foi obtido pelos modelos com $1 \%$ de fibra de aço de $2,54 \mathrm{~cm}$.

A observação da forma do diagrama carga-flecha dos modelos da série A permite assegurar que não houve escoamento da armadura longitudinal somente no modelo P1A. Em P5A e P7A, a interpretação é duvidosa. Os modelos P2A, P3A. P4A e P6A tiveram ruptura bastante dútil e certamente o estado limite último ocorreu pelo escoamento da armadura longitudinal.

A concretização da ruína por cisalhamento confirma estas observações, pois ela ocorreu apenas nas peças P1A. P5A e P7A. Considerando-se que no modelo P2A as fibras evitaram a ruptura por cisalhamento, apesar do escoamento do estribo. em todas as peças com fibras o modo de ruptura pode ter sido alterado. Seguramente, ele o foi para os modelos P2A. P3A. P4A e P6A. Nestes modelos, a deformação plástica irreversível foi mais pronunciada, como mostra a foto 4.19 .

$\mathrm{Na}$ série $\mathrm{B}$, todos os modelos romperam por cisalhamento, mas o diagrama carga-flecha da viga $\mathrm{P} 4$ se aproximou do diagrama de alguns modelos da série A. A 
ruptura deste modelo foi mais dútil que a do modelo sem fibras e com estribos. A armadura longitudinal deve ter escoado, ou seja, a forma de ruptura foi alterada mesmo sem o uso de estribos. É a única peça da série $B$ onde a deformação residual é pronunciada, como mostra a Foto 4.20 .

\subsection{5 - CAPACIDADE RESISTENTE (flexão e cisalhamento)}

A análise das Fotos 4.19 e 4.20 mostra a semelhança na trajetória das fissuras que provocaram a ruptura diagonal. No entanto, elas são mais inclinadas na meia altura da alma nos modelos sem estribos. Estes resultados confirmam as previsões da teoria. que prevê bielas mais abatidas para menores taxas de armadura transversal. Os valores da inclinação das fissuras críticas se encontram na Tabela 4.10. Quando a ruptura não se concretizou, eles foram substituidos pela inclinação da fissura mais abatida.

Para a análise da resistência foram considerados os valores da força cortante máxima atingida durante o ensaio, independente do possível escoamento da armadura longitudinal ou transversal, que caracterizaria anteriormente o estado limite último. Como a forma de ruptura das vigas da série A variou, algumas das considerações a respeito da resistência dos modelos são aproximadas. A Tabela 4.10 apresenta também os valores máximos da força cortante e a forma da ruptura dos modelos.

No caso do modelo de referência com estribo (PlA), o valor previsto pelo cálculo teórico se aproximou bastante do resultado experimental. Esperava-se que a ruptura por cisalhamento ocorresse para carga próxima de $37 \mathrm{kN}$, quase concomitante com o escoamento da armadura longitudinal, com $36,5 \mathrm{kN}$. A ruptura por cisalhamento ocorreu quando a carga atingiu $40 \mathrm{kN}$. Em relação à resistência à flexão o ensaio não é conclusivo. pois não houve escoamento da armadura longitudinal. Nas peças com fibras, os modelos de cálculo utilizados não consideraram a sua influência e não captaram a maior resistência obtida por estas vigas.

$\mathrm{Na}$ série $\mathrm{A}$. além do modelo sem fibras, apenas mais duas vigas atingiram a ruina por cisalhamento: P5 e P7, mas, mesmo assim, houve aumento da resistência. $7,5 \%$ e $12.5 \%$. respectivamente. Nos demais modelos, não se esgotou a capacidade resistente para este tipo de solicitação e a avaliação ficou prejudicada neste aspecto. Sabe-se, no entanto, que o aumento da resistencia ao cisalhamento foi de, pelo menos. 13\%, 17\%. 15\% e 17\%, para os modelos P2A, P3A, P4A e P6A, respectivamente.

Em.relação à resistência à flexão a análise comparativa também é inconclusiva. já que no modelo de referência não se esgotou a capacidade resistente da peça. Porém. se houve aumento de resistencia nas peças com fibras, ele foi modesto. Como no 
modelo P1 a resistência à flexão não se esgotou com $40 \mathrm{kN}$, o aumento foi de, no máximo, 17\%, para os modelos P3 e P6, que atingiram a maior carga, $47 \mathrm{kN}$.

Tabela 4.10 - Parâmetros relativos à ruptura

: \begin{tabular}{|c|c|c|c|}
\hline modelo & $F_{\max }(\mathrm{kN})$ & forma de ruína & $\theta_{\min }$ ou $\theta_{\text {crit }}$ (graus) \\
\hline P1A & 40 & cisal-tração & 30 \\
\hline P1B & 32 & cisal-tração & 30 \\
\hline P2A & 45,2 & flexão & 25 \\
\hline P2B & 35 & cisal-tração & 25 \\
\hline P3A & 47 & flexão & 40 \\
\hline P3B & 40 & cisal-tração & 40 \\
\hline P4A & 46 & flexão & 40 \\
\hline P4B & 44 & cisal/flexão & 25 \\
\hline P5A & 43 & cisal-tração & 35 \\
\hline P5B & 37 & cisal-tração & 20 \\
\hline P6A & 47 & flexão & 30 \\
\hline P6B & 40 & cisal-tração & 30 \\
\hline P7A & 45 & cisal-tração & 30 \\
\hline P7B & 35 & cisal-tração & 20 \\
\hline
\end{tabular}

Nas vigas sem estribos a resistência da peça se deve somente à contribuição do concreto, que conforme a expressão da NBR-6118 é representada pelo mesmo termo utilizado para subtrair a força cortante resistida pelos estribos nas peças com armadura transversal. Este procedimento resulta em valores de resistência muito abaixo dos obtidos nos ensaios, pois a formulação é muito conservativa, embora se possa justificar a adoção de coeficientes de segurança maiores devido à ruptura tipicamente frágil destas peças. Na verdade, a parcela de resistência proporcionada pelos vários mecanismos resistentes. simplificadamente considerados através do coeficiente $\tau_{c}$, deve ser mais próxima de uma situação em que a configuração de fissuras seja compatível com o escoamento da armadura longitudinal, adequada, portanto, para redução da tensão nos estribos. Como as peças sem estribos não possuem resistência suficiente para atingir o estado limite último devido ao escoamento da armadura de flexão, a parcela de resistência do concreto na transferência de forças transversais é maior, o que explica a discrepância entre os valores teóricos e experimentais.

$\mathrm{Na}$ série B. todas as vigas romperam por cisalhamento. Porém. na viga $\mathrm{P} 4$, a armadura longitudinal deve ter escoado. De qualquer modo, em todas as peças com fibras houve acréscimo de resistência: $9 \%, 25 \%, 37 \%, 16 \%, 25 \%$ e $9 \%$, para os modelos $\mathrm{P} 2 \mathrm{~B}$ a $\mathrm{P} 7 \mathrm{~B}$, respectivamente. 
Portanto, pode-se assegurar que a introdução das fibras aumenta a resistência ao cisalhamento e, em alguns casos, pode alterar o modo de ruptura. Os melhores desempenhos foram obtidos pelas peças com fibra de aço. Nos modelos com estribos, a influência foi aparentemente menor e menos sensível ao volume de fibras. Não se deve esquecer, porém, que a maioria das peças da série $\mathrm{A}$ não teve esgotada sua capacidade resistente ao cisalhamento, o que relativiza esta conclusão.

Nos modelos sem estribos o aumento de resistência proporcionado pelas fibras foi nominalmente maior e mais sensivel à variação do volume de fibras. Neste caso, a fíbra de aço de $2,54 \mathrm{~cm}$ apresentou o melhor rendimento. O maior valor da resistência à tração do concreto obtido nos modelos P4 e P6 pode justificar, em parte, o maior acréscimo de resistência observado nestas vigas, especialmente porque não há estribos e a resistência depende prioritariamente desta característica do concreto.

$O$ concreto contribui na transferência de forças transversais. Logo, sua resistência influi na resistência ao cisalhamento, especialmente nos modelos sem estribos. Há controvérsias sobre qual o melhor parâmetro para se avaliar a contribuição do concreto: a resistência à tração ou a resistência à compressão. Escolheu-se a raiz quadrada da resistência à compressão para ponderar os resultados obtidos. Conforme se observa na última coluna da Tabela 4.11. a tendência se mantém, mas os acréscimos de resistência são menores e atingem, no máximo, $12 \%$.

Tabela 4.11 - Comparação dos resultados teóricos e experimentais na ruptura

\begin{tabular}{|c|c|c|c|c|c|c|}
\hline modelo & $\begin{array}{c}f_{\mathrm{c}} \\
(\mathrm{MPa})\end{array}$ & $\begin{array}{c}\mathrm{f}_{\mathrm{t}} \\
(\mathrm{MPa})\end{array}$ & $\begin{array}{c}\mathrm{V}_{\mathrm{u.c}} \\
(\mathrm{kN})\end{array}$ & $\begin{array}{c}\mathrm{V}_{\mathrm{u}, \mathrm{f}} \\
(\mathrm{kN})\end{array}$ & $\begin{array}{c}\mathrm{V}_{\text {u.exp }} \\
(\mathrm{kN})\end{array}$ & exp/teo \\
\hline P1A & 43,8 & 3,4 & 17,3 & 18,2 & 20 & 1,16 \\
\hline P1B & 43,8 & 3,4 & 7,2 & 18,2 & 16 & 2,22 \\
\hline P2A & 48 & 3,45 & 17,6 & 17,5 & $22,6 / 20^{*}$ & 1,28 \\
\hline P2B & 48 & 3,45 & 7,4 & 17,5 & 17,5 & 2,36 \\
\hline P3A & 54,8 & 3,3 & 18,2 & 17,8 & 23,5 & 1,29 \\
\hline P3B & 54,8 & 3,3 & 8,0 & 17,8 & 20 & 2,5 \\
\hline P4A & 50 & 4,2 & 17,8 & 17,5 & 23 & 1,29 \\
\hline P4B & 50 & 4,2 & 7,7 & 17,6 & 22 & 2,86 \\
\hline P5A & 49,3 & 3,85 & 17,7 & 18,5 & 21,5 & 1,22 \\
\hline P5B & 49,3 & 3,85 & 7,6 & 18,5 & 18,5 & 2,43 \\
\hline P6A & 53,7 & 4,3 & 18,1 & 17,7 & 23,5 & 1,3 \\
\hline P6B & 53,7 & 4,3 & 7,9 & 17,7 & 20 & 2,53 \\
\hline P7A & 53,5 & 3,6 & 18 & 18,2 & 22,5 & 1,25 \\
\hline P7B & 53,5 & 3,6 & 7,9 & 18,2 & 17,5 & 2,22 \\
\hline
\end{tabular}




\subsection{6 - TENSÃO NOS ESTRIBOS}

A determinação do instante da efetiva mobilização dos estribos e do valor da tensão máxima permite estimar a contribuição das fibras na resistência à força cortante, como armadura de cisalhamento ou nos mecanismos resistentes alternativos, desde o momento em que eles são insuficientes para garantir a transferência da força cortante, até o instante da ruptura. Quanto maior a contribuição do concreto na transferência de forças transversais através dos mecanimos alternativos, menor é a tensão nos estribos.

A Tabela 4.12 apresenta a deformação máxima nos estribos nas duas posições instrumentadas, apenas do ramo mais solicitado do estribo mais solicitado entre os dois pontos correspondentes de cada lado, além do instante em que eles foram efetivamente acionados, considerando-se uma tensão mínima de $40 \mathrm{MPa}$.

Observa-se que a mobilização dos estribos na região onde o momento fletor é elevado ocorre depois nos modelos com fibras. As tensões máximas foram sempre menores naqueles com fibra de aço. Próximo dos apoios, o fenômeno é muito sensivel ao aparecimento da fissura diagonal. Exceto para os modelos P2A, P5A e P7A, em que a ruína se concretizou, as tensões foram menores nos modelos com fibras.

Tabela 4.12 - Deformações máximas nos estribos e instante de mobilização

\begin{tabular}{|c|c|c|c|c|}
\hline \multirow{2}{*}{ modelo } & \multicolumn{2}{|c|}{ E1 ou E2 } & \multicolumn{2}{c|}{ E3 ou E4 } \\
\cline { 2 - 5 } & $\varepsilon_{\max }(\%)$ & $\mathrm{F}_{\text {mob }}(\mathrm{kN})$ & $\varepsilon_{\max }(\%)$ & $\mathrm{F}_{\text {mob }}(\mathrm{kN})$ \\
\hline P1A & 0,2 & 30 & 0,19 & 15 \\
\hline P2A & 0,26 & 25 & $>1,0$ & 20 \\
\hline P3A & 0,09 & 35 & 0,07 & 30 \\
\hline P4A & 0,11 & 35 & 0,14 & 25 \\
\hline P5A & 0,20 & 25 & 0,08 & 25 \\
\hline P6A & 0,11 & 35 & 0,09 & 20 \\
\hline P7A & 0,32 & 30 & 0,1 & 17,5 \\
\hline
\end{tabular}

Para estudar a influência das fibras no desenvolvimento das tensões nos estribos. são apresentados nas Figuras 4.39 e 4.40 os gráficos de deformação dos estribos mạis solicitados da posição E1-E2 e da posição E3-E4, de todas as vigas da série A. Posteriormente, os mesmos resultados s̃ão apresentados nas Figuras $4.41 \mathrm{e}$ 4.42. ponderando-se o valor das cargas pela resistência do concreto, de modo análogo 
ao adotado na análise das flechas. E finalmente, os resultados são agrupados entre si, seguindo a mesma combinação anterior, nas Figuras 4.43 e 4.44.

Em todos os modelos a tensão nos estribos foi menor que a tensão calculada pela treliça clássica (a comparação foi feita apenas para os estribos mais solicitados). Isto confirma o conservadorismo desta formulação. Nos estribos próximos dos apoios as curvas são mais abatidas que a da treliça clássica, exceto no modelo P2A. Nos estribos E3 e E4 elas são quase paralelas, ratificando as maiores tensões onde a fissuração por flexão é mais intensa, conforme se discutiu no Capítulo 2.

$O$ valor de $\tau_{c}$, medido indiretamente pela diferença entre as curvas da analogia clássica e a curva experimental, foi sempre maior para o concreto com fibras na região próxima dos apoios. Próximo do ponto de introdução das cargas, esta diferença só foi observada nos modelos P3A, P4A e P6A, mas nos demais casos a diminuição da contribuição do concreto pelos mecanismos alternativos foi menor que no concreto sem fibras na etapa final do ensaio, após $35 \mathrm{kN}$.

A presença de fibras resistentes junto às fissuras inclinadas alivia a tensão nos estribos. Além disso, também é significativa a contribuição indireta proporcionada pelas fibras na manutenção da atuação dos mecanismos alternativos por mais tempo, quer pelo controle mais eficiente da fissuração, quer pelo efeito da atuação conjunta das fibras com as armaduras, quando a eficiência individual de cada um destes elementos é maior.

As tensões nos estribos E3 e E4 nos modelos com fibras foram sempre menores que no modelo de referência, exceto no final do ensaio de P2A. Os melhores desempenhos foram obtidos por P6A. P4A e P3A, nesta ordem. Para os estribos E1 e E2, apenas em P3A, P4A e P6A as tensões foram menores que em P1A. No modelo $\mathrm{P} 2 \mathrm{~A}$, apesar delas serem comparativamente maiores, elas tem um desenvolvimento mais uniforme, sem variação brusca.

A um acréscimo brusco de tensão em um estribo geralmente corresponde o aparecimento de uma fissura inclinada que o atravessa. Em todas as peças com fibras esta variação de tensão foi mais suave que no modelo de referência. Isso pode ser observado na posição E1-E2 na etapa de carga entre $35-40 \mathrm{kN}$, quando se formou a maioria das fissuras diagonais, e na posição E3-E4 após $20 \mathrm{kN}$, quando as fissuras de flexão começaram a inclinar (exceto em P2A, onde o estribo escoou rapidamente).

Nos modelos com fibras, os piores resultados foram obtidos pelos modelos P2A, P5A e P7A. onde as tensões nos estribos próximos do apoio aumentaram muito no final do ensaio. Coincidentemente, P5A e P7A romperam por cisalhamento, enquanto em $\mathrm{P} 2 \mathrm{~A}$ a configuração de fissuras inclinadas era muito intensa. 
Em praticamente todos os modelos, os estribos E3 e E4 foram menos solicitados que os estribos E1 e E2 no final do ensaio. Como a distância do ponto de aplicação da carga até E1-E2 era de $10 \mathrm{~cm}$, aproximadamente 1,2d, pode-se supor que a trajetória preferencial das cargas se fazia com bielas de inclinação inferior a 40 graus. Os gráficos ponderados confirmam todas as observações anteriores, já que as 'tendências se mantém.

Nos gráficos comparativos destaca-se principalmente o excelente desempenho dos modelos com fibra de aço curta. para qualquer volume. Para a fibra longa, o volume de $2 \%$ proporcionou o melhor resultado.

As maiores tensões nas proximidades da ruptura foram observadas nos estribos E3 e E4 do modelo P2A. Porém, até $35 \mathrm{kN}$, as tensões nestes estribos deste modelo eram as menores de todo o conjunto, numa região muito fissurada, situada no trecho onde atua a força cortante. Isto sugere que a contribuição das fibras foi significativa enquanto ainda atuavam os mecanismos alternativos. Possivelmente, ela se deve ao melhor controle das fissuras, o que aumenta a parcela de resistência do concreto. Porém, quando surgiu a fissura diagonal potencialmente crítica, a atuação das fíbras como armadura transversal junto a ela foi limitada. Esta hipótese é reforçada pelas tensões mais elevadas observadas nos estribos próximos dos apoios desde a metade do ensaio, na região em que ocorrem as fissuras inclinadas diretamente na alma.

No entanto, mesmo com os estribos muito solicitados, as fibras contribuíram na transferência das forças transversais. já que a peça não atingiu a ruína. Pode-se supor que a atuação das fibras de polipropileno junto às fissuras diagonais seja acompanhada de grandes deformações. Além disso. a energia necessária para promover o arrancamento destas fibras na região da ruptura é muito grande, o que pode justificar o fato da ruína não ter se concretizado.

No caso da fibra de aço, o mecanismo de reforço junto às fissuras diagonais seria similar à ação dos estribos. Por ser mais rígida, a deformação é pequena, o que proporciona redução de tensão nos estribos. A energia requerida para o arrancamento deve ser menor, apesar da melhor aderência, pois a quantidade de fibras que atravessam as fissuras é muito menor que para a fibra de polipropileno.

De qualquer modo, independentemente do tipo de fibra, a limitação da fissuração contribui para o melhor desempenho da viga. pois aumenta a contribuição dos mecanismos resistentes alternativos. 


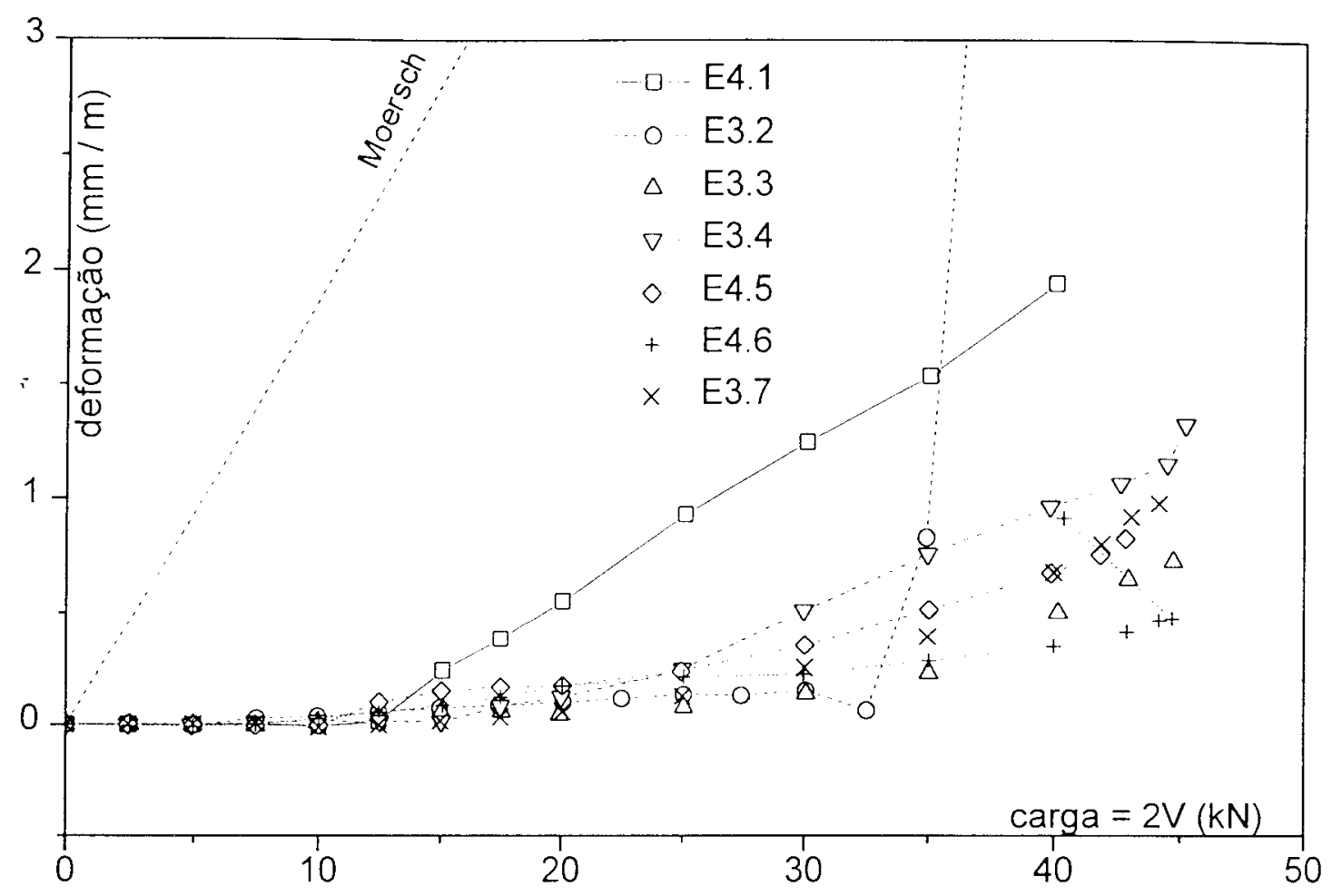

Figura 4.39 - Estribos mais solicitados da posição E3 ou E4

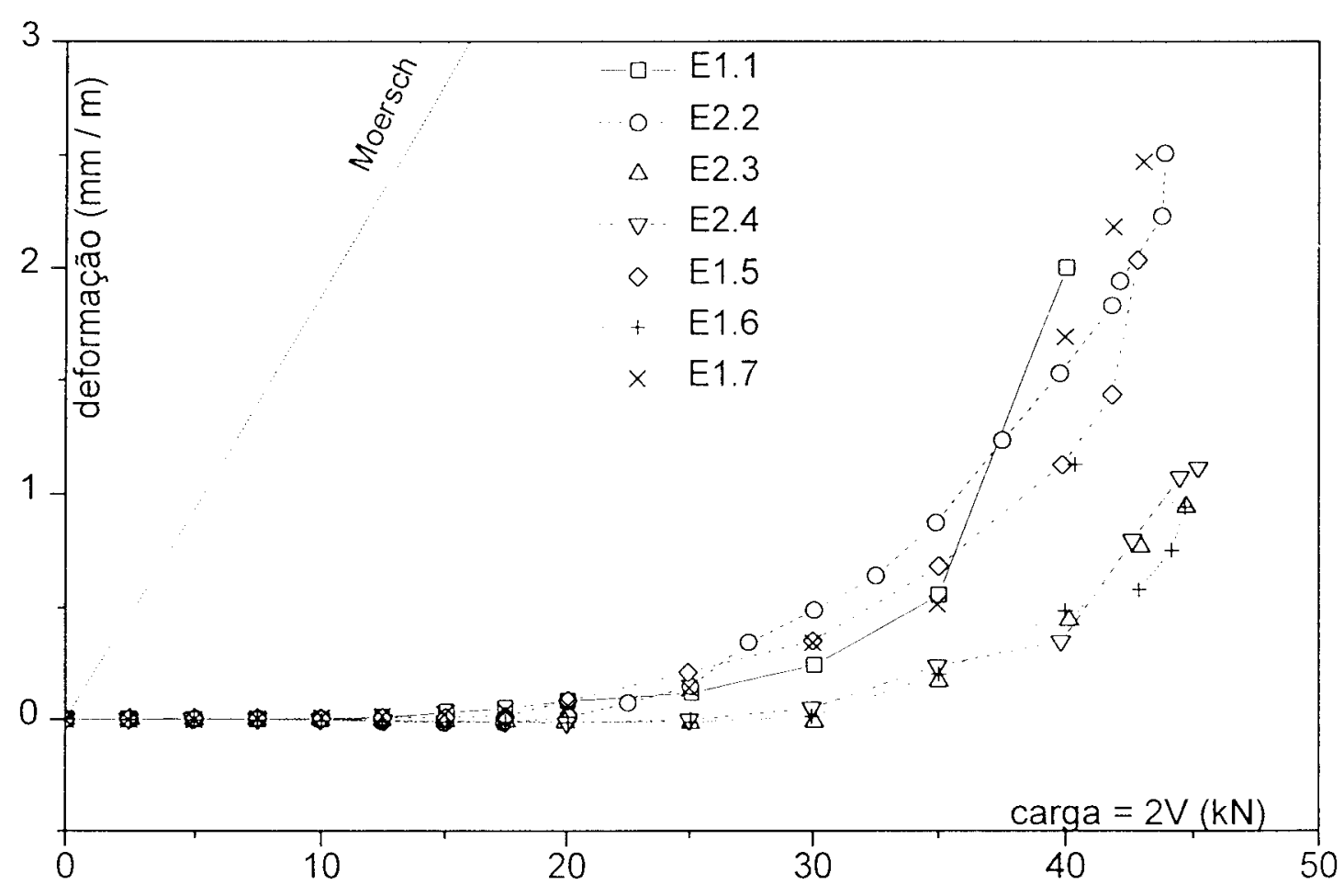

Figura 4.40 - Estribos mais solicitadós da posição E1 ou E2 


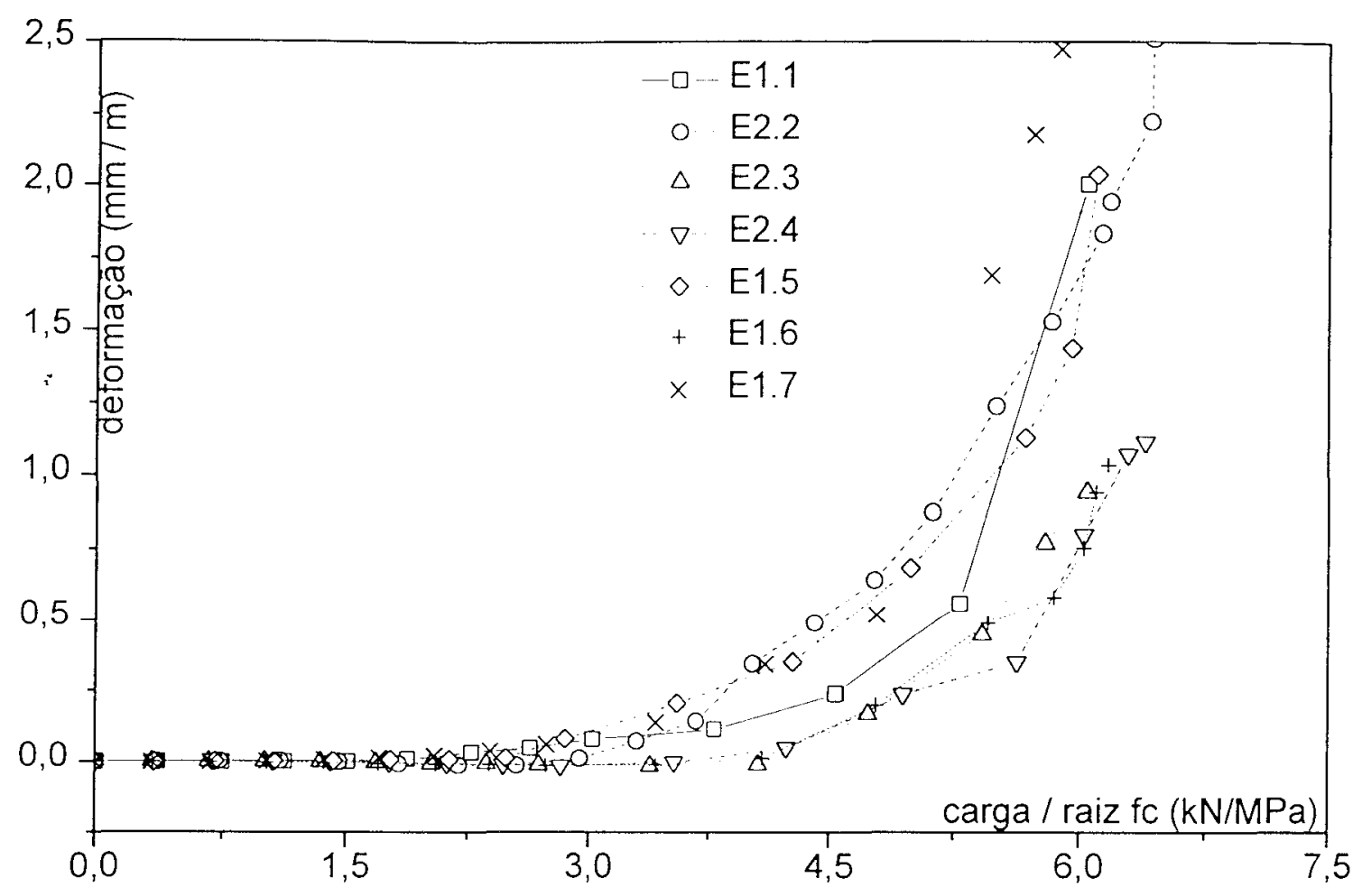

Figura 4.41 - Estribos mais solicitados da posição E1 ou E2 - ponderado

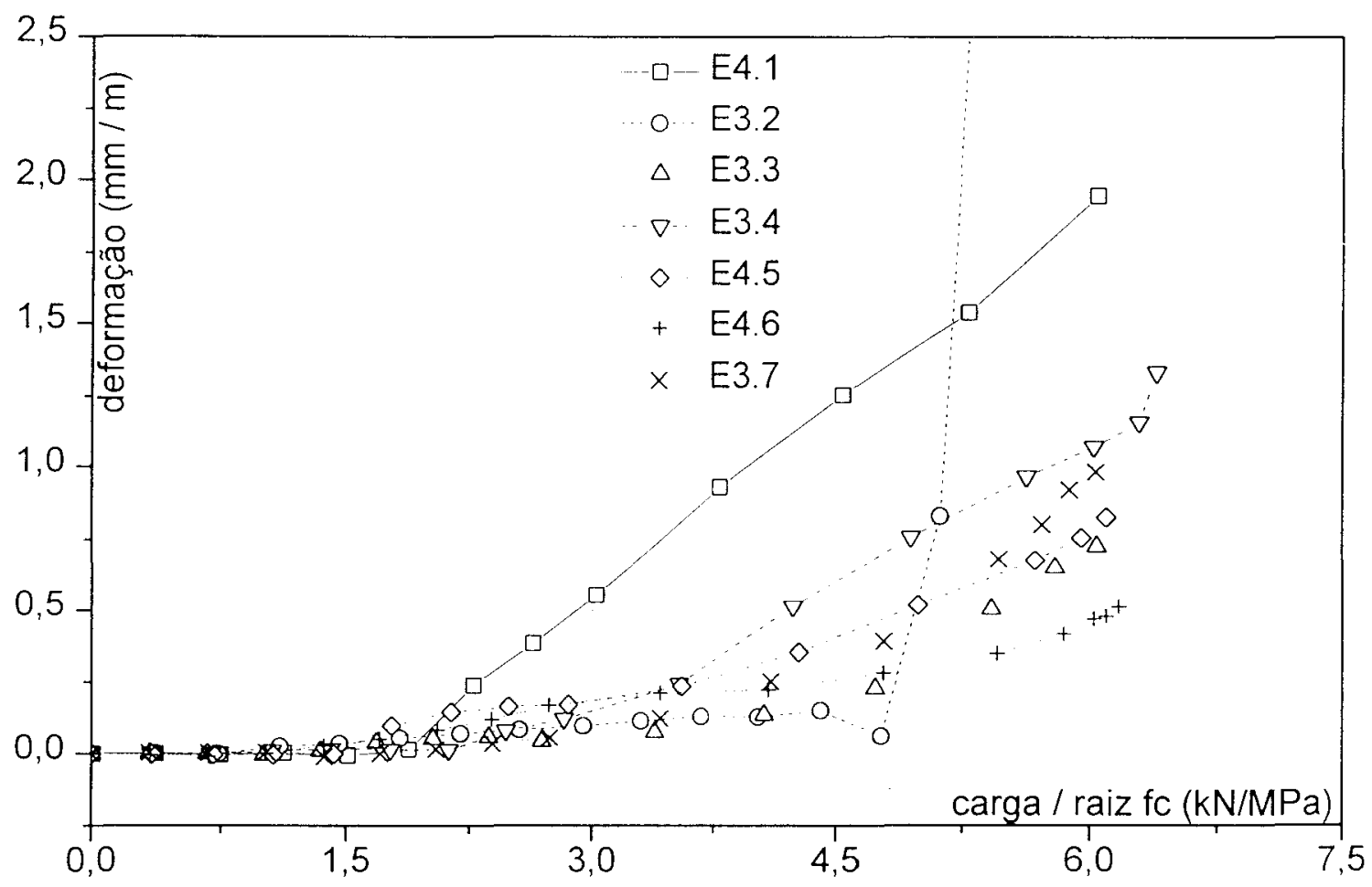

Figura 4.42 - Estribos mais solicitados da posição E3 ou E4 - ponderado 

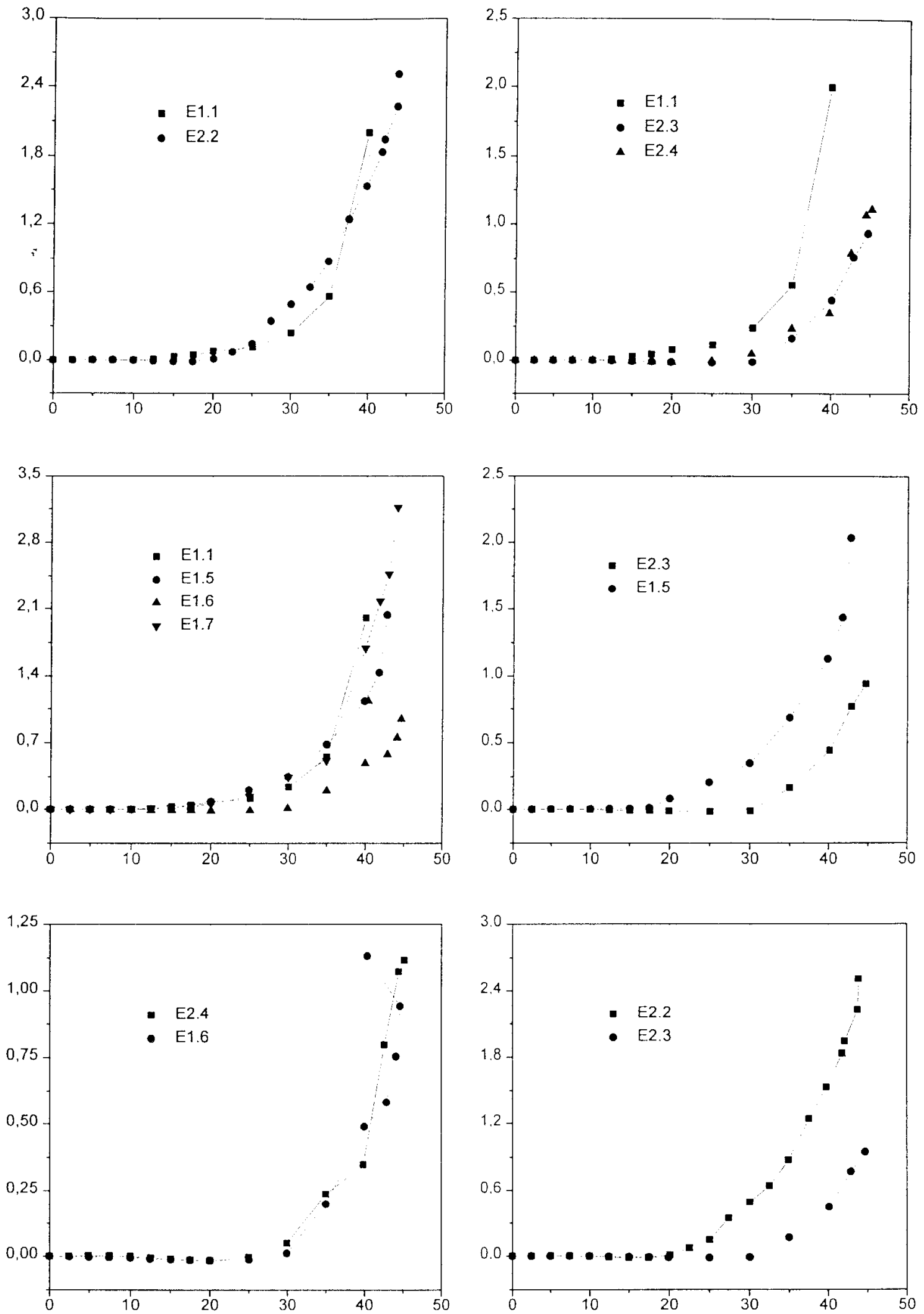

Figura 4.43 - Deformação $(\mathrm{mm} / \mathrm{m}$ no eixo y) x Carga $(\mathrm{kN}$ no eixo $\mathrm{x})$ comparativo: E1-E2 

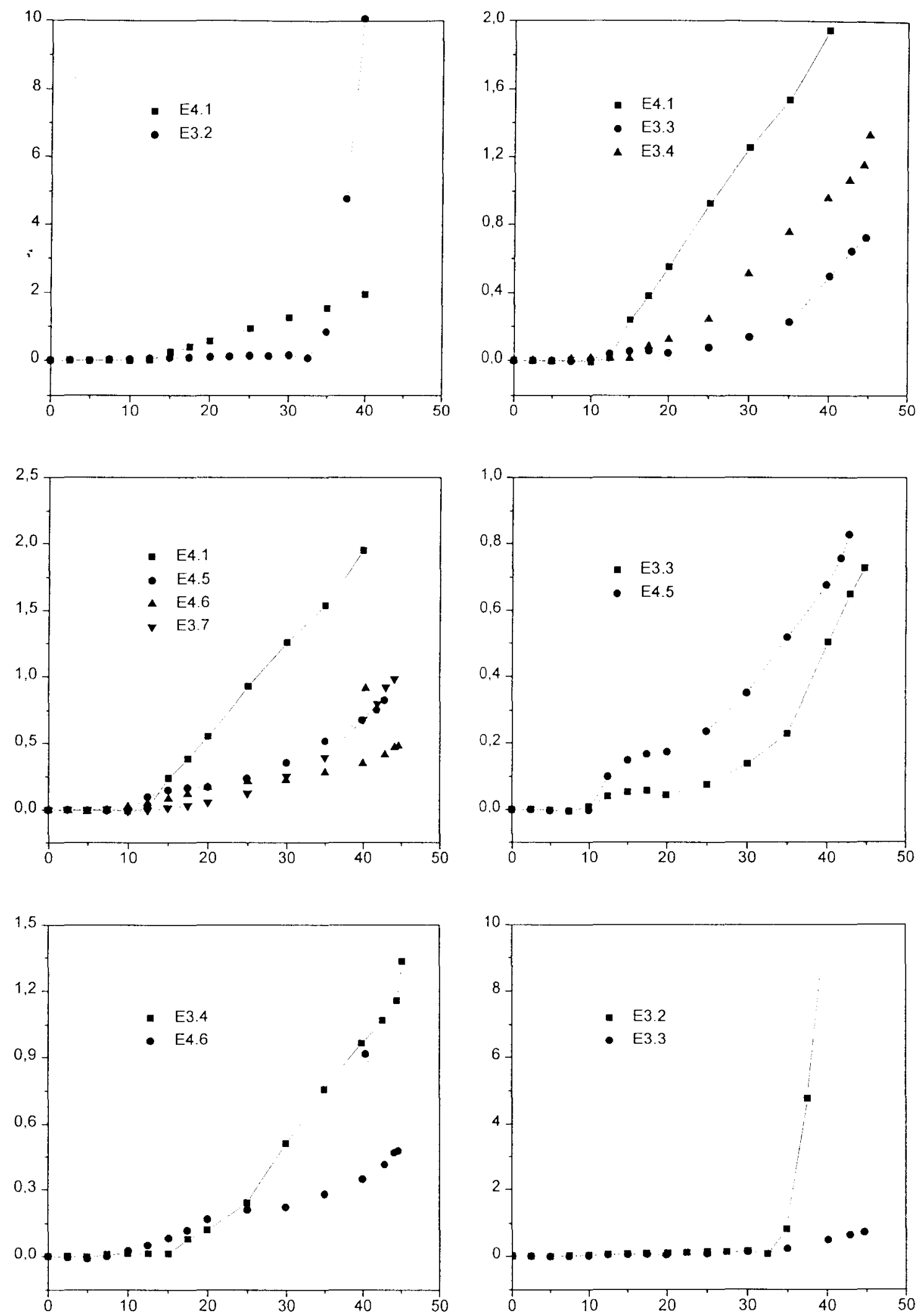

Figura 4.44 - Deformação ( $\mathrm{mm} / \mathrm{m}$ no eixo y) x Carga $(\mathrm{kN}$ no eixo $\mathrm{x})$ comparativo E3-E4 


\subsection{7 - TENSÃO NA ARMADURA LONGITUDINAL}

$\mathrm{O}$ escoamento da armadura longitudinal pode ser grosseiramente estimado a partir da análise das tensões nos pontos A3 e A4, já que a região de momento fletor máximo não foi instrumentada.

- A influência do apoio das bielas na armadura, especialmente na região do apoio, para onde convergem as principais bielas nas proximidades da ruína, foi minimizada colando-se os extensômetros na lateral das barras. No entanto, na maioria dos casos em que houve ruptura diagonal, observou-se um acréscimo significativo de tensão nesta região no lado da ruptura, que estaria relacionado com a formação do mecanismo de $\operatorname{arcos}$

Conforme se descreveu no Capítulo 3, a bibliografia registra o melhor comportamento do concreto reforçado com fibras na região afetada pelas forças de pino. Ele pode ser avaliado a partir da relação entre o valor da tensão máxima nos pontos próximos do apoio com a ocorrência ou não da ruína, especialmente quando a descompressão no concreto é mais intensa e a tensão na armadura aumenta mais.

$\mathrm{Na}$ Tabela 4.13 apresentam-se as deformações máximas nos dois pontos mais solicitados das seções instrumentadas. As Figuras 4.45 a 4.48 mostram a evolução da deformação nestes pontos para as vigas das séries $\mathrm{A}$ e $\mathrm{B}$, respectivamente. Na Figura 4.49 apresenta-se a comparação entre modelos correspondentes das séries A e B.

Tabela 4.13 - Deformação máxima na armadura longitudinal

\begin{tabular}{|c|c|c|}
\hline modelo & A1 ou A2 $-\varepsilon_{\max }(\%)$ & A3 ou A4 $-\varepsilon_{\max }(\%)$ \\
\hline P1A & 0,17 & 0,28 \\
\hline P1B & 0,08 & 0,19 \\
\hline P2A & 0,23 & $0,37^{*}$ \\
\hline P2B & $0,31^{*}$ & 0,25 \\
\hline P3A & 0,15 & 0,24 \\
\hline P3B & 0,14 & 0,23 \\
\hline P4A & 0,18 & $0,54^{*}$ \\
\hline P4B & 0,16 & 0,25 \\
\hline P5A & 0,21 & 0,25 \\
\hline P5B & 0,16 & 0,22 \\
\hline P6A & 0,14 & 0,23 \\
\hline P6B & 0,11 & 0,27 \\
\hline P7A & 0,18 & $0,32^{*}$ \\
\hline P7B & 0,10 & 0,16 \\
\hline \multicolumn{2}{|c|}{$*$ Deformação atingiu patamar de escoamento } \\
\hline
\end{tabular}




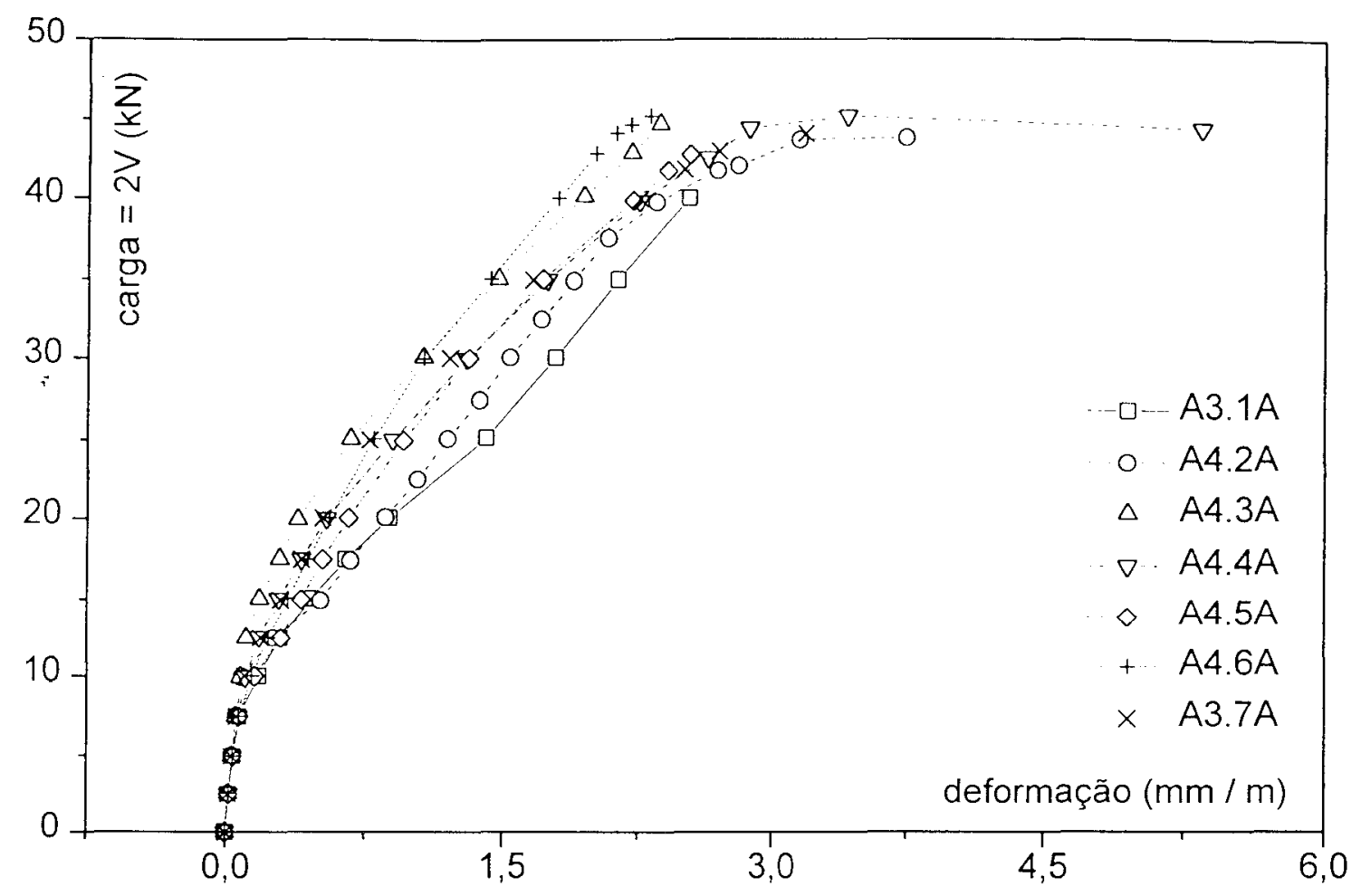

Figura 4.45 - Ponto mais solicitado na armadura: série A, posição A3 ou A4

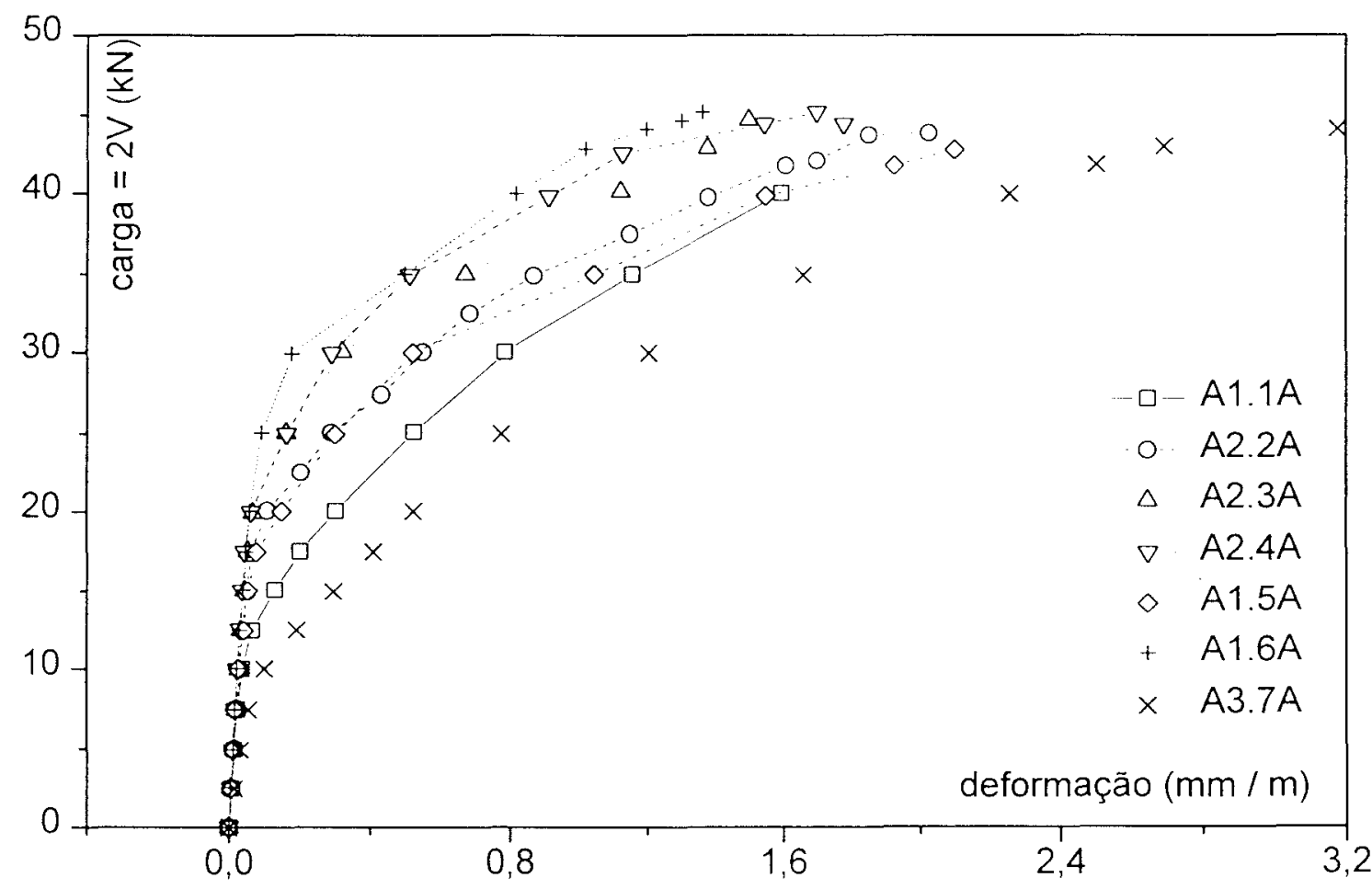

Figura 4.46 - Ponto mais solicitado na armadura: série A, posição Al ou A2 


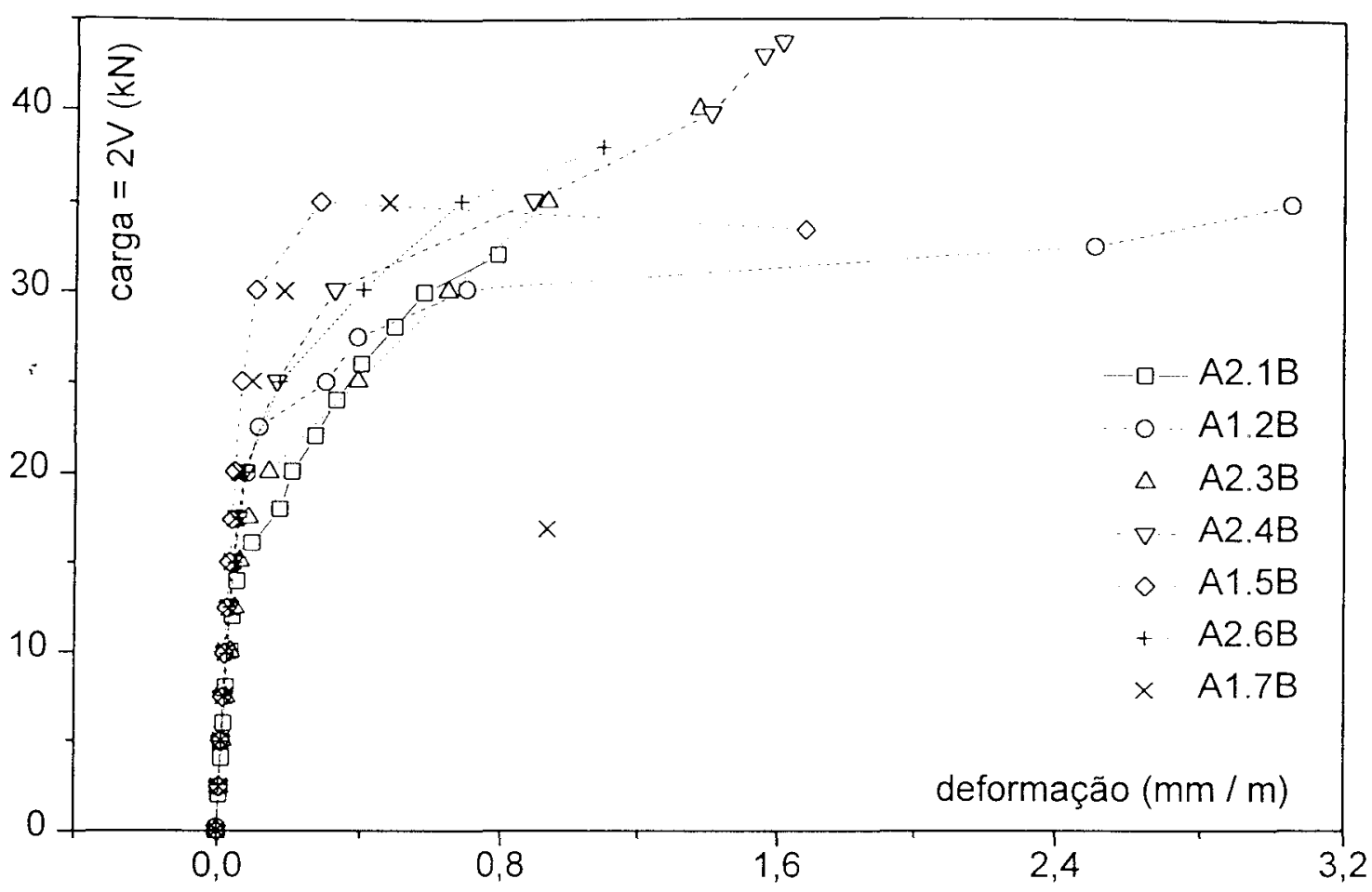

Figura 4.47 - Ponto mais solicitado na armadura: série B, posição A1 ou A2

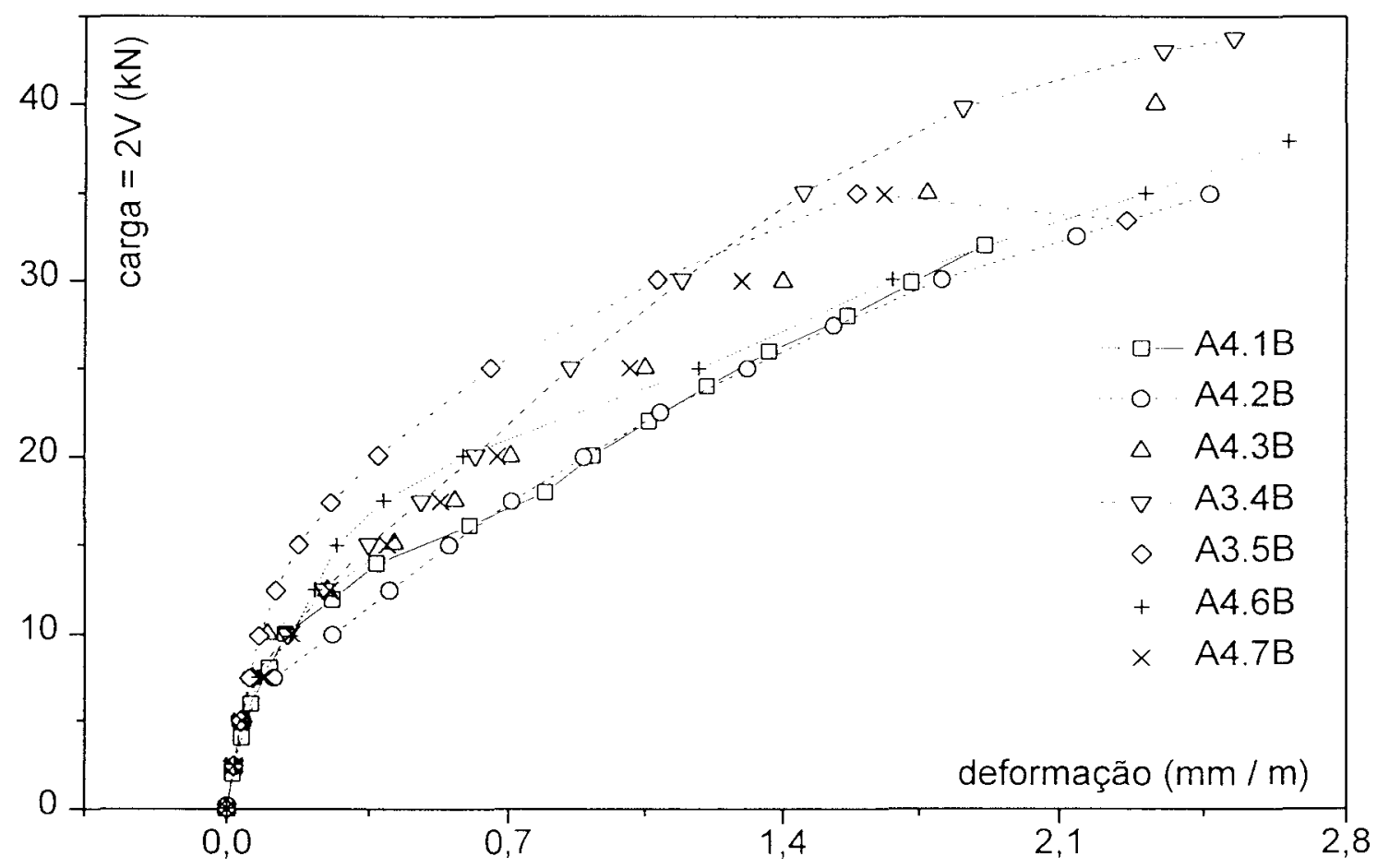

Figura 4.48 - Ponto mais solicitado na armadura: série B, posição A3 ou A4 

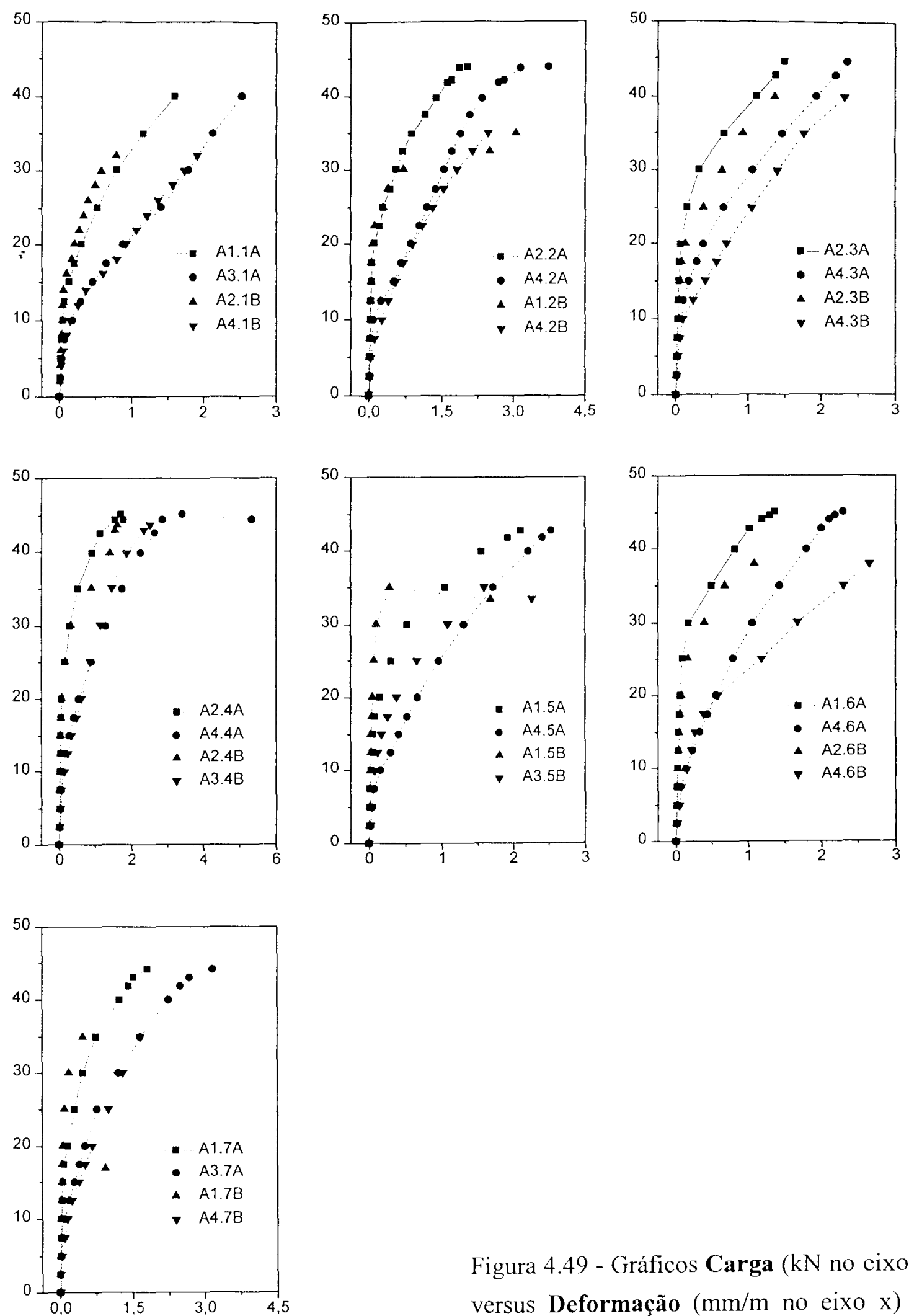

Figura 4.49 - Gráficos Carga ( $\mathrm{kN}$ no eixo y) versus Deformação $(\mathrm{mm} / \mathrm{m}$ no eixo $\mathrm{x})$ na armadura nos pontos mais solicitados $\mathrm{A} 1 / \mathrm{A} 2$ e A3/A*4: comparativo dos modelos A e B 
Observa-se uma tendência de acréscimo de tensão junto ao apoio quando a descompressão no concreto é mais intensa, devido ao atirantamento do arco formado pelas tensões de compressão no banzo de concreto, que se inclina em direção aos apoios quando a capacidade resistente da peça está se esgotando.

Nas peças da série $A$, a deformação máxima junto aos apoios foi menor nos 'modelos P3A, P4A e P6A. nos quais a descompressão foi mais suave e não havia risco de ruptura diagonal.

Quando se aproxima a ruptura por cisalhamento, o concreto no entorno das barras da armadura não consegue absorver as forças de pino decorrentes da concentração das bielas na região do apoio. Observa-se, de um modo geral, que as tensões na armadura na entrada do apoio nos modelos da série $A$ foram maiores nos modelos com fibras em que ocorreu a fissura diagonal (P2A, P5A e P7A) do que no modelo de referencia. Portanto, o efeito de pino atuou por mais tempo nos modelos com fibras. A ruína foi prematura em P1, pois a resistência do concreto para absorver as forças de pino foi menor.

O mesmo fato ocorreu na série $B$ em todas as peças, já que em todos os modelos houve ruptura por cisalhamento. Em dois modelos, P2B e P5B, houve aumento brusco da força na armadura, provocando inclusive o escoamento da armadura nesta região em $\mathrm{P} 2 \mathrm{~B}$, sem levar a peça à ruína. Nestes casos, a deformação no concreto também diminuiu drasticamente, para a mesma etapa do carregamento.

Nos pontos A3 e A4, o valor da deformação é menos sensível ao apoio das bielas e reflete mais a influência da flexão das vigas. Os valores foram comparativamente maiores no modelo sem fibras, acompanhando a mesma tendencia observada na evolução das fissuras e dos deslocamentos. Em apenas dois modelos a deformação medida atingiu o valor correspondente ao escoamento do aço, P2A e P4A.

A comparação entre os modelos correspondentes das séries A e $\mathrm{B}$ nos pontos próximos dos apoios revela que, apesar do valor nominal ser maior nos modelos com estribos. devido à maior capacidade resistente, as tensões foram proporcionalmente maiores nos modelos sem estribos nas vigas P2, P3, P4 e P6, confirmando a relação existente entre o acréscimo de tensão e a ocorrência da ruptura por cisalhamento. 


\subsection{8 - TENSÃO NO CONCRETO}

As deformações no concreto próximas dos apoios foram sempre muito baixas, como era de se esperar. O interesse desses valores se restringe à observação da descompressão do banzo comprimido, que se inicia na extremidade da viga. Os pontos intermediários, além da estimativa do encurtamento máximo na ruptura, prejudicada pela influência do arqueamento das tensões de compressão, possibilitam avaliar a extensão da descompressão, especialmente nas últimas etapas do ensaio, em que a carga caminha diretamente até os apoios. A apresentação dos resultados é similar a do item anterior, nas Figuras 4.50 a 4.53.

A correspondência entre a iminência da ruptura diagonal e a descompressão mais intensa do concreto, acompanhada da elevação da força na armadura junto ao apoio, já foi comentada anteriormente. Nas peças da série $\mathrm{A}$, o fenômeno atingiu os pontos mais internos apenas nos modelos em que houve ruptura por cisalhamento e no modelo P2. em que a ruína não se concretizou, mas apresentou todas as características desta forma de ruptura, inclusive o escoamento de um estribo. Nos outros modelos, mesmo nos pontos próximos do apoio, a diminuição da deformação foi muito discreta.

Nos modelos sem estribos o comportamento foi diferente, pois todas as vigas romperam por cisalhamento. A descompressão dos pontos internos e junto ao apoio ocorreu em praticamente todos os modelos, mais intensamente em P2B e P5B. Destacase também a tensão elevada no concreto em P4B, não acompanhada por uma maior deformação na armadura longitudinal. Isso sugere que a diferença não ocorreu devido às tensões normais, conforme mostra o diagrama $\sigma-\varepsilon$ do concreto deste modelo. mas porque a descompressão, ou o crescimento mais lento do encurtamento no concreto, foi retardado.

Até a carga de $25 \mathrm{kN}$, a deformação nos pontos junto aos apoios foram muito próximas para todos os modelos, com desenvolvimento quase linear. O mesmo ocorreu para os pontos mais distantes até a carga de $30 \mathrm{kN}$. Isto se deve à predominância do mecanismo resistente de viga naquelas seções, livres, até então, do arqueamento dos esforços de compressão. A proximidade destes resultados mostra que a variação da qualidade do concreto tem pouca influência nos resultados. 


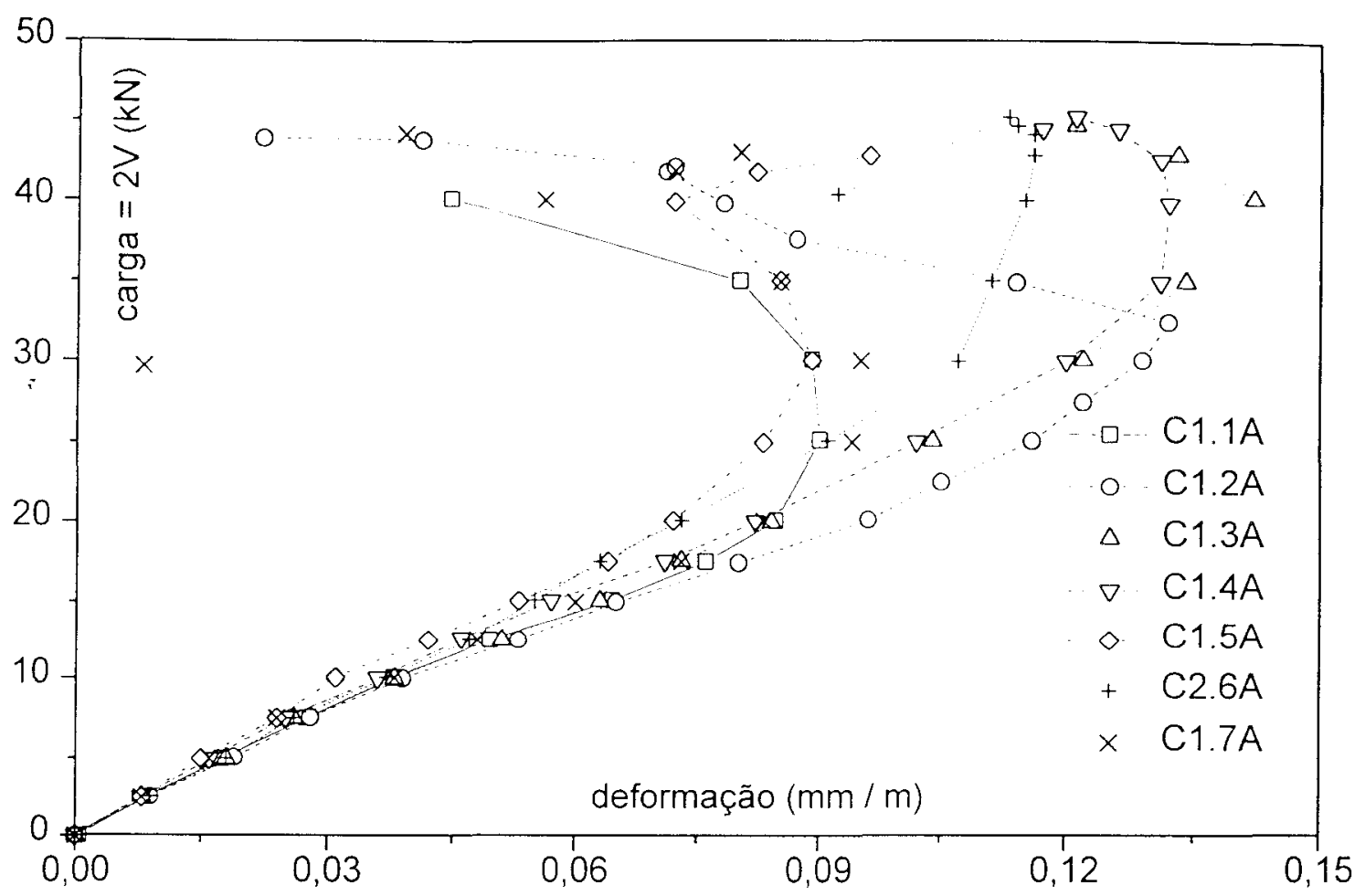

Figura 4.50 - Ponto mais solicitado no concreto: série A, posição C1 ou C2

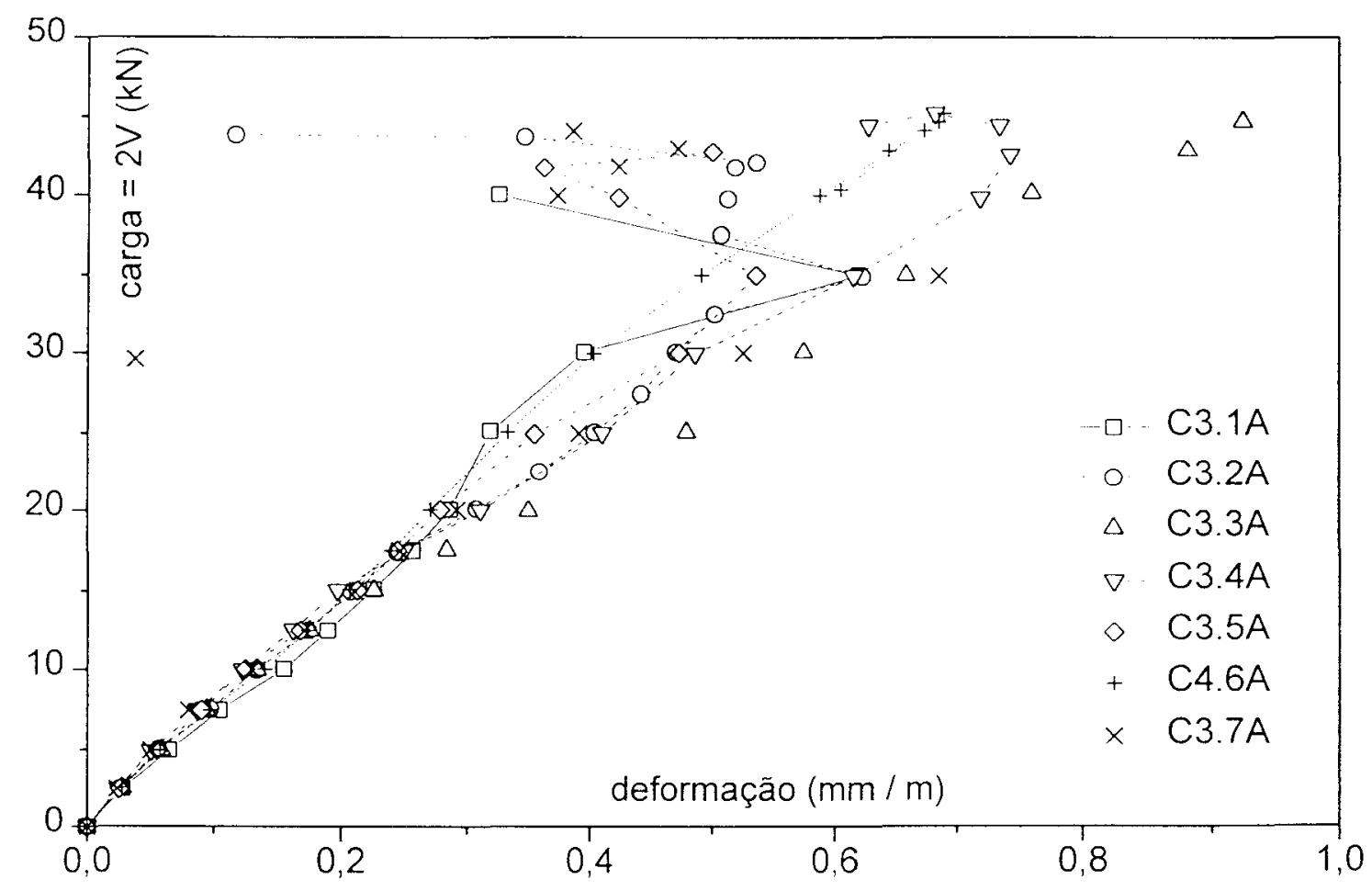

Figura 4.51 - Ponto mais solicitado no concreto: série A, posiçâo C3 ou C4 


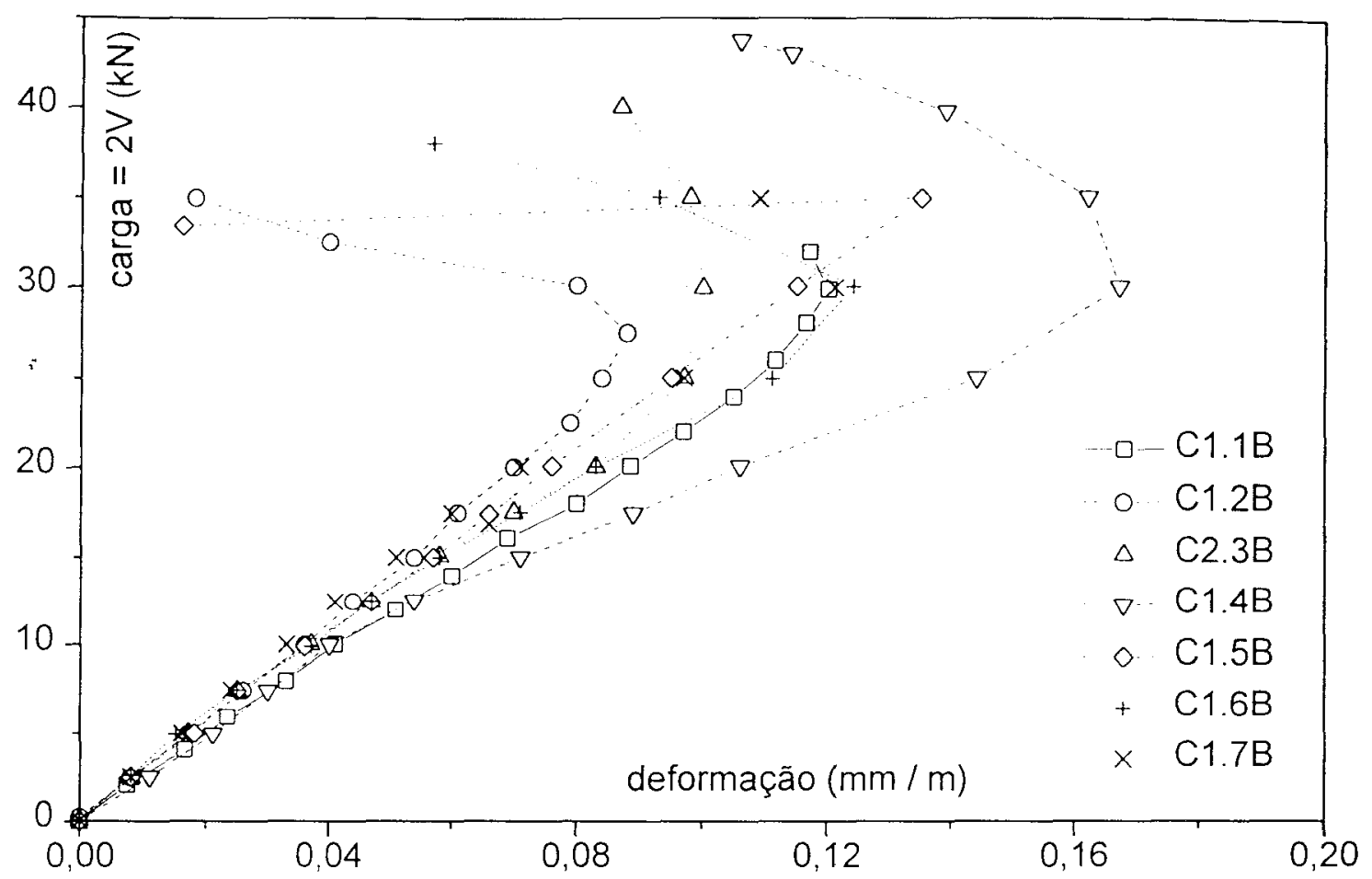

Figura 4.52 - Ponto mais solicitado no concreto: série B, posição C1 ou C2

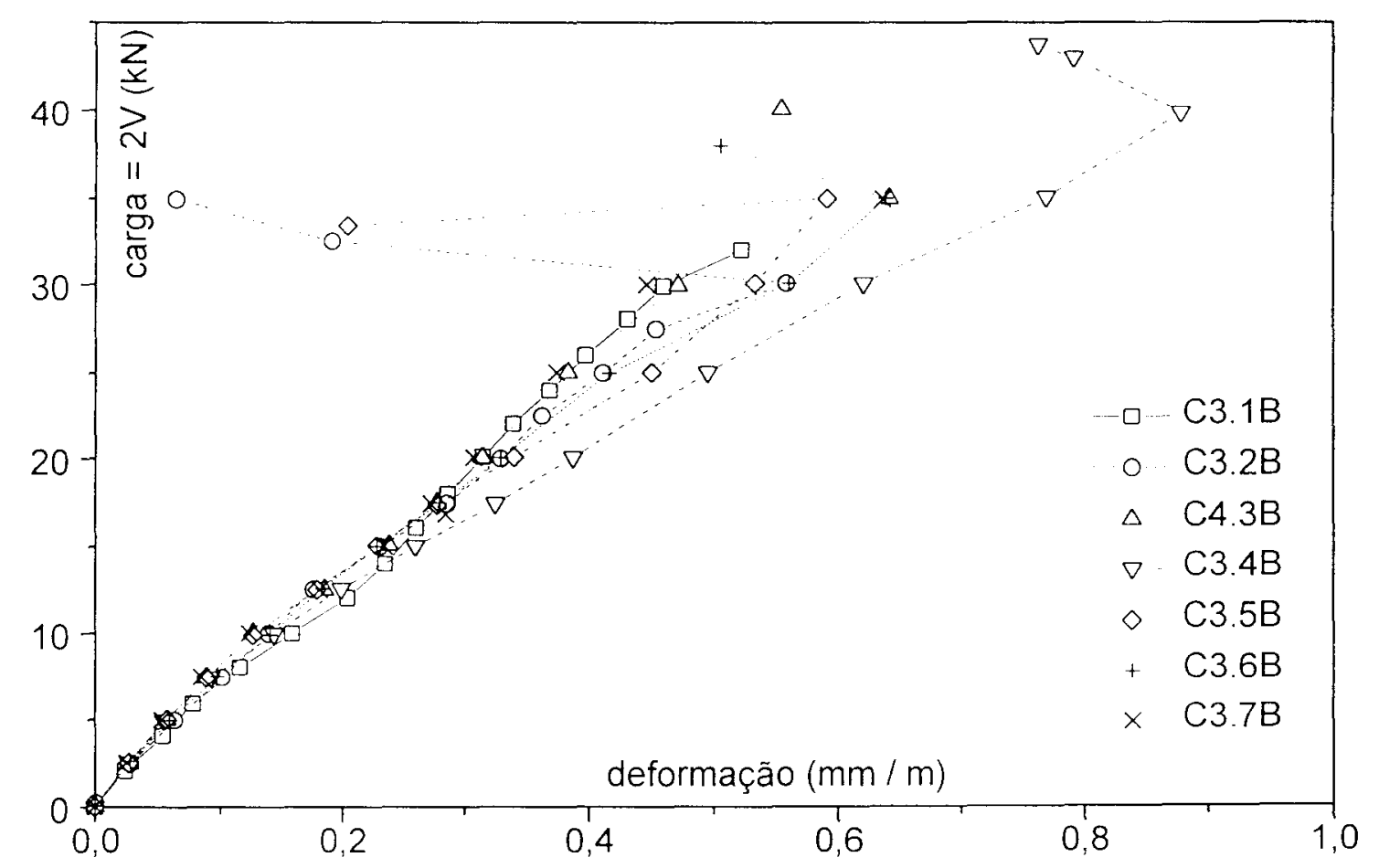

Figura 4.53 - Ponto mais solicitado no concreto: série B, posição C2 ou C4 


\section{7 - CONCLUSÕES PARCIAIS}

Além das observações sobre o comportamento dos modelos, especialmente no cisalhamento, e dos mecanismos associados a ele, as principais conclusões sobre a influência das fibras que efetivamente podem ser depreendidas destes ensaios são:

- A introdução das fibras piora a trabalhabilidade do concreto proporcionalmente ao volume adicionado. especialmente no caso da fibra de polipropileno.

- As principais vantagens nas propriedades do concreto decorrentes da introdução das fibras de aço foram um discreto aumento da resistência à tração, no caso da fibra longa, e do módulo de deformação longitudinal, especialmente para a fibra curta.

- No concreto com fibras a fissuração é mais difusa e a evolução das fissuras é relativamente mais lenta, especialmente no caso das fibras de aço, quase independente do volume adicionado. Em consequência, os deslocamentos são menores.

- Nas vigas sem estribos só houve aumento significativo da dutilidade com a adição de $2 \%$ de fibras de aço, quando se afastou o instante do aparecimento da fissura diagonal do instante da ruína, devido à atuação eficiente das fibras como armadura de cisalhamento. Para a fibra de aço curta, o desempenho foi similar ao do modelo de referência com estibos, comprovando a possibilidade de subsitituição dos estribos pelas fibras. desde que em quantidades compativeis.

- Nas vigas com estribos, em quatro modelos se alterou o modo de ruptura, sugerindo maior eficiência das fibras nesta situação. Em praticamente todos os modelos com fibras a ruptura foi mais dútil.

- A introdução das fibras aumenta a resistência ao cisalhamento e pode alterar a forma da ruptura.

- Há diferenças na atuação das fibras de aço e de polipropileno no cisalhamento, devido principalmente à diferença no módulo de deformação longitudinal dos materiais. A diferença se manifesta principalmente na tensão nos estribos, menores no caso do concreto reforçado com fibra de aço. Em qualquer caso, o controle mais eficiente da fissuração aumenta a contribuição dos mecanismos resistentes alternativos. 


\section{CAPÍTULO 5 - ENSAIOS DAS VIGAS DE SEÇÃO DUPLO-T}

Estes ensaios constituem a etapa principal do trabalho experimental, onde se estuda o comportamento resistente de vigas de microconcreto de seção transversal duplo-T com taxas reduzidas de armadura de cisalhamento. A redução da armadura transversal se insere num contexto de racionalização da produção e possível diminuição dos custos, já discutidos anteriormente. A introdução da protensão e das fibras, ao melhorar o desempenho estrutural, podem viabilizar esta alternativa em diversas situações de projeto.

\section{1 - OBJETIVOS}

Os efeitos da protensão em relação às solicitações normais são bastante significativos, especialmente para os requisitos dos estados de utilização aos quais a peça deve atender. Este assunto é praticamente consensual entre os pesquisadores. Em relação ao cisalhamento, a melhoria no comportamento em serviço também é significativa, mas no estado limite último a influência da protensão é tema ainda controverso e objeto de inúmeros estudos, conforme se comentou no Capítulo 2.

Com a adição das fibras, espera-se tornar a ruptura por cisalhamento mais dútil, o que é particularmente importante nas peças com taxa de armadura transversal reduzida, e viabilizar a substituição parcial dos estribos, já que as fibras efetivamente podem funcionar como armadura de cisalhamento, conforme registram os inúmeros trabalhos relacionados na bibliografia e os resultados dos ensaios preliminares.

Ao definir a influência destes parâmetros na resistência ao cisalhamento, espera-se oḅter resultados conclusivos sobre a possibilidade de execução de peças

delgadas com poụca armadura transversal, estabelecendo possíveis limitações decorrentes da diminuição da armadura de cisalhamento e as situações em que esta alternativa é viável. 


\section{2 - METODOLOGIA}

Baseado nos resultados dos ensaios das vigas de seção quadrada, optou-se por prosseguir os estudos utilizando-se a fibra de aço de $2,54 \mathrm{~cm}$ e a fibra de polipropileno. Para possibilitar a análise de outros parâmetros importantes, tais como a protensão e a taxa de armadura transversal, o volume de fibras foi mantido sempre constante: 1\% para a fibra de aço e $0,5 \%$ para a fibra de polipropileno, além dos modelos sem fibras.

A seção transversal escolhida, duplo-T, é representativa das peças de concreto protendido e tem as paredes relativamente delgadas. A espessura da alma se situa entre os valores convencionalmente utilizados nas peças de concreto armado/protendido e de argamassa armada. Além disso, ela não limita a resistência dos modelos devido à ruína prematura e indesejável causada pelo esmagamento do concreto da alma.

A relação comprimento/altura adotada $(l / h=13,3)$ possibilita a utilização da fôrma em futuros ensaios de flexão, tanto de peças de concreto protendido, como de concreto armado.

Além de um modelo piloto executado para testar os procedimentos relacionados com a produção e o ensaio, foram moldados e ensaiados outros nove modelos. O conjunto pode ser dividido em três séries de três vigas cada uma. com objetivos distintos e bem definidos:

a) As três primeiras vigas foram executadas sem protensão e com taxa reduzida de armadura de cisalhamento, variando-se apenas as características do concreto, para estudar a influência das fibras.

- V1 - modelo de referência, sem fibras e sem protensão;

- V2 - modelo sem protensão com $0,5 \%$ de fibra de polipropileno;

- V3 - modelo sem protensão com $1 \%$ de fibra de aço.

b) Nas três vigas seguintes manteve-se a mesma taxa de armadura transversal e a mesma armadura longitudinal dos modelos anteriores, sendo que as cordoalhas foram pré-tracionadas. Além da análise da influência das fibras, agora em vigas protendidas, a comparação dos resultados destes modelos com os correspondentes anteriores permite também o estudo da influência da protensão em peças com taxa reduzida de armadura transversal. com fibras ou sem fibras.

- V4 - mọdelo protendido sem fíbras:

- V5 - modelo protendido com 0,5\% de fibra de polipropileno;

- V6 - modelo protendido com 1\% de fibra de aço. 
c) Nos três últimos modelos manteve-se a mesma força de protensão da série anterior e variou-se a armadura transversal e as fibras, para avaliar o comportamento destas vigas em situações limites de armadura transversal reduzida.

- V7 - modelo protendido sem estribos e sem fibras;

- V8 - modelo protendido sem estribos e com 0,5\% de fibra de polipropileno;

- V9 - modelo protendido com estribos, mas com espaçamento maior que o das vigas das séries anteriores, e com 1\% de fibra de aço.

Todos os modelos protendidos foram executados com a mesma força de protensão, limitada pela verificação da segurança da peça na fabricação, durante a transferência da força para o concreto. Para isso, a força máxima ancorada em cada cordoalha inicialmente admitida foi de $42 \mathrm{kN}$. Desprezando-se as perdas de tensão até o instante da liberação das cordoalhas. isso resultaria numa tensão de tração na face superior próxima de 2,8 $\mathrm{MPa}$, desconsiderando-se qualquer alívio decorrente da ação do peso próprio. As perdas devidas ao encurtamento elástico do concreto, relaxação das cordoalhas e retração do concreto até o dia do ensaio reduziriam a força de protensão até $35 \mathrm{kN}$, valor adotado no dimensionamento dos modelos protendidos.

Portanto, variou-se apenas o tipo do concreto, a força de protensão e a taxa de armadura transversal. Outros parâmetros importantes no estudo do cisalhamento foram mantidos constantes em todos os ensaios, tais como a relação a/d, o tipo de carregamento, a taxa de armadura longitudinal e o diâmetro máximo dos agregados.

Dentre eles, o valor de a/d é o mais importante, devido à diferença na trajetória das cargas e à variação da relação V/M, que representa o grau de fissuração da peça. Os modelos teóricos normalmente consideram duas situações: carga próxima do apoio, até 2,5-3,0d, e carga distante do apoio, maior que $3 \mathrm{~d}$. No primeiro caso, a transmissão das forças para o apoio ocorre numa única biela; no segundo, outros mecanismos são acionados, especialmente o de treliça. Para mensurar apenas a influência da trajetória da carga. os resultados devem ser ponderados pela resistência da peça. Neste caso. a posição crítica da carga é aproximadamente igual a $3 \mathrm{~d}$.

A introdução da protensão também altera o panorama da fissuração. Assim, os efeitos da protensão e da posição do carregamento se confundem. Além disso, a definição do grau de protensão normalmente depende da solicitação a que a peça está submetida, ou seja, depende da relação a/d. Em vigas de alma fina, a relevância deste assunto é maior e ele deve ser tratado em outros trabalhos.

O valor de a/d adotado neste trabalho é maior que o valor crítico. No entanto. como se garantiu a segurança dos modelos contra a ruptura por flexão, nesta situação a 
transferência das forças até os apoios não ocorre diretamente e a contribuição das fibras em vigas com taxa reduzida de armadura transversal é decisiva.

A armadura longitudinal foi igual em todos os modelos, para evitar que a ação de pino pudesse alterar os resultados dos parâmetros de interesse. Deste modo, nos modelos sem protensão a armadura era constituída pelas mesmas cordoalhas dos modelos protendidos. mas sem o pré-alongamento. Apesar de se manter a mesma capacidade resistente à flexão, ela seria obtida com maior sacrifício do concreto.

A escolha da armadura longitudinal atendeu a dois requisitos: a segurança contra a ruptura por flexão, devido ao escoamento das cordoalhas, e a peculiaridade da execução da protensão. Como a diferença entre o comprimento da pista e o comprimento da viga era muito grande, o trecho da cordoalha fora da fôrma foi sucessivamente reaproveitado nas peças seguintes. Porisso, a tensão nas cordoalhas foi mantida sempre em níveis reduzidos, para evitar riscos durante o estiramento. A possibilidade de emenda de cordoalhas com o uso de luvas, pórtico intermediário e cordoalhas mais grossas no trecho livre foi descartada para este trabalho.

A influência do diâmetro máximo dos agregados também suscitou interesse. A contribuição obtida com o engrenamento dos agregados nas fissuras inclinadas pode ser proporcionalmente maior em peças com taxa reduzida de armadura de cisalhamento, mesmo que o agregado compativel com a seção delgada seja menor. No entanto, para as peças de microconcreto, a faixa de diâmetros utilizáveis é relativamente estreita e a fôma destes modelos não seria adequada para este estudo.

\section{3 - DIMENSIONAMENTO}

A Figura 5.1 mostra as características geométricas dos modelos. O esquema de carregamento e o detalhe das armaduras se encontram na Figura 5.2. Nos modelos protendidos. a armadura longitudinal na zona comprimida deveria absorver os esforços decorrentes da possível fissuração durante a liberação da protensão. Nestas peças foi utilizada uma armadura complementar nas extremidades, constituída de seis barras de 5 $\mathrm{mm}$ posicionadas entre as cordoalhas, num trecho de $20 \mathrm{~cm}$. As Fotos 5.1 e 5.2 mostram detalhes da armação dos modelos V1 e V4.

Nas extremidades das vigas os diafragmas minimizam a concentração de tensões devido à introdução das forças de reação nos apoios, que foram deslocados do centro do diafragma para diminuir os efeitos da transferência ainda parcial da força de protensão nesta região. 


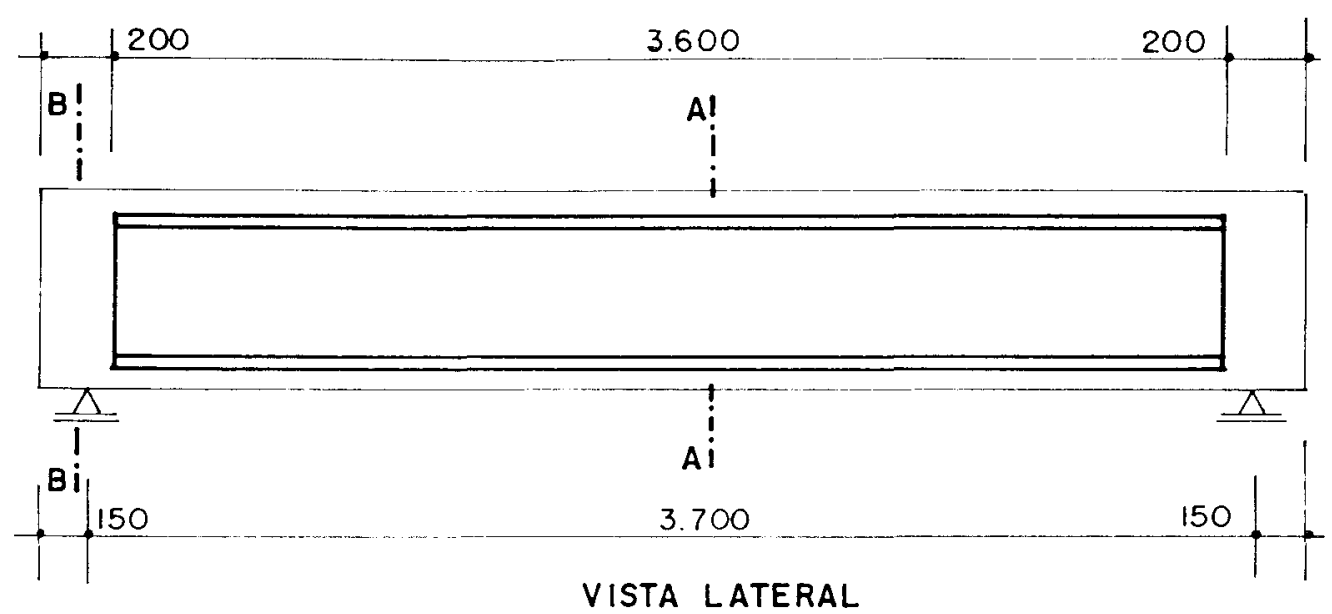

obs: medidas em $\mathrm{mm}$
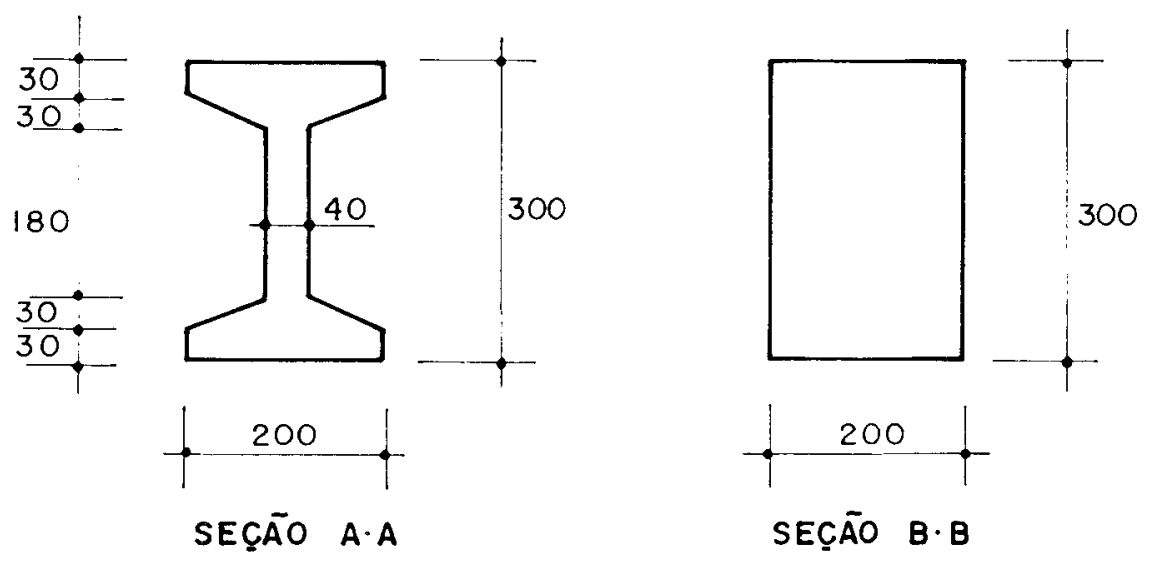

Figura 5.1 - Características geométricas dos modelos

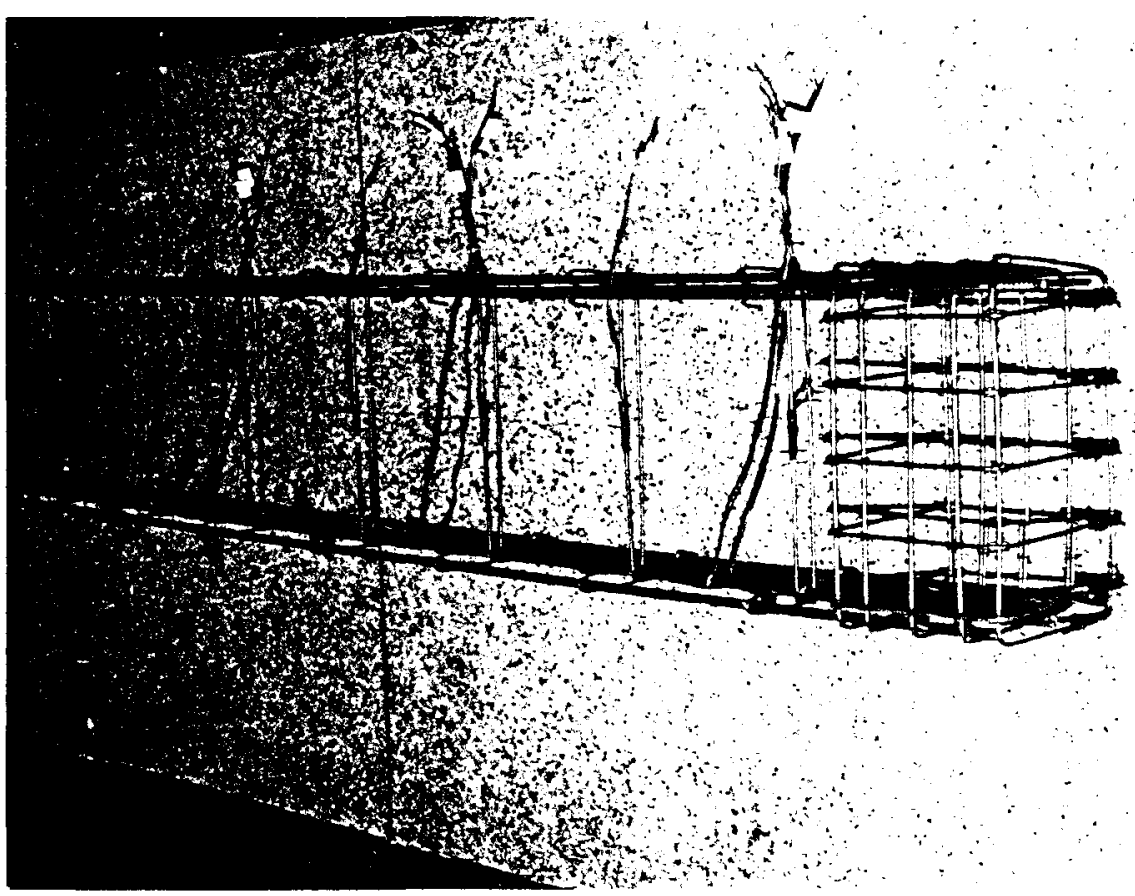

Foto 5.1 - Detalhe da armadura na extremidade do modelo V4 

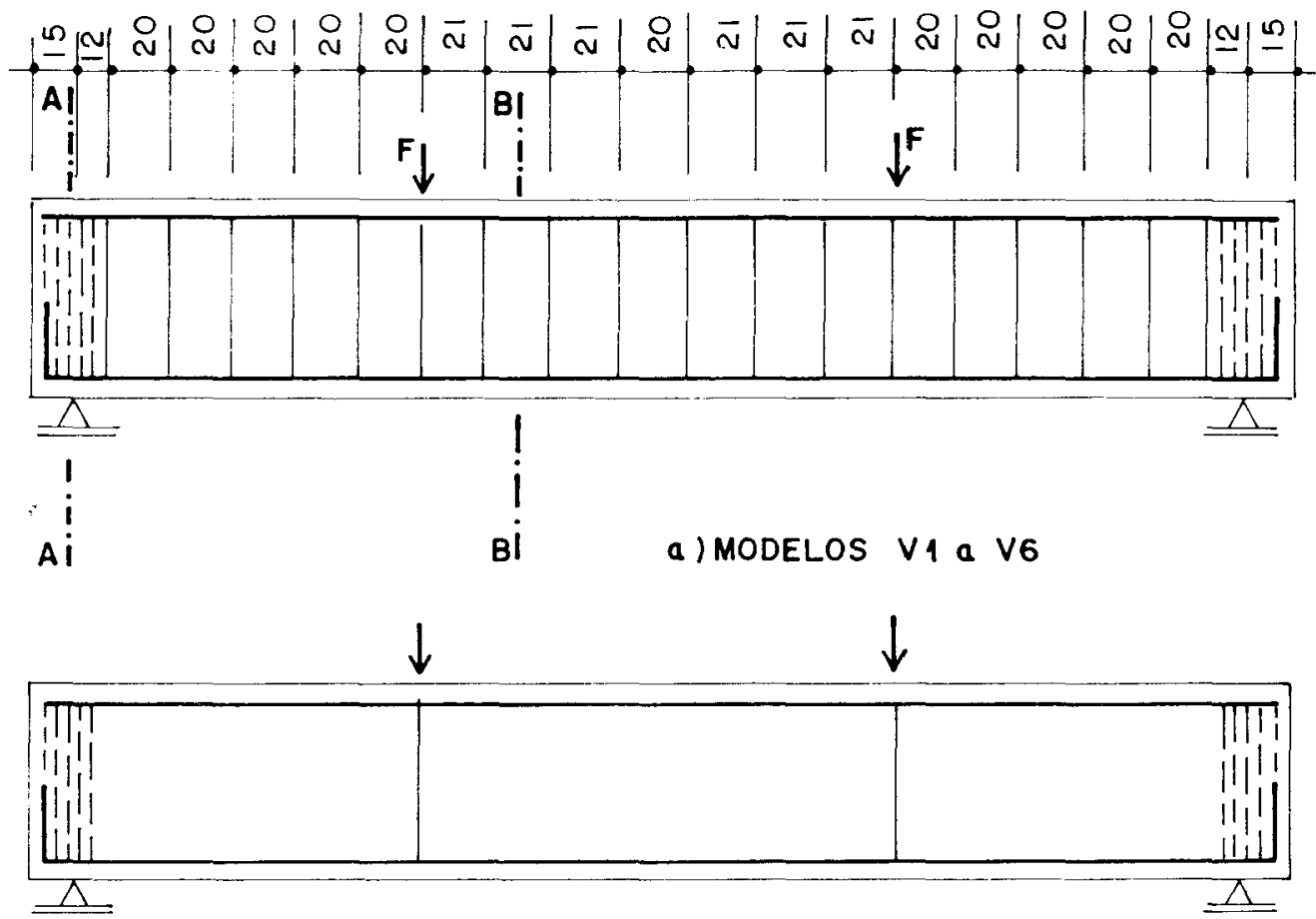

b) MODELOS V7E V8

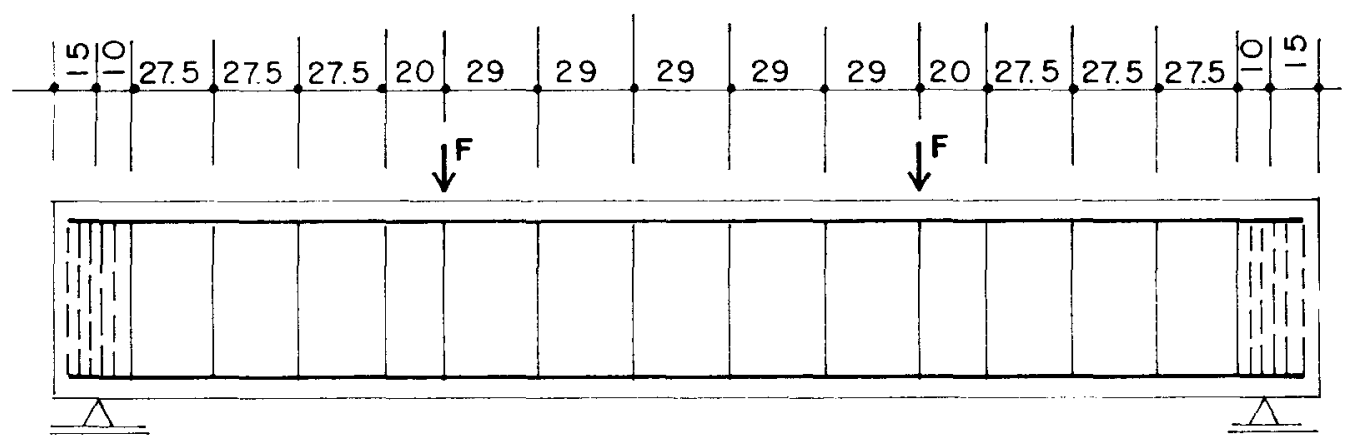

c) MODELO V9

$$
\begin{aligned}
& \left.N_{1}-2 \phi 4.2 \mathrm{~mm}+1 \phi 6.3 \mathrm{~mm} \text { ( } V_{1} \text { a } v_{3}\right) \\
& 3 \phi 6.3 \mathrm{~mm} \text { ( } \vee 4 \text { a } \vee 9)
\end{aligned}
$$

N2- $3 \phi 3 / 8 "$ CORDOALHA CP 190-RB (4.00)
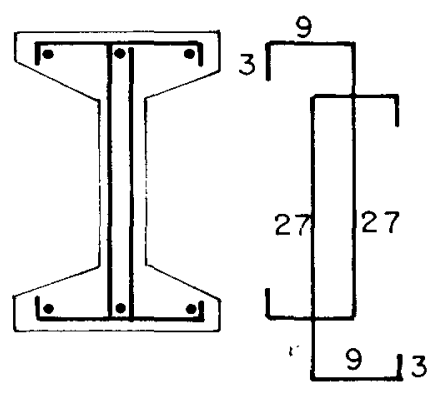

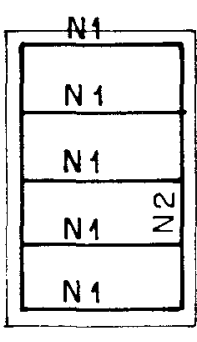

VISTA FRONTAL

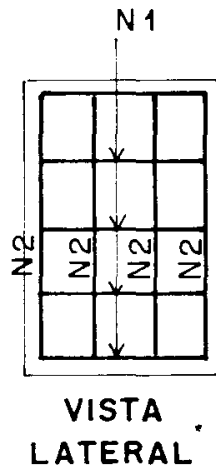

$\mathrm{N1}_{4.2 \mathrm{~mm}}$
17
17

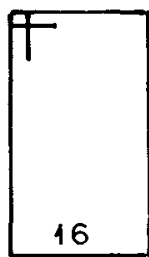

27

$\mathrm{N2}-$ $4 \phi 4.2 \mathrm{~mm}$

Figura 5.2 - Armação dos modelos: a) V1 a V6

b) V7 e V8

c) modelo V9 


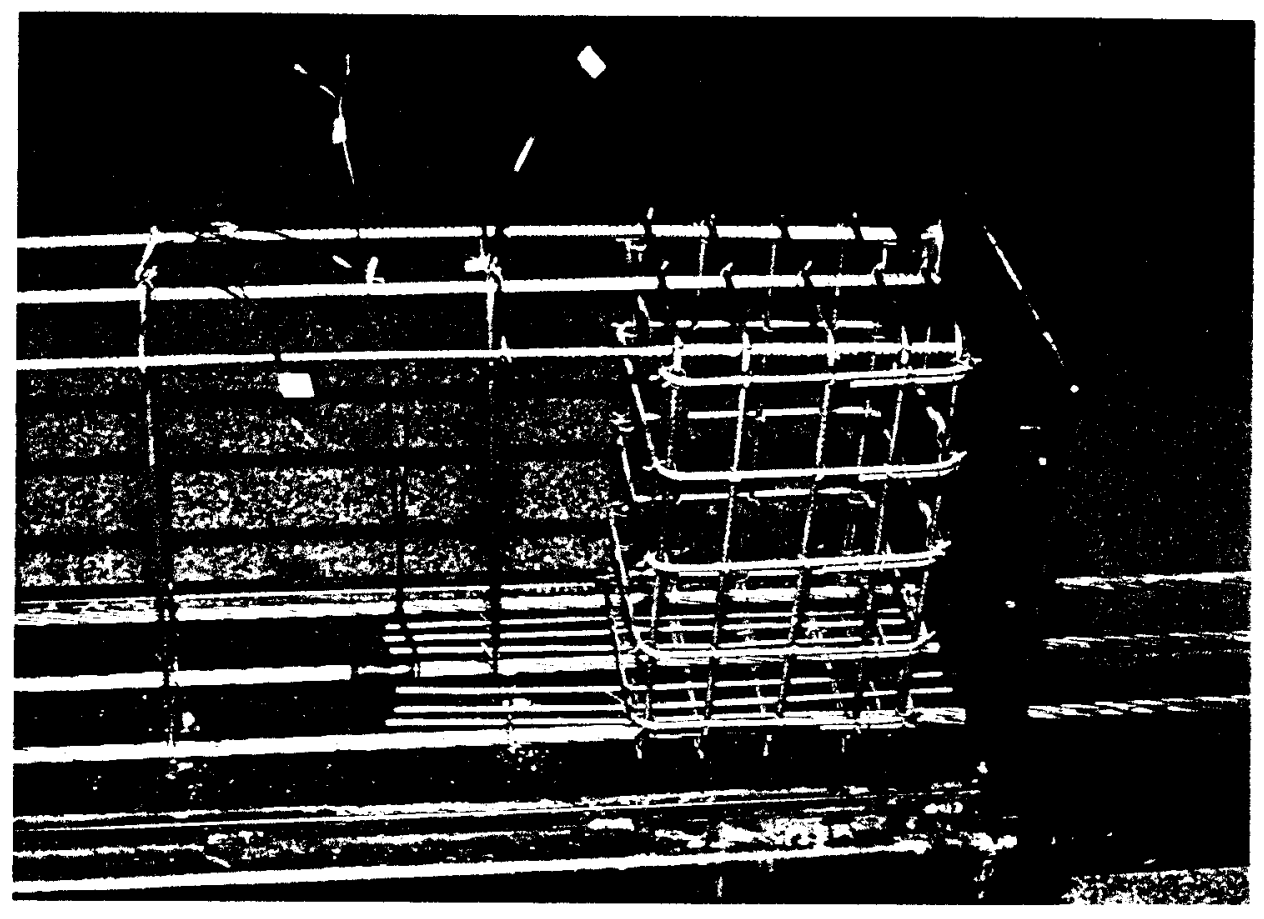

Foto 5.2 - Detalhe da armação na extremidade do modelo V4

A Tabela 5.1 apresenta as principais características relativas à composição do concreto, à presença da protensão e à armadura transversal de todos os modelos.

Tabela 5.1 - Características dos modelos

\begin{tabular}{|c|c|c|c|c|c|c|}
\hline modelo & fibra & $\begin{array}{c}\mathrm{A}_{\text {sw.e }} \\
\left(\mathrm{cm}^{2} / \mathrm{m}\right)\end{array}$ & $\rho_{\text {w.e }}$ & $\begin{array}{c}\text { s (estribo) } \\
(\mathrm{cm})\end{array}$ & $\eta$ & Protensão \\
\hline V1 & - & 0,9 & 0,225 & 20 & 0,237 & sem \\
\hline V2 & $0,5 \% \mathrm{P}$ & 0,9 & 0,225 & 20 & 0,237 & sem \\
\hline V3 & $1 \% \mathrm{~A}$ & 0,9 & 0,225 & 20 & 0,237 & sem \\
\hline V4 & - & 0,9 & 0,225 & 20 & 0.237 & com \\
\hline V5 & $0,5 \% \mathrm{P}$ & 0,9 & 0,225 & 20 & 0,237 & com \\
\hline V6 & $1 \% \mathrm{~A}$ & 0,9 & 0,225 & 20 & 0.237 & com \\
\hline V7 & - & - & - & - & - & com \\
\hline V8 & $0.5 \% \mathrm{P}$ & - & - & - & - & com \\
\hline V9 & $1 \% \mathrm{~A}$ & 0,65 & 0,162 & 28 & 0,171 & com \\
\hline
\end{tabular}

Todos os modelos foram dimensionados para atingir a ruina por cisalhamento. $\mathrm{O}$ modelo de referência V1, base do dimensiondmento, foi projetado de modo que o escoamento das cordoalhas ocorresse bem depois da ruptura por cisalhamento, pois se esperava um aumento significativo na resistência ao cisalhamento para os modelos V 5 
e V6, devido à introdução das fibras e da protensão. Para a resistência à flexão, ao contrário, não se esperava variação significativa entre os modelos. As fibras aumentam a resistência ao cisalhamento e alteram pouco a resistência à flexão, conforme resultados da bibliografia e dos ensaios das vigas de seção quadrada. O mesmo raciocínio vale para a protensão, mantendo-se a equivalência da armadura longitudinal.

$\mathrm{O}$ estado limite último devido às solicitações normais é atingido quando a deformação nas cordoalhas devido ao carregamento ultrapassa $1 \%$ e está relacionado com a fissuração do concreto. Este valor é muito próximo da deformação de escoamento das cordoalhas.

Assim, apesar da diferença nas deformações entre os modelos protendidos e não protendidos no estado limite último devido à deformação de pré-alongamento, a resistência à flexão é aproximadamente igual nos dois casos, pois, a partir de 1\%, o aumento de tensão nas cordoalhas é muito pequeno. Simplificadamente, adotou-se nos cálculos o valor de $\mathrm{f}_{p y}$ para a determinação da resistência à flexão. Este procedimento seria exato caso a tensão de estiramento fosse maior, próxima do limite admissivel.

A preocupação com a intensidade da fissuração do concreto no limite da resistência à flexão dos modelos sem protensão fícou minimizada pela diferença entre o instante da ruptura por cisalhamento e do escoamento das cordoalhas. Para a carga teórica de ruptura por cisalhamento, a deformação esperada nas cordoalhas era próxima de $0.3 \%$, calculada em estádio II, ou seja, é muito menor que o limite último convencional estabelecido para o concreto.

Desprezando-se a influência das fibras, a força cortante que provoca o escoamento dos estribos e o escoamento da armadura longitudinal nos modelos não protendidos Vl a V3 vale $26,2 \mathrm{kN}$ e $69,4 \mathrm{kN}$, respectivamente, calculadas com os valores efetivos da resistência dos materiais, exceto do concreto. A ruptura dos estribos ocorreria para força de $28,3 \mathrm{kN}$.

A variação da resistência do concreto altera pouco estes resultados. Conforme o valor de $\mathrm{f}_{\mathrm{cj}}$ dos modelos $\mathrm{V} 1$ a V3, o escoamento dos estribos, a ruptura dos estribos e o escoamento das cordoalhas eram esperados para cargas entre $25,4 \mathrm{kN}-27 \mathrm{kN}, 27,7 \mathrm{kN}$ $-29,4 \mathrm{kN}$ e $68,6 \mathrm{kN}-69,8 \mathrm{kN}$, respectivamente.

A armadura transversal adotada, $0,90 \mathrm{~cm}^{2} / \mathrm{m}$ ou $\rho_{\mathrm{w}}=0,225$, é, portanto, menor que a armadura necessária para possibilitar o escoamento da armadura longitudinal, igual a $3,3 \mathrm{~cm}^{2} / \mathrm{m}$, para força cortante de $70 \mathrm{kN}$. Segundo a NBR-6118, a armadura mínima neşte caso é de $0,56 \mathrm{~cm}^{2} / \mathrm{m}\left(\rho_{\mathrm{w}}=0,14\right)$.

Se os modelos fossem dimensionados com os valores nominais de resistência dos materiais, a armadura necessária para permitir o escoamento das cordoalhas com $70 \mathrm{kN}$ seria de $4,2 \mathrm{~cm}^{2} / \mathrm{m}$. Além disso, o espaçamento entre os estribos nos modelos 
V1 a V3 é maior que o máximo permitido pela NBR-6118, neste caso igual a d/2 ou 14 $\mathrm{cm}$. O grau de armação ao cisalhamento dos modelos não protendidos vale 0,237.

A tensão limite $\tau_{w u}$ igual a $4,5 \mathrm{MPa}$ seria atingida apenas para carga de 50,4 $\mathrm{kN}$, o que garante, a priori, a segurança contra a ruptura das bielas. Sabe-se, no entanto, que a capacidade resistente deve ser maior que a prevista pelo cálculo teórico, devido à :presença das fibras e da protensão.

Segundo o CEB-90, a inclinação das bielas nos modelos V1 a V3 seria de 13 graus, ou seja, bem abaixo do limite admissível, e o menor valor de $\rho_{w}$ para aplicação do modelo de treliça seria $0,10 \%$.

Nos modelos protendidos, a estimativa da resistência ao cisalhamento depende do tipo de ruptura. Para peças normalmente armadas, supõe-se que a viga atinja antes o estado limite último devido ao escoamento da armadura longitudinal e que a influência da protensão possa ser analisada em termos do coeficiente $\psi_{1}$, conforme a formulação do anexo da NBR-6118 que trata deste assunto. Ele majora a contribuição do concreto de acordo com a relação entre o momento fletor de descompressão e o momento solicitante máximo.

Nenhum dos modelos deste trabalho é compatível com esta situação e a resistência ao cisalhamento ficaria subestimada. Além disso, a definição do momento fletor solicitante máximo pode gerar interpretações distintas. Pode-se considerá-lo correspondente ao escoamento das cordoalhas ou à ruptura teórica por cisalhamento. Neste último caso, deve-se considerar a influência da protensão na carga limite e, portanto, o momento solicitante máximo depende da força cortante de ruptura, que varia com a protensão. Estas duas alternativas resultam em valores diferentes para o coeficiente $\beta_{1}$ (que majora o coeficiente $\psi_{1}$, iguais a 1,28 e 1,6 , respectivamente.

A influência da protensão na resistência ao cisalhamento dos modelos deste trabalho pode ser melhor quantificada através do mesmo procedimento utilizado nas peças sem estribos. Como a ruptura por cisalhamento é anterior ao escoamento das cordoalhas, a fissuração não anula os efeitos da protensão, mesmo próximo da ruptura. Assim, o acréscimo de resistência é equivalente à força cortante que provoca a descompressão na seção mais solicitada. Para a força de protensão efetiva esperada no dia do ensaio, ela vale $20 \mathrm{kN}$.

Os principais parâmetros do dimensionamento são apresentados na Tabela 5.2 , que contém dois valores para a força cortante última, correspondentes ao escoamento e a ruptura dos estribos. No caso dos modelos protendidos, ela é apresentada segundo os dois critérios discutidos acima. Para a formulação baseada no aumento de $\psi_{1}$, o valor foi calculado supondo-se o momento máximo correspondente ao instante da ruptura teórica por cisalhamento, considerando-se a influência da protensão $\left(\beta_{1}=1,6\right)$. 
Tabela 5.2 - Parâmetros do dimensionamento

\begin{tabular}{|c|c|c|c|}
\hline \multirow{2}{*}{ modelo } & \multirow{2}{*}{$\begin{array}{c}\mathrm{V}_{\mathrm{u}, \mathrm{f}} \\
(\mathrm{kN})\end{array}$} & \multicolumn{2}{|c|}{$\mathrm{V}_{\mathrm{u}, \mathrm{c}}(\mathrm{kN})$} \\
\cline { 3 - 4 } & & baseado em $\psi_{1}$ & $\begin{array}{c}\text { baseado na } \\
\text { descompressão }\end{array}$ \\
\hline V1 a V3 & 69,4 & $26,2 / 28,3$ & - \\
\hline V4 a V6 & 69,4 & $32,3 / 34,6$ & $46,2 / 48,3$ \\
\hline V7 e V8 & 69,4 & 9,8 & 29,8 \\
\hline V9 & 69,4 & $21,9 / 23,6$ & $41,9 / 43,6$ \\
\hline
\end{tabular}

Observa-se que a ruptura teórica por cisalhamento é anterior ao escoamento das cordoalhas em todos os modelos. Nos cálculos foi utilizada a resistência efetiva dos materiais, exceto a do concreto. A força de protensão no dia do ensaio foi estimada em $35 \mathrm{kN}$ por cordoalha.

O momento fletor que provoca o aparecimento da primeira fissura de flexão, calculado em estádio Ib, considerando a plastificação do concreto, para os modelos sem protensão pode ser calculado segundo a expressão abaixo. Para carga aplicada a $112 \mathrm{~cm}$ dos apoios, a força cortante correspondente é de $6,3 \mathrm{kN}$.

$$
M r=2080 f_{i k}(\mathrm{em} \mathrm{kN.cm})
$$

\section{4 - INSTRUMENTAÇÃO}

As vigas foram instrumentadas com extensômetros elétricos na face comprimida do concreto, na armadura longitudinal e nos estribos. Também foram posicionadas rosetas constituídas de três extensômetros na metade da altura da alma, em algumas posições entre dois estribos, na região de uma possível biela de concreto. As rosetas mediam as deformações do concreto da alma nas direções longitudinal, transversal e inclinada a 45 graus em relação ao eixo da viga, no sentido do caminhamento das forças aplicadas para os apoios.

Todos os estribos compreendidos entre os pontos de introdução do carregamento e os apoios foram instrumentados. O concreto e a armadura longitudinal foram instrumentados em seções coincidentes, no meio do vão e em três pontos de cada trecho onde atua a força cortante, sempre entre dois estribos. Na viga V1, as rosetas foràm colocadas nas mesmas seções em* que o concreto e a armadura foram instrumentados. Nos demais modelos elas foram colocadas somente em duas seções de cada lado da viga, não coincidentes com as anteriores. 
No caso das cordoalhas, seria inviável a colocação de extensômetros nos seus seis fios externos. Nos ensaios preliminares para caracterização do material, a colocação de dois extensômetros em dois fios diametralmente opostos se mostrou eficiente. Conforme se comentou no capítulo anterior, a inclinação da direção do extensômetro em relação ao eixo da cordoalha resulta em valores de deformação um ;pouco menores que os esperados.

A instrumentação da viga V1 foi a mais completa de todo o conjunto, seguindo o mesmo procedimento adotado nos ensaios preliminares. De um lado da viga, no lado esquerdo, que se refere aos extensômetros ímpares, foram colados dois extensômetros no concreto, próximos às bordas da face superior, e dois extensômetros nas três cordoalhas, em cada seção instrumentada, exceto na posição A3, onde foram colocados extensômetros somente na cordoalha central. Deste lado do modelo, os cinco estribos situados na região de atuação da força cortante foram instrumentados nos dois ramos. O estribo localizado sob o ponto de aplicação da carga também tinha um extensômetro num dos ramos. As rosetas foram instaladas nas duas faces da alma, nas três seções instrumentadas. Havia um total de 49 extensômetros deste lado da viga.

Do lado direito, que correspondente aos extensômetros pares, havia um extensômetro no concreto, no centro da face comprimida, e dois extensômetros na cordoalha central em cada seção instrumentada. Nos estribos situados no vão de cisalhamento foram aplicados extensômetros em apenas um ramo. As rosetas foram colocadas somente em uma das faces da alma. Inadvertidamente, esqueceu-se de instrumentar a face comprimida do concreto no meio do vão nesta viga. No total, ela tinha 72 extensômetros elétricos.

Também foram ligados ao sistema de aquisição de dados outros seis canais, correspondentes aos defletômetros indutivos e à célula de carga conectada ao macaco.

Nos modelos seguintes, V2 a V9, optou-se por colocar, em cada seção instrumentada, apenas um extensômetro por estribo, já que os ramos são muito próximos, um extensômetro no centro da face comprimida do concreto e dois extensômetros na cordoalha central. Nos modelos protendidos, as cordoalhas laterais também foram instrumentadas para o acompanhamento da força de protensão durante o estiramento e no ensaio. As rosetas foram instaladas apenas numa face, em duas seções de cada lado da viga.

Os relógios comparadores empregados para o acompanhamento das flechas foram posicionados em cinco pontos: junto aos apoios, na posição das cargas e no meio do vão. No primeiro modelo foram utilizados* defletômetros indutivos, que foram posteriormente substituídos nos outros ensaios devido aos mesmos motivos já discutidos no capítulo anterior. 
Para a identificação da instrumentação foram adotadas as letras A, C, E e R, para a armadura longitudinal, concreto, estribos e rosetas, respectivamente. Após a letra correspondente, segue o número relativo à seção instrumentada. Ao lado esquerdo correspondem os números ímpares e ao lado direito os números pares. O número 0 refere-se à seção do meio do vão. A numeração é crescente dos apoios em direção ao ponto de aplicação das cargas em todos os elementos instrumentados.

No caso dos estribos, do concreto e das rosetas, quando houver mais de um extensômetro por seção no elemento instrumentado, adiciona-se a letra fou t, referente à face da frente ou à face de trás. Para as rosetas, uma letra adicional no final identifica a direção dos extensômetros. As letras h, i e v correspondem às direções horizontal, inclinada a 45 graus e vertical. Nas cordoalhas, há sempre dois extensômetros em cada posição. Assim, acrescentam-se os números 1 e 2 , referentes aos dois fios instrumentados. Quando as deformações se referem à média entre eles, os números são substituídos pela letra m (por exemplo, Alm). Quando necessário, as letras C ou L identificam a cordoalha central ou as cordoalhas laterais (L1 e L2). A Figura 5.3 ilustra a instrumentação, a numeração e a simbologia adotadas.

\section{5 - EXECUÇÃO DA PROTENSÃO E MOLDAGEM}

As cordoalhas foram estiradas numa pista de 25 metros de comprimento, ancoradas em pórticos instalados nas suas extremidades. A altura dos pórticos de ancoragem foi definida a partir da posição das cordoalhas e da altura da mesa vibratória. As vigas foram moldadas em sua posição normal, de modo que a face tracionada ficava em contato com a fôrma. Nesta posição, o peso próprio alivia a solicitação na borda tracionada pela protensão durante a liberação das cordoalhas e diminui a altura dos pórticos de ancoragem, que podem, portanto, ser menos rígidos.

Nas duas cabeceiras da pista foram colocados dois blocos de concreto para calçar e fixar a base do pórtico durante o estiramento. Posteriormente, para a liberação das cordoalhas, eram posicionados dois macacos ao lado destes blocos em cada lado da pista. Eles empurravam a base do pórtico para liberação dos calços, o que provocava um pequeno aumento de tensão nas cordoalhas. Em seguida, os macacos eram aliviados lentamente, transferindo a força das cordoalhas para o concreto. Quando os pórticos retornavam à sua posição original, as cordoalhas eram cortadas nas extremidades das vigas. A Foto 5.3 ilustra um detalhe da cabeceira passiva. 
a)

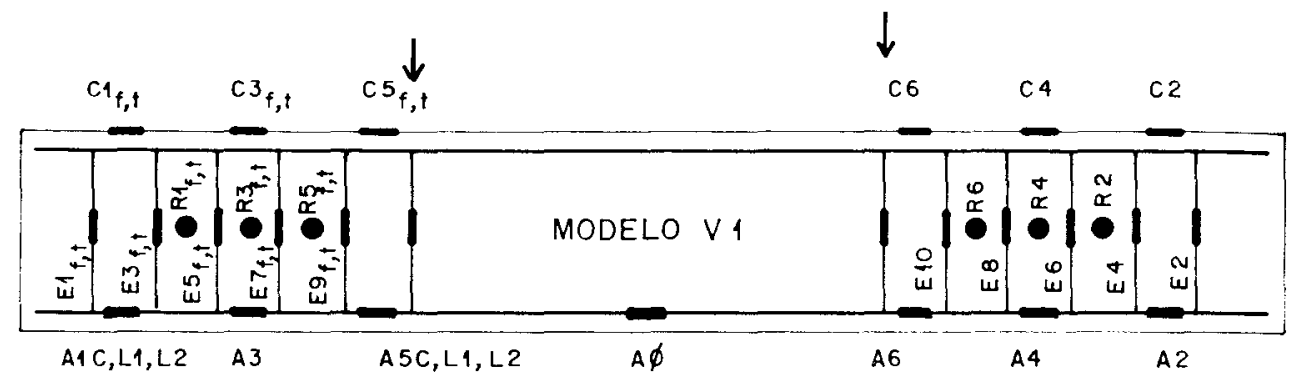

VISTA SUPERIOR

a.1)

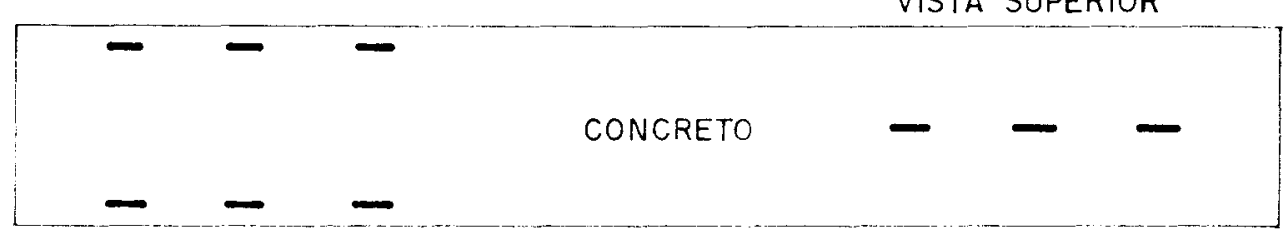

VISTA INFERIOR

a. 2)

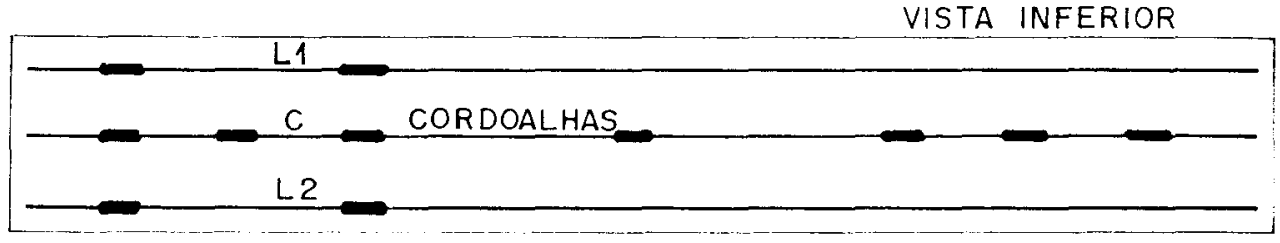

b)

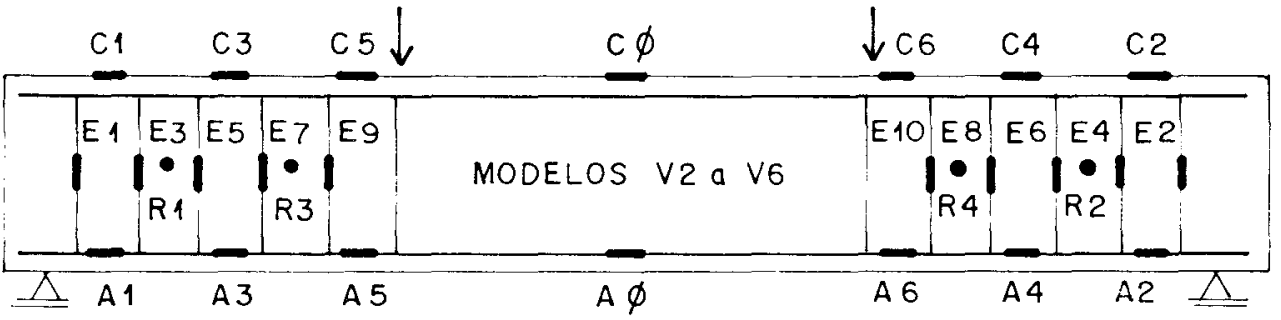

c)

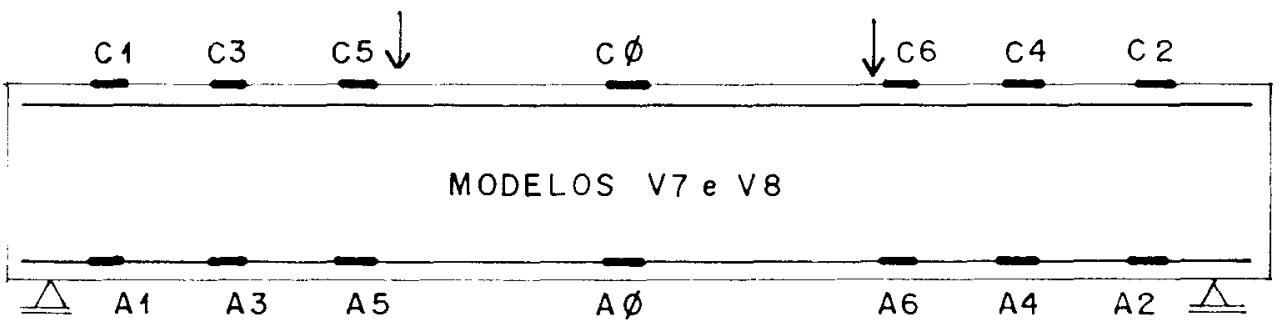

d)

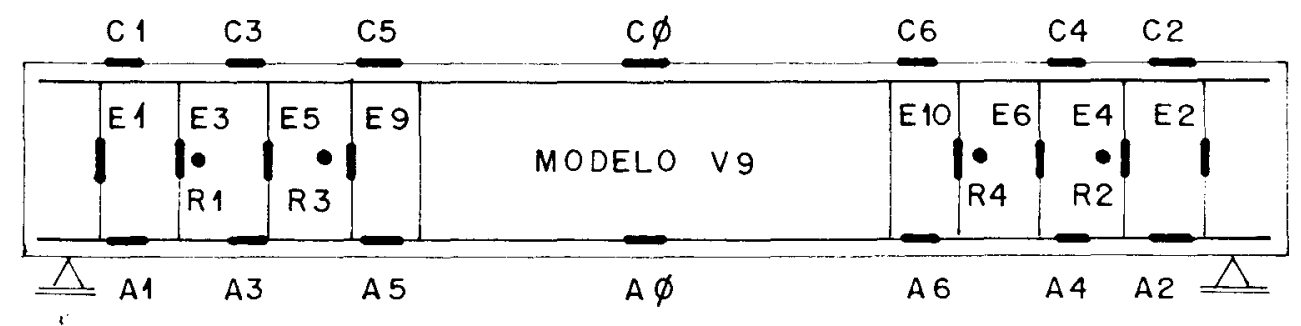

Figura 5.3 - Instrumentação dos modelos 


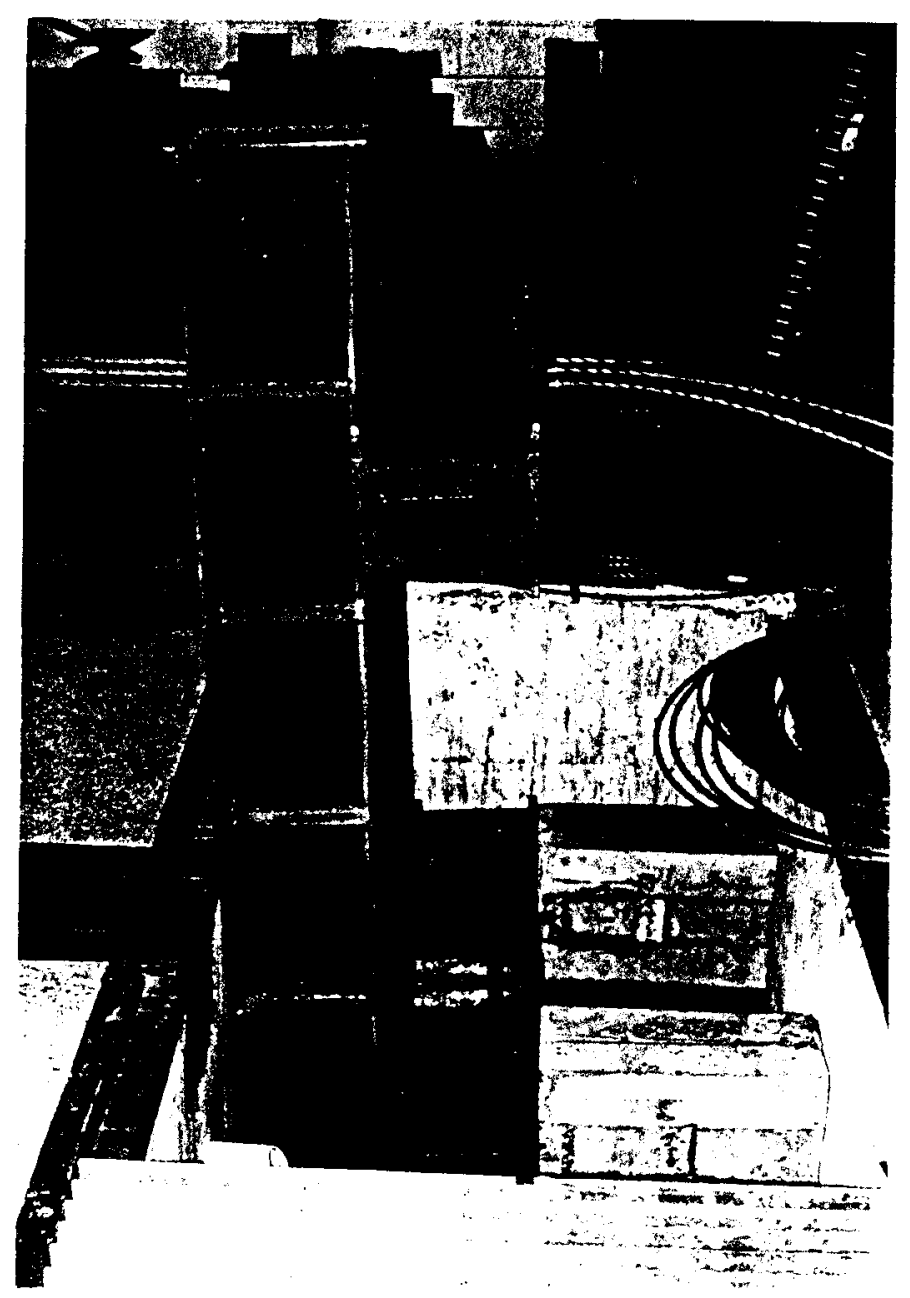

Foto 5.3 - Detalhe do pórtico na cabeceira passiva

Em cada cordoalha foi colocada uma célula de carga junto ao macaco de protensão apoiada no pórtico de ancoragem, para o acompanhamento da força aplicada. Além disso, as deformações nos extensômetros das cordoalhas proporcionavam um monitoramento adicional durante o estiramento das cordoalhas. A Foto 5.4 mostra um detalhe da cabeceira de protensão.

O diagrama tensão-deformação obtido no estiramento das cordoalhas foi utilizado como uma alternativa adicional para a avaliação da força de protensão após sua transferência para o concreto. Para cada cordoalha estirada se associava um valor do módulo de deformação longitudinal aparente. Em todos os casos observou-se um aumento do módulo em relação ao valor teórico, devido ao não alinhamento dos extensômetros com o eixo da cordoalha.

As perdas de protensão decorrentes dos diversos mecanismos de alívio (deslocaménto do pórtico, encurtamento elástico do concreto, retração e relaxação) foram estimadas à partir da variação de deformações registradas nas cordoalhas, utilizando-se o módulo aparente de cada cordoalha. 


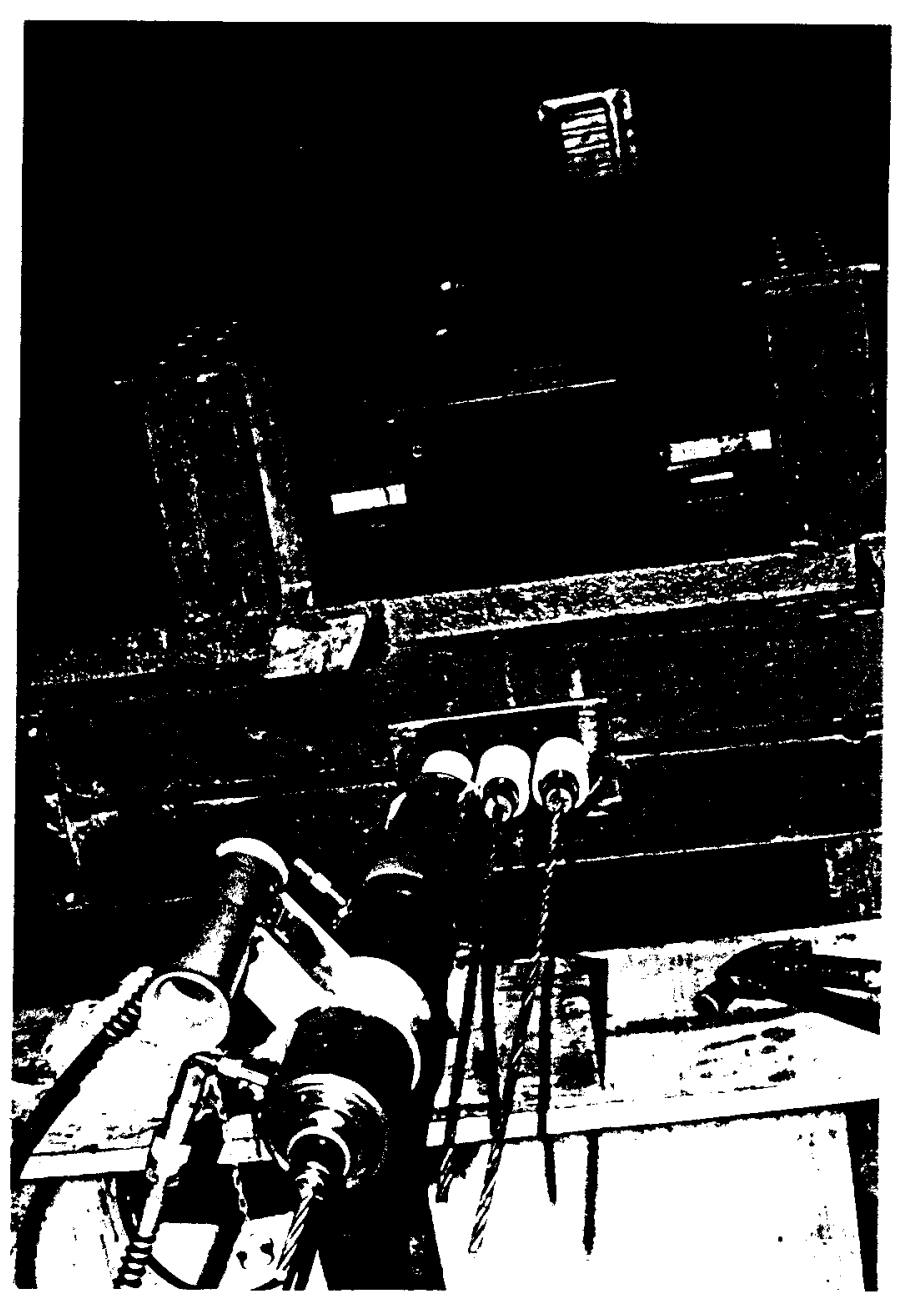

Foto 5.4 - Detalhe da cabeceira de protensão

O deslocamento do curso do macaco foi sempre maior que o alongamento teórico das cordoalhas. Isto se deve ao intervalo necessário para anular a flecha inicial das cordoalhas estendidas na pista. Em 25 metros, uma força de $43 \mathrm{kN}$ (força aplicada nas cordoalhas) provoca uma variação de comprimento de aproximadamente $90 \mathrm{~mm}$. Como o curso do macaco era de $15 \mathrm{~cm}$, a operação se dava em apenas uma etapa.

Antes do estiramento, apenas a parte inferior e os fechamentos frontais da fôrma ficavam provisoriamente posicionados. A montagem da armadura e o fechamento da fôrma eram feitos com as cordoalhas estiradas. Após a vedação dos furos do fechamento frontal a peça era concretada. O adensamento era feito com a mesa vibratória utilizada nas vigas prismáticas. Não se observou elevação de tensão nas cordoalhas devido à vibração.

Eram necessárias duas misturas na betoneira para a execução de cada viga. Simultaneąmente à concretagem, eram moldados corpos-de-prova cilíndricos para acompanhamento da resistência do concreto. Nos゙ modelos não protendidos V1 e V2, foram quatro corpos-de-prova para ensaios à compressão simples e compressão diametral no dia do ensaio de flexão. No modelo V3, este número foi aumentado para 
seis. Nos demais modelos, todos protendidos, além dos seis corpos-de-prova ensaiados no dia do ensaio de flexão (três para cada tipo de ensaio), outros quatro corpos-deprova adicionais foram moldados para ensaios antes da liberação da protensão (dois para cada tipo de ensaio), totalizando dez corpos-de-prova.

A transferência da força de protensão para o concreto se dava normalmente três ¿dias após a concretagem, quando o concreto tinha resistência compatível com os esforços a que a viga estaria submetida nesta operação. A fôrma era suspensa para retirada do fundo, liberando as partes laterais. Em seguida, a viga era recolocada na mesa sobre dois apoios relativamente móveis, que se deslocavam durante a liberação devido à diminuição do comprimento da cordoalha no trecho livre.

Inicialmente, foram estimados os seguintes valores para a força de protensão: força ancorada $\left(\mathrm{P}_{\mathrm{a}}\right)$, força após a transferência $\left(\mathrm{P}_{0}\right)$ e força no dia do ensaio $\left(\mathrm{P}_{\mathrm{t}}\right)$ iguais a $42 \mathrm{kN}, 38 \mathrm{kN}$ e $35 \mathrm{kN}$, respectivamente.

As perdas no encunhamento verificadas em trabalho anterior (FURLAN, 1991) correspondiam a um escorregamento médio de $7 \mathrm{~mm}$ do sistema de ancoragem. Para a pista de 25 metros, isso resultaria numa diminuição de tensão de $56 \mathrm{MPa}$, ou seja, numa perda de $7,1 \%$, ou $3,1 \mathrm{kN}$. Os valores obtidos neste trabalho foram menores. Houve uma diminuição média entre $1,0 \mathrm{kN}$ e $1,5 \mathrm{kN}$ em praticamente todos os modelos. Possivelmente, isso se deve ao melhor ajuste das cunhas no porta-cunhas antes do encunhamento. Em geral. a variação das deformações nos extensômetros foi compativel com a variação da força medida pela célula de carga durante esta operação.

Havia a preocupação de se avaliar continuamente a relação da força nas células de carga com as deformações nos extensômetros, para se verificar a consistência da instrumentação e possibilitar uma avaliação confiável da força nas etapas de interesse.

\section{6 - ENSAIOS}

As duas cargas concentradas eram aplicadas por dois macacos com capacidade para $200 \mathrm{kN}$, de baixo para cima, com a viga na sua posição invertida, apoiada em dois pórticos metálicos que eram ancorados numa laje de reação. A Foto 5.5 mostra uma vista geral de um modelo antes do ensaio.

O valor da carga registrado pelo sistema corresponde à média entre as forças aplicadas pelos macacos. Portanto, o valor da força cortante coincide com o valor da força aplicada. Os incrementos de carga eram iguais a $2,5 \mathrm{kN}$ ou $5 \mathrm{kN}$, conforme a etapa do ensaio. O instrumentos eram zerados após a aplicação de uma força de $1,5 \mathrm{kN}$ em cada macaco, para equilibrar o efeito do peso próprio da viga e dos apoios. 


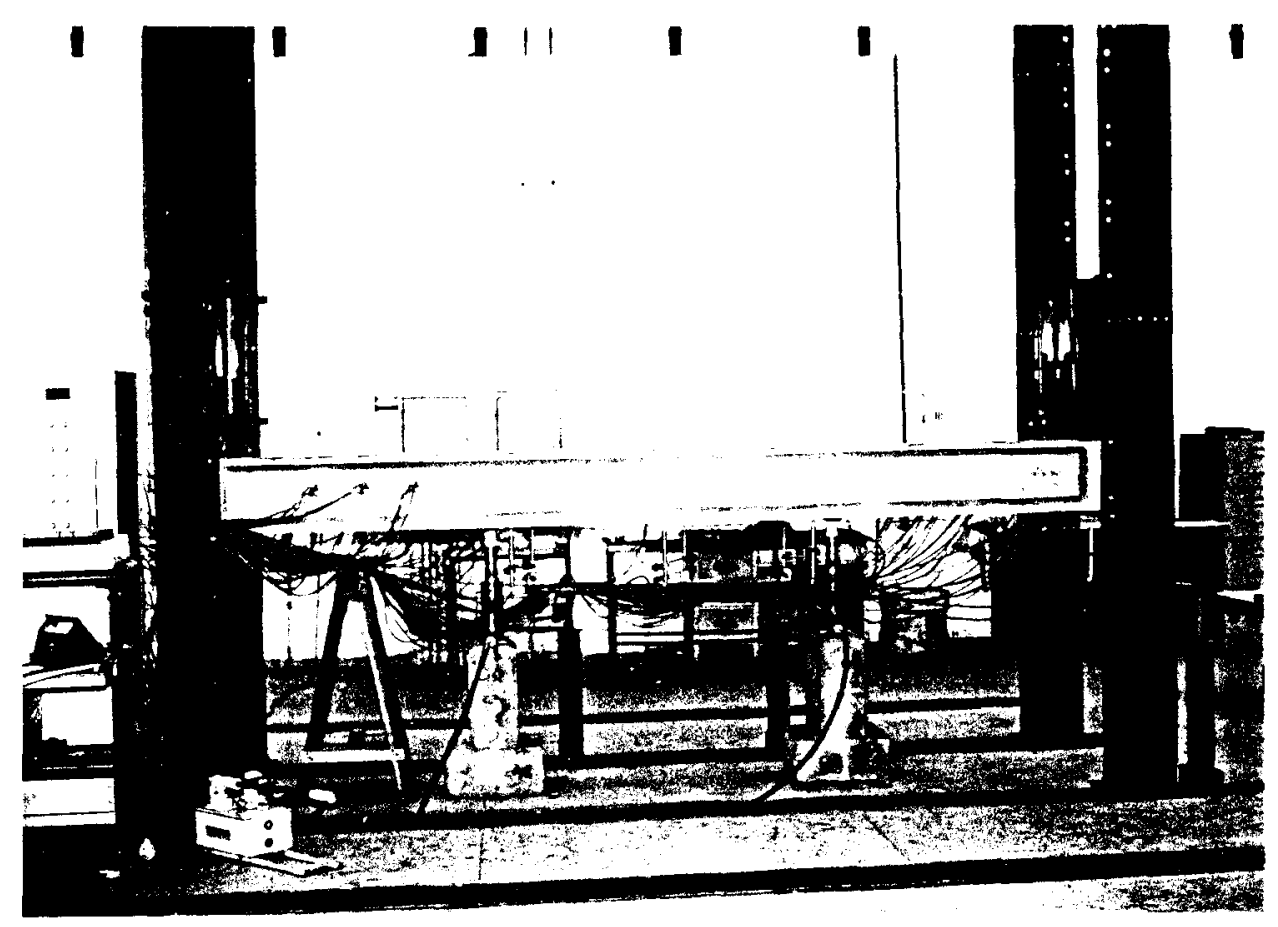

Foto 5.5 - Vista do modelo posicionado para ensaio

Nas primeiras vigas, os apoios foram formados por combinações de chapas e cilindros de aço similares aos utilizados nos ensaios das vigas de seção quadrada, que proporcionavam liberdade de rotação e de translação. Nos dois primeiros modelos, um dos apoios era fixo e o outro móvel. Posteriormente, em V3 e V4, foram adotados apoios móveis nos dois lados da viga, devido aos deslocamentos verticais mais elevados. A partir do modelo V5, as placas e cilindros de aço foram substituídas por placas de neoprene, para minimizar os problemas decorrentes do impacto da ruptura, cada vez mais violenta devido ao aumento da resistência dos modelos. A Foto 5.6 mostra um detalhe deste tipo de apoio. Todas as vigas foram ensaiadas até a ruína.

\section{7 - RESULTADOS DOS ENSAIOS}

Neste ítem são apresentados os resultados dos ensaios de todos os modelos. A apresentação é individual, com uma breve descrição do ensaio, onde se analisam basicamente os mesmos parâmetros e fenômenos estudados nas vigas prismáticas, acrescentando-se os aspectos relacionados com a execução da protensão e os seus efeitos, no caso dos modelos protendidos. Posteriormente, para cada viga apresentamse os gráficos com a evolução das deformações nos estribos, na armadura longitudinal e no concreto, em todos os pontos instrumentados, nas Figuras 5.5 a 5.38 . 


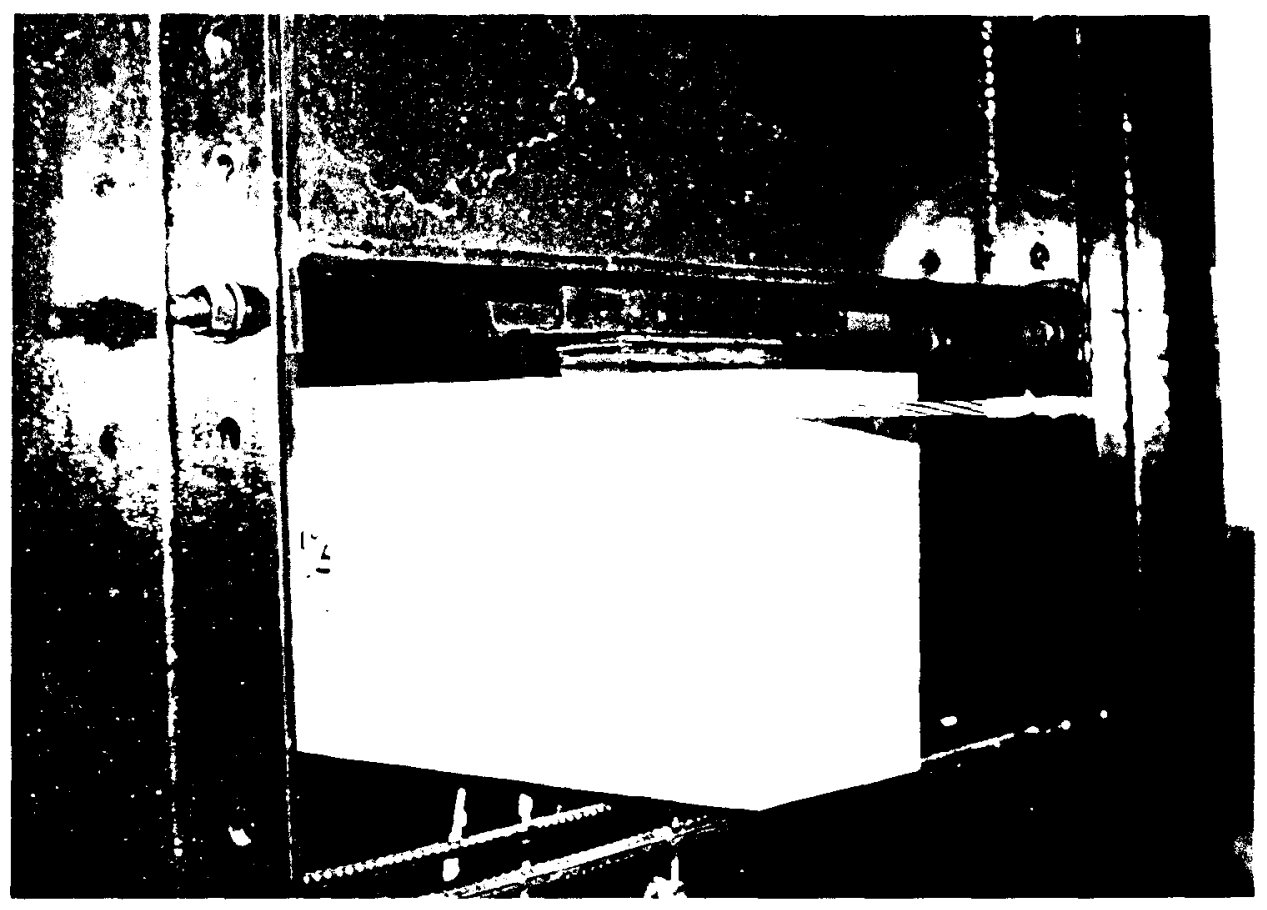

Foto 5.6 - Detalhe do apoio formado pelas placas de neoprene

Os resultados das rosetas nos modelos V6 a V9 são apresentados para duas situações distintas. Nas figuras a eles correspondem apenas às deformações causadas pelas forças aplicadas no ensaio de flexão. Nas figuras $\mathbf{b}$, é considerada a deformação inicial nas rosetas devido à protensão. As deformações principais em cada roseta são representadas pelas letras $\mathrm{T}$, tração. ou $\mathrm{C}$, compressão, seguidas da simbologia adotada para as rosetas (por exemplo, T.R1 - tração principal na roseta número 1).

A análise dos resultados é apresentada no item 5.8, onde alguns gráficos e tabelas referentes à análise de alguns parâmetros que não são mostrados na descrição individual foram elaborados para a comparação dos resultados, conforme se descreve a seguir, com o objetivo de facilitar uma possível consulta prévia a estes resultados.

- Propriędades do concreto. na Tabela 5.4, que, entre outros, apresenta os resultados dos ensaios dos corpos-de-prova, resistência à compressão, resistência à tração e módulo de deformação longitudinal. O módulo de deformação longitudinal experimental representa o resultado do ensaio de dois corpos-de-prova. Os valores 
da resistência à tração e compressão do concreto foram obtidos pela média de dois valores em V1 e V2, e três valores nos demais modelos. Para os modelos protendidos, apresenta-se também os resultados dos corpos-de-prova ensaiados antes da liberação da protensão, na Tabela 5.3. Os diagramas $\sigma-\varepsilon$ do concreto dos nove modelos estão na Figura 5.39.

- Força de protensão nos modelos protendidos, na Tabela 5.17. Ela é apresentada em três instantes distintos: força ancorada $\left(\mathrm{P}_{\mathrm{a}}\right)$, força após a liberação das cordoalhas $\left(\mathrm{P}_{\mathrm{o}}\right)$ e força no instante do ensaio de flexão $\left(\mathrm{P}_{\mathrm{t}}\right)$, calculadas de acordo com três métodos diferentes, conforme se descreve posteriormente.

- Parâmetros relativos ao estiramento das cordoalhas, na Tabela 5.18: módulo de deformação longitudinal aparente, perda de protensão devido ao encurtamento do concreto, tração na borda superior e outros.

- Fissuração por flexão, na Tabela 5.7, com os valores da carga correspondente ao aparecimento da primeira fissura de flexão, teórica e experimental, e da abertura desta fissura ao final do incremento da carga. Apresenta-se também o valor da força aplicada e da deformação máxima na armadura longitudinal no instante em que a abertura da fissura mais crítica de flexão atingiu $0,16 \mathrm{~mm}$.

- Fissuras de cisalhamento, na Tabela 5.9, que apresenta a carga em que as fissuras de flexão começaram a se inclinar, a carga em que surgiu a primeira fissura inclinada diretamente na alma e o valor das respectivas aberturas destas fissuras, quando elas foram anotadas.

- Parâmetros relativos aos deslocamentos verticais, na Tabela 5.10, que mostra a flecha correspondente à carga máxima e as cargas correspondentes aos deslocamentos iguais a $/ / 300(12,3 \mathrm{~mm}), / / 150(24,7 \mathrm{~mm})$ e $l / 100(37 \mathrm{~mm})$. Os gráficos com a evolução das flechas estão na Figura 5.42.

- Parâmetros relativos à ruptura, na Tabela 5.12, que apresenta o valor da força cortante última, teórica e experimental, o valor da inclinação mínima das bielas nos dois lados da viga e os estribos que atingiram o escoamento.

- Deformações máximas nos estribos, na Tabela 5.14, onde aparece a carga em que ocorreu a mobilização efetiva (considerando-se tensão mínima de $40 \mathrm{MPa}$ ) e o valor da deformação máxima, para todos os estribos instrumentados.

- Deformações máximas na armadura longitudinal, na Tabela 5.15, com as deformações máximas em todos os pontos instrumentados da armadura longitudinal e o instante em que a tensão nestes pontớs aumentou bruscamente, devido ao aparecimento de fissuras de flexão nestas regiões. 
Durante o estiramento das cordoalhas, os valores registrados nos extensômetros nem sempre foram compatíveis com a variação da força indicada nas células de carga, especialmente no reestiramento, no encunhamento e no intervalo até a execução do ensaio. Este fato ocorreu em vários modelos e indica a sensibilidade da instrumentação nas diversas etapas no processo. Devido a essa eventual inconsistência, foram adotados itrês procedimentos distintos para a estimativa da força de protensão, de modo a controlar possíveis desvios:

a) Força medida pela célula de carga: neste caso, o último valor registrado corresponde ao instante anterior à transferência da protensão. Depois disso, as perdas foram calculadas a partir da variação das deformações, utilizando-se o módulo de deformação longitudinal aparente obtido durante o estiramento da respectiva cordoalha;

b) Força calculada em cada instante a partir dos valores de deformação indicados nos extensômetros das cordoalhas, utilizando-se o módulo aparente obtido no estiramento, calculado para a força de tração igual a $40 \mathrm{kN}$;

c) Idem ao item anterior, utilizando-se o módulo aparente obtido nos ensaios de caracterização das cordoalhas.

Quando a diferença entre os valores obtidos por estes métodos foi significativa, adotou-se nos cálculos o valor correspondente ao método $\mathbf{b}$, pois ele elimina os efeitos decorrentes da imperfeição do apoio das células de carga no pórtico e adota o módulo real, numa situação em que a instrumentação é bastante sensível.

Nestes modelos, convencionou-se estabelecer o estado limite último no instante em que ocorreu o escoamento da armadura longitudinal ou de pelo menos um estribo de cada lado da viga. Em nenhuma viga protendida houve fissuração na face tracionada durante a liberação da protensão.

Em vigas de alma delgada, a primeira fissura inclinada pode surgir diretamente na alma. Este fato, no entanto, não foi observado em nenhum modelo. Porisso, a mobilização dos estribos ocorreu antes para aqueles mais próximos do ponto de introdução da carga, onde a solicitação por flexão é maior, atingindo sucessivamente os estribos subsequentes. $\grave{A}$ medida que se aproximava a ruptura, as fissuras de cisalhamento se abatiam.

Os estribos próximos dos apoios, E1 e E2, foram muito pouco solicitados durante quase todo o ensaio em todos os modelos. Em alguns casos eles ficaram comprimidos no ińício do ensaio. Somente nos modelos sem protensão eles apresentaram tensão superior a $40 \mathrm{MPa}$. 
No concreto, a descompressão do banzo ocorreu antes para os pontos $\mathrm{C} 1$ e $\mathrm{C} 2 \mathrm{e}$ nem sempre atingiu os pontos mais internos C5 e C6, como em V4, por exemplo. Em várias vigas a tensão nestes pontos foi maior que no meio do vão, como em V2 e V3. Em alguns casos, houve tensões de tração nos pontos próximos dos apoios, como nos modelos V2, V3 e V5.

Nas cordoalhas, nos pontos próximos dos apoios há uma concentração de bielas nas proximidades da ruptura, aumentando a força a ser ancorada, conforme se observou no modelo V1. No entanto, como a distância entre o apoio e o ponto instrumentado mais próximo do apoio é relativamente grande, igual a $22 \mathrm{~cm}$, este fato não foi registrado em diversos modelos. Nos pontos mais internos, apesar do momento fletor ser maior em A0 do que em A5 ou A6, a deformação máxima ocorreu nestes pontos em várias vigas (V1, V2, V3 e V9). Isto comprova a influência do apoio das bielas e da flexão localizada na tensão da armadura longitudinal.

Não se observou diminuição de tensão nas cordoalhas durante o ensaio em nenhum modelo, que indicaria uma possível falha na aderência. Próximo da carga teórica de ruptura por cisalhamento, a deformação máxima nas cordoalhas esteve quase sempre muito próxima de $0,3 \%$, conforme previsto pelo cálculo no estádio II.

Em todas as vigas houve ruptura por cisalhamento-tração, com o escoamento e posterior ruptura dos estribos nas vigas con armadura transversal, ou devido à tração excessiva no concreto nas vigas sem estribos. Porém, em alguns modelos, como em V6 e V9, as fissuras de cisalhamento avançaram na direção do banzo comprimido, provocando a ruptura do concreto próximo da região de introdução do carregamento, resultando numa ruptura combinada de cisalhamento-tração e cisalhamento-flexão. Portanto, em todos os casos a armadura transversal foi insuficiente.

\section{modelo piloto}

A execução de um modelo piloto tinha o objetivo de testar os procedimentos do ensaio (aplicação do carregamento, instrumentação, funcionamento dos apoios e pórtico de reação, etc) e os aspectos relacionados com a produção do modelo (fôrma e adensamento). Durante o ensaio deste modelo, somente foram acompanhados a evolução dos deslocamentos verticais e da fissuração. A armação deste modelo está representada na Figura 5.4 .

$O$ concreto não tinha fibras e nem aditivo superplastificante. A trabalhabilidade da mistura foi apenas razoável, sendo que a moldagem foi mais difícil que a das vigas prismáticas. A fôrma apresentou alguns pontos de vazamento durante a vibração. Os apoios eram fixo de um lado e móvel do outro, ambos com rotação livre. 
A resistência média à compressão e tração dos corpos-de-prova ensaiados aos sete dias foram de 50,9 MPa e 3,55 MPa, respectivamente.

Esperava-se o escoamento dos estribos para carga próxima de $31 \mathrm{kN}$. O escoamento da armadura longitudinal era esperado com $81 \mathrm{kN}$. O modelo chegou à ruína quando a carga atingiu $58 \mathrm{kN}$, de forma brusca e violenta.

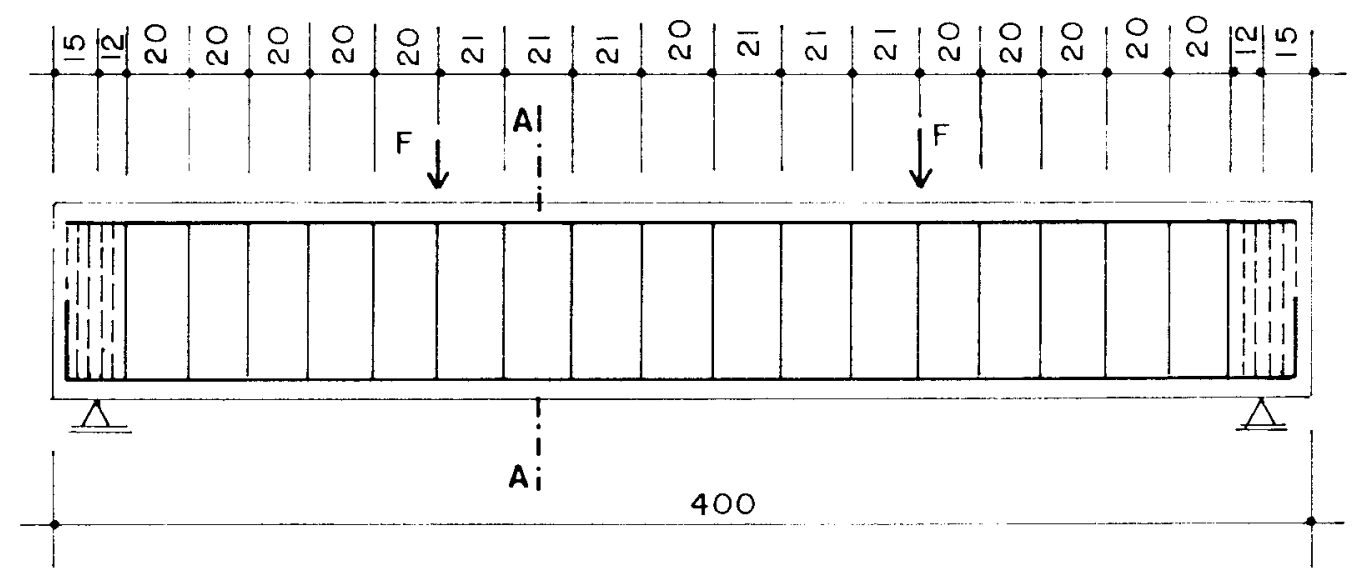

$\mathrm{N} 1-1 \varnothing 6.3 \mathrm{~mm} \quad(3.95)$

\section{$\mathrm{N} 2-5 \varnothing 12.7 \mathrm{~mm} \quad(4.10)$}

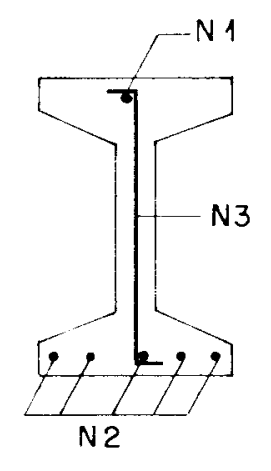

SEC̄ĀO $\quad A \cdot A$

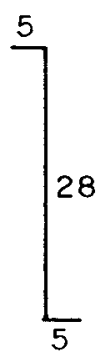

$N 3-\phi 6.3 c / 20$

Figura 5.4 - Armação do modelo piloto

Houve grandes danos na região comprimida junto ao ponto de aplicação do carregamento, com o estilhaçamento do concreto desta região. A desintegração foi maior nas laterais da mesa, devido à ineficiência dos estribos abertos de apenas um ramo e à ausência de porta-estribos nas laterais da mesa comprimida. Lembra-se que o uso de estribos de um ramo é permitido desde que haja enrijecedores de alma para absorver a flexão transversal (LEONHARDT \& MÖNNIG, 1978). 
A inclinação da fissura crítica apresentou um sensivel abatimento quando penetrou nas mesas, especialmente abaixo da mesa tracionada, possivelmente devido ao fendilhamento do concreto devido às forças decorrentes da ação de pino. O desnível entre as partes separadas na zona tracionada foi pequeno, pois o banzo era muito rígido. Esta região permaneceu praticamente intacta.

As flechas foram acompanhadas através de defletômetros indutivos, cujo funcionamento não foi satisfatório. Eles ainda foram utilizados no modelo V1 após recalibração, mas depois não foram mais utilizados, pelos problemas já discutidos no capítulo anterior. A Foto 5.7 mostra o modelo piloto após o ensaio, onde no plano anterior se observa a armação do modelo V1.

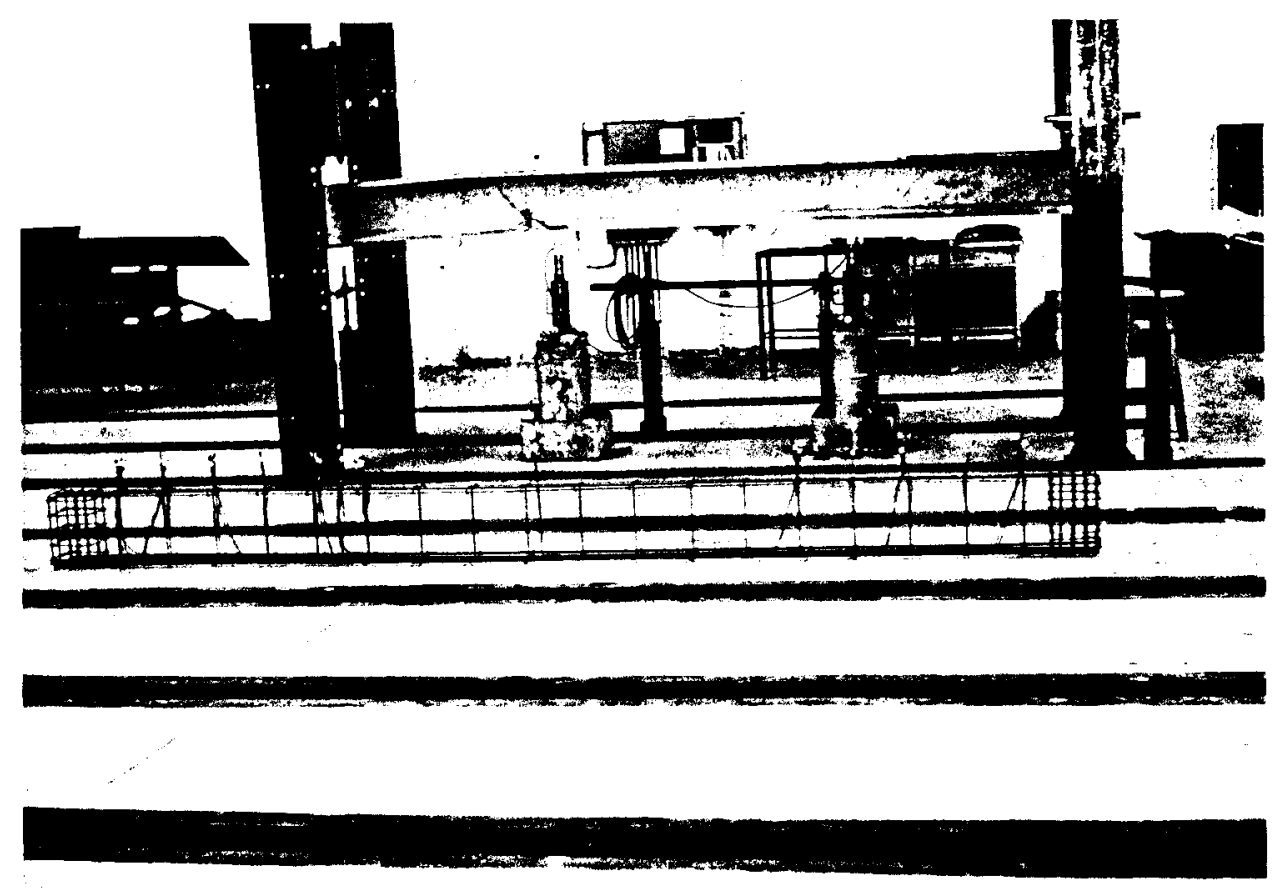

Foto 5.7 - Vista do modelo piloto após ensaio

\subsection{1 - MODELO V1}

Este era um modelo de referência, executado sem fibras e sem protensão. $O$ ensaio ocorreu sete dias após a concretagem. Quando a carga atingiu $11 \mathrm{kN}$, percebeuse que um dos defletômetros não estava corretamente posicionado. As primeiras fissuras dé flexão já tinham aparecido com $9 \mathrm{kN}$. A viga foi descarregada e o ensaio reiniciado com o ajuste do aparelho. O incremento de carga foi mantido em $2 \mathrm{kN}$ até o final do ensaio. 
O acompanhamento dos resultados na tela do computador ligado ao sistema de aquisição de dados foi parcial, já que está limitado a 44 canais. O último registro dos dados corresponde à carga de $42 \mathrm{kN}$, imediatamente antes da ruína, que ocorreu no início do incremento de carga seguinte. A ruptura foi brusca, devido ao escoamento e posterior ruptura dos estribos do lado direito da viga. Houve forte barulho e "estilhaçamento de partes de concreto.

A região danificada atingiu o estribo E6, na alma, o estribo E8, na mísula comprimida. o estribo E10, que permaneceu íntegro junto à mesa comprimida, e o estribo E4, que se abriu na mesa tracionada, onde a fissura se tornou mais abatida.

A fissura crítica partiu do ponto de aplicação da carga e atingiu a face tracionada a $30 \mathrm{~cm}$ da extremidade da peça, onde a viga se apresenta desintegrada num trecho bastante extenso, de $38 \mathrm{~cm}$. Na região comprimida também houve desintegração do concreto, num trecho de $20 \mathrm{~cm}$. A separação entre as superfícies delimitadas pela ruptura é visível. No banzo tracionado, o desnivel entre elas é significativo, e se observa as cordoalhas encurvadas devido ao apoio das bielas.

Do lado esquerdo da viga somente o estribo E9 escoou, quando a carga chegou a $40 \mathrm{kN}$. Do lado direito, lado da ruptura, três estribos escoaram após $40 \mathrm{kN}$, sendo que em E4 e E6 o escoamento foi repentino, coincidindo com o instante de formação da fissura crítica. Assim, o estado limite último ocorreu após $40 \mathrm{kN}$. A resistência adicional até a rúna foi de apenas $2 \mathrm{kN}$.

Os estribos que foram instrumentados nos dois ramos apresentaram deformações praticamente coincidentes, devido à esbeltez da alma. Em alguns casos, observa-se uma diferença muito pequena, mas as curvas são sempre proporcionais. Portanto, a colocação de extensômetros em apenas um ramo dos estribos, adotada nos modelos seguintes, representa com boa aproximação o comportamento deste elemento.

No último incremento de carga a tensão no estribo E2 subiu até $90 \mathrm{MPa}$, acompanhando a variação de tensão verificada em E4 e E6, mas não se observam fissuras inclinadas nesta região, como mostra a Foto 5.22.

Os estribos mais solicitados e que escoaram primeiro foram E6 e E9. O estribo situado sob o ponto de aplicação da carga somente foi solicitado após $22 \mathrm{kN}$. A tensão máxima neste estribo foi de $160 \mathrm{MPa}$.

O arqueamento do banzo comprimido de çoncreto foi observado nos dois lados da viga, com maior intensidade no lado da ruptura. A descompressão praticamente anulou as tensões no concreto no ponto $C 4$, distante $62 \mathrm{~cm}$ do apoio $(2,2 \mathrm{~d})$, atingindo também o ponto mais interno, C6. distante $102 \mathrm{~cm}$ do apoio $(3,6 \mathrm{~d})$. Do lado esquerdo. 
a descompressão se estendeu até o ponto C3. Próximo da ruptura, a deformação máxima no concreto foi de $0,11 \%$, no ponto $\mathrm{C} 5$, distante do limite de ruptura. Lembrase que a seção do meio do vão não foi instrumentada nesta viga.

Em relação aos extensômetros colocados próximos às bordas da face comprimida no lado esquerdo da viga, houve uma pequena diferença entre as leituras dos pontos de uma mesma seção. Ela é mais pronunciada que no caso dos estribos, provavelmente porque a largura da mesa é bem maior que a largura da alma. Assim, a diferença entre os dois lados se manifesta mais claramente. Mesmo assim, as curvas são igualmente proporcionais, seguindo sempre a mesma tendência. Porisso, a colocação de extensômetros apenas no centro da mesa comprimida deve preservar as informações mais relevantes.

Quanto à instrumentação das cordoalhas, em todos os casos houve uma defasagem entre as leituras dos dois fios de cada seção instrumentada, conforme era esperado. Os valores médios, no entanto, devem representar fielmente o comportamento da cordoalha. Qualquer referência à deformação das cordoalhas se refere sempre à média dos valores entre os dois fios instrumentados. Nas seções em que todas as cordoalhas foram instrumentadas, A1 e A5. houve boa uniformidade entre os resultados das cordoalhas central e laterais.

Os resultados das rosetas confirmaram alguns fatos já esperados. O seu funcionamento só é confiável antes do aparecimento de fissuras na região dos extensômetros. Nas seções em que foram instrumentadas as duas faces da alma (R1, R3 e R5), os resultados mostram um comportamento relativamente similar, exceto em R5. Desta forma, nas vigas seguintes, optou-se por aplicar rosetas apenas numa das faces da viga, em duas seções de cada lado, que correspondem às posições R1-R2 e R5-R6 do modelo V1, distantes $30 \mathrm{~cm}$ e $70 \mathrm{~cm}$ do ponto de introdução da carga.

A evolução das fissuras foi muito rápida. Com $14 \mathrm{kN}$ já se registrava fissuras com abertura de $0,16 \mathrm{~mm}$. Quando a carga atingiu $32 \mathrm{KN}$, surgiu uma fissura no banzo tracionado próximo do apoio. No final do ensaio, apareceu uma fissura quase horizontal na altura das cordoalhas na região do apoio, em direção à alma. Ela pode ser decorrente da concentração das bielas nesta região. Nos modelos seguintes foi colocada uma armadura adicional nesta região, que também absorveria os esforços devidos à introdução da protensão. 

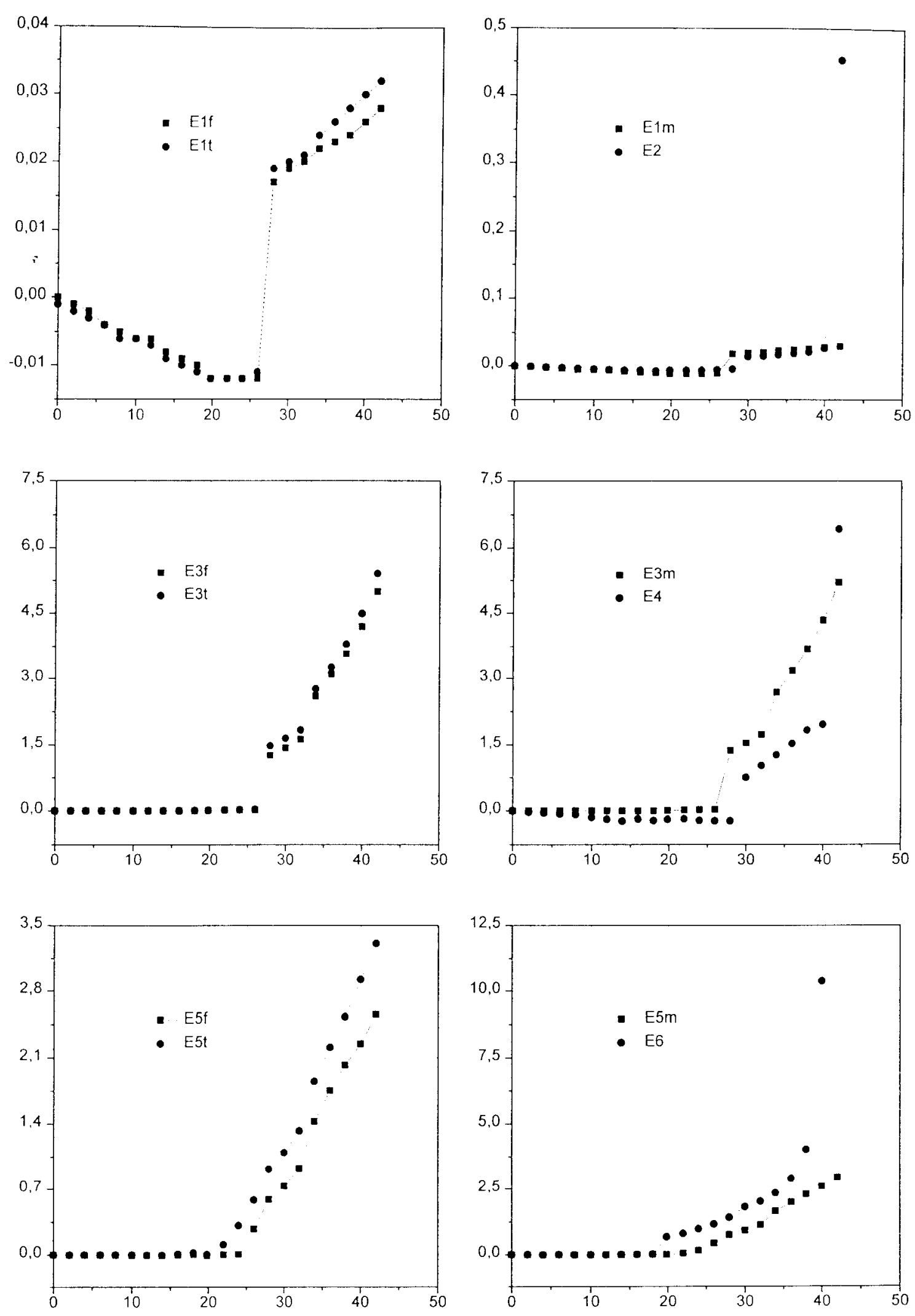

Figura 5.5a - Deformação ( $\mathrm{mm} / \mathrm{m}$ no eixo y) x Carga ( $\mathrm{kN}$ no eixo $\mathrm{x}$ ) estribos do modelo $\mathrm{V} 1$ 

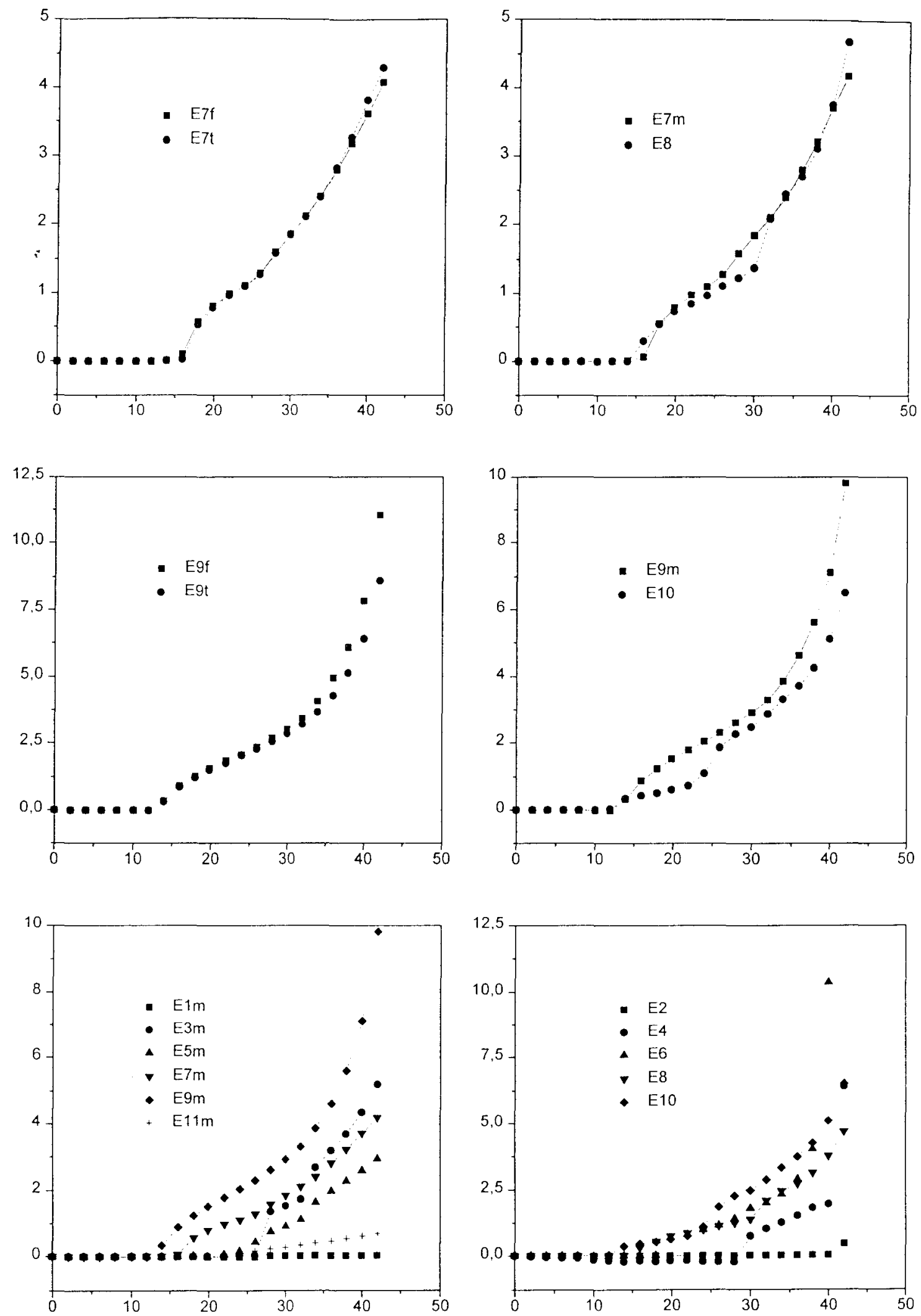

Figura 5.5b - Deformação ( $\mathrm{mm} / \mathrm{m}$ no eixo y) $\mathrm{x}$ Carga $(\mathrm{kN}$ no eixo $\mathrm{x})$ estribos do modelo $\mathrm{V} 1$ 

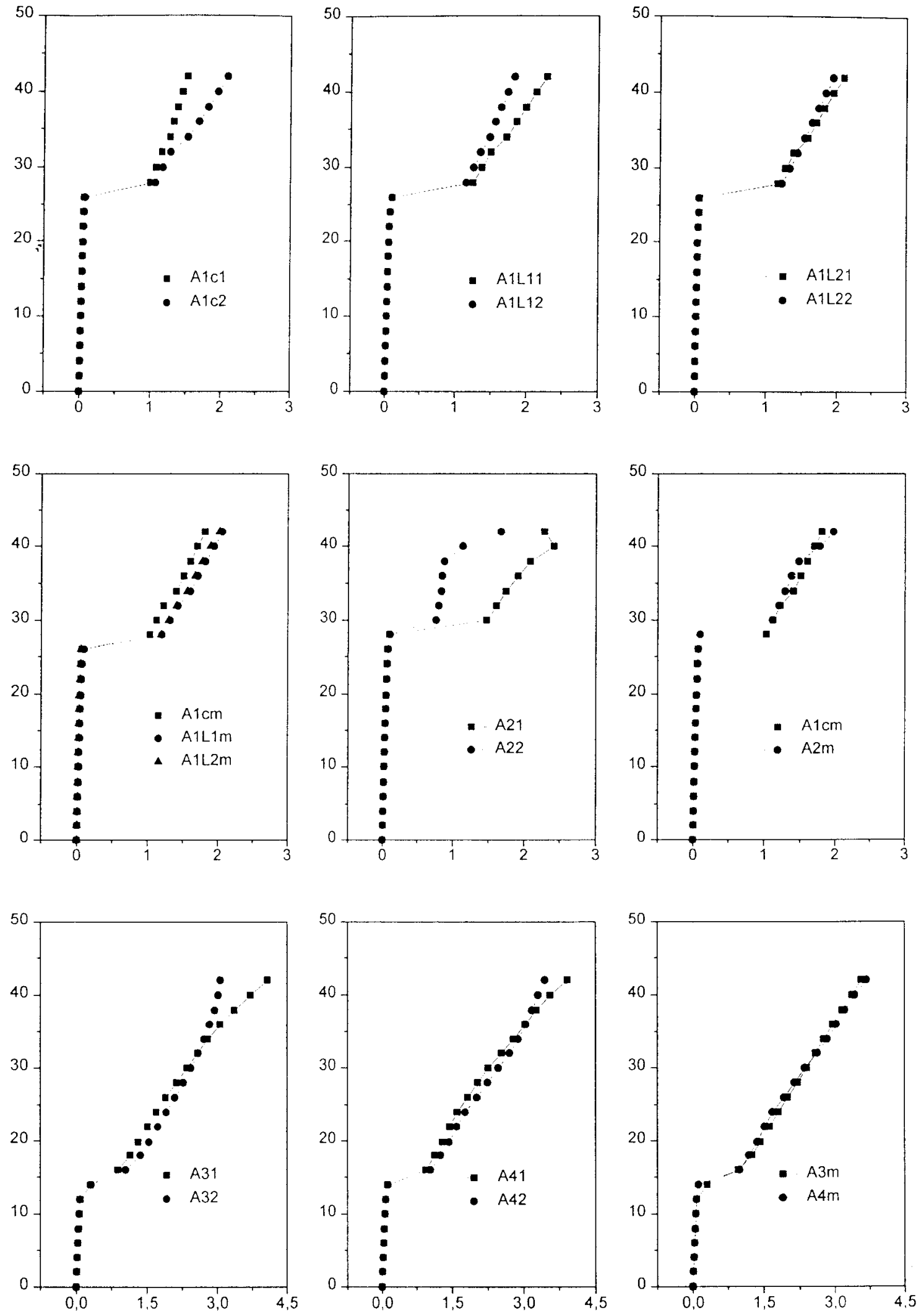

Figura 5.6a - Carga ( $\mathrm{kN}$ no eixo y) x Deformação $(\mathrm{mm} / \mathrm{m}$ no eixo $\mathrm{x})$ cordoalhas do modelo $\mathrm{V} 1$ 

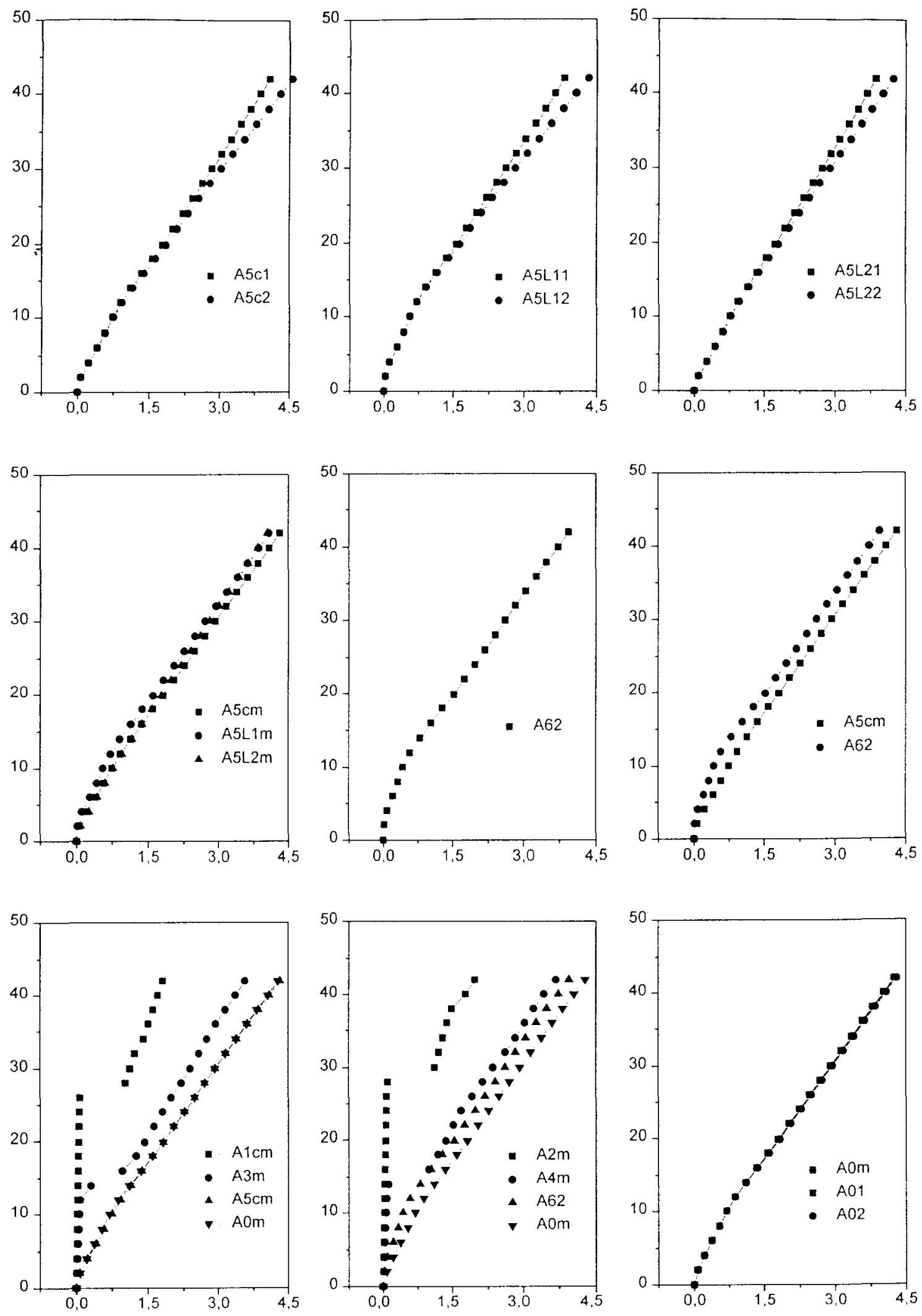

Figura 5.6b - Carga ( $\mathrm{kN}$ no eixo y) x Deformação $(\mathrm{mm} / \mathrm{m}$ no eixo $\mathrm{x})$ cordoalhas do modelo $\mathrm{V} 1$ 

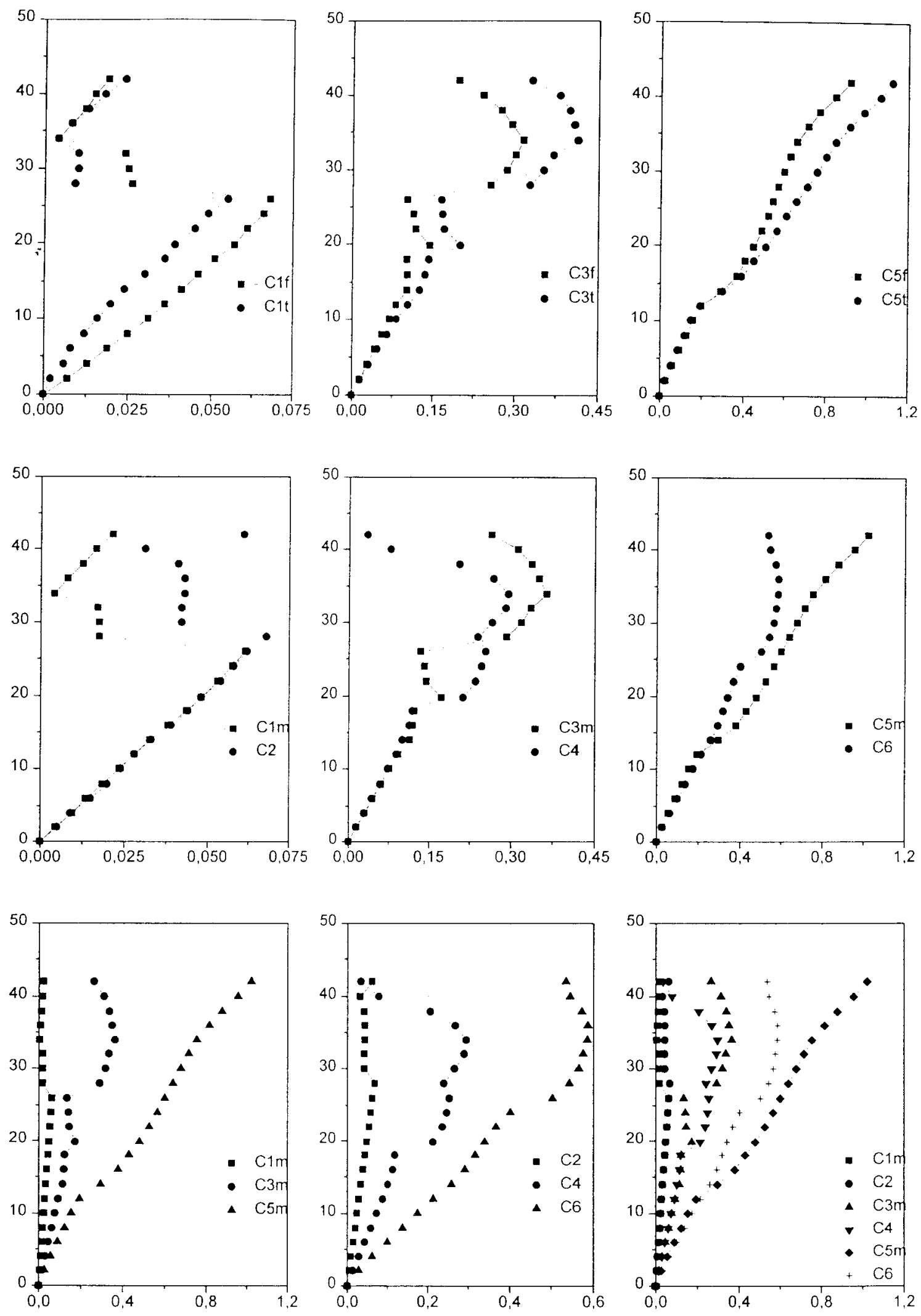

Figura 5.7 - Carga ( $\mathrm{kN}$ no eixo y) $\mathrm{x}$ Deformação $(\mathrm{mm} / \mathrm{m}$ no eixo $\mathrm{x})$ concreto do modelo $\mathrm{V} 1$ 

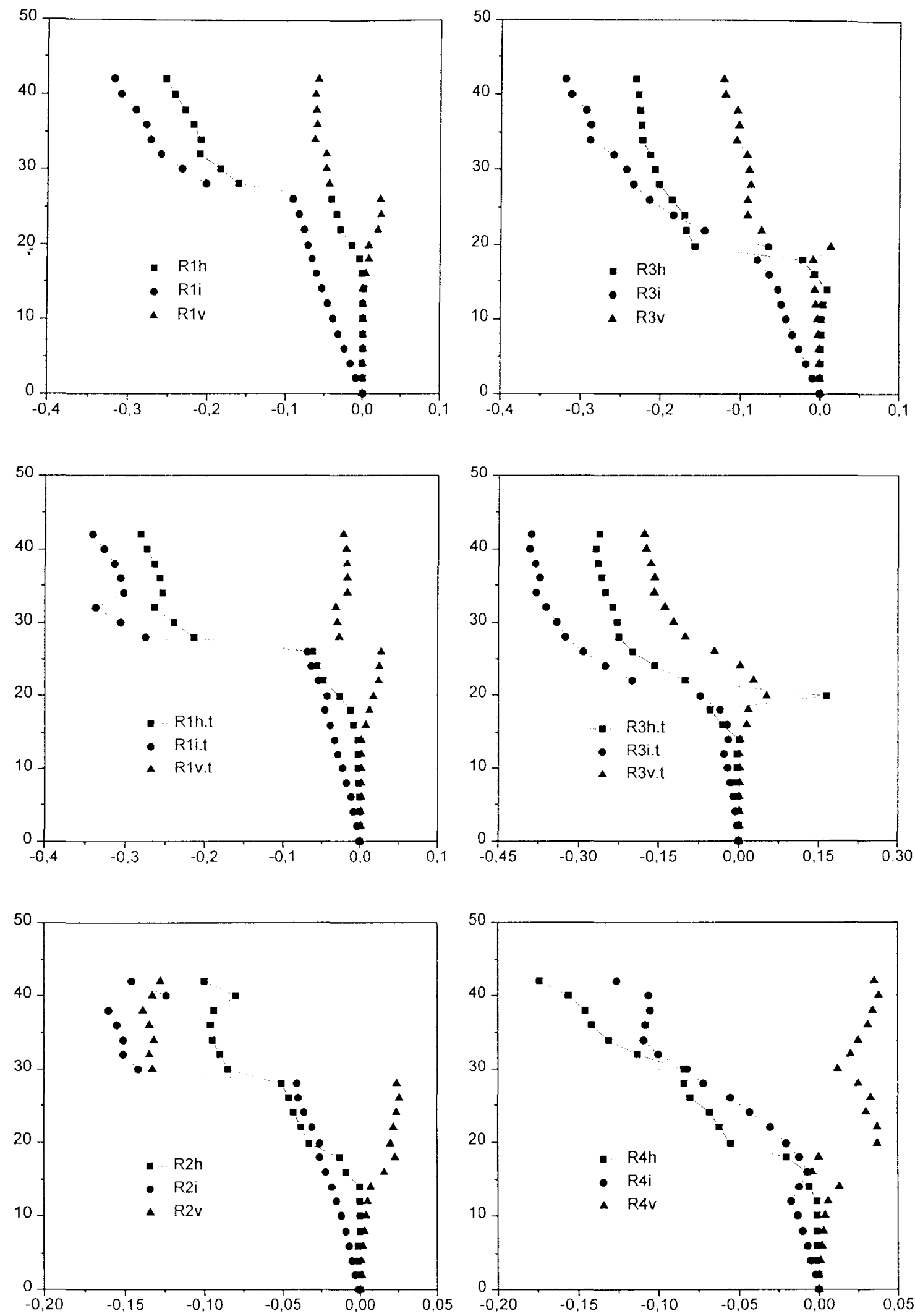

Figura 5.8a - Carga ( $\mathrm{kN}$ no eixo y) x Deformação $(\mathrm{mm} / \mathrm{m}$ no eixo $\mathrm{x})$ rosetas do modelo $\mathrm{V} 1$ 

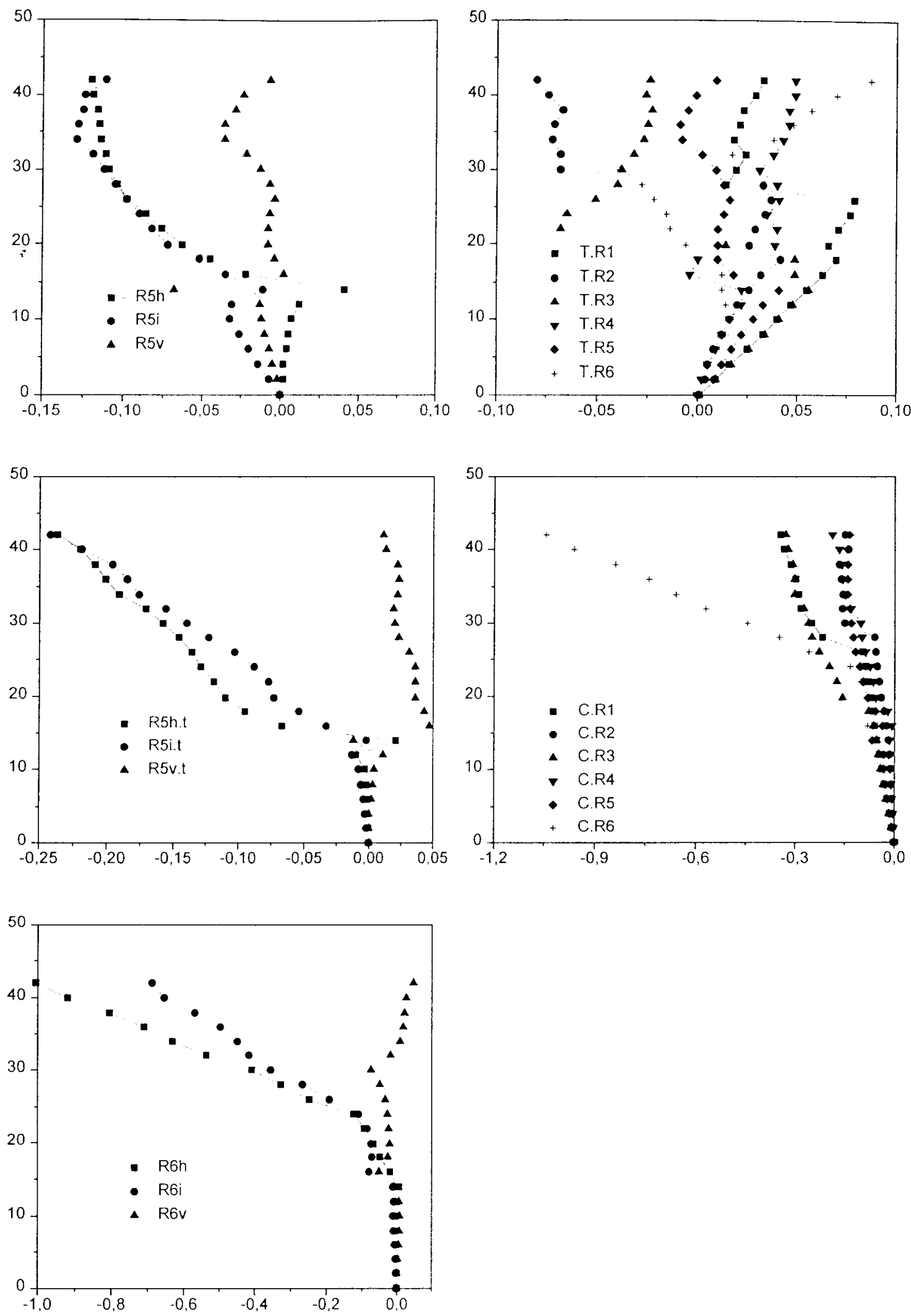

Figura $5.8 b$ - Carga $(\mathrm{kN}$ no eixo y) $\mathrm{x}$ Deformação $(\mathrm{mm} / \mathrm{m}$ no eixo $\mathrm{x})$ rosetas do modelo $\mathrm{V} 1$ 


\subsection{2 - MODELO V2}

O segundo modelo era idêntico ao anterior, exceto pela adição de $0,5 \%$ de fíbra de polipropileno e $1 \%$ de superplastificante. As fibras foram introduzidas juntamente com os demais constituintes do concreto e uma parte da água. Conforme se comentou - no capítulo anterior, isto melhora a separação dos filamentos da fibra, mas piora a trabalhabilidade. A vibração foi mais demorada e revelou o excesso de água da mistura. As Fotos 5.8 e 5.9 mostram o aspecto da viga logo após a moldagem e antes do ensaio, respectivamente, onde se observam algumas falhas e manchas, decorrentes dos pontos de vazamento e da exsudação. Consequentemente, o acompanhamento da evolução das fissuras foi mais difícil, pois, além de manchada, a superfície ficou mais rugosa, com vários filamentos de fibras visíveis.

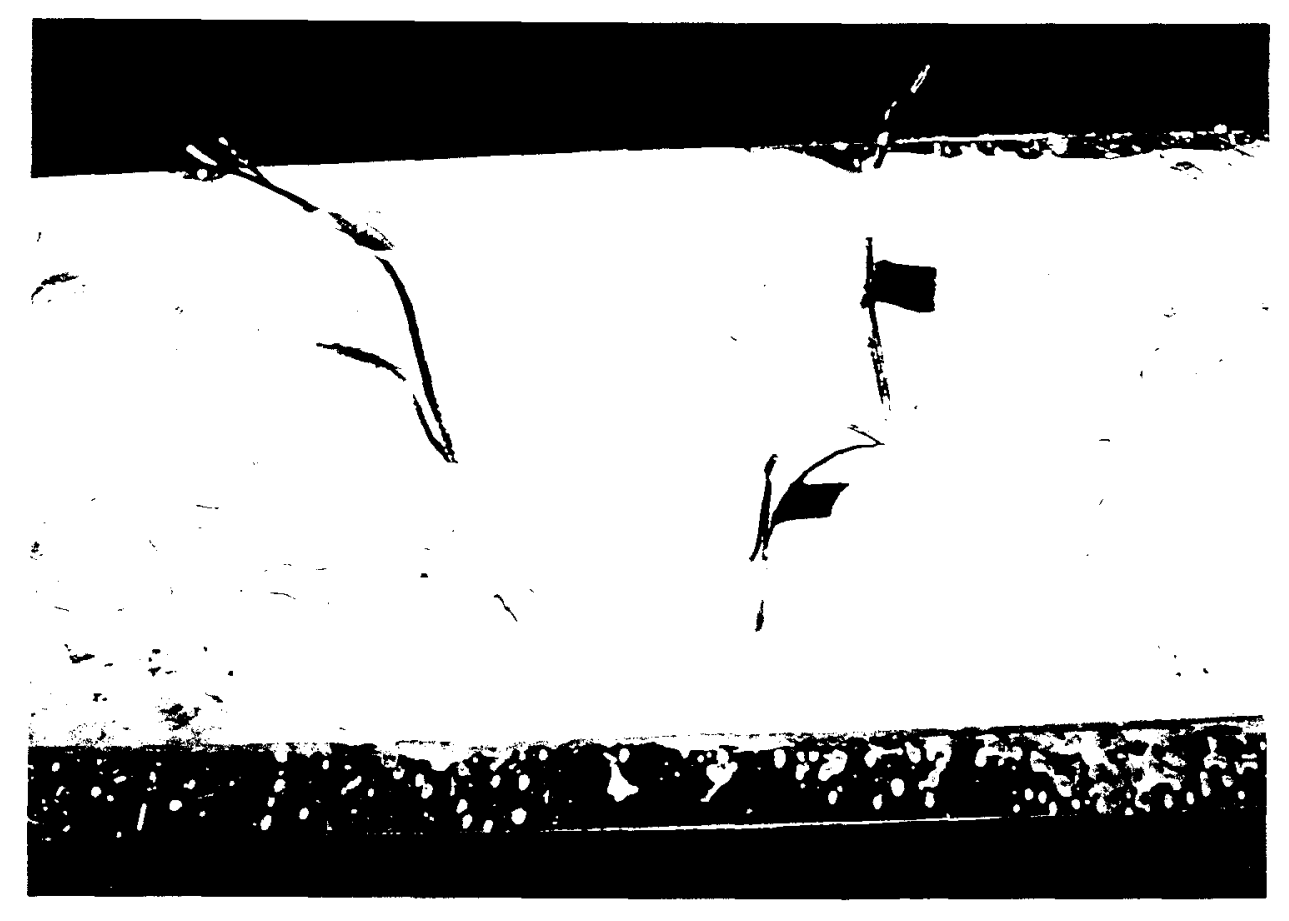

Foto 5.8 - Aspecto do concreto ainda na fôrma após a moldagem (modelo V2)

Em decorrência das dificuldades durante a produção da viga, piorou a qualidade do concreto, o que contribuiu para a diminuição do valor do módulo de deformação longitudinal. Outra particularidade observada nos ensaios dos corpos-de-prova foi a diferença significativa entre os resultados de misturas diferentes, lembrando-se que eram necessárias duas etapas para a execução da viga, o que sugere a sensibilidade das propriedades do compósito em relação ao processo de produção. 


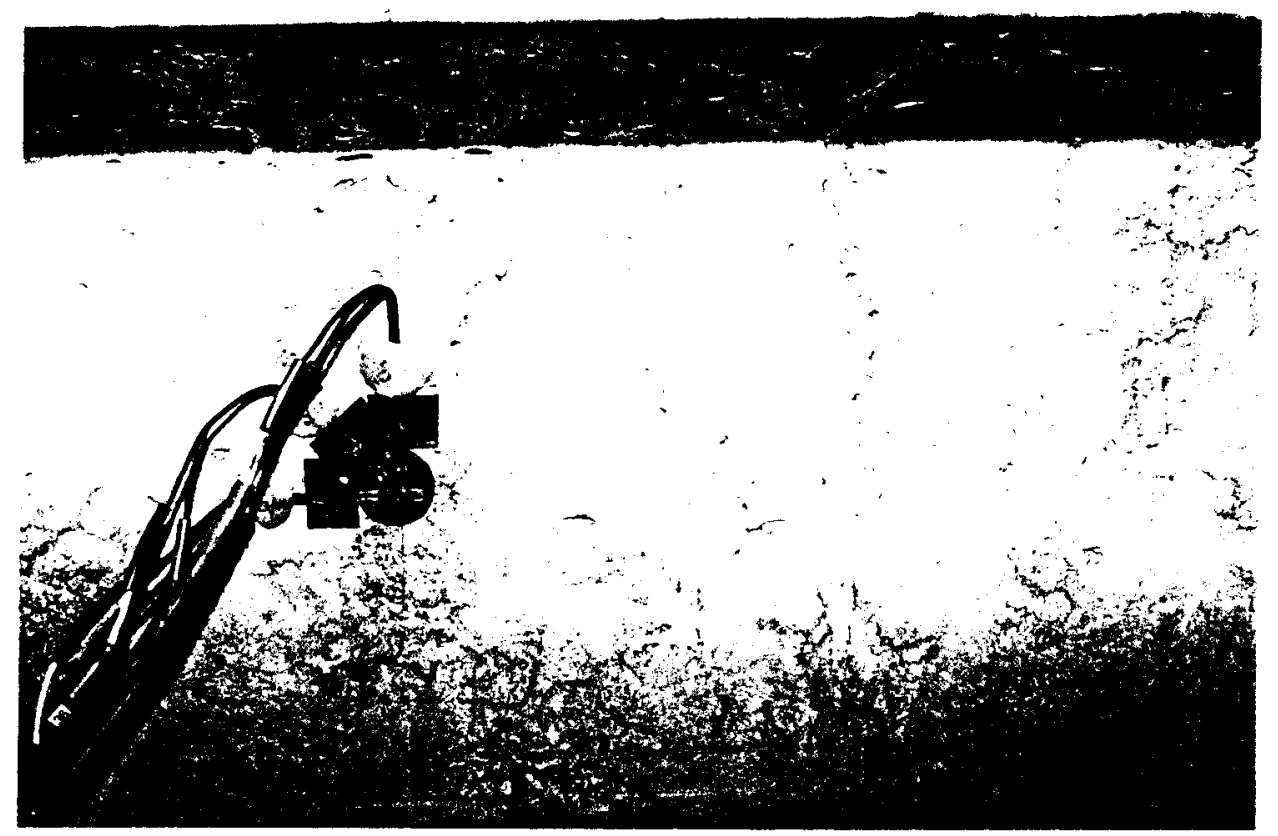

Foto 5.9 - Aspecto do concreto da viga V2 antes do ensaio e detalhe da roseta

Após a carga atingir $50 \mathrm{kN}$, a viga rompeu bruscamente no início do incremento de carga seguinte. Ao contrário do modelo de referência, não houve desintegração do concreto na região da ruína. O acréscimo de resistência devido à introdução das fibras foi de $8 \mathrm{kN}$, ou $19 \%$.

A Foto 5.10 mostra o detalhe da região da ruína, no lado esquerdo da peça. A região atingida é mais espalhada e menos danificada que no modelo anterior, especialmente nas mesas. Pelo menos duas fissuras criticas são identificadas, com inclinação de 34 graus na alma, sendo mais abatidas nas mesas, especialmente na região comprimida. O desnível entre as superfícies delimitadas pela ruptura é nítido nas mesas comprimida e tracionada, mas não houve lascamento do concreto.

A região da ruptura foi do ponto de aplicação da carga até $31 \mathrm{~cm}$ da extremidade da peça. Na mesa tracionada, atingiu o estribo E3. que abriu. Na alma. atravessou os estribos F5 e E7, e na mesa comprimida, o estribo E9, que rompeu.

Cinco estribos atingiram a deformação de escoamento. O estado limite último convencional ocorreu para carga de $45 \mathrm{kN}$, quando haviam escoado os estribos E7, com $40 \mathrm{~K}$, e E8. Há, portanto, um aumento da resistência residual até a ruína, possivelmente devido à maior contribuição dos mecanismos resistentes alternativos e à atuação das fibras junto às fissuras inclinadas. 
A descompressão não atingiu nenhum dos pontos mais internos, C5 e C6. No lado da ruptura, o ponto C2 esteve tracionado para carga acima de $45 \mathrm{kN}$ e no ponto $\mathrm{C} 4$ a tensão de compressão quase se anulou. As deformações nos pontos mais solicitados foram maiores que no modelo anterior para os mesmos valores de carga, devido à pior qualidade da mistura que, consequentemente, foi mais exigida.

As deformações nos extensômetros nos dois fios das cordoalhas são muito próximas em todos os pontos. Para seções correspondentes, os valores são similares nos dois lados da viga.

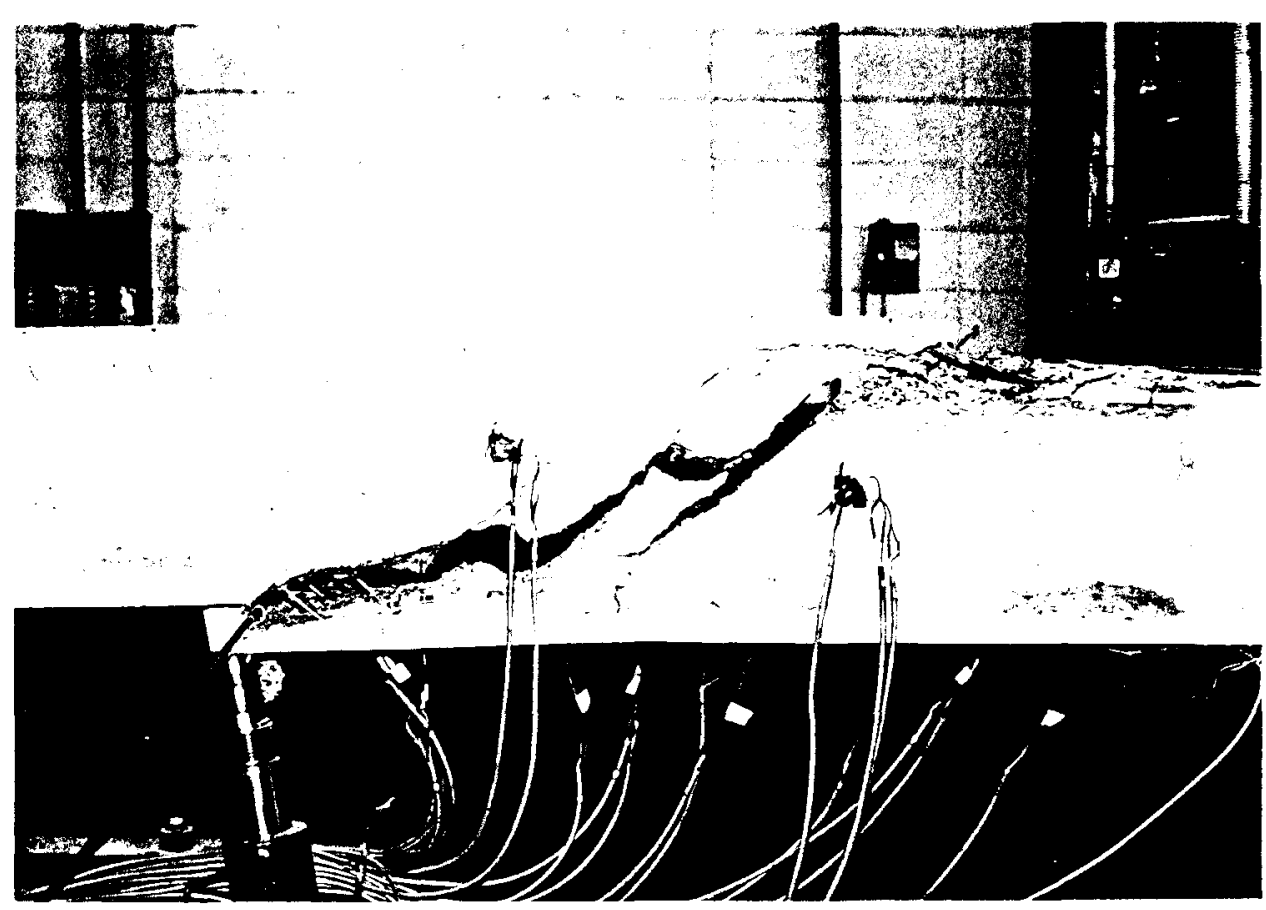

Foto 5.10 - Detalhe da região da ruína do modelo V2 após o ensaio 

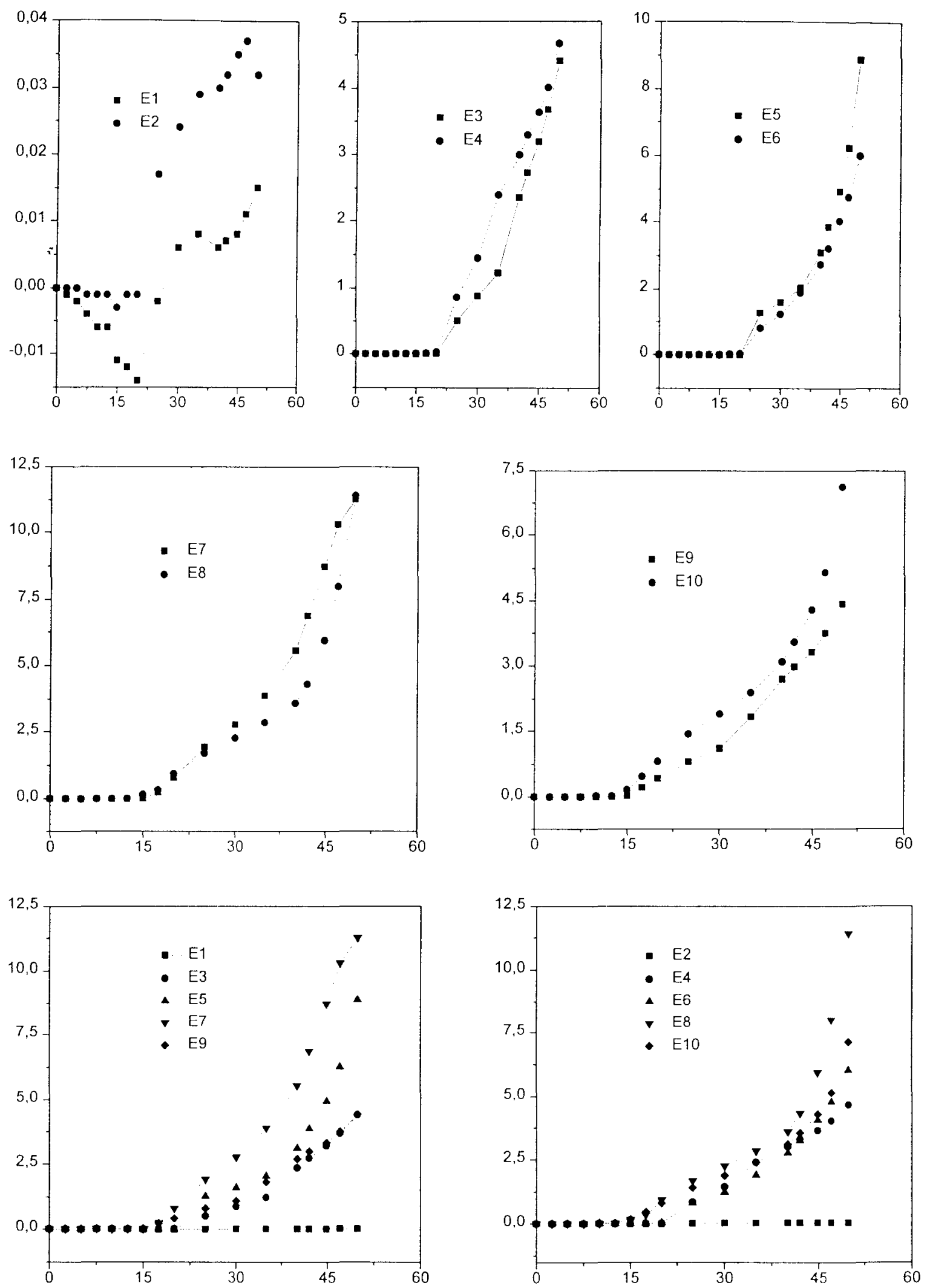

Figura 5.9 - Deformação $(\mathrm{mm} / \mathrm{m}$ no eixo y) x Carga $(\mathrm{kN}$ no eixo $\mathrm{x})$ estribos do modelo $\mathrm{V} 2$ 

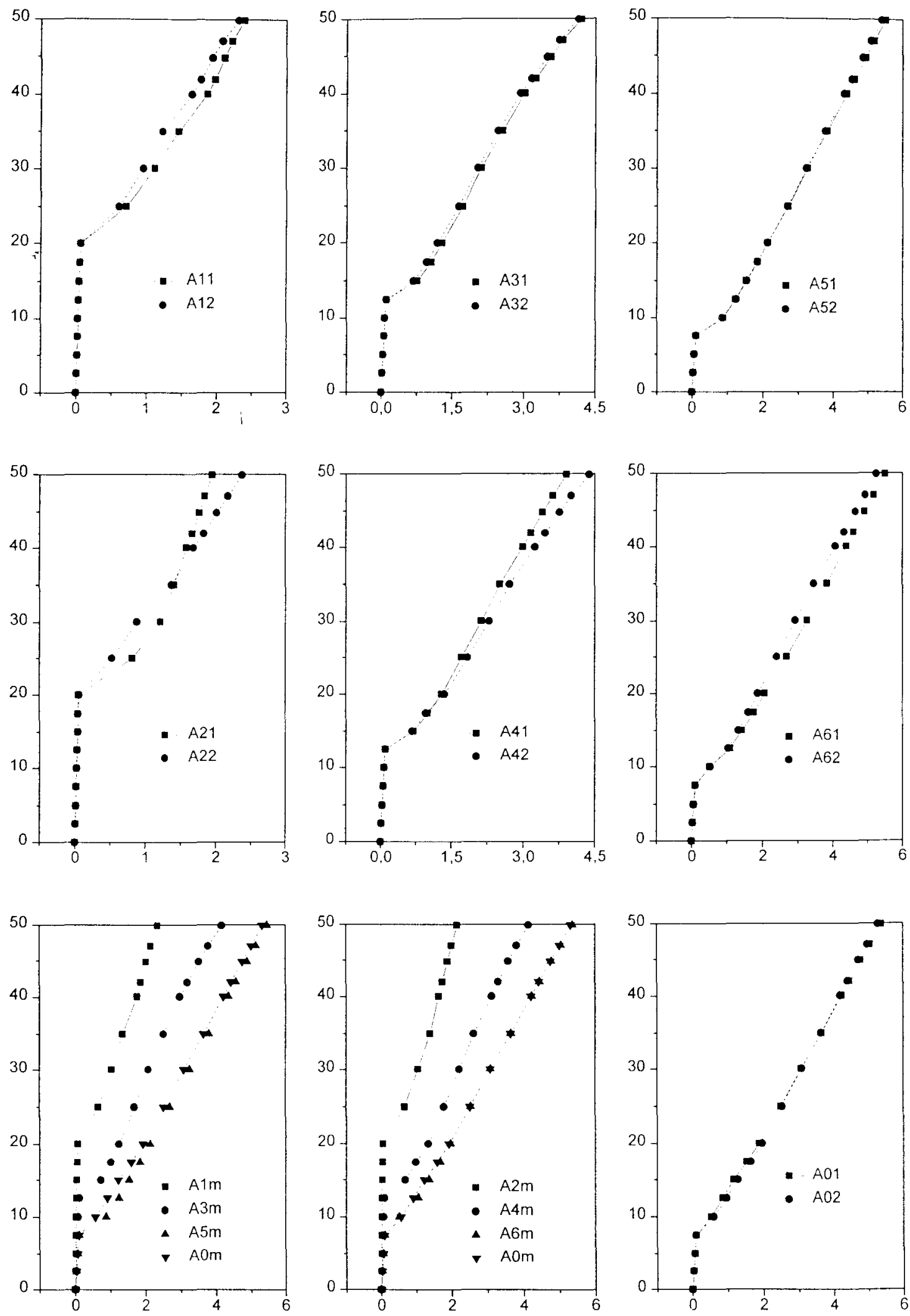

Figura 5.10 - Carga ( $\mathrm{kN}$ no eixo y) x Deformação ( $\mathrm{mm} / \mathrm{m}$ no eixo $\mathrm{x}$ ) cordoalhas do modelo V2 

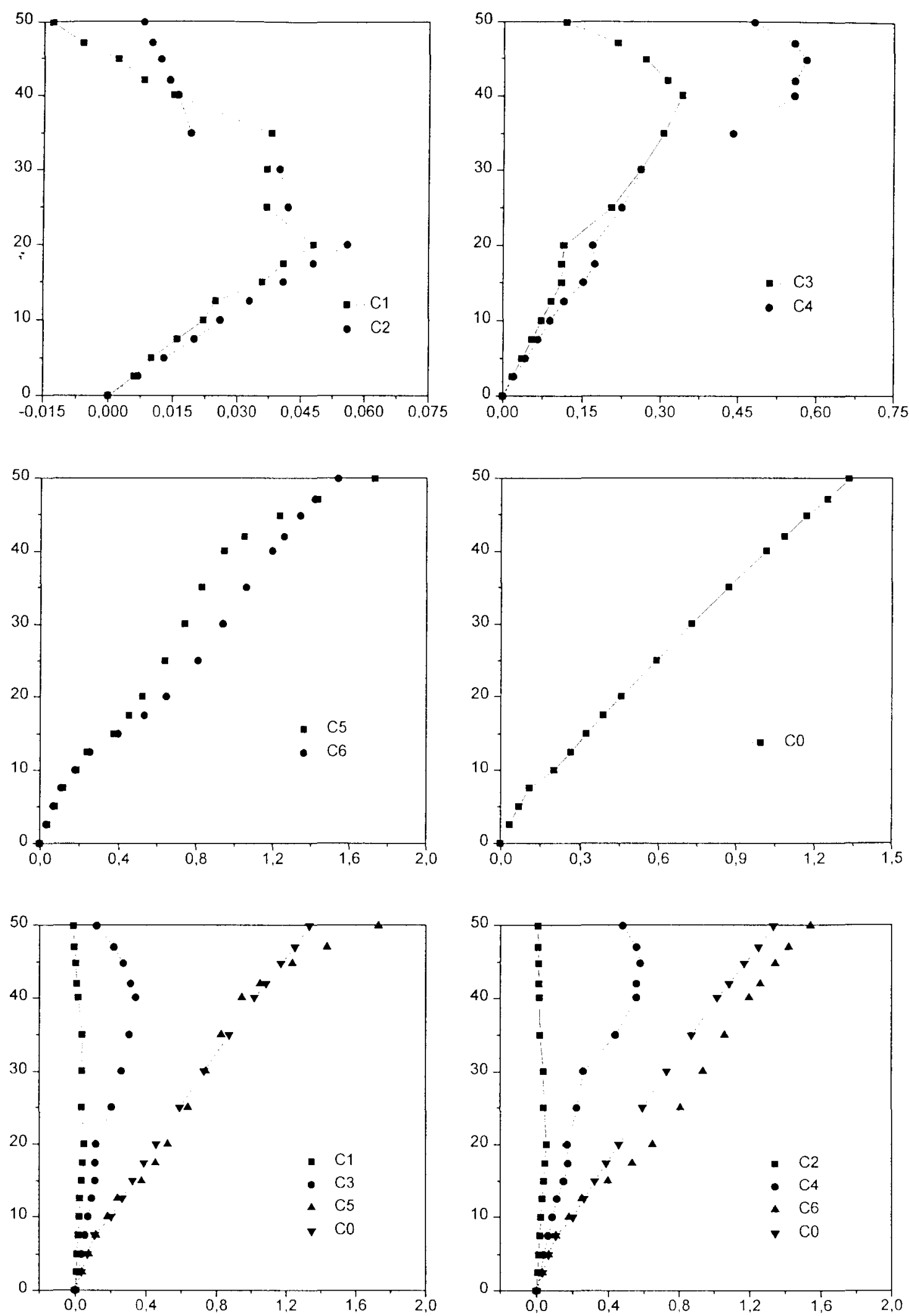

Figura 5.11 - Carga ( $\mathrm{kN}$ no eixo y) x Deformação ( $\mathrm{mm} / \mathrm{m}$ no eixo $\mathrm{x}$ ) concreto do modelo V2 

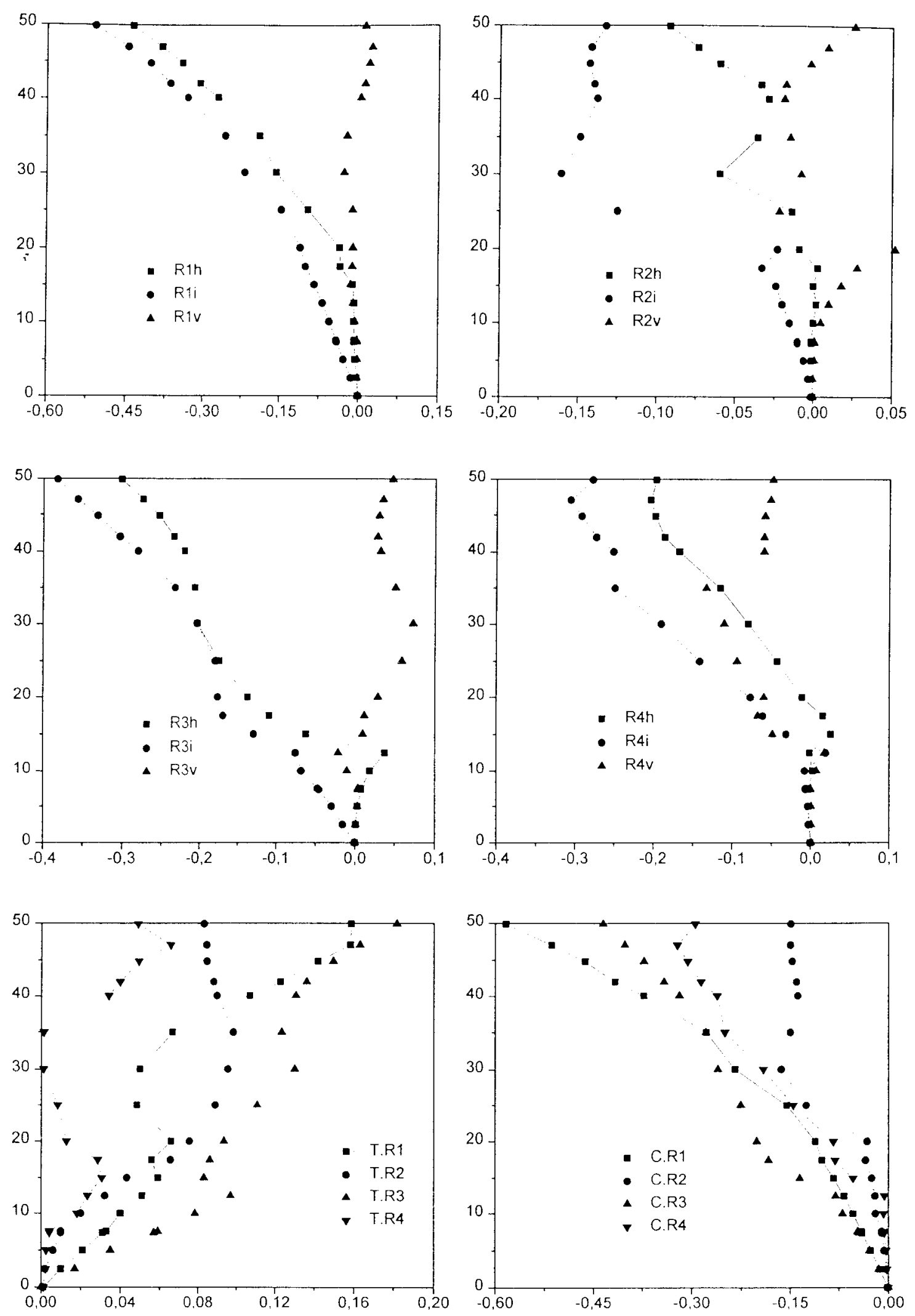

Figura 5.12 - Carga ( $\mathrm{kN}$ no eixo y) x Deformação $(\mathrm{mm} / \mathrm{m}$ no eixo $\mathrm{x})$ rosetas do modelo $\mathrm{V} 2$ 


\subsection{3 - MODELO V3}

Este modelo também era igual ao modelo de referência, exceto pela adição de $1 \%$ de fibra de aço de $2,54 \mathrm{~cm}$ e $0,65 \%$ de superplastificante. A trabalhabilidade resultante foi excelente e não houve qualquer problema durante a moldagem da peça. :Houve boa regularidade nos resultados dos ensaios dos corpos-de-prova de concreto.

Os apoios eram móveis dos dois lados da peça. A carga máxima atingida no ensaio foi idêntica a do modelo $\mathrm{V} 2,50 \mathrm{kN}$. A ruptura ocorreu no lado direito da viga e provocou o lançamento de vários pedaços de concreto à distância. As Fotos 5.11 e 5.12 mostram o aspecto da região danificada e o detalhe onde aparecem as fibras junto à superfície de ruptura, respectivamente.

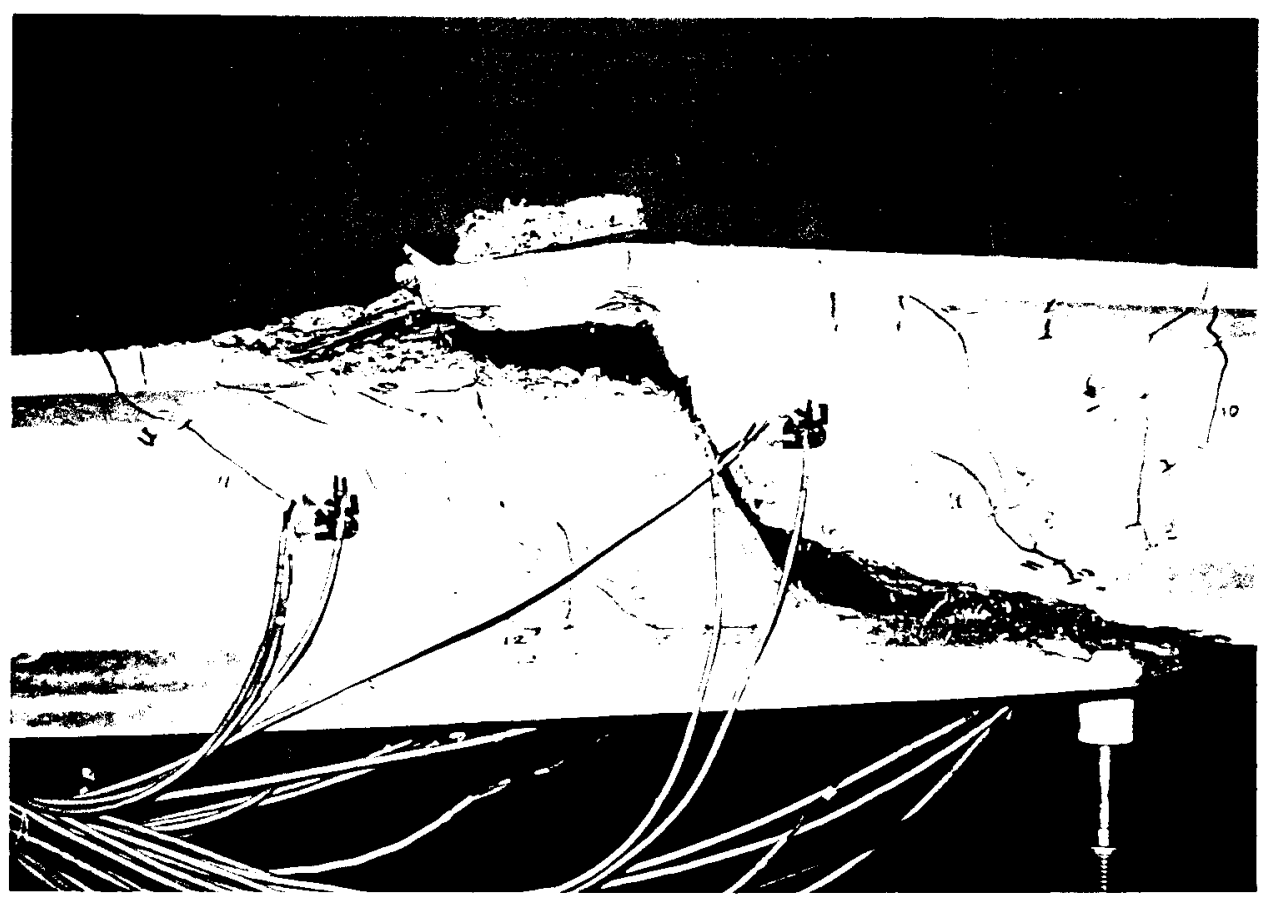

Foto 5.11 - Aspecto da região da ruptura do modelo V3

A extensão da região atingida foi menor que nos modelos anteriores, indo do ponto de aplicação da carga até $51 \mathrm{~cm}$ da extremidade da peça. Ela atravessou os estribos E6, que abriu na mesa tracionada, E8, que rompeu na alma, e E10, que rompeu na mesa comprimida. $\mathrm{O}$ banzo comprimido permaneceu quase intacto. $\mathrm{Na}$ mesa tracionada, a região desintegrada se estendeu por um trecho de $35 \mathrm{~cm}$. O desnível entre as partes śeparadas é visível, assim como a deformação nas barras superiores junto ao ponto de aplicação da carga. 


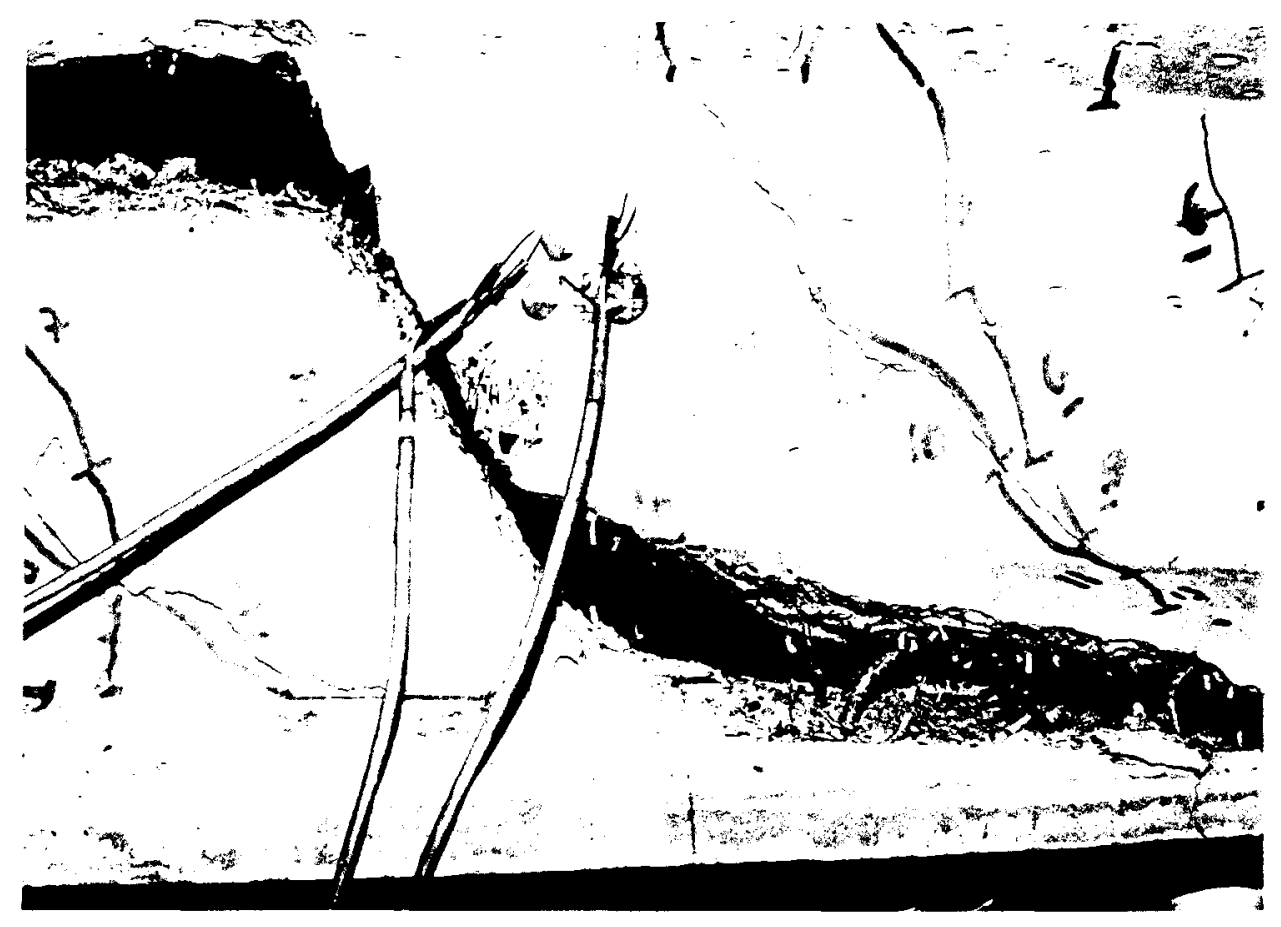

Foto 5.12 - Detalhe das fibras junto à superfície de ruptura no modelo V3

$\mathrm{O}$ último registro de dados corresponde à carga de $49 \mathrm{kN}$. Somente dois estribos escoaram até este instante, um de cada lado da viga, ambos no último incremento de carga. O estado limite último convencional foi atingido com $49 \mathrm{kN}$. Apesar do aumento da capacidade resistente, praticamente não houve acréscimo na resistência residual em relação ao modelo V1.

O estribo E2 se alongou abruptamente com $50 \mathrm{kN}$, quando a tensão atingiu 80 $\mathrm{MPa}$, mas o prolongamento da fissura inclinada não atingiu a posição deste estribo. conforme mostra a Foto 5.22, onde a posição dos estribos é marcada com linhas tracejadas nas mesas das vigas. Os estribos E5 e E6 foram os mais solicitados. Os primeiros estribos foram acionados com $12.5 \mathrm{kN}$, antes mesmo da observação da inclinação das fissuras de flexão.

O arqueamento dos esforços no banzo comprimido avançou até os pontos intermediários. Houve tensões de tração significativas em $\mathrm{Cl}$ e C2. A compressão no ponto $\mathrm{C} 6$, lado da ruptura, foi mais suave que em C5.

As'deformações nas cordoalhas foram um pouco maiores do lado esquerdo do que no lado direito, acompanhando as maiores deformações observadas no concreto deste lado da viga. 

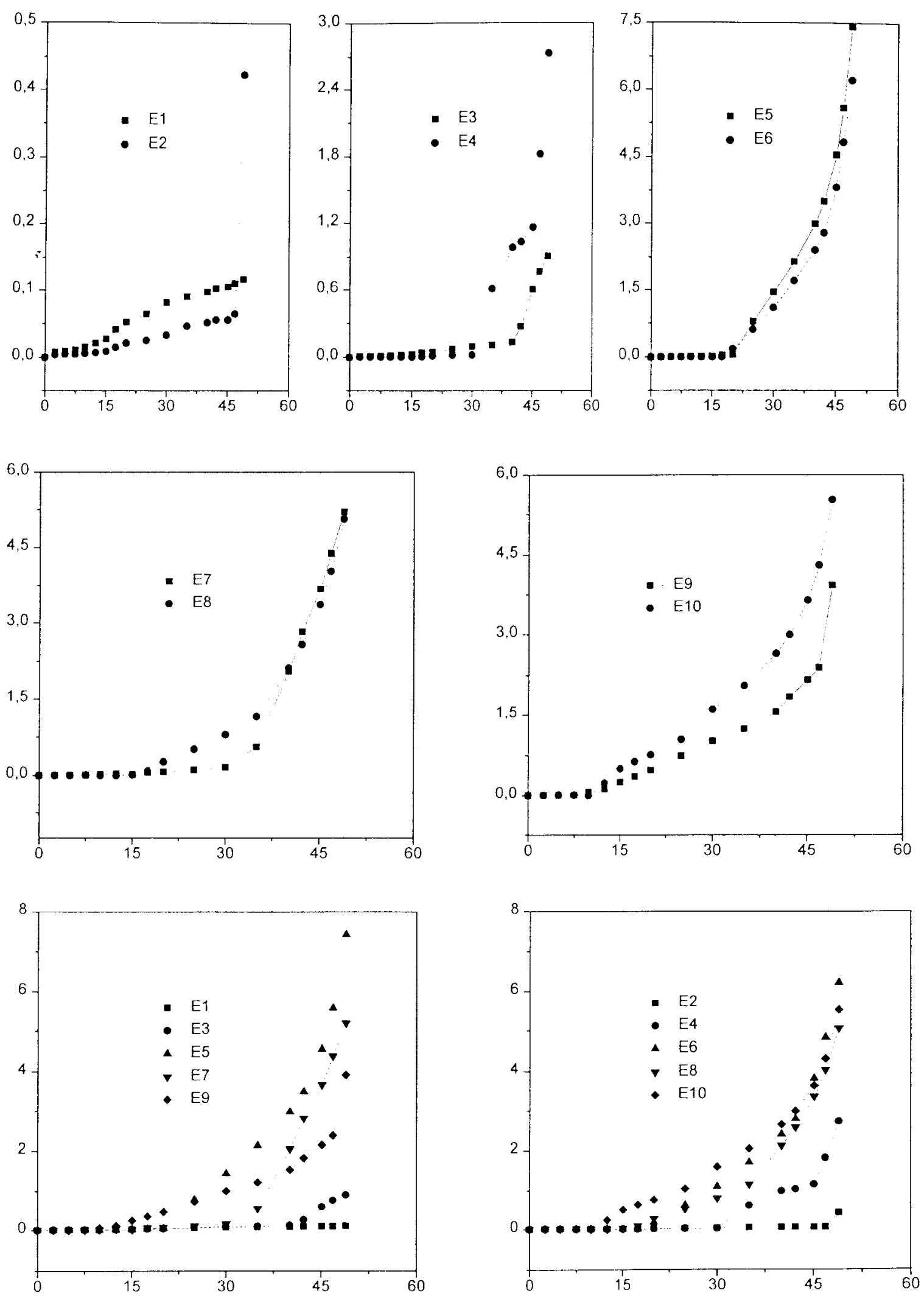

Figura 5.13 - Deformação ( $\mathrm{mm} / \mathrm{m}$ no eixo y) $\mathrm{x}$ Carga $(\mathrm{kN}$ no eixo $\mathrm{x})$ estribos do modelo $\mathrm{V} 3$ 

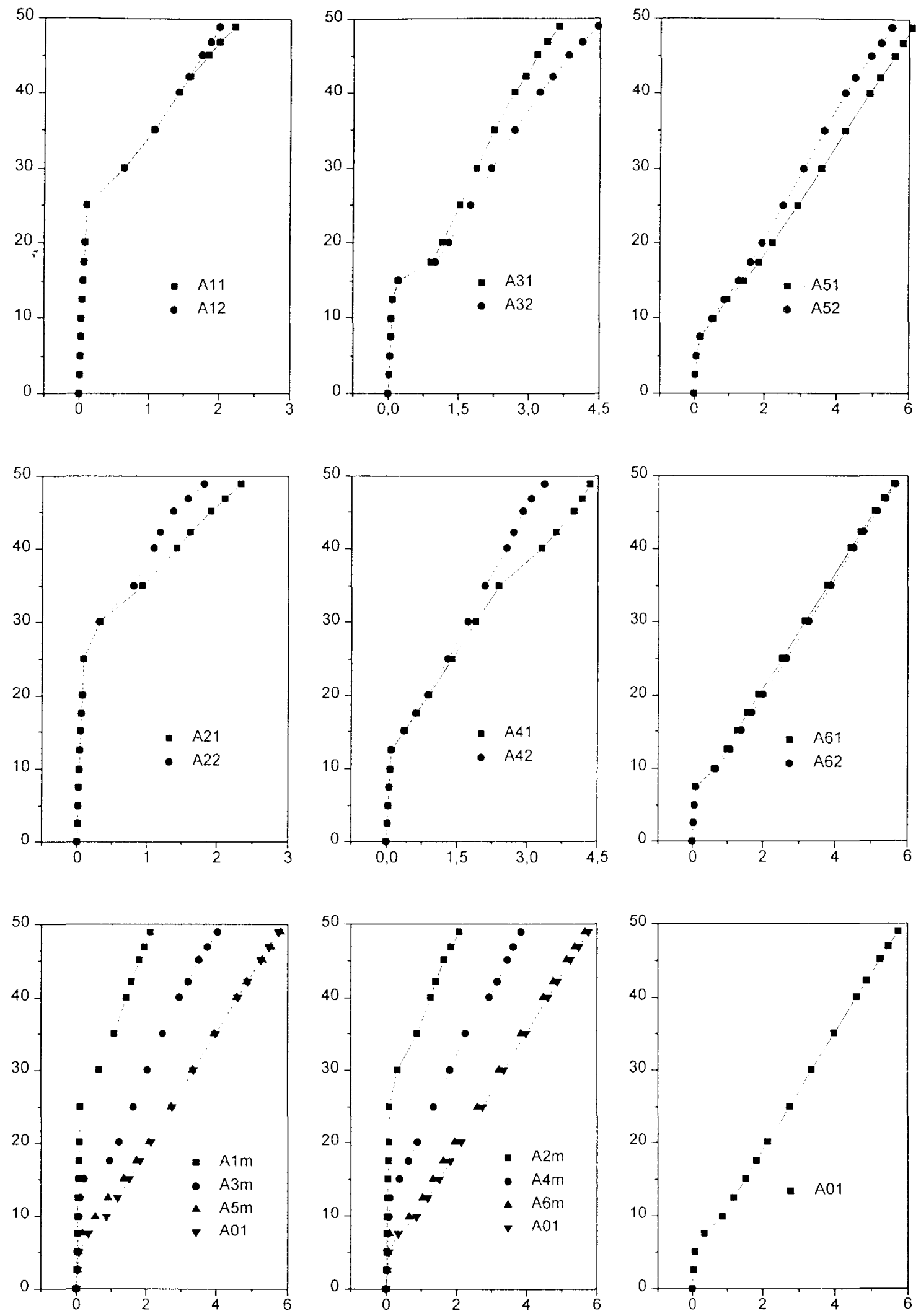

Figura 5.14 - Carga (kN no eixo y) x Deformação ( $\mathrm{mm} / \mathrm{m}$ no eixo $\mathrm{x}$ ) cordoalhas do modelo V3 

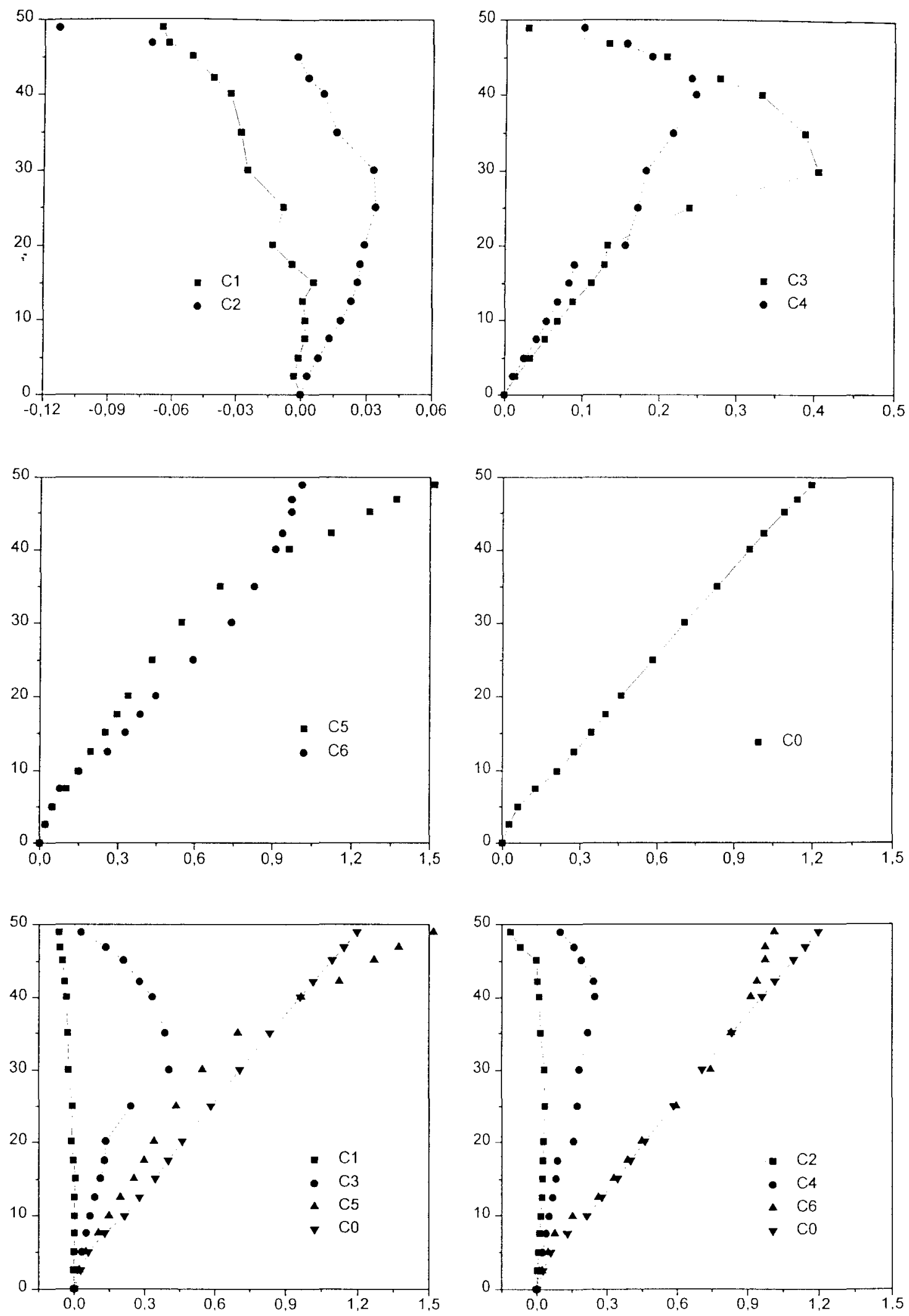

Figura 5.15 - Carga $(\mathrm{kN}$ no eixo y) x Deformação $(\mathrm{mm} / \mathrm{m}$ no eixo $\mathrm{x})$ concreto do modelo V3 

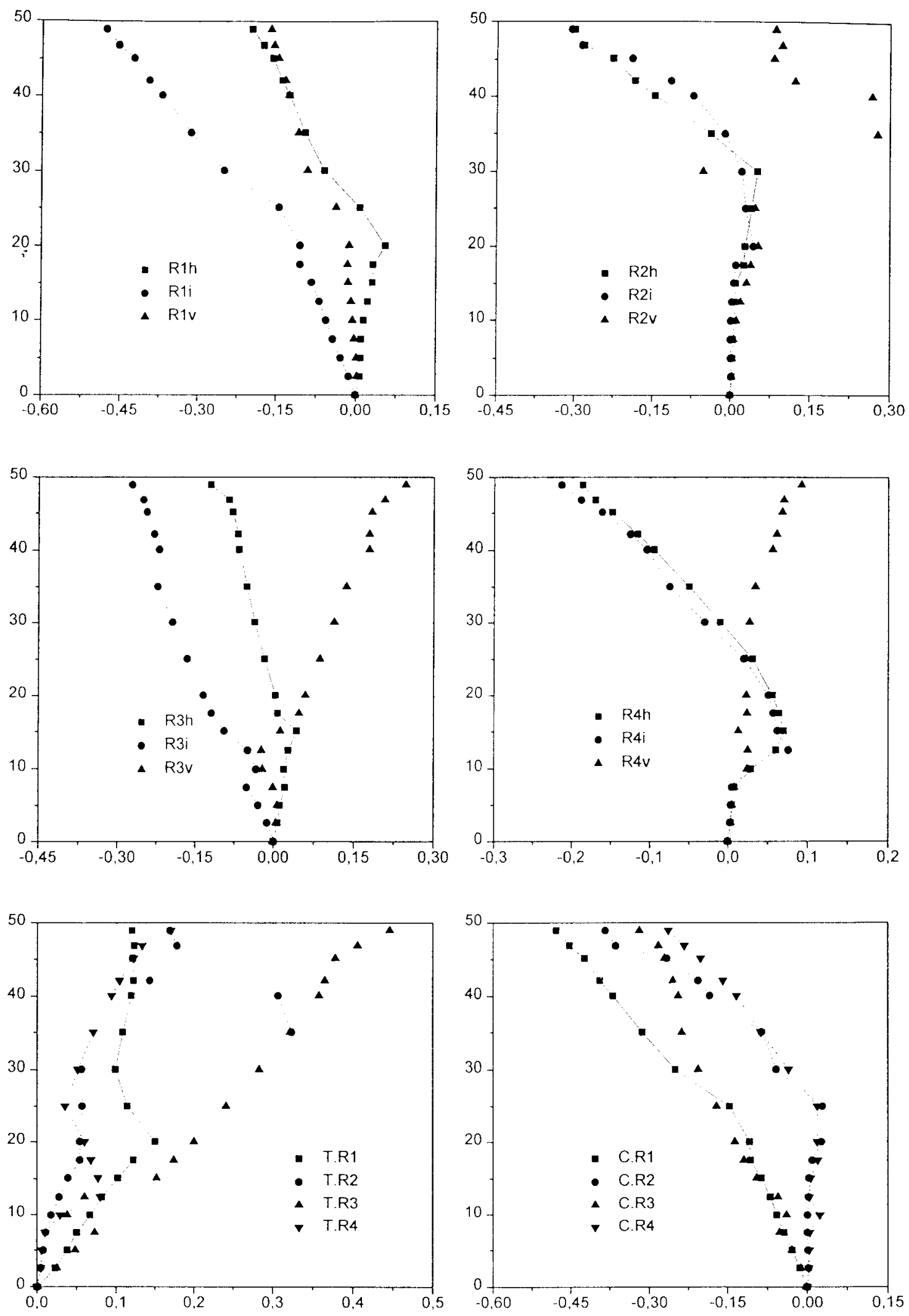

Figura 5.16 - Carga ( $\mathrm{kN}$ no eixo y) x Deformação $(\mathrm{mm} / \mathrm{m}$ no eixo $\mathrm{x})$ rosetas do modelo V3 


\subsection{4 - MODELO V4}

Este foi o primeiro modelo em que as cordoalhas foram pré-tracionadas. Apesar de não conter fibras, optou-se por acrescentar uma pequena quantidade de superplastificante $(0,3 \%)$ para facilitar a execução e melhorar a qualidade do concreto. Os extensômetros adicionais nas cordoalhas laterais foram colocados na posição A4.

As cordoalhas foram estiradas aplicando-se a força em quatro etapas, registrando-se a força nas células de carga e as deformações nos extensômetros de todas as cordoalhas em cada estágio do estiramento. Além de acompanhar o comportamento de cada cordoalha durante a operação, foram observadas as perdas devidas ao escorregamento das ancoragens e ao deslocamento do pórtico, nas cordoalhas já esticadas.

Conforme se comentou anteriormente, as cordoalhas foram tracionadas de modo que a força máxima ancorada ficasse próxima de $42 \mathrm{kN}$, para evitar, com segurança, o aparecimento de fissuras na zona tracionada pela protensão.

Elas foram sucessivamente estiradas até $43 \mathrm{kN}$ e encunhadas, começando sempre pelas cordoalhas laterais. Após o encunhamento da última cordoalha, as forças indicadas nas células de carga eram iguais a $35,2 \mathrm{kN}, 38,9 \mathrm{kN}$ e $41,7 \mathrm{kN}$, na ordem do estiramento. Todas foram reestiradas e encunhadas novamente, apresentando os valores finais de $41,8 \mathrm{kN}, 42 \mathrm{kN}$ e $42,3 \mathrm{kN}$, o que resulta uma força média ancorada de $42 \mathrm{kN}$ por cordoalha.

Após a ancoragem das cordoalhas nos pórticos, completou-se a montagem das armaduras. A moldagem da viga ocorreu somente depois de três dias. Neste dia não foram registrados os dados do sistema, quando se teria a estimativa das perdas devido à relaxação do aço até esta data.

Quatro corpos-de-prova de concreto foram ensaiados três dias após a moldagem. A resistência obtida era suficiente para que a viga absorvesse as tensões introduzidas pelas cordoalhas. Pela primeira vez o ensaio dos corpos-de-prova foi realizado numa prensa automática.

Antes da liberação da força as deformações nos extensômetros foram inadvertidamente zeradas, mas pôde-se observar que as deformações haviam diminuído um pouco, conforme era esperado, devido à relaxação do aço e à retração do concreto. Porém, a força indicada nas células de carga apresęntou ligeiro acréscimo, que pode ser decorrente da alteração do comprimento das cordoalhas e da pista causados pela variação de temperatura. Porisso. os valores de $P_{0}$ somente são apresentados conforme a indicação das células de carga. Posteriormente, estes dados foram recuperados. 
Após a transferência, a força média $\mathrm{P}_{0}$, estimada em $38,8 \mathrm{kN}$, provocaria uma tensão máxima de tração de 2,6 $\mathrm{MPa}$, menor do que a resistência obtida nos corpos-deprova. Além disso, a norma permite que a tensão de tração atinja o valor de 1,2 vezes a resistência à tração simples, já que a resistência à tração na flexão é maior, desde que se providencie armadura para absover esta solicitação.

* A variação das deformações devido ao encurtamento do concreto foi uniforme e compatível com os valores teóricos. Para uma força de $40 \mathrm{kN}$ por cordoalha, esperavase uma perda de $3,3 \mathrm{kN}$, equivalente a uma variação de $0,0285 \%$ na deformação das cordoalhas.

Até o dia do ensaio houve uma perda adicional média de quase $4 \mathrm{kN}$. Assim, a força de protensão média $P_{t}$ em cada cordoalha imediatamente antes do ensaio foi de aproximadamente $35 \mathrm{kN}$.

Conforme se verifica na Tabela 5.17, apesar da diferença entre os valores da força de protensão calculados segundo os três procedimentos descritos, os valores médios são próximos entre si em todas as etapas de interesse.

A viga foi ensaiada sete dias após a concretagem, ou seja, dez dias após o estiramento das cordoalhas. Todos os extensômetros foram zerados no início do ensaio. Portanto, as deformações nas cordoalhas a partir deste instante se devem somente aos efeitos do carregamento no ensaio de flexão.

Para uma força média de $34,8 \mathrm{kN}$ em cada cordoalha, a força cortante que provoca a descompressão do trecho mais solicitado na flexão vale $19,7 \mathrm{kN}$.

A carga máxima atingida no ensaio foi $63,5 \mathrm{kN}$. Houve, portanto, uma variação de $21,5 \mathrm{kN}$, ou $51 \%$, em relação ao modelo similar sem protensão, cujo valor é muito próximo da carga de descompressão. A ruína ocorreu do lado esquerdo da viga. Várias partes de concreto despreendidas e alguns componentes dos apoios foram atirados à distância. A Foto 5.13 mostra o detalhe da região danificada e a Foto 5.14 o aspecto do outro lado da viga após a ruína. As bielas eram nitidamente mais abatidas que nos modelos anteriores sem protensão, conforme mostra a comparação das Fotos 5.19 e 5.20, apresentadas posteriormente.

A região danificada partiu do ponto de aplicação da carga e atingiu o diafragma, a $15 \mathrm{~cm}$ da extremidade da peça. Na mesa comprimida, ela se estendeu por um trecho de mais de $40 \mathrm{~cm}$, onde os estribos E10 e E12 se abriram. Na zona tracionada formou-se um buraco que avançou até a metade da altura da viga. Junto à mesa, o concreto ficou danificado num trecho de $60 \mathrm{~cm}$. O estribo E2 se manteve intacto, mesmo com a desintegração do concreto nesta região. A trajetória da ruína atravessa ainda os estribos E4, E6 e E8 na alma, sendo que os dois primeiros 
romperam. O desnível entre as partes separadas é significativo, onde se observam as cordoalhas bastante encurvadas.

Em relação ao modelo V1, o comportamento foi similar após a descompressão, conforme mostra a análise das deformações na cordoalha e o panorama de fissuração, especialmente no trecho central da viga. O escoamento das cordoalhas ainda era distante e haveria apenas uma pequena diferença nas deformações, devido à etapa mais longa anterior à fissuração no modelo protendido. Próximo das extremidades da viga, as diferenças entre os modelos se acentuam, pois a força de descompressão nesta região é maior.

Após o ensaio, foram observadas fissuras típicas de flexão na face comprimida, além de fissuras inclinadas em direção ao centro da viga no tramo central. Não se encontrou uma explicação para estes fatos.

Até $43 \mathrm{kN}$, nenhum estribo foi efetivamente solicitado. Neste instante, E9 e E10 se alongaram subitamente, quando a tensão superou $400 \mathrm{MPa}$. Com $40 \mathrm{kN}$, algumas fissuras de flexão começaram a inclinar na região destes estribos. No modelo V1, a mobilização destes estribos ocorreu bem antes, sendo que a diferença foi maior que a etapa até a descompressão, já que nesta região ela ocorre depois. Além disso, a protensão altera a trajetória das tensões principais. Naquela viga, as fissuras começaram a inclinar com $14 \mathrm{kN}$, coincidindo com o acionamento dos estribos.

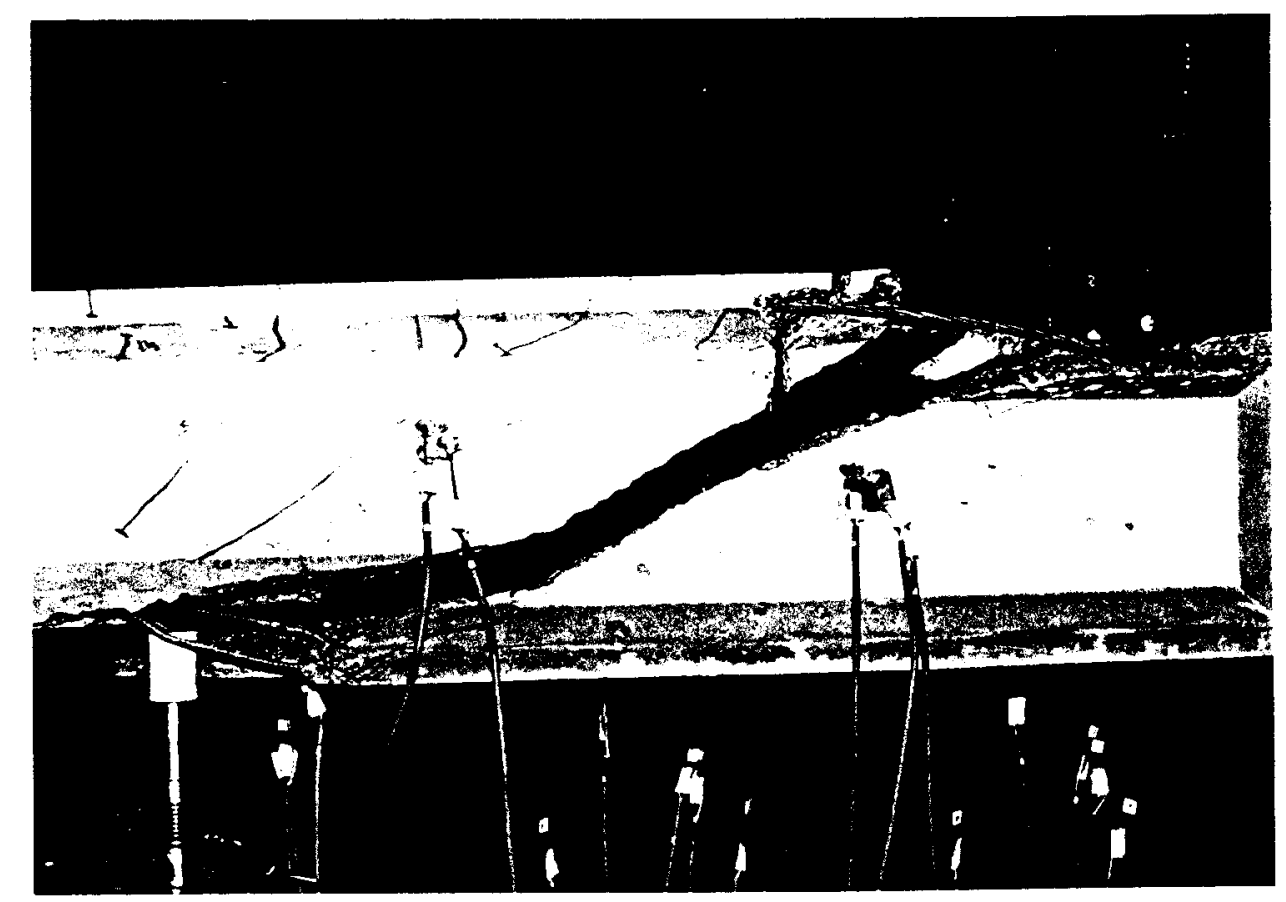

Foto 5.13 - Detalhe da região da ruptura do modelo V4 
Os últimos dados se referem à carga de $62 \mathrm{kN}$. Apenas dois estribos escoaram com $56 \mathrm{kN}$, um de cada lado da viga. Desta forma, a partir deste instante, houve uma resistência adicional de $7,5 \mathrm{kN}$ até a ruína.

A deformação máxima nas cordoalhas ocorreu no meio do vão, igual a $0,45 \%$. Computando-se a deformação de pré-alongamento $(0,29 \%$, em média), a deformação ;total foi de $0,74 \%$, que equivale a uma força total de $267,5 \mathrm{kN}$, coerente com o momento fletor correspondente à carga de $62 \mathrm{kN}$ (considerando-se o braço de alavanca igual a $27 \mathrm{~cm}$, a força esperada nas cordoalhas é de $257 \mathrm{kN}$ ).

Em relação aos modelos V2 e V3, as deformações nas cordoalhas foram menores em todos os pontos instrumentados, já que, naquelas vigas, a etapa fissurada foi mais longa em todas as regiões da peça. Em relação ao modelo V1, os valores foram similares no ponto central (desprezando-se o pré-alongamento), apesar da diferença na carga máxima, pois a diferença entre a carga de ruptura e a carga de fissuração se manteve quase constante. Isto confirma a semelhança da fissuração nesta região na ruptura. Nas extremidades, a maior deformação observada em V1 se deve à fissuração mais intensa nesta região, onde a força de descompressão é maior.

A flecha foi acompanhada até a carga de $50 \mathrm{kN}$. Os aparelhos foram retirados, pois não se tinha uma avaliação segura da proximidade da ruptura. Extrapolando-se a curva das flechas até o final do ensaio, o valor máximo seria igual a $38 \mathrm{~mm}$, praticamente igual ao do modelo $\mathrm{V} 1$.

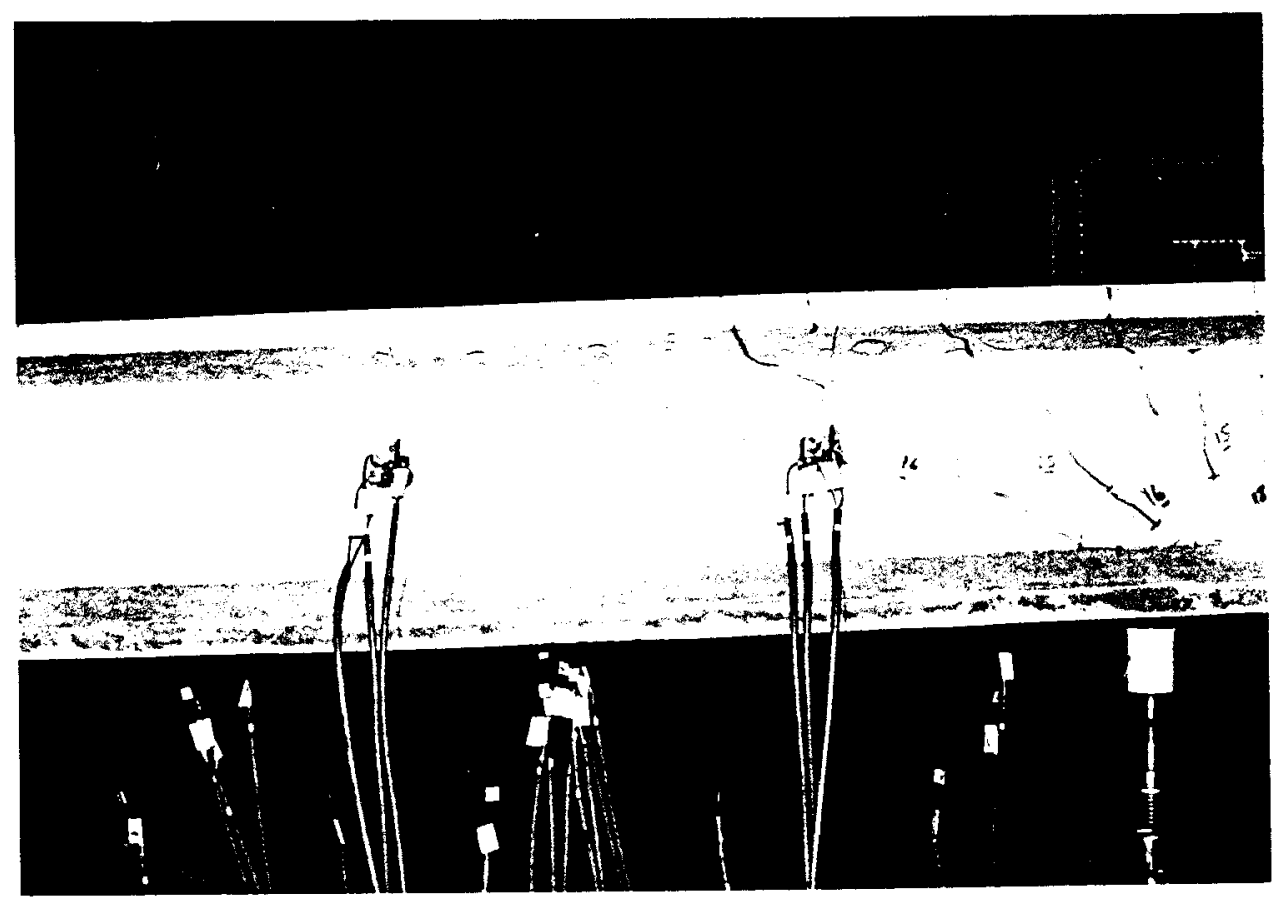

Foto 5.14 - Aspecto final do lado oposto ao lado da ruína do modelo V4 

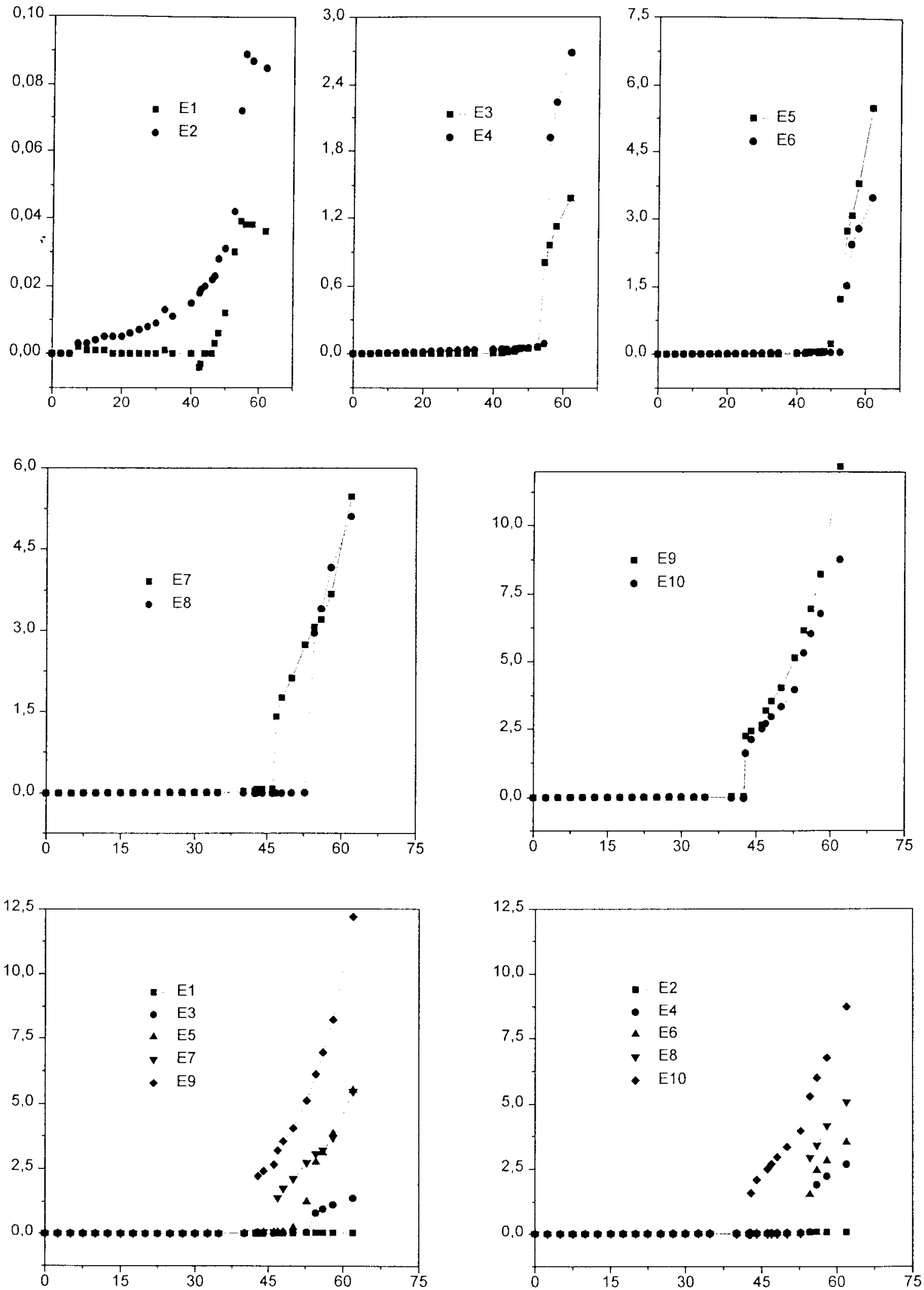

Figura 5.17 - Deformação $(\mathrm{mm} / \mathrm{m}$ no eixo y) x Carga (kN no eixo $\mathrm{x})$ estribos do modelo V4 

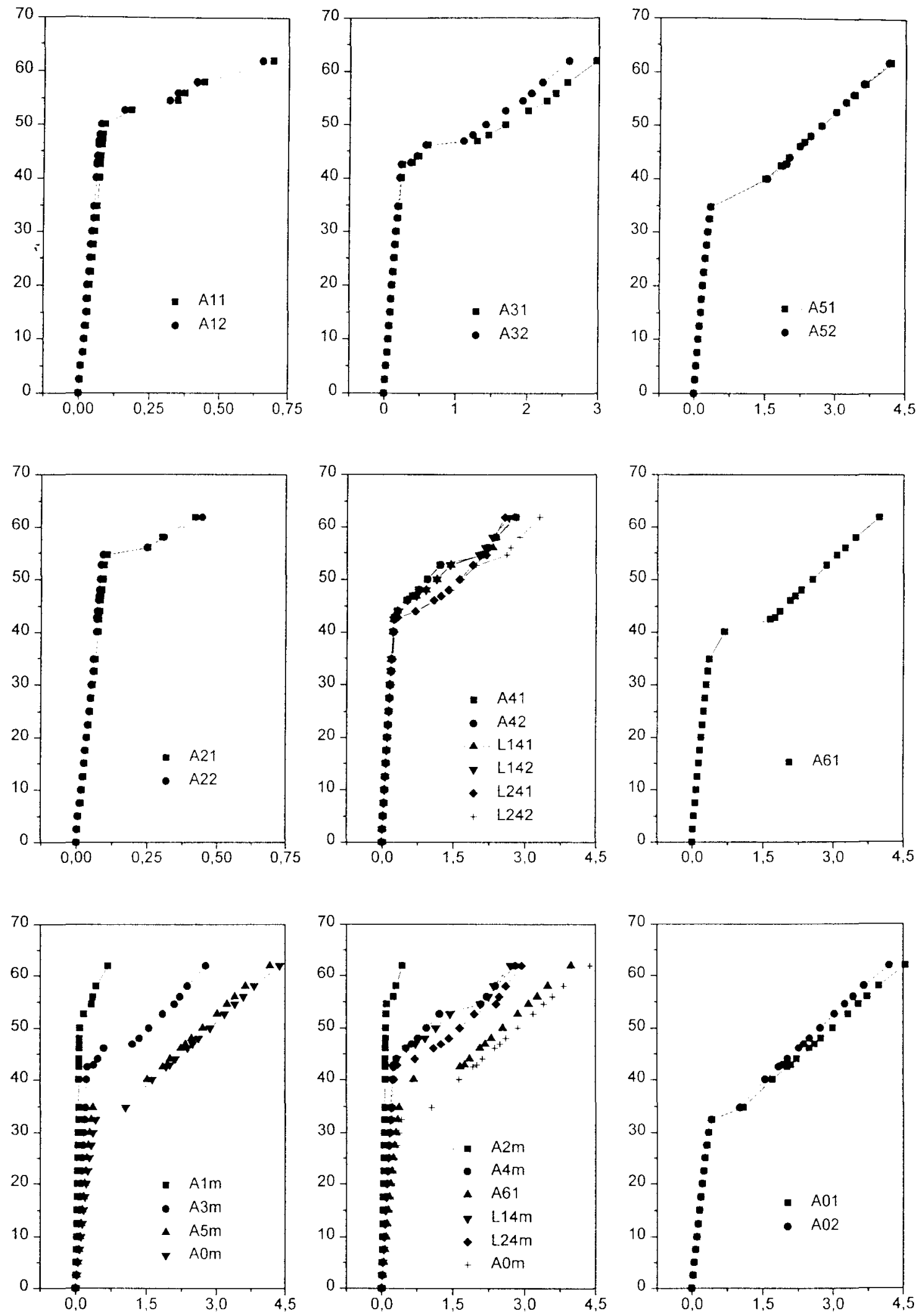

Figura 5.18 - Carga (kN no eixo y) x Deformação ( $\mathrm{mm} / \mathrm{m}$ no eixo $\mathrm{x}$ ) cordoalhas do modelo $\mathrm{V} 4$ 

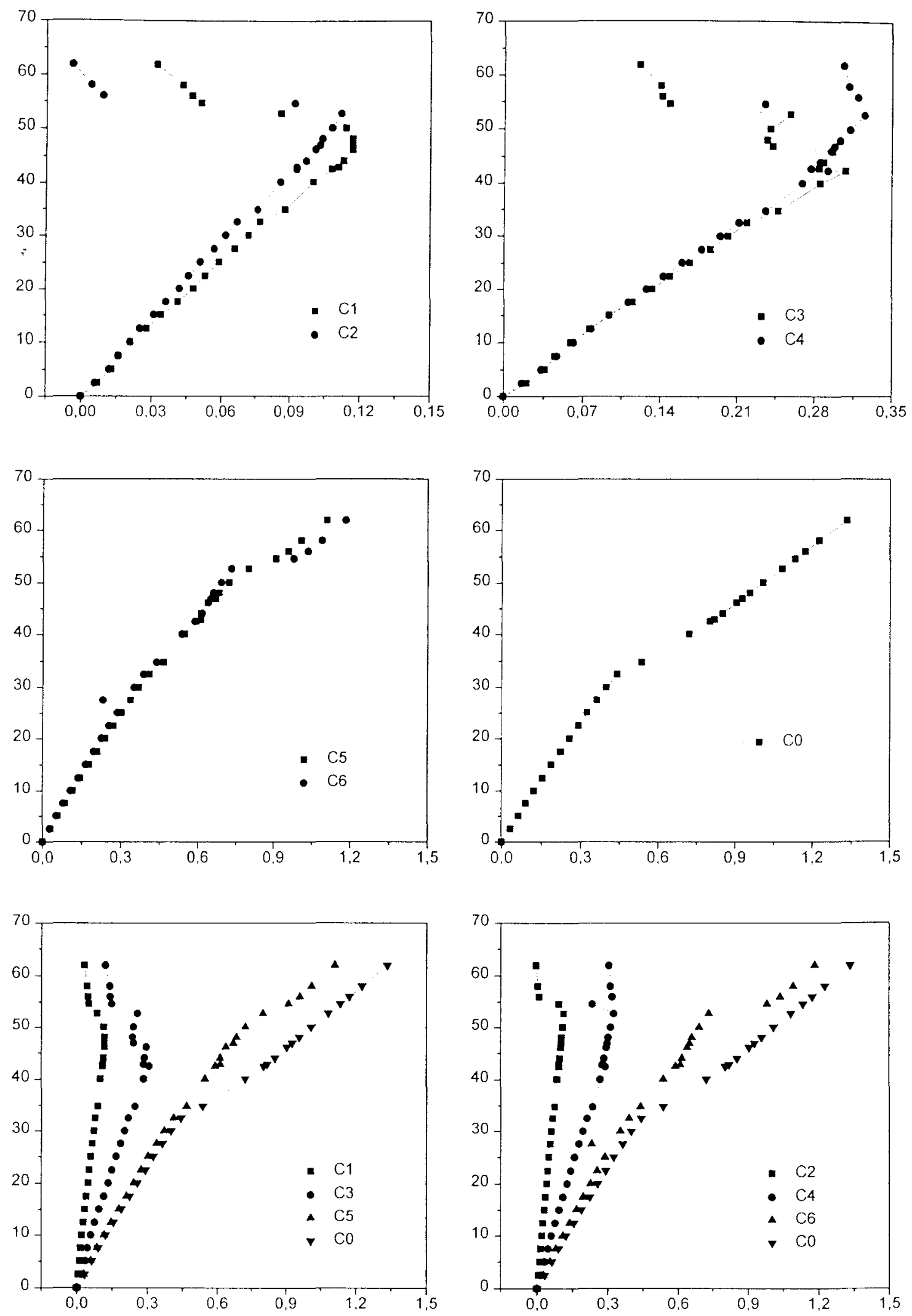

Figura 5.19 - Carga ( $\mathrm{kN}$ no eixo y) x Deformação $(\mathrm{mm} / \mathrm{m}$ no eixo $\mathrm{x}$ ) concreto do modelo V4 

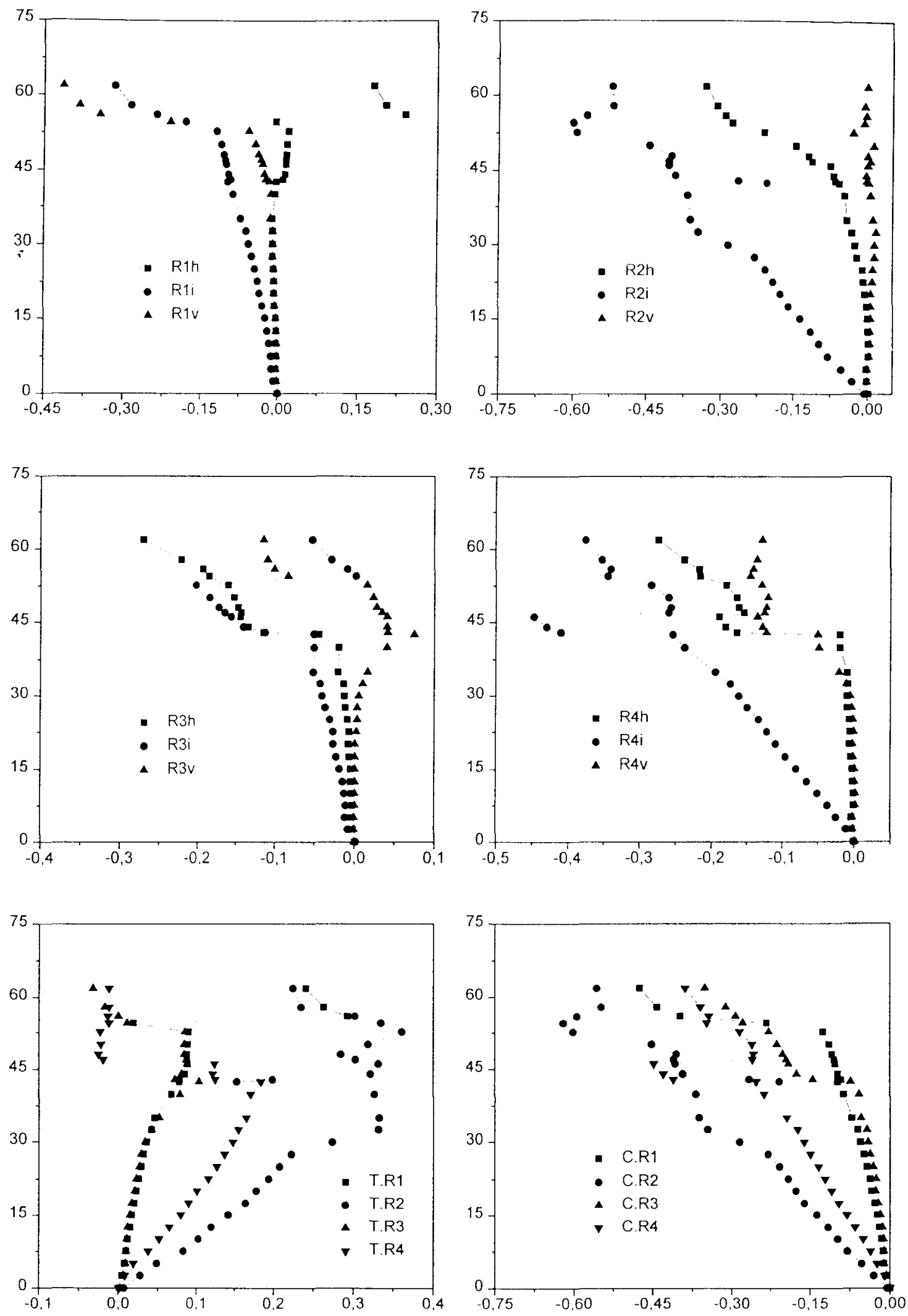

Figura 5.20 - Carga ( $\mathrm{kN}$ no eixo y) x Deformação $(\mathrm{mm} / \mathrm{m}$ no eixo $\mathrm{x})$ rosetas do modelo V4 


\subsection{5 - MODELO V5}

O segundo modelo protendido continha $0,5 \%$ de fibra de polipropileno, introduzidas no concreto pronto, e 1,5\% de aditivo superplastificante. A moldagem, sempre mais difícil com este tipo de fibra, transcorreu sem os problemas verificados na viga V2. A instrumentação e o controle de resistência do concreto foram idênticos ao do modelo anterior.

As cordoalhas foram estiradas cm dois estágios de carga. Após o encunhamento da cordoalha central, as forças nas cordoalhas eram iguais a $36,4 \mathrm{kN}, 36,5 \mathrm{kN}$ e 42,2 $\mathrm{kN}$, na ordem em que foram tracionadas. Após o reestiramento e encunhamento, os valores finais da força de protensão eram iguais a $41,8 \mathrm{kN}, 44,7 \mathrm{kN}$ e $42,4 \mathrm{kN}$, respectivamente, que equivalem a uma força média de $43 \mathrm{kN}$.

No reencunhamento da segunda cordoalha registrou-se um acréscimo na força indicada pela respectiva célula de carga igual a $2.5 \mathrm{kN}$, não acompanhado por variação nas deformações registradas nos extensômetros desta cordoalha.

A concretagem foi executada no mesmo dia, após a montagem das armaduras e o fechamento da fôrma. Três dias depois, as forças registradas nas células de carga apresentaram um ligeiro acréscimo, igual a $0,2 \%$, mas as deformações dos extensômetros diminuiram 1\%, em média. A deformação num dos extensômetros da cordoalha central aumentou muito. Conforme se comenta adiante, esta variação isolada foi observada em outros modelos, mas os valores médios quase sempre se mantiveram coerentes.

O ensaio ocorreu sete dias após a concretagem. Até este instante, as deformações nos extensômetros das cordoalhas diminuíram mais $10 \%$ em relação ao instante $t_{0}$. Desde o reestiramento até a transferência da força para o concreto persistiu uma pequena inconsistência entre os valores indicados nos extensômetros e os valores indicados nas células de carga.

Por medida de segurança, os apoios constituídos de placas e roletes de aço foram substituídos por placas de neoprene, que também permitem o deslocamento transversal e a rotação dos apoios.

A força cortante que provocava a descompressão da face pré-comprimida no trecho de momento fletor máximo era igual a $19,3 \mathrm{kN}$, considerando-se a força média igual a $34 \mathrm{kN}$ por cordoalha. A carga máxima atingida no ensaio foi de $73,5 \mathrm{kN}$, muito maior que a do modelo similar sem protensão. O aumento foi de $23,5 \mathrm{kN}$, ou $47 \%$, proporcional à força de descompressão. A introdıção das fibras novamente resultou em aumento da capacidade resistente. A carga máxima passou de $63,5 \mathrm{kN}$ para $73,5 \mathrm{kN}$, com aumento de $10 \mathrm{kN}$, ou $16 \%$. 
A ruptura ocorreu no lado esquerdo da viga. A região se apresentou pouco danificada nas duas partes separadas pela fissura diagonal, especialmente nas mesas, confirmando a eficiência destas fibras na manutenção da integridade do concreto após a ruína. $\mathrm{Na}$ alma, formou-se um buraco, já que a distância entre as superfícies separadas foi muito grande. Nas Fotos 5.23 e 5.26, observa-se o caminhamento das bielas em direção ao apoio.

A ruptura diagonal foi do ponto de aplicação da carga até o início do diafragma, atingindo todos os estribos situados no trecho onde atua a força cortante. Na alma, romperam os estribos E3, E5, E7 e E9 e a região atingida se estendeu por um trecho de $65 \mathrm{~cm}$, onde ficou delimitada por duas fissuras críticas, com inclinação de 22 e 29 graus. A Foto 5.15 mostra um detalhe da região da ruína, onde se observa a ruptura dos estribos E7 e E9.

Na mesa comprimida, houve um pequeno esmagamento superficial em toda a largura da face da viga, num trecho de $5 \mathrm{~cm}$, junto ao ponto de introdução do carregamento. Próxima a esta região, uma fissura muito aberta na face comprimida avançou até a mísula, formando uma saliência angulosa na extremidade de uma das fissuras que provocaram a ruína.

Os dois banzos permaneceram praticamente intactos. Os pedaços longos de fibras nas superfícies separadas pela ruptura ilustram a atuação das fibras como armadura de costura junto às fissuras, onde possivelmente elas foram arrancadas.

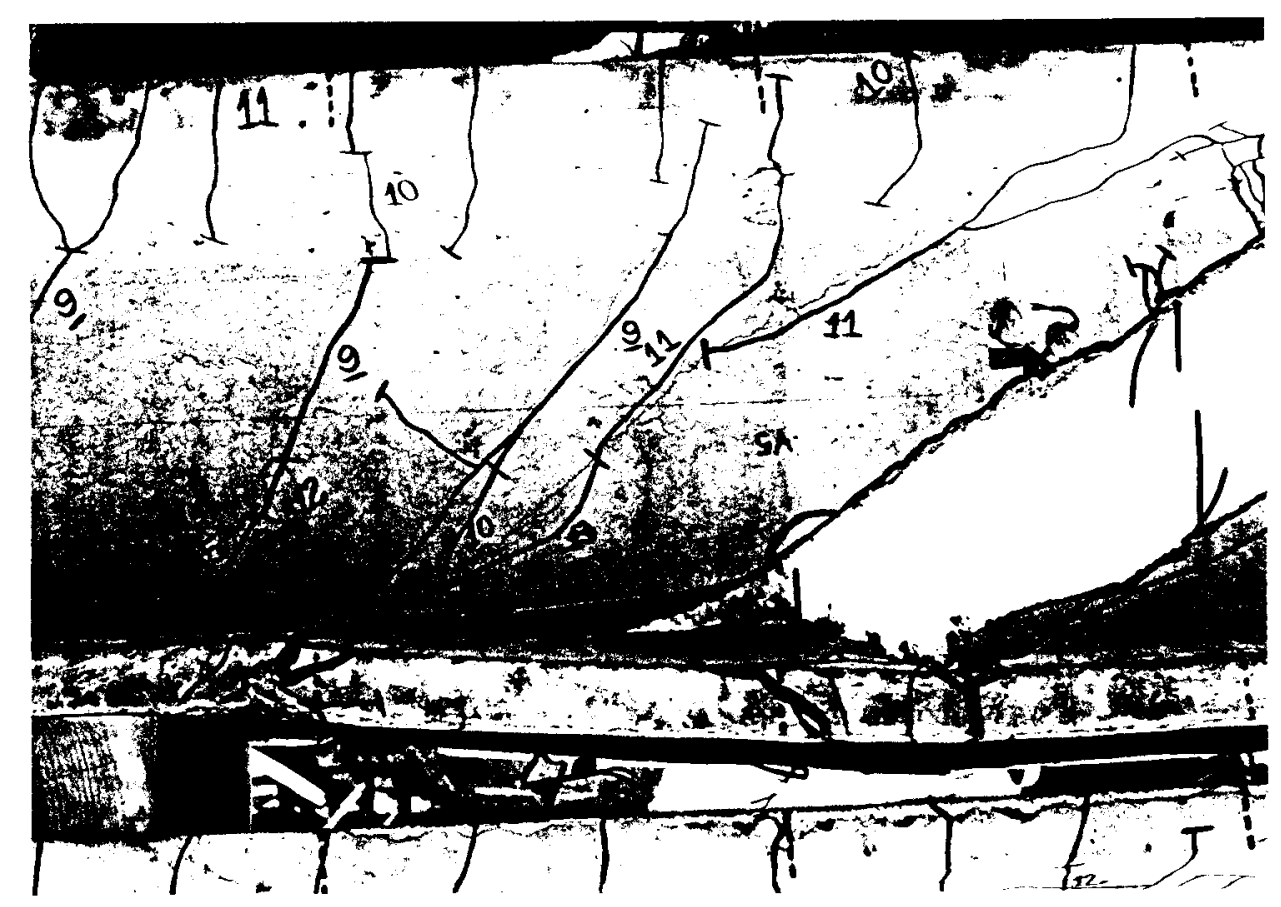

Foto 5.15 - Detalhe da região da ruptura do modelo V5 
Os últimos dados foram registrados quando a carga atingiu $72 \mathrm{kN}$. Três estribos escoaram no lado direito, o primeiro com $62 \mathrm{kN}$. No lado esquerdo, lado da ruptura, somente um estribo escoou, com $55 \mathrm{kN}$. Portanto, o estado limite último convencional ocorreu com $62 \mathrm{kN}$. A carga ainda foi aumentada mais $11,5 \mathrm{kN}$. A mobilização de um número maior de estribos repete um comportamento já observado nos ensaios ; anteriores com este tipo de fibra. A maior resistência residual também foi verificada no modelo V2, mas com menor intensidade.

As fissuras de flexão na face comprimida e as fissuras inclinadas em direção ao centro da viga no trecho central não foram percebidas durante o ensaio, enquanto os cuidados com a segurança permitiam a observação minuciosa da viga a cada incremento de carga. Após a ruína, estas fissuras estavam presentes. Portanto, elas surgiram muito próximo da ruptura e possivelmente são resultado da propagação dos danos durante a ruptura.

O acionamento dos estribos foi retardado em relação ao modelo similar sem fibras. Os primeiros estribos foram acionados com $47,5 \mathrm{kN}$, mas com $40 \mathrm{kN}$ algumas fissuras de flexão já se inclinavam. Mesmo que elas não coincidam com a posição dos estribos, o intervalo entre o surgimento das fissuras inclinadas e a mobilização dos estribos foi significativo. O mesmo fato foi observado no modelo $\mathrm{V} 2$, também de forma mais sutil.

A deformação máxima no concreto no ponto central foi muito maior que nas posições $\mathrm{C} 5$ e $\mathrm{C} 6$. No ponto $\mathrm{C} 2$ o banzo esteve tracionado a partir de $55 \mathrm{kN}$, atingindo uma tensão máxima de aproximadamente $4 \mathrm{MPa}$.

Nos pontos mais internos a deformação máxima nas cordoalhas foi quase $50 \%$ maior que no modelo V4, devido à diferença na carga máxima. Porém, com $62 \mathrm{kN}$ os valores eram aproximadamente iguais. Computando-se a deformação de préalongamento $(0,27 \%)$, a deformação máxima se aproximou de $1 \%(0,93)$. Conforme se observa no diagrama $\sigma-\varepsilon$ das cordoalhas, acima de $0,8 \%$ ele se torna curvo. Após 70 $\mathrm{kN}$ as deformações no ponto central aumentaram mais rapidamente, anunciando a proximidade do esgotamento da resistência à flexão. $O$ cálculo teórico indicava o escoamento das cordoalhas $(\varepsilon=1 \%$ ) para carga igual a $69,8 \mathrm{kN}$.

As fissuras de flexão não atingiram a região dos apoios, o que justifica as tensões reduzidas registradas nos pontos $\mathrm{A} 1$ e A2 , já observadas no modelo anterior. 

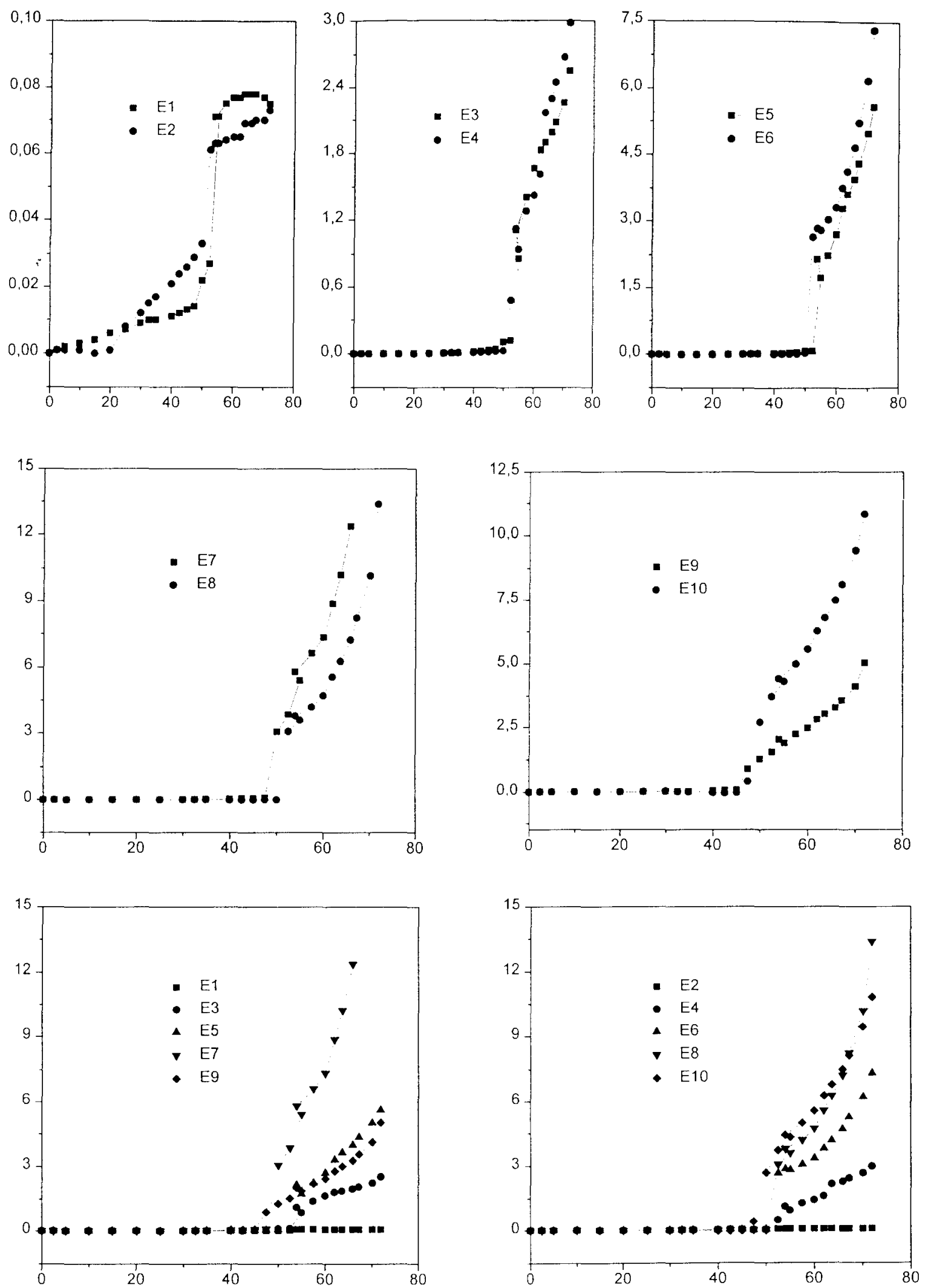

Figura 5.21 - Deformação $(\mathrm{mm} / \mathrm{m}$ no eixo y) x Carga $(\mathrm{kN}$ no eixo $\mathrm{x})$ estribos do modelo V5 

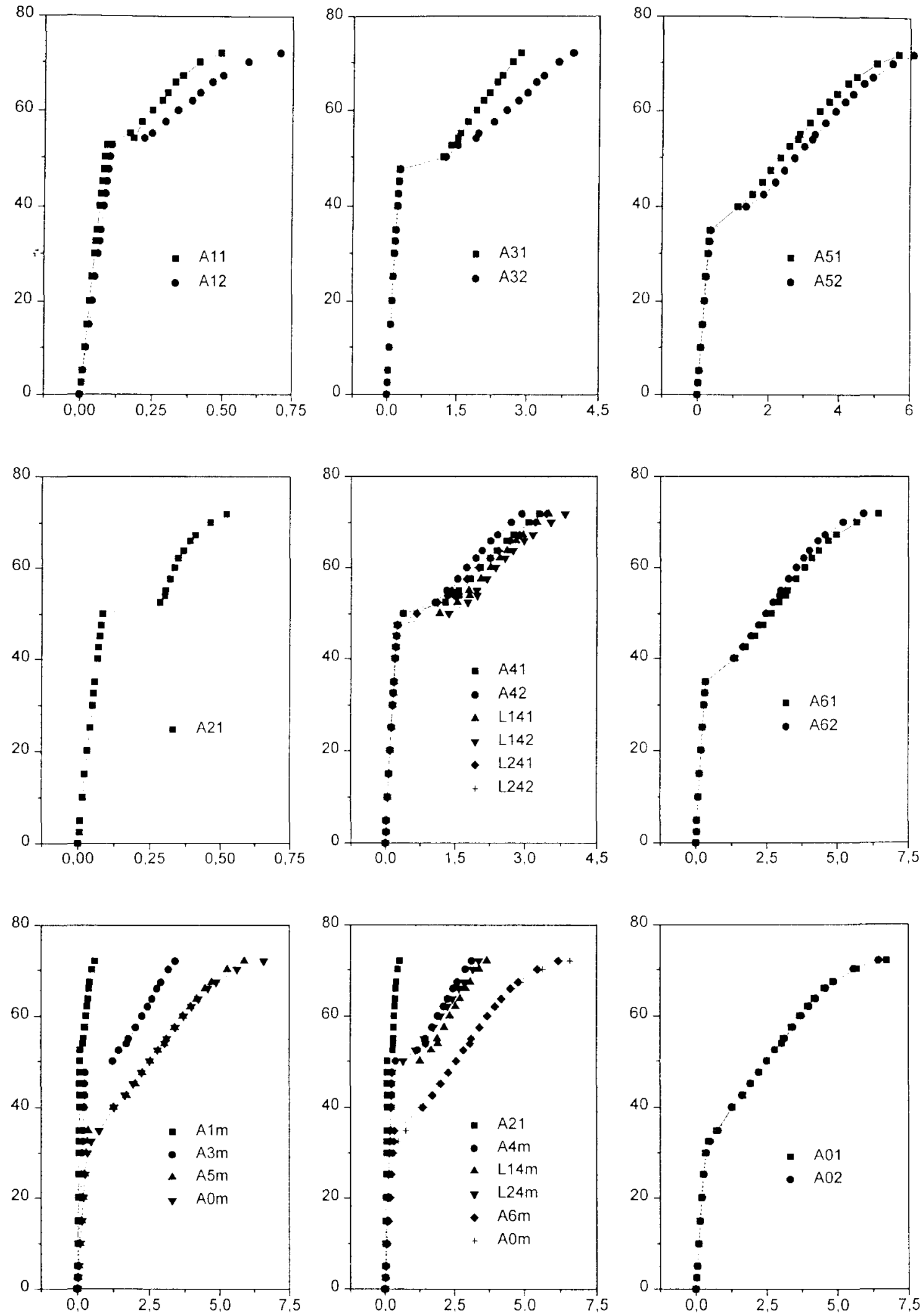

Figura 5.22 - Carga ( $\mathrm{kN}$ no eixo y) x Deformação $(\mathrm{mm} / \mathrm{m}$ no eixo $\mathrm{x})$ cordoalhas do modelo V5 

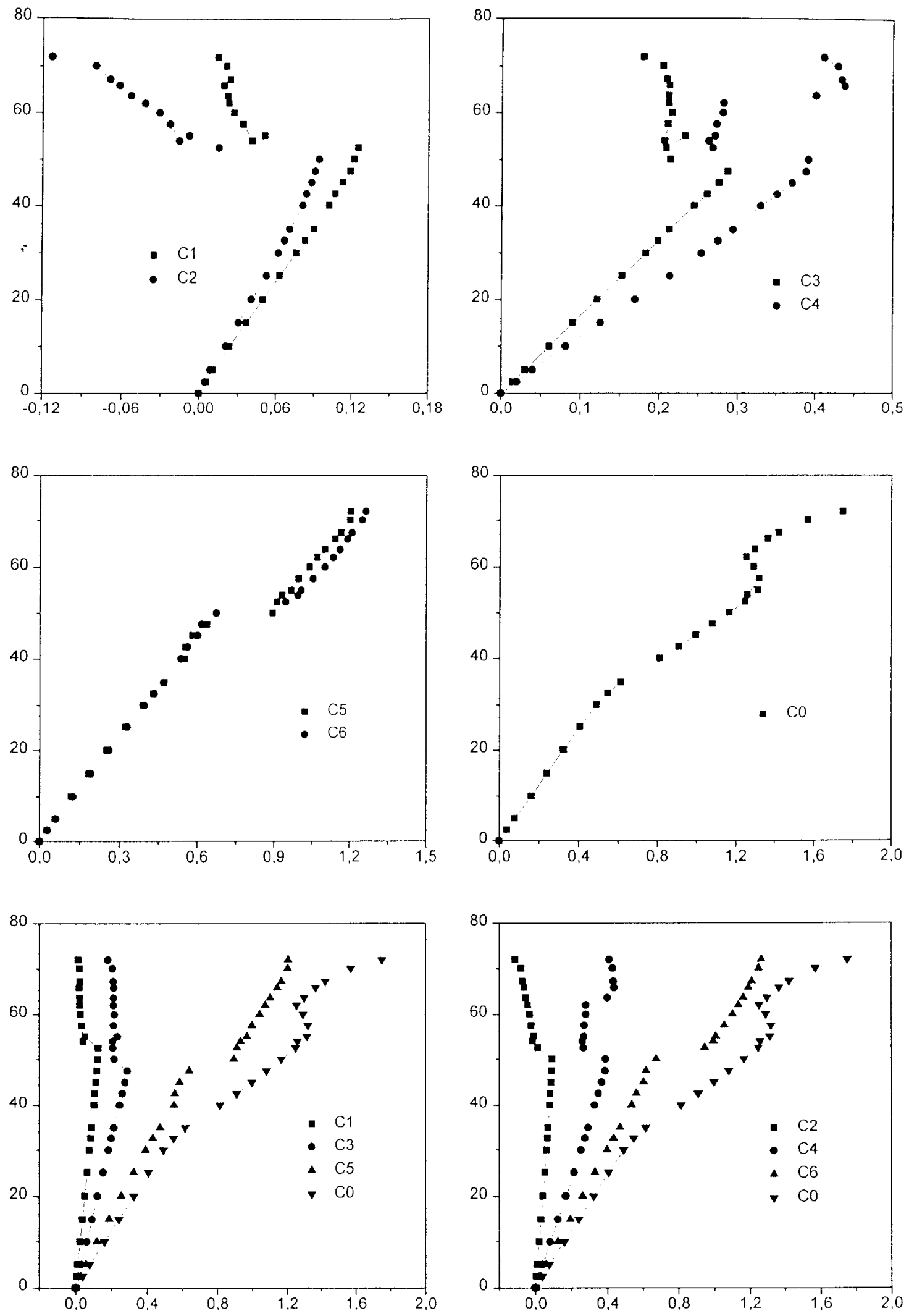

Figura 5.23 - Carga ( $\mathrm{kN}$ no eixo y) x Deformação $(\mathrm{mm} / \mathrm{m}$ no eixo $\mathrm{x})$ concreto do modelo V5 

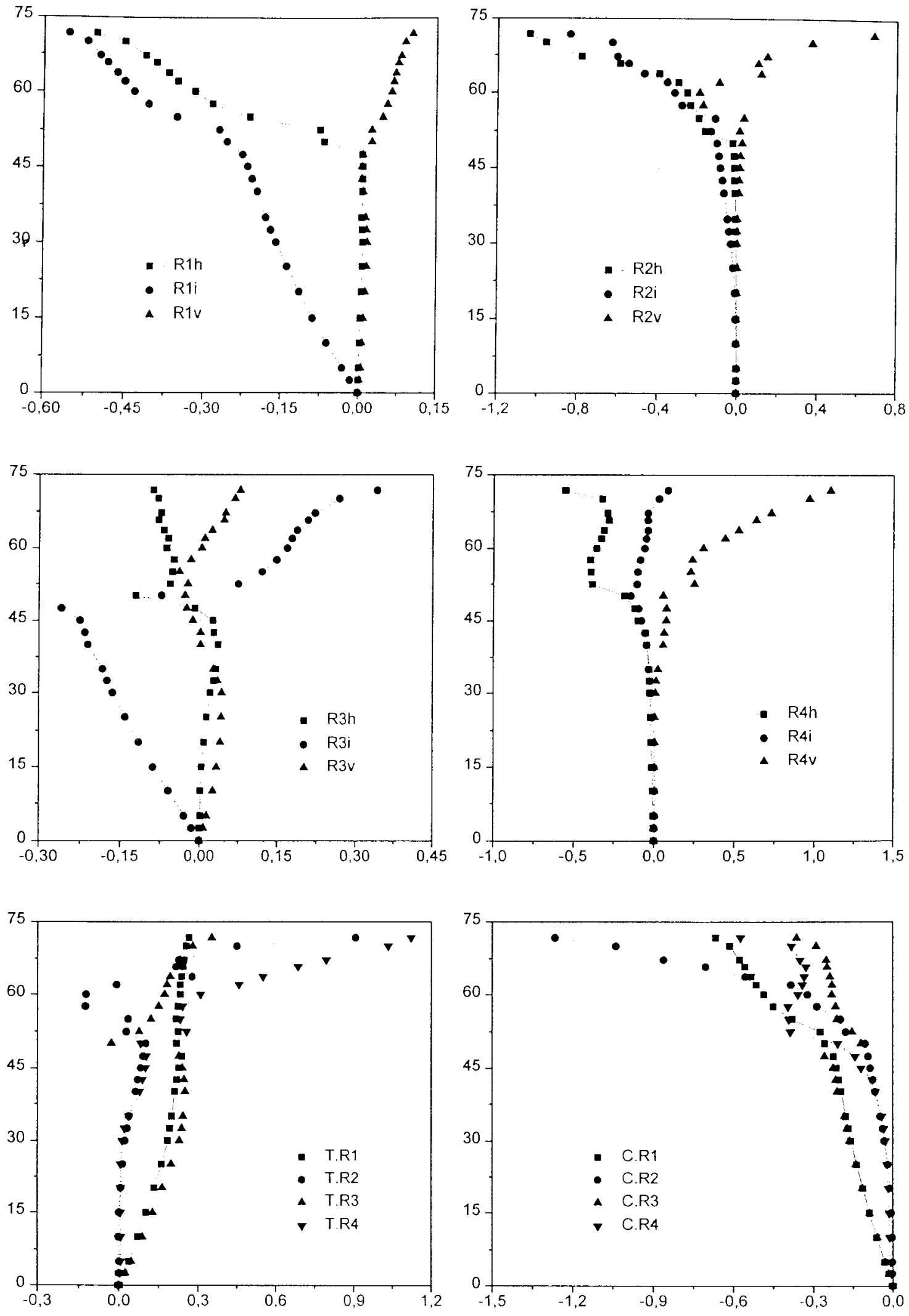

Figura 5.24 - Carga (kNno eixo y) x Deformação $(\mathrm{mm} / \mathrm{m}$ no eixo $\mathrm{x})$ rosetas do modelo V5 


\subsection{6 - MODELO V6}

Este modelo completou a segunda série de ensaios, onde se estudou a influência da protensão e das fibras no cisalhamento. Ele era idêntico às vigas V4 e V5, mas o concreto tinha $1 \%$ de fibra de aço de $2,54 \mathrm{~cm}$ e $1 \%$ de superplastificante. Por problemas diversos, o cronograma de execução desta peça sofreu algumas alterações. A moldagem ocorreu três dias após o estiramento das cordoalhas. Em relação ao dia da concretagem, a transferência da força para o concreto foi feita após seis dias e o ensaio foi executado após onze dias.

Exceto por um extensômetro adicional posicionado na face tracionada do concreto, a instrumentação foi idêntica a do modelo anterior. Este extensômetro registrava as deformações no concreto próximo das cordoalhas durante a transferência da protensão para a viga, para confirmar os resultados sobre o encurtamento elástico do concreto, e permitia o acompanhamento da evolução das tensões de tração no concreto durante o ensaio de flexão. Pela primeira vez, todos os extensômetros no concreto foram colados antes da transferência da protensão, o que permitiu avaliar a tensão de tração na borda superior e a tensão de compressão no meio da alma durante a liberação da força. Estas alterações foram mantidas em todos os modelos seguintes.

As cordoalhas foram tracionadas até um valor mais alto, tentando-se evitar a operação de reestiramento. As duas primeiras foram estiradas até $49 \mathrm{kN}$ e $48 \mathrm{kN}$. Após o encunhamento, as forças indicadas nas respectivas células de carga eram de $46,5 \mathrm{kN}$ e $47,4 \mathrm{kN}$. Ou seja, as perdas foram menores do que nos modelos anteriores, tanto no encunhamento, como no deslocamento do pórtico. Porém, as forças calculadas pelas deformações nos extensômetros foram menores, conforme se observa na Tabela 5.17. Para compensar, a terceira cordoalha foi tracionada somente até $41 \mathrm{kN}$.

Alguns extensômetros das cordoalhas apresentaram problemas após o encunhamento. As forças indicadas nas células de carga quase não sofreram alteração até o dia da transferência da força. mesmo tendo decorridos nove dias. Este fato já tinha sido observado anteriormente. sendo que a ausência de perda por relaxação do aço pode ser explicada pela baixa tensão de estiramento das cordoalhas. No entanto, houve variações significativas e irreģulares na deformação de vários extensômetros.

$\mathrm{Na}$ cordoalha central, onde havia 14 extensômetros, os valores antes da liberação da protensão variavam de $0.137 \%$ a $0,435 \%$. No dia do estiramento, os valores extremos eram 0,303\% e $0.345 \%$. Mesmo assim, os valores médios se mantiveram consistentes. Do instante do encunhamento até antes da liberação da protensão, a deformação média passou de $0,329 \%$ para $0,320 \%$, com diminuição de quase $3 \%$, não acompanhada por redução da força na célula de carga, que registrou 
aumento de $0,5 \%$. Nas outras duas cordoalhas, em que havia apenas dois extensômetros, o problema se repetiu. mas de forma mais grave, pois os valores médios não se mantiveram. Assim, os valores da força de protensão calculados com as deformações nestes extensômetros diferem muito dos indicados pelas células de carga. Nestes casos, adotou-se a mesma perda verificada na cordoalha central.

* $\mathrm{O}$ extensômetro do concreto posicionado na face inferior registrou encurtamento de $0,031 \%$ durante a transferência da força, enquanto a variação média nas cordoalhas, bastante uniforme. foi de $0,027 \%$. A diferença é coerente com a altura destes pontos na seção transversal. Os extensômetros do concreto na face superior apresentaram alongamento médio de $0,006 \%$, que equivale a uma tensão de 2,3 MPa, calculada com o módulo de deformação longitudinal obtido nos ensaios dos corpos-deprova (38030 MPa). O valor esperado era aproximadamente igual a $2.5 \mathrm{MPa}$, considerando-se a força de protensão total igual a $113,1 \mathrm{kN}$ e desprezando-se as tensões causadas pelo peso próprio. Os extensômetros horizontais das rosetas apresentaram encurtamento médio de $0,0101 \%$ : para o mesmo módulo experimental do concreto, ele corresponde a uma força média de $33.8 \mathrm{kN}$ em cada cordoalha.

Até o dia do ensaio se passaram mais cinco dias. As deformações nos extensômetros diminuíram 7\% na cordoalha central e 5\% numa das cordoalhas laterais. $\mathrm{Na}$ outra, em que os problemas citados anteriormente foram maiores, a variação foi de $23 \%$. O extensômetro posicionado na face inferior do concreto também variou desordenadamente: o encurtamento provocado pela protensão aumentou aproximadamente 70\%. Seguramente, estas discrepâncias decorrem de alguma irregularidade, possivelmente devido ao desligamento dos extensômetros para o transporte da viga até o local do ensaio. onde eram novamente soldados.

Desde o modelo V4 os ensaios dos corpos-de-prova foram executados numa máquina de ensaios automática. Anteriormente, eles não eram carregados até a ruptura. Ao primeiro indício da ruína, a carga era retirada. Com o novo equipamento. pôde-se observar mais claramente a resistência residual proporcionada pelas fibras.

A resistência e o módulo de deformação longitudinal obtidos foram comparativamente altos, mas a idade do concreto era maior, onze dias.

Para uma força de protensão de $105,6 \mathrm{kN}$. a força de descompressão da borda inferior no trecho central era de $19.9 \mathrm{kN}$. A carga máxima no ensaio foi de $71.5 \mathrm{kN}$.

Imediatamente antes da ruptura. quando a abertura da fissura diagonal anunciava "a proximidade da ruína, decidiu-se pelo término do ensaio. A região foi fotografada, mas antes do alívio da carga a viga rompeu, com menos barulho que as demais peças protendidas. Não houve estilhaçamento do concreto, que se manteve relativamente integro nas duas partes separadas. Conforme já se tinha observado 
anteriormente, a fibra de aço é menos eficiente que a de polipropileno na manutenção da integridade do concreto após a ruína.

A ruptura diagonal foi do ponto de aplicação da carga até $50 \mathrm{~cm}$ da extremidade direita da viga. Na alma, provocou a ruptura dos estribos E8 e E10. No banzo comprimido, ela se estendeu por $30 \mathrm{~cm}$ nas laterais da face comprimida, onde o concreto lascou. O porta-estribos ficou encurvado e se observa um desnivel de $3 \mathrm{~cm}$ entre as partes separadas. Na mesa tracionada formou-se um buraco num trecho de 30 $\mathrm{cm}$, na região do estribo $\mathrm{E} 6$, que se abriu. Na posição deste estribo formou-se uma fissura vertical bem visivel. Os estribos E2 e E4 ficaram fora da região afetada.

A eficiencia das fibras como armadura transversal pode ser analisada pela quantidade de estribos mobilizados. Assim como o aumento da taxa de armadura transversal torna as bielas menos abatidas, a atuação das fibras pode proporcionar o mesmo resultado. Neste modelo a extensão da região atingida foi menor, ratificando os resultados da primeira série, devido à maior inclinação das bielas.

Os últimos dados correspondem à carga máxima de 71,5 kN. Do lado direito, a partir de $64 \mathrm{kN}$, dois estribos escoaram. Do outro lado, somente E7 escoou no último incremento de carga. Pela primeira vez os estribos E3 e E4 estiveram muito pouco solicitados até o final do ensaio. pois as fissuras inclinadas quase não atingiram aquela região, conforme se observa nas Fotos 5.23 e 5.26. Os primeiros estribos foram acionados com $45 \mathrm{kN}$. coincidindo com o início da inclinação das fissuras de flexão. Desprezando-se a atuação das fỉbras. o estado limite último convencional ocorreu com $71 \mathrm{kN}$. Portanto, não houve resistência adicional até a ruptura. No entanto, a tensão nos estribos foi sistematicamente menor que em todas as outras vigas. Todos estes fatos já tinham sido observados no modelo V3.

Não surgiram fissuras transversais no banzo comprimido, possivelmente porque a ruptura foi mais suave. As fissuras inclinadas para o centro da viga novamente foram observadas ao final do ensaio.

A deformação máxima total nas cordoalhas no meio da viga foì de aproximadamente $0,85 \%$, menor que no modelo anterior devido ao acionamento retardado das cordoalhas.

Até então, o instante do aparecimento da primeira fissura de flexão era avaliado visualmente ou pela evolução das flechas e das deformações nas cordoalhas. A partir deste modelo, o comportamento do extensômetro posicionado na face tracionada do concreto no centro da viga também pôde auxiliar nesta análise. Ele se alongou uniformemente até $32.5 \mathrm{kN}$. Com $35 \mathrm{kN}$ a déformação diminuiu, provavelmente devido ao aparecimento de uma fissura nas proximidades. Conforme se observa na Tabela 5.7, os outros métodos sugerem que a fissuração começou depois. 

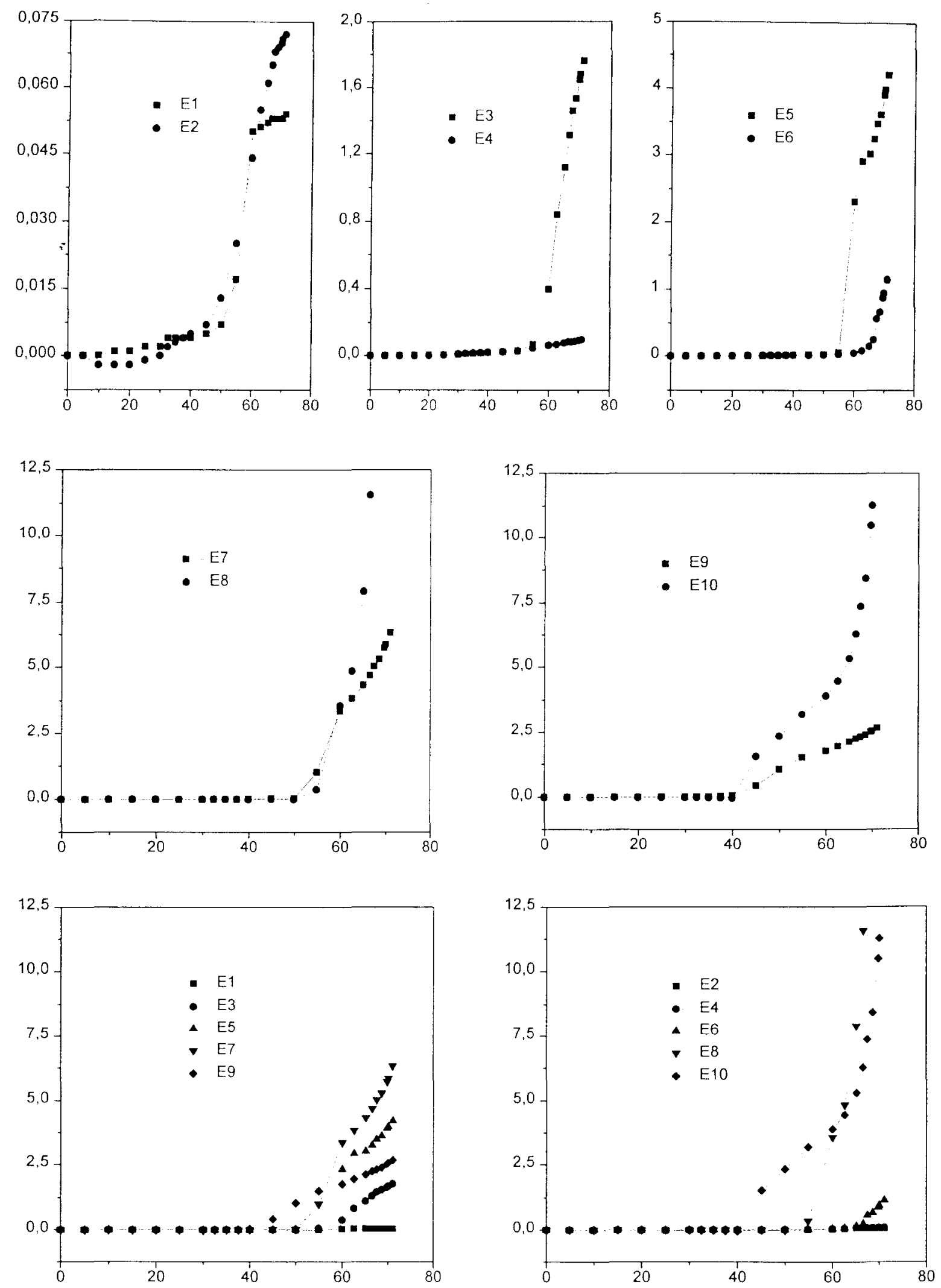

Figura 5.25 - Deformação $(\mathrm{mm} / \mathrm{m}$ no eixo y) x Carga ( $\mathrm{kN}$ no eixo $\mathrm{x}$ ) estribos do modelo V6 

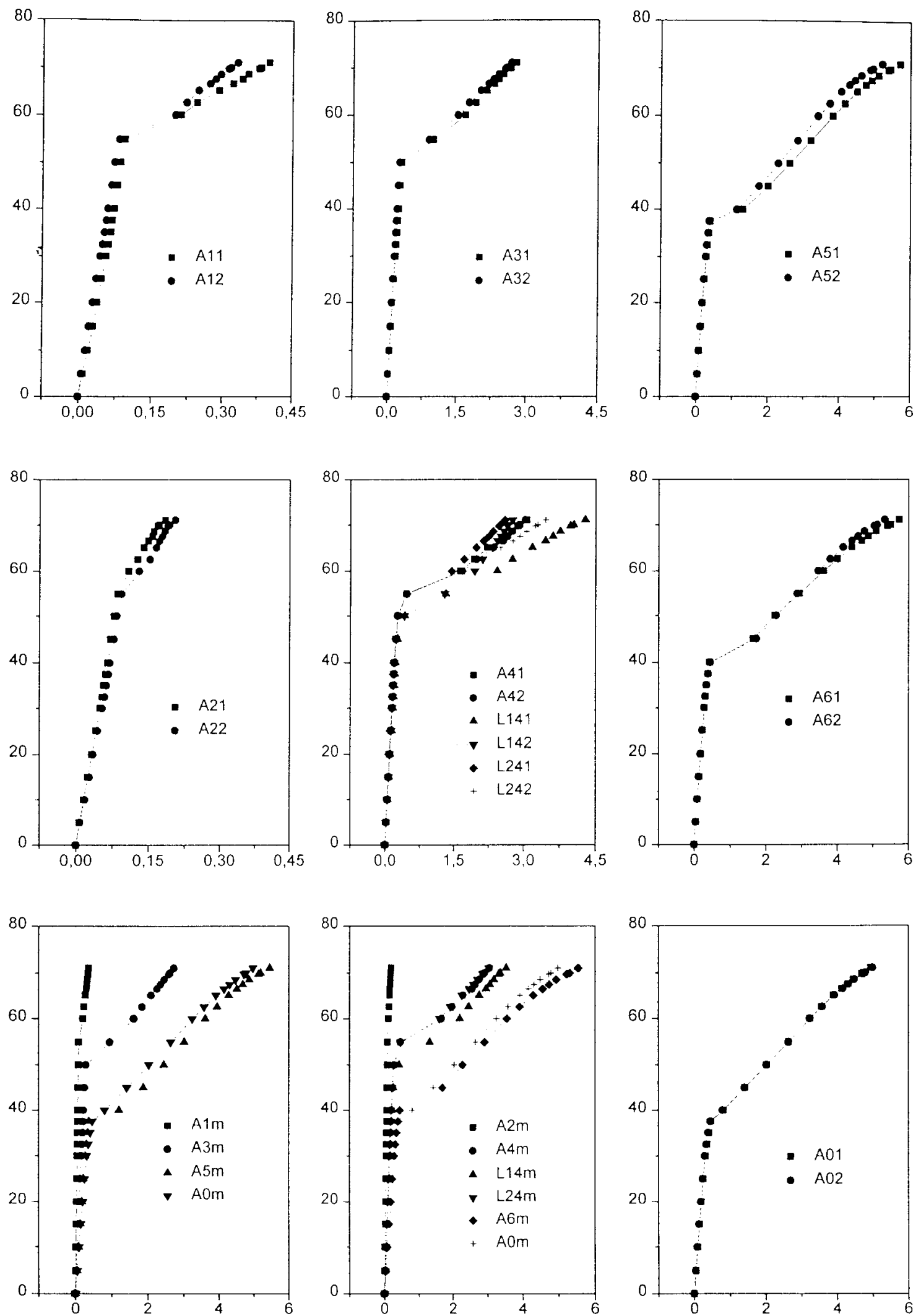

Figura 5.26 - Carga ( $\mathrm{kN}$ no eixo y) $\mathrm{x}$ Deformação $(\mathrm{mm} / \mathrm{m}$ no eixo $\mathrm{x})$ cordoalhas do modelo V6 

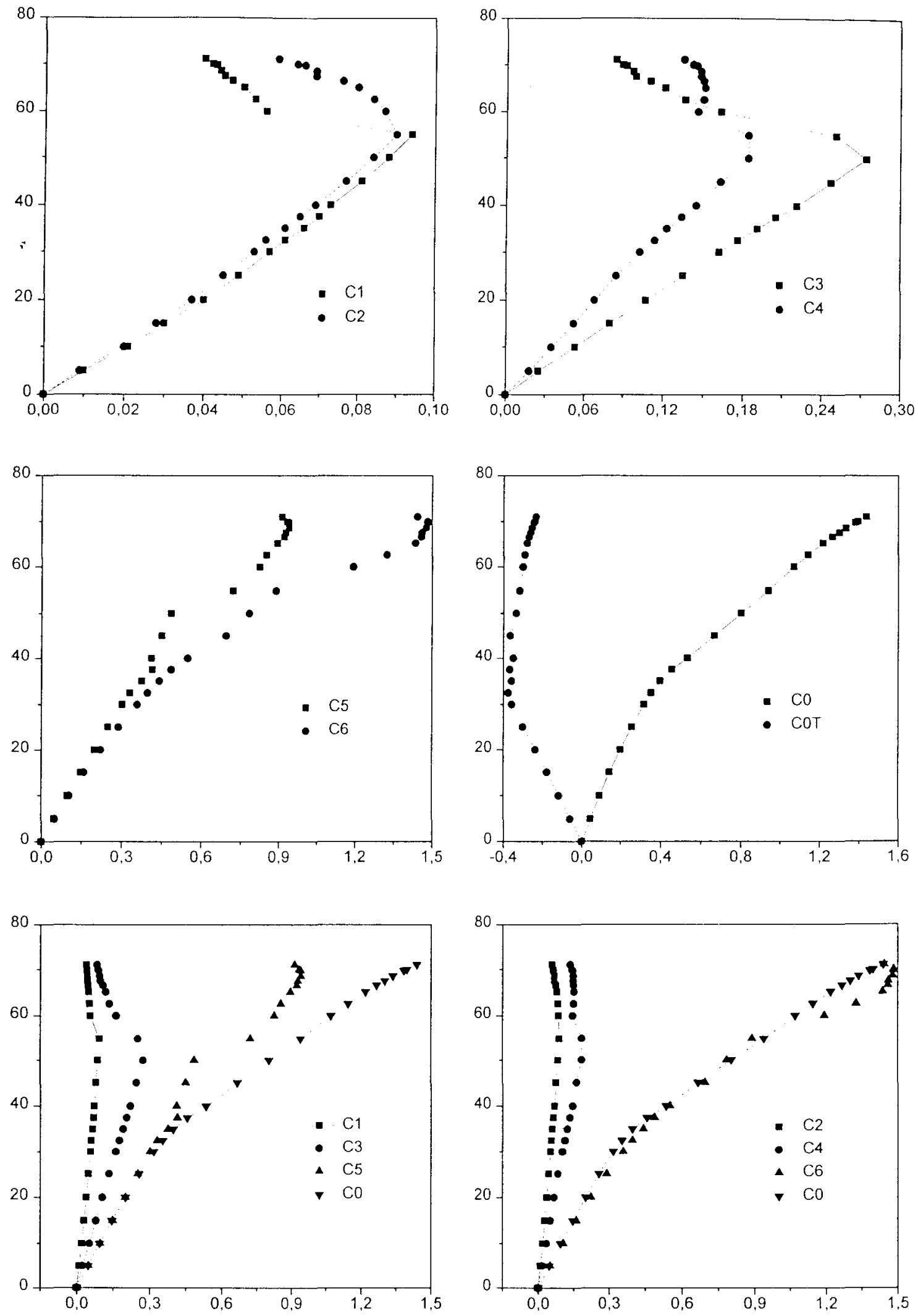

Figura 5.27 - Carga ( $\mathrm{kN}$ no eixo y) x Deformação $(\mathrm{mm} / \mathrm{m}$ no eixo $\mathrm{x})$ concreto do modelo V6 

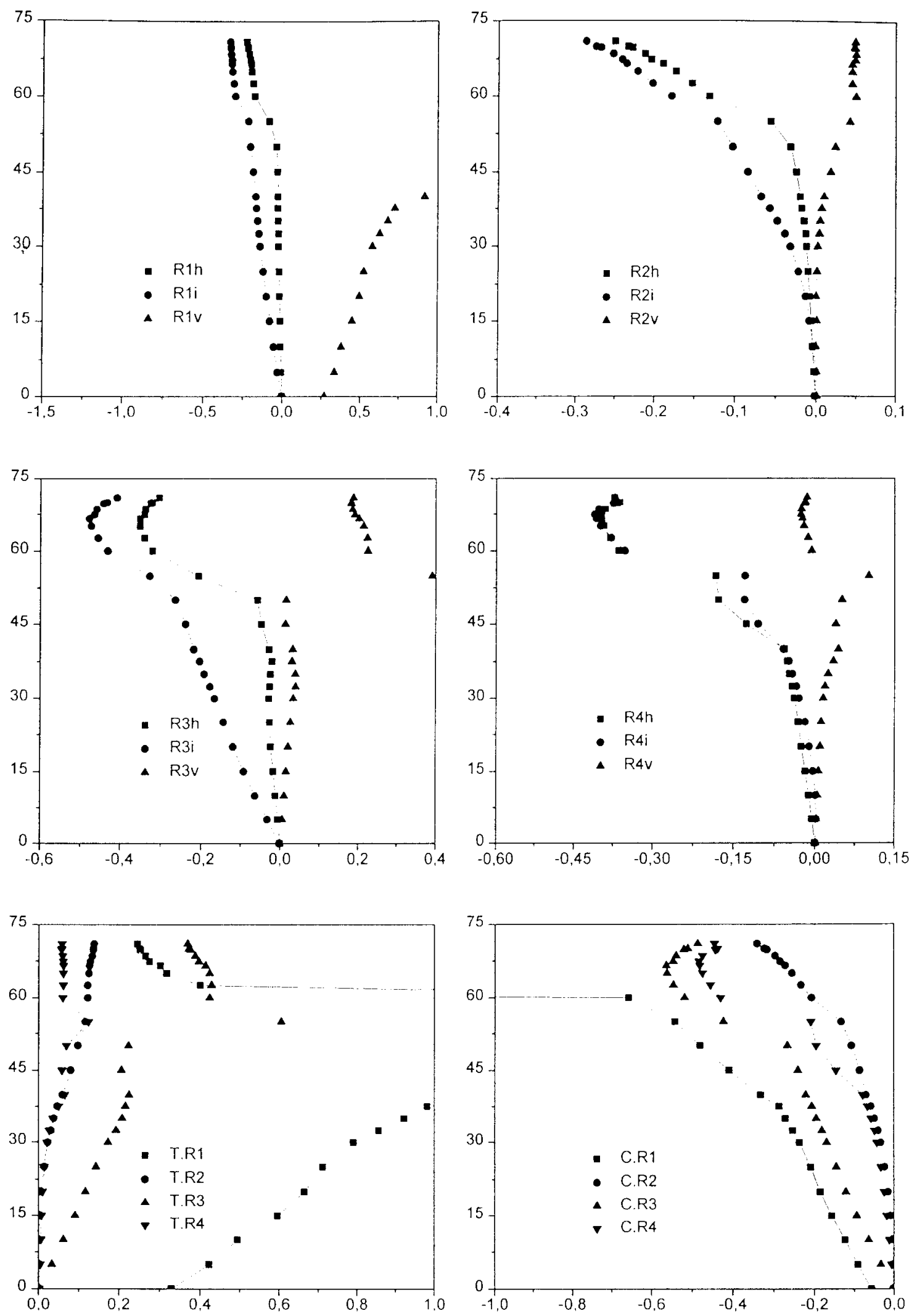

Figura 5.28a - Carga ( $\mathrm{kN}$ no eixo y) $\mathrm{x}$ Deformação $(\mathrm{mm} / \mathrm{m}$ no eixo $\mathrm{x})$ rosetas do modelo $\mathrm{V} 6$ 

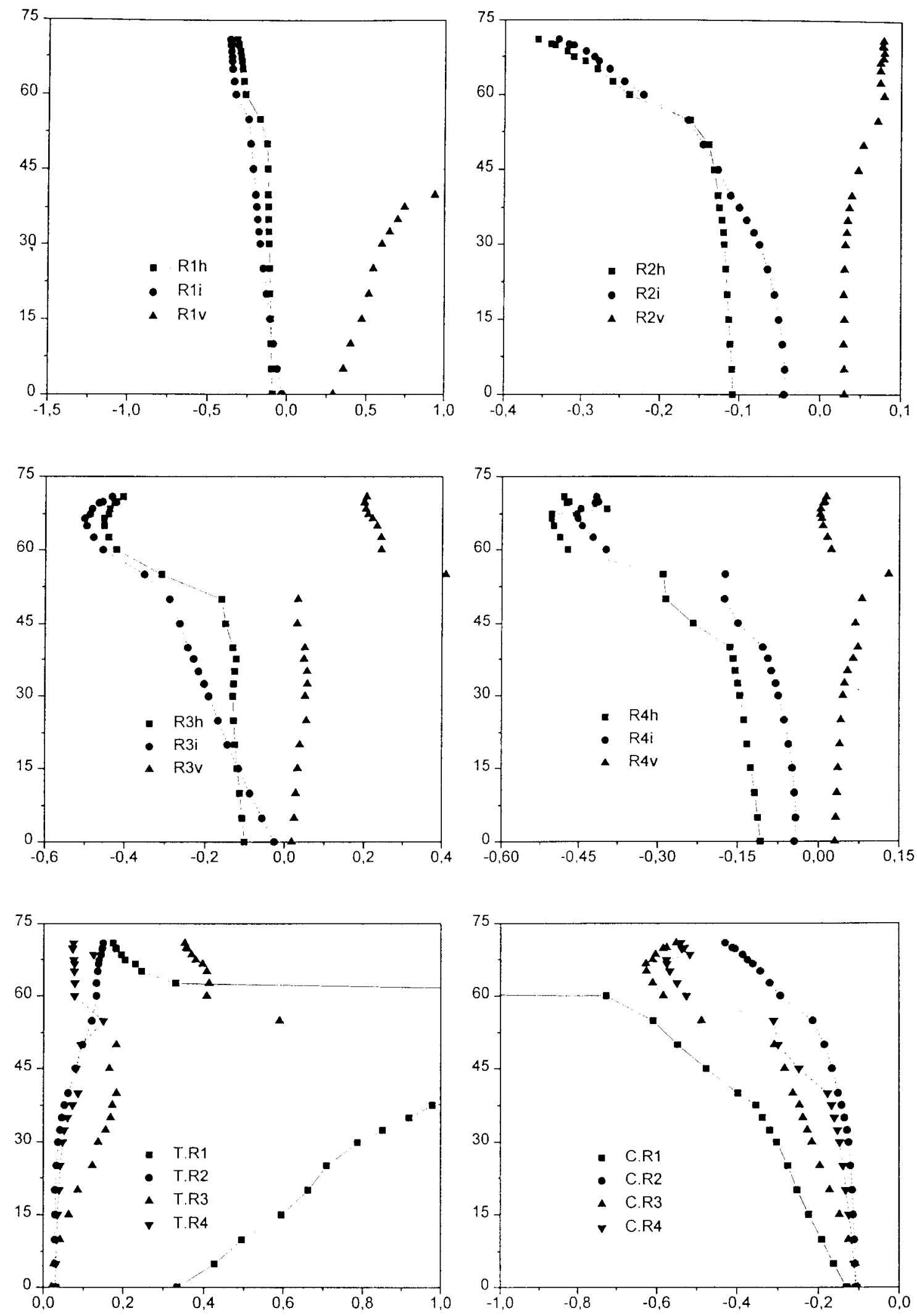

Figura 5.28b - Carga ( $\mathrm{kN}$ no eixo y) x Deformação $(\mathrm{mm} / \mathrm{m}$ no eixo $\mathrm{x})$ rosetas do modelo V6 


\subsection{7 - MODELO V7}

Este modelo iniciou a última série de ensaios, onde se analisou o comportamento de peças protendidas sem armadura transversal ou com taxas muito reduzidas, e a possibilidade de substituição total ou parcial dos estribos pelas fibras. Este modelo não tinha fibras e foi executado com $0,5 \%$ de superplastificante.

A força de protensão era igual a dos modelos da série anterior. Foram colocados apenas estribos com função construtiva, sob as cargas e no meio do vão, para garantir o posicionamento das armaduras longitudinais. Exceto pelos estribos, a instrumentação foi idêntica à da viga anterior.

Tentou-se novamente fazer o estiramento das cordoalhas em apenas uma etapa. As duas primeiras cordoalhas foram tracionadas com $47 \mathrm{kN}$ e $44,5 \mathrm{kN}$. Após o encunhamento, as forças registradas nas células de carga eram de $44 \mathrm{kN}$ e $43,1 \mathrm{kN}$. A cordoalha central foi tracionada até $43 \mathrm{kN}$. Após o seu encunhamento, os valores obtidos foram $40 \mathrm{kN}, 39,5 \mathrm{kN}$ e $39,9 \mathrm{kN}$, menores que o desejado. As perdas retornaram aos valores anteriores ao modelo V6. Após o reestiramento e encunhamento. os valores finais foram iguais a $41,1 \mathrm{kN}, 41,7 \mathrm{kN}$ e $43,1 \mathrm{kN}$, resultando uma força média de $42 \mathrm{kN}$ por cordoalha.

As deformações registradas nos extensômetros durante o estiramento se desenvolveram de forma bem regular. Porém, após o reestiramento da cordoalha central. observou-se uma variação significativa em três extensômetros após o encunhamento: em dois extensômetros a deformação aumentou e em um diminuiu. Um pequeno barulho também foi percebido neste instante. Associou-se o fato ao possível escorregamento de alguns fios da cordoalha no encunhamento, num processo de acomodação. Quando coincide com o fio instrumentado, a deformação diminui; caso contrário, ela aumenta. Os valores médios, no entanto, foram consistentes com a diminuição da força indicada na célula de car@a.

Novamente, alguns extensômetros das cordoalhas apresentaram problemas até o dia do ensaio. O problema é sempre mais grave quando ocorre nas cordoalhas laterais, que tinham apenas dois extensômetros. Um extensômetro de cada cordoalha lateral apresetou problemas Apesar disso os valores se mantiveram consistentes, exceto em algumas etapas para a cordoalha I.2.

As deformações registradas nos extensometros das cordoalhas e do concreto na face comprimida e na alma foram maiores que no modelo anterior e podem ser decorrentes de uma força de protensãu maior que aquela indicada nas células de carga. 
Considerando-se a força de protensão total igual a $111,9 \mathrm{kN}$, a etapa no ensaio até a descompressão do trecho central da viga foi até $21,1 \mathrm{kN}$. A carga máxima atingida foi de $47 \mathrm{kN}$, quando se formou uma fissura crítica no lado esquerdo da viga, separando-a em duas partes bem definidas. A viga foi descarregada, sem atingir a ruína total.

: A ruptura diagonal partiu do ponto de aplicação da carga e foi até $57 \mathrm{~cm}$ da extremidade da viga. Na alma, a fissura foi muito abatida, com inclinação de 17 graus. Conforme se esperava, a ausência de estribos tornou as bielas mais inclinadas. Não surgiram fissuras transversais no banzo comprimido e nem fissuras inclinadas para o centro da viga no trecho central.

A deformação máxima no concreto no meio do vão foi bem maior que nos pontos C5 e C6, já que o arqueamento das resultantes de compressão atingiu estes dois pontos a partir de $42.5 \mathrm{kN}$. Não houve diminuição de deformação nos pontos C1 e C3 durante o carregamento até o último registro, mas uma leitura após a descarga parcial, com $33 \mathrm{kN}$, registrou tensão praticamente nula no lado da ruptura em todos os pontos instrumentados. Isto aconteceu devido à ruptura frágil e sem aviso que ocorre na viga sem estribo, dificultando o registro do fenômeno. Mesmo assim, depois do aparecimento de fissuras inclinadas diretamente na alma, a viga ainda suportou um acréscimo de carga de quase $5 \mathrm{kN}$.

Próximo da ruptura, houve acréscimo de tensão nas cordoalhas junto ao apoio somente no lado direito. Nos pontos intermediários, A3 e A4, as fissuras de flexão somente atingiram este lado da viga. No entanto, elas avançaram primeiro em direção ao apoio esquerdo, conforme mostram os dados das Tabelas 5.15.

O extensômetro do concreto na região tracionada se alongou regularmente até $30 \mathrm{kN}$. Novamente, ele sugere que a fissuração começou antes do que indicaram os outros métodos de avaliação. 

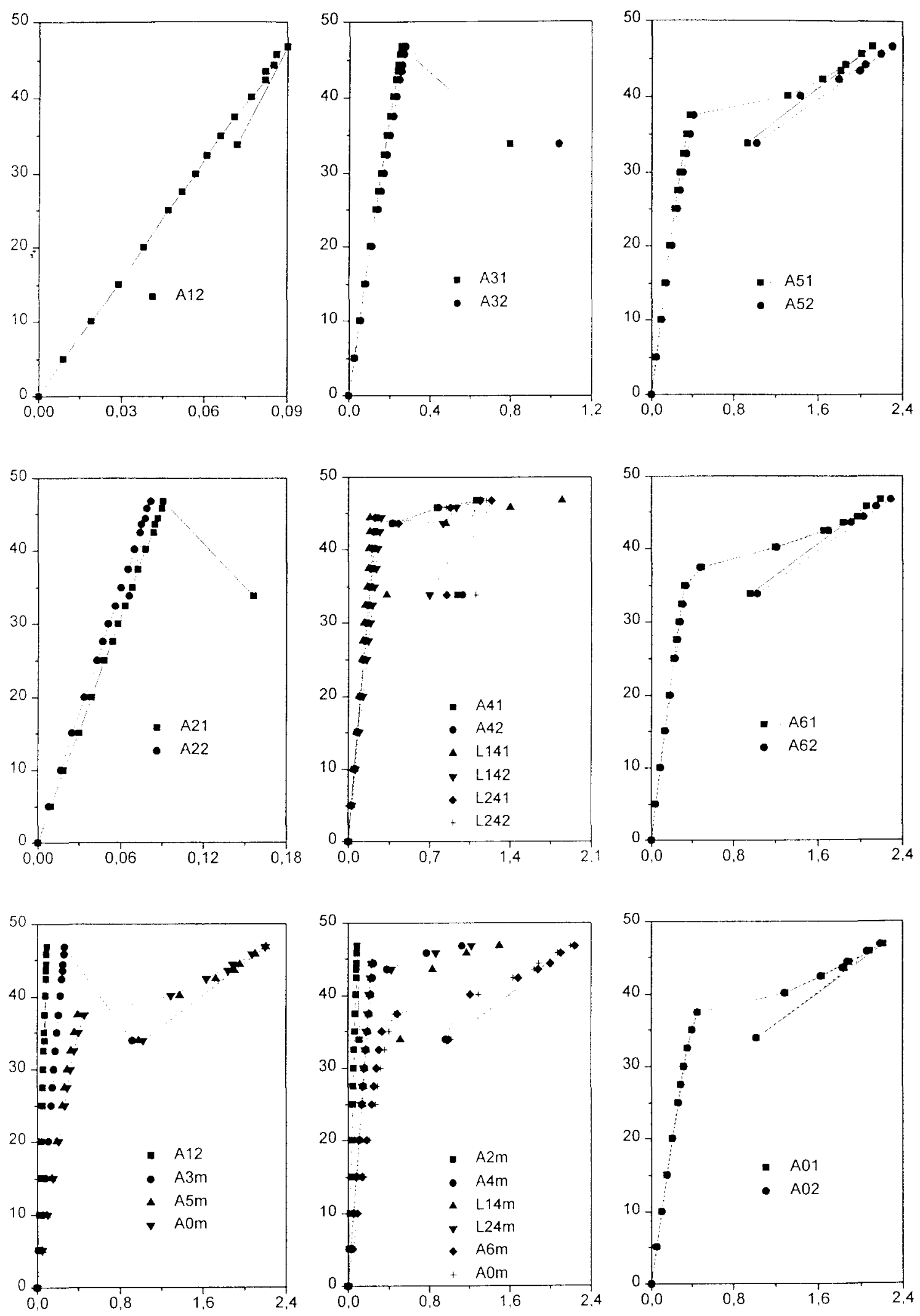

Figura 5.29 - Carga $(\mathrm{kN}$ no eixo y) $\mathrm{x}$ Deformação $(\mathrm{mm} / \mathrm{m}$ no eixo $\mathrm{x})$ cordoalhas do modelo $\mathrm{V} 7$ 

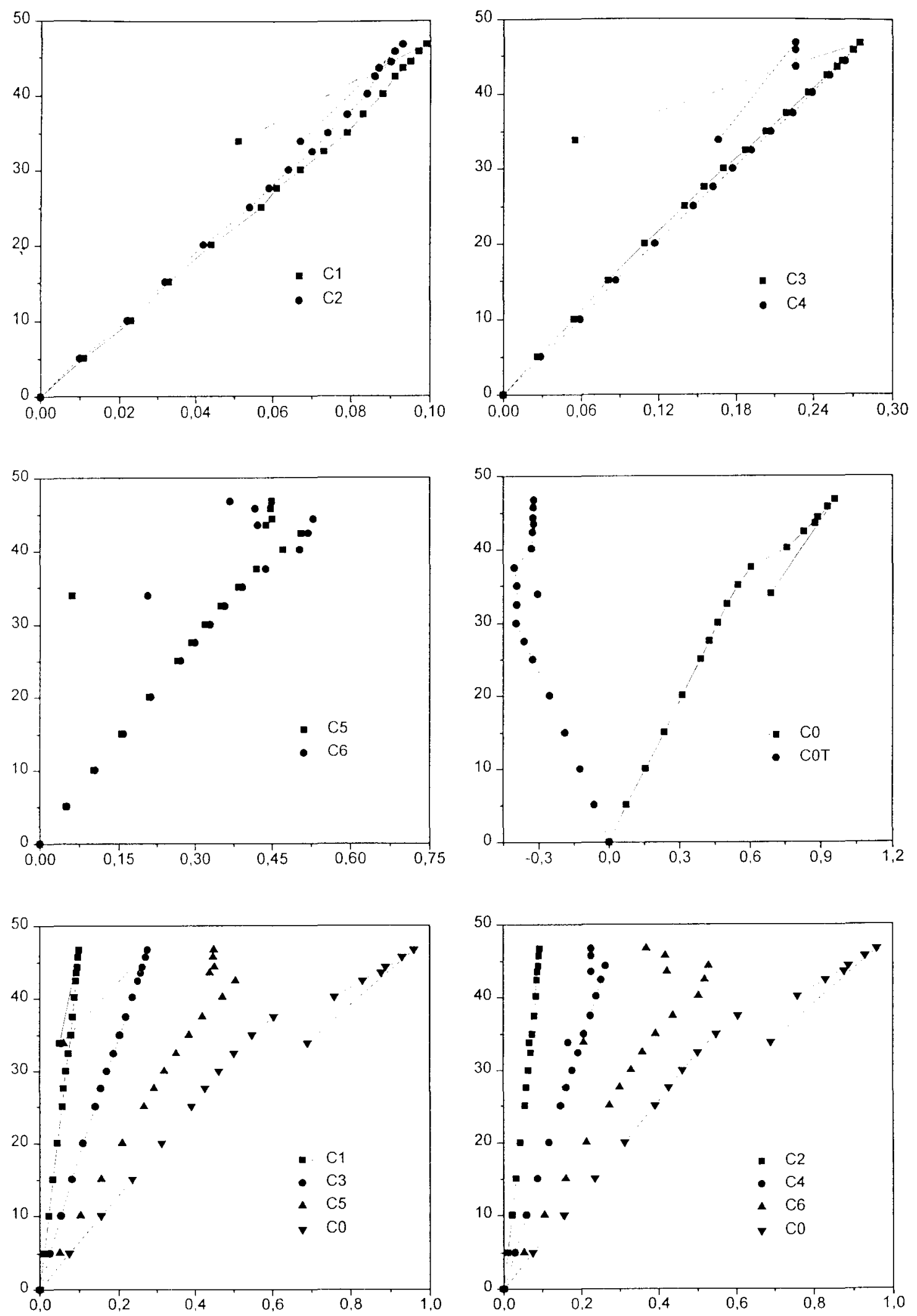

Figura 5.30 - Carga ( $\mathrm{kN}$ no eixo y) x Deformação $(\mathrm{mm} / \mathrm{m}$ no eixo $\mathrm{x})$ concreto do modelo V7 

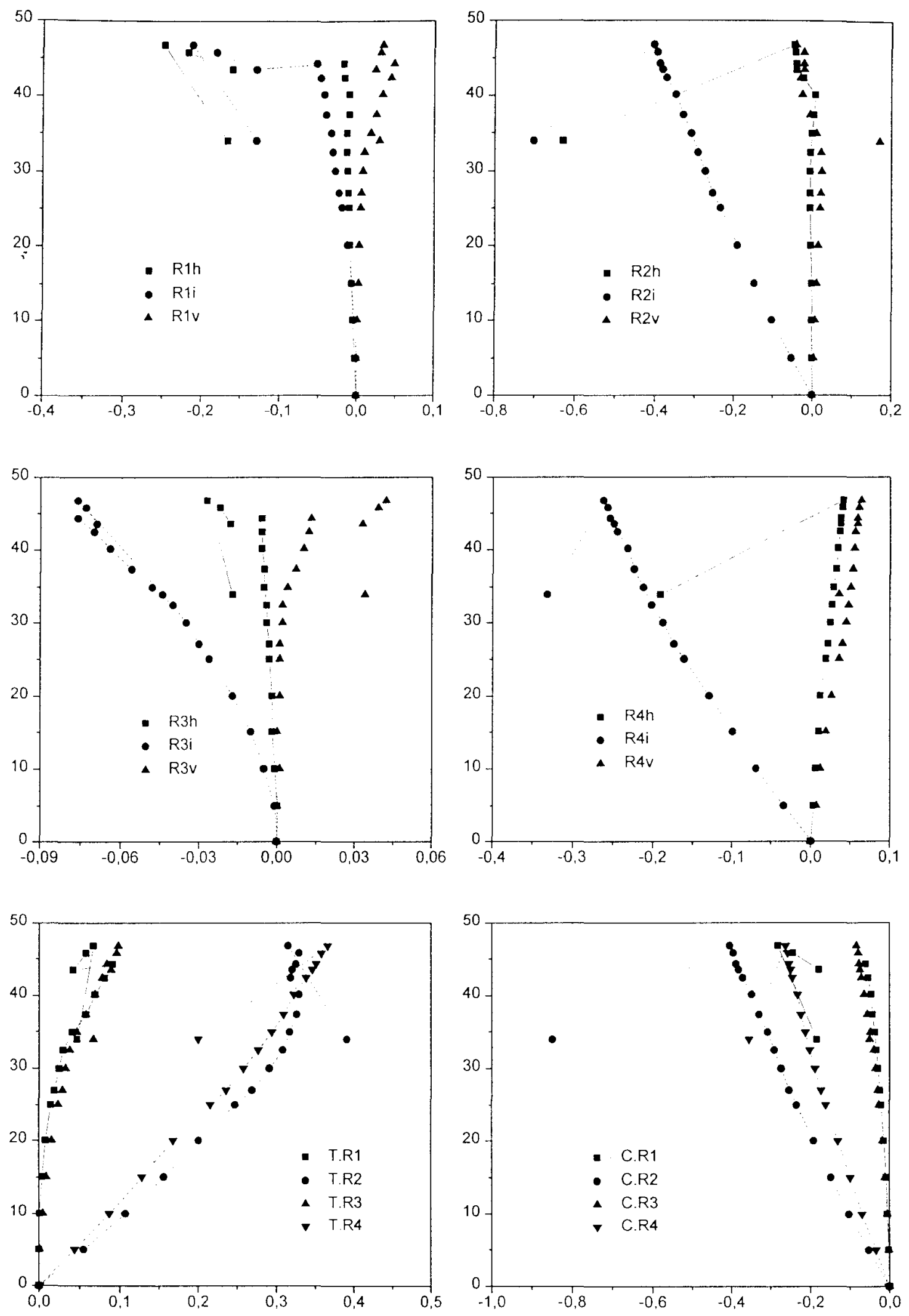

Figura 5.31a - Carga ( $\mathrm{kN}$ no eixo y) x Deformação $(\mathrm{mm} / \mathrm{m}$ no eixo $\mathrm{x})$ rosetas do modelo $\mathrm{V} 7$ 

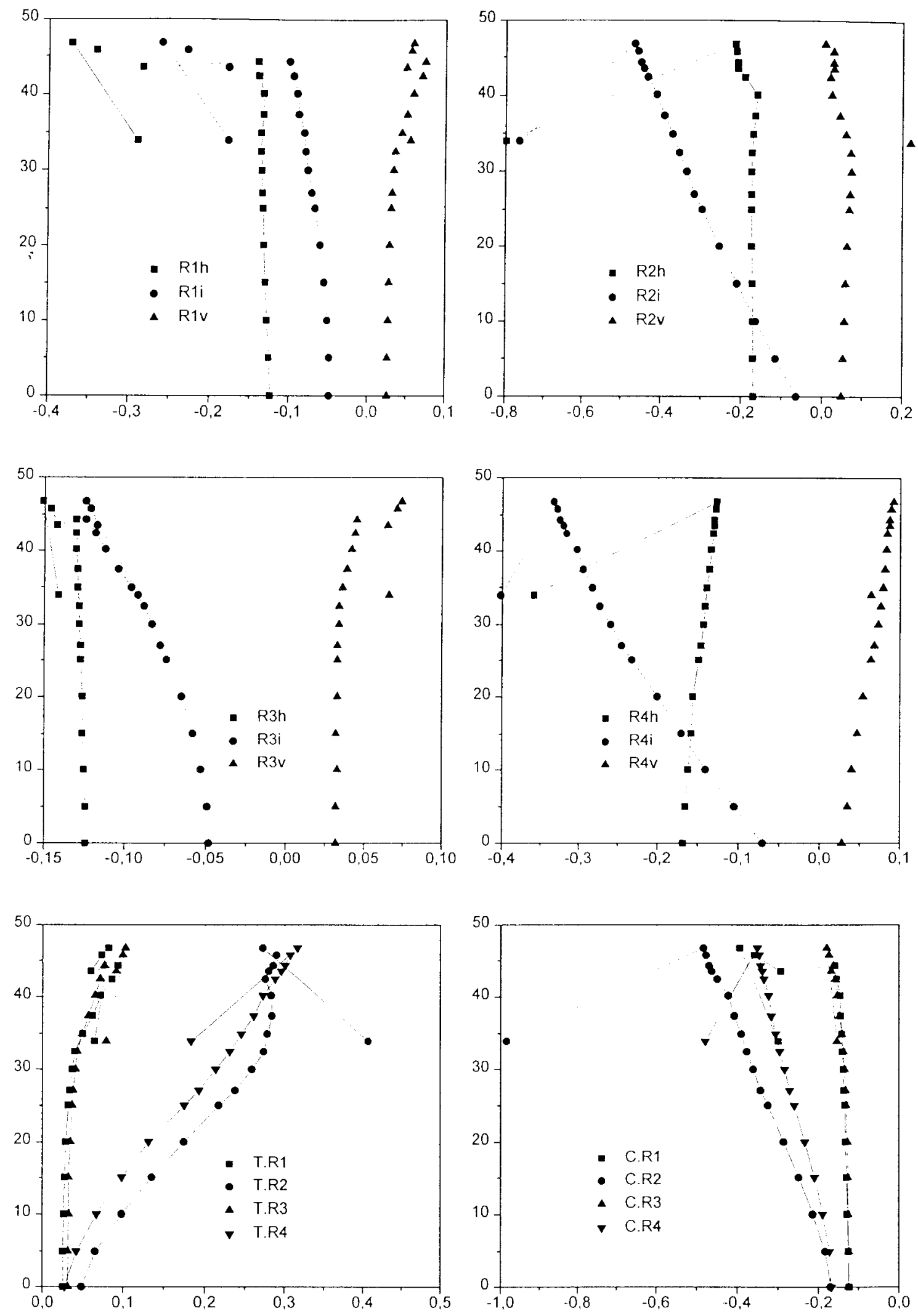

Figura $5.31 \mathrm{~b}$ - Carga $(\mathrm{kN}$ no eixo y) x Deformação $(\mathrm{mm} / \mathrm{m}$ no eixo $\mathrm{x})$ rosetas do modelo $\mathrm{V} 7$ 


\subsection{8 - MODELO V8}

Este modelo era idêntico ao anterior, exceto pelo concreto, com $1,5 \%$ de superplastificante e $0,5 \%$ de fibra de polipropileno. As cordoalhas foram tracionadas com $47 \mathrm{kN} .45 \mathrm{kN}$ e $44 \mathrm{kN}$. Após o encunhamento, os valores obtidos foram menores que o desejado, iguais a $39.6 \mathrm{kN}, 40.9 \mathrm{kN}$ e $42,7 \mathrm{kN}$. As duas primeiras cordoalhas foram reestiradas e encunhadas, e os valores finais ancorados foram iguais a $42,7 \mathrm{kN}$, $41,9 \mathrm{kN}$ e $42 \mathrm{kN}$, resultando uma força média de $42,2 \mathrm{kN}$.

O comportamento geral da instrumentação foi excelente até o dia do ensaio. Além da uniformidade e da consistência dos valores, nenhum extensômetro apresentou problemas. Até o instante da liberação da protensão as deformações aumentaram $2 \%$, em média, igual à variação da força nas células de carga.

Para uma força de protensão total igual a $110.1 \mathrm{kN}$, a etapa de descompressão no meio do vão foi até $20,8 \mathrm{kN}$. A viga suportou uma carga máxima de $45 \mathrm{kN}$, quando se formou a fissura crítica. Ela permaneceu com este nível de carga enquanto se faziam os últimos registros fotográficos e a leitura de fissuras. Posteriormente, tentou-se aumentar a carga, sem sucesso. Um conjunto de fissuras muito abatidas, com ângulos de 13 graus, formadas a partir da fissura principal, apareceu na parte inferior da viga em direção ao apoio. Do outro lado não haviam aparecido fissuras de cisalhamento diretamente na alma.

A ruptura diagonal partiu do ponto de aplicação da carga e foi até $70 \mathrm{~cm}$ da extremidade direita da viga. Na alma, a fissura tinha inclinação entre 20 e 25 graus. Não surgiram fissuras transversais no banzo comprimido e nem fissuras inclinadas para o centro da viga no trecho central. A Foto 5.16 mostra um detalhe das superfícies separadas pela fissura, onde se observa a presença das fibras.

Praticamente não houve descompressão do concreto no banzo comprimido. A ruptura ocorreu $\operatorname{logo}$ após o aparecimento da fissura diagonal. Na região das cordoalhas, as fissuras de flexão só atingiram os pontos A0, A5 e A6.

$\mathrm{O}$ extensômetro do concreto na região tracionada se alongou regularmente até $30 \mathrm{kN}$. Neste caso, o instante da fissuração coincidiu com o aumento de tensão registrado nas cordoalhas. 

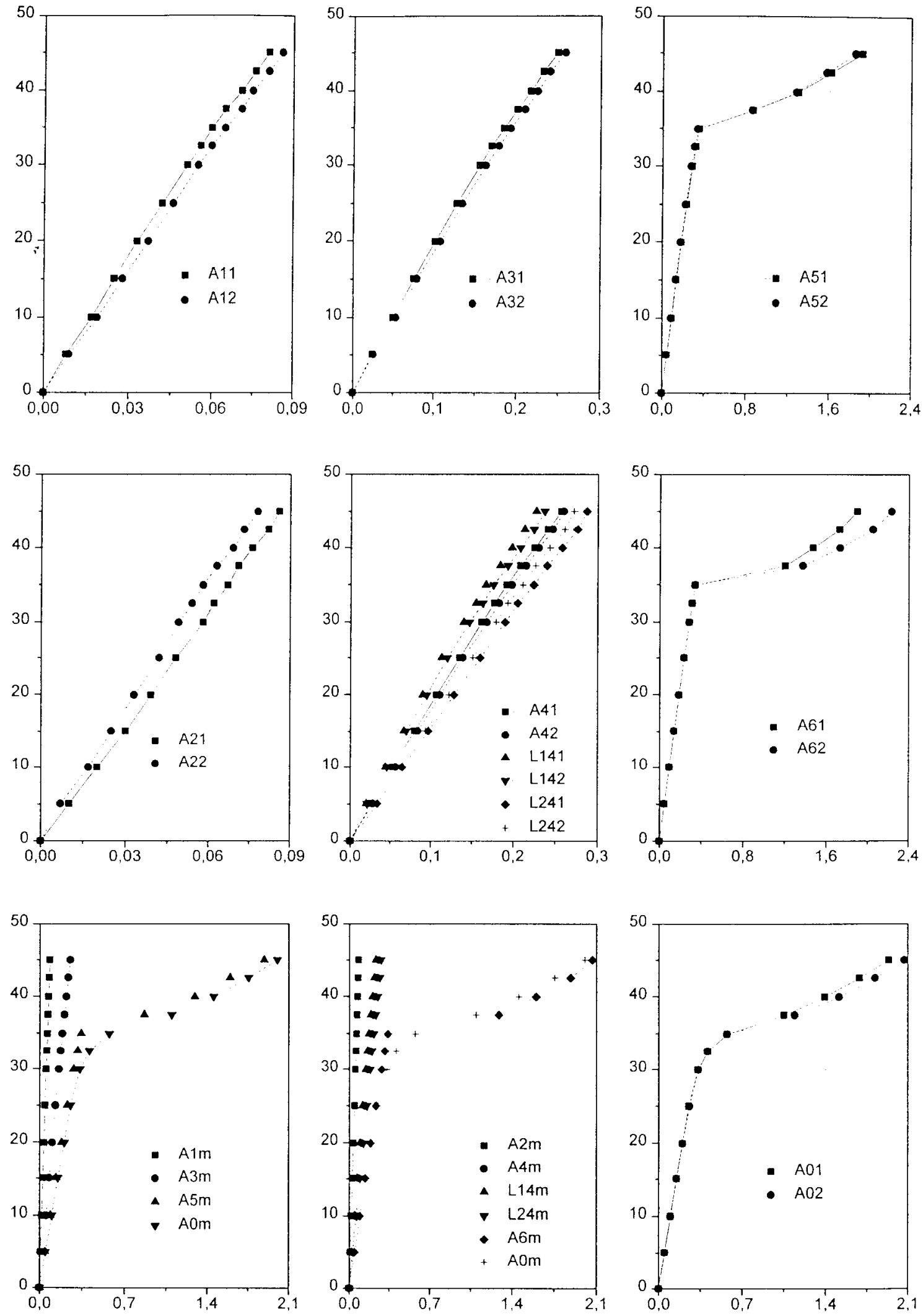

Figura 5.32 - Carga $(\mathrm{kN}$ no eixo y) x Deformação $(\mathrm{mm} / \mathrm{m}$ no eixo $\mathrm{x})$ cordoalhas do modelo V8 

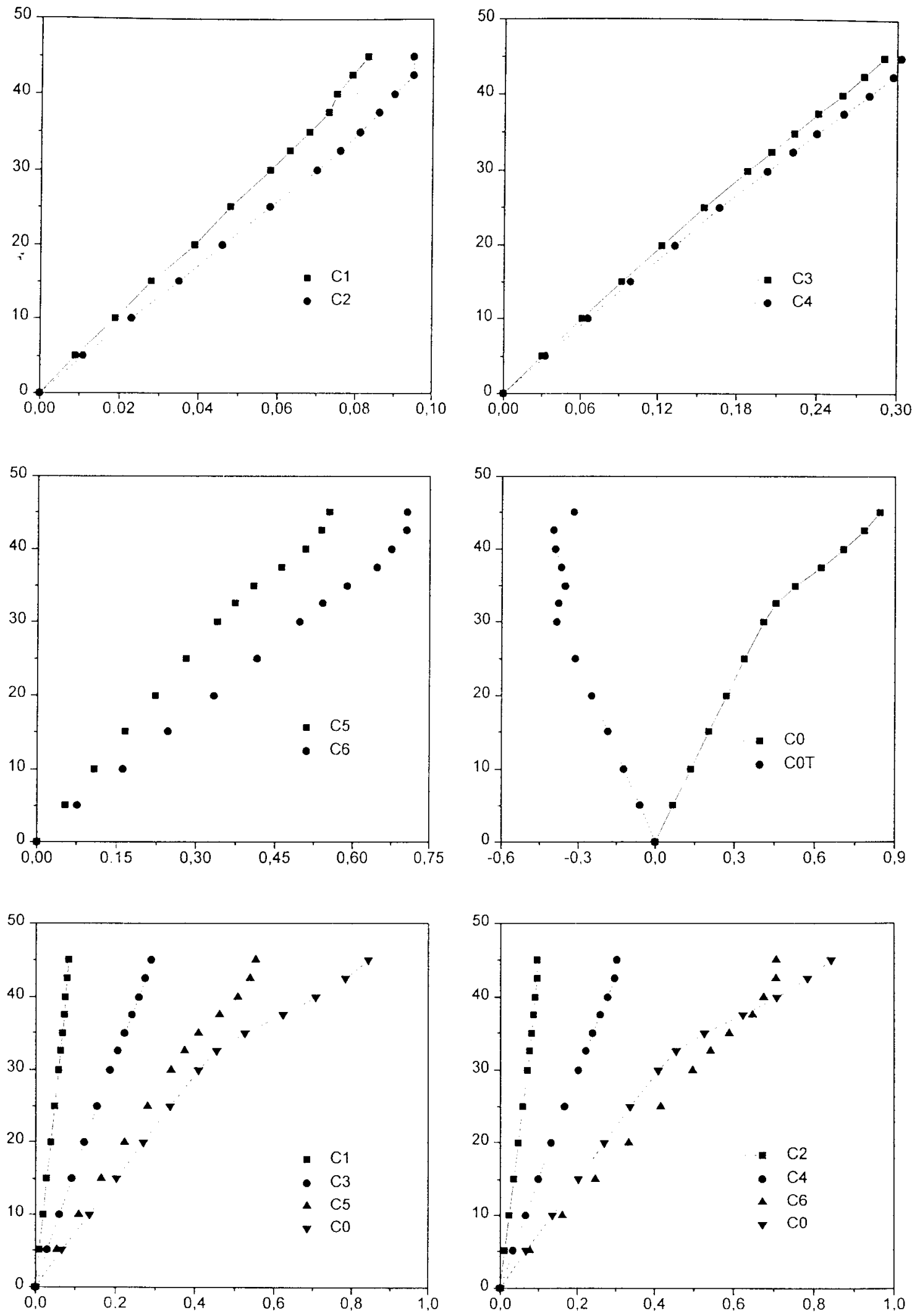

Figura 5.33 - Carga ( $\mathrm{kN}$ no eixo y) x Deformação $(\mathrm{mm} / \mathrm{m}$ no eixo $\mathrm{x})$ concreto do modelo V8 

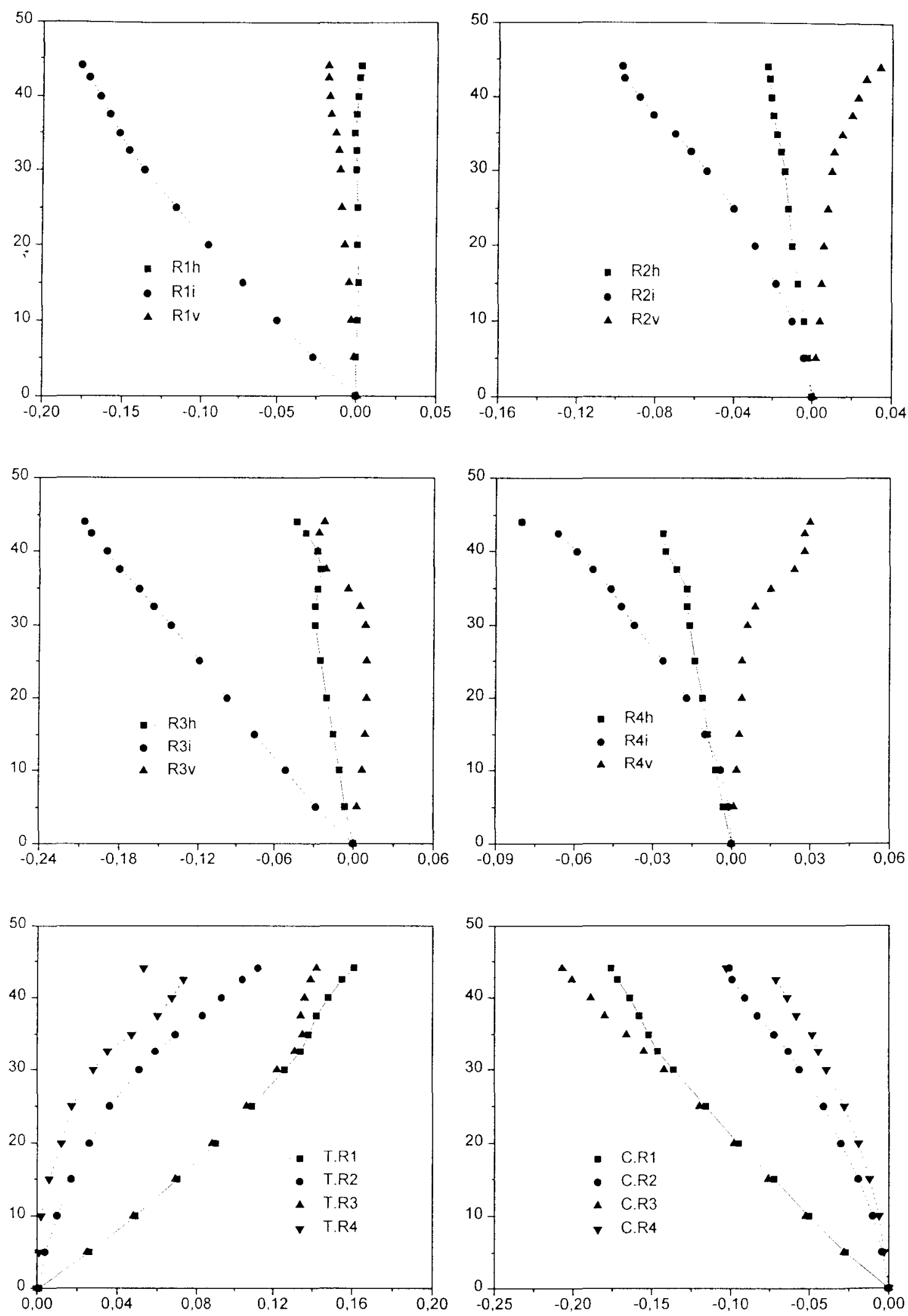

Figura $5.34 \mathrm{a}$ - Carga ( $\mathrm{kN}$ no eixo y) x Deformação $(\mathrm{mm} / \mathrm{m}$ no eixo $\mathrm{x})$ rosetas do modelo $\mathrm{V} 8$ 

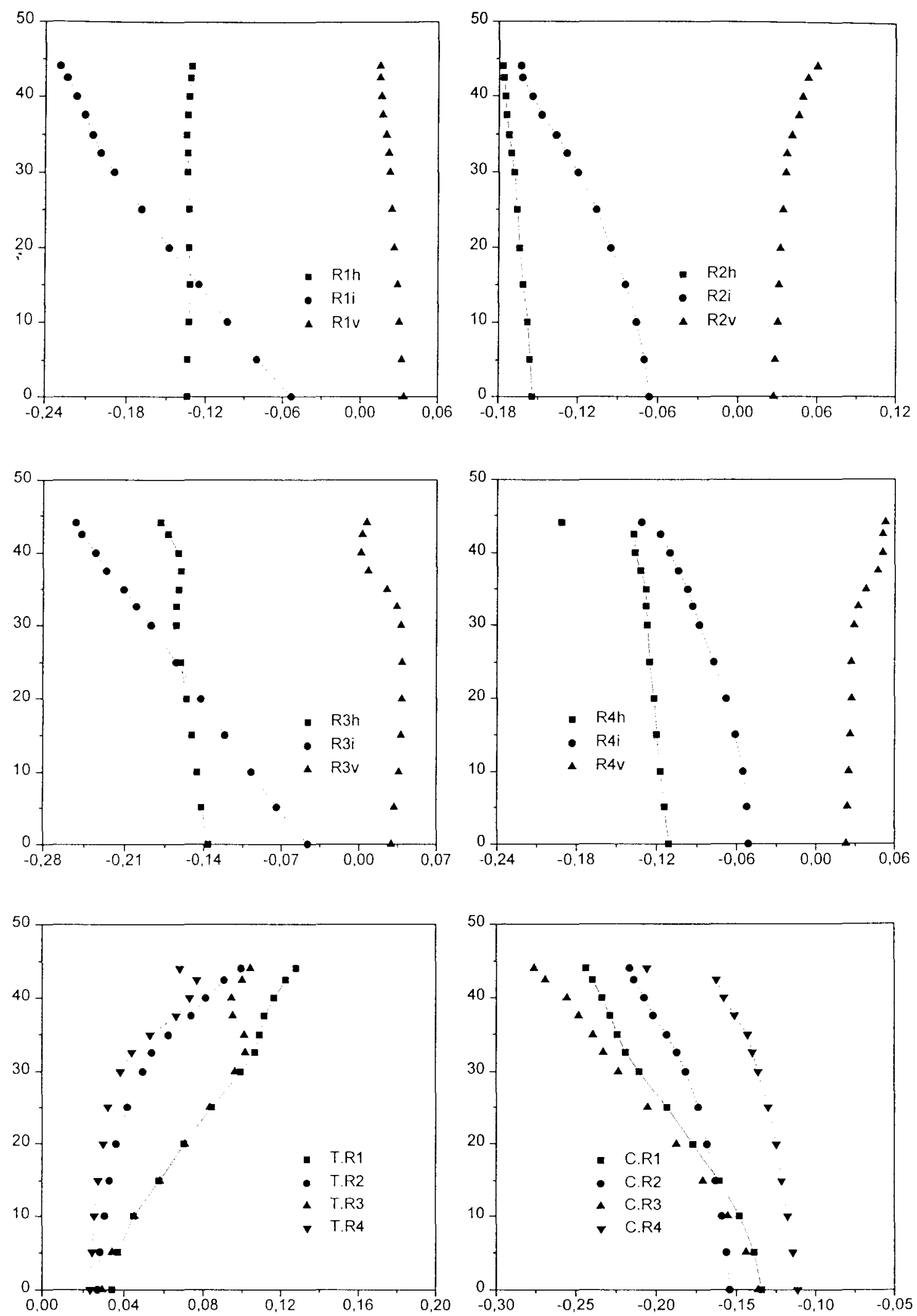

Figura 5.34b - Carga ( $\mathrm{kN}$ no eixo y) x Deformação $(\mathrm{mm} / \mathrm{m}$ no eixo $\mathrm{x})$ rosetas do modelo V8 


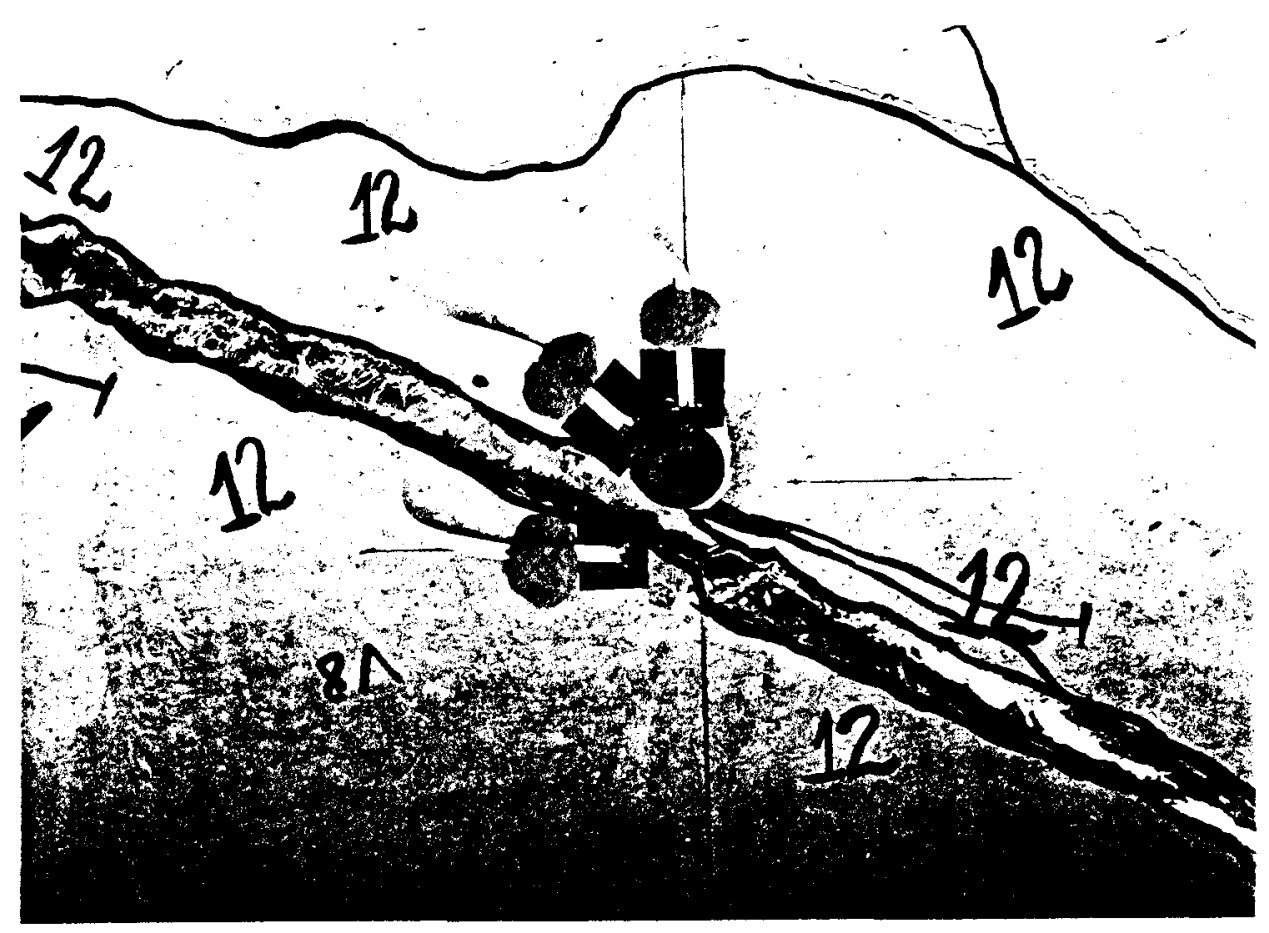

Foto 5.16 - Detalhe das fibras na fissura diagonal do modelo V8

\subsection{9 - MODELO V9}

Este modelo foi produzido com $1 \%$ de fibra de aço de $2,54 \mathrm{~cm} \mathrm{e} 1 \%$ de superplastificante. A armadura transversal era constituída por estribos iguais aos dos seis primeiros modelos, mas o espaçamento entre eles passou de $20 \mathrm{~cm}$ para $27.5 \mathrm{~cm}$.

Novamente, as cordoalhas foram estiradas em quatro incrementos de carga. Apesar de ser um fato quase irrelevante, devido à pequena frequência e à interferência reduzida nos resultados, as falhas apresentadas por alguns extensômetros de alguns modelos anteriores foram investigadas nesta viga. Os valores registrados pelo sistema foram acompanhados várias vezes ao dia, durante todo o período entre o estiramento das cordoalhas e o ensaio, para detectar quando ocorria a eventual mudança no comportamento dos extensometros. Os valores foram sempre consistentes, exceto para os extensômetros do concreto que, no dia seguinte à liberação da protensão, apresentaram variações injustificadas. Na verdadẻ, as falhas observadas são isoladas e intrínsecas ao trabalho experimental, e não comprometem os dados relativos à execução da protensão. 
As cordoalhas foram tracionadas com 49,7 kN, 48,9 kN e 40,1 kN. Após o encunhamento, as forças eram iguais a $45,3 \mathrm{kN}, 46 \mathrm{kN}$ e $40 \mathrm{kN}$.

Até o dia da liberação da protensão, as deformações nos extensômetros das cordoalhas diminuiram, em média, 4\%, enquanto a força nas células de carga ficou praticamente constante.

Considerando-se a força de protensão total igual a $109,8 \mathrm{kN}$ no dia do ensaio, a força que provoca a descompressão da borda inferior no trecho central vale $20,7 \mathrm{kN}$. A carga máxima atingida no ensaio foi de $72,5 \mathrm{kN}$. Apesar da diminuição da armadura transversal, houve um acréscimo de resistência em relação ao modelo V4 igual a $9 \mathrm{kN}$. A resistência também foi levemente superior a do modelo V6. No primeiro caso, destaca-se a possibilidade de substituição parcial dos estribos pelas fibras, com vantagens; no segundo, fica realçada a importância das fibras, já que, mesmo com a diminuição da armadura transversal, a resistência aumentou.

O último registro dos dados foi feito com $72 \mathrm{kN}$. A ruptura foi violenta e repentina. A região danificada partiu do ponto de aplicação da carga e foi até $35 \mathrm{~cm} \mathrm{da}$ extremidade direita da viga. O concreto do banzo comprimido lascou num trecho de 15 $\mathrm{cm}$, onde se observa os porta-estribos encurvados. $O$ estribo posicionado sob o ponto de introdução do carregamento se abriu. O desnível entre as partes separadas nesta região foi significativo, próximo de $5 \mathrm{~cm}$.

Dois estribos romperam na alma. A inclinação média da fissura que originou a ruína foi de 23 graus. Novamente, o concreto entre duas fissuras inclinadas rompeu, deixando um buraco de quase $10 \mathrm{~cm}$ nesta região, que se estendeu para a mesa tracionada num trecho de $30 \mathrm{~cm}$. O estribo desta região, E4, se abriu e o estribo E2 ficou fora do trecho atingido. As Fotos 5.17 e 5.18 mostram detalhes da região da ruína. A distribuição das fibras não é uniforme nas superfícies separadas e a quantidade de fibras é bem menor que nos modelos com fibra de polipropileno, dadas as características diferentes das fibras. A orientação das fibras junto à fissura diagonal ilustra a necessidade de se considerar o fator de orientação para avaliar a sua eficiência como armadura de cisalhamento.

Os dois estribos mais próximos da carga escoaram dos dois lados da viga. $\mathrm{O}$ estado limite último convencional foi atingido com $68 \mathrm{kN}$, sendo que a resistência adicional ąté a ruína foi de $4,5 \mathrm{kN}$. As primeiras fissuras de flexão começaram a inclinar com $40 \mathrm{kN}$ no lado direito e $45 \mathrm{kN}$ no lado esquerdo. Os primeiros estribos foram efetivamente acionados com $45 \mathrm{kN}$. A tensão nos estribos foi maior no lado direito da viga, pois as fissuras de cisalhamento surgiram antes nesta região. 
As fissuras transversais no banzo comprimido e as fissuras inclinadas para o centro da viga na região central da viga foram novamente observadas.

A deformação máxima no concreto ocorreu no meio da viga, muito próxima da registrada no ponto $C 6$, repetindo um fato já verificado na viga V6, quando a tensão foi bem maior no lado da ruptura. $\mathrm{O}$ arqueamento dos esforços se manifestou claramente dos dois lados da viga até os pontos C3 e C4. Portanto, na presença dos estribos, o fenômeno esteve sempre presente, pois a resistência é maior e a ruptura é mais dútil.

A deformação máxima nas cordoalhas no meio do vão chegou a $0.54 \%$. Assim como no modelo V6, ela foi menor que no modelo com fibra de polipropileno, lembrando-se que, nestas três vigas, a carga máxima foi praticamente igual. A diferença se deve ao instante do acionamento das cordoalhas.

O comportamento do extensômetro posicionado na face tracionada do concreto foi uniforme até $37,5 \mathrm{kN}$. No entanto, a primeira fissura visivel foi observada antes, com $35 \mathrm{kN}$, assim com a diminuição da rigidez.

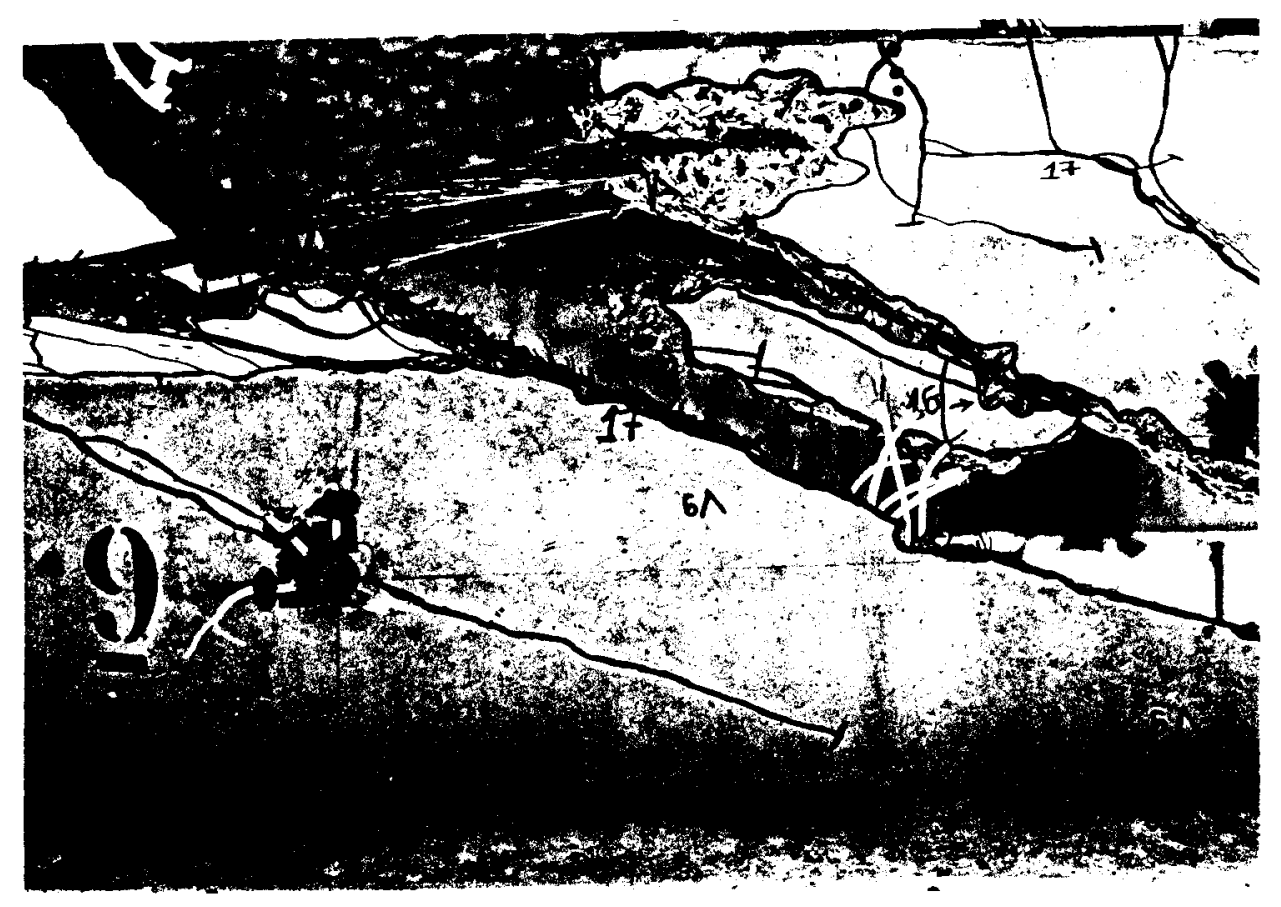

Fóto 5.17 - Detalhe da ruptura na região das cordoalhas do modelo V9 

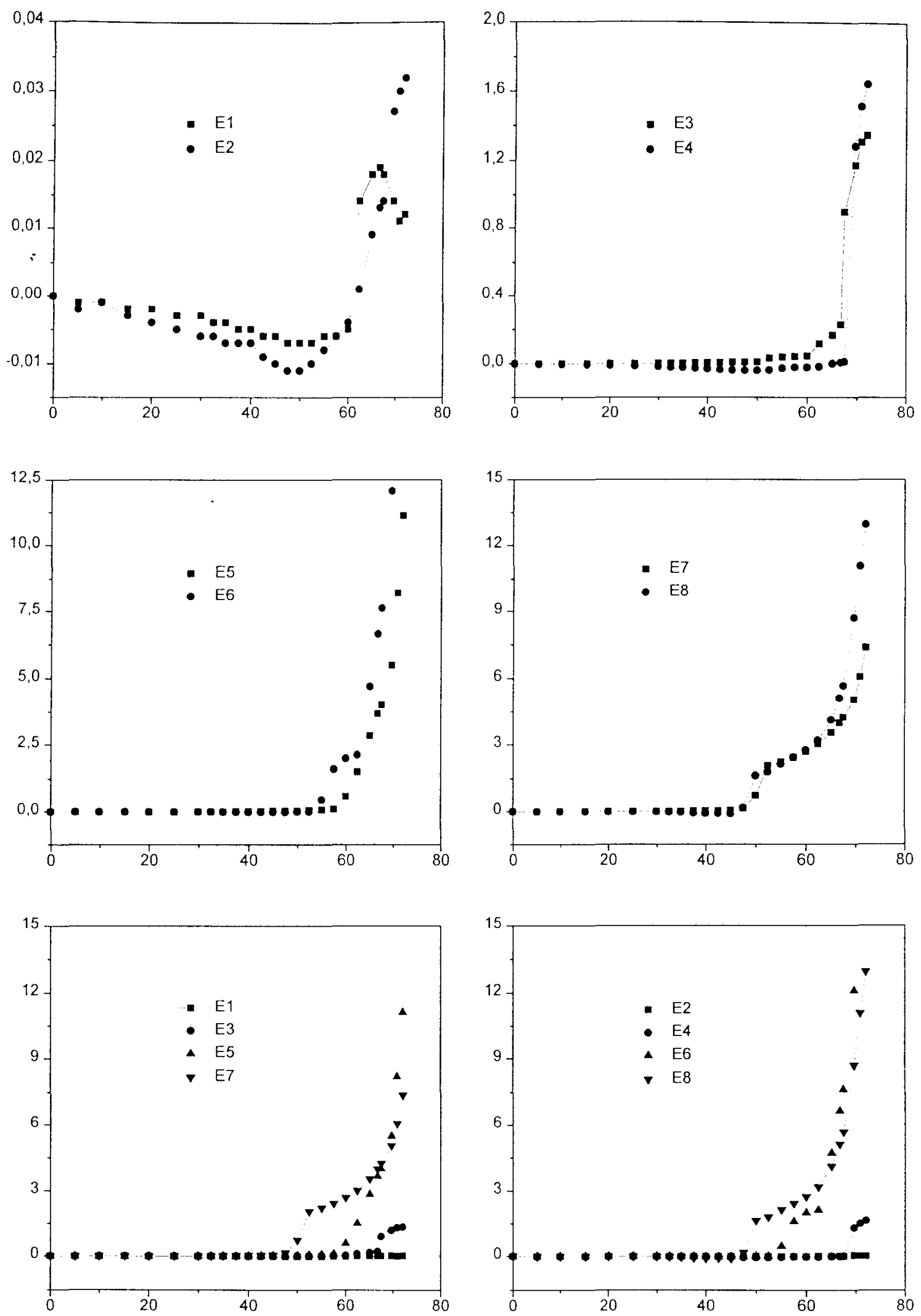

Figura 5.35 - Deformação $(\mathrm{mm} / \mathrm{m}$ no eixo y) x Carga $(\mathrm{kN}$ no eixo $\mathrm{x})$ estribos do modelo V9 

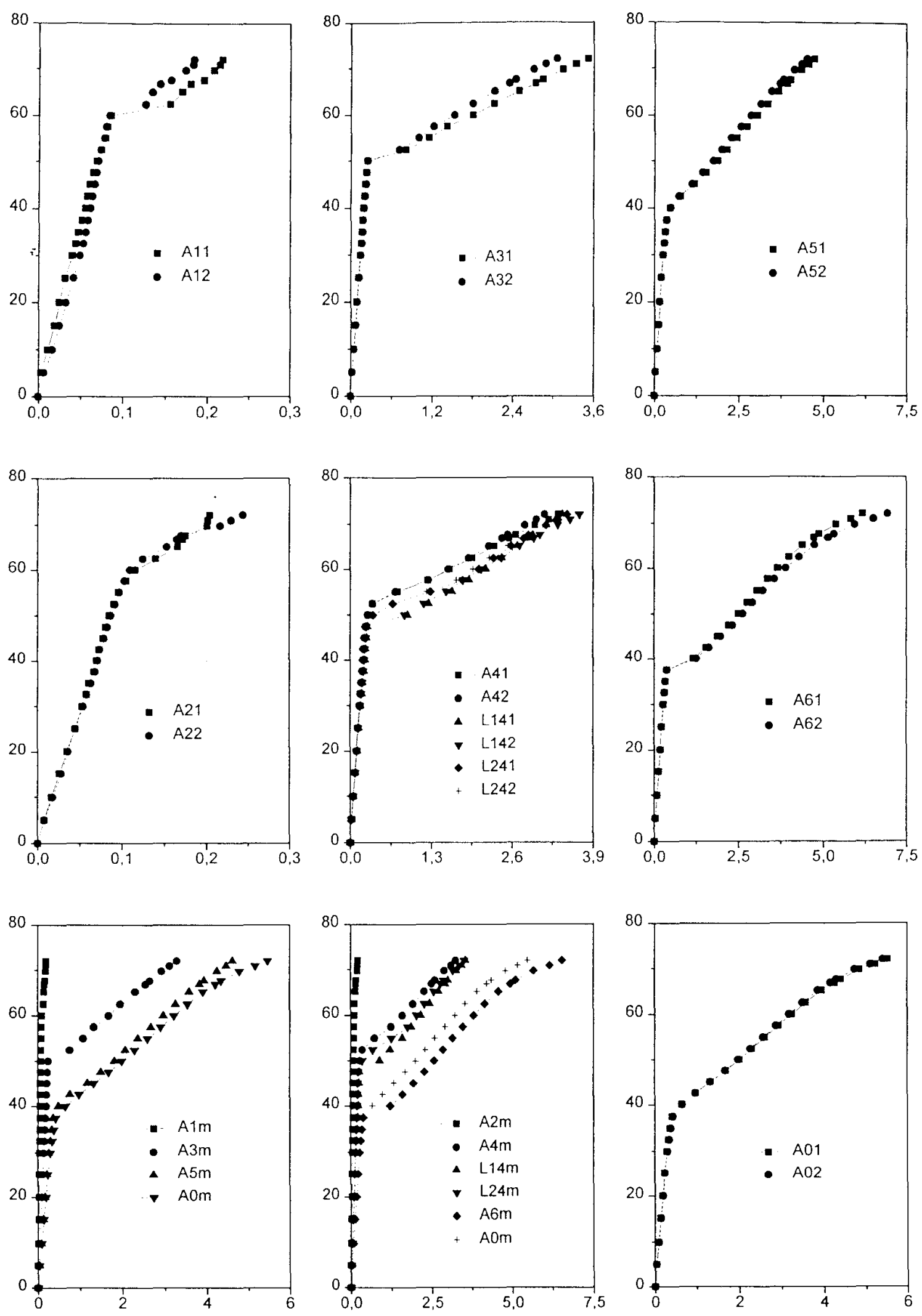

Figura 5.36 - Carga ( $\mathrm{kN}$ no eixo y) x Deformação $(\mathrm{mm} / \mathrm{m}$ no eixo $\mathrm{x})$ cordoalhas do modelo V9 

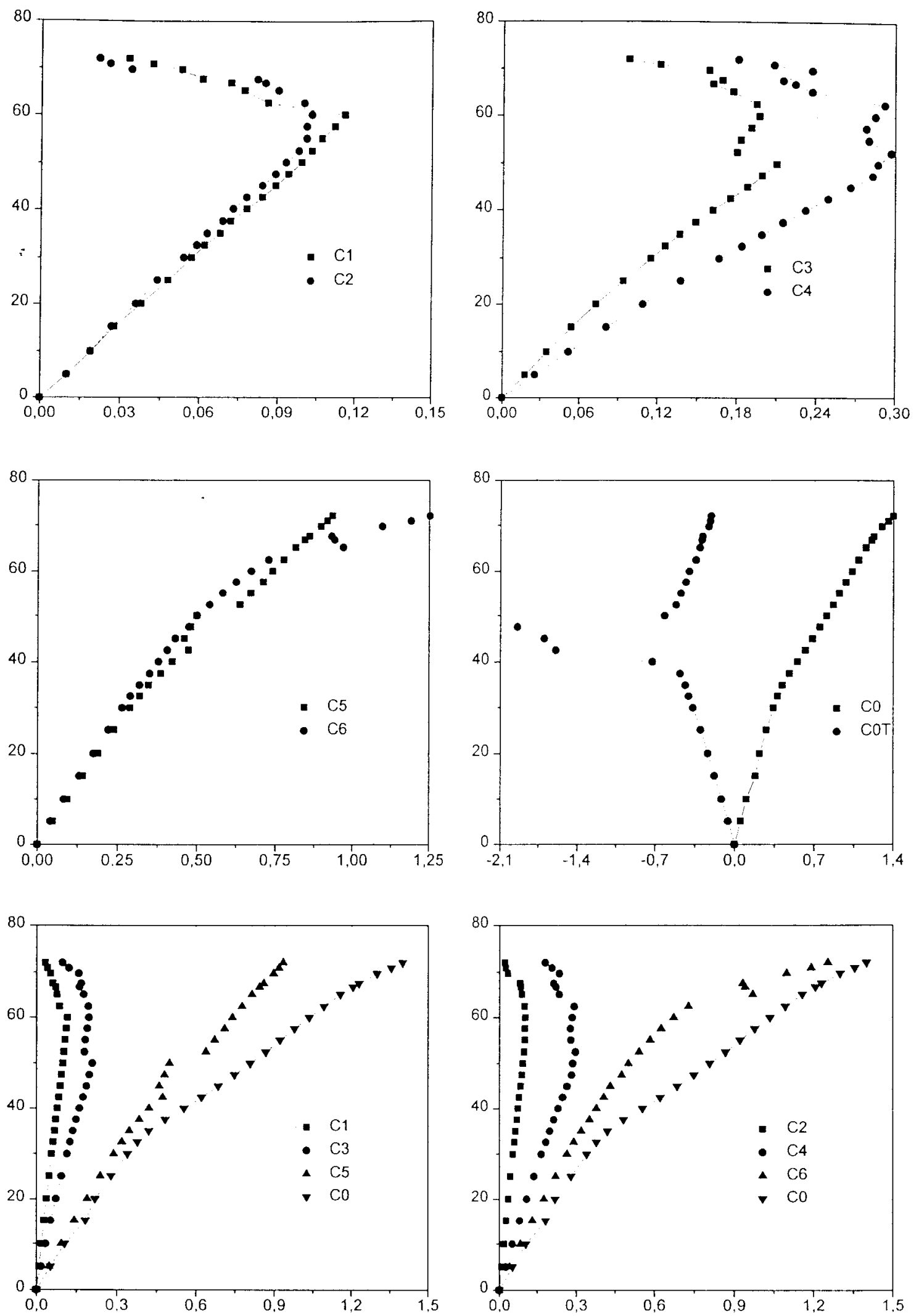

Figura 5.37 - Carga ( $\mathrm{kN}$ no eixo y) x Deformação $(\mathrm{mm} / \mathrm{m}$ no eixo $\mathrm{x})$ concreto do modelo V9 

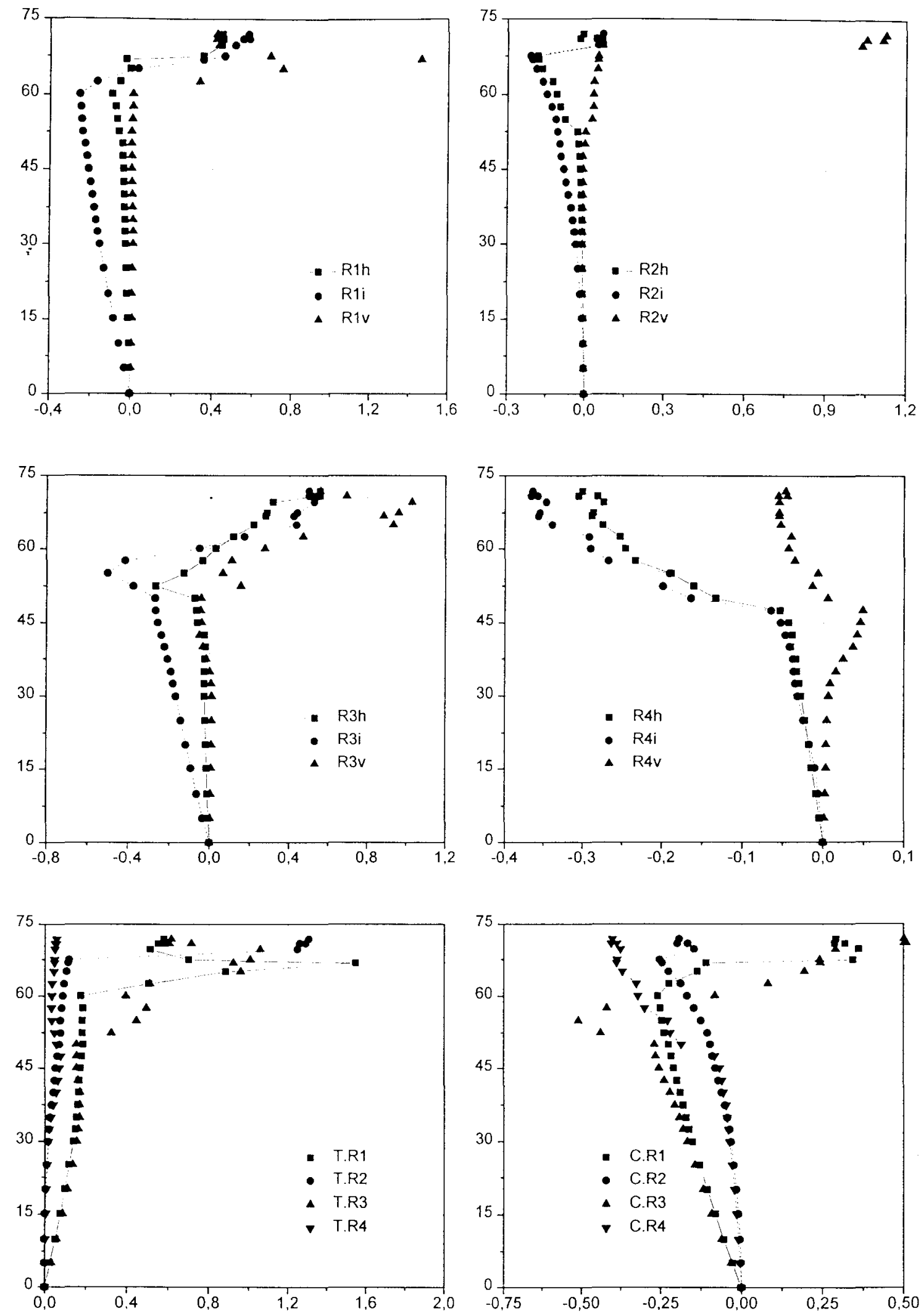

Figura 5.38a - Carga ( $\mathrm{kN}$ no eixo y) x Deformação $(\mathrm{mm} / \mathrm{m}$ no eixo $\mathrm{x})$ rosetas do modelo V9 

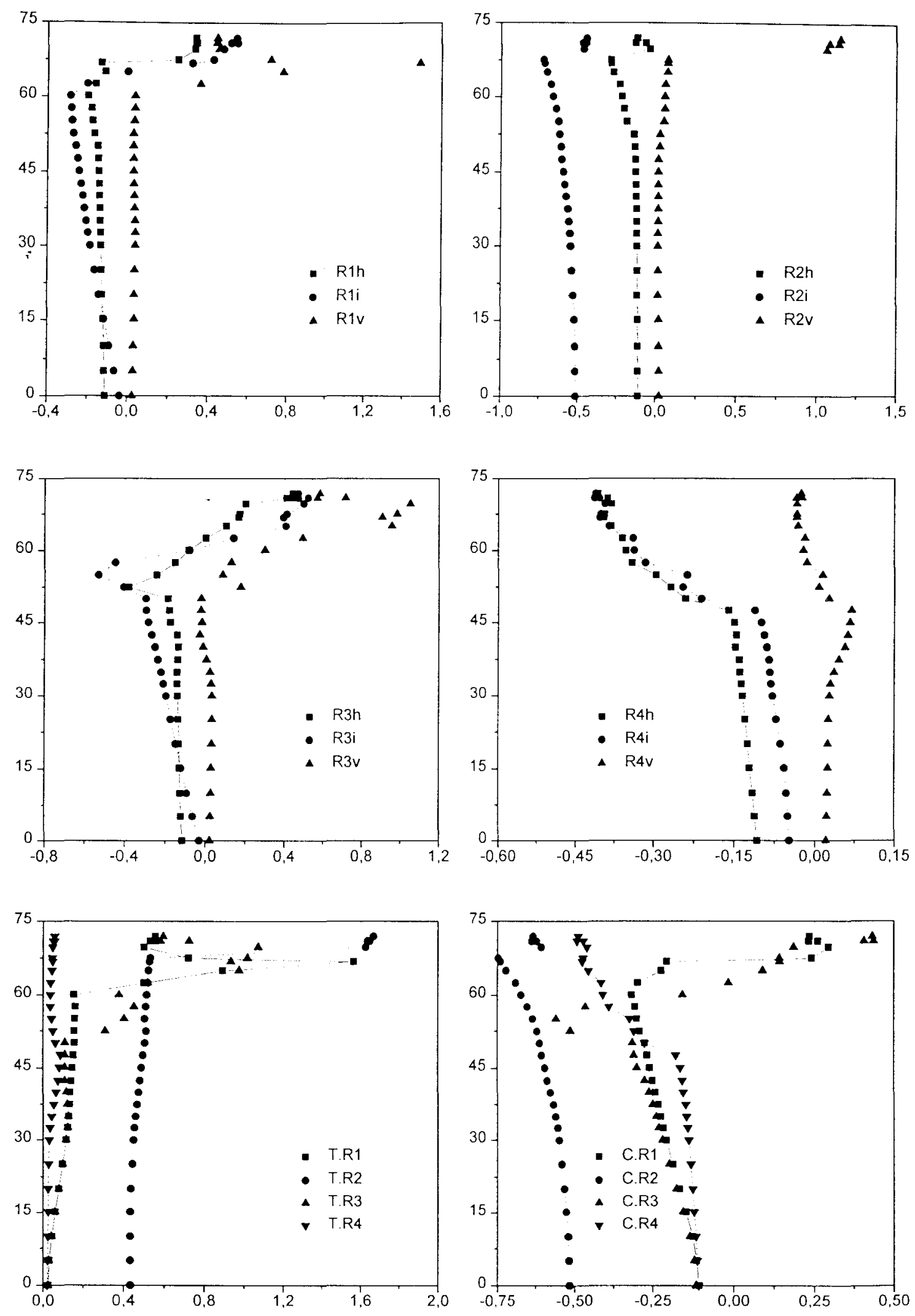

Figura $5.38 b$ - Carga $(\mathrm{kN}$ no eixo y) x Deformação $(\mathrm{mm} / \mathrm{m}$ no eixo $\mathrm{x})$ rosetas do modelo $\mathrm{V} 9$ 


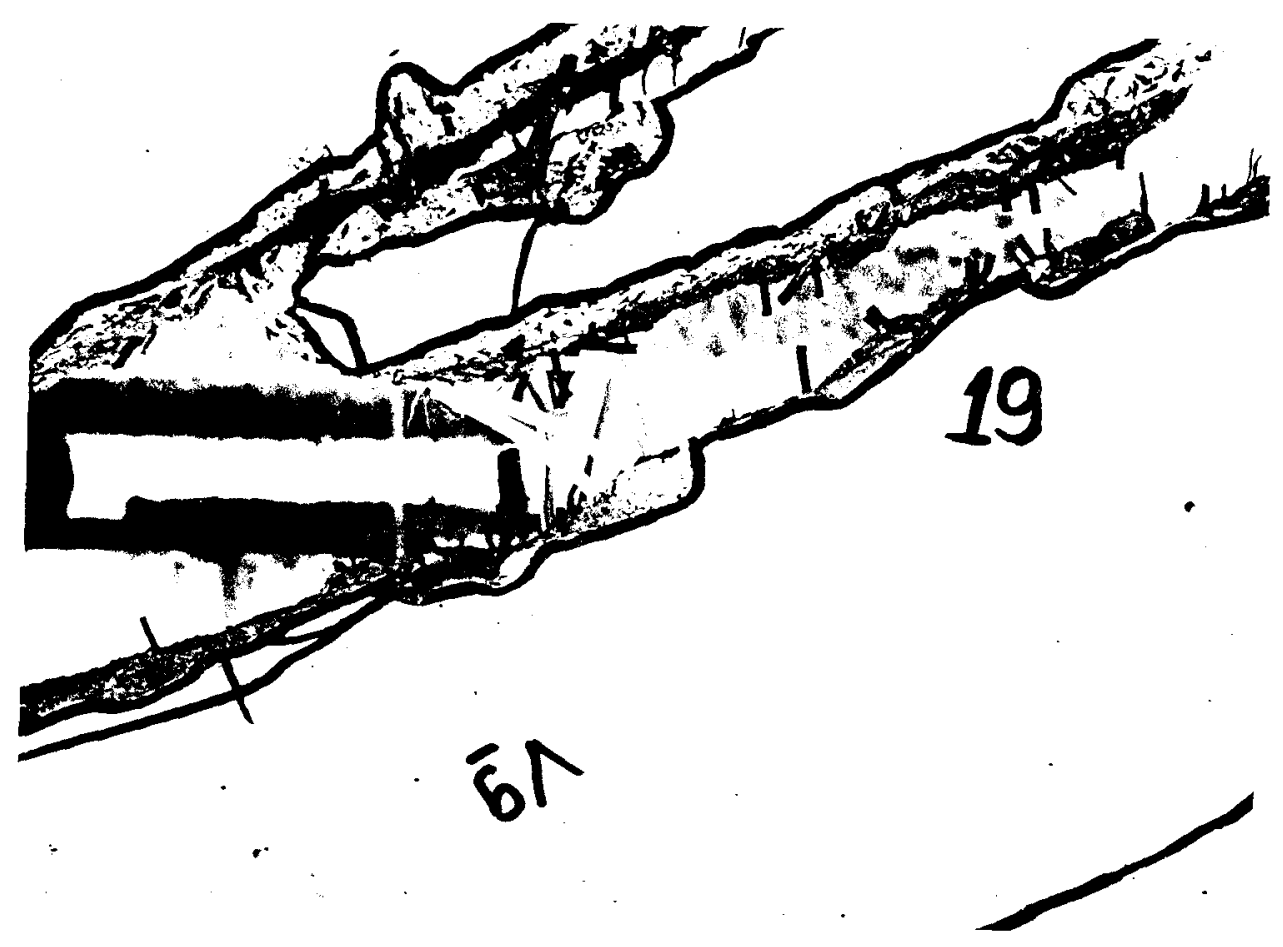

Foto 5.18 - Detalhe da ruptura na alma do modelo V9

As Fotos 5.19 a $5.21,5.22$ a 5.24 e 5.25 a 5.27 mostram o panorama geral e os detalhes dos dois lados das vigas após os ensaios, dos modelos V1 a V3, V4 a V6 e V7 a V 9 , respectivamente.

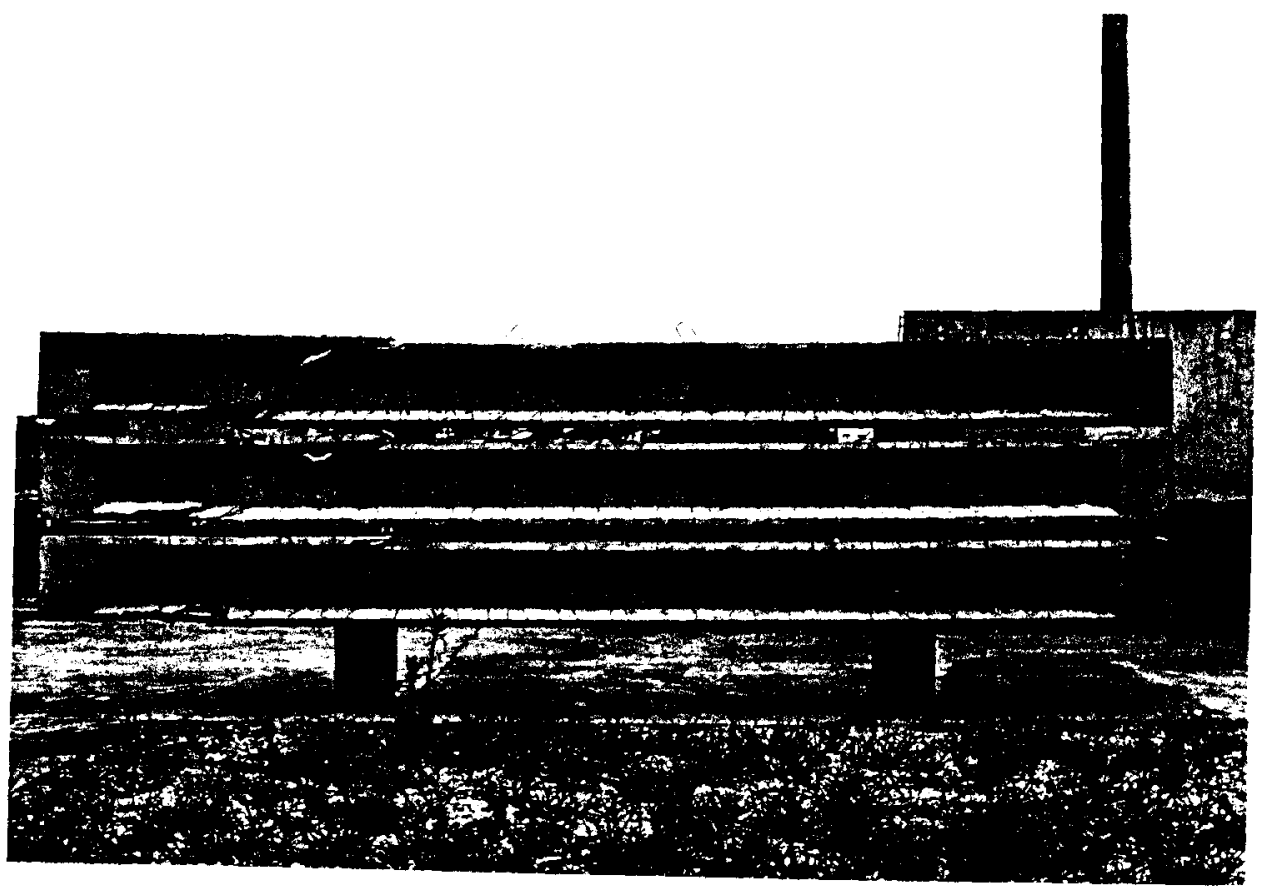

Foto 5.19 - Panorama geral dos modelos V1 a V3 após o ensaio 


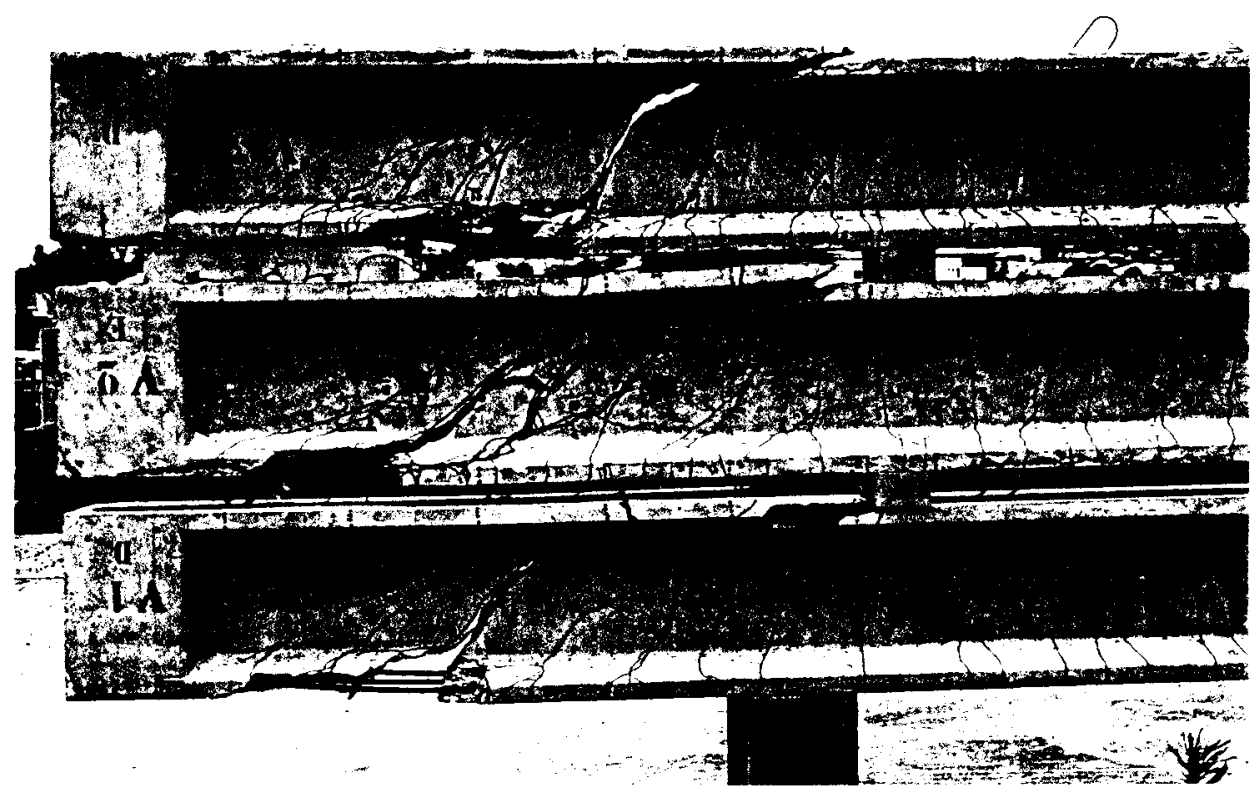

Foto 5.20 - Detalhe do lado da ruína nos modelos V1 a V3

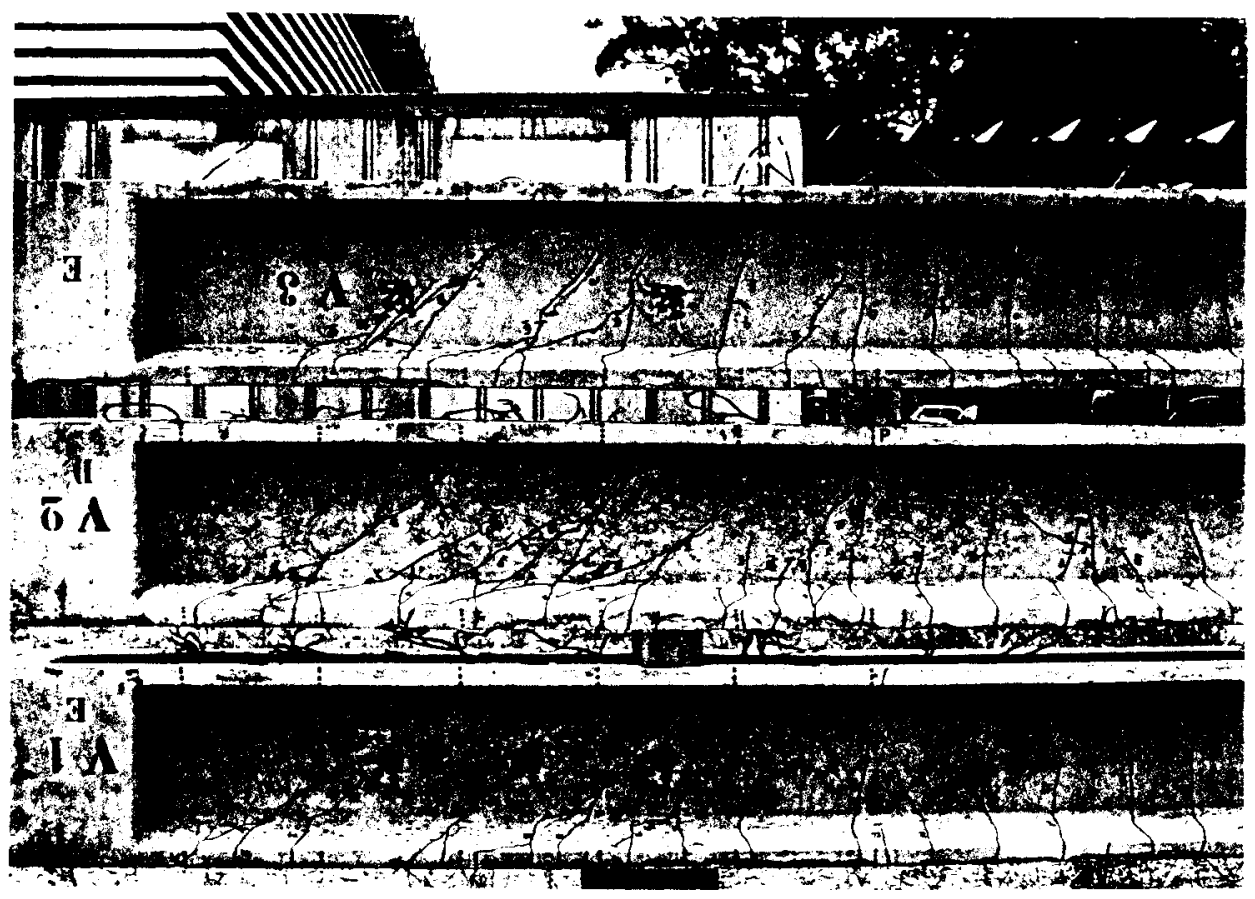

Foto 5.21 - Detalhe do lado em que não howe a ruína nos modelos V1 a V3 


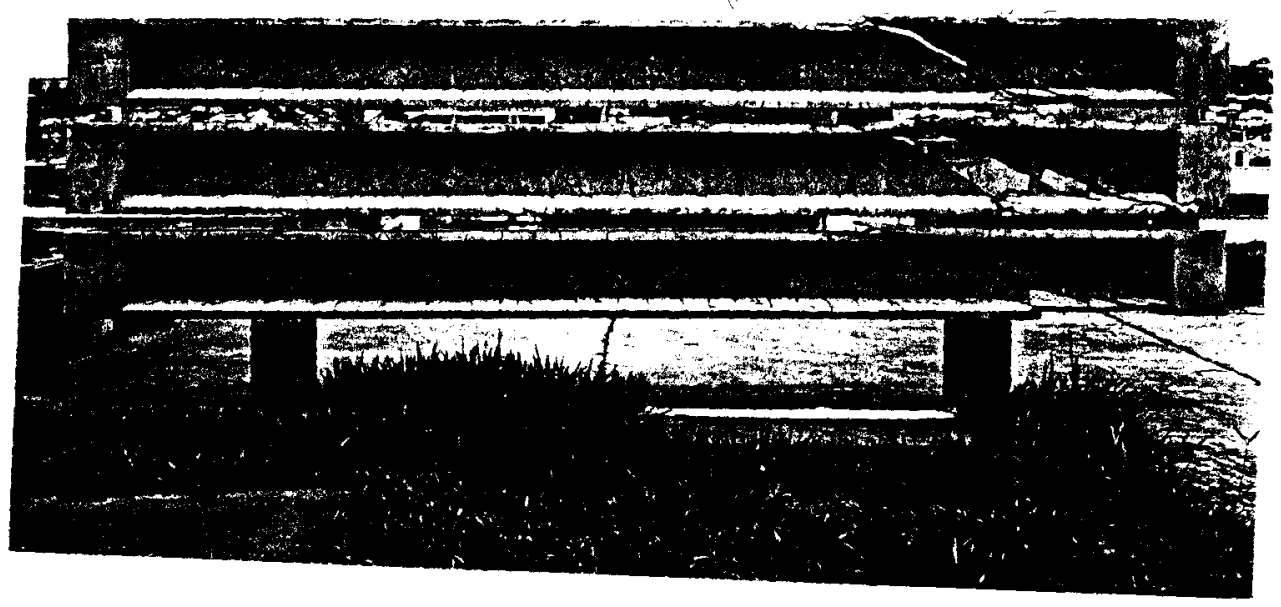

Foto 5.22 - Panorama geral dos modelos V4 a V6 após o ensaio

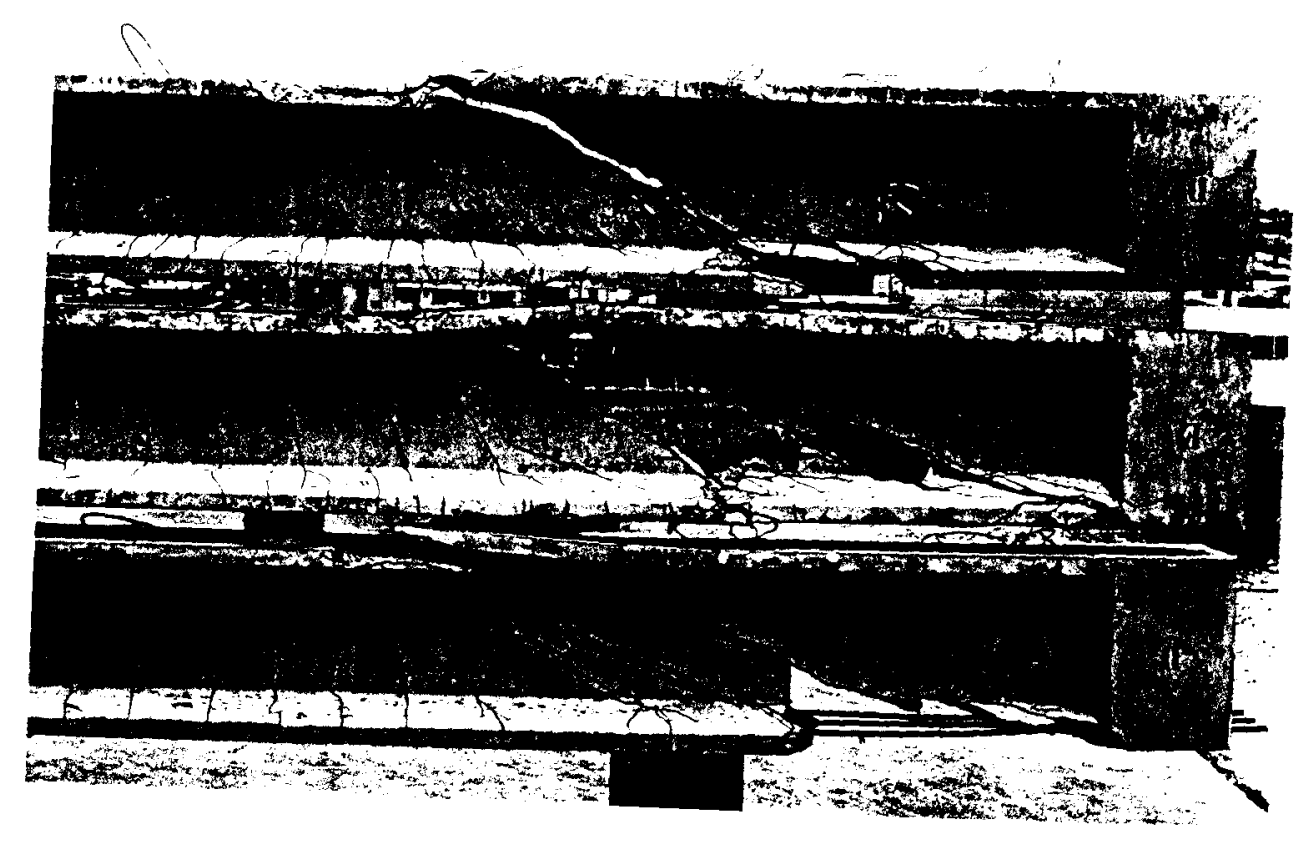

Foto 5.23 - Detalhe do lado da ruína nos modelos V4 a V6 


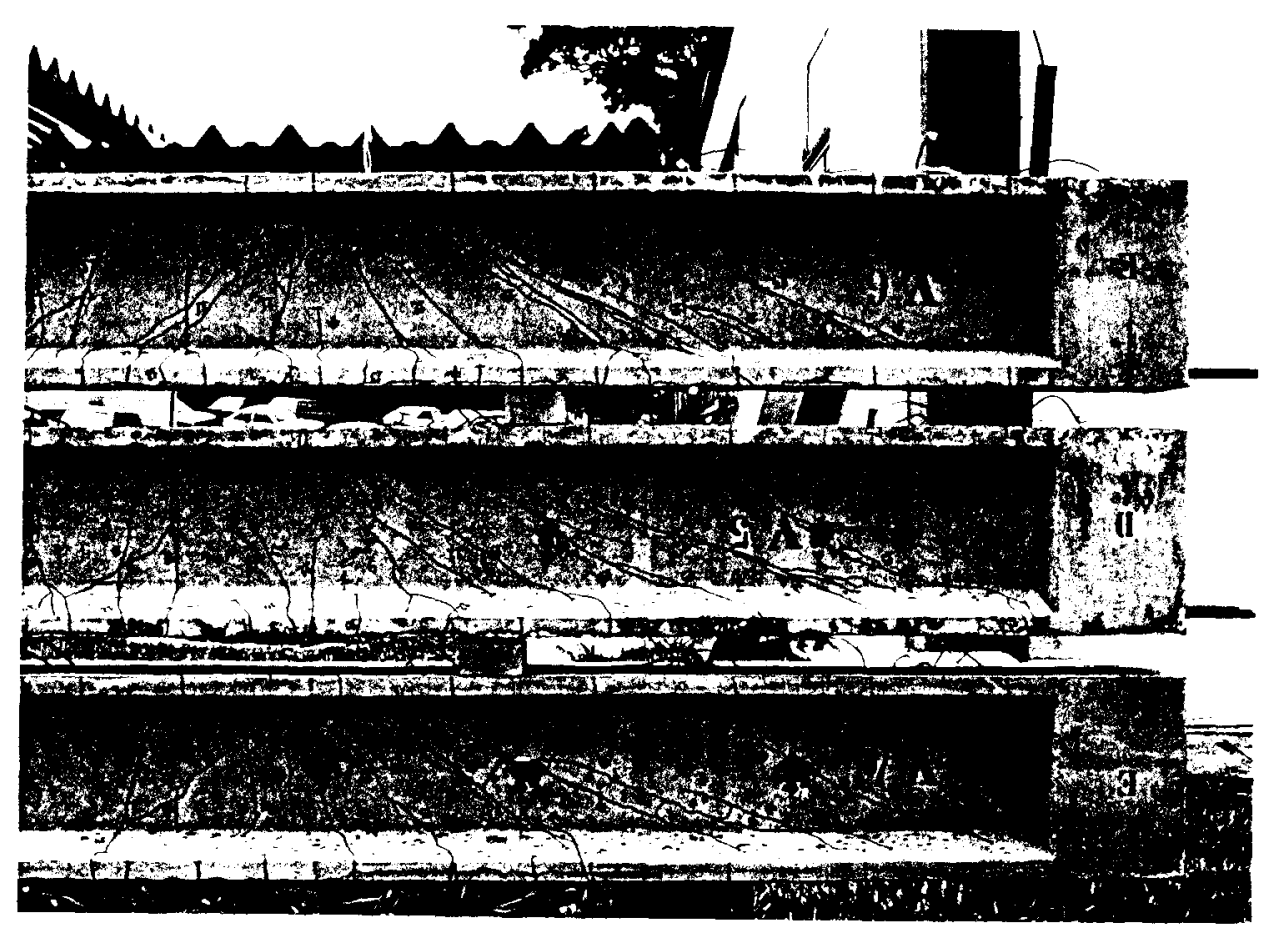

Foto 5.24 - Detalhe do lado em que não houve a ruína nos modelos V4 a V6

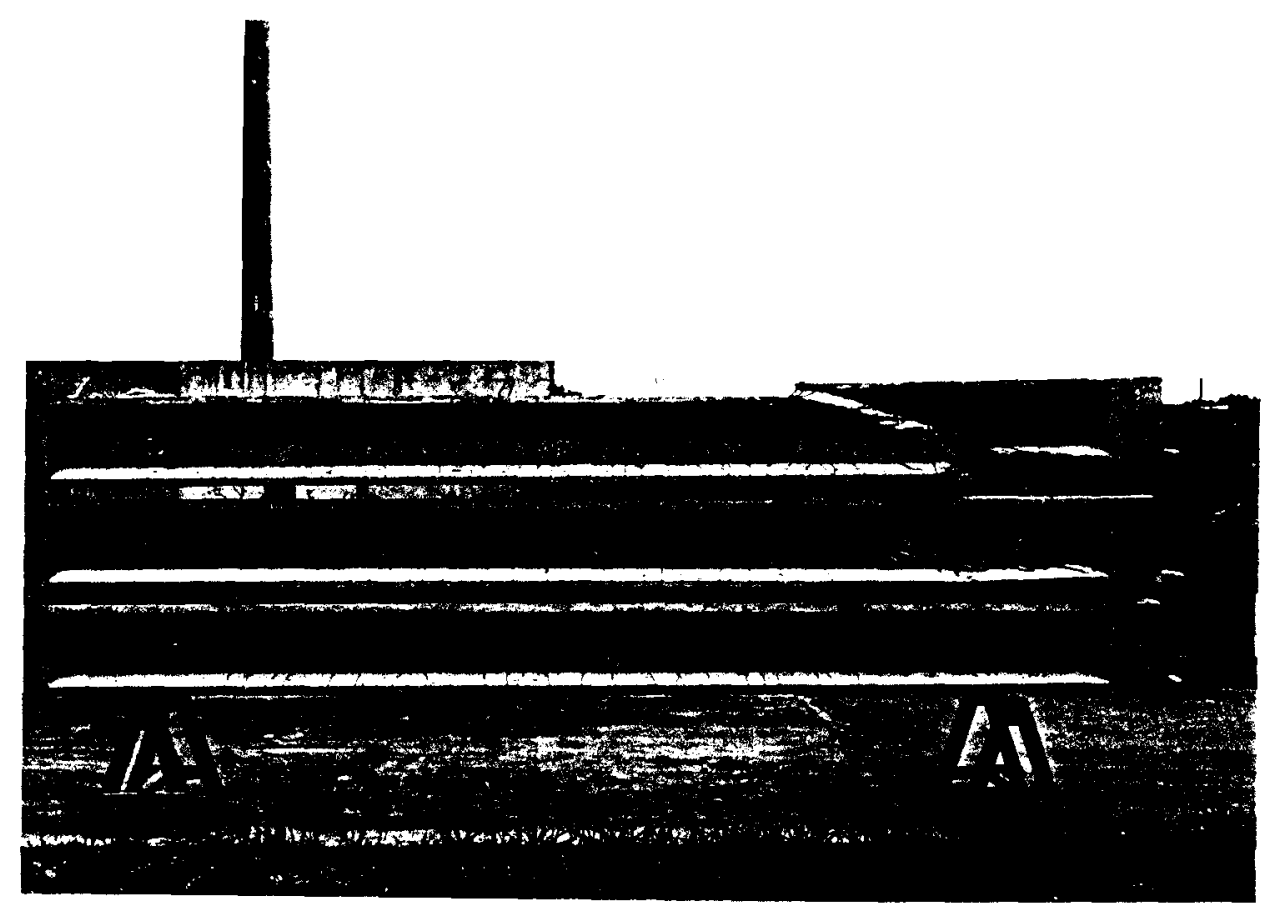

Foto 5.25 - Panorama geral dos modelos V7 a V9 após o ensaio 


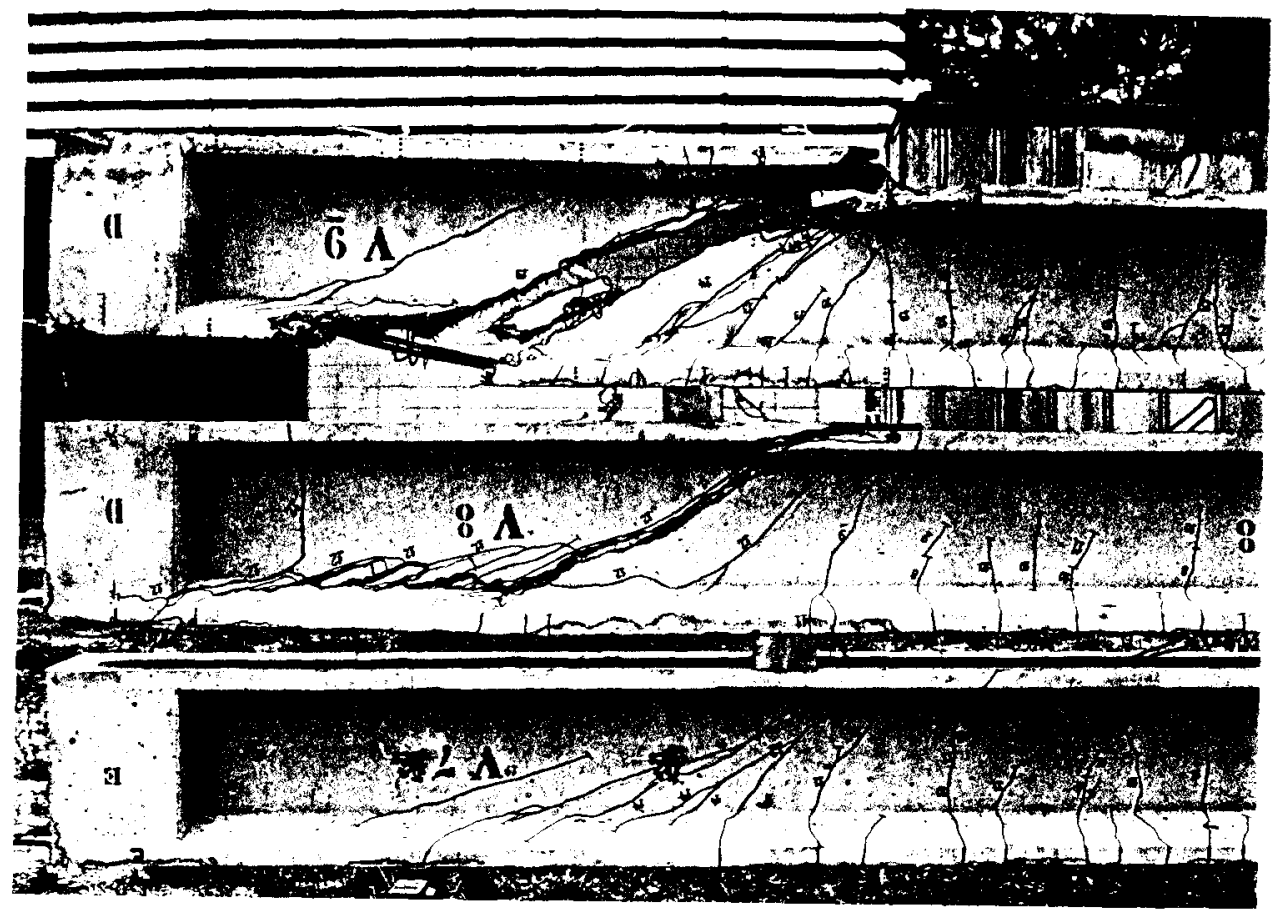

Foto 5.26 - Detalhe do lado da ruína nos modelos V7 a V9

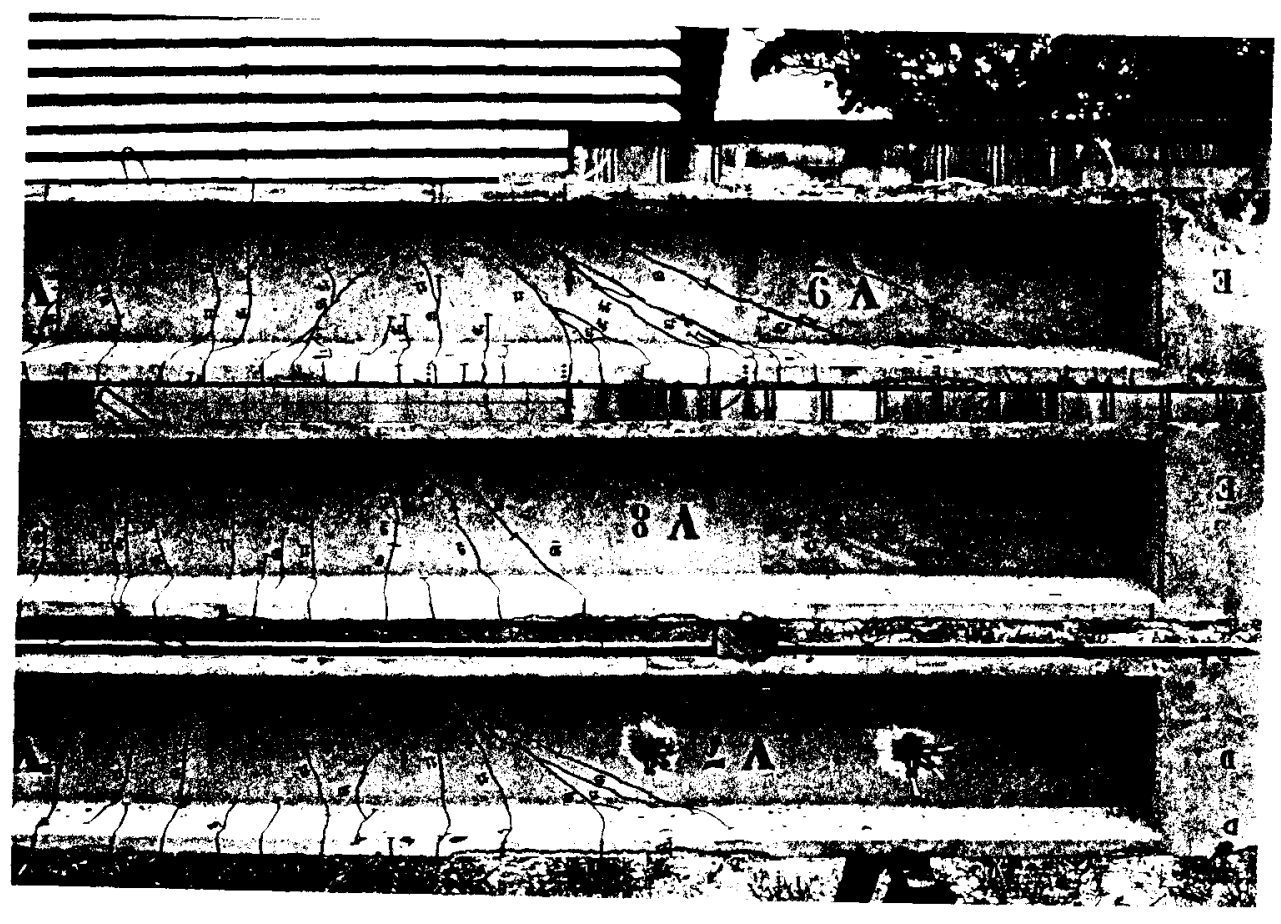

Foto 5.27 - Detalhe do lado em que não houve a ruína nos modelos V7 a V9 


\section{8 - ANÁLISE DOS RESULTADOS}

Apresenta-se neste ítem uma análise individual e comparativa sobre o desempenho dos modelos, onde se discutem as diferenças decorrentes da introdução da protensão e das fibras no comportamento resistente. São abordados basicamente os ¿mesmos aspectos discutidos na apresentação individual dos resultados.

Em alguns tópicos principais, como a tensão nos estribos e na armadura longitudinal e a evolução dos deslocamentos, os modelos são agrupados em conjuntos específicos, para realçar a influência dos parâmetros estudados: protensão. fibras e armadura transversal.

Em relação à tensão nos estribos em cada posição instrumentada, os modelos foram divididos em seis grupos, cinco deles referentes às seis primeiras vigas:

- a - vigas sem protensão (V1 a V3 - para análise da influência das fibras);

- b - vigas com protensão (V4 a V6 - para análise da influência das fibras nos modelos protendidos);

- c, d, e - vigas com o mesmo tipo de fibra (V1 e V4, V2 e V5, V3 e V6 - para análise da influência da protensão);

- $\mathrm{f}$ - todas as vigas.

Para análise das flechas e da tensão na armadura longitudinal, em cada ponto instrumentado, os modelos foram divididos em nove conjuntos:

- a, b, c - vigas das séries a, b e c (V1 a V3, V4 a V6, V7 a V9 - para análise da influência das fibras);

- d, e, f - vigas com o mesmo tipo de fibra (V1, V4 e V7; V2, V5 e V8; V3. V6 e V9 - para análise da influência da protensão e dos estribos);

- g - vigas com a mesma armadura transversal e com fibra (V2, V3, V5 e V6 - para comparação entre os modelos com diferentes tipos de fibra);

- h - vigas protendidas (V4, V8 e V9 - para análise das fibras em substituição aos estribos do modelo V4);

- i - vigas V1, V8 e V9 (idem ao item h, mas em relação ao modelo de referência sem protensạ̃o). 


\subsection{1 - PROPRIEDADES DO CONCRETO}

As conclusões sobre as propriedades da mistura fresca são as mesmas dos ensaios anteriores, ou seja, a trabalhabilidade do concreto piora com a introdução das fibras, principalmente no caso da fibra de polipropileno.

A Tabela 5.3 mostra os resultados da resistência à tração e à compressão axial do concreto antes da liberação da protensão, para os modelos V4 a V9. Na Tabela 5.4, apresentam-se os mesmos resultados referentes ao dia do ensaio de flexão, além dos valores do módulo de deformação longitudinal, do módulo ponderado pela raiz quadrada da resistência à compressão e do módulo relativo, tendo como referência o valor do modelo V1. A título de comparação, nas duas tabelas consta o valor da resistência à tração calculado segundo a expressão da NBR-6118, calculada de acordo com a resistência à compressão axial obtida experimentalmente.

Tabela 5.3 - Propriedades da mistura antes da liberação da protensão

\begin{tabular}{|c|c|c|c|c|}
\hline modelo & idade & $f_{c}(\mathrm{MPa})$ & $f_{\mathrm{t}}(\mathrm{MPa})$ & $\mathrm{f}_{\mathrm{t.teo}}(\mathrm{MPa})$ \\
\hline 4 & 3 & 43,5 & 3,2 & 3,3 \\
\hline 5 & 4 & 42,2 & 3,1 & 3,2 \\
\hline 6 & 6 & 53,5 & 2,9 & 3,9 \\
\hline 7 & 5 & 48,5 & 3,0 & 3,6 \\
\hline 8 & 3 & 45,5 & 3,0 & 3,8 \\
\hline 9 & 6 & 55,4 & 3,1 & 4,0 \\
\hline
\end{tabular}

Tabela 5.4 - Propriedades da mistura endurecida

\begin{tabular}{|c|c|c|c|c|c|c|c|c|}
\hline viga & idade & $f_{\mathrm{c}}(\mathrm{MPa})$ & $\mathrm{f}_{\mathrm{t}}(\mathrm{MPa})$ & $\mathrm{f}_{\mathrm{t}, \mathrm{te} o}(\mathrm{MPa})$ & $\mathrm{E}(\mathrm{MPa})$ & $\mathrm{E}_{\text {teo }}(\mathrm{MPa})$ & $\mathrm{E} / \mathrm{f}_{\mathrm{c}}^{0.5}$ & $\mathrm{E}_{\text {rel }}$ \\
\hline 1 & 8 & 48,5 & 3,1 & 3,6 & 37490 & 41400 & 5383 & 1,0 \\
\hline 2 & 7 & 37,4 & 2,1 & 2,9 & 30800 & 36300 & 5036 & 0,82 \\
\hline 3 & 7 & 52,8 & 3,6 & 3,9 & 37050 & 43200 & 5099 & 0,99 \\
\hline 4 & 8 & 57,2 & $3,0 *$ & 4,1 & 35870 & 44900 & 4742 & 0,96 \\
\hline 5 & 7 & 52,1 & $3,2^{*}$ & 3,8 & 32860 & 42900 & 4552 & 0,88 \\
\hline 6 & 11 & 59,1 & 3,5 & 4,2 & 38030 & 45700 & 4947 & 1,01 \\
\hline 7 & 7 & 52,1 & 2,2 & 3,8 & 33580 & 42900 & 4652 & 0,90 \\
\hline 8 & 7 & 44,9 & 3,1 & 3,4 & 34670 & 39800 & 5174 & 0,93 \\
\hline 9 & 8 & 52,3 & 3,4 & 3,8 & 35280 & 43000 & 4878 & 0,94 \\
\hline \multicolumn{7}{|c|}{$*$ Desprezado o resultado muito baixo de um corpo-de-prova } \\
\hline
\end{tabular}


Ao contrário do que foi observado nos ensaios preliminares, não houve aumento da resistência à compressão com a introdução das fibras. Deve haver, no entanto, uma variação da resistência associada às condições da consistência da matriz. No concreto sem fibras, a resistência foi maior quando se utilizou superplastificante (V4 e V7). A resistência do concreto com fibra de polipropileno foi, em geral, menor.

A resistência à tração do concreto com fibra de aço foi sempre maior, independentemente do valor da resistência à compressão. Nos ensaios preliminares com a fibra de $2,54 \mathrm{~cm}$, o aumento só foi verificado para o volume de $2 \%$. Em todos os casos a expressão da norma superestima a resistência à tração.

Inexplicavelmente, houve diminuição da resistência à compressão (modelos V8 e V9) e da resistência à tração (modelos V4 e V7) com a idade.

A Tabela. 5.5 resume os resultados agrupados para os três tipos de concreto utilizados. O módulo de deformação longitudinal do concreto com fibra de aço foi maior, em média, confirmando os resultados dos ensaios preliminares. A fibra de polipropileno apresentou o pior desempenho. Os valores relativos médios foram iguais a $0,95,0,88$ e 0,98 , para o concreto sem fibra, com fibra de polipropileno e com fibra de aço, respectivamente. As diferenças praticamente desaparecem para os valores ponderados, respectivamente iguais a 4926, 4921 e 4975, sugerindo que a resistência do concreto seja o fator determinante no valor do módulo.

Tabela 5.5 - Valores médios das misturas correspondentes

\begin{tabular}{|c|c|c|c|c|c|c|}
\hline concreto & $\mathrm{f}_{\mathrm{c}}(\mathrm{MPa})$ & $\mathrm{E}(\mathrm{MPa})$ & $\mathrm{E}_{\text {teo }}(\mathrm{MPa})$ & $\exp /$ teo & $\mathrm{E} / \mathrm{f}_{\mathrm{c}}^{0.5}$ & $\mathrm{E}_{\mathrm{rel}}$ \\
\hline simples & 52,6 & 35647 & 43067 & 0,83 & 4926 & 0.95 \\
\hline poliprop. & 44,8 & 32777 & 39667 & 0,83 & 4921 & 0.88 \\
\hline aço & 54,7 & 36787 & 43967 & 0,84 & 4975 & 0,98 \\
\hline
\end{tabular}

No entanto, quando se analisa os diagramas $\sigma-\varepsilon$ dos corpos-de-prova apresentados nas Figuras 5.39 e 5.40, os resultados destacam as diferenças entre os compósitos para tensões mais elevadas (módulo secante), mas ainda parcialmente atrelados à resistência do concreto. As deformações crescem mais rapidamente no concreto com fibra de polipropileno, que corresponde às três curvas inferiores do conjunto. Exceto para o modelo V5, a deformação de ruptura foi baixa nestes casos.

Para a fibra de aço. as deformações forạm menores até o final. Excetuando-se o modelo V4, đe resistência elevada, as curvas superiores correspondem ao concreto com fibra de aço. Além disso, para resistências iguais, o valor do módulo decresce, na ordem, para o concreto com fibra de aço, sem fibra e com fibra de polipropileno. 


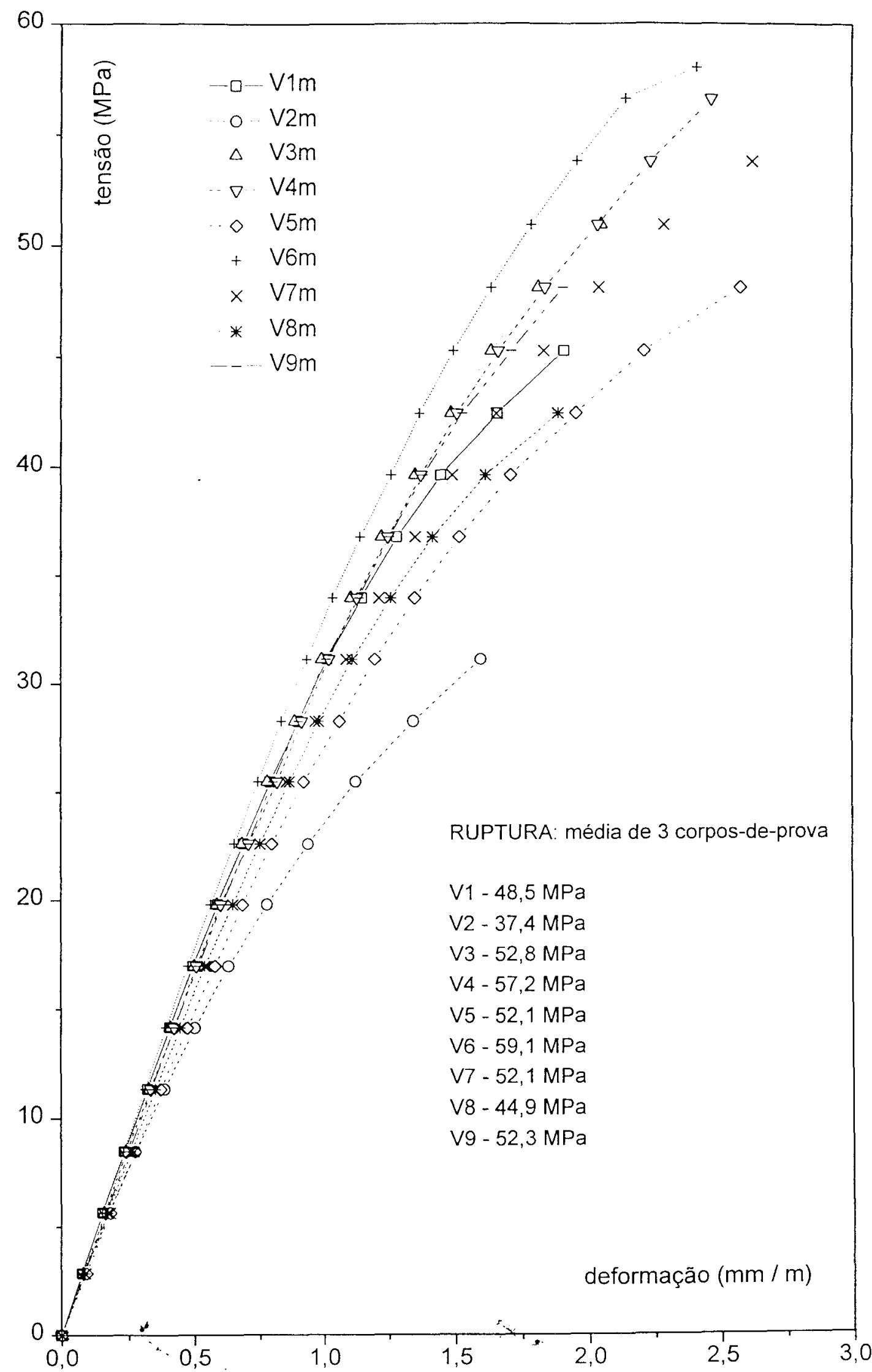

Figura 5.39 - Diagrama $\sigma-\varepsilon$ dos corpos-de-prova de concreto (valores médios) 

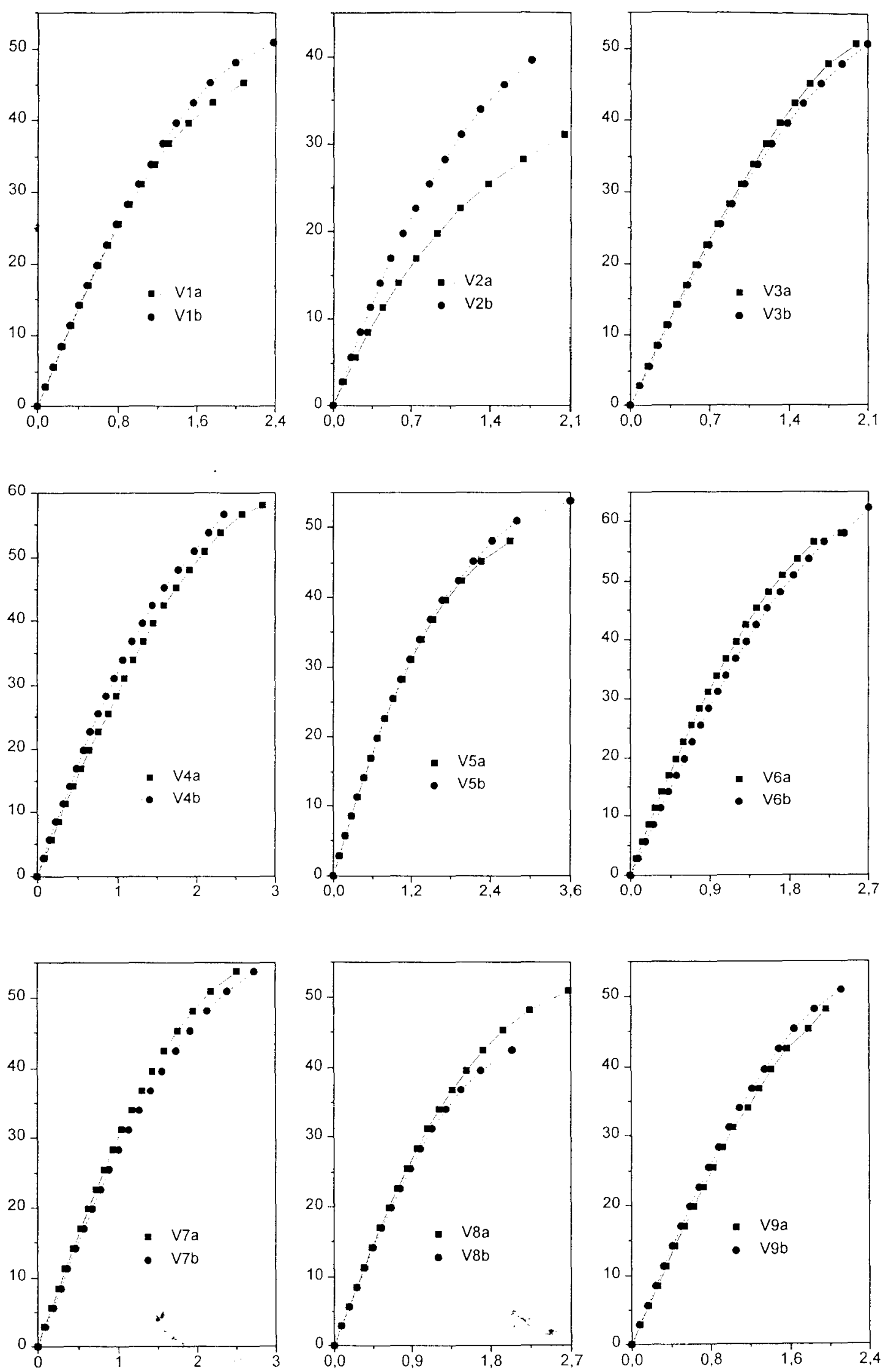

Figura 5.40 - Diagrama $\sigma-\varepsilon$ dos corpos-de-prova de concreto (valores individuais) deformação $(\mathrm{mm} / \mathrm{m}$ no eixo $\mathrm{x}) \times$ tensão (MPa no eixo y) 
O módulo de deformação longitudinal calculado de acordo com a expressão da NBR-6118 varia proporcionalmente com a resistência à compressão do concreto. Os valores obtidos neste trabalho variaram entre $30800 \mathrm{MPa}$ e $38030 \mathrm{MPa}$, para uma variação da resistência de $37.4 \mathrm{MPa}$ a $59,1 \mathrm{MPa}$. Ou seja, a relação entre os valores máximo e minimo foi de 1,24 e 1,58, para o módulo e a resistência, respectivamente.

A relação entre os valores teóricos máximo e mínimo do módulo calculados pela expressão da NBR-6118 é igual a 1.26 (36300 MPa e 45700 MPa), para a mesma variação da resistência experimental. Logo, a variação do módulo de deformação longitudinal com a resistencia à compressão do concreto foi bem representada pela expressão da norma. No entanto, o valor teórico foi muito maior que o experimental em todos os casos. A relação média entre eles foi de 0,83. Assim, o fator redutor de 0,8 , utilizado nas peças de argamassa armada, também pode ser indicado para o microconcreto. Além disso, esta relação foi igual para o concreto sem fibras, com fibra de polipropileno e com fibra de aço, o que permite extrapolar a conclusão para as matrizes com fibras e ratifica a predominância da influência da resistência do concreto na variação do módulo de deformação longitudinal.

Quando se acrescentam os resultados do capítulo anterior, na Tabela 5.6, as vantagens das fibras ficam realçadas. A introdução da fibra de aço aumenta o módulo de deformação longitudinal, independentemente da resistência do concreto. Para a fibra de polipropileno. apesar da diminuição nominal, o valor ponderado é maior, assim como a sua relação com o valor teórico.

Tabela 5.6 - Resultados de todos os ensaios do trabalho experimental

\begin{tabular}{|c|c|c|c|c|c|}
\hline concreto & $\mathrm{f}_{\mathrm{c}}(\mathrm{MPa})$ & $\mathrm{E}(\mathrm{MPa})$ & $\mathrm{E}_{\text {teo }}(\mathrm{MPa})$ & exp/teo & $\mathrm{E} / \mathrm{f}_{\mathrm{c}}{ }^{0.5}$ \\
\hline simples & 50,4 & 33985 & 42128 & 0,81 & 4787 \\
\hline poliprop. & 45,6 & 33268 & 40111 & 0,83 & 4944 \\
\hline aço & 54,7 & 37270 & 43967 & 0,85 & 5039 \\
\hline
\end{tabular}

\subsection{2 - FISSURAÇÃO - FLEXÃO}

Entre os seis primeiros modelos, o menor espaçamento das fissuras de flexão ocorreu nos modelos com fibras. Como se observa nas Fotos 5.19 e 5.20, a quantidade de fissuras nestas vigas é maior. Entre os modelos similares protendidos e não protendidos, não se observa diferença significativa no trecho central, onde as deformações nas cordoalhas são similares, conforme se discute posteriormente. 
A diferença entre a carga de fissuração e a carga de ruptura não aumentou com a protensão, ao contrário do que ocorreu com as fibras. Ela foi de $33 \mathrm{kN}, 41 \mathrm{kN}, 42,5 \mathrm{kN}$, $31 \mathrm{kN}, 38,5 \mathrm{kN}, 34 \mathrm{kN}, 22 \mathrm{kN}, 20 \mathrm{kN}$ e $35 \mathrm{kN}$, para os modelos V1 a V9, respectivamente. Estes dados são coerentes com a observação do parágrafo anterior e justificam outras conclusões apresentadas adiante.

Entre os modelos sem protensão e entre os modelos protendidos, a extensão da etapa fissurada foi maior em V3 e menor em V4, respectivamente. A profundidade das fissuras de flexão acompanhou estes resultados. Nos modelos sem estribos as fissuras foram mais espaçadas. O espaçamento mínimo foi registrado no modelo V9.

A Tabela 5.7 contém os valores da força correspondente ao início da fissuração por flexão (valores experimentais e tcóricos), com o respectivo valor da abertura da fissura no final do incremento de carga. Os valores experimentais foram determinados visualmente, pela diminuição da rigidez no gráfico das flechas e pela evolução das deformações no ponto central das cordoalhas. Na maioria dos casos esses valores coincidiram. Quando houve diferenças, a variação de tensão nas cordoalhas foi mais sensivel do que a diminuição da rigider.

Apresenta-se também o valor da força a que corresponde a deformação máxima de $0,15 \%$ na armadura longitudinal, medida em qualquer ponto instrumentado, e os valores da força e da deformação máxima na armadura no meio do vão no instante em que a abertura da fissura mais crítica atingiu $0,16 \mathrm{~mm}$.

Em relação ao instante do aparecimento da primeira fissura, os resultados não são conclusivos sobre a influência das fibras, nem mesmo sobre o valor da abertura da primeira fissura visível. No entanto, eles sĩo coerentes com os valores teóricos.

Tabela 5.7 - Parâmetros relativos à fissuração por flexão

\begin{tabular}{|c|c|c|c|c|c|c|c|c|}
\hline \multirow[t]{2}{*}{ viga } & \multirow{2}{*}{$\begin{array}{l}\mathrm{V}_{\mathrm{r}, \mathrm{teo}} \\
(\mathrm{kN})\end{array}$} & \multicolumn{3}{|c|}{$\overline{V_{r, e x p}(k N)}$} & \multirow{2}{*}{$\begin{array}{c}\mathrm{W} \\
(\mathrm{mm})\end{array}$} & \multirow{2}{*}{$\begin{array}{c}\mathrm{V}_{\varepsilon}=0.15 \% \\
(\mathrm{kN})\end{array}$} & \multicolumn{2}{|c|}{$\mathrm{w}=0,16 \mathrm{~mm}$} \\
\hline & & visual & dest. & $A_{s 1}$ & & & $V(k N)$ & $\varepsilon_{s 1}(\%)$ \\
\hline V1 & $\overline{5,8}$ & 9,0 & 6,0 & - & 0.14 & 17 & 14 & 0,11 \\
\hline V2 & 3,9 & $9,0 * *$ & 7,5 & 7.5 & 0.07 & $16,5 / 15^{*}$ & 17,5 & 0,17 \\
\hline V3 & 6,7 & $7,5 * *$ & 5.0 & 5.0 & 0.09 & 15 & 15 & 0,15 \\
\hline $\mathrm{V4}$ & 5,6 & $32,5^{* *}$ & 32.5 & 32.5 & 0.06 & 38 & 40 & 0,16 \\
\hline V5 & 5,9 & 35 & 35 & 30 & 0.07 & 41 & 42,5 & 0,17 \\
\hline V6 & 6,5 & 37,5 & 37.5 & 37,5 & 0,07 & $45 / 42^{*}$ & 45 & $0,15 / 0,18^{*}$ \\
\hline V7 & 4,1 & 35 & 35 & 35 & 0,07 & $41 / 40^{*}$ & 42,5 & $0,16 / 0,17^{*}$ \\
\hline V8 & 5,8 & 32,5 & 35 & 30 & 0.05 & $40 / 39^{*}$ & 37,5 & $0,11 / 0,13^{*}$ \\
\hline V9 & 6,3 & 35 & 37.5 & 37.5 & 0.07 & $46 / 42^{*}$ & 45 & $0,13 / 0,19^{*}$ \\
\hline
\end{tabular}


Nos modelos protendidos, o aumento da força de fissuração foi sempre maior que a força de descompressão do ponto mais solicitado na flexão. Isso pode sugerir que os valores da força de protensão estejam subestimados. No entanto, conforme se comentou anteriormente, o instante da fissuração é difícil de ser avaliado e nem sempre corresponde à observação visual ou à variação na inclinação dos gráficos analisados, como mostrou o extensômetro posicionado na face tracionada do concreto.

A carga correspondente à abertura de fissura máxima igual a $0,16 \mathrm{~mm}$ foi maior nos modelos com fibras, exceto em V8. Entretanto, os valores das deformações neste instante são muito diferentes e podem revelar a fragilidade destes resultados, principalmente porque, nos modelos em que o desempenho foi aparentemente pior, as deformações foram muito menores, independentemente do tipo do concreto (V1 e V8). Os melhores desempenhos foram obtidos pelos modelos com fibra de aço e, neste caso, as deformações são consistentemente menores, em média; ou seja, pode-se afirmar que o controle da abertura das fissuras foi mais eficiente.

Os resultados não são conclusivos sobre a deformabilidade da matriz, já que os modelos sem fibras e com fibra de polipropileno apresentaram resultados irregulares.

A comparação do valor da carga correspondente à deformação igual a $0,15 \%$ nas cordoalhas também não permitiu outras conclusôes acerca deste assunto, já que os resultados não foram uniformes em relação à possivel influência das fibras.

Portanto, ao contrário dos ensaios das vigas quadradas, estes parâmetros não se mostraram adequados para observação da eficiência das fibras no controle da abertura de fissuras, detectada apenas no caso da fibra de aço.

Para completar esta análise, apresenta-se na Tabela 5.8 os valores das forças correspondentes à abertura de fissuras igual a $0,10 \mathrm{~mm}$ e $0,15 \mathrm{~mm}$ e a respectiva deformação máxima nas cordoalhas, medida em qualquer ponto instrumentado.

Tabela 5.8 - Evolução das fissuras de flexão

\begin{tabular}{|c|c|c|c|c|}
\hline \multirow{2}{*}{ modelo } & \multicolumn{2}{|c|}{$\mathrm{w}=0,10 \mathrm{~mm}$} & \multicolumn{2}{c|}{$\mathrm{w}=0,15 \mathrm{~mm}$} \\
\cline { 2 - 5 } & $\mathrm{V}(\mathrm{kN})$ & $\varepsilon_{\text {s.max }} \%$ & $\mathrm{~V}(\mathrm{kN})$ & $\varepsilon_{\mathrm{s} \text { max }(\%)}$ \\
\hline V1 & 9 & 0,07 & 14 & 0,11 \\
\hline V2 & 12,5 & 0,12 & 17,5 & 0,19 \\
\hline V3 & 8,5 & 0,05 & 12,5 & 0,12 \\
\hline V4 & 34,5 & 0,10 & 39 & 0,15 \\
\hline V5 & 37 & 0,10 & 42,5 & 0,17 \\
\hline V6 & 39 & 0,09 & $* 44$ & 0,18 \\
\hline V7 & 37,5 & 0,05 & 42 & 0,17 \\
\hline V8 & 35 & 0,06 & 37,5 & 0,11 \\
\hline V9 & 39 & 0,10 & 45 & 0,19 \\
\hline
\end{tabular}


Os resultados confirmam as observações anteriores. Não há regularidade para se afirmar sobre a influência positiva das fibras no controle da fissuração. Ela só foi verificada na segunda série de vigas, mas as deformações são maiores que no modelo sem fibra. Novamente, os piores desempenhos (V1, V3 e V8) foram acompanhados de deformações muito reduzidas. Os estribos têm pouca influência nos resultados.

Outro aspecto interessante a destacar se refere à extensão das zonas fissuradas e não fissuradas. Nos modelos protendidos, a extensão do trecho não fissurado nas extremidades da peça foi maior, embora a fissuração no trecho central seja similar. Isto ocorre porque a descompressão nas extremidades da viga ocorre depois.

\subsection{3 - FISSURAÇÃO - CISALHAMENTO}

Embora o modelo tenha a alma relativamente delgada, as primeiras fissuras de cisalhamento surgiram sempre como prolongamento de fissuras de flexão. A Tabela 5.9 contém os valores da carga correspondente ao aparecimento das fissuras de cisalhamento (tipo 1 e tipo 2) e o valor da abertura destas fissuras. Na maioria dos casos, não se apresenta o valor da ahertura das fissuras de cisalhamento que surgiram diretamente na alma, pois o valor ultrapassava o limite da lupa graduada utilizada na leitura de fissuras ao final do incremento da carga.

Tabela 5.9 - Parâmetros relativos à fissuração por cisalhamento

\begin{tabular}{|c|c|c|c|c|}
\hline \multirow{2}{*}{ modelo } & \multicolumn{2}{|c|}{ tipo 1 } & \multicolumn{2}{c|}{ tipo 2 } \\
\cline { 2 - 5 } & $\mathrm{V}_{\mathrm{r} 1}(\mathrm{kN})$ & $\mathrm{w}(\mathrm{mm})$ & $\mathrm{V}_{\mathrm{r} 2}(\mathrm{kN})$ & $\mathrm{w}(\mathrm{mm})$ \\
\hline $\mathrm{V} 1$ & 14 & 0,07 & 26 & - \\
\hline V2 & 15 & 0,07 & 25 & - \\
\hline V3 & 12,5 & 0,13 & 20 & 0,06 \\
\hline V4 & 40 & 0,15 & 47 & - \\
\hline V5 & 40 & 0,10 & 50 & - \\
\hline V6 & 45 & 0,15 & 55 & - \\
\hline V7 & 40 & 0,08 & 42,5 & 0,12 \\
\hline V8 & 37,5 & 0,09 & 45 & - \\
\hline V9 & 40 & 0,09 & 50 & - \\
\hline
\end{tabular}

Neste caso também não se define a influêrĩcia das fibras em relação ao instante do aparecimento das fissuras de cisalhamento. Esta mesma observação foi registrada nos ensaios preliminares. 
No entanto, após o aparecimento das fissuras de cisalhamento, a resistência adicional foi maior em todos os modelos com libras, à exceção das vigas sem estribos. Além da atuação direta das fibras como armadura de cisalhamento, isto se deve também aos efeitos indiretos nos mecanismos alternativos e à maior eficiência dos estribos nesta situação.

* Nos seis primeiros modelos, as fissuras de cisalhamento nas extremidades da peça foram mais numerosas no caso dos modelos com fibras, conforme ilustram as Fotos 5.19 e 5.20 . Isto permitiu o aumento da capacidade resistente.

Nos modelos sem estribos, esta vantagem não existiu. Após a formação da fissura diagonal, a ruptura sobreveio quase instantaneamente. Portanto, nesta situação, as fibras não foram capazes de incorporar dutilidade à viga.

As Fotos 5.19 e 5.20 mostram também a menor inclinação das bielas nos modelos protendidos.

Nos modelos sem protensão. a tensão de cisalhamento convencional correspondente ao instante de aparecimento das fissuras diagonais, que surgiram entre $20 \mathrm{kN}$ a $26 \mathrm{kN}$, vale entre $2,0 \mathrm{MPa}$ e $2.7 \mathrm{MPa}$. Ela é menor, portanto, que a resistência à tração do concreto, como era esperado. Nos modelos protendidos, ao contrário, a resistência à fissuração diagonal (ou à ruptura. no caso das vigas sem estribos) foi maior que a resistência à tração do concreto.

\subsection{4 - DESLOCAMENTOS VERTICAIS}

Os valores da flecha e as forças correspondentes às flechas de $12,3 \mathrm{~mm}, 24,7$ $\mathrm{mm}$ e $37 \mathrm{~mm}(1 / 300,1 / 150$ e 1/100. respectivamente, referências para análise do desempenho em serviço) são apresentados na Tabela 5.10. A flecha no instante imediatamente anterior à ruptura nem sempre foi obtida, já que em alguns modelos os aparelhos foram retirados antes. Nestes casos, o valor foi estimado extrapolando-se linearmente a curva até a carga de ruptura.

Excetuando-se as vigas sem estribos. em todos os outros casos os deslocamentos foram menores nos modelos com fibras. Os melhores desempenhos foram obtidos com a fibra de aço.

Observa-se que deslocamentos excessivos que limitam a utilização da peça são alcançados „ para cargas relativamente baixas. especialmente nos modelos sem protensão. Ós valores da flecha projetados até o instante da ruptura mostram que eles são muito próximos para os modelos similares com e sem protensão, ratificando as observações do item 5.8 .2 sobre a fissuração nestas vigas. 
Tabela 5.10 - Paràmetros relativos às flechas

\begin{tabular}{|c|c|c|c|c|c|}
\hline modelo & $\Delta_{\max }(\mathrm{mm})$ & $l^{*} l / \Delta$ & $\begin{array}{c}V_{12 \mathrm{~mm}} \\
(\mathrm{kN})\end{array}$ & $\begin{array}{c}\mathrm{V}_{25 \mathrm{~mm}} \\
(\mathrm{kN})\end{array}$ & $\begin{array}{c}V_{37 \mathrm{~mm}} \\
(\mathrm{kN})\end{array}$ \\
\hline $\mathrm{V} 1$ & 39 & $l / 95$ & 16,5 & 28 & 39,5 \\
\hline $\mathrm{V} 2$ & 48 & $l / 77$ & 17,5 & 30 & 41 \\
\hline $\mathrm{V} 3$ & 46 & $l / 80$ & 17,5 & 30 & 41 \\
\hline $\mathrm{V} 4$ & $25 / 38^{*}$ & $l / 97^{*}$ & 41 & 50 & 61 \\
\hline $\mathrm{V} 5$ & $34 / 49^{*}$ & $l / 76^{*}$ & 42 & 52,5 & 63 \\
\hline $\mathrm{V} 6$ & $37 / 44^{*}$ & $l / 84^{*}$ & 43,5 & 54,5 & 66 \\
\hline $\mathrm{V} 7$ & 18 & $l / 205$ & 42 & - & - \\
\hline $\mathrm{V} 8$ & 17 & $l / 217$ & 41,5 & - & - \\
\hline $\mathrm{V} 9$ & $40 / 48^{*}$ & $l / 77^{*}$ & 44 & 55,5 & 66 \\
\hline \multicolumn{7}{|r}{ O segundo valor foi estimado no instante da ruptura } \\
\hline
\end{tabular}

Para facilitar a análise comparativa. acrescenta-se aos diagramas carga-flecha mostrados na Figura 5.41, o diagrama ponderado pela raiz quadrada da resistência à compressão do concreto, que divide o valor das flechas, na Figura 5.42, para tentar eliminar a influência do módulo do concreto na rig̣idez da peça, ressaltando-se apenas as diferenças decorrentes da fissuração. Posteriomente, na Figura 5.43, os resultados são agrupados segundo a divisão comentada anteriormente.

Os gráficos não indicam a ocorrência do escoamento da armadura longitudinal, mesmo quando a deformação das cordoalhas atingiu o trecho curvo do diagrama $\sigma-\varepsilon$ do aço, devido à retirada prematura dos defletometros. Todas as curvas apresentam três etapas distintas, mas o estágio linear foi mais extenso nos modelos protendidos.

Com exceção das vigas sem estribos. a rigidez foi maior em todos os modelos com fibras após o início da fissuração. Liste é resultado é conclusivo sobre a influência das fibras no controle da abertura das fissuras. já que ele ocorreu independentemente do valor do módulo de deformação longitudinal. Os melhores desempenhos foram obtidos com a fibra de aço, mas o valor do módulo de deformação pode contribuir para acentuar as diferenças. A mesma tendência se mantém nos gráficos dos deslocamentos transversais ponderados. Neste caso, as curvas destacam a vantagem do concreto com fibra de polipropileno. Não fossem os prohlemas observados durante a produção, seu desempenho poderia ser melhor.

O acréscimo na extensão da ctapa não fissurada dos modelos protendidos, equivalente a $25 \mathrm{kN}$, em média, foi superior à clapa até a descompressão da região mais solicitada, talvez porque a diminuição da rig̣idez reflete o comportamento da viga como um todo e a descompressão se refere apenas ao trecho central. 
Os gráficos da Figura 5.43 confirmam as observações anteriores. Os três primeiros revelam a influência positiva das fibras, exceto nas vigas sem estribos. Nos três gráficos seguintes, destaca-se a importância da protensão e a indiferença dos estribos. Após a fissuração as curvas são paralelas, ressaltando a importância da rigidez da armadura longitudinal nesta etapa. Nos três últimos gráficos observa-se que a rigidez dos modelos com fibra de aço foi maior que naqueles com fibra de polipropileno somente nas vigas protendidas e que. independentemente da quantidade de estribos, a rigidez dos modelos com fibras foi maior que a dos modelos sem fibras.

A relação entre os deslocamentos no trecho onde atua a força cortante com a intensidade das forças de pino também foi investigada. Conforme SWAMY \& BAHIA (1978), ela poderia ser analisada através dos valores dos deslocamentos sob os pontos de introdução do carregamento. Optou-se por comparar a relação entre os deslocamentos nestes pontos com a flecha no meio do vão, ao invés dos valores nominais, já que eles acompanham o desempenho geral da viga.

O valor teórico da relação entre o deslocamento transversal na seção de introdução das cargas e a flecha no meio do vão vale 0,80. A Tabela 5.11 apresenta a evolução desta relação com o carregamento. Os valores foram obtidos considerando-se a média entre os deslocamentos nos dois pontos sob as forças aplicadas nas vigas. Os valores experimentais foram sempre muito próximos entre si, inclusive para as vigas sem estribos, onde a proteção da armadura longitudinal é precária. Além disso, a variação com o carregamento foi muito discreta, quando se imagina que a variação das forças de pino seja maior. Assim, o procedimento para se mensurar as forças de pino não se mostrou adequado. No entanto. os deslocamentos sob as cargas foram maiores do que prevê o cálculo teórico, devido ao apoio das bielas. Também não se definiu uma relação entre os deslocamentos nos dois lados da viga com o lado da ruptura.

Tabela 5.11 - Relação entre os deslocamentos sob as cargas e a flecha

\begin{tabular}{|c|c|c|c|c|c|c|}
\hline \multirow{2}{*}{ modelo } & \multicolumn{5}{|c|}{ deslocamento sob carga / flecha no meio do vão } \\
\cline { 2 - 7 } & $10 \mathrm{kN}$ & $20 \mathrm{kN}$ & $30 \mathrm{kN}$ & $40 \mathrm{kN}$ & $50 \mathrm{kN}$ & $60 \mathrm{kN}$ \\
\hline $\mathrm{V} 2$ & 0,87 & 0,85 & 0.87 & 0,88 & - & - \\
\hline $\mathrm{V} 3$ & 0,85 & 0,86 & 0.85 & 0,85 & - & - \\
\hline $\mathrm{V} 4$ & 0,88 & 0,87 & 0.88 & 0,85 & - & - \\
\hline V5 & 0,79 & 0,87 & 0.84 & 0,86 & 0,86 & 0,87 \\
\hline V6 & 0,96 & 0,90 & 0.89 & 0,87 & 0,82 & 0,87 \\
\hline V7 & 0,91 & 0,86 & 0,86 & 0,84 & - & - \\
\hline V8 & 0,81 & 0,86 & 0,85 & 0,85 & - & - \\
\hline V9 & 0,83 & 0,84 & 0.85 & 0,85 & 0,86 & - \\
\hline
\end{tabular}




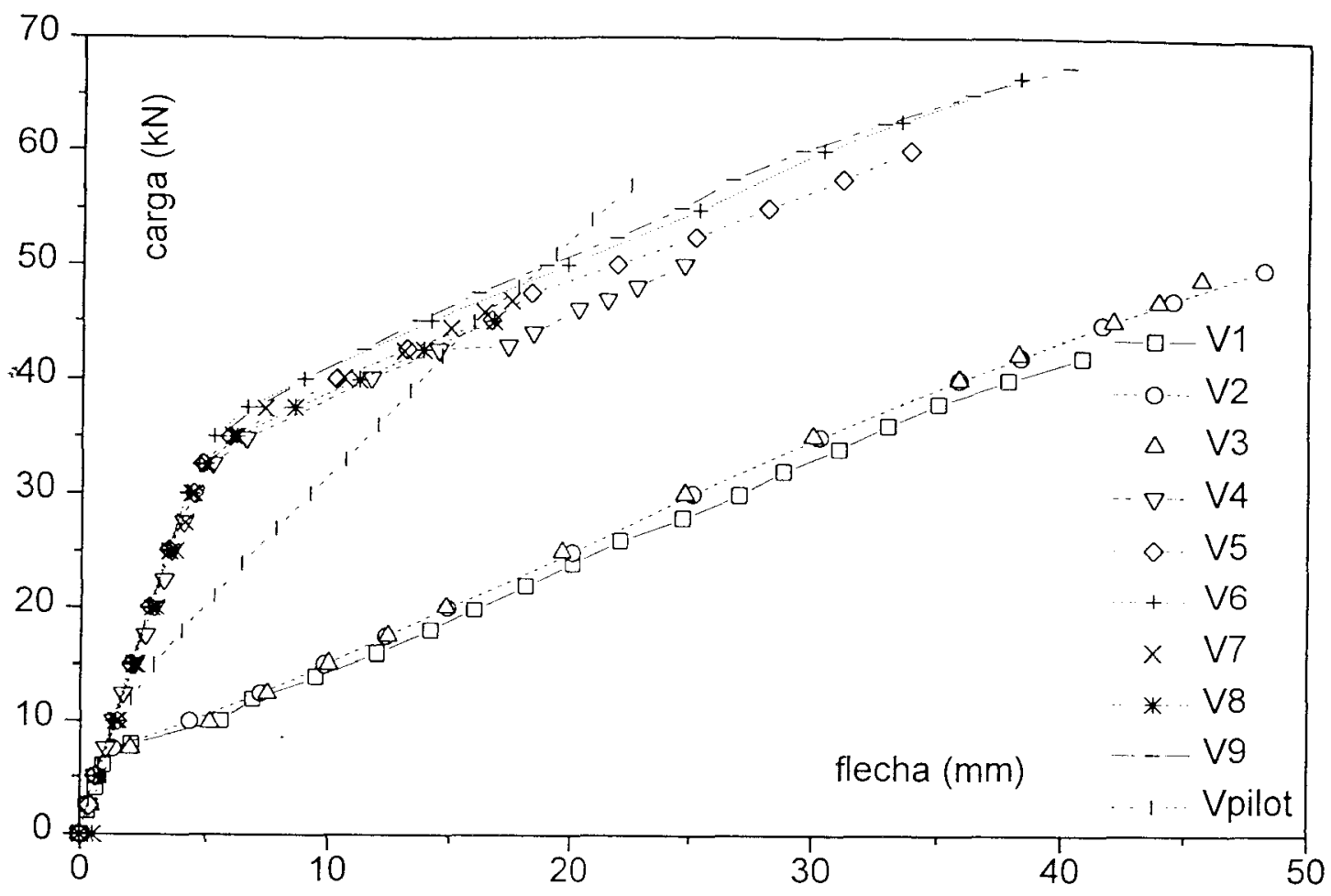

Figura 5.41 - Diagrama Carga-Flecha dos modelos (inclui modelo piloto)

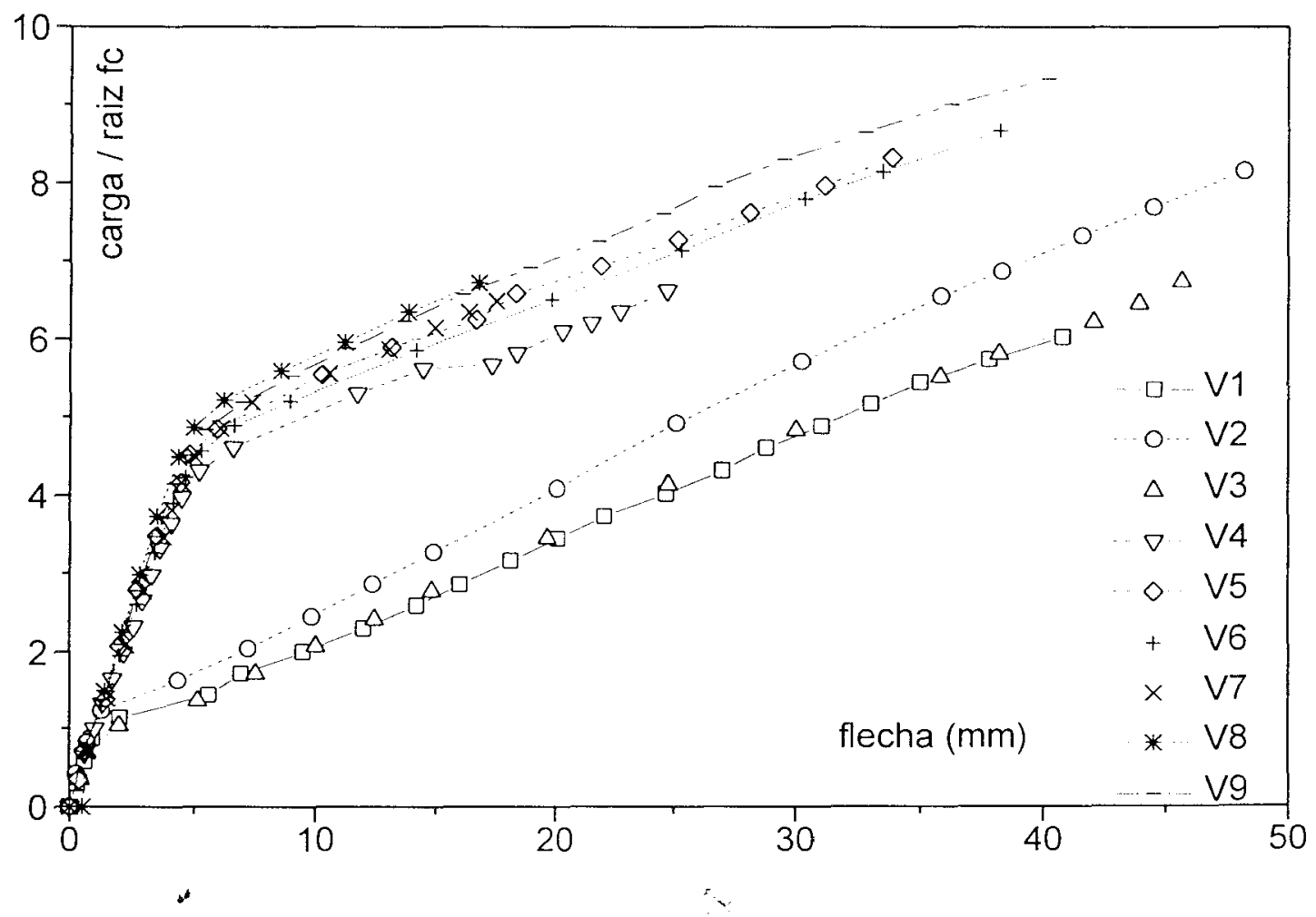

Figura 5.42 - Diagrama Carga-Flecha (ponderado) dos modelos 

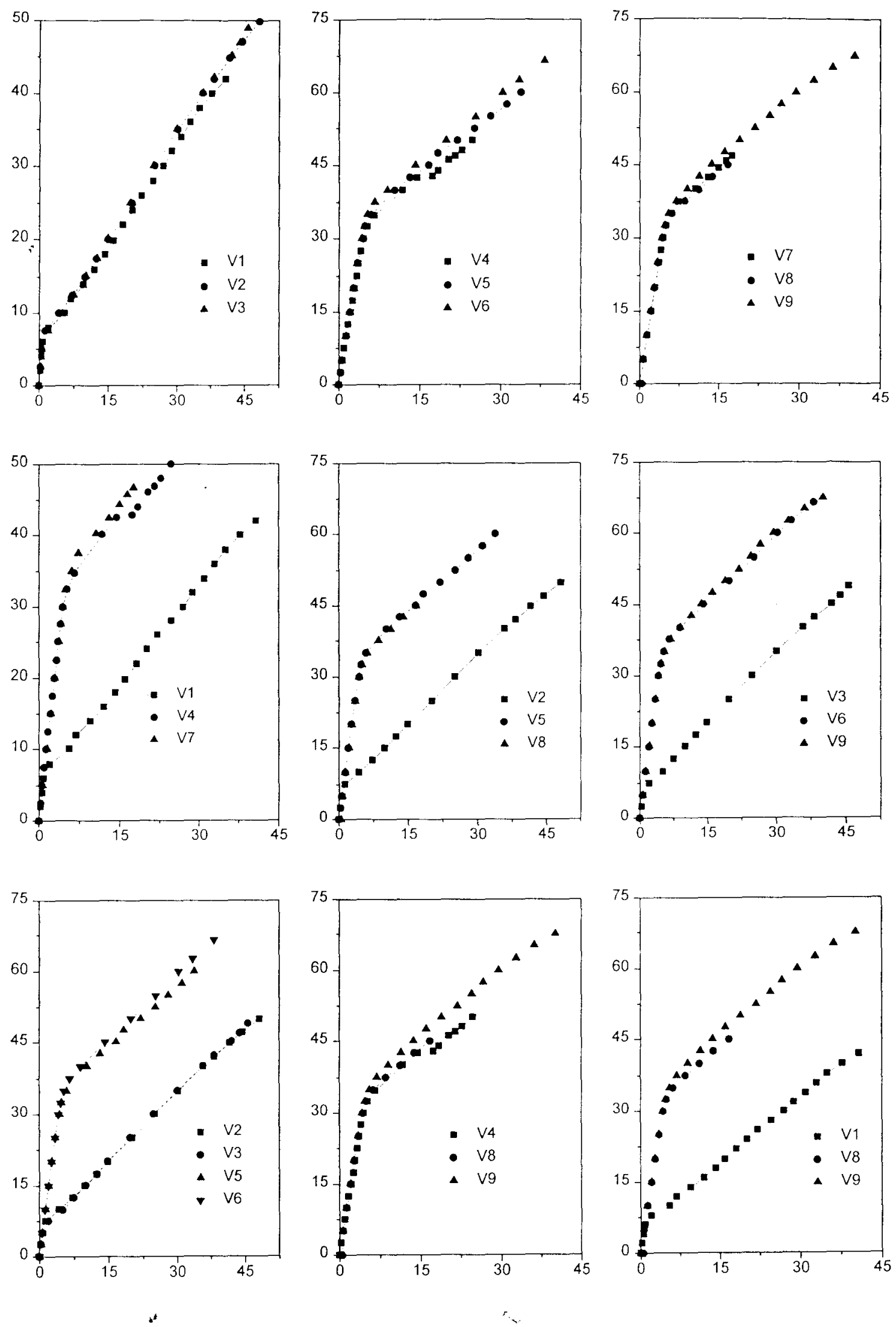

Figura 5.43 - Gráficos comparativos: Carga (eixo $y$ - kN) x Flecha (eixo $x-\mathrm{mm}$ ) 


\subsection{5 - CAPACIDADE RESISTENTE}

A Tabela 5.12 contém os principais parâmetros relativos à ruptura: força cortante máxima, inclinação mínima das bielas nos dois lados da viga, tensão convencional máxima de cisalhamento e lado em que se deu a ruptura.

Tabela 5.12 - Parâmetros relativos à ruptura

\begin{tabular}{|c|c|c|c|c|c|}
\hline \multirow{2}{*}{ modelo } & \multirow{2}{*}{$\begin{array}{l}V_{\text {max }} \\
(\mathrm{kN})\end{array}$} & \multicolumn{2}{|c|}{$\theta_{\min }$ (graus) } & \multirow{2}{*}{$\begin{array}{c}\tau_{\mathrm{wlu}} \\
(\mathrm{MPa})\end{array}$} & \multirow{2}{*}{$\begin{array}{l}\text { ruptura } \\
\text { (lado) }\end{array}$} \\
\hline & & esquerdo & direito & & \\
\hline$\overline{\text { V1 }}$ & 42 & 29 & 24 & 3,75 & direito \\
\hline V2 & 50 & 27 & 29 & 4,46 & esquerdo \\
\hline V3 & 50 & 35 & 26 & 4,46 & direito \\
\hline V4 & 63,5 & 20 & 26 & 5,67 & direito \\
\hline V5 & 73,5 & 22 & 20 & 6.56 & esquerdo \\
\hline V6 & 71,5 & 21 & 26 & 6,38 & direito \\
\hline V7 & 47 & 17 & 29 & 4,20 & esquerdo \\
\hline V8 & 45 & - & $20-25$ & 4,02 & direito \\
\hline V9 & 72,5 & 20 & 23 & 6,47 & direito \\
\hline
\end{tabular}

A adição das fibras melhorou a capacidade resistente das viggas. exceto naquelas sem estribos. A protensão proporcionou o mesmo resultado, mas com maior intensidade e independentemente da armadura transversal.

A inclinação das bielas nas proximidades da ruptura foi um pouco menor nos modelos com fibras, devido à contribuição direta ou indireta das fibras na transferência das forças transversais, que alivia os estribos ou possibilita a mobilização de um número maior de estribos.

O abatimento das bielas foi muito mais significativo nos modelos protendidos. $O$ valor de $\theta_{\text {min }}$ e a extensão da região danificada confirmam este fato, que também pode ser observado nas Fotos 5.19 a 5.21. A diminuição da armadura transversal provocou o mesmo efeito, de forma mais sutil. Não houve correspondência entre o lado da ruptura com a fissura mais abatida.

A comparação entre os resultados experimentais e teóricos aparece na Tabela 5.13. Os valores teóricos da força cortante de ruptura dos modelos protendidos foram calculados segundo os dois métodos discutidos anteriormente. O primeiro valor se refere ao método baseado na majoração do coeficiente $\psi_{1}$ e o segundo considera o acréscimo de resistência equivalente à força cortante de descompressão. Na penúltima 
coluna da tabela, a força cortante última é dividida pela raiz quadrada da resistência à compressão do concreto, já que ela altera a capacidade resistente da peça, para minimizar a influência da qualidade do concreto e destacar a influência das fibras e da protensão nos resultados. Na última coluna, a relação entre os valores experimentais e teóricos dos modelos protendidos também aparece com dois valores, referentes aos dois -métodos citados acima.

Tabela 5.13 - Capacidade resistente - resultados teóricos e experimentais

\begin{tabular}{|c|c|c|c|c|c|c|c|}
\hline modelo & $\begin{array}{c}f_{\mathrm{c}} \\
(\mathrm{MPa})\end{array}$ & $\begin{array}{c}\mathrm{f}_{\mathrm{t}} \\
(\mathrm{MPa})\end{array}$ & $\begin{array}{c}\mathrm{V}_{\text {u.c }} \\
(\mathrm{kN})\end{array}$ & $\begin{array}{c}\mathrm{V}_{\text {u.f }} \\
(\mathrm{kN})\end{array}$ & $\begin{array}{c}\mathrm{V}_{\text {u.exp }} \\
(\mathrm{kN})\end{array}$ & $\begin{array}{c}\mathrm{V}_{\text {u.rel }} \\
(\mathrm{kN})\end{array}$ & exp/teo \\
\hline $\mathrm{V} 1$ & 48,5 & 3,0 & 28,9 & 69,6 & 42 & 6,03 & 1,45 \\
\hline $\mathrm{V} 2$ & 37,4 & 2,1 & 27,7 & 68,6 & 50 & 8,18 & 1,81 \\
\hline $\mathrm{V} 3$ & 52,8 & 3,6 & 29,4 & 69,8 & 50 & 6,88 & 1,7 \\
\hline $\mathrm{V} 4$ & 57,2 & 3,0 & $36,4 / 49,5$ & 70,1 & 63,5 & 8,40 & $1,74 / 1,28$ \\
\hline $\mathrm{V} 5$ & 52,1 & 3,2 & $35,6 / 48,6$ & 69,8 & 73,5 & 10,18 & $2,06 / 1,51$ \\
\hline $\mathrm{V} 6$ & 59,1 & 3,5 & $36,7 / 49,9$ & 70,2 & 71,5 & 9,3 & $1,95 / 1,43$ \\
\hline $\mathrm{V} 7$ & 52,1 & 2,2 & $21 / 42,2$ & 69,8 & 47 & 6,5 & $2,24 / 1,11$ \\
\hline $\mathrm{V} 8$ & 44,9 & 3,1 & $19,6 / 40,4$ & 69,3 & 45 & 6,72 & $2,30 / 1,11$ \\
\hline V9 & 52,3 & 3,4 & $30,4 / 51,1$ & 69,8 & 72,5 & 10,03 & $2,39 / 1,42$ \\
\hline
\end{tabular}

Ao contrário do que foi observado nos ensaios preliminares das vigas de seção quadrada com estribos, o valor da força cortante máxima foi muito maior que o valor teórico nos modelos sem protensão, pois a contribuição do concreto na resistência ao cisalhamento foi subestimada pelo processo de cálculo adotado, mesmo com a alma delgada. As diferenças se acentuam nos modelos com fibras, cuja influência não foi considerada nos cálculos.

Os resultados teóricos e experimentais são aparentemente mais próximos para as vigas sem estribos, no caso em que se considera o acréscimo de resistência devido à protensão equivalente à força de descompressão. No entanto, desprezando-se o efeito da protensão, que parece ser adequadamente previsto pelo método acima e, portanto, diminui a diferença relativa entre os valores experimentais e teóricos, a proporção entre eles fica igual a 2,38 e 2,35, para os modelos V7 e V8, supondo-se a etapa da descompressão até $22 \mathrm{kN}$ (que equivale ao aumento médio na capacidade resistente dos modelos anteriores). Assim, estes valores são praticamente iguais aos obtidos nos ensaios das vigas retangulares sem estribos, ou seja, a contribuição do concreto, única parcela resistente, é subestimada. 
Nas peças com estribos. pode-se supor que a pequena diferença entre os valores teóricos e experimentais observada nas vigas quadradas se deve não apenas à resistência dos estribos - que além de ser significativa, é a parcela mais previsível, aproximando os valores teóricos e experimentais - mas à proximidade do escoamento da armadura longitudinal naquelas peças. onde a ruptura por flexão também era iminente (lembra-se que ela ocorreu em vários modelos). Assim, a contribuição dos mecanismos alternativos era menor, já que cla diminui com a evolução da fissuração.

Nos modelos principais. como o escoamento das cordoalhas era mais distante, especialmente naqueles sem protensão, a contribuição destes mecanismos resistentes era maior, embora fosse sempre inferior a dos modelos sem estribos. Como a atuação dos mecanismos alternativos é considerada de forma muito conservativa na formulação, a diferença entre os valores teóricos e experimentais foi maior.

Os gráficos que apresentam a evolução de $\tau_{\mathrm{c}}$ com o carregamento (diferença da tensão real nos estribos com a analogia clássica) mostram que esta parcela realmente decresce com o aumento da carga, embasando consistentemente a análise acima. Resultado similar foi obtido por FERRARI (1995), especialmente para peças com taxas de armadura transversal crescentes.

Para os modelos protendidos, o acréscimo de resistência calculado a partir do aumento no valor de $\psi_{1}$, de acordo com a relação entre o momento fletor de descompressão c o momento solicitante máximo, subestimou a influência da protensão, pois a deformação nas cordoalhas era haixa. Os melhores resultados foram obtidos considerando-se o acréscimo correspondente à força cortante de descompressão da seção mais solicitada, mas ainda assim persiste uma diferença significativa.

No entanto, tomando-se como referencia os resultados dos modelos similares sem protensão, verifica-se que o acréscimo de resistência é apenas um pouco superior à força de descompressão $(21 \mathrm{kN}, 23,5 \mathrm{kN}$ e $21,5 \mathrm{kN}$ para as vigas V1-V4, V2-V5 e V3V6, respectivamente). Ou seja. a diferença se deve ao erro na estimativa da resistência da viga sem protensão, discutida anteriomente, e não à influência da própria protensão. O fato deste acréscimo ser um pouco maior que a força de descompressão pode decorrer da escolha da seção em que se calcula a descompressão. Caso o processo fosse mais rigoroso, na seção crítica o valor térico seria maior e, portanto, a aproximação seria melhor. Além disso, a protensão altera a direção das resultantes de compressão, que se tornam mais abatidas.

Os valores teóricos e experimentais foram mais próximos nos modelos protendidos do que nos modelos sem protensão. Isto ocorre porque a influencia da protensão, quando adequadamente considerada. minimiza o erro relativo decorrente da estimativa do modelo similar sem protensĩo. já que o valor total é muito maior. 
$\mathrm{O}$ acréscimo de resistência proporcionado pela adição das fibras nas vigas com estribos não protendidas foi de $19 \%(8 \mathrm{kN})$ para V2 e V3. Quando se considera a variação da relação entre as carg̣as máximas experimentais e teóricas, que embute timidamente a influência da qualidade do concreto, o aumento é de $24 \%$ para V2 e $17 \%$ "para V3. A variação nos valores experimentais ponderados (na penúltima coluna da tabela), que provavelmente superestimam a influência do concreto, foi de $35,7 \%$ para V2 e 14,1\% para V3. Portanto. pode-se concluir que nos modelos sem protensão o melhor desempenho foi obtido com a fibra de polipropileno.

Nos modelos protendidos, procedendo-se a mesma análise acima (comparação nominal e ponderada), destaca-se novamente o excelente desempenho da fibra de polipropileno. Os aumentos da resistência dos modelos V5, V6 e V9 em relação ao modelo V4 foram iguais a:

a - variação nominal - 16\%.13\% e 14\%(10 kN. $8 \mathrm{kN}$ e $9 \mathrm{kN})$;

b - variação da relação entre valores experimentais e teóricos - 18\%, 12\% e 11\%;

c - variação dos valores experimentais ponderados - 35,7\%, 14,1\% e 19,4\%.

Nas vigas sem estribos houve diminuição nominal da resistência igual a 4\%, ou $2 \mathrm{kN}$. No entanto. os valores são similares quuando se considera a relação com o cálculo teórico, havendo um aumento de $3,4 \%$ para os valores ponderados.

Exceto para os modelos sem estribos. em todos os outros o acréscimo nominal da resistência foi praticamente constante. variando de $8 \mathrm{kN}$ a $10 \mathrm{kN}$. Isto sugere que a contribuição das fibras possa ser avaliada como se fosse uma armadura transversal equivalente adicional.

Portanto. conclui-se que o melhor desempenho foi obtido pelo concreto com fibras, especialmente para a fibra de polipropileno. Sobressai também o excelente desempenho da viga V9, com fibra de aço. que apesar da menor taxa de armadura transversal. apresentou resistência muito maior que o modelo de referência. Este caso, em particular. confirma a possibilidade de substituição parcial dos estribos pelas fibras, com vantagens.

Nas vigas sem estribos a eficiencia das fibras foi aparentemente nula, ao menos para o caso estudado. Este resultado confirma algumas conclusões da bibliografia, mas contradiz qs ensaios preliminares. Não se deve esquecer, entretanto, que neste caso a influência da resistência do concreto é significativáa, ao contrário do que prevê o cálculo teórico, que subestima esta parcela. Os resultados que consideram a diferença da qualidade do concreto (casos b e c) são vantajosos para o modelo com fibras. 
Em relação à resistência à flexão. os ensaios não permitem praticamente nenhuma conclusão, pois não houve escoamento da armadura longitudinal.

A introdução das fibras não alterou significativamente a forma de ruína para nenhum modelo. No entanto, isto só não ocorreu porque as vigas foram dimensionadas de modo que a ruptura por cisalhamento cocoresse muito antes do escoamento das cordoalhas. Caso contrário, os modelos V5. V6 e V9 poderiam ter atingido o estado limite último devido ao escoanento da armalura longitudinal.

Finalizando, pode-se assegurar, confirmando resultados da bibliografia e dos ensaios preliminares, que a introdução das tỉbras aumenta a resistência ao cisalhamento e, em alguns casos, pode alterar o modo de ruptura. Outra conclusão que coincide com as referências bibliográficas, mas difere dos resultados dos ensaios preliminares, é a menor influência das fibras nas peças sem estribos, o que contraria as propostas de substituição total dos estribos pelas fibras. pelo menos para os volumes de fibras reduzidos estudados neste trabalho.

Com relação à tensão tangencial convencional, o valor máximo observado foi maior que 6.5 MPa. sem a ocorrência de quaisquer danos para o concreto da alma.

\subsection{6 - ESTRIBOS}

Os valores da defomação máxima de todos os estribos instrumentados e o instante em que eles foram cetivamente acionados. quando a tensão superou $40 \mathrm{MPa}$, estão nas Tabelas 5.14 a c 5.1 4b.

A protensão retarda o surgimento das fissuras de cisalhamento e, consequentemente, a mobilização dos estribos. Além disso, os estribos próximos dos apoios nos modelos protendidos praticamente não foram solicitados, pois a fissuração geralmente não atingiu esta região naquelas peças, onde a extensão da zona não fissurada foi maior.

Normalmente, um estribo é solicitado quando atravessa uma fissura inclinada. Para os estribos próximos dos pontos de introduçĩo das cargas (E1, E2, E9 e E10), a mobilização se relacionou diretamente com a lomação das fissuras inclinadas naquelas regiões. Nos demais estribos. em cuja região não se tem claramente um panorama da evolução das físsuras, mas certamente o fato também está relacionado com elas, observa-se que eles foram acionados depois nos modelos com fibra de aço e que as tensões foram sempre menores nestas vigas. Portanto, as fibras de aço aliviam a tensão nos estribos. seja retardando a fissuração por cisalhamento, o que é pouco provável. conforme se discute no item 5.8.9, ou auxiliando os estribos após a fissuração. 
Tabela 5.14a - Deformação máxima nos estribos e mobilização - lado ímpar

\begin{tabular}{|c|c|c|c|c|c|c|c|c|c|c|}
\hline \multirow{2}{*}{ modelo } & \multicolumn{3}{|c|}{ deformação máxima (\%) } & \multicolumn{4}{c|}{ carga de mobilização $(\mathrm{kN})$} \\
\cline { 2 - 12 } & E1 & E3 & E5 & E7 & E9 & E1 & E3 & E5 & E7 & E9 \\
\hline V1 & 0.03 & 0,55 & 0,33 & 0,42 & $1,1^{*}$ & - & 28 & 24 & 18 & 14 \\
\hline V2 & 0.02 & 0,44 & $0,61^{*}$ & $1,13^{*}$ & 0,45 & - & 25 & 25 & 17,5 & 17,5 \\
\hline V3 & 0.01 & 0,09 & $0,75^{*}$ & 0,52 & 0,4 & - & 42 & 25 & 35 & 12,5 \\
\hline V4 & - & 0,14 & 0,55 & 0,55 & $1,22^{*}$ & - & 55 & 53 & 47 & 43 \\
\hline V5 & 0,01 & 0,25 & 0,56 & $1,23^{*}$ & 0,5 & - & 52,5 & 55 & 50 & 47,5 \\
\hline V6 & 0.01 & 0.18 & 0,42 & $0,62^{*}$ & 0,28 & - & 60 & 60 & 55 & 45 \\
\hline V9 & - & 0.14 & $1,11^{*}$ & $0,74^{*}$ & - & - & 67 & 57 & 50 & - \\
\hline \multicolumn{18}{|c|}{ * estribos cuja deformação atingiu o patamar de escoamento } & \\
\hline
\end{tabular}

Tabela 5.14b - Deformação máxima nos estribos e mobilização - lado par

\begin{tabular}{|c|c|c|c|c|c|c|c|c|c|c|}
\hline \multirow{2}{*}{ modelo } & \multicolumn{5}{|c|}{ deformação máxima (\%) } & \multicolumn{5}{|c|}{ carga de mobilização $(\mathrm{kN})$} \\
\hline & $\mathrm{E} 2$ & $\mathrm{E} 4$ & E6 & E8 & $\mathrm{E} 10$ & E2 & $\mathrm{E} 4$ & $\mathrm{E} 6$ & E8 & E10 \\
\hline V1 & 0.05 & $0,65^{*}$ & $1,05^{*}$ & $\overline{0,47}$ & $0,66^{*}$ & 42 & 30 & 20 & 16 & $\overline{14}$ \\
\hline V2 & 0.04 & 0,47 & $0,89^{*}$ & $1,13^{*}$ & $0,71^{*}$ & 30 & 25 & 25 & 17,5 & 17,5 \\
\hline V3 & 0,04 & 0,27 & $0,63^{*}$ & 0,51 & 0,56 & 49 & 35 & 25 & 20 & 12,5 \\
\hline V4 & 0.01 & 0,27 & 0,36 & 0,51 & $0,89^{*}$ & - & 56 & 55 & 55 & 43 \\
\hline V5 & 0.01 & 0,30 & $0,72^{*}$ & $1,32^{*}$ & $1,08^{*}$ & - & 52,5 & 52,5 & 52.5 & 47,5 \\
\hline V6 & 0.01 & 0,01 & 0,11 & $1,14^{*}$ & $1,12^{*}$ & - & - & 65 & 55 & 45 \\
\hline V9 & - & 0,17 & $1.21^{*}$ & $1,3 *$ & - & - & 70 & 57,5 & 50 & - \\
\hline
\end{tabular}

Não houve correspondência direta entre os valores das tensões nos estribos dos dois lados da viga com o lado da ruptura.

Pară facilitar a análise comparativa sobre ọ comportamento dos estribos durante os ensaios, os gráficos das Figuras 5.44 a 5.48 mostram a deformação dos estribos mais solicitados nas cinco posições instrumentadas nos trechos de cisalhamento, somente para o estribo mais solicitado entre os dois correspondentes dos dois lados da viga. 
Posteriormente, nas Figuras 5.49 a 5.53, o valor da deformação nos estribos é dividido pela raiz quadrada da resistência do concreto. Finalmente, os resultados são agrupados entre si, seguindo a combinação apresentada anteriormente, nas Figuras 5.54 a 5.58.

Sabe-se que a inclinação das bielas é próxima de 45 graus apenas nos casos de vigas com taxas reduzidas de armadura transversal e/ou de alma delgada. Mesmo satisfazendo estas condições, nas vigas deste trabalho a tensão nos estribos foi sempre menor que a tensão calculada pela treliça clássica. Ainda que a inclinação das bielas fosse mais próxima de 45 graus no instante da ruptura. outras simplificações da teoria clássica superestimam a tensão nos estribos. Conforme se observa nos gráficos das Figuras 5.44 a 5.53, as diferenças se devem especialmente à contribuição do concreto, menosprezada na teoria original. Observa-se também que, em alguns casos, as tensões em determinados estribos aumentou mais que o previsto pela analogia clássica, principalmente após o seu escoamento, quando a expressão que origina a reta de Mörsch não é mais válida e a comparação perde o rigor. Isso ocorreu, por exemplo, nos estribos E5-E6 e E9-E10 de alguns modelos.

Praticamente em todas as posições instrumentadas as tensões nos estribos dos modelos com fibra de aço foram menores que nos demais modelos correspondentes, assim como foi posterior o seu acionamento. Para a fibra de polipropileno, o fato que mais se destaca é o desenvolvimento mais lento das tensões nos estribos, que geralmente se mantiveram mais baixas que nos modelos sem fibras, exceto em E7-E8, mesmo quando o seu acionamento ocorreu antes, como em E3-E4.

A tensão nos estribos próximos dos apoios (E1-E2) foi baixa em quase todos os casos. Nos modelos V1 e V3, ela aumentou bruscamente no lado da ruptura no último incremento de carga, atingindo $100 \mathrm{MPa}$, apesar de as fissuras inclinadas não terem atingido aquela região. como mostra a Foto 5.22. Quando estes estribos foram acionados. o desenvolvimento das tensões foi igual àquele previsto pela treliça clássica. Nos modelos protendidos a tensão ficou sempre limitada a $20 \mathrm{MPa}$, sem acréscimos significativos de tensão.

Devido às tensões reduzidas, não se observa claramente a influência das fíbras, exceto pelo acionamento posterior destes estribos nos modelos protendidos com fibras.

Os éstribos da posição E3-E4 só escoárạ̣ na viga V1, mas a fissura diagonal também alcançou estes pontos nas vigas V4 e V5. Como eles estão a $80 \mathrm{~cm}$ (2,9d) do ponto de aplicação da carga, conclui-se que as bielas têm dificuldade de se desenvolver com inclinação próxima de 19 graus, já que as tensões foram relativamente baixas. 
Nos modelos protendidos, a parcela de contribuição do concreto foi maior que nos modelos sem protensão. A variação, estimada pela diferença entre o instante de acionamento dos estribos, foi aproximadamente igual a $30 \mathrm{kN}$ para V1-V4, V2-V5 e V3-V6. O valor é maior que a força de descompressão porque a região não é a mais solicitada na flexão. Portanto, as tensões nestes estribos foram sempre menores nos imodelos protendidos.

Os gráficos comparativos ilustram as menores tensões registradas nos modelos com fibra de aço, o desenvolvimento mais suave das tensões nos modelos com fibra de polipropileno, o aumento no valor de $\tau_{\mathrm{c}}$ devido à protensão e o desenvolvimento quase paralelo das curvas dos modelos similares protendidos e não protendidos, após o acionamento dos estribos.

Os estribos da posição E5-E6 escoaram em quatro modelos e foram sempre muito solicitados, pois se situam numa seção para onde convergem várias bielas, especialmente aquelas que partem do ponto de aplicação da carga. Eles estão localizados a $60 \mathrm{~cm}$ das cargas, $2,15 \mathrm{~d}$, o que equivale a admitir bielas principais com inclinação de aproximadamente 25 graus.

As tensões nestes estribos foram sempre maiores nos modelos sem fibras. Nos modelos com fibras, o comportamento foi muito próximo entre si. $\mathrm{O}$ aumento no valor de $\tau_{\mathrm{c}}$ devido à protensão foi equivalente a uma diferença de aproximadamente $25 \mathrm{kN}$ na força cortante, coerente com os resultados dos estribos anteriores, dada a diferença na posição dos estribos.

Os gráficos comparativos destacam as maiores tensões nos estribos dos modelos sem fibras e um discreto aumento no valor de $\tau_{\mathrm{c}}$ nos modelos protendidos, coerente com o provável acréscimo da contribuição dos mecanismos alternativos, pois a fissuração foi menos intensa nesta região.

Os estribos da posição E7-E8 situam-se a $40 \mathrm{~cm}$ das cargas, 1,45 d, e foram os mais solicitados em praticamente todas as vigas. A variação das tensões foi comparativamente mais brusca, pois quase todas as curvas são mais inclinadas que a curva da treliça clássica. Portanto, pode-se concluir que a inclinação preferencial das bielas principais foi próxima de 35 graus.

$\mathrm{O}$ acréscimo no valor de $\tau_{\mathrm{c}}$ devido à protensão foi equivalente a uma força de $30 \mathrm{kN}, 32 \mathrm{kN}$ e $20 \mathrm{kN}$, para os modelos V1-V4, V2-V5 e V3-V6, respectivamente. Observa-se que estes estribos não foram muito solicitados nos modelos sem fibras (não escoaram em nenhum deles). Isso confirma os resultados da Tabela 5.12, que mostra a menor inclinação das bielas nestas vigas. 
Os efeitos das fibras ficam realçados nos gráficos comparativos. As curvas dos modelos sem fibras se situam entre as curvas dos modelos com fibra de aço e de polipropileno. Observa-se também que, ao contrário da posição anterior, o acréscimo no valor de $\tau_{\mathrm{c}}$ devido à protensão diminuiu com a evolução do carregamento nos três casos. Não se tem uma explicação segura para este fato, mas ele pode ser consequência - da semelhança da fissuração nesta região entre os modelos com e sem protensão, já que ela está mais próxima da seção de momento fletor máximo. A diminuição mais significativa foi observada em V3-V6, justamente onde o acréscimo de $\tau_{c}$ devido à protensão foi menor, equivalente a $20 \mathrm{kN}$.

Os estribos E9-E10 só não escoaram no modelo V3, mas mesmo assim estiveram muito solicitados. Esta região é, portanto, sempre crítica, pois aí as fissuras de flexão começam a inclinar. Como eles foram os primeiros estribos acionados em todos os modelos, são também solicitados por mais tempo.

As tensões foram sempre maiores nos modelos sem fibras. O acréscimo no valor de $\tau_{\mathrm{c}}$ proporcionado pela protensão foi correspondente a uma variação de $29 \mathrm{kN}$. $32 \mathrm{kN}$ e $32 \mathrm{kN}$ no valor da força aplicada, para os modelos V1-V4, V2-V5 e V3-V6, respectivamente. Não se tem uma explicação para estes valores elevados.

Nos gráficos comparativos, observa-se que os valores finais das tensões nos estribos dos modelos protendidos foram maiores do que nos modelos similares sem protensão. O mesmo fato ocorreu para os estribos E7-E8 e também não se encontrou uma razão para justificar este fato. Destaca-se também nestes gráficos o melhor desempenho dos modelos com fỉbras, onde as tensões foram menores e o desenvolvimento foi mais suave, especialmente nos modelos sem protensão.

A parcela resistente ao esforço cortante atribuida ao concreto, que reduz a força nos estribos na analogia clássica de treliça pela teoria aditiva, pode ser representada pelo valor da força cortante correspondente ao instante do acionamento dos estribos, mais conhecida como carga de fissuração por força cortante. Conforme se observa para os estribos mais solicitados, esta parcela da força cortante foi inicialmente maior que 50 kN na posição dos estribos E1-E2, E3-E4 e E5-E6. Para a posição de E7-E8, variou entre 45-50 kN e somente para E9-E10 foi um pouco menor que $45 \mathrm{kN}$.

Como a resistência dos modelos sem estribos foi esgotada para força cortante entre $45 \mathrm{kN}$ e $47 \mathrm{kN}$, pode-se concluir que a parçela de resistência proporcionada pelo concreto foi inicialmente muito próxima da resistência da viga similar sem estribos, podendo. em alguns casos, diminuir com a evolução do carregamento, conforme se discutiu anteriormente. $A$ protensão, ao tornar as bielas mais abatidas, e as fibras foram 
responsáveis pela maior contribuição do concreto, que normalmente é considerada menor que a resistência da viga sem estribos nos resultados experimentais.

Para os gráficos ponderados valem praticamente todas as observações anteriores, ressaltando-se principalmente o excelente desempenho do modelo V2, no ¿qual o concreto apresentou resistência muito menor que os demais.

A tensão nos estribos dos modelos com fibra de polipropileno foi sempre maior que nos modelos com fibra de aço. Este fato já tinha sido observado nos ensaios preliminares. Ele se deve à diferença no mecanismo de atuação destas fibras.

Nos ensaios dos prismas retangulares, as tensões nos estribos na região onde a solicitação por flexão era intensa (E3-E4) foram baixas em todos os modelos com fibras até o final do ensaio. inclusive no caso da fibra de polipropileno. Este fato se repetiu parcialmente nestes ensaios, na posição E9-E10. Anteriormente, justificou-se este comportamento supondo-se que a contribuição das fibras de polipropileno era significativa enquanto os mecanismos alternativos ainda atuavam efetivamente, devido ao melhor controle da abertura das fissuras. Porém, quando surgiram as fissuras diagonais, a atuação desta fibra como armadura transversal foi limitada. Isso justificaria os valores mais elevados das tensões nos estribos mais próximos dos apoios, onde surgem as fissuras inclinadas diretamente na alma.

Mesmo assim, as fibras continuam a contribuir na transferência das forças transversais, já que a resistência destas vigas foi sempre maior que nos modelos sem fibras. Ainda que a deformação excessiva das fibras permita a elevação da tensão nos estribos, a ruptura é retardada devido à energia necessária para promover o arrancamento das fibras.

No caso da fibra de aço as observações do capítulo anterior também continuam válidas. A redução da tensão nos estribos se deve à maior rigidez das fibras. que limitam a deformação junto às fissuras. A energia necessária para o arrancamento deve ser menor, pois a quantidade de fibras que atravessam as fissuras é reduzida.

Para qualquer tipo de fibra utilizado, novamente o melhor controle de fissuras contribuiu para o melhor desempenho da viga, pois as fibras melhoram a contribuição dos mecanismos resistentes alternativos. 


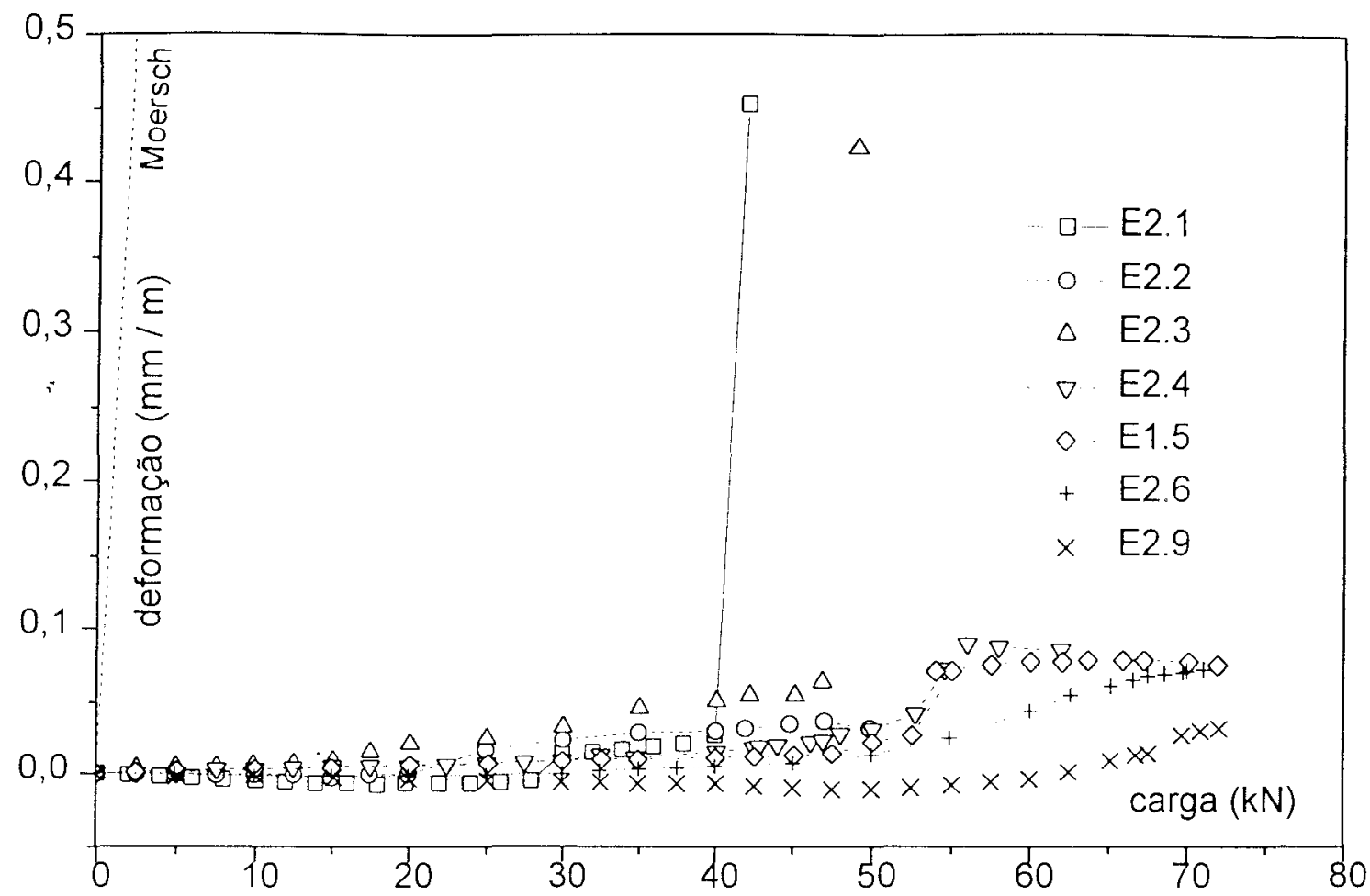

Figura 5.44 - Deformação nos estribos mais solicitados da posição E1-E2

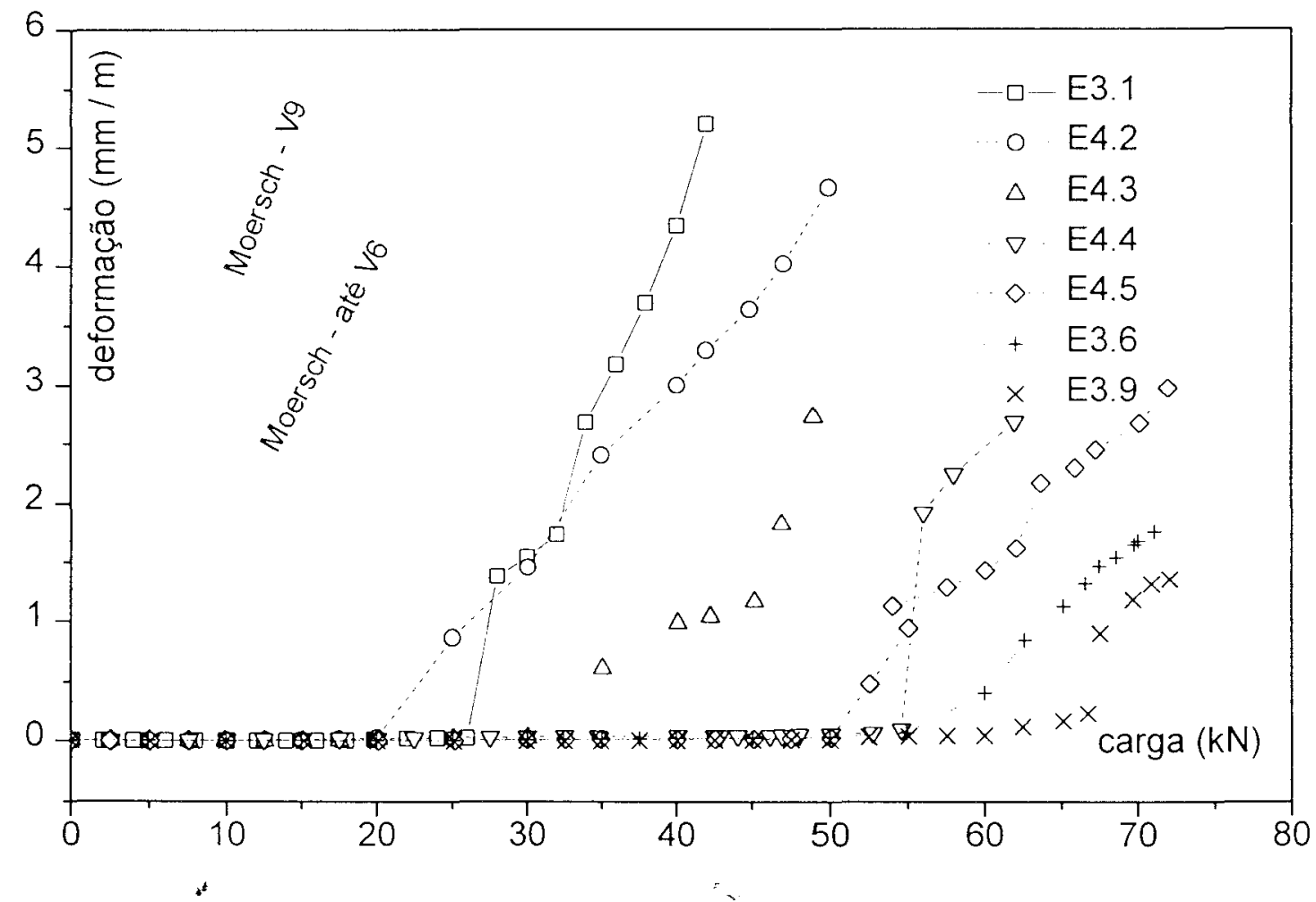

Figura 5.45 - Deformação nos estribos mais solicitados da posição E3-E4 


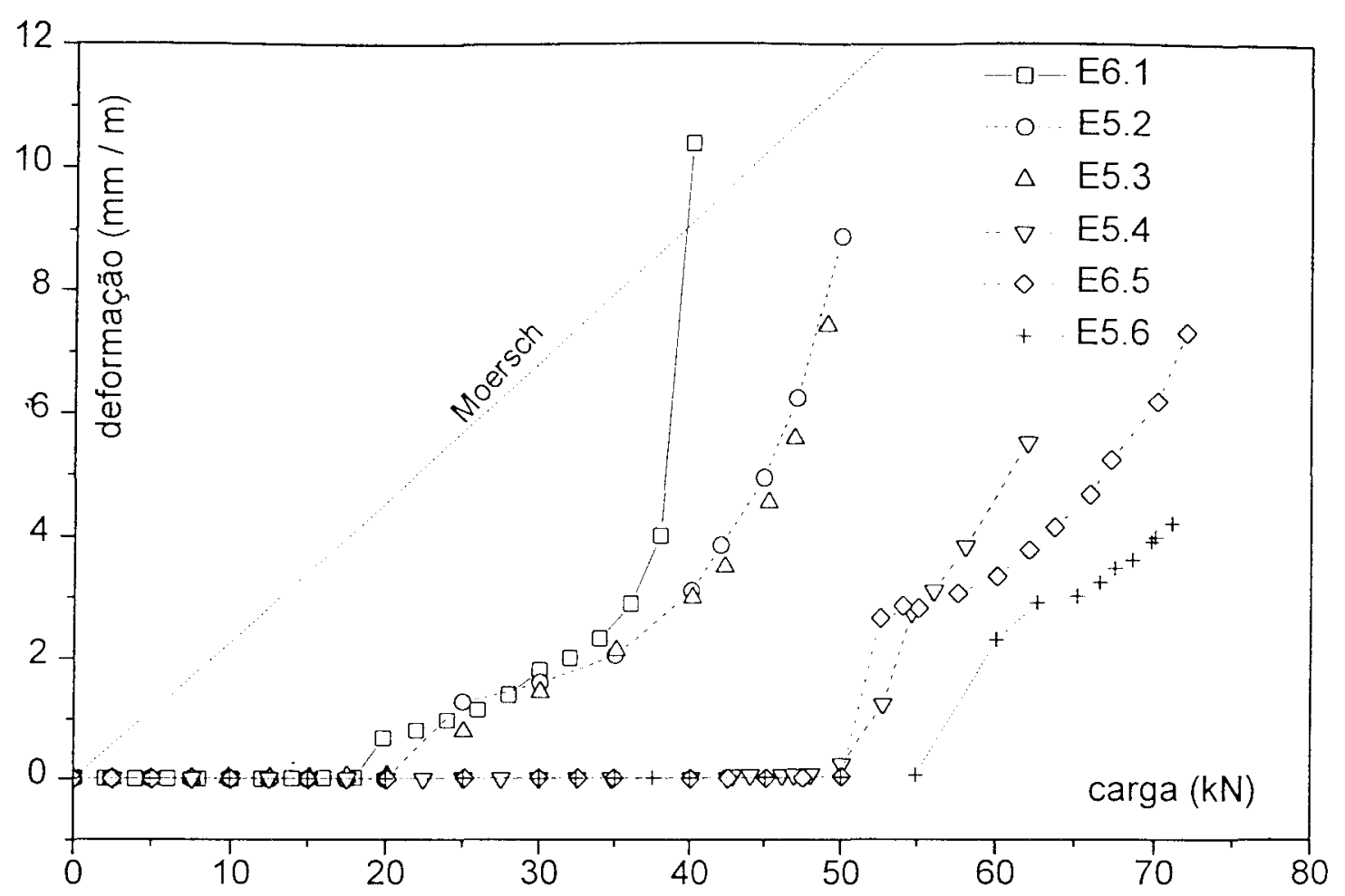

Figura 5.46 - Deformação nos estribos mais solicitados da posição E5-E6

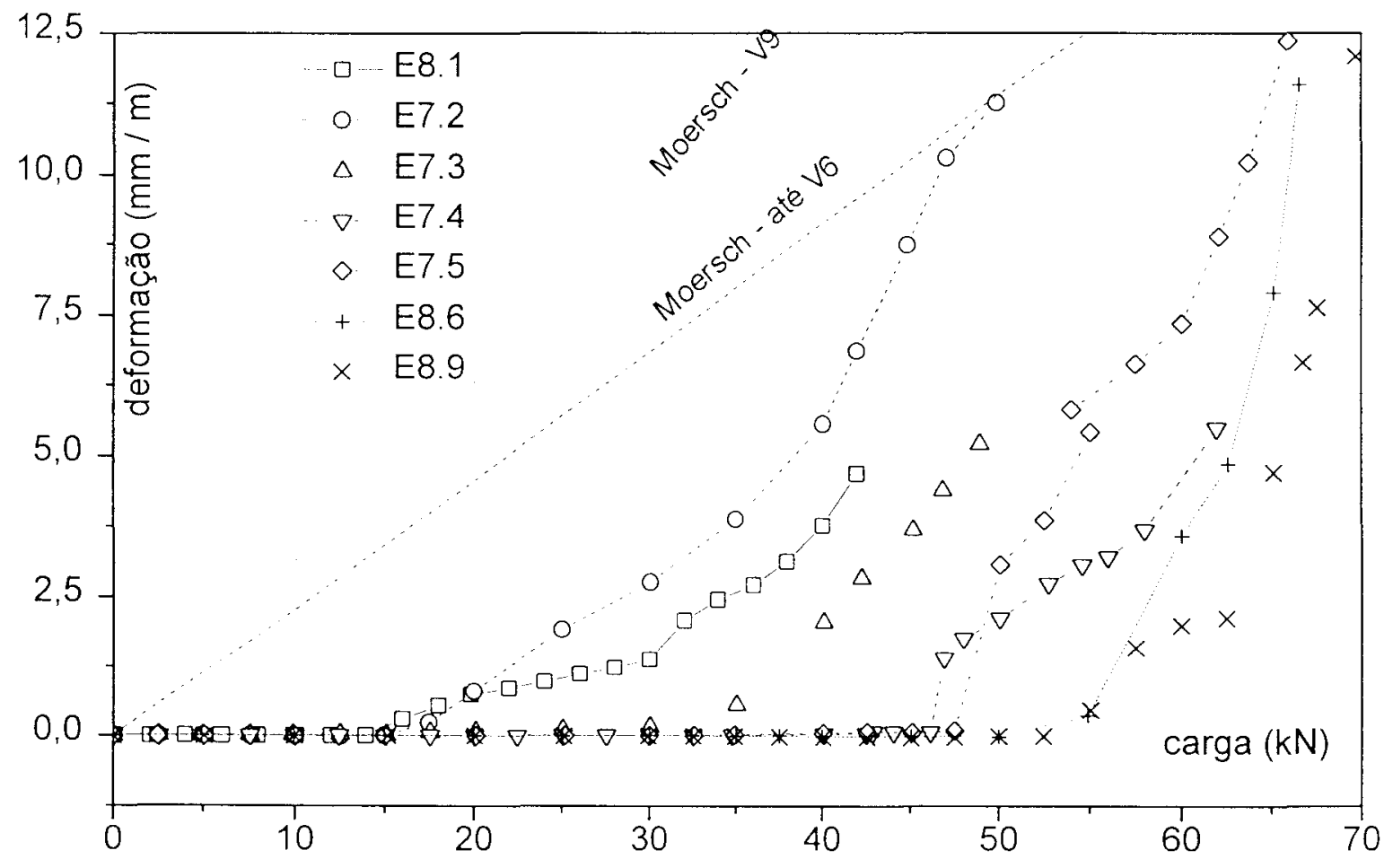

Figura 5.47 - Deformação nos estribos mais solicitados da posição E7-E8 


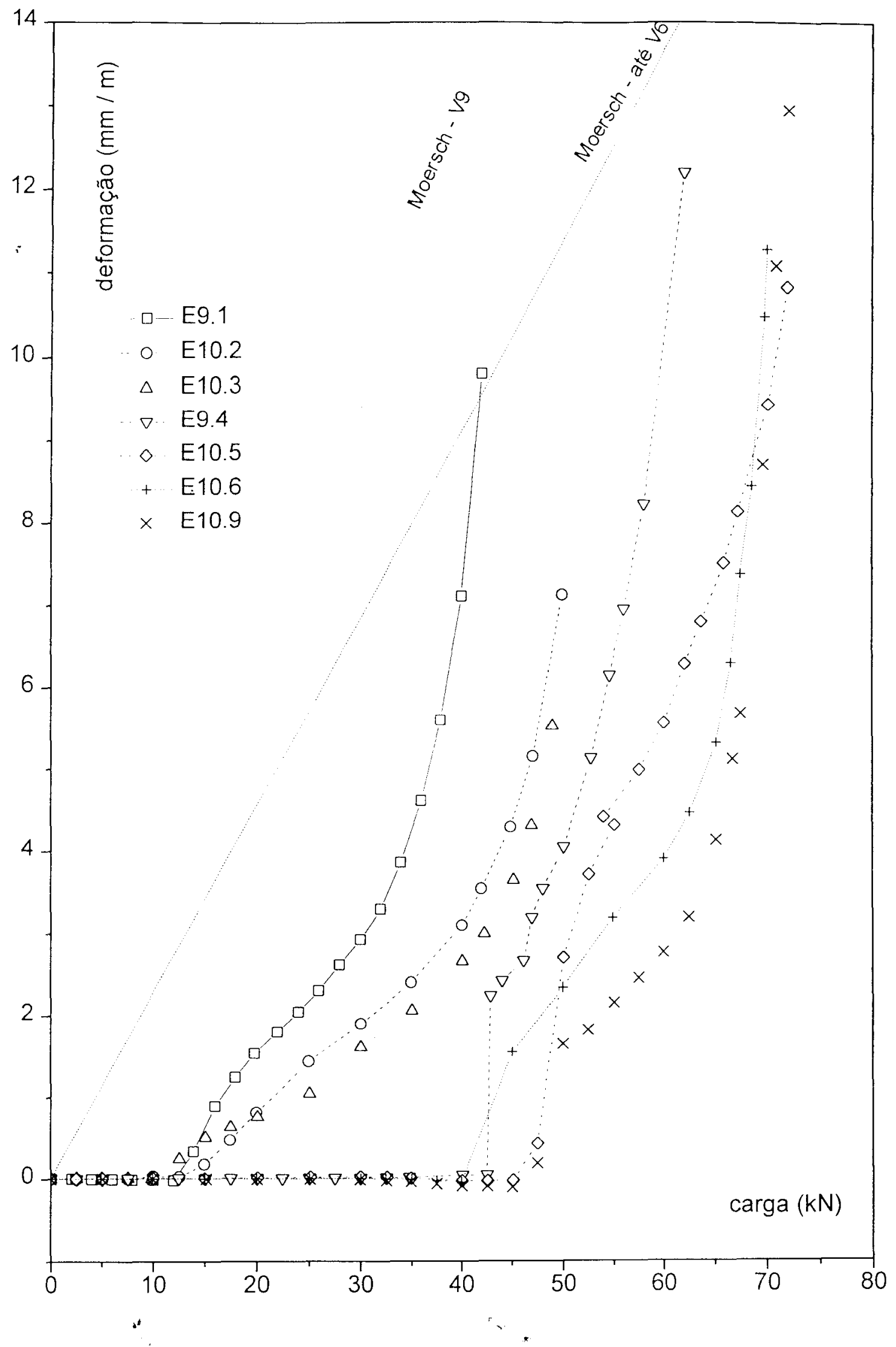

Figura 5.48 - Deformação nos estribos mais solicitados da posição E9-E10 


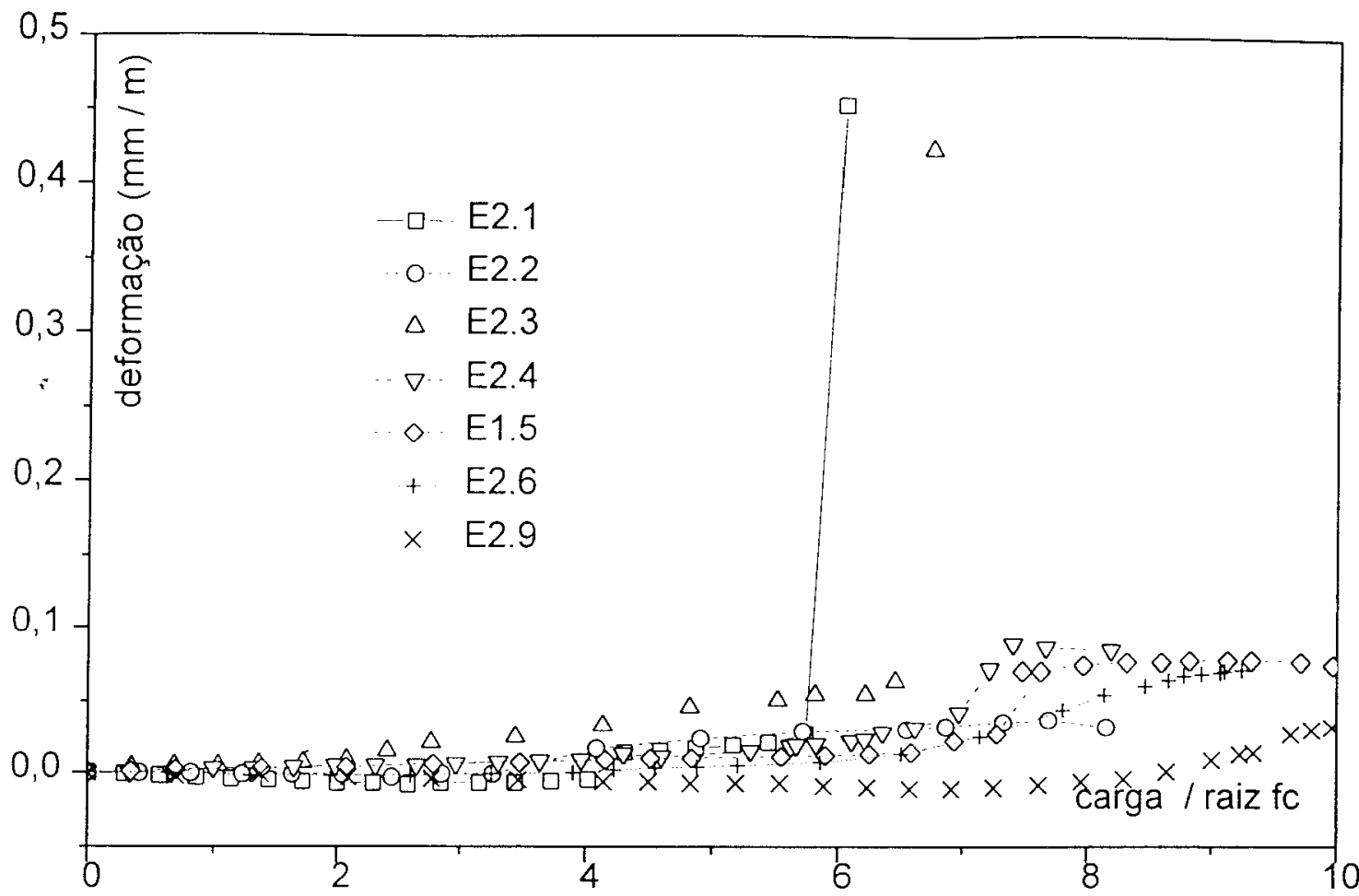

Figura 5.49- Deformação nos estribos mais solicitados E1-E2 (ponderado)

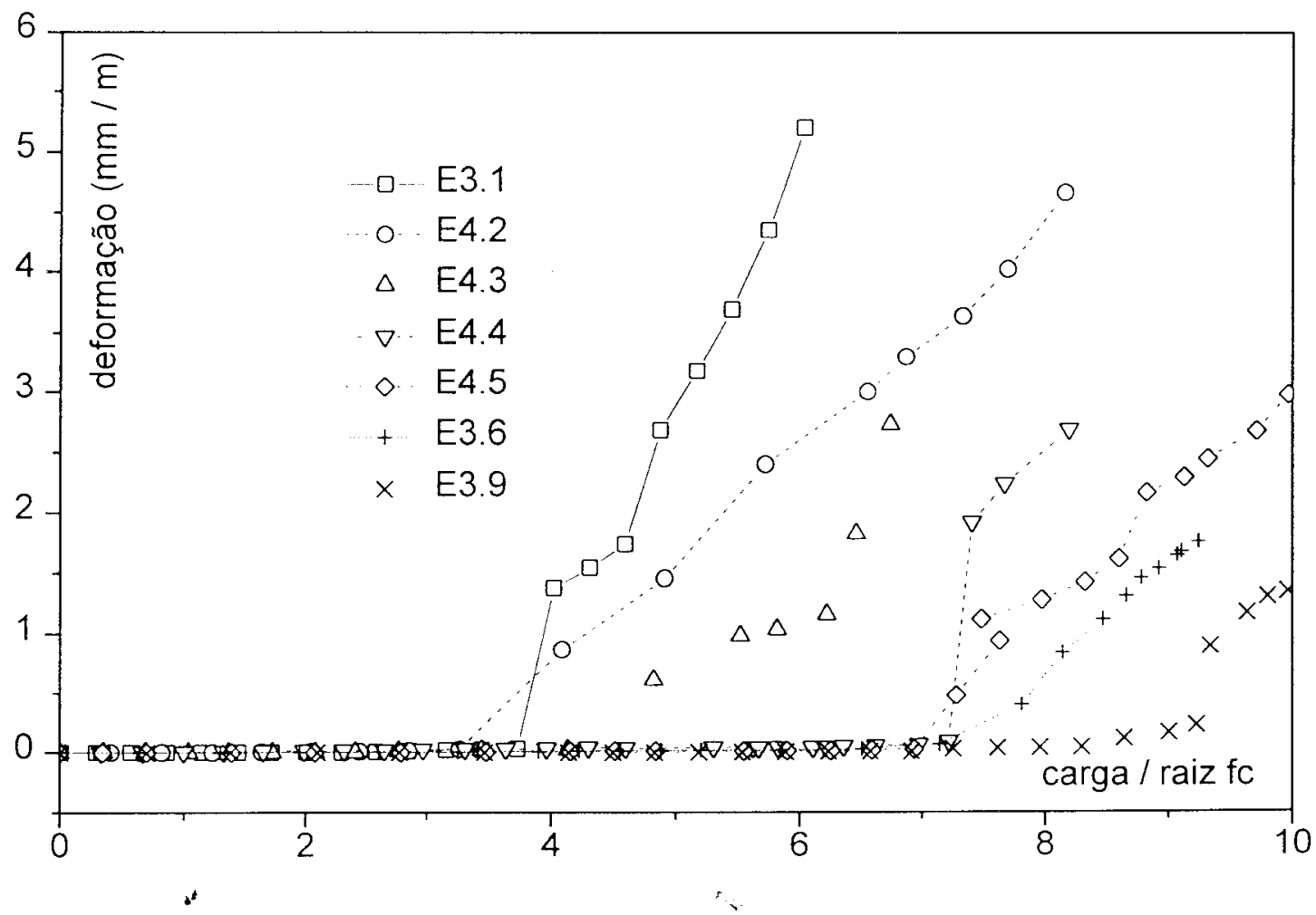

Figura 5.50 - Deformação nos estribos mais solicitados E3-E4 (ponderado) 


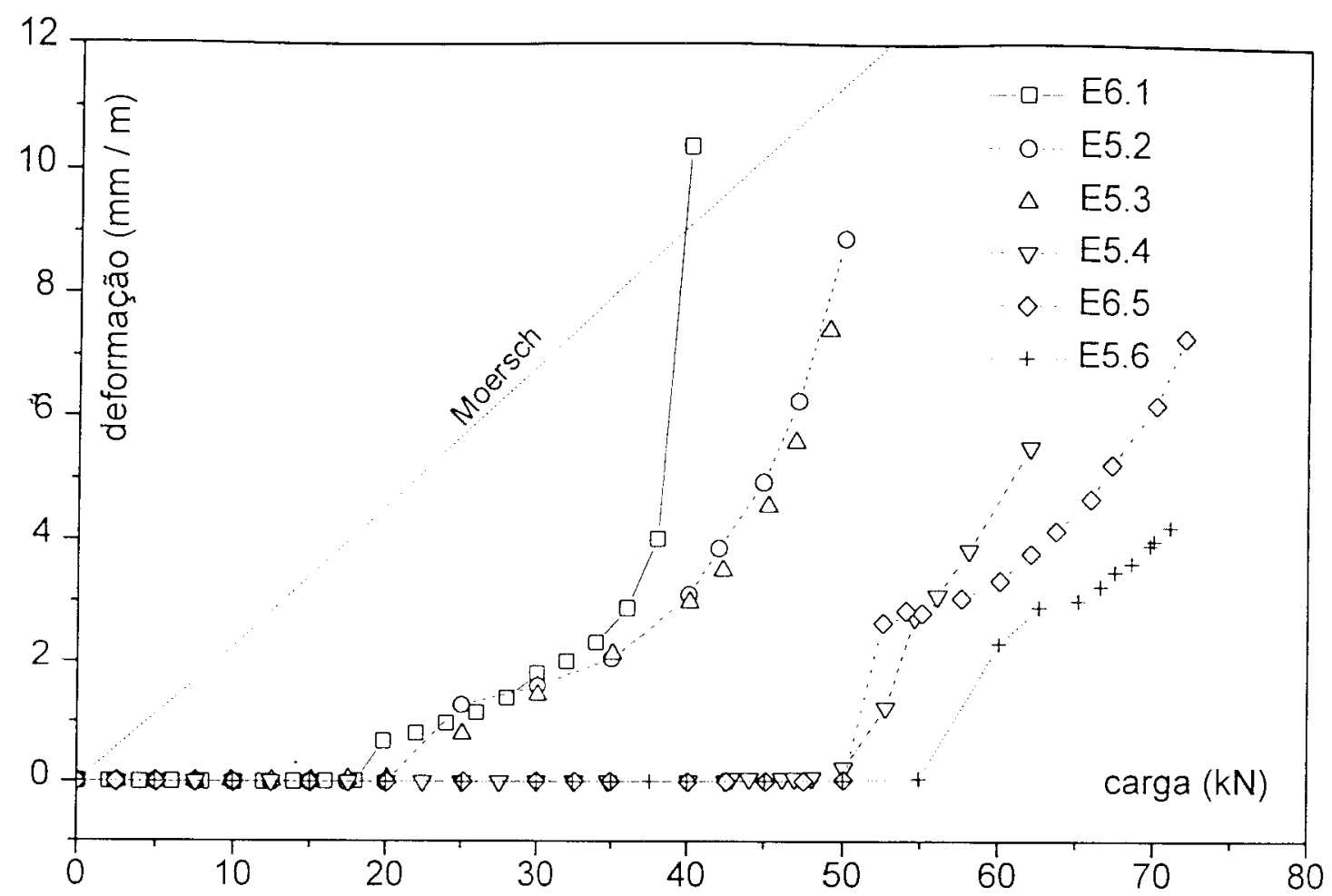

Figura 5.51 - Deformação nos estribos mais solicitados E5-E6 (ponderado)

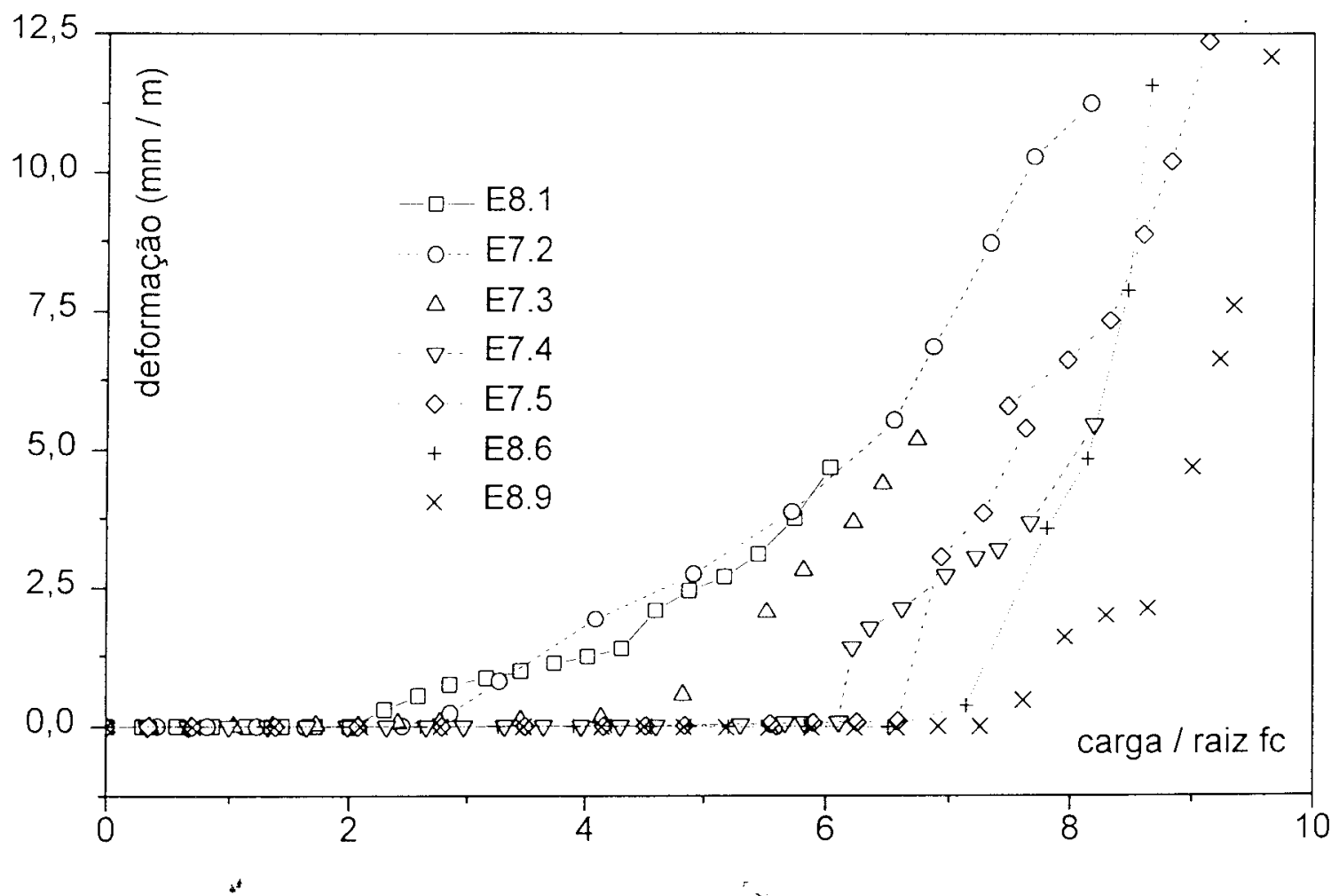

Figura 5.52 - Deformação nos estribos mais solicitados E7-E8 (ponderado) 


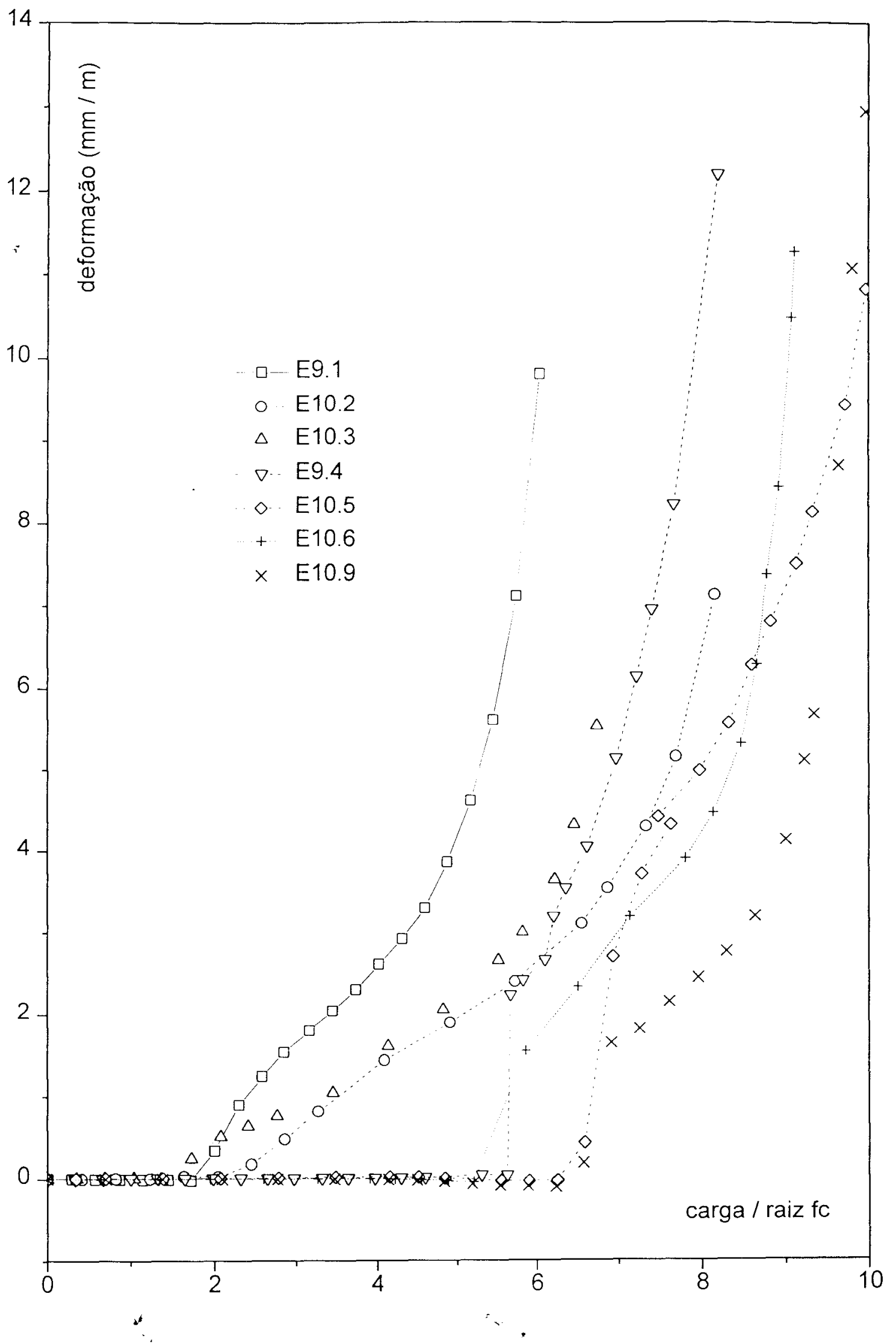

Figura 5.53 - Deformação nos estribos mais solicitados E9-E10 (ponderado) 

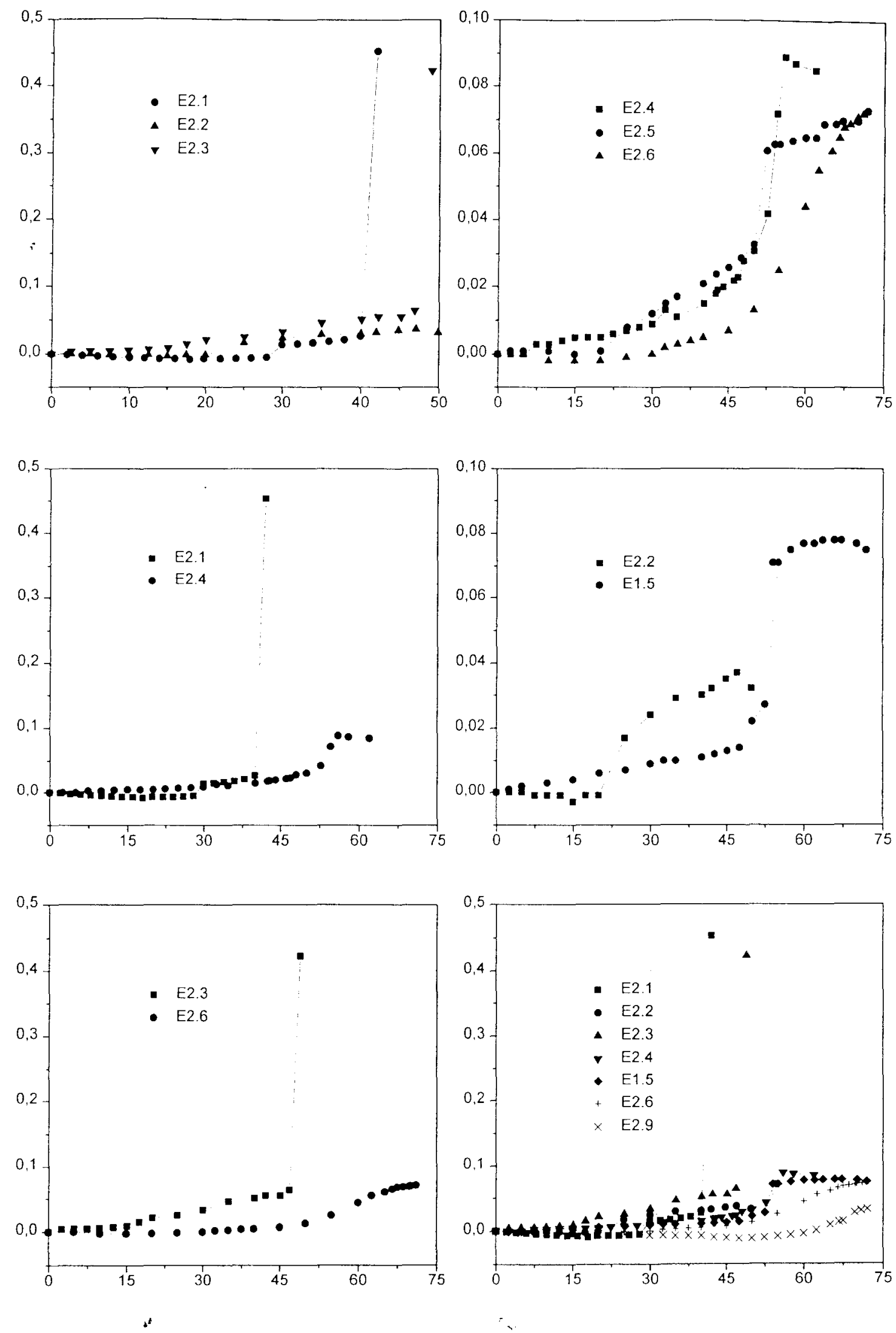

Figura 5.54 - Gráficos comparativos E1-E2: Carga (eixo x: kN) x $\varepsilon$ (eixo y: mm/m) 

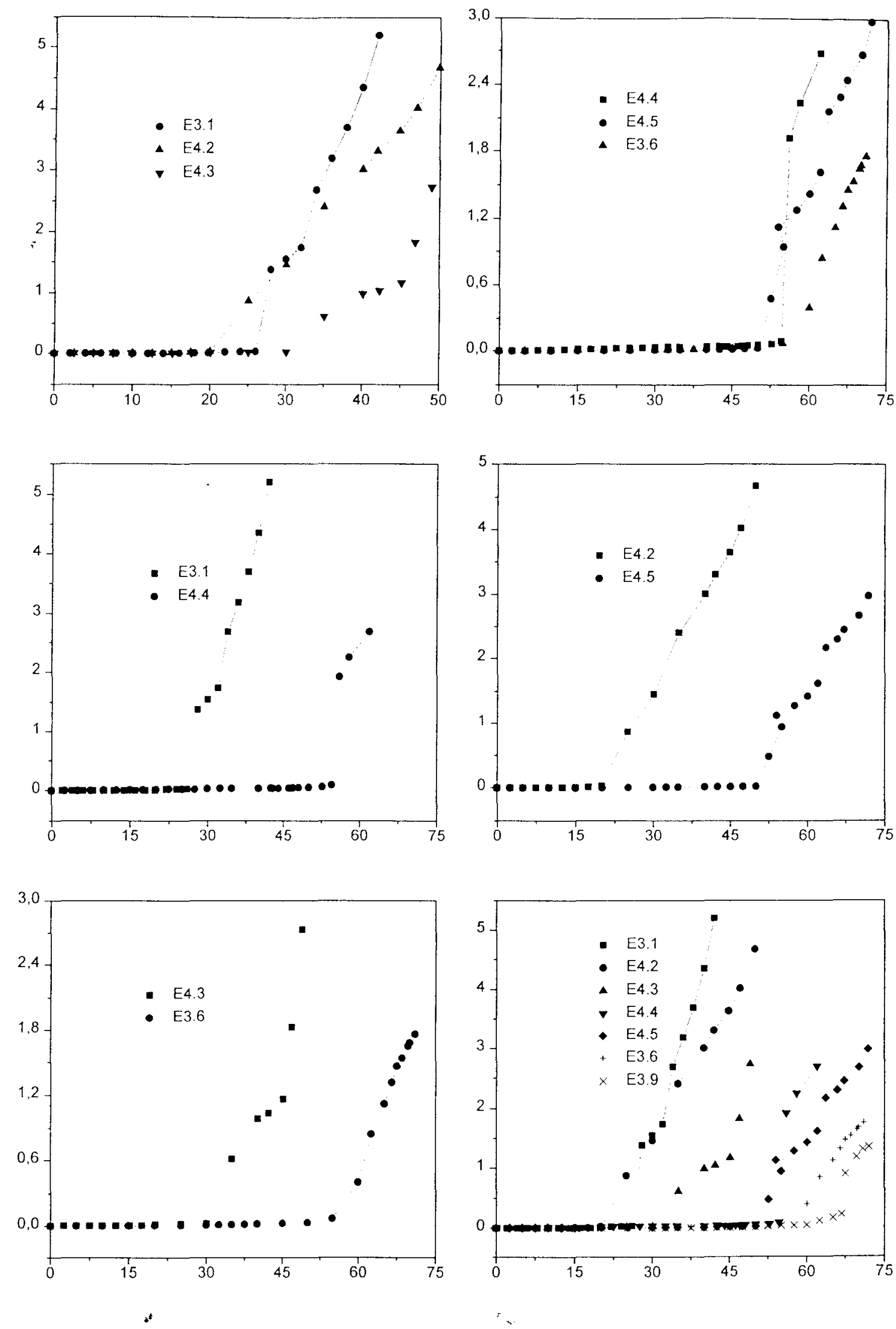

Figura 5.55 - Gráficos comparativos E3-E4: Carga (eixo $\mathrm{x}$ : $\mathrm{kN}$ ) $\mathrm{x} \varepsilon$ (eixo y: $\mathrm{mm} / \mathrm{m}$ ) 

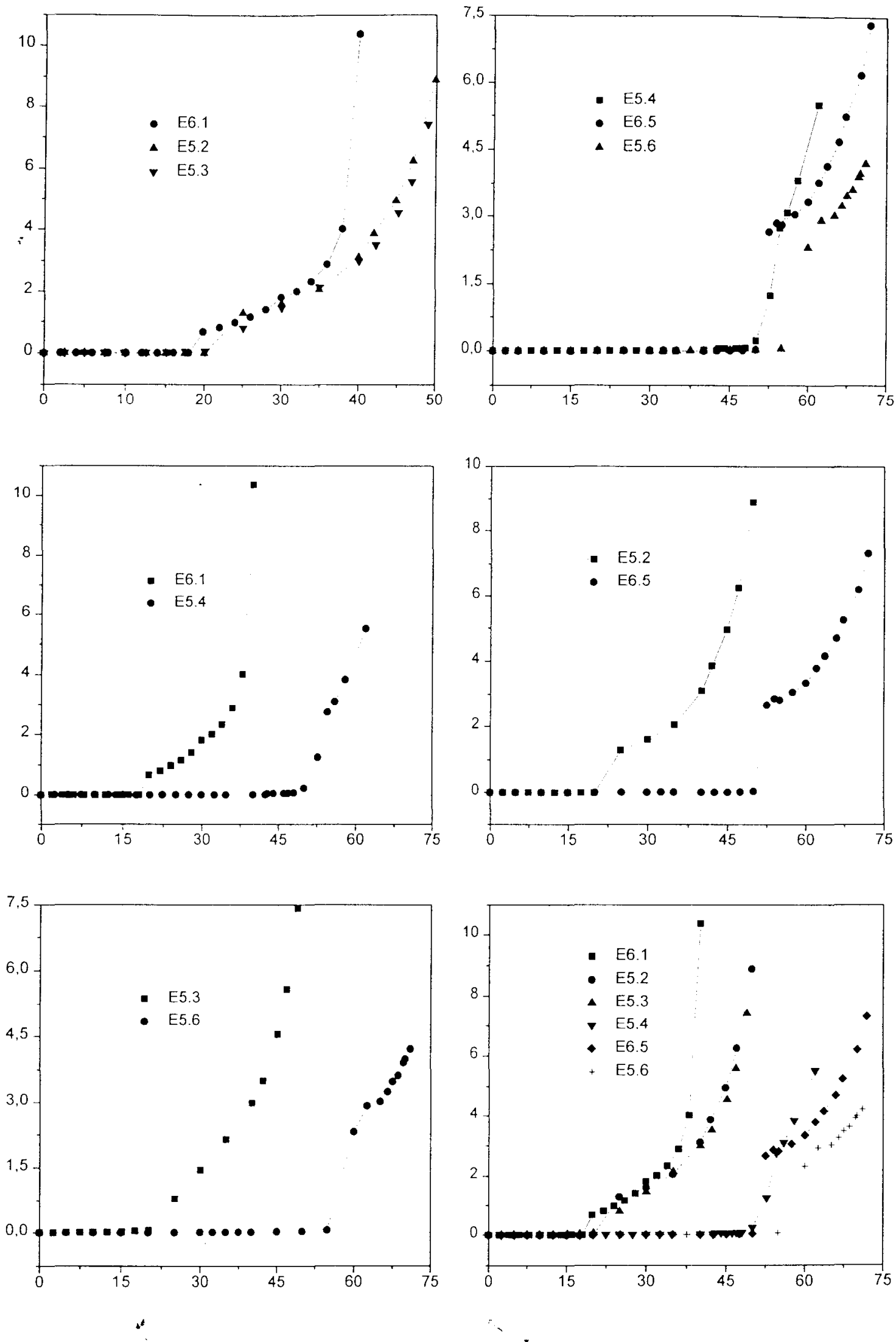

Figura 5.56 - Gráficos comparativos E5-E6: Carga (eixo x: $\mathrm{kN}$ ) x $\varepsilon$ (eixo y: $\mathrm{mm} / \mathrm{m}$ ) 

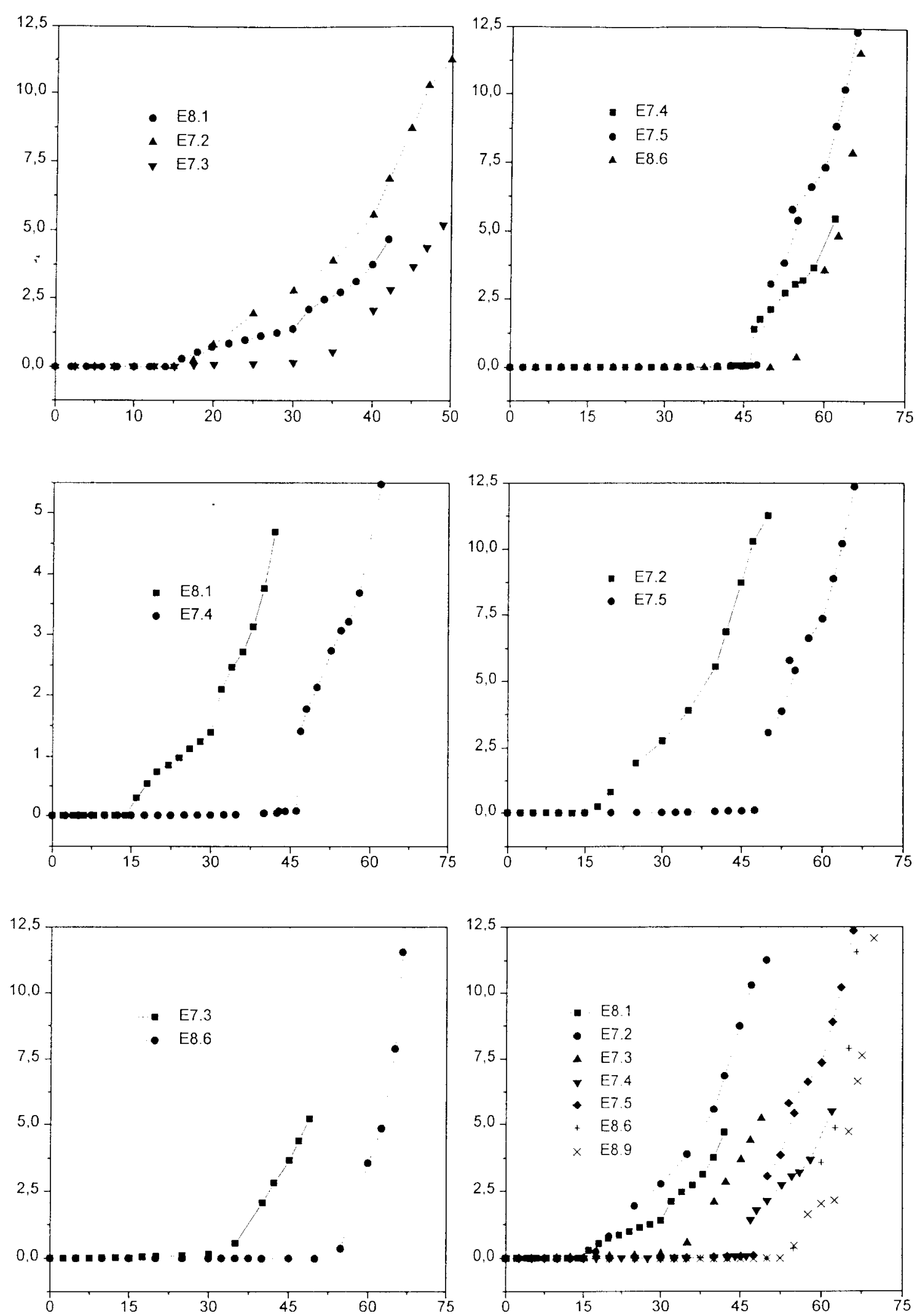

Figura 5.57 - Gráficos comparativos E7-E8: Carga (eixo $\mathrm{x}: \mathrm{kN})$ x $\varepsilon$ (eixo y: $\mathrm{mm} / \mathrm{m})$ 

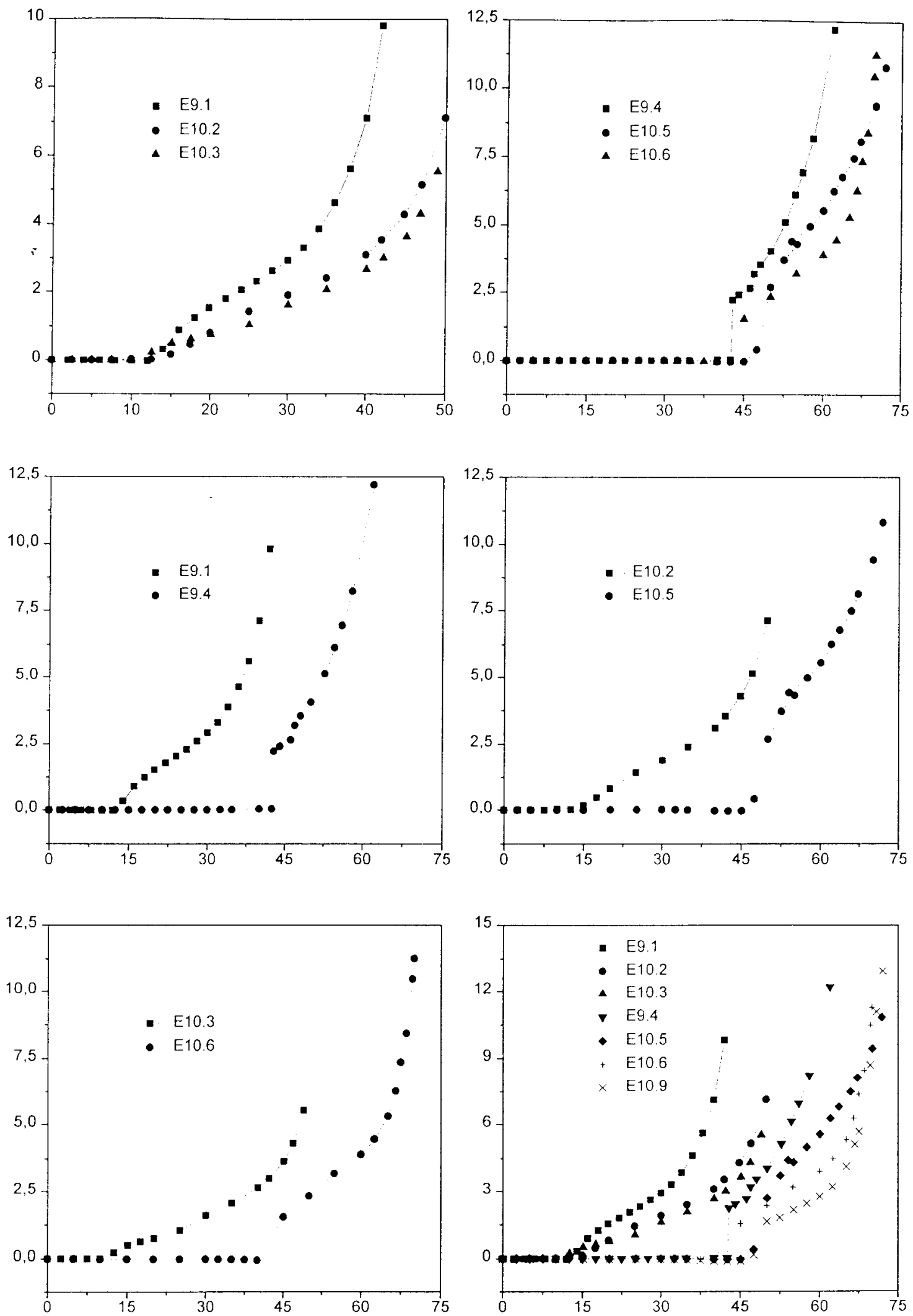

Figura 5.58 - Gráficos comparativos E9-E10: Carga (eixo x: $\mathrm{kN})$ x $\varepsilon($ eixo y: $\mathrm{mm} / \mathrm{m})$ 


\subsection{7 - ARMADURA LONGITUDINAL}

Os valores das deformações máximas em todos os pontos instrumentados das cordoalhas e o respectivo instante em que a tensão aumentou bruscamente, quando surgiram fissuras de flexão nas proximidades do extensômetro, são apresentados nas 'Tabelas 5.15 a e $5.14 \mathrm{~b}$.

Tabela 5.15a - Deformação máxima nas cordoalhas - lado ímpar

\begin{tabular}{|c|c|c|c|c|c|c|c|c|}
\hline \multirow{2}{*}{ modelo } & \multicolumn{3}{|c|}{ deformação máxima (\%) } & \multicolumn{4}{c|}{ carga de mobilização $(\mathrm{kN})$} \\
\cline { 2 - 9 } & A1 & A3 & A5 & A0 & A1 & A3 & A5 & A0 \\
\hline V1 & 0,2 & 0,35 & 0.43 & 0,43 & 28 & 14 & 9 & - \\
\hline V2 & 0,24 & 0,42 & 0,55 & 0,53 & 25 & 15 & 10 & 10 \\
\hline V3 & 0,21 & 0,41 & 0.61 & 0,58 & 30 & 15 & 7,5 & 7,5 \\
\hline V4 & 0,07 & 0,27 & 0.41 & 0,44 & 52 & 43 & 40 & 35 \\
\hline V5 & 0,06 & 0,33 & 0.57 & 0,66 & 55 & 50 & 40 & 32,5 \\
\hline V6 & 0,04 & 0,27 & 0.55 & 0,48 & 60 & 55 & 40 & 40 \\
\hline V7 & 0,01 & 0,1 & 0.22 & 0,22 & - & 47 & 40 & 40 \\
\hline V8 & 0,01 & 0,03 & 0.18 & 0,20 & - & - & 37,5 & 32,5 \\
\hline V9 & 0,04 & 0,27 & 0.55 & 0,48 & 62 & 52 & 40 & 40 \\
\hline
\end{tabular}

Tabela 5.15b - Deformação máxima nas cordoalhas - lado par

\begin{tabular}{|c|c|c|c|c|c|c|c|c|c|c|}
\hline \multirow{2}{*}{ modelo } & \multicolumn{4}{|c|}{ deformação máxima (\%) } & \multicolumn{4}{c|}{ carga de mobilização (kN) } \\
\cline { 2 - 12 } & A2 & A4 & A4L & A6 & A0 & A2 & A4 & A4L & A6 & A0 \\
\hline V1 & 0,2 & 0,36 & - & 0.39 & 0,43 & 30 & 16 & - & 9 & - \\
\hline V2 & 0,22 & 0,42 & - & 0.54 & 0,53 & 25 & 15 & - & 10 & 10 \\
\hline V3 & 0,21 & 0,39 & - & 0.56 & 0,58 & 30 & 15 & - & 10 & 7,5 \\
\hline V4 & 0,04 & 0,27 & 0,29 & 0.4 & 0,44 & 56 & 43 & 43 & 40 & 35 \\
\hline V5 & 0,05 & 0,31 & 0,37 & 0.61 & 0,66 & 52 & 50 & 50 & 40 & 32,5 \\
\hline V6 & 0,02 & 0,31 & 0,36 & 0,55 & 0,48 & 60 & 55 & 50 & 45 & 40 \\
\hline V7 & 0,01 & 0,11 & 0,15 & 0.22 & 0,22 & - & 45 & 45 & 37,5 & 40 \\
\hline V8 & 0,01 & 0,03 & 0,03 & 0.21 & 0,2 & - & - & - & 37,5 & 32,5 \\
\hline V9 & 0,02 & 0,32 & 0,36 & 0,55 & 0,48 & 62 & 55 & 50 & 40 & 40 \\
\hline
\end{tabular}


Em nenhum modelo se registrou o escoamento da armadura longitudinal, mas $\mathrm{em}$ alguns casos as deformações atingiram o trecho curvo do diagrama $\sigma-\varepsilon$ do aço.

A proporção entre a deformação teórica dos pontos A1-A2, A3-A4 e A5-A6 com a deformação no meio do vão devido aos esforços de flexão é igual a $0,20,0,55$ e 0,91 , respectivamente. Conforme se observa, os valores obtidos geralmente foram inaiores, confirmando a necessidade de cobertura do diagrama de momento fletor.

Os pontos A3-A4 são os mais adequados para se analisar a possível influência do apoio das bielas na armadura longitudinal e a consequente alteração das tensões, pois estão situados em seções onde convergem as bielas principais, a 1,82 d, conforme mostram as Fotos 5.19 a 5.21 e a análise das tensões nos estribos. O eventual aumento da resistência às forças de pino proporcionado pela adição das fibras ao concreto pode ser estudado relacionando-se o valor da tensão máxima nas cordoalhas nestes pontos, mais susceptíveis ao apoio das bielas, com o instante da ruína.

Próximo dos apoios, o fenômeno só ocorreria caso as bielas alcançassem esta região no final do ensaio, o que provavelmente não aconteceu, exceto em V1 e V3, conforme se comentou no item 5.8.6. Nestes pontos, esperava-se a elevação de tensão devido efeito do atirantamento no final do ensaio. No entanto. o ponto instrumentado está a $22 \mathrm{~cm}$ dos apoios, distância aparentemente excessiva para captar este fenômeno.

As Figuras 5.59 a 5.63 mostram a evolução das deformações na cordoalha central de todos os modelos no meio do vão e em cada um dos três pontos instrumentados no trecho de cisalhamento, apenas no lado mais solicitado, além das deformações nas cordoalhas laterais, só para a mais solicitada. Nas Figuras 5.64 a 5.67 , apresentam-se os resultados comparativos agrupados segundo descrito anteriormente.

Não se observaram diferenças significativas na evolução das tensões nas cordoalhas devido à introdução das fibras. Em relação à protensão, a alteração mais significativa foi a maior extensão das etapas não fissuradas, já que os gráficos correspondentes são quase sempre paralelos.

Nos pontos mais próximos dos apoios, A1-A2, as tensões nos modelos sem protensão foram menores em V3; nos modelos protendidos, foram maiores em V4. Como a fissuração não atingiu esta região nas vigas protendidas, as deformações se mantiveram baixas. Nas vigas sem protensão, a tensão máxima foi próxima de 510 MPa. equivalente a uma força de $28 \mathrm{kN}$ em cada cordoalha, ou seja, a força total a ancorar na tegião do apoio é maior que a força corțante máxima (até 1,7 vezes).

Não houve coincidência entre o lado da ruptura e o lado em que a cordoalha esteve mais solicitada na região dos apoios. No único caso em que se registrou a deformação após a ruptura, na viga V7, observou-se um aumento significativo da 
tensão nesta região. Pode-se concluir que este acréscimo somente surge na iminência da ruptura e porisso não foi registrado mais vezes. Assim, ao contrário dos ensaios preliminares, não se observou acréscimo de tensão nas cordoalhas próximo dos apoios, nem mesmo quando a descompressão no concreto foi mais intensa.

Os valores máximos das deformações foram maiores que os valores teóricos em "todos os modelos sem protensão. Isso reforça a necessidade de se dispor sempre uma armadura mínima para garantir a ancoragem das forças nos apoios nestas vigas.

A diferença no instante de mobilização das armaduras nestes pontos entre os modelos com e sem protensão foi de $22,5 \mathrm{kN}, 27,5 \mathrm{kN}$ e $30 \mathrm{kN}$, para V1-V4, V2-V5 e V3-V6, respectivamente. Conclui-se, portanto, que nos modelos protendidos, a progressão das fissuras em direção aos apoios foi mais rápida no modelo V4. Nos modelos não protendidos, o acionamento das cordoalhas ocorreu antes em V2, mas o desenvolvimento das tensões foi mais suave. Estes resultados sugerem a influência das fibras na limitação da fissuração e sua contribuição (ou do concreto entre fissuras) na resistência à flexão, na resultante de tração.

Nos pontos A3-A4 as tensões máximas foram nominalmente maiores nos modelos com fibras, mas para cargas iguais elas praticamente não diferem. Em V2, V3, V6 e V9 as deformações foram relativamente altas quando comparadas com o meio do vão, possivelmente devido ao apoio das bielas. Caso haja uma asssociação entre a deformação máxima nestes pontos com a ruína por cisalhamento, devido à ruptura do concreto no entorno das barras longitudinais, pode-se concluir pelo melhor desempenho dos modelos com fibras, onde o efeito de pino atuou por mais tempo e retardou a ocorrência da ruína.

Nos modelos protendidos as tensões foram menores, pois a fissuração não se desenvolveu plenamente nesta região. As tensões foram sempre maiores nas cordoalhas laterais. Houve relativa coincidência entre o lado em que ocorreram as tensões máximas e o lado da ruptura. Isso pode estar relacionado com o esgotamento da resistência às forças de pino.

Nos pontos A5-A6 os resultados foram análogos. Em V2, V3, V6 e V9 as deformações foram comparativamente altas: nos dois lados da viga foram maiores que no meio do vão. exceto em V3, onde o lado mais solicitado não coincidiu com o lado da rupturz Nos modelos protendidos os valores foram similares aos dos correspondentes sem protensão, apesar do aumento da carga máxima, possivelmente devido à proximidade com a seção de momento máximo, onde a configuração de fissuras é semelhante. 
No ponto central, as deformações deveriam ser proporcionais à solicitação por flexão, já que, teoricamente, não há influência da força cortante. No entanto, isso nem sempre ocorreu. Nos modelos V6 e V9 os valores foram muito baixos, discrepantes dos demais resultados.

Em V2 e V3 a carga máxima atingiu 50 kN. Esperava-se uma deformação de aproximadamente $0,6 \%$ nas cordoalhas. Em V4, esperava-se uma deformação de 0,78\%, ou, descontando-se o pré-alongamento, $0.47 \%$. No modelo 15 as cordoalhas deveriam escoar. Até então os resultados obtidos foram relativamente consistentes. No modelo V6 a deformação deveria aproximar-se de 1,1\%. O valor obtido foi bem menor, pois a deformação total atingiu $0,78 \%$ e corresponde, no cálculo teórico, a uma carga de $64 \mathrm{kN}$. Em .V8, a deformação esperada era de $0.54 \%$, ou $0.25 \%$ no ensaio, descontando-se o pré-alongamento.

Em todos estes cálculos se considerou um braço de alavanca interno igual a 27 $\mathrm{cm}$. Este valor seria praticamente exato caso a ruptura ocorresse por flexão. Como todos os modelos romperam por cisalhamento, ele deve ser menor. Neste caso, as deformações teóricas seriam maiores. 


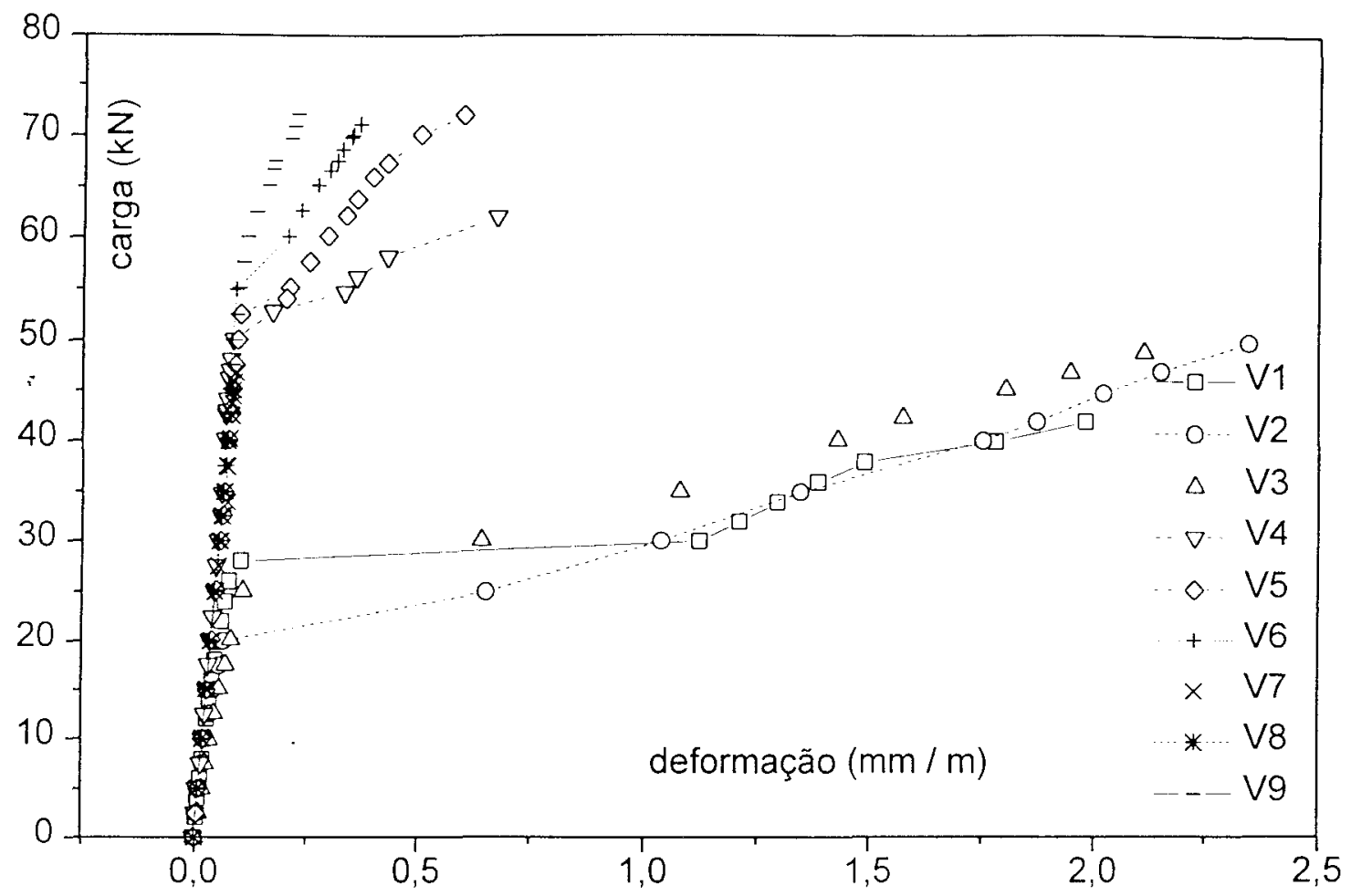

Figura 5.59 - Deformação no ponto mais solicitado da cordoalha central (A1-A2)

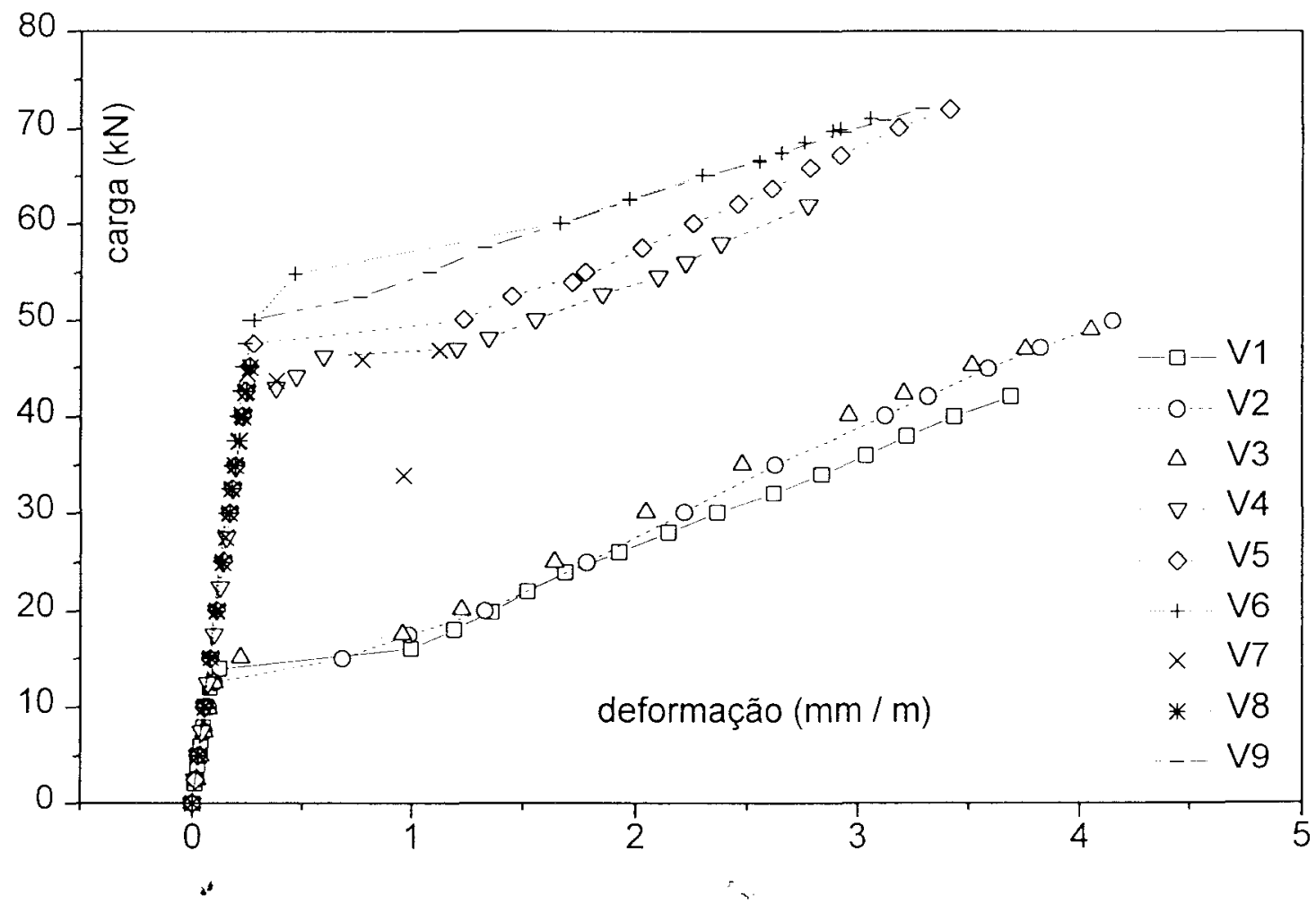

Figura 5.60 - Deformação no ponto mais solicicitado da cordoalha central (A3-A4) 


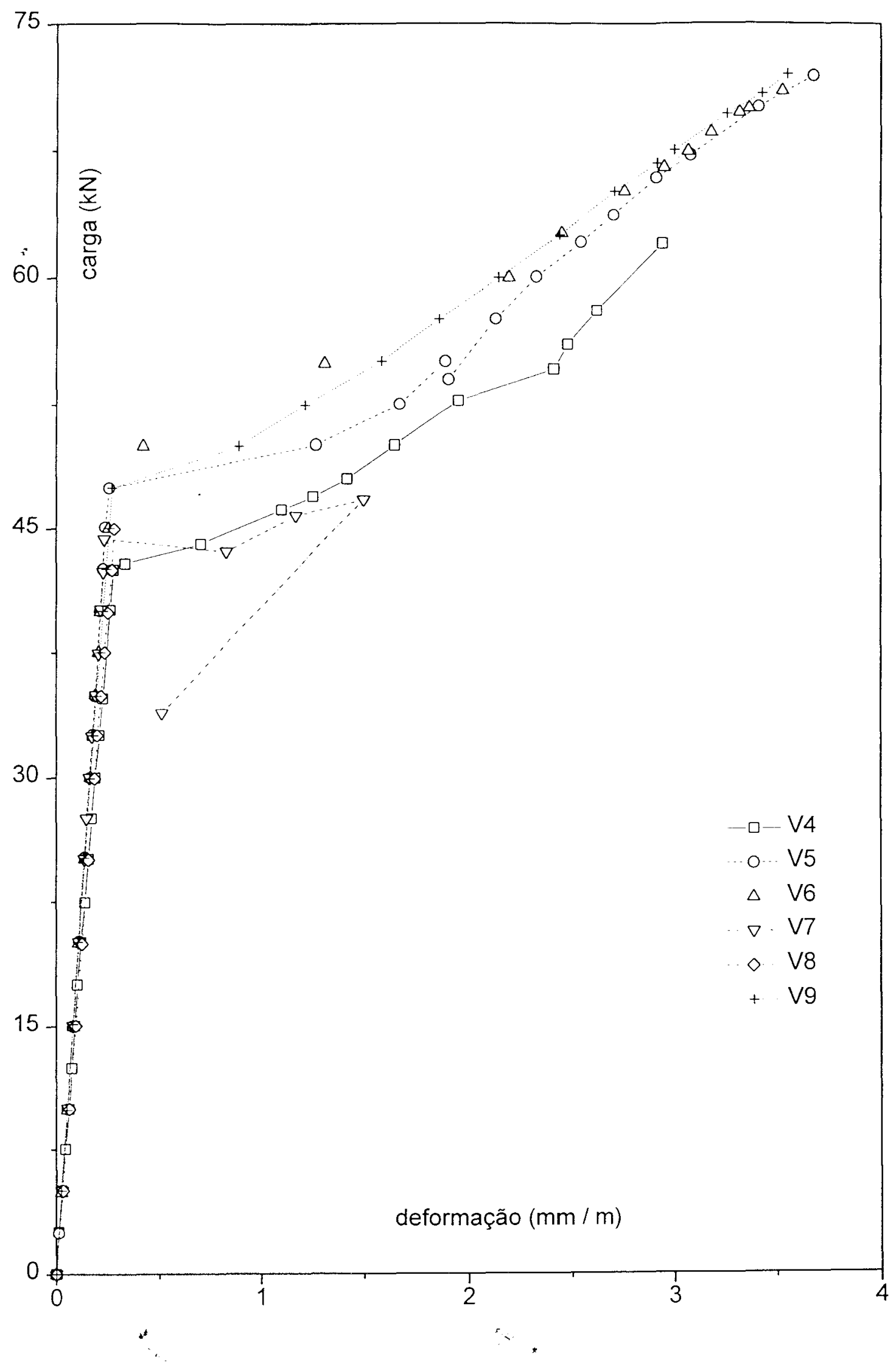

Figura 5.61 - Deformação no ponto mais solicitado das cordoalhas laterais (A4) 


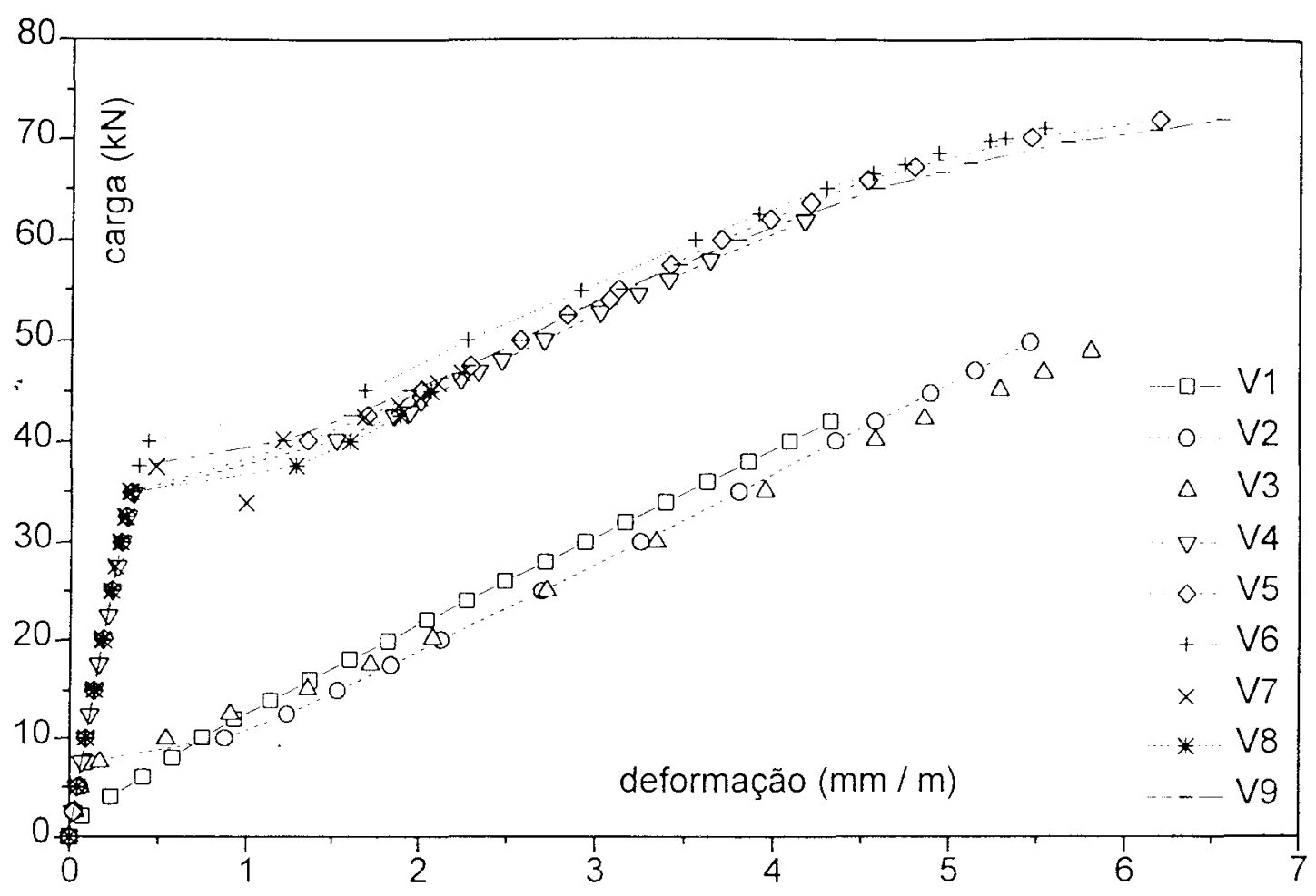

Figura 4.62 - Deformação no ponto mais solicitado da cordoalha central (A5-A6)

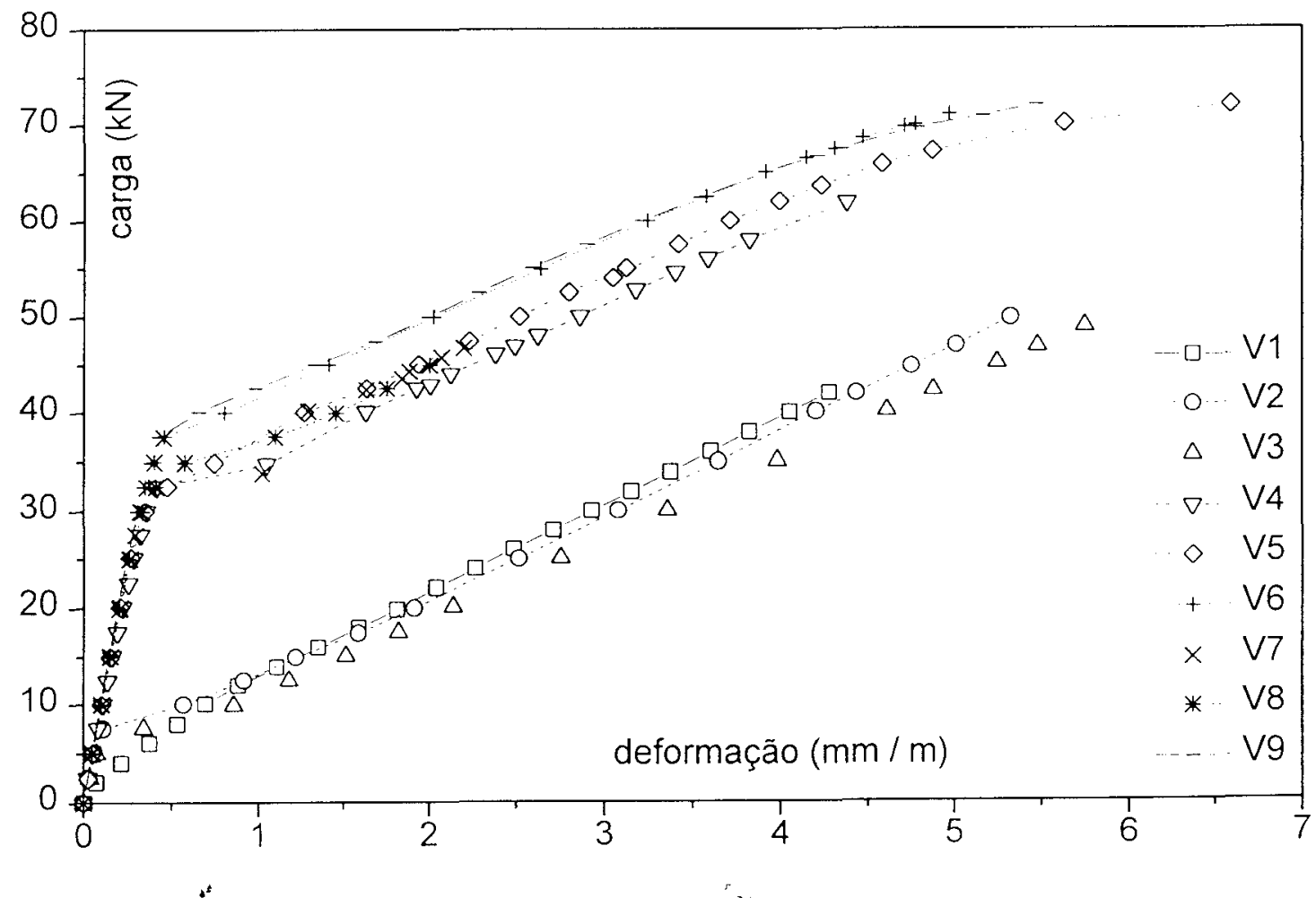

Figura 4.63 - Deformação no ponto mais šolicitado da cordoalha central (A0) 

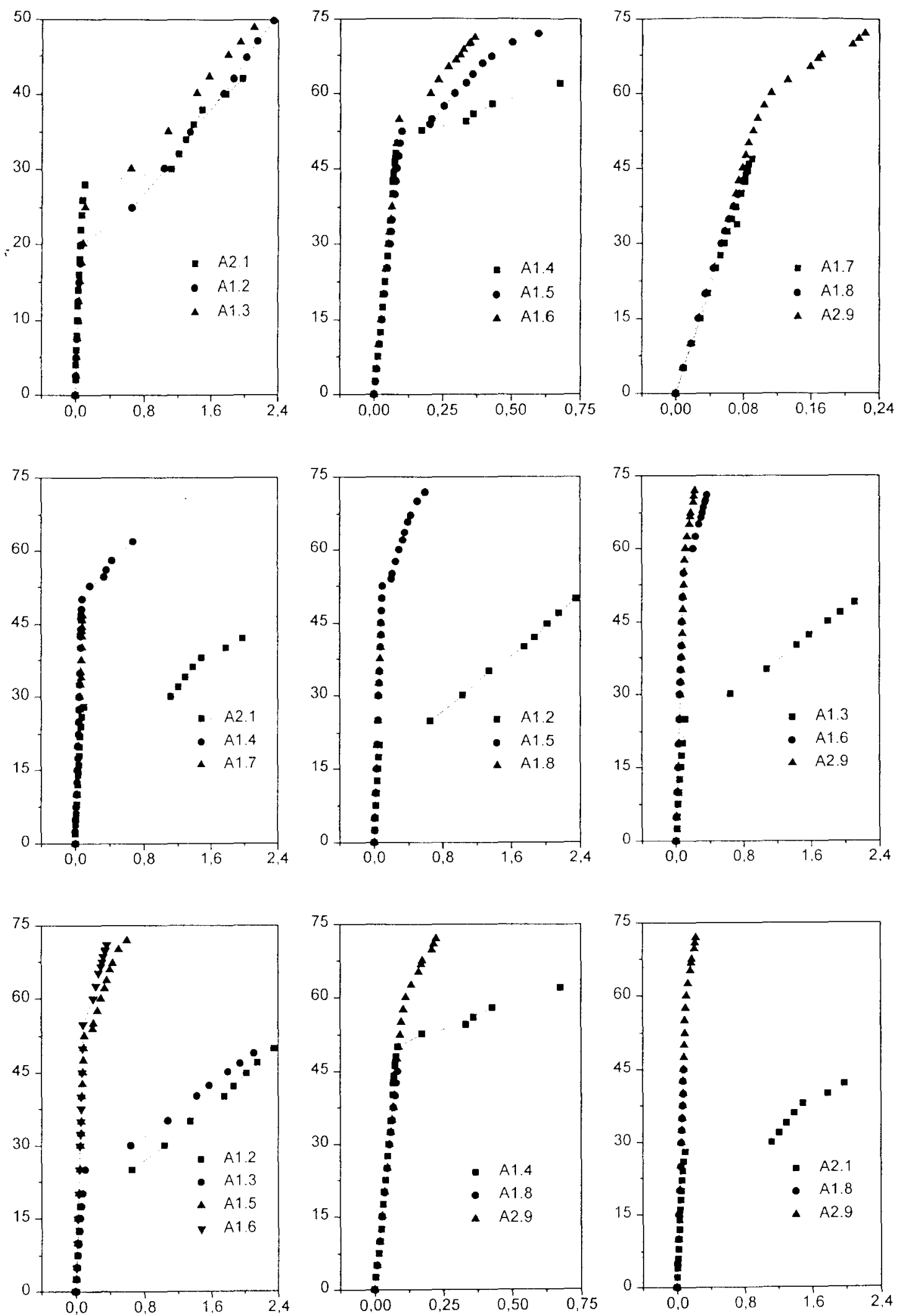

Figura 5.64 - Gráficos comparativos A1-A2: $\varepsilon$ (eixo x: $\mathrm{mm} / \mathrm{m}$ ) x Carga (eixo y: $\mathrm{kN}$ ) 

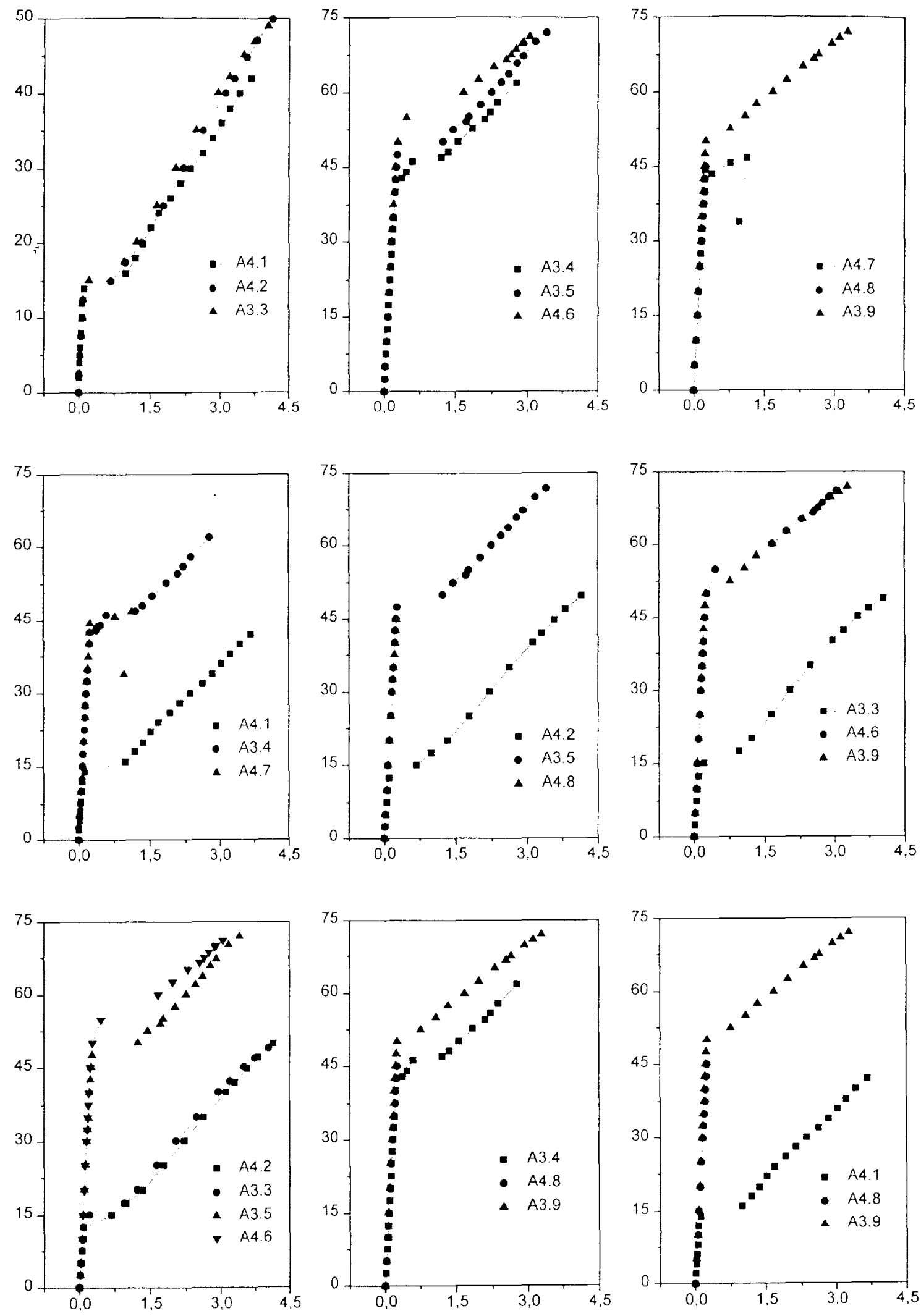

Figura 5.65 - Gráficos comparativos A3-A4: $\varepsilon$ (eixo x: $\mathrm{mm} / \mathrm{m}$ ) x Carga (eixo y: $\mathrm{kN}$ ) 

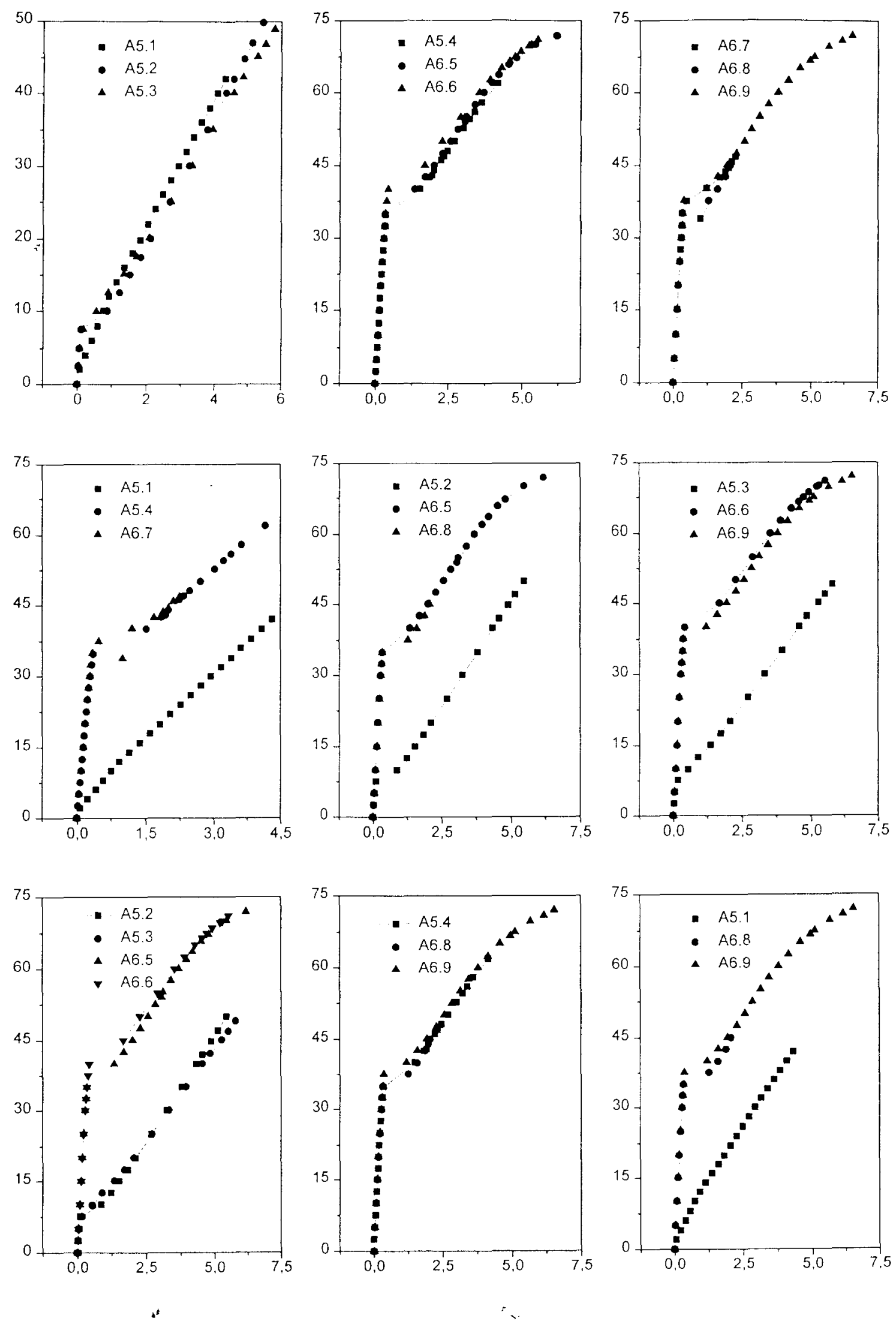

Figura 5.66 - Gráficos comparativos A5-A6: $\varepsilon$ (eixo x: $\mathrm{mm} / \mathrm{m}$ ) x Carga (eixo y: kN) 

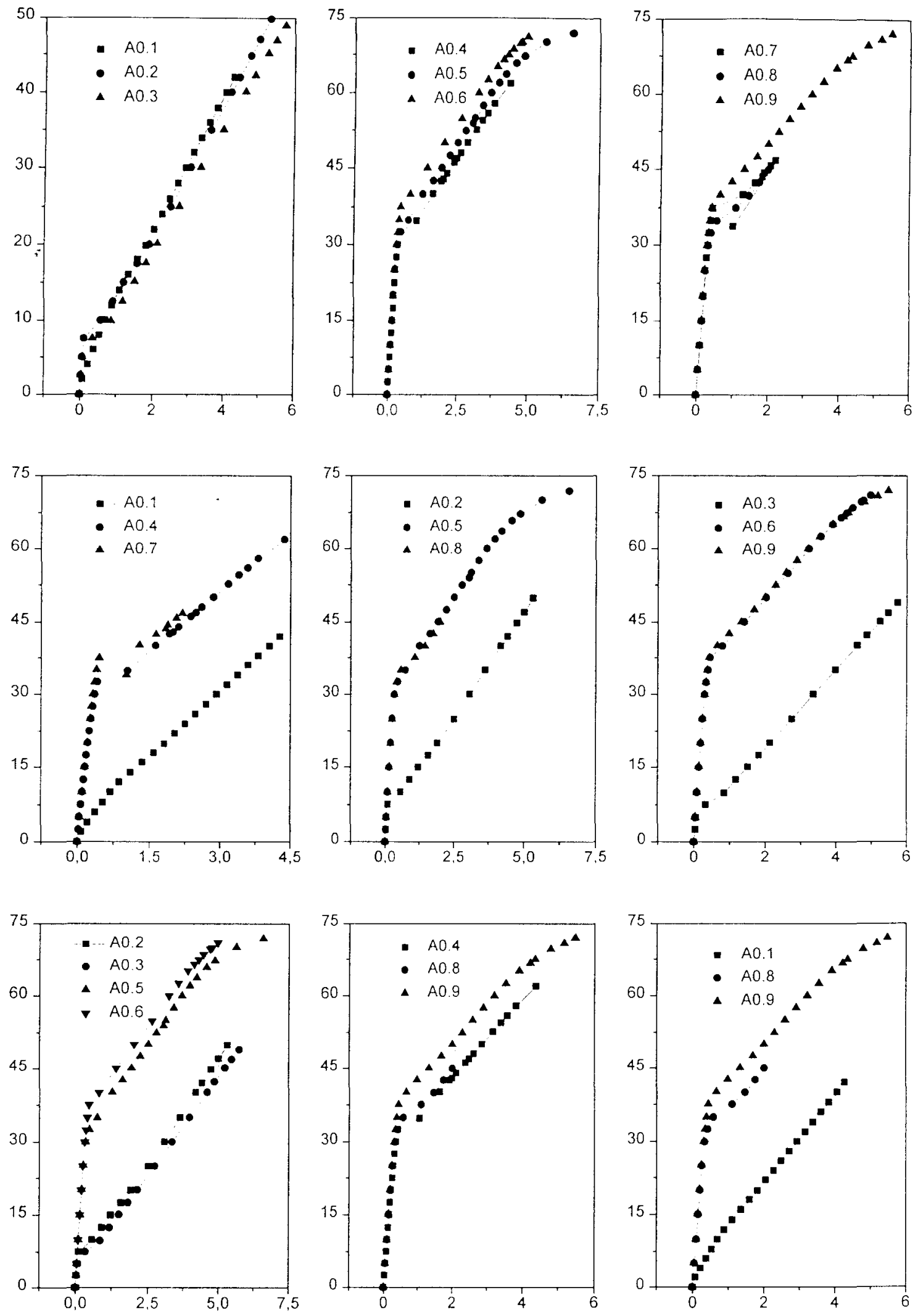

Figura 5.67 - Gráficos comparativos $\mathrm{A} 0: \varepsilon($ eixo $\mathrm{x}: \mathrm{mm} / \mathrm{m})$ x Carga (eixo y: $\mathrm{kN}$ ) 


\subsection{8 - CONCRETO NO BANZO COMPRIMIDO}

As Figuras 5.68 a 5.71 mostram as deformações no meio do vão e nos três pontos instrumentados em cada trecho onde atua a força cortante, apenas no lado mais solicitado, agrupadas para todos os modelos.

As deformações no concreto nos pontos próximos dos apoios foram sempre muito baixas, limitadas a uma tensão máxima de compressão de aproximadamente 4 MPa. Nos dois modelos sem estribos não se observou diminuição de tensões na parte final do ensaio, possivelmente porque este tipo de ruptura é muito frágil e não se consegue registrar o fenômeno. Nos demais modelos protendidos, a descompressão ocorreu para cargas maiores que a carga de ruptura dos modelos sem armadura transversal. A leitura dos dados após o alívio da carga no modelo V7 comprova a existência do fenômeno, que ocorreu na iminência da ruptura.

Foram registradas tensões de tração significativas nos pontos $\mathrm{C} 1-\mathrm{C} 2$ em dois modelos no final do ensaio (V3 e V5), cujos valores se aproximaram da tensão máxima de compressão registrada, igual a $4 \mathrm{MPa}$. Como estes pontos estão a aproximadamente $0,8 \mathrm{~d}$ dos apoios, conclui-se que, pelo menos até este ponto, pode haver tensões de tração no banzo comprimido. Caso a resistência das vigas fosse maior, esta região seria mais extensa.

Nos modelos sem protensão, a descompressão ocorreu antes naqueles com fibras, mas só foi significativa em V3. Ela se manifestou nos pontos mais externos quando as cargas estavam entre $20 \mathrm{kN}$ e $30 \mathrm{kN}$. Nos modelos protendidos ela surgiu depois, entre $50 \mathrm{kN}$ e $60 \mathrm{kN}$ e, neste caso, ocorreu primeiro no modelo sem fibra, sendo mais suave na viga com fibra de aço.

$O$ instante em que as tensões de compressão começam a diminuir é quase sempre coincidente com a mobilização efetiva da armadura longitudinal na seção correspondente, mas não houve relação entre a intensidade da descompressão com o valor da deformação nas cordoalhas.

Nos ensaios preliminares se observou uma correspondencia relativa entre a iminência da ruptura diagonal e a intensidade da descompressão do concreto. Este fato não se repetiu de forma tão clara nestas vigas, onde o fenômeno se manifestou de forma sutil, somente em alguns casos. Além disso, como todos os modelos romperam por cisalhamento, a comparação ficou parcialmente prejudicada. 
Nos pontos C3-C4 houve diminuição da tensão de compressão em todos os modelos, exceto naqueles sem estribos. Ela foi sempre posterior à descompressão dos pontos extremos. Em nenhum caso, entretanto, foram registradas tensões de tração nesta região, que era esperada até aproximadamente $1.5 \mathrm{~d}$ dos apoios, conforme vários registros bibliográficos. A distância destes pontos até os apoios era de 2,2d. Portanto, a - descompressão comprova a possibilidade de transmissão direta da carga dos banzos até os apoios a partir desta posição.

A descompressão nestes pontos ocorreu antes nos modelos sem fibras. Não se define uma relação entre os valores da tensão no concreto e nas cordoalhas nesta seção. Nas cordoalhas, as tensões entre vigas correspondentes são muito mais próximas entre si do que no concreto, onde as curvas são mais espalhadas.

Os pontos mais próximos do carregamento estão a 3,65d dos apoios. Apenas nos modelos V6 e V7 se observou uma discreta diminuição de tensão, ou seja, eles praticamente estão fora da região perturbada pela descompressão.

No meio do vão, as tensões se desenvolveram de modo mais uniforme, acompanhando as características do concreto e a solicitação por flexão. Em todos os modelos a deformação máxima ficou compreendida entre $0,12 \%$ e $0.17 \%$, dentro dos limites esperados. Considerando-se a resistência à compressão do concreto igual a 45 $\mathrm{MPa}$, por exemplo, esperava-se que a posição da linha neutra no instante da ruptura por flexão, para força aplicada igual a $70 \mathrm{kN}$. estivesse a $3.05 \mathrm{~cm}$ da borda superior, o que corresponderia a uma deformação máxima de $0,135 \%$ no concreto. Nos modelos em que a carga máxima se aproximou deste valor as deformações foram um pouco maiores.

Em todos os pontos instrumentados as deformações correspondentes ao trecho linear dos gráficos de cada posição na parte incial do ensaio, quando a descompressão ainda não ocorreu, foram maiores para os modelos com fibra de polipropileno. Isto se deve ao menor valor do módulo de deformação longitudinal do concreto destas vigas. 


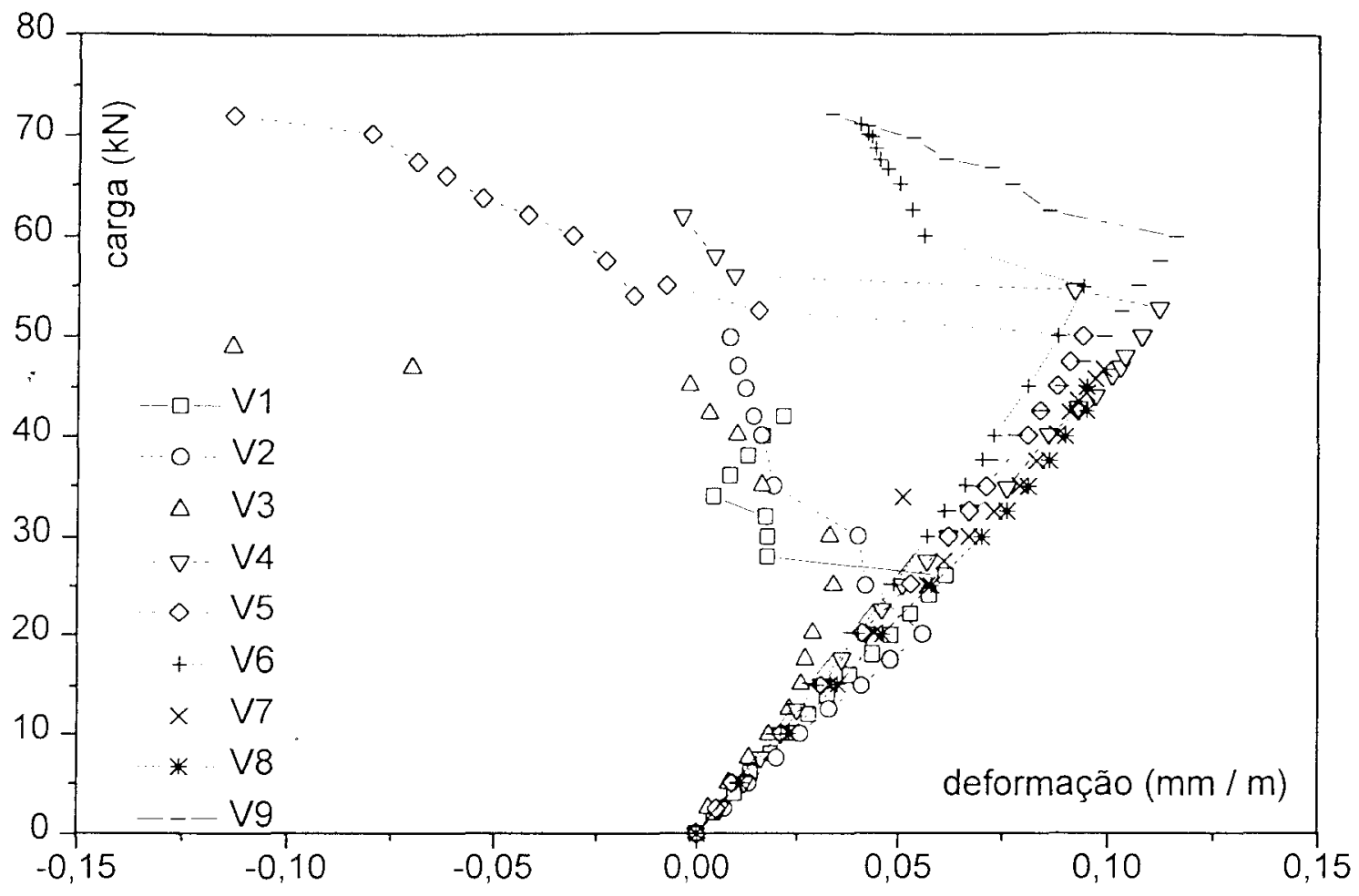

Figura 5.68 - Deformação no ponto mais solicitado no concreto (C1-C2)

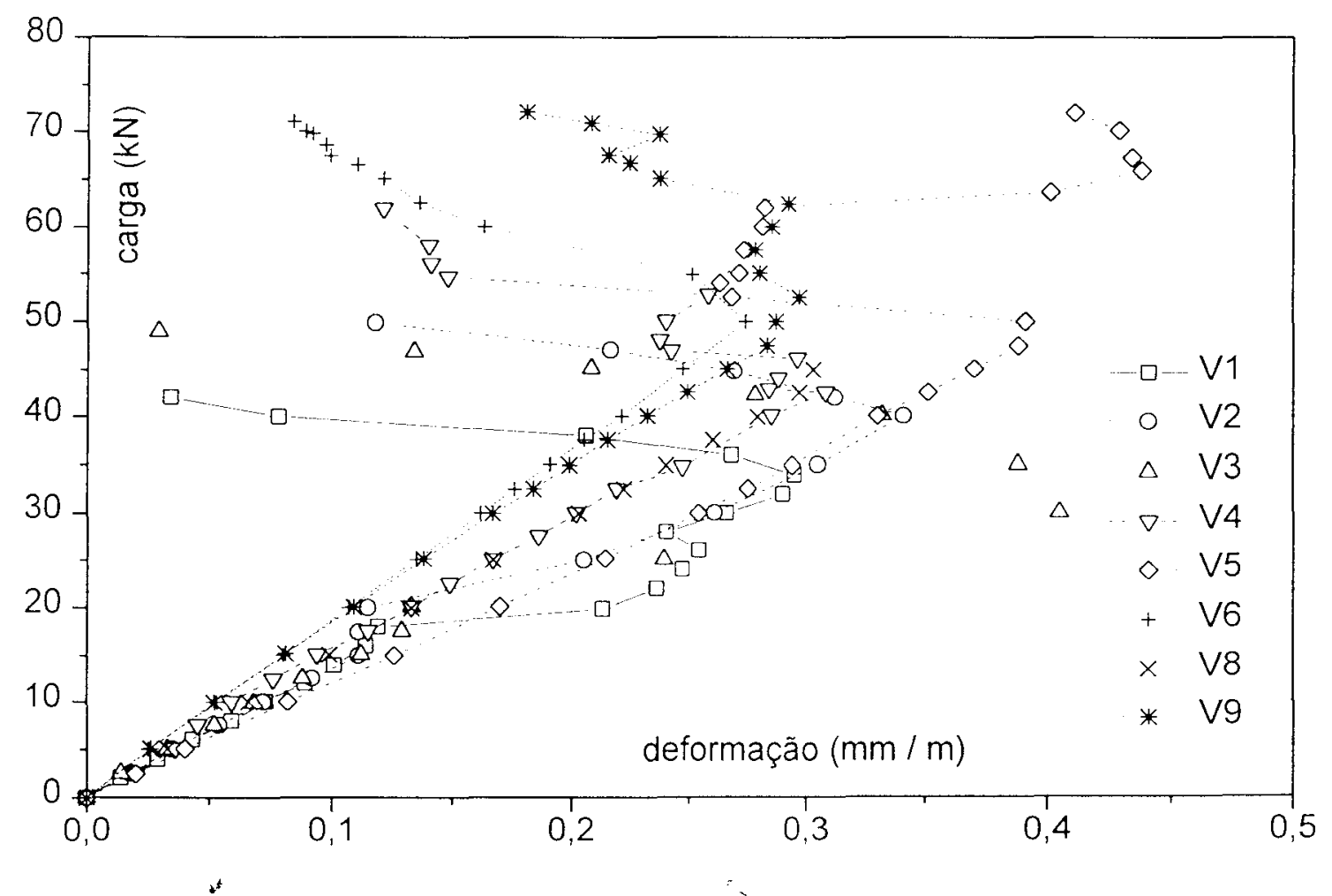

Figura 5.69 - Deformação no ponto maîs solicitado no concreto (C3-C4) 


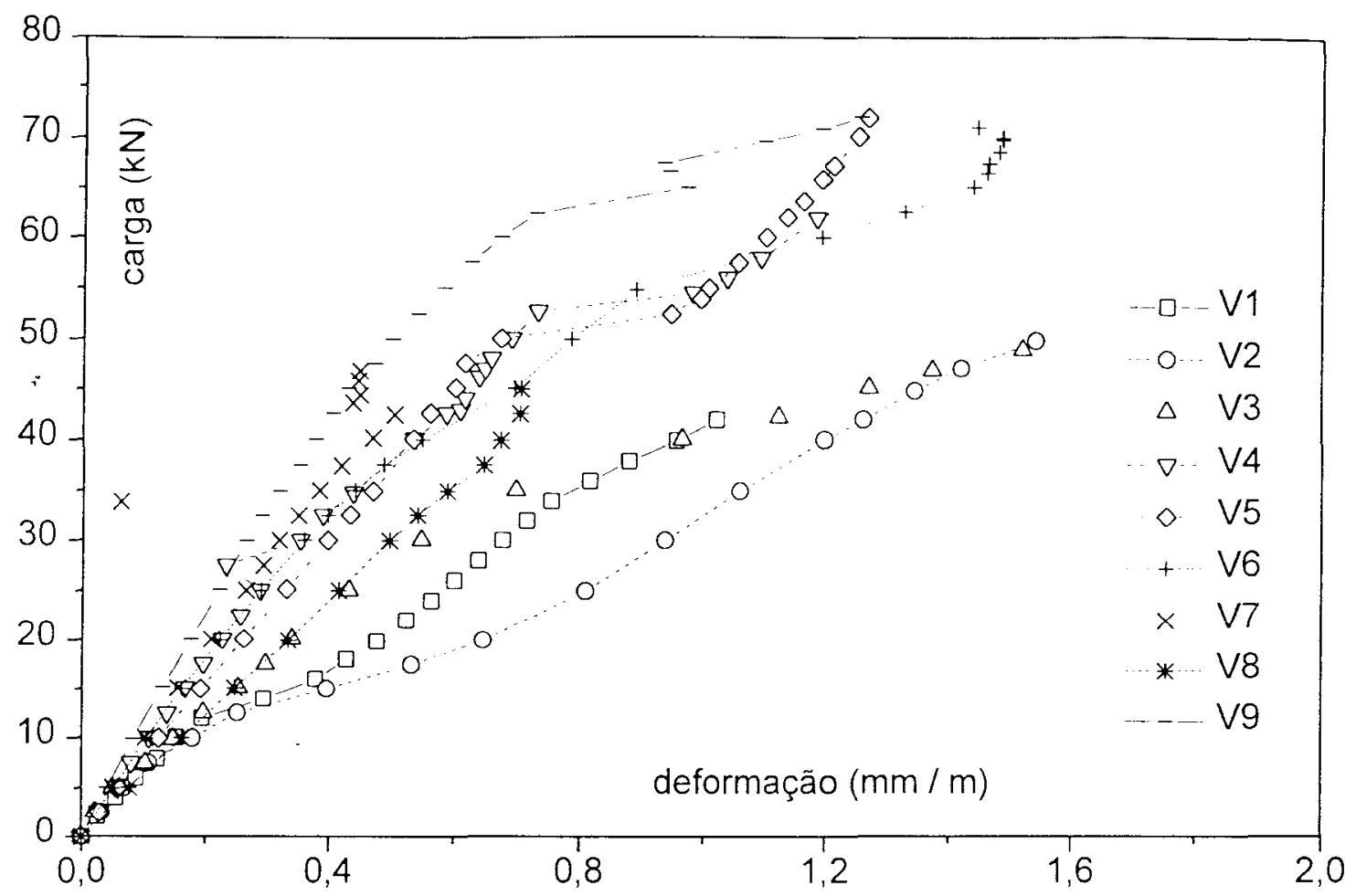

Figura 5.70 - Deformação no ponto mais solicitado no concreto (C5-C6)

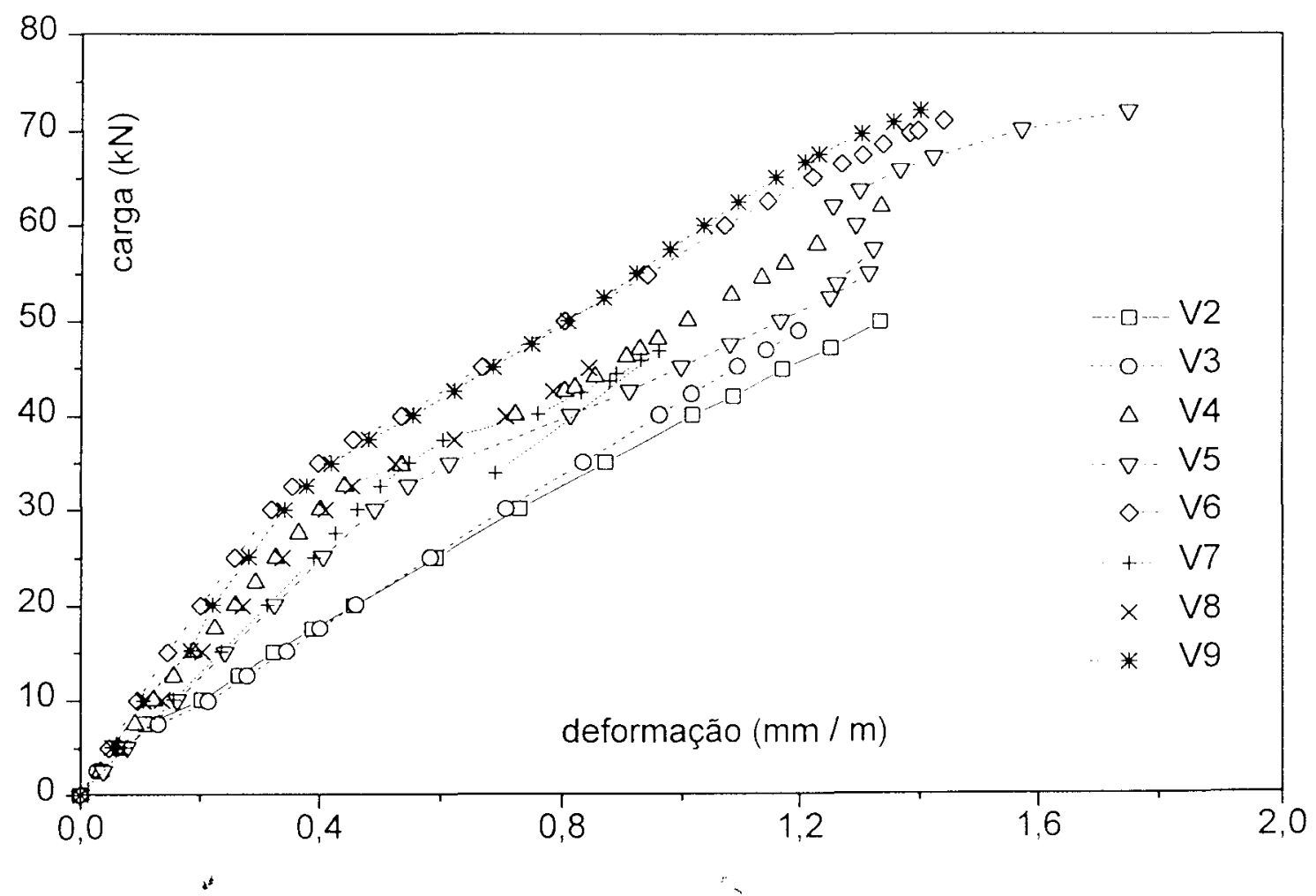

Figura 5.71 - Deformação no ponto máais solicitado no concreto (C0) 


\subsection{9 - CONCRETO NA ALMA}

O comportamento do concreto na região da alma pode ser avaliado a partir dos resultados das rosetas. Os extensômetros elétricos aplicados ao concreto sofrem a influência direta das fissuras que surgem próximas a eles. Porisso, as rosetas foram posicionadas sempre entre dois estribos, numa região de uma provável biela. No entanto, a transferência da carga através de outras bielas complementares e o consequente aparecimento de fissuras de cisalhamento na posição das rosetas provocam irregularidades nos resultados após o surgimento das fissuras inclinadas.

Tendo em vista as perturbações decorrentes da fissuração, que normalmente coincidem com o aparecimento de fissuras nas proximidades das rosetas, a análise dos resultados após a fissuração por cisalhamento é pouco consistente. Nos modelos sem protensão, portanto, o intervalo onde o desenvolvimento das deformações é linear foi menor. Nos modelos protendidos, as fissuras só atingiram as rosetas R1 e R2 no final do ensaio.

De um modo geral, a alteração do estado de tensões devido à introdução da protensão influiu mais no valor da tensão principal de compressão do que na tensão principal de tração. A principal modificação, no entanto, está na direção das tensões principais, quando as bielas se tornam mais abatidas.

A Tabela 5.16 apresenta os parâmetros relativos à compressão da alma. Os valores de $\operatorname{cotg} \theta, \theta$ (inclinação da biela) e da tensão de compressão nesta direção foram calculados conforme expressão do CEB-90 para a treliça generalizada, utilizando-se o valor médio de $800 \mathrm{MPa}$ para a tensão nos estribos, já que em todos os modelos eles escoaram. Esta tensão corresponde a uma deformação de aproximadamente $1 \%$.

Tabela 5.16 - Parâmetros relativos à compressão da alma

\begin{tabular}{|c|c|c|c|c|c|}
\hline modelo & $\mathrm{V}_{\mathrm{u}}(\mathrm{kN})$ & $\operatorname{cotg} \theta$ & $\theta$ (graus) & $\sigma_{\mathrm{c} \theta}(\mathrm{MPa})$ & $\sigma_{\mathrm{c} \theta} / \tau_{\mathrm{ou}}$ \\
\hline $\mathrm{V} 1$ & 42 & 2,4 & 23 & 12,2 & 2,8 \\
\hline $\mathrm{V} 2$ & 50 & 2,9 & 19 & 16,4 & 3,2 \\
\hline $\mathrm{V} 3$ & 50 & 2,9 & 19 & 16,4 & 3,2 \\
\hline $\mathrm{V} 4$ & 63,5 & 3,6 & 15 & 25,4 & 3,9 \\
\hline $\mathrm{V} 5 \mathrm{x}^{*}$ & 73,5 & 4,2 & 13 & 33,4 & 4,4 \\
\hline $\mathrm{V} 6$ & 71,5 & 4,1 & 14 & 31,8 & 4,3 \\
\hline $\mathrm{V} 9$ & 72,5 & 5,7 & 10 & 44,4 & 6,0 \\
\hline
\end{tabular}


Conforme se observa, a introdução das fíbras torna as bielas mais abatidas, sobrecarregando a tensão no concreto e aliviando a tensão nos estribos. O mesmo acontece com a protensão, de forma mais pronunciada.

Como o grau de armação ao cisalhamento é muito reduzido, as diagonais de concreto resultaram bastante abatidas, com valores de $\operatorname{cotg} \theta$ próximos de 3,0 no caso * dos modelos sem protensão, sem que se tenha atingido o escoamento da armadura longitudinal. Além disso, a intensa fissuração no concreto e os deslocamentos transversais excessivos limitam a utilização da peça para cargas bem menores que a carga de ruptura, o que sugere a necessidade de se adotar um limite menor. Para os modelos protendidos, este valor pode ser comparativamente maior.

A relação entre a tensão máxima de compressão no concreto na direção da biela e a tensão máxima de cisalhamento convencional resultou maior que 2,0 em todos os casos, que é o valor previsto pela treliça clássica.

\subsubsection{0 - FORÇA DE PROTENSÃO}

A Figura 5.72 apresenta a evolução das forças durante o estiramento das cordoalhas para todos os modelos. As Figuras 5.73 a 5.84 ilustram o comportamento das cordoalhas durante o estiramento: para cada modelo protendido, apresentam-se os diagramas $\sigma-\varepsilon$ construídos a partir das deformações médias nas três cordoalhas e das deformações nos extensômetros da cordoalha central (C3). Estas figuras confirmam a boa aproximação das leituras dos extensômetros. especialmente para os valores médios da cordoalha central, e a consistência da instrumentação, .

Os valores da força de protensão dos modelos protendidos nos três instantes de interesse $\left(\mathrm{P}_{\mathrm{a}}, \mathrm{P}_{\mathrm{o}}\right.$ e $\left.\mathrm{P}_{1}\right)$ estão na Tabela 5.17. Eles foram calculados pelos três processos já discutidos anteriormente.

Os valores obtidos permitem considerar a força de protensão praticamente constante em todos os modelos. Além disso, revelam a consistência da instrumentação e dos métodos de avaliação da força de protensão. As diferenças máximas da força de protensão no instante do ensaio foram de $6,6 \%, 9,7 \%$ e $6,5 \%$, para os processos a. b e c, respectivamente. Nos três últimos modelos, onde a força registrada foi um pouco maior, ouṭ̣os indicadores relacionados com a força de descompressão, tais como a evolução das flechas e da deformação nas cordoalhas ou nos estribos, não confirmaram a diferença. 
Tabela 5.17 - Força de protensão nos modelos protendidos.

\begin{tabular}{|c|c|c|c|c|c|c|c|c|c|c|}
\hline \multirow{2}{*}{ viga } & \multirow{2}{*}{ cord } & \multicolumn{3}{|c|}{$\mathrm{P}_{\mathrm{a}}(\mathrm{kN})$} & \multicolumn{3}{|c|}{$P_{0}(k N)$} & \multicolumn{3}{|c|}{$\mathrm{P}_{\mathrm{t}}(\mathrm{kN})$} \\
\hline & & $\mathrm{a}$ & $\mathrm{b}$ & $\mathrm{c}$ & $\mathrm{a}$ & $b$ & c & $\mathrm{a}$ & $\mathrm{b}$ & $\mathrm{c}$ \\
\hline \multirow[b]{4}{*}{ V4 } & $\mathrm{L} 1$ & 41,8 & 42,8 & 41,7 & 38.3 & - & - & 34,7 & 35,5 & 34,7 \\
\hline & L2 & 42 & 40,6 & 40,1 & 38.8 & - & - & 34,4 & 33,2 & 32,8 \\
\hline & $\mathrm{C}$ & 42,3 & 42,6 & 40,5 & 39.3 & - & - & 35,4 & 35,7 & 34 \\
\hline & média & 42 & 42 & 40,8 & 38.8 & - & - & 34,8 & 34,8 & 33,8 \\
\hline \multirow[b]{4}{*}{ V5 } & $\mathrm{Ll}$ & 41,8 & 38,3 & 37,3 & 37.5 & 34,3 & 33,4 & 34 & 31,1 & 30,3 \\
\hline & $\mathrm{L} 2$ & 44,7 & 45,4 & 46,9 & 40,5 & 41,1 & 42,4 & 36,7 & 37,3 & 38,5 \\
\hline & $\mathrm{C}$ & 42,4 & 41,5 & 40 & 38 & 37,2 & 35,8 & 34,5 & 33,7 & 32,5 \\
\hline & média & $\overline{43}$ & 41,7 & 41,4 & 38.7 & 37.5 & 37,2 & 35,1 & 34 & 33,8 \\
\hline \multirow[b]{4}{*}{ V6 } & L1 & 44,7 & 43,2 & 42,5 & 40.4 & 39,1 & 38,5 & 37,9 & 36,6 & 36,1 \\
\hline & $\mathrm{L} 2$ & 46,6 & 43,3 & 43,6 & 42.3 & 39,2 & 39,6 & 39,8 & 36,7 & 37,2 \\
\hline & $\mathrm{C}$ & 40,5 & 38,9 & 38,3 & 36,2 & 34,8 & 34,3 & 33,7 & 32,3 & 31,9 \\
\hline & média & 43,9 & 41,8 & 41,5 & 39,6 & 37,7 & 37,5 & 37,1 & 35,2 & 35,1 \\
\hline \multirow[b]{4}{*}{ V7 } & $\overline{\mathrm{L} 1}$ & 41,1 & 42,7 & 41,2 & 38.3 & 39,2 & 37,7 & 36,2 & 37,1 & 35,8 \\
\hline & L2 & 41,7 & 43,4 & 40,9 & 41.2 & 42,8 & 40,4 & 39,1 & 40,6 & 38,3 \\
\hline & $\mathrm{C}$ & 43,1 & 43,1 & 42.7 & 36.4 & 36,4 & 36,2 & 34,3 & 34.2 & 34 \\
\hline & média & 42 & 43,1 & 41,6 & 38.6 & 39.4 & 38,1 & 36,5 & 37,3 & 36 \\
\hline \multirow[b]{4}{*}{ V8 } & L1 & 42,7 & 42,1 & 36,8 & 38.4 & 39.2 & 37,8 & 35,2 & 34,7 & 30,3 \\
\hline & $\mathrm{L} 2$ & 41,9 & 41,7 & 40,6 & 40.2 & 42.8 & 39,9 & 37,7 & 37,5 & 36,5 \\
\hline & $\mathrm{C}$ & 42 & 43,7 & 40 & 39.1 & 40.7 & 37,3 & 36,3 & 37,8 & 34,6 \\
\hline & média & 42,2 & 42,5 & 39,1 & 39.2 & 40,9 & 38,3 & 36,5 & 36,7 & 33.8 \\
\hline \multirow[b]{4}{*}{ V9 } & L1 & 45,3 & 44,1 & 41,5 & 40.4 & 39.3 & 37,1 & 39,1 & 38,1 & 35,9 \\
\hline & $\mathrm{L} 2$ & 46 & 46 & 42,2 & 40.6 & 40,6 & 37,3 & 38,9 & 38,9 & 35.7 \\
\hline & C & 40 & 39,1 & 37,2 & 35 & 34.2 & 32,5 & 33,4 & 32,7 & 31,1 \\
\hline & média & 43,8 & 43,1 & 40,3 & 38.7 & 38 & 35,6 & 37,1 & 36,6 & 34,2 \\
\hline
\end{tabular}

A Tabela 5.18 apresenta alguns parâmetros relativos ao instante da liberação da força de protensão para o concreto: módulo de deformação longitudinal aparente das cordoalhas (valor médio), encurtamento das cordoalhas (em alguns modelos apresentase dois valores, quando a média das três cordoalhas difere da média da cordoalha central; nestes casos, o segundo valor se refere à cordoalha central), variação da força de protensão devido ao encurtamento das cordoallias, e tensão de tração na borda superior dețido à protensão (calculada com as deformações médias dos extensômetros do concreto na mesa comprimida e o respectivo módulo de deformação experimental). As duas últimas colunas foram acrescentadas como alternativas para análise da força de protensão. Na penúltima coluna, os valores nos instantes $t_{0}$ e $t$ foram estimados a partir 
da variação percentual na deformação da cordoalha central, que era mais instrumentada, e que foi descontada do valor de $\mathrm{P}_{\mathrm{a}}$ registrado nas células de carga. Isso corresponde à aplicação do método a, empregando-se apenas os resultados da cordoalha central. $\mathrm{Na}$ última coluna, a partir das deformações médias dos extensômetros horizontais das rosetas e do módulo de deformação longitudinal do concreto, estimou-se o valor da i força de protensão.

Tabela 5.18 - Parâmetros relativos à protensão dos modelos protendidos

\begin{tabular}{|c|c|c|c|c|c|c|}
\hline modelo & $\mathrm{E}_{\mathrm{a}}(\mathrm{MPa})$ & $\Delta \varepsilon(\%)$ & $\Delta \mathrm{P}(\mathrm{kN})$ & $\sigma_{\mathrm{tab}}(\mathrm{MPa})$ & $\mathrm{P}_{0} / \mathrm{P}_{\mathrm{t}}$ & $\mathrm{P}_{\mathrm{o}}(\mathrm{kN})$ \\
\hline $\mathrm{V} 4$ & 218800 & 0,029 & 3,5 & - & $39 / 35,2$ & - \\
\hline V5 & 214900 & $0,028 / 29$ & 3,3 & - & $37,6 / 34,1$ & - \\
\hline V6 & 214300 & 0,027 & 3,1 & 2,3 & $38,9 / 36,1$ & 33,8 \\
\hline V7 & 220000 & $0,032 / 28$ & 3,8 & 2,35 & $36,4 / 34,2$ & 43,1 \\
\hline V8 & 231000 & $0,03 / 29$ & 3,7 & 2,4 & $40,6 / 36,5$ & 40,9 \\
\hline V9 & 226800 & 0,026 & 3,2 & 1,95 & $38,3 / 36,6$ & 34,5 \\
\hline
\end{tabular}

Os valores do encurtamento das cordoalhas durante a liberação da protensão devido ao encurtamento elástico do concreto confirmam a uniformidade da força de protensão dos modelos, especialmente quando se compara o comportamento da cordoalha central, que é mais confiável. Além disso. as tensões de tração na borda superior estão dentro dos limites admissíveis. coicindindo com o não aparecimento de fissuras de flexão nesta etapa.

Os valores da força de protensão calculados pela variação da deformação da cordoalha central também são próximos daqueles calculados anteriormente. A diferença entre os valores extremos no dia do ensaio foi de 7\%. As perdas até o instante $t_{0}$, medidas na cordoalha central, variaram de $14 \%$ a $21 \%$, tomando-se os valores finais em relação aos valores ancorados.

Os valores da última coluna e da tensão de tração na borda superior foram calculados a partir das deformações nas rosetas. Eles apresentaram maior variação, provavelmente devido à introdução de outras variáveis no cálculo, principalmente o módulo de deformação do concreto. 

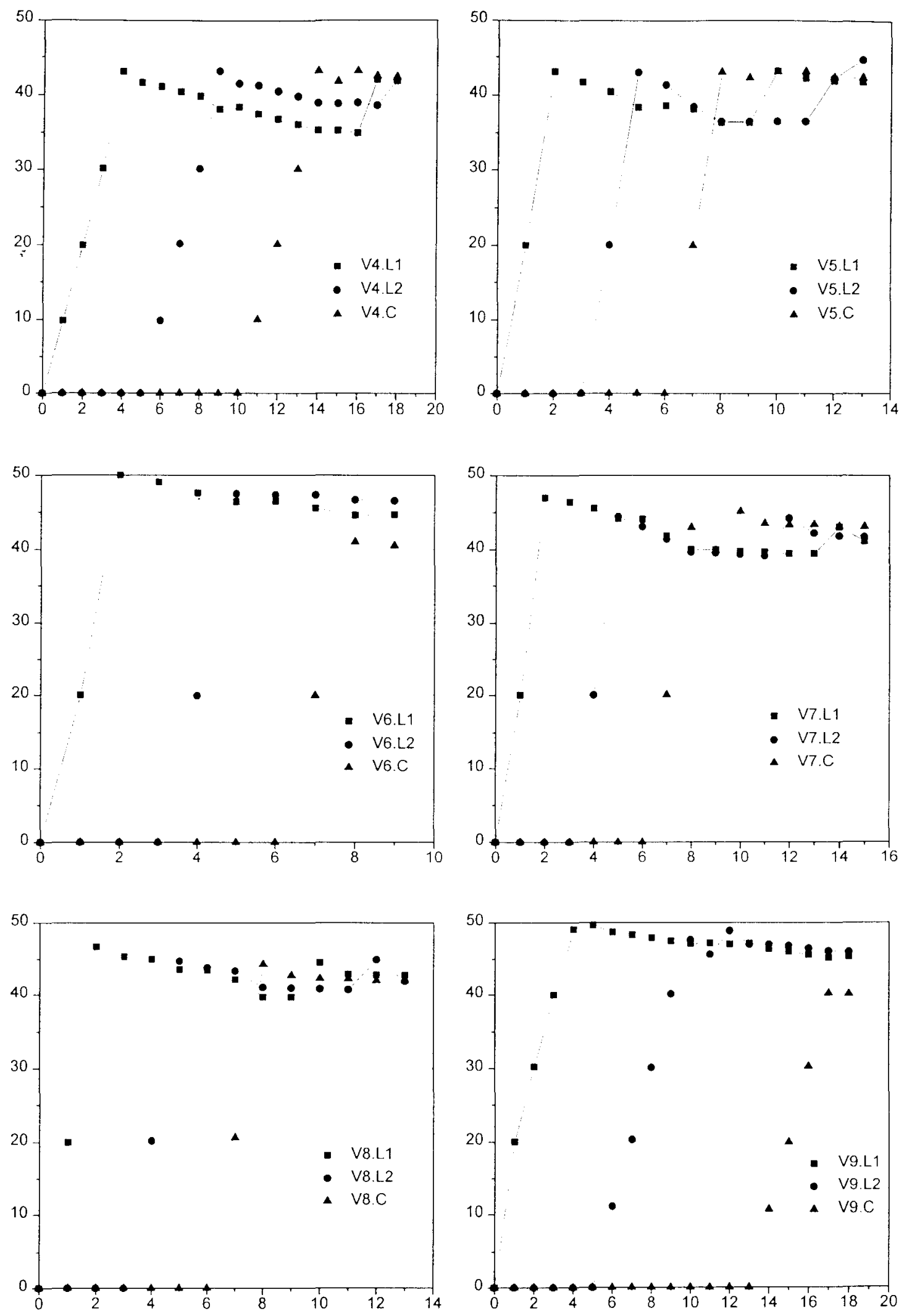

Figura 5.72 - Evolução da força nas cordoalhas $(\mathrm{kN})$ durante o estiramento 


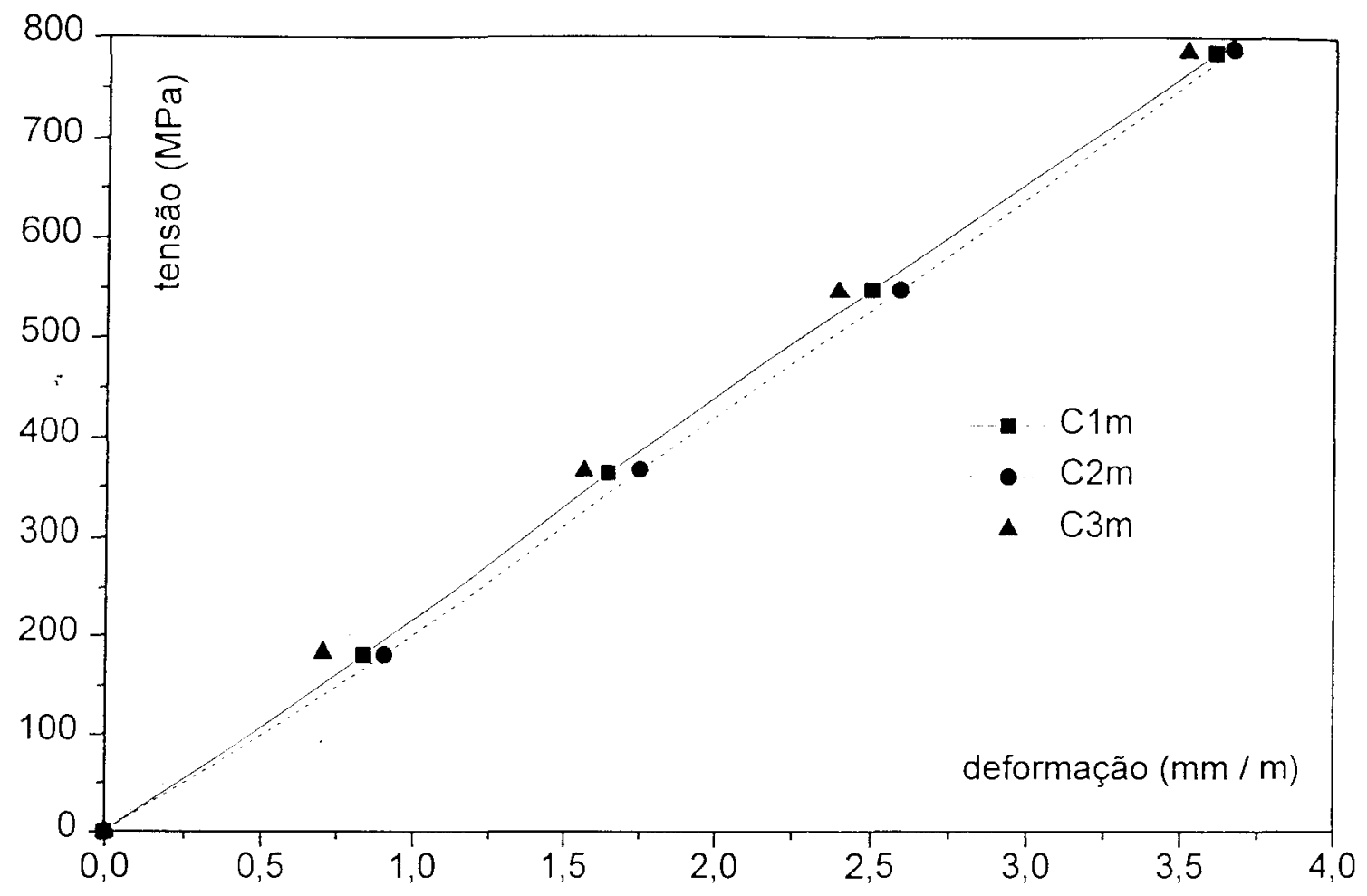

Figura 5.73 - Diagrama $\sigma-\varepsilon$ obtido no estiramento (média das três cordoalhas): V4

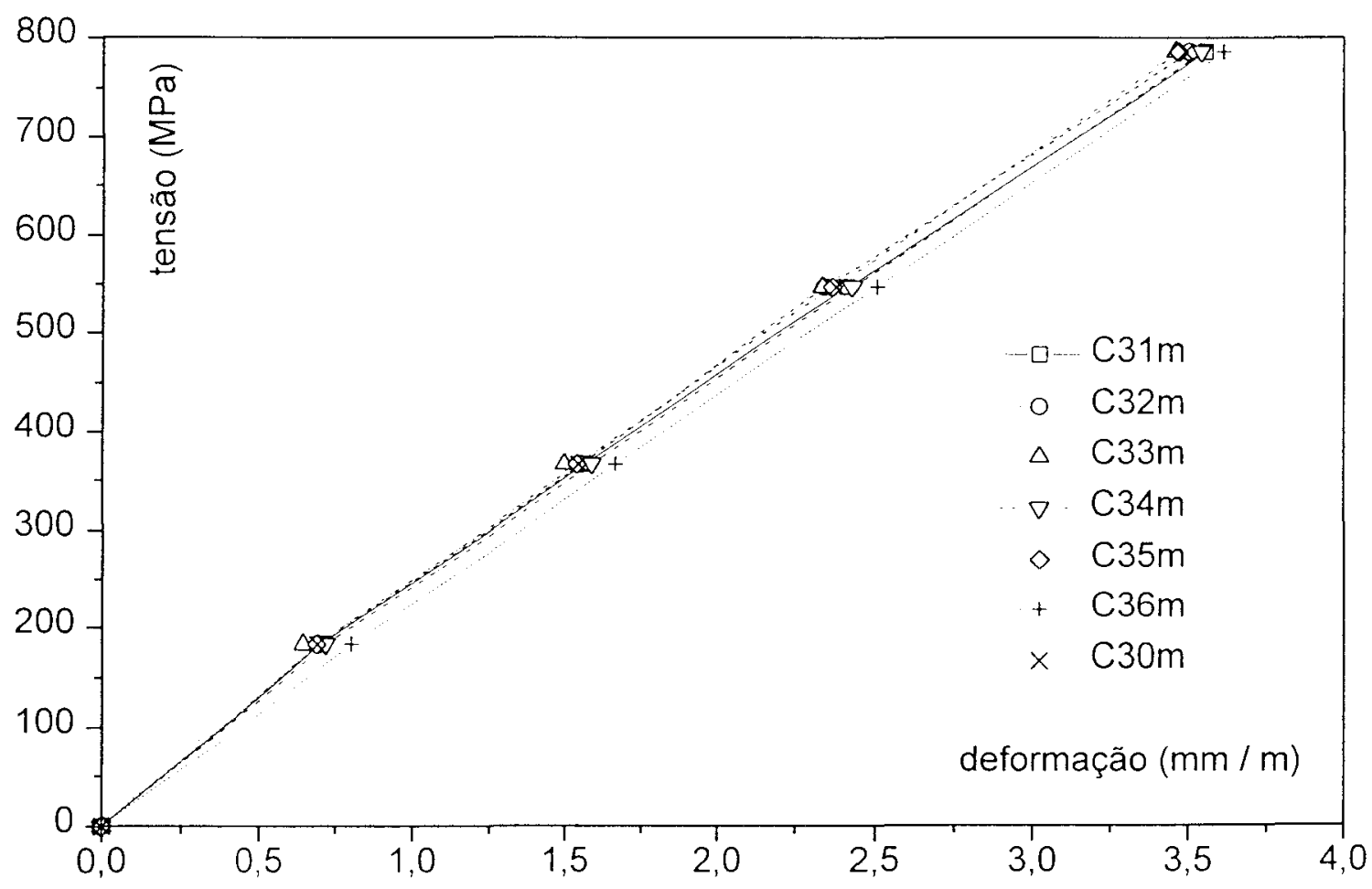

Figura 5.74 - Diagrama $\sigma-\varepsilon$ obtido no estiramento (média da cordoalha central): V4 


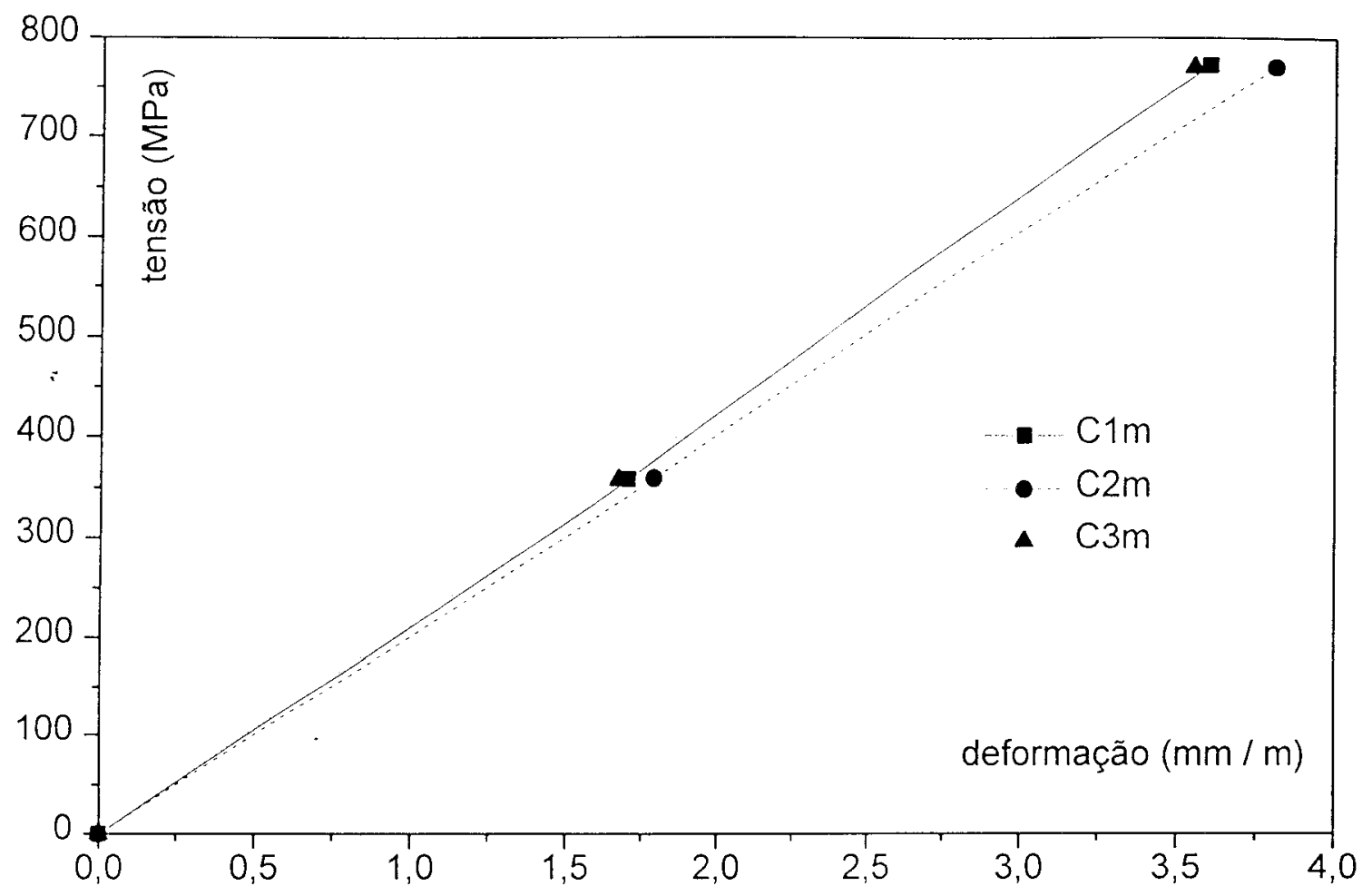

Figura 5.75 - Diagrama $\sigma-\varepsilon$ obtido no estiramento (média das três cordoalhas): V5

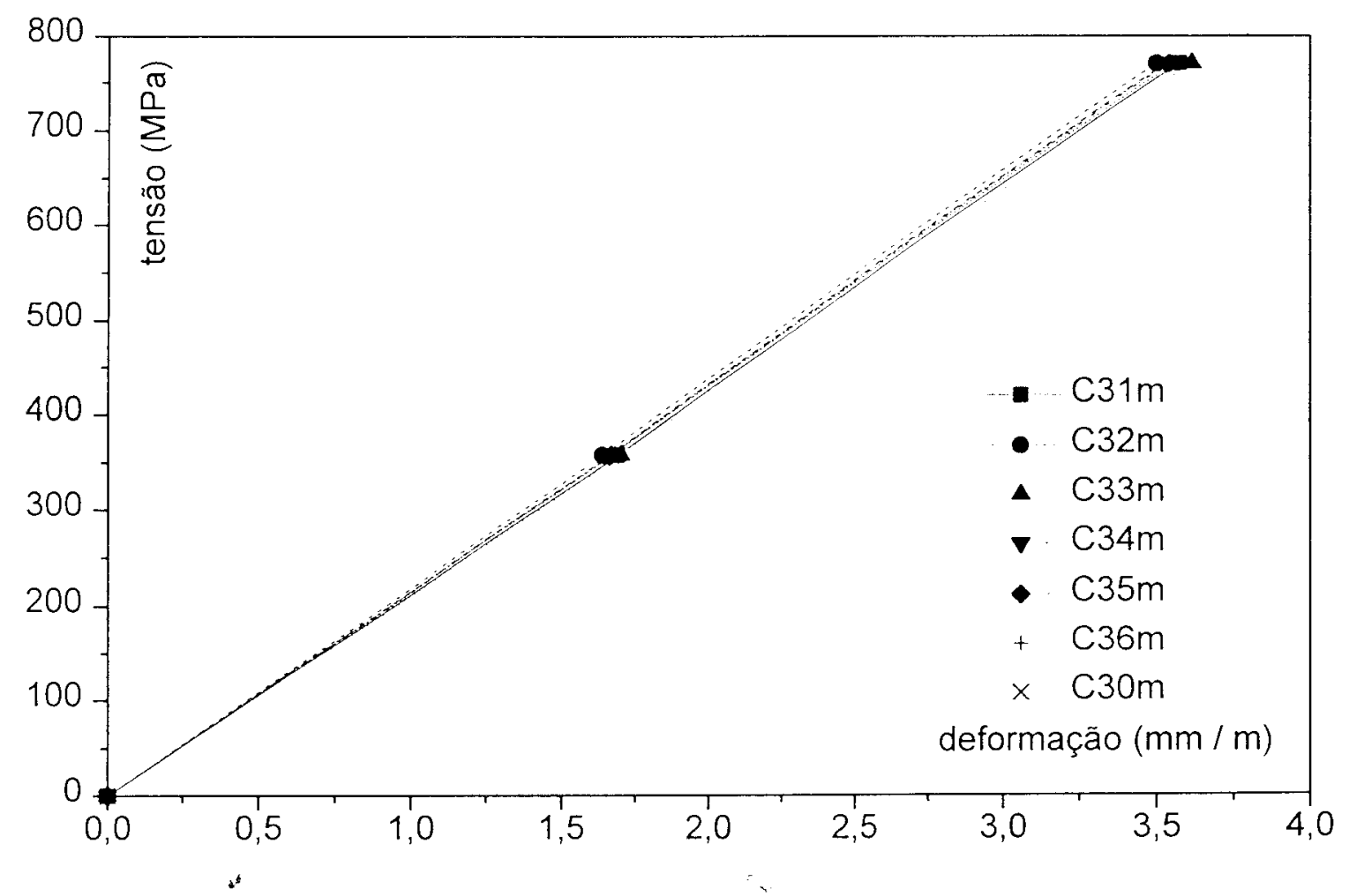

Figura 5.76 - Diagrama $\sigma-\varepsilon$ obtido no estiramento (média da cordoalha central): V5 


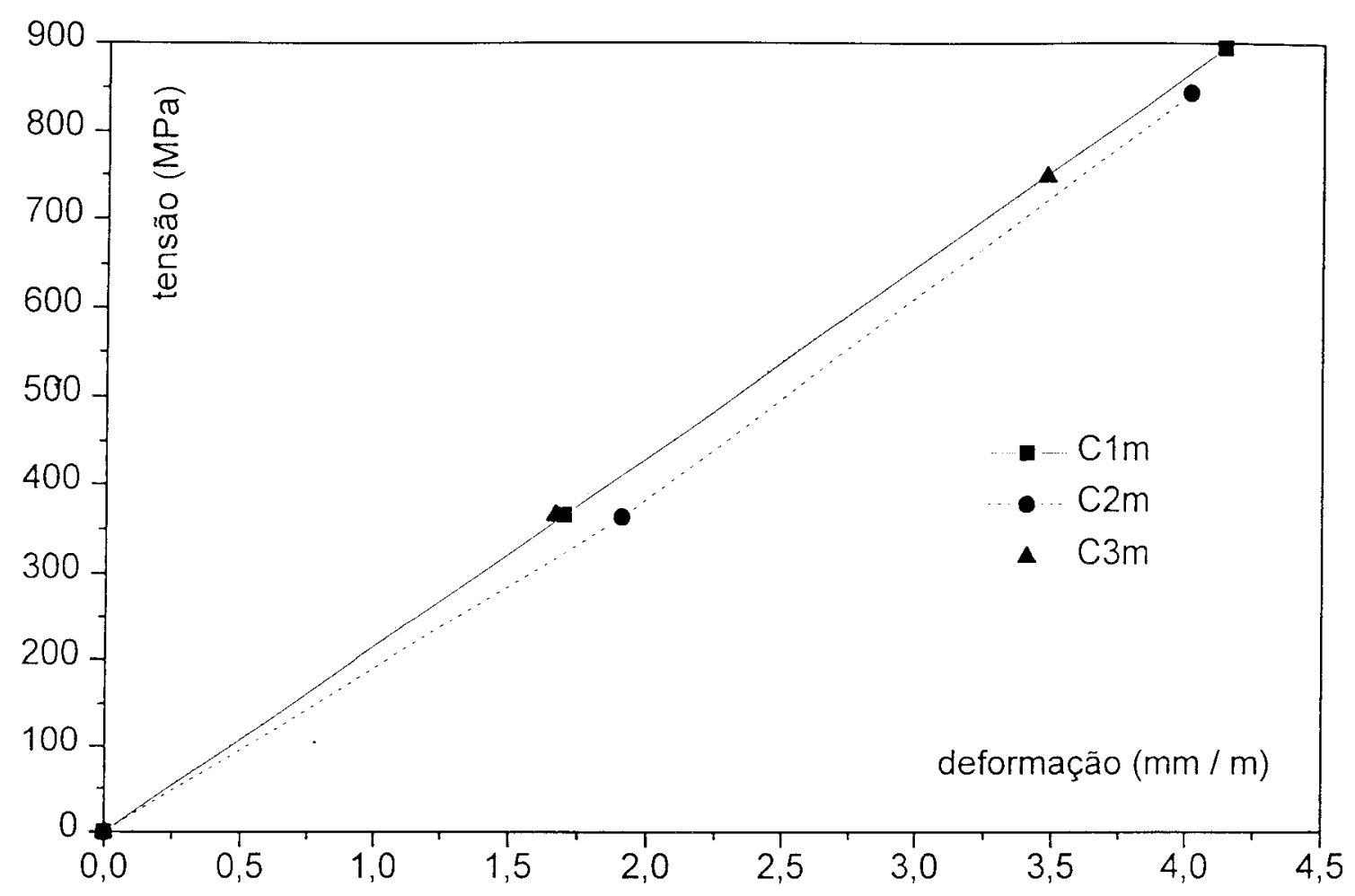

Figura 5.77 - Diagrama $\sigma-\varepsilon$ obtido no estiramento (média das três cordoalhas): V6

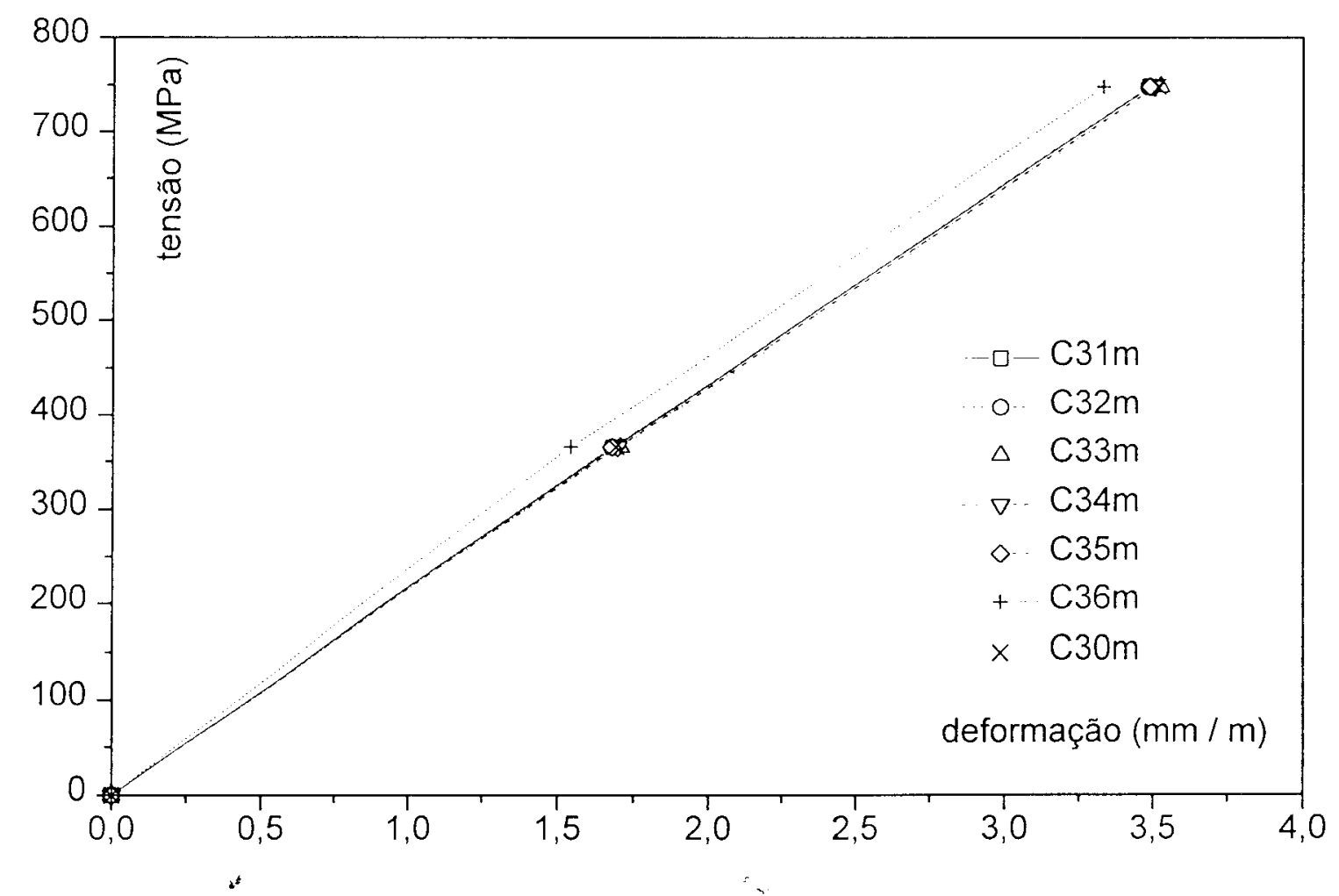

Figura 5.78 - Diagrama $\sigma-\varepsilon$ obtido no estiramento (média da cordoalha central): V6 


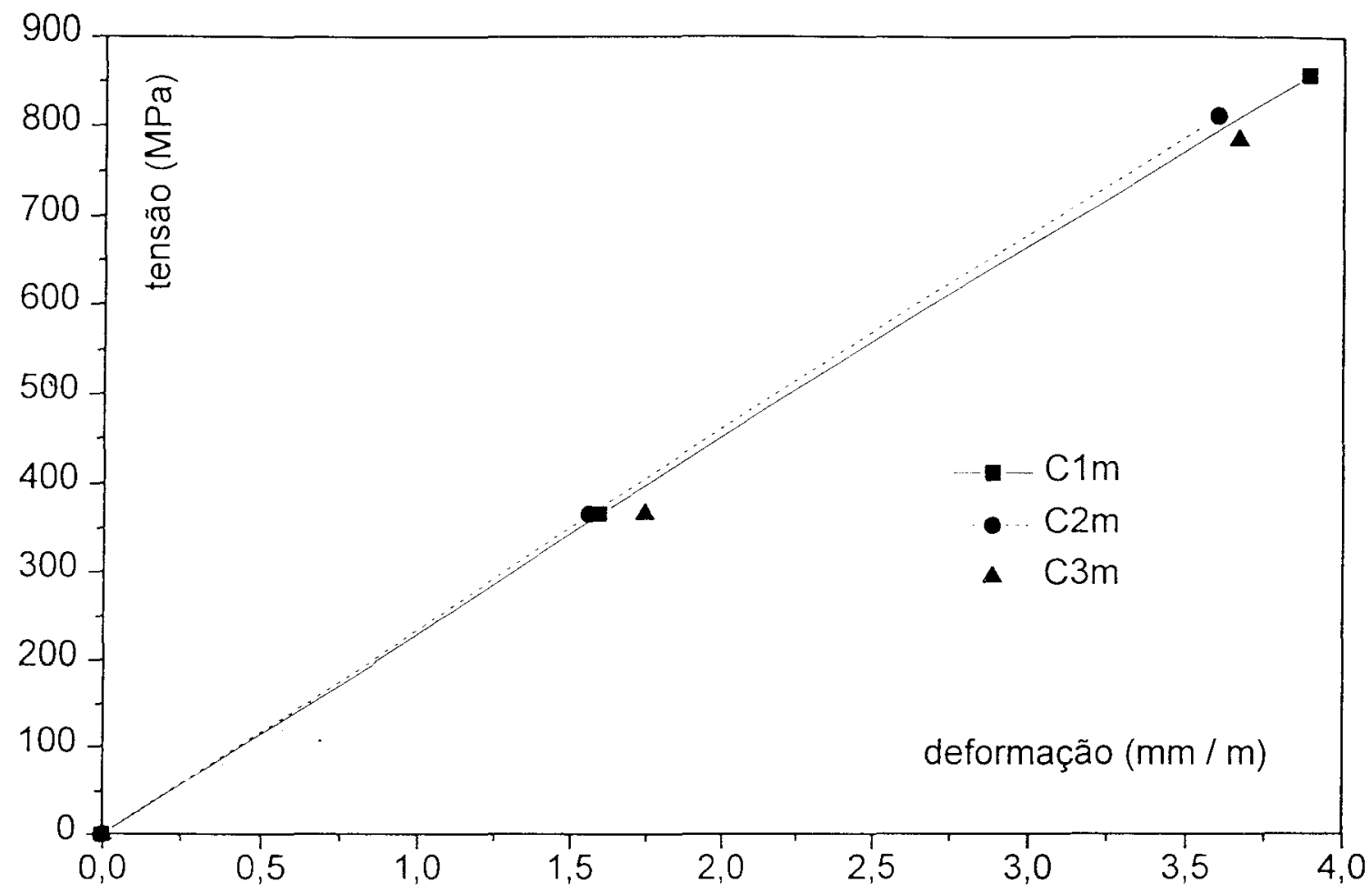

Figura 5.79 - Diagrama $\sigma-\varepsilon$ obtido no estiramento (média das três cordoalhas): V7

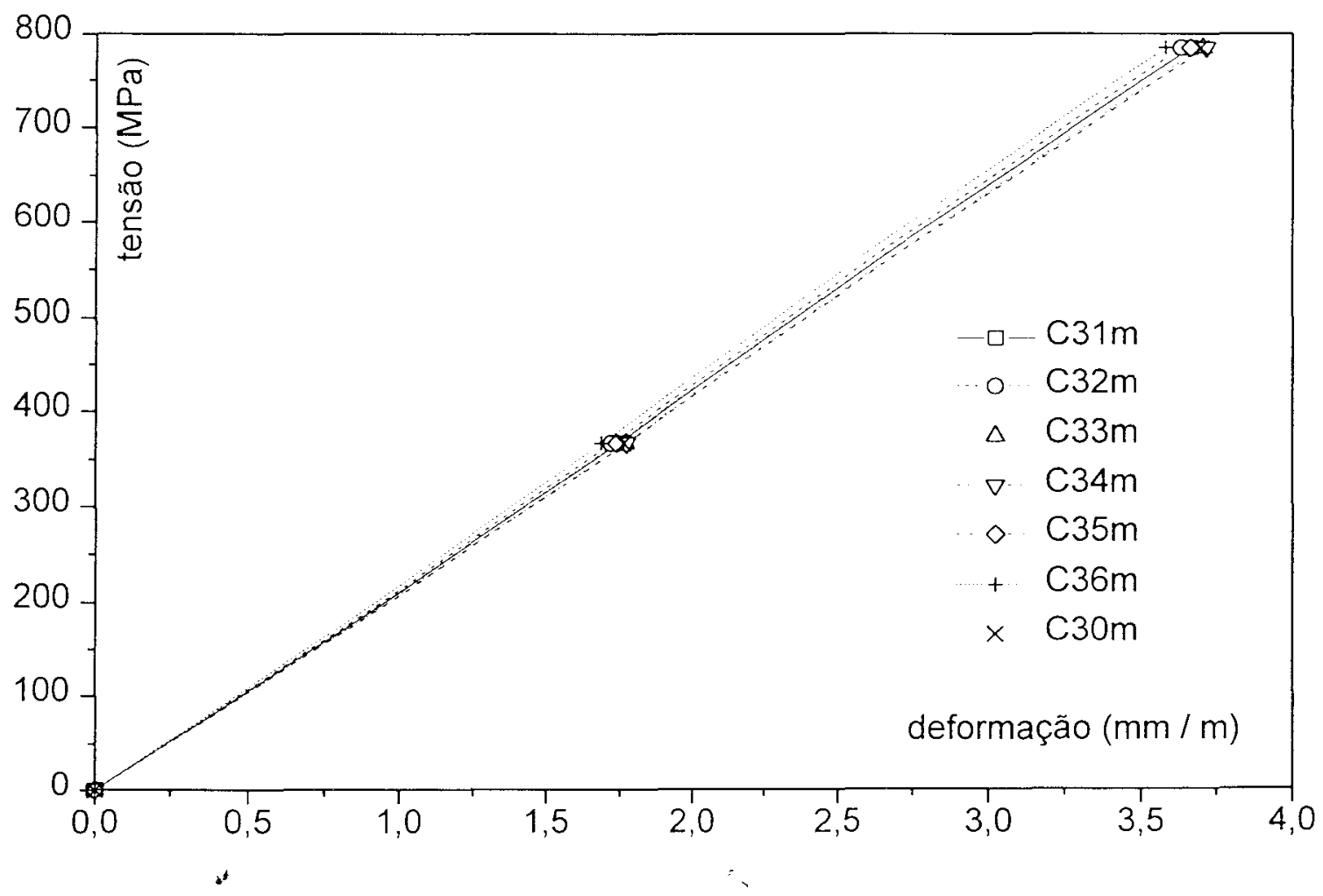

Figura 5:80 - Diagrama $\sigma-\varepsilon$ obtido no estiramento (média da cordoalha central): V7 


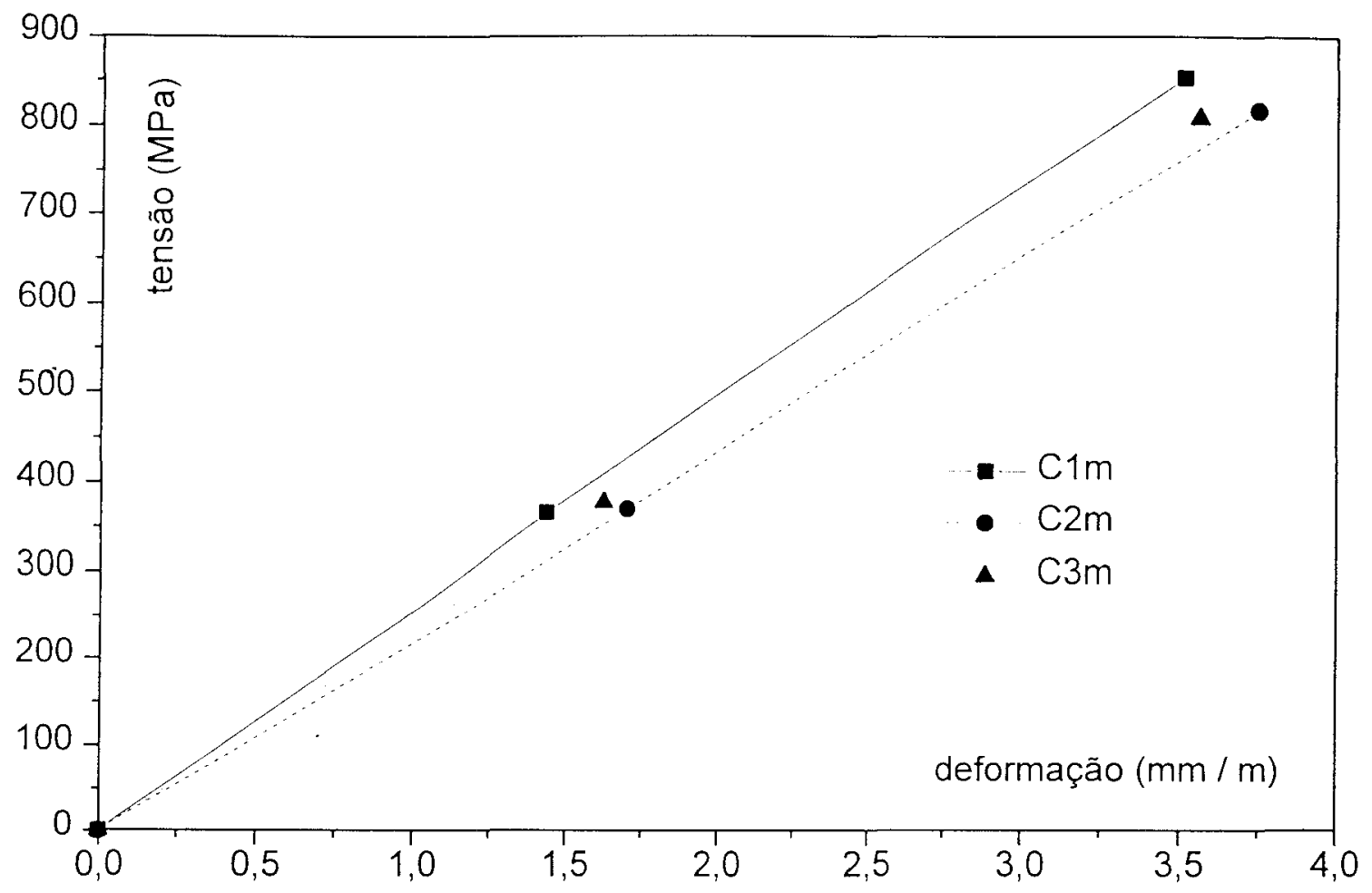

Figura 5.81 - Diagrama $\sigma-\varepsilon$ obtido no estiramento (média das três cordoalhas): V8

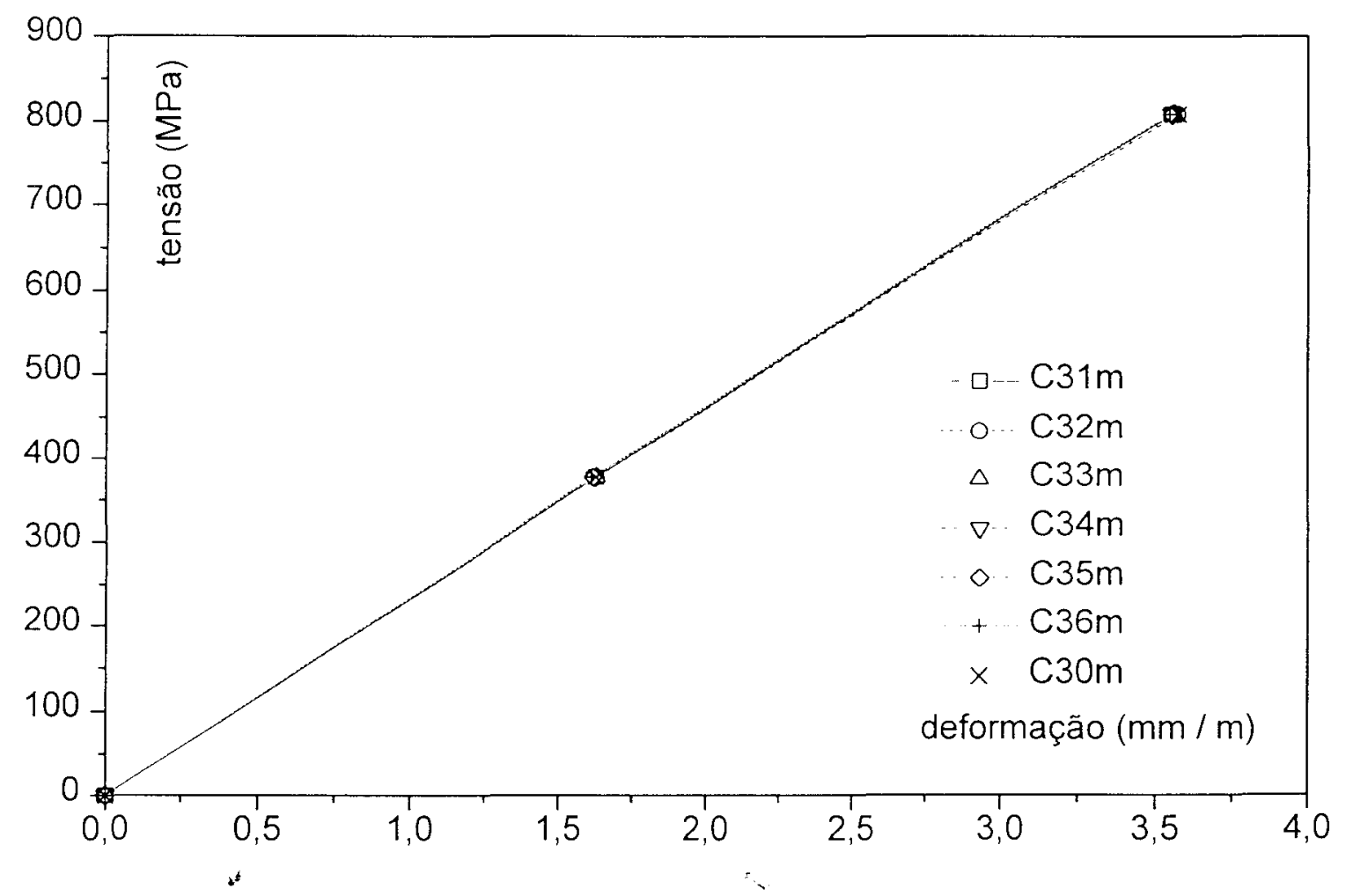

Figura 5.82 - Diagrama $\sigma-\varepsilon$ obtido no estiramiento (média da cordoalha central): V8 


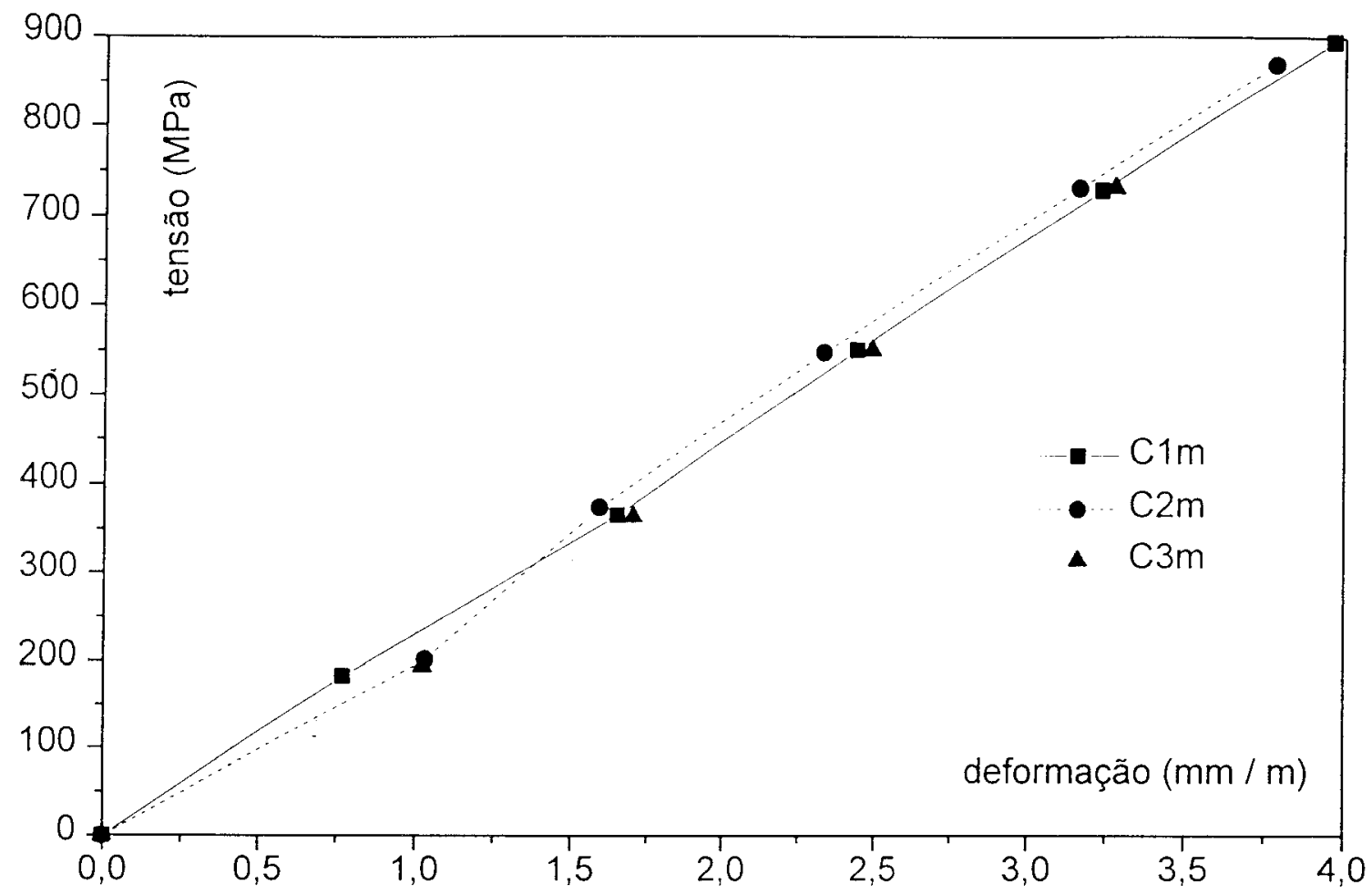

Figura 5.83 - Diagrama $\sigma-\varepsilon$ obtido no estiramento (média das três cordoalhas): V9

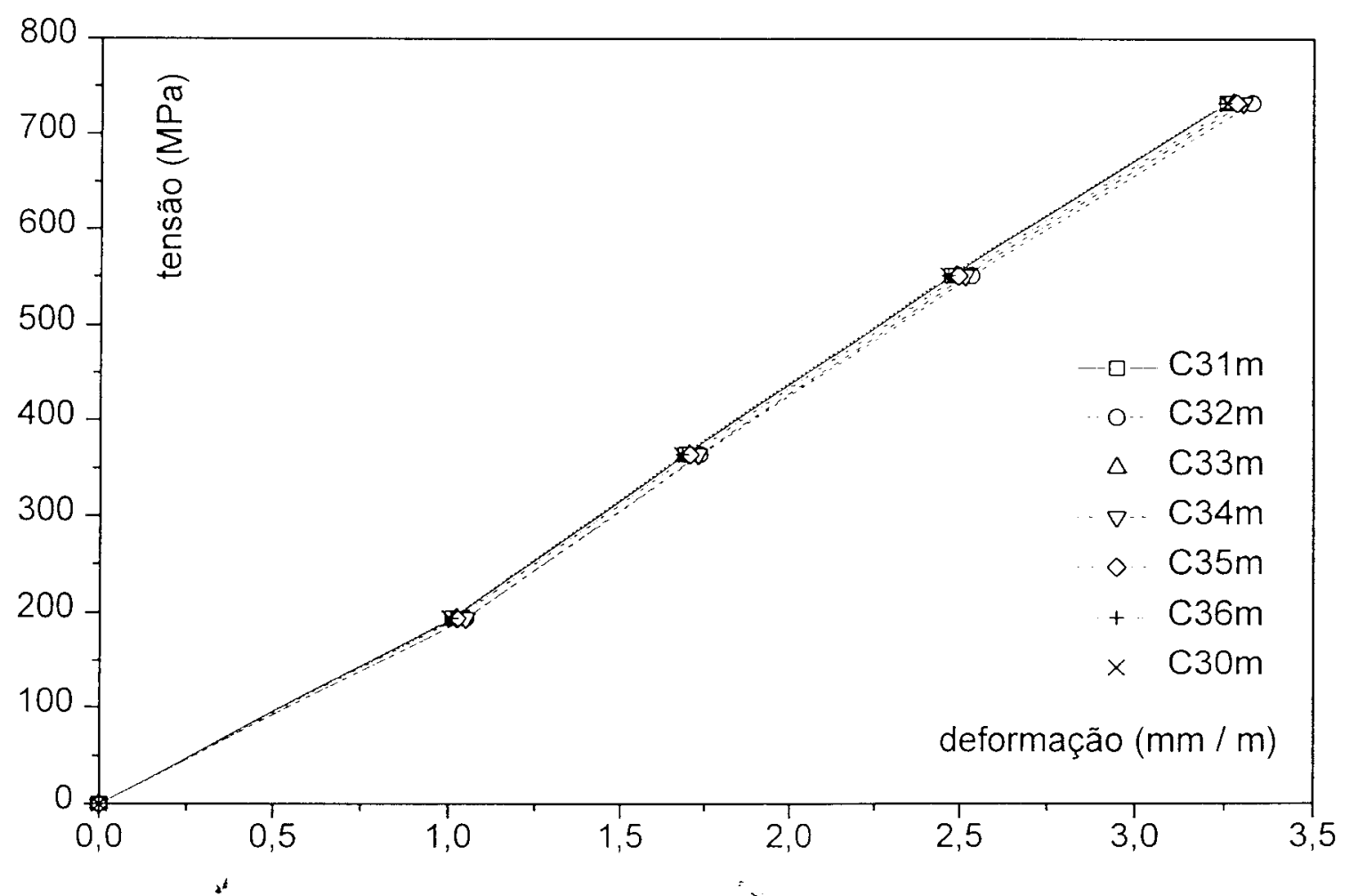

Figura 5.84 - Diagrama $\sigma-\varepsilon$ obtido no estiramento (média da cordoalha central): V9 


\section{9 - CONCLUSÕES PARCIAIS}

As principais conclusões obtidas com os ensaios das vigas de seção transversal duplo-T são descritas a seguir.

- A introdução das fibras não aumenta a resistência à compressão do concreto, mais associada à consistência da mistura. mas pode aumentar a resistência à tração.

- O valor do módulo de deformação longitudinal do concreto pode se alterar com a introdução das fibras. No entanto, o parâmetro determinante é a resistência à compressão. A expressão da NBR-6118 prevê com fidelidade a variação do valor do módulo com a resistência, mas para o microconcreto, com fibra ou sem fibra, deve-se aplicar um fator redutor próximo de 0.83 .

- Nos concretos com fibras o espaçamento entre fissuras é menor e a evolução da abertura das fissuras é mais lenta, especialmente no caso das fỉbras de aço. Consequentemente, os deslocamentos são menores. As fibras também são responsáveis pelo aparecimento de um maior número de fissuras inclinadas antes da peça atingir a ruína.

- As fissuras de cisalhamento surgem com aberturas maiores que as fissuras de flexão. O valor da tensão tangencial convencional correspondente ao início da fissuração diagonal foi menor que a resistência à tração do concreto nos modelos sem protensão.

- A protensão aumentou a etapa elástico-linear. mas, ao contrário das fibras, não alterou a diferença entre o instante da fissuração diağonal e o instante da ruptura por cisalhamento. O aparecimento de fissuras inclinadas é retardado e, consequentemente, os estribos são acionados depois, devido ao aumento na contribuição do concreto.

- A protensão torna as bielas mais abatidas e aumenta a extensão da zona não fissurada.

- A eficiência das fibras é maior nas vigas com estribos. Em todos os modelos com fibras a ruptura foi mais dútil e houve acréscimo na capacidade resistente ao cisalhamento, sempre entre $8 \mathrm{kN}$ e $10 \mathrm{kN}$. As fibras podem ser analisadas como uma armadura transversal equivalente. $\Lambda$ s vantagens proporcionadas pelas fibras de aço e polipropileno neste aspecto são similares, mas, considerando-se a diferença da resistênçia do concreto, o desempenho da fibra de polipropileno foi melhor. Não se registrou diferenças quantitativas significativas em relação às vigas de seção quadrada devido à menor concentração de fỉbras na alma, tendo em vista o menor volume da alma em relação ao volume da peça. 
- A protensão também aumenta a resistência ao cisalhamento, independentemente da taxa de armadura transversal (desde que não haja escoamento da armadura longitudinal), mas de forma mais significativa que as fibras. Nas vigas com taxas reduzidas de armadura transversal, a influência da protensão é equivalente à descompressão da seção analisada.

- A formulação da Norma Brasileira subestima a parcela resistente do concreto, que pode diminuir com a evolução do carregamento. O valor de $\tau_{c}$ aumenta com as fibras e a protensão, tendo-se registrado valores próximos da resistência de modelos similares sem estribos.

- As tensões nos estribos foram sempre menores do que o valor previsto pela treliça de Mörsch, devido à menor inclinação das biclas e à contribuição do concreto. As tensões nos estribos foram sempre menores nos modelos com fibra de aço.

- A inclinação preferencial das bielas situou-se entre 25 e 35 graus, na situação em que os estribos são mais solicitados.

- As tensões na armadura longitudinal foram maiores do que prevê o equilíbrio da resultante de compressão devido às solicitações normais, confirmando a necessidade de cobertura do diagrama de momento fletor, devido à mobilização do mecanismo de treliça na transferência das forças transversais. Além disso, outras perturbações podem alterar a força na armadura. tais como a flexão localizada devido ao apoio das bielas e o atirantamento da resultante de compressão junto aos apoios.

- A diminuição da tensão de compressão no concréto seguramente atinge as seções distantes 2,2d dos apoios, podendo se estender até mais de $3,5 \mathrm{~d}$, quando a ruptura por força cortante não é prematura. Consequentemente. a partir destas seções, a carga pode ser transmitida diretamente até os apoios. Em vigas sem estribos o fenômeno só ocorre na iminência da ruptura.

- A aplicação de rosetas para avaliar o comportamento do concreto na alma tem utilidade restrita, devido ao aparecimento prematuro de lissuras nesta região. 


\section{CAPÍTULO 6 - CONCLUSÕES}

Ao final deste trabalho, espera-se que os principais objetivos propostos tenham sido alcançados. A revisão dos conhecimentos sobre o comportamento estrutural nas solicitações por força cortante de elementos de concreto armado e protendido, além de ilustrar o panorama atual dos trabalhos nesta área, permitiu avaliar as possíveis particularidades dos elementos protendidos de microconcreto de seção delgada reforçados com fibras curtas.

O desempenho dos elementos de concreto protendido de seção delgada com fibras, com pouca ou nenhuma armadura transversal, e a melhoria do comportamento resistente ao cisalhamento decorrente da adição de fibras curtas ao concreto e da aplicação da protensão foi analisada através de ensaios em laboratório.

A série de ensaios das vigas de seção quadrada abordou especificamente os efeitos da adição de fibras de aço ondulada e de polipropileno ao concreto, tanto em relação à produção, como em relação ao desempenho estrutural, sob situações distintas de armadura transversal. A série de ensaios de vigas de seção transversal duplo-T continuou esta análise, limitada a um volume constante de cada tipo de fibra. Nestes ensaios, investigou-se ainda a influência da protensão no cisalhamento em vigas com taxas reduzidas de armadura transversal. Além do panorama global de desempenho, os resultados sugerem algumas indicações sobre a possibilidade de redução da armadura de cisalhamento, conforme as condições e restrições levantadas neste trabalho.

A introdução das fibras piora a trabalhabilidade do concreto proporcionalmente ao volume adicionado. No entanto, este problema só foi efetivamente observado para a fibra de polipropileno. A utilização de técnicas convencionais de mistura limita $o$ volume de fibras possivel de ser misturado, em função do tipo de fibra e da sua relação de aspecto. 
As propriedades mecânicas do concreto reforçado com volume reduzido de fibras, sobretudo no que se refere à resistência e ao módulo de deformação, são similares às do concreto comum. Em geral, as fibras não alteram a resistência à compressão, que estaria mais associada à consistência da mistura. Pode haver um pequeno acréscimo na resistência à tração, como se observou no caso da fibra de aço de $\$ 3,81 \mathrm{~cm}$. O valor do módulo de deformação longitudinal do concreto também pode variar. como ocorreu com o concreto reforçado com fibra de aço de $2,54 \mathrm{~cm}$. Porém, independentemente das fibras, o valor foi sempre proporcional à resistência à compressão. A expressão da NBR-6118 prevê com fidelidade a variação no valor do módulo com a resistência, mas para o microconcreto, com fibra ou sem fibra, deve-se aplicar um fator redutor próximo de 0,83 .

No concreto com fibras a fissuração é mais difusa, a evolução das fissuras é mais lenta e o espaçamento entre as fissuras é menor. Com isso, a rigidez após a fissuração aumenta e os deslocamentos diminuem. Estes resultados foram mais claros para a fibra de aço, independentemente do volume adicionado. Além disso, as fibras permitem o aparecimento de um maior número de fissuras inclinadas antes da peça atingir a ruína.

As fibras aumentam a resistência ao cisalhamento: em praticamente todos os ensaios houve aumento da resistência no caso de concreto com fibras. Eventualmente, o modo de ruptura pode se alterar.

Nas vigas sem estribos a eficiência das fibras foi menor. Somente nas vigas de seção quadrada reforçadas com $2 \%$ de fibra de aço houve acréscimo significativo da dutilidade e da resistência adicional após a fissuração diagonal. Nestas peças, o desempenho foi similar ao da viga de concreto sem fibras e com estribos, comprovando a possibilidade de substituição dos estribos.

Nas vigas de seção quadrada com estribos, em quatro modelos alterou-se o modo de ruptura. Em todos os modelos com fibras a ruptura foi mais dútil. Nas vigas de seção transversal duplo-T, embora a forma de ruptura não tenha mudado, também houve aumento da dutilidade e da capacidade resistente. O aumento da resistencia esteve sempre entre $8 \mathrm{kN}$ e $10 \mathrm{kN}$, o que sugere a possibilidade de se analisar as fibras como uma armadura transversal equivalente. A eficiencia das fibras de aço e polipropileto foram similares, mas considerando-se a diferença no valor da resistência do concreto. o desempenho da fibra de polipropileno foi surpreendente.

Não se registraram diferenças significativas entre as vigas de seção quadrada e as vigas de seção duplo- $T$, no que se refere à contribuição das fibras na resistência ao 
cisalhamento. A menor quantidade de fibras na alma da seção delgada, devido ao menor volume da alma em relação ao volume da peça, talvez seja compensada pela melhor orientação das fibras, mais alinhadas à direção da solicitação de tração.

Observou-se ainda que a forma de atuação das fibras de aço e de polipropileno nas fissuras diagonais são distintas, principalmente devido à diferença no módulo de deformação longitudinal. No concreto reforçado com fibras de aço as tensões nos estribos são menores. Porém, independentemente do tipo de fibra, o controle da fissuração toma-se mais eficiente, melhorando a contribuição dos mecanismos resistentes alternativos.

A protensão propicia o aumento da etapa elástico-linear, retardando o aparecimento das fissuras de flexão e de cisalhamento. Conseqüentemente, os estribos são acionados depois. Porém, ao contrário das fibras, ela não altera a diferença entre o instante da fissuração diagonal e o instante da ruptura por cisalhamento, o que evidencia a diferença entre os mecanismos de atuação das fibras e da protensão: as fibras são eficientes após a fissuração; a protensão. antes da fissuração.

A protensão também provoca o abatimento das bielas e aumenta a extensão da zona não fissurada. A resistência ao cisalhamento é maior, independentemente da taxa de armadura transversal, desde que não haja escoamento da armadura longitudinal. $O$ acréscimo de resistência é muito mais significativo do que o proporcionado pelas fibras. Nas vigas com taxas reduzidas de armadura transversal. a influência da protensão é equivalente à descompressão da seção analisada.

Em relação ao comportamento geral das vigas e aos modelos de cálculo, observou-se que, nos modelos sem protensão, o valor da tensão tangencial convencional correspondente ao início da fissuração diagonal foi menor do que a resistência à tração do concreto. O valor de $\tau_{c}$ aumenta com a introdução das fibras e da protensão. A formulação da norma brasileira subestima a parcela resistente inicial do concreto, a qual pode entretanto diminuir com a evolução do carregamento.

As tensões nos estribos são menores do que prevê a analogia clássica de treliça. A inclinação preferencial das bielas próximo da ruptura situou-se entre 25 e 35 graus.

É necessário cobrir o diagrama de momento fletor para o dimensionamento da armadura longitudinal, pois as tensões na armadura são maiores do que aquelas previstas pelo equilíbrio devido às solicitações normais. A flexão localizada devido ao apoio das bielas e o atirantamento da resultante de compressão junto aos apoios introduzem tais variações de tensão. 
A diminuição da tensão de compressão no concreto junto aos apoios revela a transmissão direta da carga ao apoio pelo efeito de arco. $A$ região influenciada depende da relação entre a resistência ao cisalhamento e à flexão, podendo estender-se até $3,5 \mathrm{~d}$ quando a ruptura por cisalhamento não é prematura.

Em relação aos objetivos práticos que motivaram este trabalho, ou seja, a possibilidade de diminuição da armadura transversal $\mathrm{cm}$ elementos de microconcreto, algumas considerações podem ser feitas. A diminuição da resistência ao cisalhamento decorrente da redução ou eliminação da armadura transversal pode ser compensada pela protensão e pelas fibras. O problema da dutilidade é mais difícil de ser contornado, mas também pode ser minimizado com estes procedimentos.

O acréscimo de resistência obtido com a protensão é proporcional à força necessária para a descompressão da seção analisada, no caso de vigas sem estribos ou com taxa reduzida de armadura de cisalhamento. Com armadura transversal abundante, ou em quantidade suficiente para permitir o escoamento da armadura longitudinal, a influência da protensão diminui próximo da ruptura. limitando-se à diferença na inclinação das bielas.

Caso a resistência ao cisalhamento seja o fator limitante do projeto, o acréscimo de resistência devido à protensão é significativo. Ela é facilmente ajustada às solicitações. mas persiste o problema da ruptura frágil na eventualidade de uma carga excepcional que leve a peça à ruptura por cisalhamento. devido à diminuição da influência da protensão. No entanto, não se pode atribuir a esta forma de ruptura o mesmo nível de dutilidade de alguns tipos de ruptura por cisalhamento. Mesmo sem o escoamento da armadura longitudinal. que incorpora deformações plásticas significativas, a fissuração deve ser intensa para que os efeitos da protensão sejam minimizados, o que configura um certo aviso da proximidade da ruptura.

A introdução das fibras também melhora a resistência ao cisalhamento e elas podem substituir parcialmente os estribos. Porém. é preciso estabelecer uma relação entre o volume de fibras e a taxa de armadura transversal equivalente. Este trabalho não conseguiu quantificá-la, apesar de se verificar a viabilidade desta proposta. Para se quantificar a resistência adicional proporcionada pelas fibras deve-se caracterizar quantitativamente a aderência entre a fibra e a matriz.

O acréscimo de dutilidade talvez seja um dos maiores atrativos das fibras. Porém. especificamente para a aplicação em questão, a dutilidade somente será ideal se o volume de fibras for capaz de alterar a forma de ruptura. permitindo o escoamento da armadura longitudinal. Mas, mesmo que isso não ocorra, a ruptura por cisalhamento se torna mais dútil. 
$\mathrm{Na}$ verdade, a melhoria da dutilidade passa por uma adequação do projeto. $\mathrm{Na}$ pior das hipóteses, pode-se utilizar elementos de concreto reforçado com fibras sem armadura transversal, protendidos ou não (conforme os requisitos de utilização), em situações de pequena responsabilidade estrutural. Nos elementos de maior importância estrutural dimensionados convencionalmente, as fibras melhoram a resistência ao "cisalhamento e o comportamento em geral, aumentando a segurança e a dutilidade, mesmo que não mudem a forma de ruptura.

Diversos trabalhos podem dar continuidade a este estudo, preenchendo algumas lacunas e avançando em outras direções. Os modelos de cálculo citados nos Capítulo 3 para quantificar a contribuição das fibras no cisalhamento pressupõem a caracterização da aderência entre a fibra e a matriz, que varia para cada tipo de fibra, através de ensaios de arrancamento. A utilização dos conceitos da Mecânica da Fratura também pode auxiliar na análise da ruptura por cisalhamento, especialmente em se tratando de vigas com taxas reduzidas de armadura transversal. Com isso, pode-se estabelecer parâmetros de equivalência entre o volume de fibras e a taxa de armadura transversal.

Outros tipos de fibras devem ser investigados, priorizando-se o aumento da resistência de aderência. A busca de um processo produtivo mais eficiente também pode trazer melhores resultados.

Em relação à influência da protensão no cisalhamento, outros ensaios em que os instantes da ruptura por cisalhamento e o do escoamento da armadura longitudinal sejam mais próximos podem completar este estudo. caracterizando melhor a lacuna de conhecimentos entre as peças sem armadura transversal e as peças com armadura transversal abundante. 


\section{REFERÊNCIAS BIBLIOGRÁFICAS}

AMERICAN CONCRETE INSTITUTE. Committee 544, (1987) State of the art report : on fiber reinforced concrete - ACI Manual of Concrete Practice, v 5, Detroit (ACI 544.1R-86).

AMERICAN CONCRETE INSTITUTE. Committee 544, (1987) Measurements of properties of fiber reinforced concrete - ACl Manual of Concrete Practice, v 5 , Detroit (ACI 544.2R-86).

AMERICAN CONCRETE INSTITUTE. Committee 318, (1985) Building Code requirements for reinforced concrete, Detroit (ACI 318M-83).

AGOPYAN, V. (1991) Materiais reforçados com fibras para a construção civil nos países em desenvolvimento: o uso de fibras vegetais. São Paulo. Tese de livredocência, Escola Politécnica, USP.

AGOPYAN, V. (1993) O emprego de materiais fibrosos na construção civil. In: SIMPÓSIO INTERNACIONAL SOBRE MATERIAIS REFORÇADOS COM FIBRAS PARA CONSTRUÇÃO CIVIL, São Paulo, 1993, Anais.

AHAMAD. S.H; KHALOO, A.R; POVEDA, A. (1986) Shear capacity of reinforced high strength concrete beams. ACl Journal, Detroit, p 97-305, mar-apr.

AHAMAD, S.H; XIE, Y; YU, T. (1994) Shear strength of reinforced lightweight concrete beams of normal and high strength concrete. Magazine of Concrete Research. London, v 46, n 166, p 57-60, mar.

AL-NAHLAWI, K. A; WIGHT, J.K. (1992) Beam analysis using concrete tensile strength in truss model. ACI Structural Journal, Detroit, v 89 n 3, p 282-289, mayjun.

AL-TA'AN. S. A; AL-FEEL, J. R. (1990) Evaluation of shear strength of fibre reinforced concrete beams. Cement and Concrete Composites, v 12, p 87-94.

ALSAYED. S.H. (1993) Flexural deflection of reinforced fibrous concrete beams. $A C l$ Structural Journal, Detroit, v 90, n 1, p 72-76, jan-feb.

ALSHEGEIR, A; RAMIREZ, J.A. (1992) Strut-tie approach in pretensioned deep beams. ÁCI Structural Journal, Detroit, p 296-304, may-jun. 
ALWAN, J.M; NAAMAN, A.E; HANSEN, W. (1991) Pull-out work of steel fibers from cimentitious composites: analytical investigation. Cement \& Concrete Composites, v 13, p 247-255.

ANDERSON, N.S; RAMIREZ, J.A. (1989) Detailing of stirrup reinforcement. $A C I$ Structural Journal, Detroit, v 86 n 5, p 507-515, sep-oct.

ANDREWS, G; SHARMA, A.K. (1990) Repaired reinforced concrete beams failing in shear. Concrete International: Design and Construction, p 53-57, mar.

ARMELIN. H. (1993) Concreto projetado reforçado com fibras de aço. In: SIMPÓSIO INTERNACIONAL SOBRE MATERIAIS REFORÇADOS COM FIBRAS PARA CONSTRUÇÃO CIVIL, São Paulo, 1993, Anais.

ASHOUR, S.A; HASANAIN, G.S; WAFA, F.F. (1992) Shear behavior of high strength fiber reinforced concrete beams. ACI Structural Journal, Detroit, r 89, n 2 , p 176-184, mar-apr.

ASSOCIAÇÃO BRASILEIRA DE NORMAS TÉCNICAS (1978) Projeto e Execução de Obras de Concreto Armado. Rio de Janeiro, NBR-6118/1978.

ASSOCIAÇÃO BRASILEIRA DE NORMAS TÉCNICAS (1988) Projeto de Estruturas de Concreto Protendido. Rio de Janeiro, NBR-7197/1988.

AZIZ, M.A. et alii. (1981) Prospects for natural fibre reinforced concretes in construction. The International Journal Cement Composites and Lightweigth Concrete. v 3, n 2, p 123-152.

BALAGURU, P. (1994) Contribution of fibers to crack reduction of cement composites during the initial and final setting period. ACI Materials Journal, Detroit. r 91, n 3 , p 280-288, may-jun.

BATSON. G; JENKINS, E; SPATNEY, R. (1972) Steel fibers as shear reinforcement in beams. ACI Journal, Detroit, $\mathrm{p}$ 640-644, oct.

BAYASI, Z; ZENG, J. (1993) Properties of polypropilene fiber concrete. ACI Materials Journal, Detroit, Nov/Dec 1993.

BAZANT, Z.P; SUN, H.H. (1987) Size effect in diagonal shear failure: influence of aggregate size and stirrups. ACI Materials. Journal, Detroit, p 259-272, jul-aug.

BELARBI, A; HSU, T.T.C. (1990) Stirrup stresses in reinforced concrete beams. $A C I$ Structural Journal, Detroit, v 87, n 5, p 530-538, sep-oct.

BENTES, R.F; VASCONCELLOS, L.A.E. (1993) O reforço das fibras. Revista Techne, p 28-30, mar-abr. 
BENTUR, A. Fiber reinforced cementitious materials. Materials Science of Concrete, 223-283.

BENTUR, A; MINDESS. S. (1990) Fibre reinforced cimentitious composites. Elsevier Applied Science, London and New York, 1990.

BENTUR, A; MINDESS, S; VONDRAN, G. (1989) Bonding in polypropilen fibre reinforced concrete. The International Journal of Cement Composites and Lightweight Concrete, v 11, n 3, p 153-158, aug.

BRAESTRUP (1992) Discussion from Sep/Oct 1991 ACI Structural Journal p 592. ACI Structural Journal, Detroit, p 475-482, jul-aug.

BURNLEY, G.P.E; ASWAD, A.P.E. (1989) Omission of web reinforcement in prestressed double tees. PCI Journal, p 48-65, mar-apr.

CARVALHO FILHO, A.C; AGOPYAN, V. (1993) Argamassas reforçadas com fibras de sisal: comportamento mecânico à flexão. Boletim Técnico, São Paulo, EPUSP, 21 p. (BT/PCC/85).

CEB-FIP Model Code 1978, Shear and torsion, CEB Bulletin d'Information n 126.

CEB-FIP (1987) Shear in prestressed concrete members (State of the Art), Bulletin d'Information, n 180.

CEB-FIP (1987) Anchorage zones of prestressed concrete members, Bulletin d'Information, n 181.

CEB-FIP Model Code 1990, final draft, CEB Bulletin d'Information, 204.

CHANA, P.S. (1987) Investigation of the mechanism of shear failure of reinforced concrete beams. Magazine of Concrete Research, v 39, n 141, p 196-204. dec.

CHANA, P.S. (1988) Analytical and experimental studies of shear failures in reinforced concrete beams. Proc Instn Civ Engrs, Part 2, 85, p 609-628, dec.

CHERN, J.C; YOU. C.M; BAZANT, Z.P. (1992) Deformation of progressively cracking partially prestressed concrete beams. PCI Journal, p 74-85, jan-feb.

CHUNG, W; AHMAD, S.H. (1994) Model for shear critical high-strength concrete beams. ACI Structural Journal, Detroit, p 31-41, jan-feb.

COUSINS, T.E; BADEAUX, M.H; MOUSTAFA, S. (1992) Proposed test for determining bond characteristics of prestressing strand. PCI Joulnal, p 66-73, janfeb. 
CURRIER. B; GARDINER, T. (1989) Bond between polypropilen fibers and cement matrix. The International Journal of Cement Composites and Lightreight Concrete. v 11, n 1. p 3-9, feb.

DANTAS. F.A.S. (1987) Concretos de baixo consumo de cimento reforçados com fibras: propriedades e análise da fissuração devida à retração. São Paulo, Tese (doutorado) - Escola Poliptécnica, USP.

DARWISH. I. Y ; NARAYANAN, R. (1990) Design charts for reinforced and prestressed fibre concrete elements. The Structural Engineer, v 68, n 2, p 34-39, jan.

DEI POLI. S: DI PRISCO, M; GAMBAROVA, P.G. (1993) Cover and stirrup effects on the shear response of dowel bar embedded in concrete. ACI Structural Journal, Detroit. v 90, n 4, p 441-450, jul-aug.

DWARAKANATH, H.V; NAGARAJ, T.S. (1992) Deformational behavior of reinforced fiber reinforced concrete beams in bending. Journal of Structural Engineering, v 118, n 10, p 2691-2698, oct.

ELZANATY, A.H: NILSON. A.H; SLATE, F.O. (1986) Shear capacity of reinforced concrete beams using high strength concrete. ACI Journal, Detroit. p 290-296. marapr.

FEENSTRA. P. H; BORST, R. (1993) Aspects of robust computational modeling for plain and reinforced concrete. Heron, v 58, n 4, p 1-76.

FERNANDES, G.B. (1992) (isalhamento em vigas de concreto de alta resistencia. São Paulo. Tese (doutorado) - Escola Politécnica, USP.

FERRARI. P. (1994) Armadura reduzida para cisalhamento em vigas de concreto armado de alta resistência. Campinas. Dissertação (mestrado) - Escola de Engenharia Civil da UNICAMP.

FURLAN Jr, S. (1991) O uso da protensão em peças de concreto de seção delgada (argamassa armada protendida). São Carlos. Dissertação (mestrado) - Escola de Engenharia de São Carlos, EESC-USP.

FUSCO. P.B. (1984) Estruturas de concreto: solicitações tangenciais. São Paulo, Depto de Engenharia de Estruturas e Fundações, Escola Politécnica, USP.

GOPALARATNAN, V.S; SHAH, S.P; BATSON, G.B; CRISWELL, M.E: RAMAKRISHNAN, V; VECHARATANA: M. (1991) Fracture toughness of fiber reinforced concrete. A (I Materials. Journal, Detroit, v 88, n 4, p 339-353, jul-aug. 
GRONDZIEL, M. (1993) Development of steel fibre and steel-fibre-reinforcedconcrete during the past 10 years in Europe. In: SIMPÓSIO INTERNACIONAL SOBRE MATERIAIS REFORÇADOS COM FIBRAS PARA CONSTRUÇÃO CIVIL, São Paulo, 1993, Anais.

GUINEA. G. V; PLANAS, J; ELICES. M. (1994) A general bilinear fit for the softening curve of concrete. Materials and Stuctures, n 27, p 99-105.

GUSTAFSSON, P.J; HILLERBORG, A. (1988) Sensivity in shear strength of longitudinally reinforced concrete beams to fracture energy of concrete. $A C I$ Structural Journal, Detroit, p 286-294, may-jun.

HANNANT, D.J. (1978) Fibre cements and fibre concretes. Wiley-Interscience Publication: John Wiley \& Sons, Chichester, New York, Brisbane, 'Toronto, 1978.

HUGGES, B.P; FATTUHI, N.I. (1989) Reinforced steel and polypropilen fibre concrete corbel tests. The Structural Engineer, v 67, n 4, p 68-72, feb.

JOHN, V.M; AGOPYAN, V. (1993) Materias reforçados com fibras vegetais. In: SIMPÓSIO INTERNACIONAL SOBRE MATERIAIS REFORÇADOS COM FIBRAS PARA CONSTRUÇÃO CIVIL. São Paulo, 1993, Anais.

JOHNSON, M.K; RAMIREZ, J.A. (1989) Minimum shear reinforcement in beams with higher strength concrete. ACI Structural Journal, Detroit, v 86, n 4, p 376-382. jul-aug.

KANG, G.Y; WU, G.M; WANG, L.Y: XUE, B.H. (1989) Ultimate shear tests of prestressed I-beams. Proc. Instn. Civ. Engrs, part 2, n 87, p 401-414. sep.

KAUFMAN, M.K; RAMIREZ, J.A. (1988) Re-evaluation of the ultimate shear behaviour of high strength concrete prestressed I-beams. ACI Structural Journal, Detroit, p 295-303. may-jun.

KIM, J.K; PARK, Y.D. (1994) Shear strength of reinforced high strenth concrete beams without web reinforcement. Magazine of Concrete Research, v 46, n 166, p 7-16. mar.

KIM, W; WHITE, R.N. (1991) Iniciation of shear cracking in reinforced concrete beams with no web reinforcement. AC'1 Structural Journal, Detroit, p 301-308, mayjun.

KORDINA, K; HEGGER, J; TEUTSCH. M. (1989) Shear strength of prestressed concrete beams with unbonded tendons. ACI Stuctural Joumal. Detroit, v 86, n 2, p 143-149, mar-apr. 
KOTSOVOS. M.D. (1984) Behavior of reinforced concrete beams with a shear span to depth ratio between 1,0 and 2,5. ACI Journal. Detroit, p 279-286, may-jun.

KOTSOVOS. M.D. (1988) Compressive force path concept: basis of reinforced concrete ultimate limit state design. ACI Structural Joumal. Detroit, p 68-75, janfeb.

KOTSOVOS. M.D; BOBROWSKY, J. (1993) Design model for structural concrete based on the concept of compressive force path. ACI Structural Journal. Detroit, $v$ 90, n 1, p 12-20, jan-feb.

KOTSOVOS. M.D; LEFAS, I.D. (1990) Behavior of reinforced concrete beams designed in compliance with the concept of compressive-force path. ACI Structural Journal, Detroit, v 87, n 2, p 127-138. mar-apr.

LEONHARDT, F; MÖNNIG, E. (1977) Principios básicos de dimensionamento de estruturas de concreto armado, Interciência, v 1.

LEONHARDT, F; MÖNNIG, E. (1978) Casos especiais de dimensionamento de estruturas de concreto armado, Interciência, $\vee 2$.

LEONHARDT, F. - Cracks and crack control in concrete stuctures. PCI Journal, p 124145. jul-aug.

LI, V.C. (1992) A simplified micromechanical model of compressive strength of fiber reinforced cimentitious composites. Cement \& Concrete Composites, n 14, p 131141.

LI. V.C: WARD, R; HAMZA, A.M. (1992) Steel and synthetic fiber as shear reinforcement. ACI Materials. Journal. Detroit. p 499-508. sep-oct.

LIM, T. Y; PARAMASIVAM, P; LEE. S. L. (1987) Shear and moment capacity of reinforced steel fiber concrete beams. Magazine of Concrete Research, v 39, n 140 , p 148-160. sep.

LUB, K.B; MATHEWS, M.S. (1989) Influence of steel fibres on the behaviour of conventionally reinforced thin-walled hollow beams. The International Journal of Cement Composites and Lightweight Concrete. $v 11, \mathrm{n} 1, \mathrm{p} 47-55$, feb.

MACLEODD. I.A; HOUMSI, A. (1994) Shear strength of haunched beams without shear reinforcement. ACI Struchural Journal. Detroit. p 79-89, jan-feb.

MANSUR. 'M.A; ONG, C.G; PARAMASIVAM,P. (1986) Shear strength of fibrous concrete beams without stirrups. Journal of Structural Engineering, v 112, n 9. p 2066-2079. sep. 
MATTOCK, A.H; WANG, Z. (1984) Shear strength of reinforced members subject to high axial compressive stress. A I Journal, Detroit, p 287-298, may-jun.

MEITA. P.K: MONTEIRO, P.J.M. (1994) Concreto: estrutura, propriedades e materiais. São Paulo, Editora Pini.

:MONTEIRO). P.I.M. (1993) Controle da microestrutura para o desenvolvimento de concretos de alto desempenho. Boletim Técnico, São Paulo, EPUSP, 22p (BT/PCC/86).

MPHONDE, A. G. (1988) Aggregate interlock in high strength reinforced concrete beams. Proc Inst Civ Engn, Part 2, v 85, p 397-413. sep.

MPHONDE. A.G. (1989) Use of stirrup efectiveness in shear design of concrete beams. ACI Structural Journal, Detroit, v 86, n 5, p 541-545, sep-oct.

MPHONDE, A.G; FRANTZ, G.C. (1994) Shear tests of high and low strength concrete beams. ACI Journal, Detroit, p 350-357, jul-aug.

NAAMAN. A.E; NAJM, H. (1991) Bond-slip mechanisms of steel fibers in concrete. ACI Matrials Journal, Detroit, v 88, n 2, p 135-145, mar-apr.

NANNI. A. (1991) Fatigue behavior of steel fiber reinforced concrete. Cement \& Concrete Composites, n 13, p 239-245.

NANNI, A: UTSUNOMIYA, T; YONEKURA, H; TANIGAKI. M. (1992) Transmission of prestressing force to concrete by bonded fiber reinforced plastic tendons. ACI Structural Journal, Detroit. p 335-344, may-jun.

NARAYANAN, R; DARWISH, I.Y.S. (1987) Use of steel fibers as shear reinforcement. ACI Structural Journal, Detroit, p 216-227. may-jun.

NARAYANAN, R; DARWISH, I.Y.S. (1986) Shear in mortar beams containing fibers and fly ash. Journal of Structural Engineering, v 114, n 1. p 84-102, jan.

NARAYANAN. R; DARWISH, I.Y.S.(1988) Fiber concrete deep beams in shear. $A C I$ Structural Jounal, Detroit, p 141-149, mar-apr.

NIYOGI, S.K: DWARAKANATHAN, G.I. (1985) Fiber reinforced beams under moment and shear. Journal of Structural Engineering, v 111 . n 3, p 516-527, mar.

NOBRL, E.M. (1992) Argamassa armada estudo experimental de vigas submetidas à força cớtante. São Carlos, Dissertação (mẻstrado) - Escola de Engenharia de São Carlos. EESC-USP. 
OH, B.H. (1992) Flexural analysis of reinforced concrete beams containing steel fibers. Journal of Structural Engineering, v 118, n 10, p 2821-2838, oct.

OHNO, S; HANNANT, D.J. (1994) Modelling the stress-strain response of continuous fiber reinforced cement composites. ACI Materials Journal, Detroit, v 91, n 3, p 306-312, may-jun.

OUYANG, C; SHAH, S.P. (1994) Fracture energy approach for predicting cracking of reinforced concrete tensile members. ACI Structural Journal, Detroit, p 69-78, janfeb.

PARAMESWARAN, V.S; KRISHNAMOORTHY, T.S; BALASUBRAMANIAN, K. (1990) Behaviour of high volume fibre cement mortar in flexure. Cement \& Concrete Composites, n 12, p 293-301.

PELED, A; GUTTMAN, H; BENTUR, A. (1992) Treatments of polypropilene fibres to optimize their reinforcing efficiency in cement composites. Cement \& Concrete Composites, n 14, p 277-285.

PFEIL, W. (1978) Concreto Armado. Livros Técnicos e Científicos Editora S.A.

PIZANTY. A. (1992) The shear strength of extruded hollow-core slabs. Materials and Structures, n 25, p 224-230.

POLILlo. A. (1977) Dimensionamento de concreto armado. Rio de Janeiro, Editora Científica, v 2.

REBEIZ, K.S; SERHAL, S; FOWLER, D.W. (1993) Shear behavior of steel reinforced polymer concrete using recycled plastic. ACI Structural Journal, Detroit, v 90, n 6, p 675-682. nov-dec.

REGAN, P.E. (1993) Research on shear: a benefity to humanity or a waste of time? The Structural Engineer, p 337-346, oct.

REINECK, K.H. (1991) Ultimate shear force of structural concrete members without transverse reinforcement derived from a mechanical model. ACI Structural Journal, Detroit. p 592-602, sep-oct.

RICHARDSON, B.W. (1990) High volume polypropilen reinforcement for shotcrete. Concrete Construction, p 33-35, jan.

ROLLER, J.J; RUSSEL, A.H. (1990) Shear strength of high strength beams with web reinforcẹment. ACI Structural Journal, Detroit, v 87, n 2, p 191-198, mar-apr.

ROSSI, P. (1994) S.F.R. concretes (SFRC): an exemple of French research. $A(l$ Materials Journal, Detroit, v 91, n 3, p 273-279. may-jun. 
ROSSI. P; WU, X. (1992) Dimensioning and numerical modelling of metal-fibre reinforced concrete (MFRC) structures. Cement \& Concrete Composites, n 14, $\mathrm{p}$ 195-198.

RUSSO, G; ZINGONE, G; PULERI, G. (1991) Flexure shear interaction model for - Iongitudinally reinforced beams. ACI Structural Journal, Detroit, v 88, n 1, p 60-68. jan-feb.

SACHAN. A.K; RAO, K.C.V.S. (1988) A Cone penetration test of workability of fibre reinforced concrete. Materials and Structures, n 21, p 448-452.

SACHAN, A. K; RAO, C.V.S.K. (1990) Behaviour of fibre reinforced concrete deep beams. Cement \& Concrete Composites, n 12, p $211-218$.

SARSAM, K.F; AL-MUSAWI, J.M.S. (1992) Shear design for high and normal strength concrete beams with web reinforcement. ACI Structural Journal, Detroit, $\mathrm{p}$ 658-664, nov-dec.

SAVASTANO Jr, H. (1992) Zona de transição entre fibras e pasta de cimento portland: caracterização e inter-relação com as propriedades mecánicas do compósito. São Paulo. Tese (doutorado) - Escola Politécnica, USP.

SAVASTANO Jr, H; DANTAS, F.A.S; AGOPYAN, V. (1993) Fibras, zona de Transição. Revista Techne, p 24-27. nov-dez.

SCHALANGEN, E. (1993) Experimental and numerical analysis of fracture process in concrete. Heron, v 38.

SERAJ, S.M; KOTSOVOS, M.D; PAVLOVIC, M.N. (1993) Compressive force path and behaviour of prestressed concrete beams. Materials and Structures, n 26, p 7489.

SHAH, S.P. (1991) Do fibers increase the tensile strength of cement-based matrixes? ACI Materials, Joumal, Detroit, v 88, n 6, p 595-602, nov-dec.

SHAH, S.P: BATSON, G.B. (1987) Fiber reinforced concrete - properties and applications. ACISP-105, Detroit.

SHAH, S.P; OUYANG, C. (1991) Mechanical behavior of fiber-reinforced cementbased composites. Journal of the American Ceramic Society, v 74, n 11, p 22272238 e $2947-2953$.

SHAH, S.P; RANGAN, B.V. (1971) Fiber reinforced concrete properties. ACI Journal. Detroit, p 126-135, feb. 
SHARMA, A.K. (1986) Shear strength of steel fiber reinforced concrete beams. ACI Journal, Detroit, p 624-628, jul-aug.

SIIORNE, H; RODE, U. (1991) Numerical simulation of Crack propagation from microcracking to fracture. Cement \& Concrete (omposites, n 13, p 87-94.

SII.VA, R.C. (1991) Concreto armado: aplicaçoes de modelos de bielas e tirantes. São Carlos. Dissertação (mestrado) - Escola de Engenharia de São Carlos. EESC-USP.

SILVA, L.F; TESUKA. Y. (1992) Comportamento à flexão de placas de argamassa armada com fibras de aço onduladas. Boletim Técnico. São Paulo, 19p (BT/PCC/72USP).

SO, K.O; KARIHALOO, B.L. (1993) Shear capacity of longitudinally reinforced beams - a fracture mechanics approach. ACI Structural Journal, Detroit, v 90, n 6, p 591-600, nov-dec.

SOROUSHIAN, P; BAYASI, Z. (1991) Fiber type effects on the performance of steel fiber reinforced concrete. ACI Materials Journal, Detroit, v 88, n 2, p 129-134, marapr.

SOROUSHIAN, P; KHAN, A: HSU, J.W. - Mechanical properties of concrete materials reinforced with polypropilene ou poliethilene Fibers. ACI Materials Journal, nov/dec 1992, p 535-540.

SOROUSHIAN, P; MIRZA, F; ALHOZAIMY, A. - Bonding of Confined Steel Fiber Reinforced Concrete to Deformed Bars. ACI Materials Journal, vol 91 n. 2, Mar/Apr 1994, p $141-149$.

SWAMY, R.N; BAHIA, H.M. (1979) Influence of fiber reinforcement on the dowel resistance to shear. $A C I$ Journal. Detroit. p 327-355. feb.

SWAMY, R.N; BAHIA, H.M. (1985) The effectiveness of steel fibers as shear reinforcement. Concrete International, p 35-40, mar.

SWAMY, R.N; BARR, B (1989) Fibre reinforced cements and concretes - recent developments. Elsevier Applied Science. London and New York.

SWAMY, R.N; JONES, R; CHIAM. A.T.P. (1993) Influence of steel fibers on the shear resistance of lightweight concrete I-beams. A I Structural Journal, Detroit, v 90, n 1. p 103-114. jan-feb.

TAN, K.H: MANSUR, M.A. (1992) Partial prestressed in concrete corbels and deep beams. AC'I Structural Journal, Detroit, v 89, n 3, p 251-262, may-jun. 
TAN, K.H; MURUGAPPAN, P. (1992) Shear behavior of steel fiber reinforced concrete beams. ACI Structural Journal, Detroit, v 89, n 6, p 3-11, nov-dec.

TESUKA. Y. (1989) Concreto armado com fibras. Associação Brasileira de Cimento Portland, p 1-20, ago.

;TIIPTOBROTO, P; HANSEN, W. (1991) Mechanism for tensile strain hardening in high performance cement-based fiber reinforced composites. Cement \& Concrete Composites, n 13, p 265-273.

VECCHIO, F.J; COLLINS, M.P. (1986) The modified compression-field theory for reinforced concrete elements subjected to shear. ACI Journal. Detroit, p 219-231, mar-apr.

VALLE, M; BUYUKOSTURK, O. (1993) Behavior of fiber reinforced high-strength concrete under shear. ACI Materials Journal, Detroit, p 122-133, mar-apr.

VONK. R.A. (1993) A micromechanical investigation of softening of concrete loaded in compression. Heron, v $38, \mathrm{n} 3$.

WAFA. F.F; ASIHOUR, S.A. (1992) Mechanical properties of high strength fiber reinforced concrete. ACI Materials, Journal, Detroit, v 89, n 5, p 449-454, sep-oct.

WALRAVEN, J; BLAAUWENDRAAD, J. (1992) Discussion from Sep/Oct $1991 \mathrm{ACl}$ Structural Journal p 592. ACI Structural Journal, Detroit, p 475-482, jul-aug.

WANG, Y; LI, V.C; BACKER, S. (1990) Tensile properties of sinthetic fiber reinforced mortar. Cement \& Concrete Composites, n 12, p 29-40.

WU, K.C: LI, V.C. (1994) Trade-off between strength and ductility of random discontinous fiber reinforced cimentitious composites. Cement \& Concrete Composites, n 16, p 23-29. 